\title{
Riparian Research and Management: Past, Present, Future: Volume 1
}


Johnson, R. Roy; Carothers, Steven W.; Finch, Deborah M.; Kingsley, Kenneth J.; Stanley, John T., tech. eds. 2018.

Riparian research and management: Past, present, future: Volume 1. Gen. Tech. Rep. RMRS-GTR-377. Fort Collins, CO: U.S. Department of Agriculture, Forest Service, Rocky Mountain Research Station. 226 p.

doi: https://doi.org/10.2737/RMRS-GTR-377

\section{Abstract}

Fifty years ago, riparian habitats were not recognized for their extensive and critical contributions to wildlife and the ecosystem function of watersheds. This changed as riparian values were identified and documented, and the science of riparian ecology developed steadily. Papers in this volume range from the more mesic northwestern United States to the arid Southwest and Mexico. More than two dozen authors-most with decades of experience-review the origins of riparian science in the western United States, document what is currently known about riparian ecosystems, and project future needs. Topics are widespread and include: interactions with fire, climate change, and declining water; impacts from exotic species; unintended consequences of biological control; the role of small mammals; watershed response to beavers; watershed and riparian changes; changes below large dams; water birds of the Colorado River Delta; and terrestrial vertebrates of mesquite bosques. Appendices and references chronicle the field's literature, authors, "riparian pioneers," and conferences.

Keywords: riparian, ecosystem, ecology, riparian processes, restoration, aquatic, arid, semi-arid, upland, freshwater, groundwater, hydrology

Front cover: A backwater with beaver dam along the Gunnison River at Neversink, Curecanti National Recreation Area, Gunnison County, Colorado (photo by Kenneth J. Kingsley).

All Rocky Mountain Research Station publications are published by U.S. Forest Service employees and are in the public domain and available at no cost. Even though U.S. Forest Service publications are not copyrighted, they are formatted according to U.S. Department of Agriculture standards and research findings and formatting cannot be altered in reprints. Altering content or formatting, including the cover and title page, is strictly prohibited. 


\section{Technical Editors}

R. Roy Johnson, Research Associate, Museum of Northern Arizona, Emeritus Professor, University of Arizona, and retired Research Scientist, National Park Service, Tucson, Arizona.

Steven W. Carothers, Founder, Senior Scientist, and Member of the Board of Directors of SWCA Environmental Consultants, Phoenix, Arizona.

Deborah M. Finch, Biological Scientist and Program Manager, USDA Forest Service, Rocky Mountain Research Station, Albuquerque, New Mexico.

Kenneth J. Kingsley, Retired Senior Scientist, SWCA Environmental Consultants, Tucson, Arizona, and Volunteer Scientist, Black Canyon of the Gunnison National Park, Montrose, Colorado.

John T. Stanley, Restoration Ecologist, WWWRESTORATION; formerly Principal Ecologist at Harvey \& Stanley Associates, Inc.; Principal Restoration Ecologist, The Habitat Restoration Group; and Program Manager, Tahoe Regional Planning Agency.

\section{Contributing Authors}

Steven W. Carothers, Founder, Senior Scientist, and Member of the Board of Directors of SWCA Environmental Consultants, Phoenix, Arizona.

Hisham EI Waer received his Ph.D. at the University of Denver in Biological Sciences in 2013, after which he returned to Libya as faculty at the University of Al-Fateh, Faculty of Agriculture, Department of Range and Forestry. He has been unreachable since his return to his home country. The research presented here was work for his dissertation.

Helen C. Fairley, Sociocultural Program Manager, Grand Canyon Monitoring and Research Center, U.S. Geological Survey, Flagstaff, Arizona.

Deborah M. Finch, Biological Scientist and Program Manager, USDA Forest Service, Rocky Mountain Research Station, Albuquerque, New Mexico.

Suzanne C. Fouty, Hydrologist and Soils Specialist, USDA Forest Service, Wallowa-Whitman National Forest, Baker City, Oregon.

Jonathan M. Friedman, Research Scientist, the Fort Science Center, U.S. Geological Survey, Fort Collins, Colorado.

Jennifer K. Frey, College Professor and Member of the Graduate Faculty, Department of Fish, Wildlife, and Conservation Ecology, New Mexico State University in Las Cruces, New Mexico.

Stanley V. Gregory, Distinguished Professor of Fisheries-Emeritus, Department of Fisheries and Wildlife, Oregon State University, Corvallis, Oregon.

Robert H. Hamre, retired Leader, Research Information Group at the USDA Forest Service Rocky Mountain Research Station, Fort Collins, Colorado.

Annie Henry, Ph.D. student, University of Denver, Colorado.

Osvel Hinojosa-Huerta, Director of the Water and Wetlands Conservation Program for Pronatura Noroeste, a non-profit organization, Ensenada, B.C., Mexico.

Elaine E. Johnson, Project Leader, Southwest Arizona National Wildlife Refuge Complex, Yuma, Arizona.

R. Roy Johnson, Research Associate, Museum of Northern Arizona, Emeritus Professor, University of Arizona, and retired Research Scientist, National Park Service, Tucson, Arizona.

Kenneth J. Kingsley, Retired Senior Scientist, SWCA Environmental Consultants, Tucson, Arizona, and Volunteer Scientist, Black Canyon of the Gunnison National Park.

Mary Anne McLeod, Senior Scientist, SWCA Environmental Consultants, Flagstaff, Arizona. 
Eric Mellink, Senior Researcher, Centro de Investigación Científica y de Educación Superior de Ensenada, B.C., Mexico.

Katie Merewether, Avian Field Biologist, Bird Conservancy of the Rockies, Brighton, Colorado.

Duncan T. Patten, Emeritus Professor of Life Sciences, Arizona State University, Founding President, Arizona Riparian Council, and Emeritus Research Professor and past Director of the State Water Center at Montana State University, Bozeman, Montana.

John S. Richardson, Department Head, Forest and Conservation Sciences, University of British Columbia, Vancouver, B.C.

Anne Sands, Aquatic Biologist, editor of first riparian conference proceedings published in the United States; Woodville Ranch, Dogtown, California.

Michael L. Scott, Adjunct Faculty, Watershed Sciences Department, Utah State University, Logan, Utah.

Bo Shelby, Professor, Department of Forest Ecosystems and Society, Oregon State University, Corvallis, Oregon.

Anna A. Sher, Professor, Department of Biological Sciences, University of Denver, Denver, Colorado.

D. Max Smith, Research Associate, USDA Forest Service, Rocky Mountain Research Station, Albuquerque, New Mexico; lives in Portland, Oregon.

John T. Stanley, Restoration Ecologist, WWWRESTORATION; formerly Principal Ecologist of Harvey \& Stanley Associates, Inc.; Principal Restoration Ecologist, The Habitat Restoration Group; and Program Manager, Tahoe Regional Planning Agency, Paradise, California.

Frederick J. Swanson, Pacific Northwest Research Station, USDA Forest Service, Corvallis, Oregon.

Raymond M. Turner, retired from the U.S. Geological Survey, Tucson, Arizona.

Robert H. Webb, Adjunct Faculty, University of Arizona, Tucson, Arizona.

William E. Werner, Wildlife Biologist, Bureau of Land Management, Phoenix, Arizona; formerly Environmental Program Manager, Arizona Department of Water Resources; retired Habitat Specialist, Arizona Game and Fish Department. 


\section{Foreword}

The availability of drinking water is the paramount environmental issue of the $21^{\text {st }}$ century in the western United States and especially in the Southwest. Growing populations in Albuquerque, Phoenix, Tucson, Las Vegas, and Southern California are already testing water supply and delivery infrastructure in the face of just a moderate drought. Conservation in major cities and innovations in agriculture have greatly reduced per capita and per acre water use over the last 15 years, providing a margin of security to water supplies. But as populations continue to grow, it's important for the people of the Southwest to reflect upon and confront the stresses caused by modest drought. Now is the time to collaborate to develop responses and put in place coordinated systems that can handle deeper drought, reduced water availability, and greater variability in precipitation predicted in upcoming decades.

Water delivery in the arid Southwest relies on the connection of forests, particularly the National Forests, to water storage facilities and eventually the faucets in our homes. The National Forests are a small part of the watershed, but they are disproportionally where rain and snowfall can become the water supply the system relies upon. Forests, streams, and riparian areas are the green infrastructure that captures, stores, and releases water, which is then delivered to our cities through the dams, canals, and pipelines we've built in support of our daily lives. Without the water supply provided by the green infrastructure, the built infrastructure is useless.

Just as the built infrastructure has been recently tested by drought, the green infrastructure is now being tested by fire and land use practices. Can the green infrastructure reliably provide human communities drinking water, wildlife habitat, and other critical ecosystem services? Can riparian ecosystems in particular produce the expected level of services as populations increase, and the climate changes, with the Southwest becoming both warmer and drier? Healthy riparian systems are linchpins connecting land and water, and they are integral to future water availability. This compendium of research on riparian areas could not be timelier or address a more essential need in the West.

In the past couple of decades, researchers, land managers, and regulators have focused on the holistic management of ecosystems, watersheds, and meeting the needs of human communities, while still addressing individual species, habitat components, and services. Community leaders and land managers have also embraced collaborative planning and cooperative solutions across broader landscapes. They have worked in a more inclusive manner to look past previous polarized thinking to see shrinking streams and riparian systems and value them beyond managing for individual interests. This publication, guided by the inseparable nature of streams and riparian ecosystems, emphasizes the interrelationships and continuity of riparian areas along with dependent wildlife and human services.

The scientific papers in this General Technical Report continue the long, demanding, and now urgent task of conveying scientific information on riparian systems, organisms, and their human interactions to give the reader a better sense of the history, conditions, and working of these resources, along with potential solutions for today's challenges. This report represents the current state of knowledge and points to some essential steps for connecting science, management, and politics for the restoration and sustenance of riparian ecosystems in the West and the sustainability of the human communities that depend on them.

\section{Calvin Joyner \\ Regional Forester \\ Southwestern Region \\ USDA Forest Service}




\title{
Preface-The Western Riparian Project
}

\author{
"You can't talk about streams without talking about riparian ecosystems." \\ (David L. Rosgen, Leader in Stream Classification and Stream Restoration; Western Riparian Project Science Advisor) \\ "Most impacts are insidious and cumulative." \\ (Christopher C. Estes, At-Large Director, Instream Flow Council; Western Riparian Project Science Advisor)
}

The Western Riparian Project (WRP) is a riverine project with emphasis on riparian ecosystems in western North America. Our objectives are:

- To review the historic needs for and beginnings of the science of riparian ecology;

- To assess the current state of riparian research and management; and

- To lay a foundation for the planning of conservation and research activities.

To attain these objectives, the WRP consists of two basic parts: (1) publishing a General Technical Report of selected papers that review the past 50 years of research and management activities to be distributed electronically and in print, and (2) convening a conference with invited speakers consisting of many of the report chapter authors. A conference is planned near the time of the release of this General Technical Report. Speakers will be selected by the Steering Committee. This General Technical Report is to be issued by the Rocky Mountain Research Station of the Forest Service, U.S. Department of Agriculture, in two volumes. More than 50 scientists from Mexico to Alaska contributed to this effort, which covers a broad spectrum of issues from "phreatophyte control" to current and future impacts of the newly introduced tamarisk beetles (Diorhabda spp.) on naturalized and native riparian ecosystems. The effort also covers implications of global climate change for riparian habitat restoration and conservation.

This discussion of riparian ecosystems uses a watershed approach that recognizes connectedness of the entire waterdriven continuum, from atmospheric moisture to instream flows and groundwater. The term "riparian" is used to describe a range of conditions:

Wet riparian ecosystems (hydroriparian and mesoriparian) associated with lotic waters-on the banks of flowing and intermittent streams. These range from the Rio Grande, Colorado, Gila, and Sacramento rivers, some of the nation's largest rivers, to the Salt, Bill Williams, and San Pedro rivers, southwestern streams that are perennial in the upper portions of their watersheds but become intermittent downstream.

- Ecosystems associated with lentic waters-on the shores of lakes.

- Xeroriparian ecosystems-along banks of usually dry ephemeral streams such as desert washes.

In short, we are concerned with biotic and abiotic factors related to biologically available water. Our watershed approach emphasizes both the instream flow model of connectivity as well as the connectedness of the hydrologic cycle. Our motto, "You can't talk about streams without talking about riparian ecosystems," acknowledges the importance of healthy riparian ecosystems to the health of a stream. This motto is also reversible, i.e., "You can't talk about riparian ecosystems without talking about streams," thereby acknowledging the interconnectedness of water and instream flows to riparian ecosystems. Thus, aquatic ecosystems and instream flow characteristics are considered an integral part of the riparian story. This approach emphasizes connectivity in time and space as proposed by the Instream Flow Council-longitudinal, lateral, and vertical space—and the natural hydrograph, addressing the temporal factors of seasonality.

The connectedness of water is conceptualized as the hydrologic cycle, often referred to as "the water cycle," detailing the movement of water from the earth's surface into the atmosphere, through evaporation, and finally back to the earth's surface as precipitation, much of it then percolating underground. In riverine systems, biotic and abiotic factors associated with aquatic and riparian ecosystems, and even interconnected upland ecosystems, are inseparably linked in a feedback loop related to water and instream flows. A thorough analysis of these systems requires information from ecology, hydrology, geomorphology, biochemistry, and a multitude of related disciplines.

We use the term "regeneration" to include both natural reestablishment and humanly assisted restoration of riparian habitats, while "restoration" is generally used only to indicate intentional human-induced changes. Our project includes 
practical field applications for riparian ecosystem restoration and riparian zone management as well as observations of naturally occurring habitat reestablishment as evidenced by natural revegetation and wildlife repopulation of recovering riparian areas. We include these findings with the goal of encouraging integration of riparian ecology and wildlife conservation with the routine operations of land and water resource management agencies at all levels of government as well as non-governmental groups.

The geographic area to be covered in this phase of the project extends from California eastward to Trans-Pecos Texas and adjacent northwestern Mexico and from there, northward, to the Pacific Northwest but emphasizing the more arid and semiarid regions of the West. Our reason for emphasis on this region is the suite of biophysical differences compared to regions of the eastern United States. We particularly emphasize the Rio Grande, Colorado, Gila, and Sacramento-San Joaquin watersheds because of the extensive change effected by anthropogenic activities in their riparian and aquatic ecosystems. In addition, a great deal of research, related to regeneration and restoration, has been and continues to be conducted along these rivers.

This General Technical Report is the book part of the Project and covers three primary topics:

- Review of the development of the science of riparian ecology, the history of riparian research, and the riparian movement in the region from their beginnings in the 1960s until the present;

- Determination of the current status of research and of riparian ecosystem conditions, in relation to ongoing management actions (e.g., biological control of Tamarix); and

- Evaluation of needed research studies and management actions in response to climate change and future water resource development.

Chapters in the book are designed for widespread applicability to particular riparian issues, examining each topic as it pertains especially to the region. A philosophical and practical approach to these issues is presented with examples of specific projects used to illustrate wider scale concepts. Chapter authors for the book have been selected because of first-hand field experience as well as a robust publication record and/or reports of successful accomplishments. Most of the participants have a long-time record of involvement in research and/or conservation of riparian ecosystems.

We consider this the most comprehensive publication yet produced on riparian ecosystems. Unlike most previous efforts, our focus is on examining watersheds as a whole to facilitate regeneration of sustainable riparian ecosystems now and into the future. Unlike most previous riparian literature that primarily presents a series of reports on specific projects, here we use project reports only as illustrations of larger scale riparian issues. We hope that this endeavor will serve to inspire and support continuing and future efforts in the study, protection, and restoration of our western riparian resources.

\section{R. Roy Johnson \\ Steven W. Carothers \\ Co-Directors}

\section{Acknowledgments}

This is the first of a two-volume technical report on riparian habitats in the western United States. The idea for this series of technical reports was an outgrowth of what is now recognized as The Western Riparian Project, a project initiated by a group of riparian ecologists and resources managers, all of whom have decades of experience in the biological aspects of riparian habitat productivity, management, and conservation. The Western Riparian Project is in its sixth year and has benefitted from participation by more than 50 scientists who have collectively spent thousands of uncompensated hours to ensure the success of the Project. Several of us have been involved with riparian ecology since the earliest days of its establishment as a science beginning in the late-1960s. The idea for the project originated Thanksgiving week, 2012, during a three-way conversation in Yuma, Arizona, between Karen Reichhardt, Bureau of Land Management, Elaine Johnson, U.S. Fish and Wildlife Service, and R. Roy Johnson. Reichhardt and E. Johnson had been involved in our Arizona Verde River riparian habitat avian field studies almost 50 years earlier (Carothers and Johnson 1970; Carothers et al. 1974; Johnson 1971). Now, they suggested it was time to examine the progress made in western aridland riparian ecology and conservation since those early studies. 
As the idea for a book on the status of southwestern riparian habitat began to fully develop, and we began to focus on what we know, what we don't know, and what we still need to know about the remarkably productive riparian habitats in western North America, we naturally revisited the primary literature on the subject and began searching for potential chapter authors. Most of the authors of the chapters in this General Technical Report (GTR) have spent decades attempting to document the importance of conserving and managing riparian habitats due to their disproportionate value to wildlife and people compared to upland habitats.

The Project began in earnest in June of 2014 when 19 Project participants attended a 2-day workshop at the Museum of Northern Arizona, Flagstaff. Workshop attendees were from as far as Alaska-Christopher Estes, At-Large Director of the Instream Flow Council; New York-Jon Kusler, Associate Director, Association of State Wetland Managers; OregonSuzanne Fouty, USDA Forest Service; Colorado-Robert Hamre, retired, former Leader, Research Information Group, USDA Forest Service Rocky Mountain Research Station, Fort Collins, Colorado, who had previously issued proceedings of several riparian conferences; Utah-Dale A. Jones, co-editor of the nation's second riparian conference (Johnson and Jones 1977) and retired Director of Wildlife, Fisheries, and Endangered Species, USDA Forest Service, Washington DC; and California-F. Thomas Griggs, River Partners.

Travel to the workshop and additional funding was provided by SWCA Inc. Environmental Consultants, Phoenix, Arizona, and local arrangements were made by Larry Stevens and Jeri Ledbetter of the Museum of Northern Arizona. In addition to many of these participants being involved in ongoing riparian studies, a sense of the history of the development of riparian ecology prevailed at that meeting. Six of the 19 workshop attendees had been directly involved in the aforementioned Verde Valley riparian studies of the early 1970s: Steve Carothers, Christopher Estes, Elaine Johnson, Kenneth J. Kingsley, Larry Stevens, and R. Roy Johnson. Two of the workshop attendees had helped to provide funding for those early studies: Bud Bristow, then with Arizona Game and Fish Department, and Dale Jones of the USDA Forest Service. Besides those already recognized, we have been fortunate to have scientists and managers of many agencies, universities, and NGOs associated with riparian and related issues involved in the Project. Without their input, this work would not be complete. This includes Duncan T. Patten, founding President of The Arizona Riparian Council, the nation's first State riparian council; and three of the five founding board members of the Society for Ecological Restoration (SER): John Reiger, Founding President, John T. Stanley, and Anne Sands, SER Board Members. Anne also served as a co-director of our project during 2013 and 2014.

Critical assistance has been rendered on an assortment of issues throughout the project by members of our Science Advisory Board, including Exequiel Ezcurra, Director, Institute for Mexico and the United States, U.C. Riverside, CA; Stefan Lorenzato, Coordinator of the California Riparian Habitat Joint Venture, an association of 18 government and NGOs involved in protecting and enhancing riparian habitat; Daniel and Ellen Plunkett, founders of the 7,200 Acre Doris Wilderness sanctuary, Belize; Ann Riley, member of the California State Water Quality Control Board; David Rosgen, leading authority and practitioner in stream classification and restoration; Bo Shelby, leading researcher on issues related to recreation in riparian habitats; and Robert Webb, hydrologist, and one of the leading experts on the Colorado River in Grand Canyon.

In addition to appreciation for our co-editors (Deborah Finch, Kenneth Kingsley, and John Stanley), Bob Hamre deserves special mention for untold hours spent editing most of the GTR chapters, including several renditions of some chapters. Additional reviewers included Dale A. Jones, Duncan T. Patten, Harley G. Shaw, and Patricia M. Woodruff. Deborah Finch assisted throughout the project and with the review process by "loaning" us several USDA Forest Service employees working for the Forest Service Southwest Regional Office and Rocky Mountain Research Station, including Katelyn P. Driscoll, Roy Jemison, Ernest Taylor, and F. Jack Triepke. We also thank David L. Hawksworth, of the Rocky Mountain Research Station, for help in reviewing the overall manuscript for formatting errors. Space prohibits us from thanking all of the authors, individually, of the various chapters but their affiliations can be found in this GTR's front matter. Finally, we thank Cal Joyner for writing the insightful Foreword to the report.

\section{R. Roy Johnson and Steven W. Carothers \\ Co-directors \\ The Western Riparian Project}




\section{Contents}

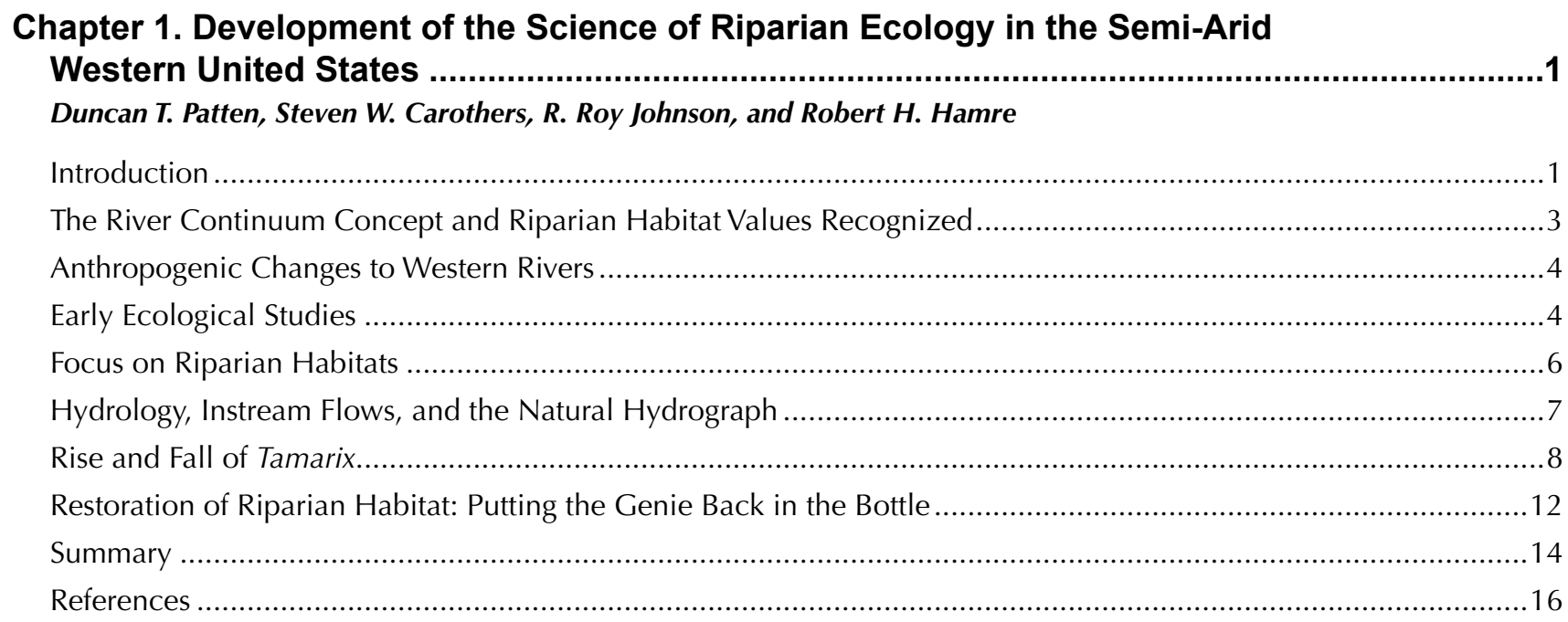

\section{Chapter 2. Development of Riparian Perspectives in the Wet Pacific Northwest}

Since the 1970s.

Frederick J. Swanson and Stanley V. Gregory

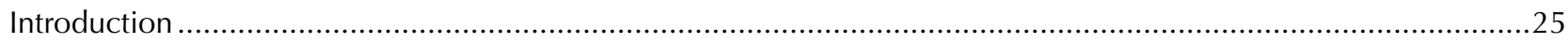

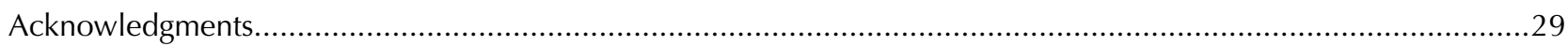

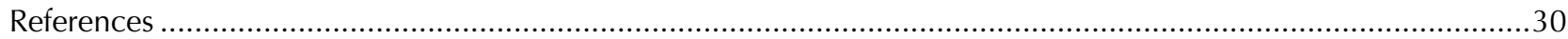

\section{Chapter 3. Impacts of Interacting Fire, Climate, and Hydrologic Changes on}

Riparian Forest Ecosystems in the Southwest

D. Max Smith and Deborah M. Finch

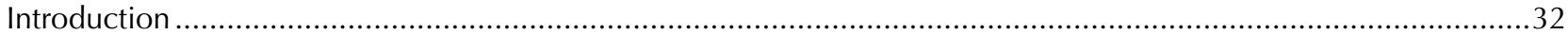

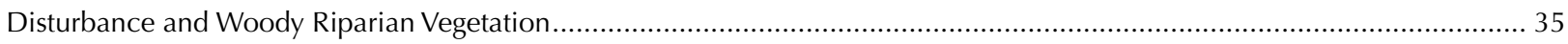

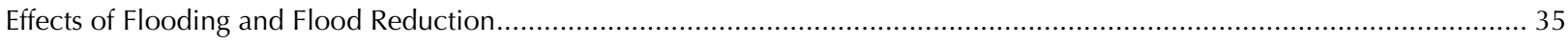

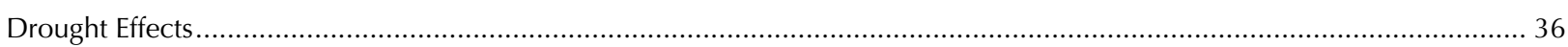

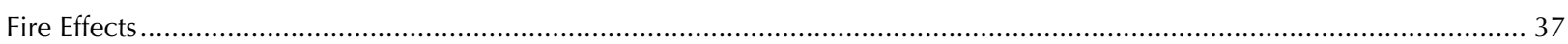

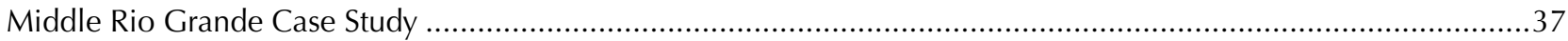

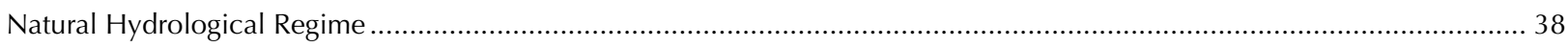

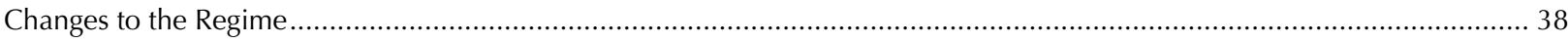

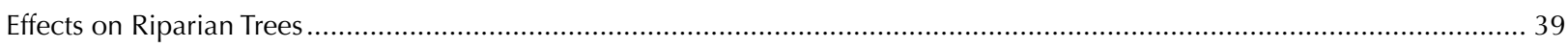

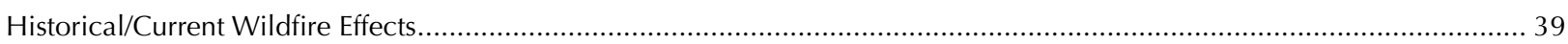

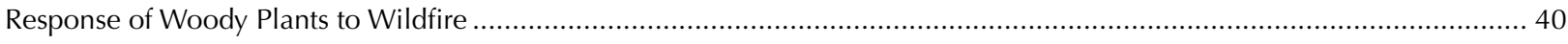

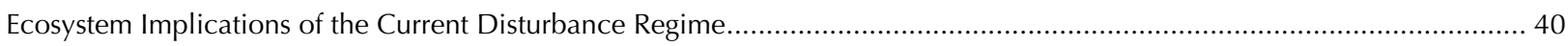

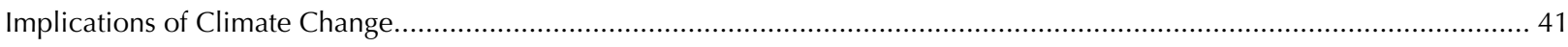

Conclusions: Disturbance Change and the Future of Aridland Riparian Forests .............................................41

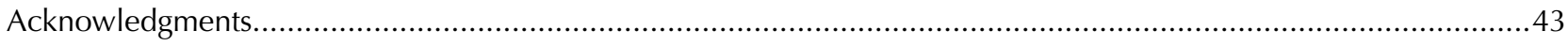

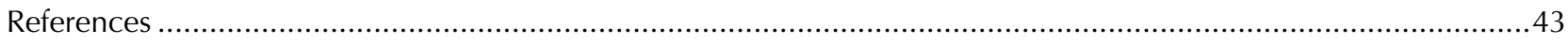


Chapter 4. Invasion and Restoration of Western Rivers Dominated by Tamarix spp.

Hisham N. El Waer, Annie Henry, Katie Merewether, and Anna A. Sher

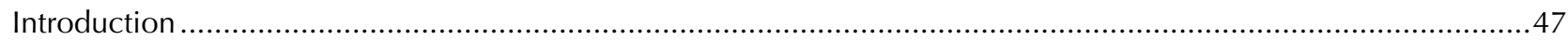

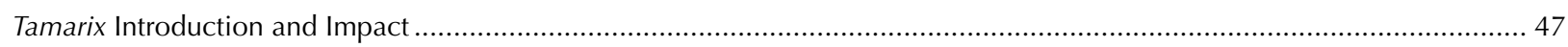

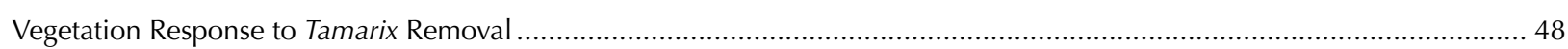

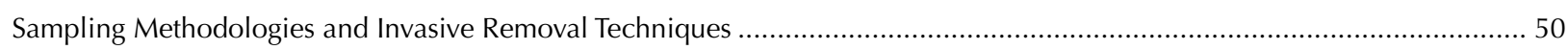

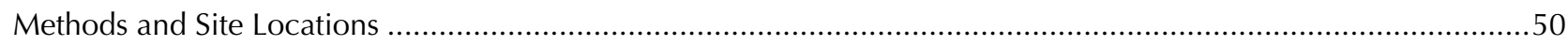

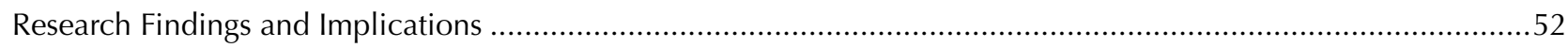

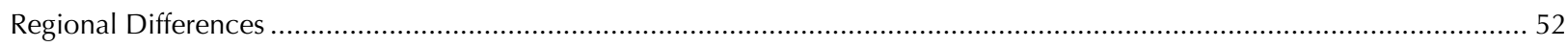

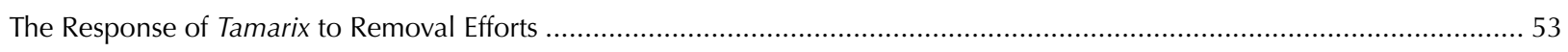

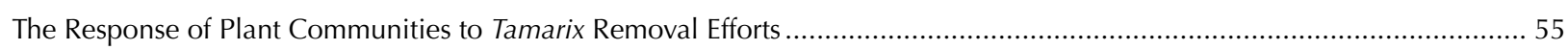

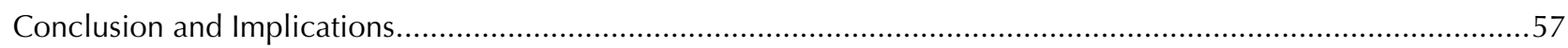

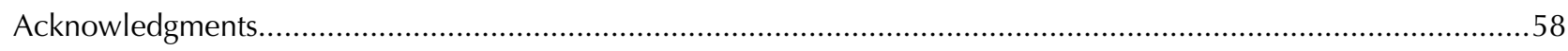

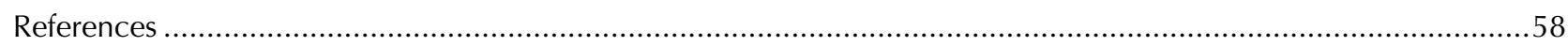

\section{Chapter 5. Unintended Consequences: Tamarisk Control and Increasing Threats}

to the Southwestern Willow Flycatcher.............................................................................62

Mary Anne McLeod

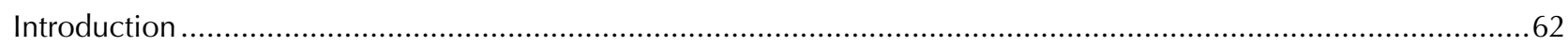

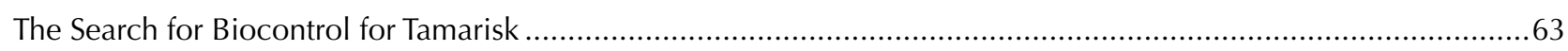

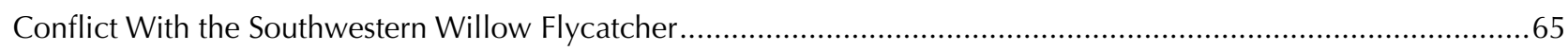

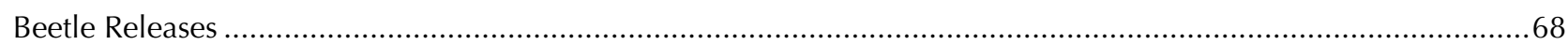

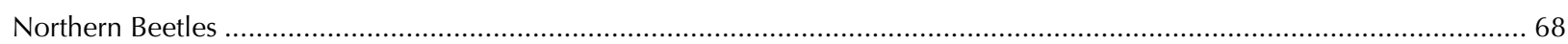

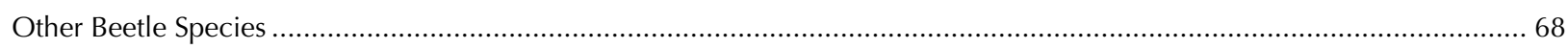

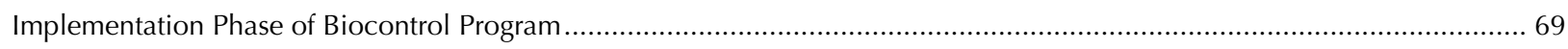

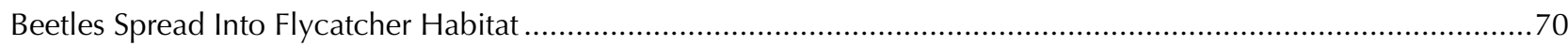

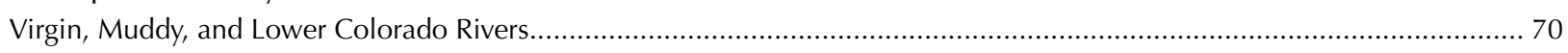

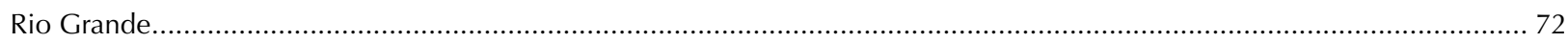

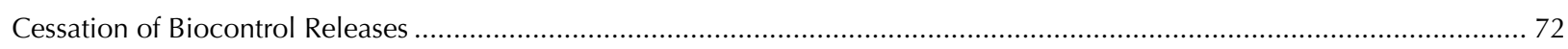

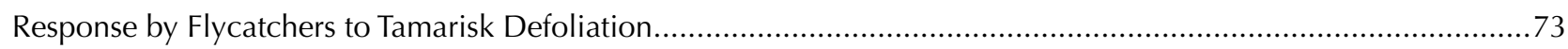

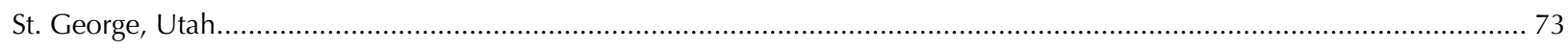

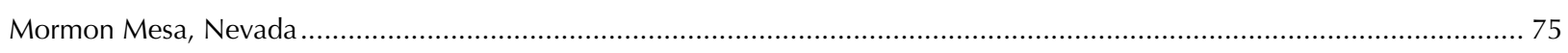

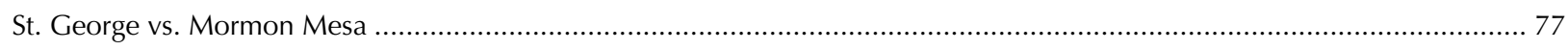

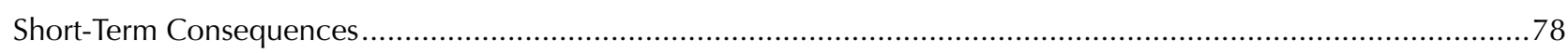

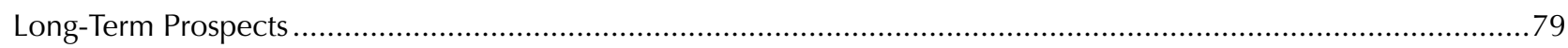

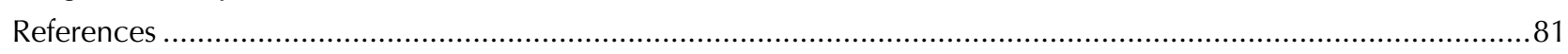

\section{Chapter 6. Beavers, Livestock, and Riparian Synergies: Bringing Small Mammals}

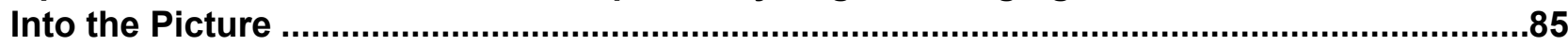

Jennifer K. Frey

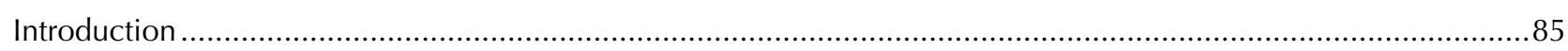

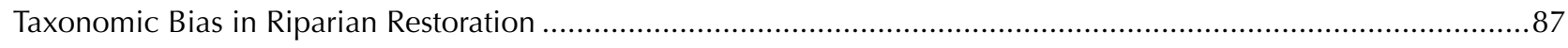

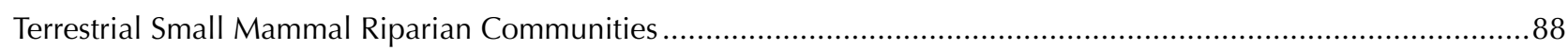

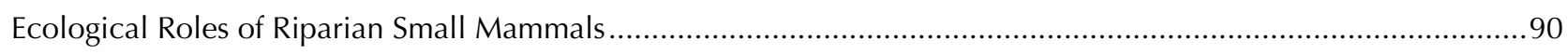

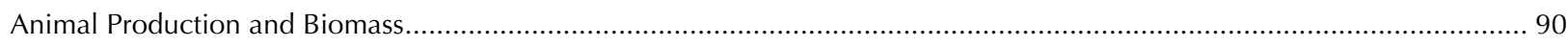

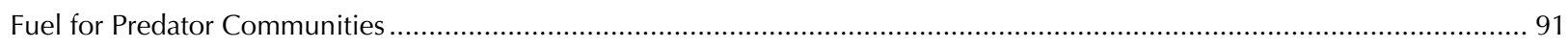




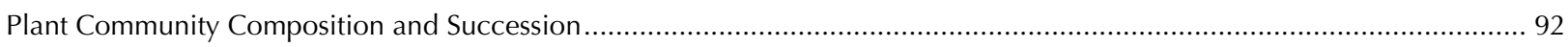

Terrestrial Small Mammal Community Habitat Relationships ...................................................................93

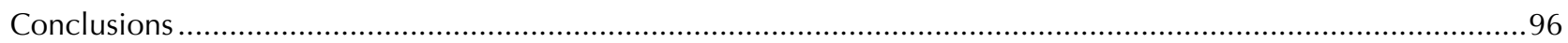

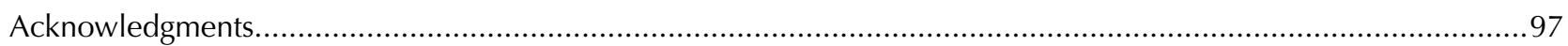

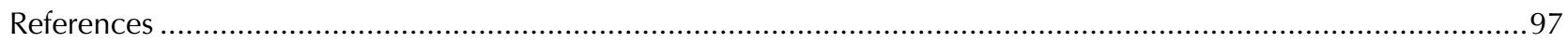

\section{Chapter 7. Euro-American Beaver Trapping and Its Long-Term Impact on Drainage} Network Form and Function, Water Abundance, Delivery, and System Stability.................102 Suzanne C. Fouty

Introduction

Conceptual Model Part 1: Watershed Response to Long-Term Beaver Presence ................................................103

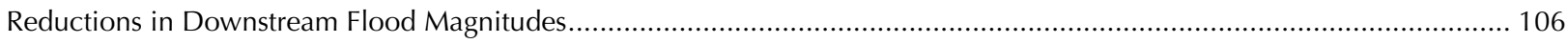

Conceptual Model Part 2: Watershed Response to Beaver Trapping After a Long-Term Presence.........................107

The Geographies of Euro-American Beaver Trapping, General Land Office Surveys, and Early Expeditions ............113

Arroyo Formation in the Southwest and Intermountain West .................................................................. 115

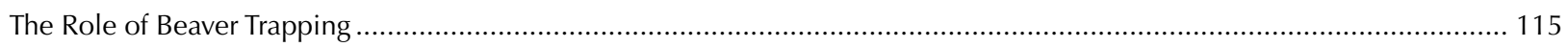

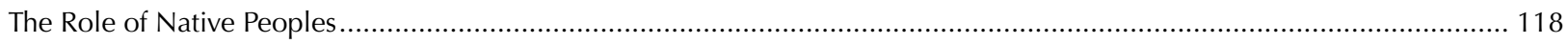

Reexamining Changes on the Gila River in Light of Beaver Trapping ........................................................119

Explaining the Absence of Arroyo Formation From 1750 to 1825 Despite Large Herds of Spanish and Mexican

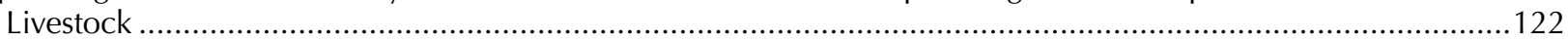

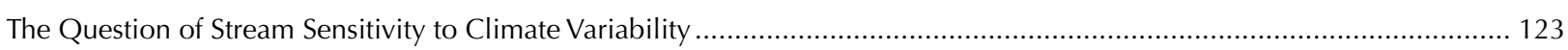

From Past to Present: Placing Hydraulic Geometry Relationships in Their Historic Disturbance Context................123

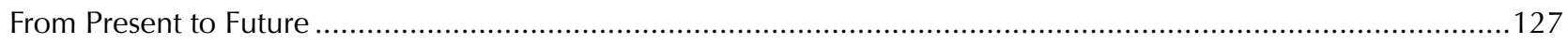

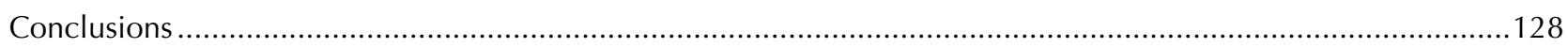

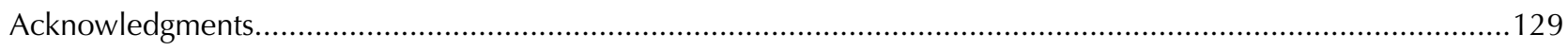

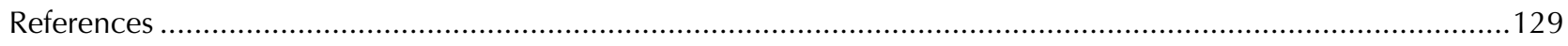

\section{Chapter 8. Arizona as a Watershed-Then and Now: Case Studies of Changed}

Management of Rivers and Habitat in the Lower Colorado River System...........................134

William E. Werner

Introduction

Colorado River Below Glen Canyon Dam and the Role of Tributaries ...................................................137

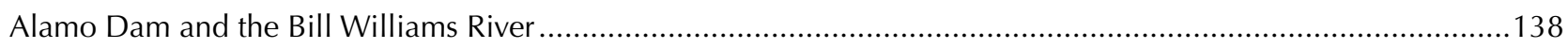

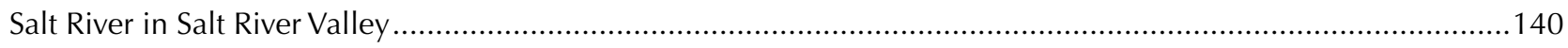

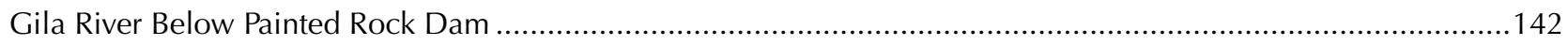

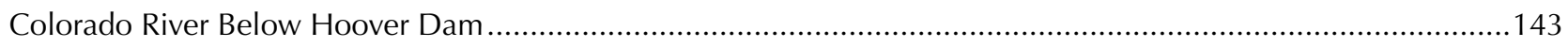

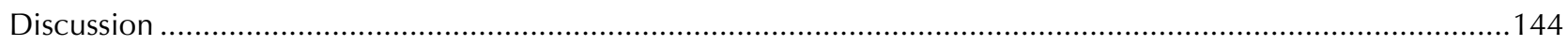

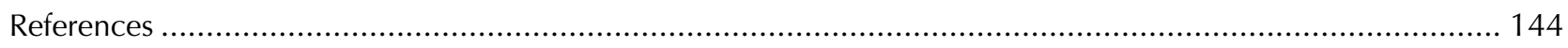

\section{Chapter 9. Evaluating Riparian Vegetation Change in Canyon-Bound Reaches} of the Colorado River Using Spatially Extensive Matched Photo Sets ...............................148 Michael L. Scott, Robert H. Webb, R. Roy Johnson, Raymond M. Turner, Jonathan M. Friedman, and Helen C. Fairley

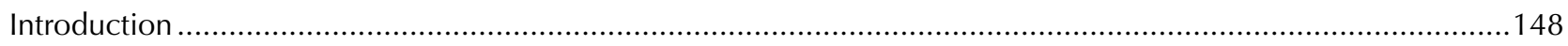

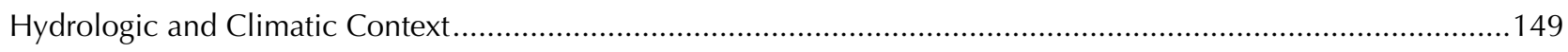

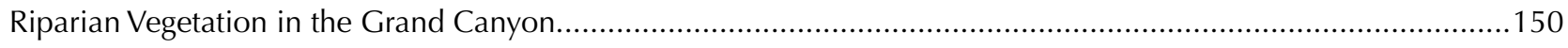




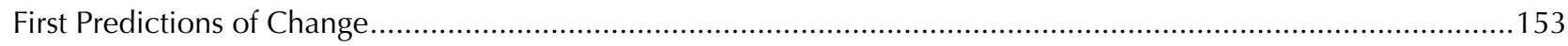

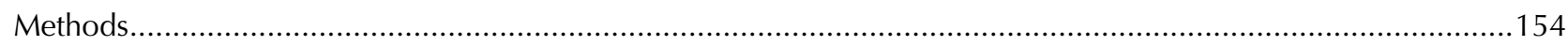

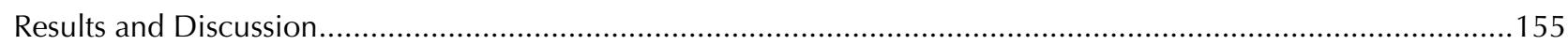

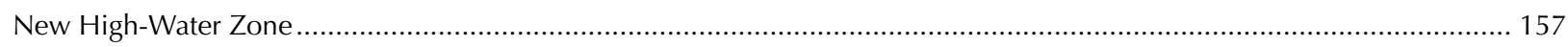

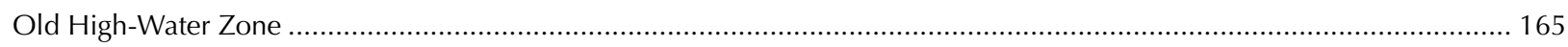

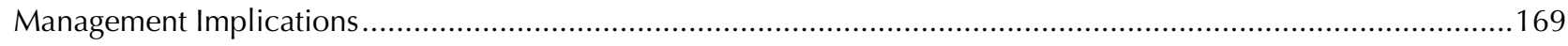

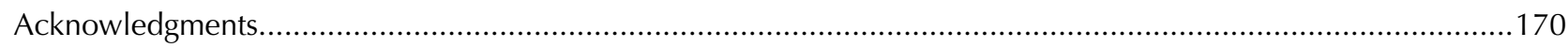

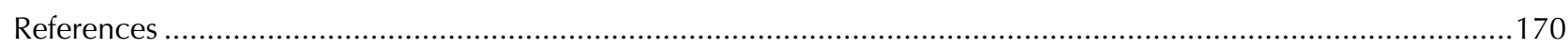

Chapter 10. Breeding Waterbirds of the Mexican Portion of the Colorado River Delta...........174

Eric Mellink and Osvel Hinojosa-Huerta

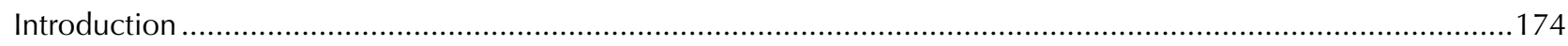

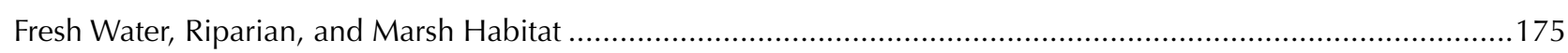

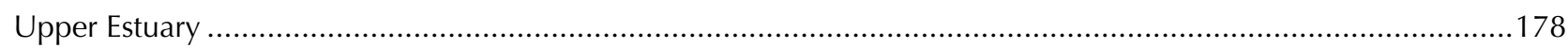

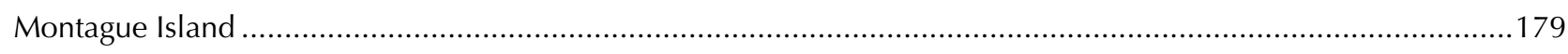

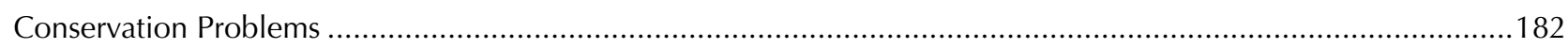

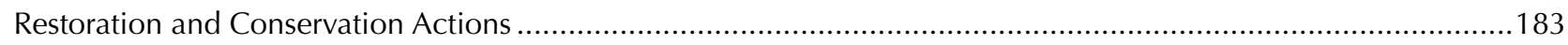

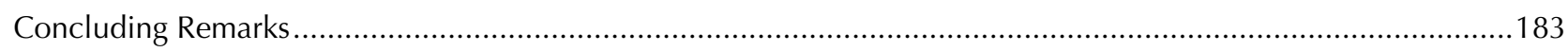

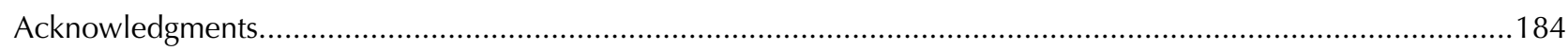

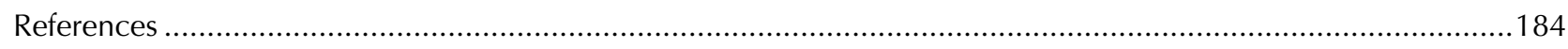

Chapter 11. Terrestrial Vertebrates of Mesquite Bosques in Southwestern North America ...188

R. Roy Johnson, Elaine E. Johnson, and Steven W. Carothers

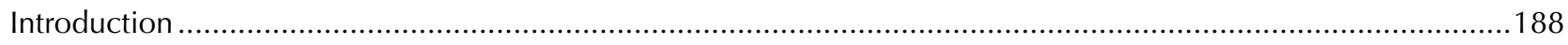

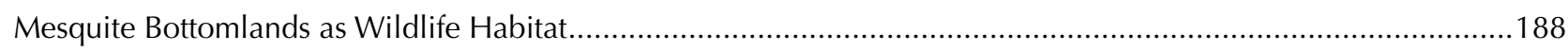

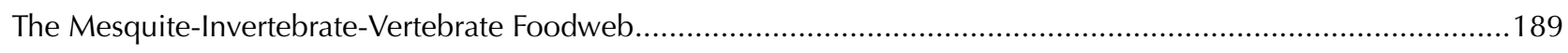

Mesquite Bosques and Cottonwood-Willow Riparian Gallery Forests............................................................205

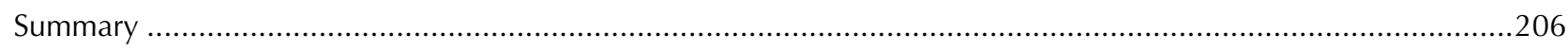

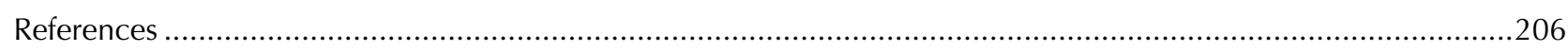

Appendix A: Western Pioneers of Riparian Study Through the 1980s .................................212

Compiled by: Kenneth J. Kingsley, John T. Stanley, Steven W. Carothers, R. Roy Johnson, Deborah M. Finch,

Duncan T. Patten, Anne Sands, Bo Shelby, and Frederick J. Swanson

Appendix B: Conferences, Symposia, and Other Gatherings Pertaining To Riparian Ecosystems, Riparian Ecology, Riparian Habitat Restoration, and Riparian Area Conservation.

Compiled by: John T. Stanley, R. Roy Johnson, Steven W. Carothers, Duncan T. Patten, and John S. Richardson 


\title{
Chapter 1. Development of the Science of Riparian Ecology in the Semi-Arid Western United States
}

\author{
Duncan T. Patten, Steven W. Carothers, R. Roy Johnson, and Robert H. Hamre
}

\section{Introduction}

The science of riparian ecology in the West developed over several decades, especially in the Southwest and California, as the importance of this ecosystem, its components, productivity, functions, and relationship to system hydrology became better understood. While it seems incredible today, it was only 50 years ago that streamside vegetation in the arid Southwest and portions of California were the subject of much concern as most flood control and water agencies wanted the permanent removal of riparian habitat. The early research within riparian habitats in the 1950s and 1960s focused primarily on methods of removal and reasons for its destruction (Gatewood et al. 1950; Fox 1977; Horton et al. 1964; Robinson 1952). Most studies of western rivers in the 1960s addressed the "fact" that riparian vegetation, referred to mostly as phreatophytes (i.e., plants tapping groundwater), was utilizing a large portion of the shallow groundwater moving through watersheds. At that time, most water managers believed that this water could be better allocated to human activities and needs, primarily agricultural, municipal, and industrial uses. In the semi-arid West, water lost to evapotranspiration by watersheds and phreatophytic plants was considered to be water unavailable for human use, and thus "wasted." Consequently, several studies beginning in the early 1950s were designed to demonstrate water consumption by watersheds (Gottfried et al. 1999) as well as riparian/phreatophytic plant communities with little or no concern or focus for other values such as the unique riparian habitat (Decker et al. 1962; Robinson 1952). In fact, at the time, a U.S. Department of Agriculture scientist and leading water expert wrote: "Phreatophyte vegetation seriously affects water supplies in arid and semi-arid regions. Knowledge of the extent and nature of the vegetation cover is needed as a basis for planning treatments of the vegetation and estimating the potential water savings and other effects" (Horton et al. 1964: 34).

The Horton et al. 1964 paper was typical of phreatophyte-focused papers and reports of the time. During these early days, most riparian research focused on water use by individual plants, while other research projects attempted to determine water saving through modification of large tracts of land by removing riparian vegetation. Some of these habitat modification projects began as early as 1950 when woody riparian plants in general (native and nonnative) were targeted for removal (Gatewood et al. 1950) and continued well into the 1960s when the focus had mostly shifted to removing the exotic or invasive shrub/tree tamarisk (saltcedar; Tamarix spp.) (Chew 2013; Culler et al. 1982). Anticipated results of these studies prompted governmental and private agencies to invest significant financial resources in attempting to reduce or rid drainage ways of riparian vegetation. Studies of water use by riparian plant communities, especially nonnative communities, continued from the 1950s and 1960s into the 1980s and 1990s 
(e.g., Sala et al. 1996; Smith et al. 1998). The practice of removing phreatophytes, especially large tracts of tamarisk, continues to today. Indeed, controversy over the relative costs/values of tamarisk vs. native riparian species is greatly debated today. For example, efforts to control tamarisk by introducing several species of beetle (Diorhabda spp.) from Asia continue to remind us that threats to riparian ecosystems still persist (see below and chapters 4 and 5).

During the late 1960s in Arizona, phreatophyte issues were mostly focused on native streamside vegetation. At that time, the Salt River Project and Army Corps of Engineers either removed or planned removal of extensive stands of cottonwoods (Populus fremontii) and other riparian plants along watercourses, including the Verde and Gila Rivers, in Arizona, to "salvage" water and "enhance" river flow. The Verde project resulted not only in loss of terrestrial wildlife habitat but also aquatic impacts including "siltation of the river gravels and spawning beds" (Tellman et al. 1997). Under pressure from avian experts (see below) and in consideration of alteration of spawning gravels, the practice, at least within native stands of riparian habitat, was "found to have little long-term impact on water supplies downstream, so it was discontinued after more than a decade of effort" (Tellman et al. 1997). However, as detailed below, efforts at Tamarix removal have persisted into the early 21 st century.

U.S. Department of Agriculture scientists were joined by scientists from other agencies in developing comprehensive literature on water salvage. From 1958 (Robinson 1958) into the 2000s, and even as early as 1927 (Meinzer 1927), the U.S. Geological Survey (USGS) issued a series of Professional Papers that addressed both surface water and groundwater issues (e.g., Culler et al. 1982). In addition, USGS issued numerous publications as Water Supply Papers suggesting, as the title implies, that the importance of water was primarily viewed in the context of human usage. Earlier in that era Horton compiled and abstracted 691 publications on the general subject of phreatophyte control (Horton 1973). In general, the publications Horton cited assigned little to no value to the ecological importance of streamside vegetation. As Water Supply project results accumulated, however, it became increasingly clear that the projected water savings from most phreatophyte control projects were ephemeral to non-existent (Barz et al. 2009; Graf et al. 1984).

In the early 1970 s, the scientific community was awakening to the ecological uniqueness and high biotic productivity of streamside habitats (see Appendix A for early riparian scientists), and it was after several of these ecological studies, primarily on birds, that the disproportionate productivity of riparian habitats compared to upland habitats was being documented (Carothers et al. 1974; Hubbard 1971, 1977a,b; Hynes 1975; Johnson 1971; Johnson et al. 1977, 1987; Wauer 1977; Zimmerman 1970). In addition, between the late 1960s and early 1980s, a series of events occurred that ushered out the era of phreatophyte control targeted on native riparian species and initiated the establishment of the science of riparian ecology and the riparian habitat conservation movement. Academic and management conferences in Arizona, California, and Colorado were held documenting the importance of the relationship of the riparian ecosystems to the natural riverine community (see Appendix B for a list of conferences).

One of the early studies, a 5-year riparian breeding bird study, documented the highest population densities of nesting birds ever recorded in any habitat in North America (Carothers and Johnson 1970; Carothers et al. 1974). The study was initially 
funded by the Forest Service, U.S. Department of Agriculture and later by the Arizona Game and Fish Department in direct response to the request by the Salt River Project in Phoenix, Arizona, to the Forest Service to remove the cottonwood and willow habitat on public land along the Verde River in central Arizona. One of the more pragmatic results of this study was that the ecological damage of indiscriminate phreatophyte control was exposed, and the practice, especially with native riparian habitats, began to decline significantly. During this same time, the series of riparian conferences continued to highlight and strengthen the data on the importance of the riparian corridor and its significance to wildlife and general riverine ecology.

\section{The River Continuum Concept and Riparian Habitat Values Recognized}

The recognition of both high species diversity and high density of obligate wildlife and plant species within riparian ecosystems was coincident with the introduction of another important ecological concept, the River Continuum Concept (RCC) (Vannote et al. 1980). The RCC emphasized the interrelatedness of riparian and aquatic riverine ecosystems. In addition, it recognized and fully valued the synergism of the interdependency of biological and physical interactions in a river system, both longitudinally and laterally, which included the stream side community. Before then, riverine studies tended to focus on individual elements of aquatic systems, e.g., fisheries or limnology, or else components of riparian system, e.g., birds, mammals and plants. Other important riparian-related activities during the 1980s included classification of riparian plant communities (e. g., Brown 1982; Szaro 1989), a systematic evaluation of the state of riparian ecology, and an assessment of needs for further, especially quantified, information about riparian ecosystems (Johnson et al. 1985; Knopf et al. 1988).

About this time, some investigators began to recognize the value of the invasive Tamarix as functional wildlife habitat and considered hundreds of miles of streamside habitats on some rivers dominated by Tamarix as productive and "naturalized" components of riparian ecosystems (Johnson 1977; Johnson and Carothers 1982, 1987; see also Chew 2009, 2013). Studies thereafter and into the 1990s focused on the need for maintaining a natural hydrograph for the recruitment of native vegetation and proper functioning of the riverine system (e.g., Junk et al. 1989; Poff et al. 1997). Finally, in the late 1990 s and continuing to the present, widespread concern developed for the protection of existing native riparian habitats as well as restoration of previously degraded habitats where possible (Rieger et al. 2014; Zeedyk and Clothier 2012).

Development of riparian ecology and the riparian environmental movement were mostly western undertakings with much of the research located in West Coast States of California, Oregon, and Washington, and semi-arid States of Utah, Nevada, Arizona, New Mexico, and Texas. Other studies were going on in Colorado and the northern Rockies as well. Johnson and Lowe (1985) described development of riparian ecology in the Southwest, attributing its late appearance to a lack of interest in the transition zone from water to upland as well as "the complexity of riparian ecosystems [forming] the ecotone [and] a textbook example of the edge effect." The term riparian was found mostly in "western" publications while terms such as "bottomland hardwoods," "floodplain forests," and similar terms were used mostly in the East. The U.S. Fish and Wildlife Service (USFWS) "wetlands manual," written by three eastern and one 
midwestern scientists, did not even use the term "riparian" (Cowardin et al. 1979). A search of the Library of Congress catalog by a committee of the National Research Council of the National Academy of Science (NRC 2002) using the term "riparian" disclosed an increasing number of entries from 1960 to 1990, mostly from western United States. A search using Google Scholar for the first 20 riparian publications also showed, for the United States, very few when the terms "riparian" and "eastern U.S." were used together.

\section{Anthropogenic Changes to Western Rivers}

By the 1960s, both surface water and groundwater resources in the vicinity of large metropolitan and high-intensity agricultural areas had been severely impacted by human activity. Instream flow levels in stream reaches above ground, as well as levels of water tables below ground, had been greatly reduced throughout much of the region (Zektser et al. 2005). Large rivers in which flow levels were measurably reduced or modified by large dams, diversions for urban and agricultural use, and other water projects included most lower reaches and tributaries of the Colorado, Gila, Salt, and Verde Rivers in Arizona; Rio Grande and Pecos Rivers in New Mexico and western Texas; and Sacramento, San Joaquin, and Owens Rivers in California. In most of these river systems the natural hydrograph had been irrevocably modified in all but relatively short reaches of their headwaters.

In addition to large dams and water diversion projects, many smaller dams along major tributaries further reduced normal flows interrupting the natural hydrograph along thousands of miles of rivers, drowning riparian habitat in reservoirs above dams and desiccating downstream riparian ecosystems through dewatering. Even rivers in lands set aside as "natural areas," such as Big Bend and Grand Canyon National Parks, have been impacted by large dams, upstream and downstream of the Park's boundaries, such as Glen Canyon Dam and Hoover Dam on the Colorado River in Arizona (Carothers and Brown 1991; Johnson 1991; Johnson and Carothers 1987;) and Elephant Butte, Caballo, and Amistad Dams on the Rio Grande in New Mexico and Texas (Chew 2006, 2013; Wikipedia 2016).

Rivers such as the Santa Cruz, Rillito, and Gila Rivers in southern Arizona were perennial streams at time of settlement by Euro-Americans but had been largely reduced to intermittent or ephemeral streams by excessive groundwater and irrigation withdrawals by the mid-1950s (Webb and Leake 2006; Webb et al. 2014). Indeed, by the first few decades of the 20th century it was the rare western river system where any semblance of the natural hydrograph was preserved for any distance below its headwaters. The exception to this is the Yellowstone River, which is the longest undammed, naturally flowing river in the West although 2016 plans for a dam on its lower reaches may change this.

\section{Early Ecological Studies}

By the early- and mid-1970s, numerous ecological studies, especially on birds, were underway along rivers of the Southwest and California (Carothers and Johnson 1975; Carothers et al. 1974; Gaines 1974, 1980; Gavin and Sowls 1975; Hubbard 
1971, 1977a,b; Johnson and Simpson 1971; Ohmart and Anderson 1977; Wauer 1977; Zimmerman 1970). We found only one much earlier study comparable to these studies conducted in 1949 along Dry Creek in the San Joaquin Valley, California (Ingles 1950). In addition to data on avian population densities and species richness, most of the early studies also contained information on vegetation associated with birds.

The studies conducted throughout the Southwest and California in the 1970s were undertaken, in part, due to increasing losses of riparian and related riverine habitat, losses that had started with the settlement of the West by Euro-Americans (Carothers 1977; Dobyns 1981; Knopf et al. 1988). Conservation and loss of these ecosystems were not of much general environmental concern until the 1970s and 1980s when several riparian conferences addressed these issues. To counter loss or removal of riparian plant communities, studies were designed to demonstrate that these communities were, in reality, complex ecosystems supporting a broad range of other species. Some of these studies were cooperative ventures among several individuals and agencies.

For example, the project to demonstrate the avian impacts of cutting down cottonwood trees along the Verde River was a joint effort of the Forest Service, U.S. Department of Agriculture, Arizona Game and Fish Department, U.S. Fish and Wildlife Service, Museum of Northern Arizona, and Prescott College. These earliest avian studies were of great scientific interest, demonstrating the critical habitat characteristics of the riparian plant community. Simultaneously, studies of riparian forests in the Gila River Valley of New Mexico documented the remarkable density and diversity of riparian birds (Hubbard 1971, 1977a,b; Zimmerman 1970). Shortly thereafter similar information was developed for the birds of the lower Rio Grande (Wauer 1977) and in the Lower Colorado River Valley (Anderson and Ohmart 1977; Rosenberg et al. 1991).

To our knowledge, the aforementioned studies provide the earliest quantified documentation of the importance of riparian vegetation as avian habitat in the Southwest. This also triggered a demand to better understand the importance of riparian ecosystems not only as habitat for birds and other wildlife and invertebrates (e.g., Patton 1977), but also as an ecological system that offers other important functions and services, including water quality, flood control, groundwater recharge, nutrient cycling, seed dispersal, migratory corridors, and recreation.

Even today, studies focused on other riparian vertebrates, i.e., amphibians, reptiles, and mammals, as well as invertebrates, have not received the same amount of attention as birds. Birds are generally more visible and more easily studied than other vertebrates because they are mostly diurnal, arboreal, and call attention through song. To determine factors such as species richness and population densities of the other three vertebrate groups, trapping and other special equipment and techniques are generally required. We have shown that riparian avian studies were widespread in the West by the mid to late 1970s. However, a 1988 publication by the Forest Service (Szaro et al. 1988) entitled Management of Amphibians, Reptiles and Small Mammals in North America, containing 54 papers, had only one paper on riparian amphibians and reptiles and three on riparian mammals. Not surprisingly, only one of these papers compares species richness in upland habitat types to riparian types in Arizona, finding much higher species diversity of amphibians and reptiles in riparian habitat compared to upland habitat (Jones 1988). 


\section{Focus on Riparian Habitats}

During the 1970s and continuing through the 1990s, with increasing interest in riparian systems, mapping and classification of vegetation in the Southwest became the focus of some researchers (Brown 1982; Lowe and Brown 1973). Different riparian communities were recognized based on elevation differences with lower elevation communities along river systems ranging from ephemeral to perennial, while higher elevation riparian systems where available water was more certain tended to include a mix of riverine and upland species (Szaro 1990). Lowe $(1961,1964)$ illustrated these communities in his "The Vertebrates of Arizona”, and more recently, Patten (1998) recognized the importance of the interaction of elevation and water availability gradients. Brown et al. (1977) published a drainage map for Arizona and in 1993-1994 the Arizona Game and Fish Department developed a dataset that identified and mapped riparian vegetation associated with perennial waters in response to the requirements of the 1992 Riparian Area Act (this act amended Arizona Revised Statute CARS 45-101; Kubly et al. 1997). Maps were created using two major sources of imagery: Landsat Thematic Mapper digital satellite data and Multiple Resolution Aerial Videography. The data were created to serve as base information for use in GIS systems for a variety of planning and analysis purposes. These data also demonstrated how much perennial vegetation had been lost along streams and rivers since the early $1900 \mathrm{~s}$, with nearly all losses associated with dams, groundwater pumping, agricultural clearing, and phreatophyte control.

Other impacts of human land use such as ranching (i.e., livestock grazing) and other forms of agriculture, especially when linked to irrigation, also were documented as causing major changes and loss of riparian areas (Belsky et al. 1999; Ohmart 1996). William Platts was a pioneer in many studies of livestock impacts on riparian systems (Platts 1979, 1981). Also, many of his studies dealt with grazing effects on fisheries and thus indirectly on riparian systems (Platts 1981). Platts' articles, although not all necessarily from the Southwest, greatly influenced thinking about impacts of grazing in the Southwest as did articles by Wayne Elmore who headed Bureau of Land Management's riparian program for many years (e.g., Elmore 1992; Elmore and Beschta 1987). In the late 1960s, the USFS Southwest Region realized that many riparian forests did not include multiple age classes but only mature trees. This apparent lack of recruitment led to greater control of grazing along rivers and reduction of removal of riparian plant communities.

From the 1970s well into the 21st century, riparian research continued to expand from descriptive studies of riparian plant and animal communities, to ecophysiological studies, to ecosystem studies, with emergence of new journals such as Ecohydrology in 2008. Many of these studies addressed functional relationships, such as between environmental drivers, e.g., water table and streamflow changes and vegetation response (Busch et al. 1992; Fenner et al. 1985; Shafroth et al. 1998, 2000; Stromberg et al. 2005, 2010), or canopy changes including avian community responses (e.g., Anderson and Ohmart 1977; Anderson et al. 1983; Johnson and Haight 1985; Stromberg et al. 1993). As riparian communities declined or were altered, ecologists attempted to explain those factors that were causing this decline, many being associated with water management (Busch and Smith 1995). As more water was removed from rivers of the West, studies 
were developed to demonstrate the range of instream flow requirements of riparian ecosystems (Arthington et al. 2006; Shafroth et al. 2010). These eventually were called environmental flows as they were flows that supported all components of the riverine system and often mimicked natural flow requirements, flows necessary for a healthy riverine system (Poff et al. 1997; Poff and Zimmerman 2010).

Riparian research in semi-arid regions during the 1980s and into the 1990s and later was being conducted not only in the Southwest but also along the eastern Sierras of California. Unlike the more mesic west slopes of the Sierras, the eastern slopes support riparian ecosystems similar to those along rivers in the Southwest. Most of the research in this region related to water relations of the riparian system, or components of it, since many of the eastern Sierra streams were being controlled and/or diverted to move water into the Los Angeles aqueduct or for hydropower production. Examples of this research included studies by Stromberg and Patten $(1990,1992)$ and Smith et al. (1991). Also, in the late 1970s and 1980s, a group of students from California studied the flows into and dropping levels of Mono Lake, a closed basin lake in the eastern Sierra. This group, led by David Gaines (1974), an environmental activist and ornithologist, helped form the Mono Lake Committee which today works toward protection of the lake. In 1987 a committee of the National Research Council/National Academy of Sciences studied dropping lake levels of Mono Lake, its causes, reduced stream inflows, and consequences (NRC 1987).

\section{Hydrology, Instream Flows, and the Natural Hydrograph}

Further concern for appropriate flows for riparian and riverine processes was based on, and stimulated research on, the hydrological processes that triggered responses of the riparian ecosystem. Flooding was shown to be an essential disturbance process for the long-term maintenance of riparian systems because most characteristic riparian woody species were successional species recruited during and after flood (Brady et al. 1985; Stromberg 2001). For example, the importance of uncontrolled flood flows and their timing and magnitude was found to be critical to establishment and maintenance of riparian systems (Brown et al. 1977). The "recruitment box" model developed by Mahoney and Rood (1998) documented how these processes interacted to enhance seedling establishment of riparian plant species. Other disturbance processes that were found to be important to riparian dynamics included fire that results in a change in population size structure with more mature cottonwoods, smaller willows, and fewer Tamarix (Stromberg and Rychener 2010).

A significant change in the long-term pattern of annual flows can substantially reduce the vigor and productivity of riparian ecosystems or the basic characteristics of a stream's natural hydrograph (Annear et al. 2004; Merritt and Poff 2010; Poff et al. 1997). Those elements of the "natural hydrograph" currently recognized as necessary to protect and nurture aquatic and terrestrial ecosystems consist of seasonally variable flows that include relatively stable flows as well as flood flows from winter storm events and summer monsoon rains (Annear et al. 2004). The annual pattern, and the multi-year variability, in these flows set the stage for the aquatic and terrestrial biological resources that can survive and evolve in the system. Each stream, unless it is dam regulated or otherwise significantly altered by anthropogenic influences, or natural causes such as 
earthquakes, has a pattern of flow that is generally dictated by climate, topography, geology, depth to groundwater, and other factors (Annear et al. 2004).

A fundamental understanding of what is needed to maintain aquatic and terrestrial riverine ecosystems includes four elements of the important instream flow principle of connectivity: longitudinal flows (flows that extend over the length of a stream course); lateral flows (flows that cover the width of the channel and floodplain); vertical flows (flows that provide sufficient stream depth and connect to the hyporheic corridor); and flow duration (the amount of time a flow is at a particular level) (see Annear et al. 2004). Moderate to high floods reshape the riparian habitats by scouring and depositing sediments onto substrates above the active stream channel and redistributing organic material that can benefit healthy riparian vegetation (Annear et al. 2004; Bunn and Arthington 2002; Leenhouts et al. 2006; Poff et al. 1997; Shafroth et al. 2000; Smith et al. 1991). These same flows also can benefit aquatic habitats by redistributing gravel and fine substrates that are important for fish spawning and rearing. Extreme flooding events can uproot riparian vegetation and scour instream aquatic food upon which fish species rely (Meffe and Minckley 1987). Large floods preferentially impair nonnative fishes over flood-adapted natives (Gido et al. 2013; Propst et al. 2008). This "re-setting" of the fish community can give the native fishes at least a temporary window in time to rebound from the negative (competitive and predatory) interactions with nonnatives.

During the later decades of the 1900s, several river systems were studied as integrated ecosystems along elevation and river volume or flow gradients. Some were small, such as Aravaipa Creek (e.g., Barber and Minckley 1966; Lowe 1964; Minckley 1981), some intermediate in size, such as San Pedro River (e.g., Stromberg and Tellman 2009), and some large, such as the Colorado River (e.g., Carothers and Brown 1991; Johnson and Carothers 1987) and studies by the Bureau of Reclamation's Glen Canyon Environmental Studies and other Federal and State agencies in the 1980s and early 1990s (NRC 1991).

\section{Rise and Fall of Tamarix}

One of the more interesting issues in telling the history of our understanding aridland riparian ecosystem concerns the role of introduced species, especially Tamarix species. Although Russian olive (Elaeagnus angustifolia) has also been introduced and spread throughout western North America, it does not occupy as dominant a role as tamarisk in the riparian ecosystems of the arid Southwest where understanding the role of tamarisk and methods for its eradication dominate discussions about nonnative riparian species (Nagler et al. 2011).

Since Tamarix was introduced to the United States from Asia in the early 1800 s, the complex of several species that we know today as saltcedar or tamarisk have garnered a significant amount of attention from erosion control specialists, horticulturalists, wildlife ecologists, and, of course, water managers whose responsibilities include providing water for the human environment. As discussed earlier, it was those water managers and the rapidly proliferating complex of Tamarix species that led to phreatophyte control in the mid-1900s. In the past several decades it has become apparent that Tamarix as wildlife habitat, while not as productive as native riparian woodlands, can have significant value (Bateman et al. 2013; Davis et al. 2011; Hunter et al. 1988; 
Johnson and Carothers 1987; Paxton et al. 2011; Stromberg et al. 2009). High wildlife use and the "naturalization" of Tamarix is well documented for hundreds of miles of river downstream of dams where either pre-dam conditions precluded the establishment of extensive riparian woodlands, or alternatively where regulated floodplains were no longer suitable for native riparian species (Anderson et al. 1977; Carothers and Brown 1991; Carothers and Dolan 1982; Johnson and Carothers 1987).

Now, with the introduction of biological control of Tamarix and its apparent success in defoliating the plant throughout most of its range in western riparian habitats, another important riparian resource is well on its way to being lost (see Chapter 5). Interestingly, when the U.S. Department of Agriculture biologists of Animal and Plant Health Inspection Service (APHIS) developed their effective Diorhabda spp. beetle release program, they made several fundamental errors in judgment including inadequate experimental evidence concerning the effect of the beetles (APHIS 2005).

For example, while acknowledging that the post-beetle revegetation with native species would not be possible in some areas, they generally approached this biological control project with the expectation that removal of Tamarix alone was the goal. APHIS generally assumed that once Tamarix was disadvantaged, native species, especially cottonwoods and willows, would return to riparian systems. It is now apparent that without "strategic restoration approaches" the native riparian community is unlikely to recover (Shafroth et al. 2013). Observations of the Colorado River above, within, and below Grand Canyon include the unfortunate reality that once the beetles have done their work, nonnative perennials and annual non-woody weeds and shrubs sprout and spread under the dying Tamarix. Unfortunately, recolonization of native riparian species in the shadow of the declining Tamarix has proven to be unlikely without significant restoration of soils and other biotic and abiotic environmental elements (see references in Chapter 5; Paxton et al. 2011; Shafroth et al. 2008).

APHIS also significantly underestimated the rate at which the beetles would spread. They predicted decades for the beetle to eventually occupy much of the western range of Tamarix (DeLoach et al. 2000); however, the reality is that within less than a decade the beetles swept like a plague through the western range of the species and occupied and defoliated a large part of the Tamarix range (see Tamarisk Coalition information online, http://www.tamariskcoalition.org). The beetles have neither invaded central or eastern Arizona below the Mogollon Rim nor occupied the Lower Gila and Salt Rivers or the Lower Colorado River below Bill Williams River, but it is only a matter of time before it will be difficult to find stands of Tamarix that have not been infested with the beetles. Perhaps the greatest oversight made by APHIS was their apparent assumption that Tamarix was of little wildlife value. They ignored a large body of knowledge regarding the value of Tamarix to wildlife, including studies documenting the significant use and carrying capacity for birds, mammals, reptiles, amphibians, and invertebrates (see references in Sher and Quigley 2013).

Attitudes toward Tamarix have changed since it was first introduced. Chew (2013) has recognized three phases of scientific and management attitudes toward the species. Clearly, we are now entering the fourth stage of the focus on Tamarix as a significant riparian species (Stromberg et al. 2009). In this fourth phase we are entering the unknown. What replaces Tamarix and the rate at which recolonization occurs are not predictable at this time. In Chew's first phase from introduction to the early 
1900s, the species were celebrated and widely propagated for their role in erosion control, wind breaks, ornamental landscaping, and shade, especially in dryland situations where available water was limited and the species could thrive. By the second phase in the mid-1900s, when Tamarix was beginning to be reviled for its heavy water consumption and rapid proliferation throughout aridland watersheds, the word phreatophyte or "well plant" was first used (Meinzer 1923). This is when the phreatophyte control concept was born.

Unfortunately, while the focus was on Tamarix, other native riparian woodland species were also targeted (Carothers et al. 1974). It was firmly believed during the mid1900s to the late 1960s that if Tamarix and, secondarily, native riparian species were eliminated or controlled, the water used in evapotranspiration by these "water wasters" would be more available for beneficial uses (see above and Gatewood et al. 1950). It was during Chew's second phase when limited local and regional attempts were made, including mechanical removal, burning, poisoning and drowning, to remove Tamarix, albeit ineffectively. This focus on Tamarix and other riparian woodland species occurred decades before the disproportionately high value to wildlife of riparian habitats compared to upland habitats was fully recognized (see Carothers 1977).

Additionally, later studies demonstrated that projected savings in "water salvage" had been greatly exaggerated and, in some cases, seemed to be non-existent. This was the case for a USGS Tamarix removal study area of about 5,500 acres $(2,225 \mathrm{ha})$ upstream of the Coolidge Dam and its reservoir, San Carlos Reservoir, on the Gila River in Arizona (Culler et al. 1982, Graf et al. 1984). Not only did removal of Tamarix not improve water savings, Tamarix rapidly recovered and the floodplain is now densely covered with the plant.

It was not until Chew's third phase (1960s to early 2000) that "Tamarix suppression" began in earnest (Chew 2013). Notwithstanding organized attempts at eradication in the 1960s and 1970s, little success on Tamarix control was ever realized. We know now that part of the reason for the success of the species is the fact that Tamarix easily proliferates, dispersing seed over many months. Compared to seed dispersal patterns of native species that disperse seed aligned with winter/spring high-water, Tamarix are especially successful and replaces the native species in areas where the natural hydrograph has been modified by dams, irrigation withdrawal, flood control structures, declining water tables, livestock overgrazing and other anthropogenic watershed and stream alterations (Culler et al. 1982; Johnson 2013; Merritt and Poff 2010; Stromberg et al. 2007; Turner 1974).

Indeed, along river systems within the Southwest where the natural hydrograph has not been significantly modified, Tamarix is often relatively rare and unable to gain a foothold. Examples can be found along the upper portions of the Verde River and tributaries (Beauchamp and Stromberg 2007) and the San Pedro River and tributaries (Stromberg and Tellman 2009) in Arizona, and portions of the Upper Gila and tributaries (Hubbard 1971, 1977b) in New Mexico where the native riparian community remains largely intact.

For sections of those rivers where anthropogenic perturbations to the stream occur, Tamarix has been found to dominate. Merritt and Poff (2010) have convincingly demonstrated that the decline of western riparian systems can be primarily traced to flow alterations and that, with or without the introduction of Tamarix, the native riparian 
gallery forests would have declined. However, Tamarix is sufficiently adaptive such that it may establish and sometimes proliferate even in areas where the natural hydrograph has not been modified (Merritt and Poff 2010; see also Johnson 2013).

Following Chew's chronological sequence, we now find ourselves in the fourth and what may prove to be the final phase of the rise and fall of Tamarix in the Southwest. This fourth phase began in earnest in about 2000 with the introduction of biological control. The release of exotic Asian beetles has to be considered the most aggressive and finally successful attempt at removing Tamarix. As documented in McLeod's excellent account of the history of the beetle release program (Chapter 5), the biological control of the Tamarix was far more effective than its designers could have ever hoped or imagined. The Tamarix-defoliating beetle is now invading the nesting areas of the endangered southwestern willow flycatcher (and 90-plus other avian species and countless other vertebrates and invertebrates) in Arizona, California, New Mexico, Nevada, Texas and Utah http://www.tamariskcoalition.org/events/tamarisk-beetlemaps). If the beetle spreads farther without mitigation, the flycatcher's survival is likely to be threatened - and perhaps that of several other species - and it may significantly change the wildlife carrying capacity of hundreds of thousands of acres of naturalized second-growth riparian habitat comprised of non-native tamarisk.

APHIS indicated that mitigation could be needed if the release of beetles resulted in defoliation of occupied habitat of the endangered flycatcher (APHIS 2005). Mitigation could include planting native willows and cottonwoods or appropriate riparian species to replace dying Tamarix - to help endangered birds. The Center for Biological Diversity and the Maricopa Audubon Society are currently suing APHIS in U.S. District Court for Arizona [Case 4:09-cv-00172-FRZ]. The Plaintiffs allege that APHIS violated its affirmative obligations under the Endangered Species Act section $7(a)$ (1) by failing to adopt a program to offset the harm caused by the beetle release, and by taking no action to mitigate the adverse effects of the beetle prior to and after suspending the program. (Note: As of June 2010 APHIS's beetle release program was formally suspended in 13 States: Colorado, Idaho, Iowa, Kansas, Missouri, Nebraska, Nevada, North Dakota, Oregon, South Dakota, Montana, Washington, and Wyoming. The Lower Colorado River States were not included because the southwestern willow flycatcher continues to use Tamarix for nesting in those States.)

APHIS is taking the position that the Plaintiffs are mistaken about the scope of an agency's duties under ESA section 7 by improperly assuming the agency has a duty to offset all adverse effects of their action. APHIS also argues that it did the best it could and took a variety of affirmative conservation actions to benefit numerous listed species, including the flycatcher, and that the mitigation the Plaintiffs seek is beyond APHIS' authority. While the legal case ${ }^{1}$ is far from being resolved, one thing is certain: The introduced riparian species complex Tamarix is predicted to soon be a shadow of its former value to western riparian wildlife. With some luck, once Tamarix is further reduced (nobody really expects complete eradication), the beetles' appetite will not switch to native riparian species. Additionally, if appropriate hydrological conditions can be maintained in areas with Tamarix removal, cottonwood and willow can compete in the early growth stages and may prevent further invasion and enhance natural recovery (Stromberg 1997). 


\section{Restoration of Riparian Habitat: Putting the Genie Back in the Bottle}

During the developing period of riparian studies, the young science of restoration ecology, including efforts to restore denuded riparian habitat, was also gaining significant traction and attention (e.g., Goodwin et al. 1997; and Stanley et al., in prep.). The rapid expansion of this interest in riparian habitat restoration is documented by Koehler and Thomas' (2000) annotated bibliography Managing for Enhancement of Riparian and Wetland Areas of the Western United States, which lists approximately 250 documents focused primarily on riparian restoration along living streams. In a 2007 study of riparian and river restoration projects in the Southwest, approximately 33 percent were riparian management while others included, for example, flow modification and instream habitat recovery (Shah et al. 2007). Riparian management included intensive management of livestock allotments to protect or improve the conditions of riparian areas.

In the past several years, riparian habitat studies have expanded beyond hydroriparian ecosystems (associated with perennial streams) and mesoriparian ecosystems (associated with intermittent streams) (Johnson et al. 1984). Now workers ranging from ecologists to city planners (Krausman et al. 1985; Steiner et al. 1999) conduct investigations on conservation, management, and restoration of xeroriparian ecosystems associated with the long-overlooked but spatially abundant and wildlife-rich ephemeral river systems along washes and arroyos (Cooke and Reeves 1976; Levick et al. 2008).

Most published studies available today indicate that while some restoration successes are impressive, complete restoration of riverine systems is often an elusive goal once they are damaged. This includes both the aquatic and terrestrial components. However, in some situations, riparian ecosystem resilience is remarkable in its ability to recover from direct destructive impacts like flooding, wildfire, and livestock overgrazing. In fact, ample evidence exists that once floods and fires have passed, it is not unusual for natural processes to return the damaged areas to their original vitality. For example, a massive $850 \mathrm{cms}$ (30,000 cfs) flood in Arizona's Aravaipa Canyon in October 2008 scoured over 25 miles of the canyon bottom and destroyed approximately half of the cottonwood-willow gallery forest; however, within a decade the area was largely recovered to pre-flood conditions (Burtell 2013). Similarly, a human-caused wildfire in Grand Canyon's Deer Creek in 1972 completely denuded a mile of floodplain of mature cottonwoods; yet again, within a decade or so, the area was naturally revegetated to a closed gallery forest (Carothers and Brown 1991). The most remarkable example of the impact of overgrazing on riparian habitat and the resilience of the riparian system to recover is the Bureau of Land Management's San Pedro Riparian National Conservation Area in southern Arizona. Once livestock grazing was prohibited within the conservation area (approximately 50 miles), cottonwood-willow gallery forest tripled in size in a 30-year period (NRST 2012; Stromberg and Tellman 2009).

While many and varied techniques are available to reestablish riparian vegetation once it is damaged or removed, the constant onslaught of human activities that change fluvial processes and natural channel ecological functions, combined with the long history of exotic species introductions and our general inability to counteract these aliens, provides a constant frustration to river restoration attempts. Moreover, as Stanley et al. (in prep.) have documented for the State of California, most restoration projects 
are extremely small and of 276 separate restoration projects analyzed in the 1990s, 83 percent were less than 20 acres in size. Shah et al. (2007), when analyzing data from 576 riparian restoration projects in the Southwest, indicated that few were over $3 \mathrm{~km}$ in length thus allowing for a better chance of success.

What is important to emphasize in the above flooding, fire, and grazing examples of natural restoration of the riparian habitat is that in all three areas, the natural hydrograph and the ground-water recharge system were largely intact. In areas where the hydrologic regime can be restored to some semblance of the "natural hydrograph" and the deviation from normal surface and subsurface flow and storage cycle conditions can be understood, large-scale restoration is possible. An excellent example of riparian restoration success is the effort of The Nature Conservancy (TNC) in the Lower San Pedro River Basin to acquire and protect large tracts of land adjacent to riparian areas. Once the land is acquired and it is possible to remove ecosystem stresses, such as excessive groundwater pumping, removal of diversion structures, restoration of base flows, control of grazing, and off-road vehicle use, riparian habitat eventually comes back as watersheds restore in the uplands and groundwater recharge returns to some semblance of pre-depletion levels (Haney 2005, Stromberg and Tellman 2009).

However, there are locations where riparian restoration is almost impossible on a large scale and will rarely occur without the intervention of intense management. These include situations where impoundments, diversions, depletion of surface and groundwater supplies, and proliferation of exotic species are the reasons for native riparian habitat declines. While we can celebrate the recent efforts of TNC in the Lower San Pedro River and elsewhere throughout the arid Southwest, we have clearly reached a new level of crisis with the release of the tamarisk beetle and the destruction of thousands of acres of "second class" riparian habitat. This has clearly reduced wildlife-supporting riparian habitat throughout the arid Southwest.

The ravages of the tamarisk beetle have set this crisis stage and there does not seem to be a reasonable solution in the near future. Major dams and impoundments altered the natural hydrograph on most large streams and rivers and ushered in the first profoundly destructive phase of riparian habitat demise. Many of those impoundments, while clearly controlling most flood flows, precluded conditions necessary for the recruitment of cottonwoods and willows (Mahoney and Rood 1998) and allowed for the proliferation of the nonnative Tamarix. As detailed in earlier sections of this paper, Tamarix was largely reviled by water managers and conservationists alike. Nevertheless, the nonnative woody plant did proliferate over thousands of acres of hydrologically altered stream channels. Though a nonnative, Tamarix was better than no woody vegetation along the native-plant-denuded stream channels, and it did form suitable habitat for hundreds of native wildlife species as well as provide stream cover and nutrient input in the form of allochthonous organic material. Now, as the tamarisk beetle has proliferated virtually unchecked throughout the arid Southwest, there are hundreds of stream channels where dead and dying Tamarix are no longer even second-class riparian habitat. Areas under the dying Tamarix are mostly revegetating with non-woody shrubs and herbaceous species, many of which are nonnatives (Chapter 5).

It is important to point out that the Tamarisk Coalition, founded in 1999 in advance of the onslaught of the tamarisk beetle, is a non-profit dedicated to the advancement of the restoration of riparian lands through collaboration, education, and technical 
assistance (http://tamariskcoalition.org/about-us/accomlishments). They are actively pursuing restoration of habitat where the Tamarix has been defoliated, but their efforts to date are relatively small and include removing dead and dying vegetation and reestablishment of native grasses combined with planting some woody cottonwood and willow species. Large-scale efforts to restore more than a few acres of habitat are extremely costly and non-existent at this time.

Additionally, restoring non-salt-tolerant trees such as willows and cottonwood is initially difficult because Tamarix alters soil chemistry enough to reduce restoration success (Siemion and Stevens 2015). On the Rio Grande in the vicinity of Elephant Butte Reservoir, the Bureau of Reclamation has been initiating riparian restoration efforts as mitigation for listed species, but like most attempts to restore native species where Tamarix has dominated for years, the restoration areas are quite small ( $<20$ acres) (BOR 2016). Reintroduction of beaver to restore local hydrology and stimulate recovery of a woody riparian community has been used along some smaller rivers in the semiarid West with some success (Carrillo et al. 2009; Castro et al. 2015; Welch 1997). Unfortunately, beavers' preference for cottonwood and willow over the nonnative Tamarix slows recovery of a native riparian forest (see chapters 6 and 7 [beavers] and 4, and restoration chapters in Johnson et al., in prep.).

Climate change also poses significant problems for riparian habitat restoration. The conventional wisdom for the trajectory of climate change seems to tend toward understanding that the arid Southwest will become warmer and drier, thus piling on additional threats to existing riparian habitat. Some researchers are now advocating that the use of "local stocks" of riparian vegetation be replaced with more southerly stocks where the plants are already adapted to warmer and drier conditions. The belief is that climate change is happening so quickly that the local seed and cuttings that are currently sources for revegetation are maladapted.

Thus, if the objective is to revegetate cottonwood and willow stands along the Verde River in central Arizona, seed sources and cuttings should come from farther to the south, perhaps from the San Pedro River drainage (Carroll et al. 2014; T. Whitham, Northern Arizona University, personal communication; Whitham et al. 2006).

Additionally, a warmer climate will change winter and spring runoffs from higher elevations where snow collects. This is expected to affect the phenology of riparian species and thus results of restoration activities. Genotypic elasticity of woody riparian species may be sufficient to overcome this, but use of more adapted genotypes may be required for successful restoration.

\section{Summary}

A review of the history of riparian ecological science shows an evolution from attempting to solve anthropogenic issues relating to water supply to guiding broad programs of riverine management. In the early years of riparian ecology, river systems were primarily considered sources of water for urban systems, agriculture, and industry. Consequently, the more water made available for these uses, that is, the social ecological system, the more the economy and human welfare would be advanced. To improve delivery of water by riverine systems, science was expected to reduce competing uses of water along the delivery system. This included lining canals and removing, or 
challenging, the use of water by vegetation growing along the riverine floodplain, that is, riparian vegetation.

Scientists began to evaluate the amount of water used by riparian vegetation and suggested that removing this vegetation could salvage enough water to balance any negative aspects of removal. Consequently, "experiments" were untaken to remove riparian trees and shrubs from the edge of the rivers, or total removal of that plant community where it had overrun the extended floodplain. Success in improving water yield by these procedures was never proven as significant.

Concurrent studies in the 1970s and 1980s shed light on the ecological values of the riparian vegetation, not just as an aggregation of plants but as a complex ecosystem important to riverine functions and one that formed important habitat for many species. Other studies documented the ecological values and disproportionate diversity and density of some vertebrates using these systems. Most early studies along these lines were avian studies. Birds were found to use many strata of the riparian vegetation and thus these habitats were critical in survival and maintenance of most of the avian species of the Southwest lowlands. This information, along with evidence of little or no water savings with riparian vegetation removal, essentially put a stop to programs that removed or highly modified riparian vegetation.

Unfortunately, discovery of the importance of riparian vegetation followed on a lengthy period of dam building in the West. Some dams were constructed many years earlier but, again to improve water delivery to urban/industrial/agricultural centers, water needed to be "stored" and these social ecological systems also needed electrical power that the dams could supply. Dams were managed to control downstream flows along with inundating upstream riverine systems. Many important riparian systems went under water and the negative consequences of a highly modified downstream river flow was demonstrated by riparian research. The importance of the whole riverine system took on a new meaning with the development of the River Continuum Concept, and importance of natural flows (including the concept of environmental flows) was emphasized and supported through extensive riparian/riverine research.

Into the 1980s, more riparian research was initiated to address the response of different components of riparian ecosystems to alterations of the many drivers that influenced these systems. Changes in flows, alteration of groundwater levels, introduction of exotic species, and diversion of channel systems are all examples of modifications studied. Exotic species became of great importance with the expansion of Tamarix throughout the West. Tamarix impacted many functions of both modified and unmodified riparian ecosystems. Consequently, removing or destroying some riparian systems, those dominated by Tamarix, was back in vogue. The rise and fall of the Tamarix spp. in the western United States is a classic story of the unintended consequences of not just the introduction of an exotic species, but of ecosystem destruction. Tamarix changed the natural hydrograph of streams and rivers, followed later by largely unadvisable attempts to fight it, but it was found to be beneficial as wildlife habitat, with yet another introduced species, the tamarisk leaf beetle.

Today, basic research on riparian functions is still ongoing but more emphasis is being placed on understanding and restoring riparian systems that have been altered. This effort will reach new heights in the shadow of the Tamarix beetle's impacts as hundreds of thousands of acres of second-growth riparian habitats are becoming available 
for restoration efforts. Although costs for this restoration will be substantial, benefits to wildlife and stream ecology should more than adequately justify the expense and effort.

Riparian research in the West will continue to develop more refined data on function and how this information can guide management. These efforts must include continuing dialog among riparian specialists, users, and the public if we expect riparian systems to continue to be part of the western mosaic of ecosystems and habitat for those species for which this system is critical. The future of riparian ecology is not only better understanding of functional components of these important systems but better ways in which scientists, managers, decisionmakers, and the public can work together to use all forms of data to create a successful future for these critical western riverine systems.

Note

This case was legally resolved in June 2018 (see McLeod, volume 1) as this publication was in press.

\section{References}

Anderson, B.W.; Ohmart, R.D. 1977. Vegetation structure and bird use in the Lower Colorado River Valley. In: Johnson, R.R.; Jones, D.A., tech. coords. Importance, preservation, and management of riparian habitat: A symposium. Gen. Tech. Rep. RM-43. Fort Collins, CO: U.S. Department of Agriculture, Forest Service, Rocky Mountain Forest and Range Experiment Station: 23-34.

Anderson, B.W.; Higgins, A.E.; Ohmart, R.D. 1977. Avian use of Tamarix communities in the Lower Colorado River valley. In: Johnson, R.R.; Jones, D.A., tech. coords. Importance, preservation, and management of riparian habitat: A symposium. Gen. Tech. Rep. RM-43. Fort Collins, CO: U.S. Department of Agriculture, Forest Service, Rocky Mountain Forest and Range Experiment Station: 128-136.

Anderson, B.W.; Ohmart, R.D.; Rice, J. 1983. Avian and vegetation community structure and their seasonal relationships in the Lower Colorado River Valley. Condor. 85: 392-405.

Animal and Plant Health Inspection Service (APHIS). 2005. Program for biological control of saltcedar (Tamarix spp.) in thirteen states: Environmental assessment, June 2005. Riverdale, MD: U.S. Department of Agriculture, Marketing and Regulatory Programs, Animal and Plant Health Inspection Service. $56 \mathrm{p}$.

Annear, T.; Chisholm, I.; Beecher, H.; Locke, A.; Aarrestad, P.; Coomer, C.; Estes, C.; Hunt, J.; Jacobson, R.; Jobsis, G.; Kauffman, J.; Marshall, J.; Mayes, K.; Smith, G.; Wentworth, R.; Stalnaker, C. 2004. Instream flows for riverine resource stewardship, revised edition. Cheyenne, WY: Instream Flow Council. 268 p.

Arthington, A.H.; Bunn, S.E.; Poff, N.L.; [et al.]. 2006. The challenge of providing environmental flow rules to sustain river ecosystems. Ecological Applications. 16: 1311-1318.

Barber, W.E.; Minckley, W.L. 1966. Fishes of Aravaipa Creek, Graham and Pinal Counties, Arizona. Southwestern Naturalist. 11(3): 313-24.

Barz, D.; Watson, R.P.; Kanney, J.F.; [et al.]. 2009. Cost/benefit considerations for recent saltcedar control, Middle Pecos River, New Mexico. Environmental Management. 43(2): 282-298.

Bateman, H.L.; Paxton, E.H.; Longland, W.S. 2013. Tamarix as wildlife habitat. In: Sher, A.; Quigley, M.F., eds. Tamarix: A case study of ecological change in the American west. New York: Oxford University Press: 168-188.

Beauchamp, V.B.; Stromberg, J.C. 2007. Flow regulation of the Verde River, Arizona encourages Tamarix recruitment but has minimal effect on Populus and Salix stand density. Wetlands. 27: 381-389.

Belsky, A.J.; Matzke, A.; Uselman, S. 1999. Survey of livestock influences on stream and riparian ecosystems in the western United States. Journal of Soil and Water Conservation. 54: 419-431. 
Brady, W.; Patton, D.R.; Paxson, J. 1985. The development of southwestern riparian gallery forests. In: Johnson, R.R.; Ziebell, C.D.; Patton, D.R.; Ffolliott, P.F.; Hamre, R.H., tech. coords. Riparian ecosystems and their management: Reconciling conflicting uses. Tucson, AZ. First North American Riparian Conference (proceedings). April 16-18, 1985. Gen. Tech. Rep. RM-120. Fort Collins, CO: U.S. Department of Agriculture, Forest Service: 39-43.

Brown, D.E., ed. 1982. Biotic communities of the American Southwest-United States and Mexico. Desert Plants 4: 1-342 (reissued by University of Utah Press).

Brown, D.E.; Carmony, N.B.; Turner, R.M. 1977. Drainage map of Arizona showing perennial streams and some important wetlands. 1:1,000,000 map, Phoenix: Arizona Game and Fish Department. (Updated maps published in 1978 and 1981).

Brown, D.E.; Lowe, C.H.; Hausler, J.F. 1977. Southwestern riparian communities: Their biotic importance and management in Arizona. In: Johnson, R.R.; Jones, D.A., tech. coords. Importance, preservation, and management of riparian habitat: A symposium. Fort Collins, CO. Gen. Tech. Rep. RM-43. U.S. Department of Agriculture, Forest Service, Rocky Mountain Forest and Range Experiment Station: 201-211.

Bunn, S.E.; Arthington, A.H. 2002. Basic principles and ecological consequences of altered flow regimes for aquatic biodiversity. Environmental Management. 30: 492-507.

Bureau of Reclamation (BOR). 2016. Continued implementation of the 2008 operating agreement for the Rio Grande Project, New Mexico and Texas. Final Environmental Impact Statement. Albuquerque, NM: U.S. Department of the Interior, Bureau of Reclamation, Upper Colorado Region. 147 p.

Burtell, R.T. 2013. Hydrologic review of BLM's federal reserved right claims for Aravaipa Canyon Wilderness Area. In: Aravaipa Canyon Wilderness Area (In re the General Adjudication of the Gila River System and Source). Phoenix, AZ: Plateau Resources LLC.

Busch, D.E.; Smith, S.D. 1995. Mechanisms associated with decline of woody species in riparian ecosystems of the southwestern U.S. Ecological Monographs. 65: 347-350.

Busch, D.E.; Ingraham, N.L.; Smith, S.D. 1992. Water uptake in woody riparian phreatophytes of the southwestern United States: A stable isotope study. Ecological Applications. 2: 450-459.

Carothers, S.W. 1977. Importance, preservation, and management of riparian habitats: An overview. In: Johnson, R.R.; Jones, D.A., tech. coords. Importance, preservation, and management of riparian habitat: A symposium. Gen. Tech. Rep. RM-43. Fort Collins, CO: U.S. Department of Agriculture, Forest Service, Rocky Mountain Forest and Range Experiment Station: 2-4.

Carothers, S.W.; Brown, B.T. 1991. The Colorado River through Grand Canyon: Natural history and human change. Tucson, AZ: University of Arizona Press. 235 p.

Carothers, S.W.; Dolan, R. 1982. Dam changes on the Colorado River. Natural History. 91(1): 74-83.

Carothers, S.W.; Johnson, R.R. 1970. Phreatophyte control and effects on bird populations in central Arizona. In: Mewaldt, L.R., ed. Proceedings of the eighty-seventh stated meeting of the American Ornithologists' Union. Auk. 87: 136-153.

Carothers, S.W.; Johnson, R.R. 1975. The effects of stream channel modification on birds in the southwestern United States. In: Proceedings of symposium on stream channel modification. Washington, DC: U.S. Department of the Interior, Fish and Wildlife Service, Office of Biological Services: 60-76.

Carothers, S.W.; Johnson R.R.; Aitchison, S.W. 1974. Population structure and social organization of southwestern riparian birds. American Zoologist. 14(1): 97-108.

Carrillo, C.; Bergman, D.; Taylor, J.; [et al.]. 2009. An overview of historical beaver management in Arizona. USDA National Wildlife Research Center-Staff Publications. Paper 882.

Carroll, S.P.; Jørgensen, P.S.; Kinnison, M.T.; [et al.]. 2014. Applying evolutionary biology to address global challenges. Science. 346: 1245993. 
Castro, J.; Pollock, M.; Jordan, C.; [et al.]. 2015. The beaver restoration guidebook: Working with beaver to restore streams, wetlands, and floodplains. Version 1.0. Portland, OR: U.S. Department of the Interior, U.S. Fish and Wildlife Service. 189 p. https://www.fws.gov/ oregonfwo/toolsforlandowners/RiverScience/Documents/BRG percent20v.1.0 percent20final percent20reduced.pdf [Accessed November 21, 2016].

Chew, M.K. 2009. The monstering of tamarisk: How scientists made a plant into a problem. Journal of the History of Biology. 42: 231-266.

Chew, M.K. 2013. Tamarisk introduction, naturalization, and control in the United States, 1818-1952. In: Sher, A.; Quigley, M.F., eds. Tamarix: A case study of ecological change in the American west. New York: Oxford University Press: 269-286.

Cooke, R.U.; Reeves, R.W. 1976. Arroyos and environmental change in the American Southwest. UK: Oxford University Press. 213 p.

Cowardin, L.M.; Carter, V.; Golet, F.C.; [et al.]. 1979. Classification of wetlands and deepwater habitats of the United States. FWS/OBS-79/31. Washington, DC: U.S. Department of the Interior, U.S. Fish and Wildlife Service. 131 p.

Culler, R.C.; Hanson, R.L.; Mydrick, R.M.; [et al.]. 1982. Evapotranspiration before and after clearing phreatophytes, Gila River flood plain, Graham County, Arizona. Geological Survey Professional Paper 655-P. Washington, DC: U.S. Government Printing Office: 81 p.

Davis, M.A.; Chew, M.K.; Hobbs, R.J.; [et al.]. 2011. Don't judge species on their origins. Nature. 474: 153-154.

Decker, J.P.; Gaylor, W.D.; Cole, F.D. 1962. Measuring transpiration of undisturbed tamarisk shrubs. Plant Physiology. 37: 393-397.

DeLoach, C.J.; Carruthers, R.I.; Lovich, J.; [et al.]. 2000. Ecological interactions in the biological control of saltcedar (Tamarix spp.) in the U.S.: Toward a new understanding. In Spencer. N.R., ed. Proceedings of X international symposium on biological control; 1999 July. Bozeman, MT: Montana State University: 819-874.

Dobyns, H.F. 1981. From fire to flood: Historic human destruction of Sonoran Desert river oases. Socorro, NM: Ballena Press: 222 p.

Elmore, W. 1992. Riparian responses to grazing practices. In: Naiman, R.J., ed. Watershed management. New York: Springer-Verlag: 442-457.

Elmore, W.; Beschta, R. 1987. Riparian areas: Perceptions in management. Rangelands. 9: 260-265.

Fenner, P.; Brady, W.W.; Patton, D.R. 1985. Effects of regulated water flows on regeneration of Fremont Cottonwood. Journal of Range Management. 38: 135-138.

Fox, K. 1977. Importance of riparian ecosystems: Economic considerations. In: Johnson, R.R.; Jones, D.A., tech. coords. Importance, preservation, and management of riparian habitat: A symposium. Gen. Tech. Rep. RM-43. Fort Collins, CO: U.S. Department of Agriculture, Forest Service, Rocky Mountain Forest and Range Experiment Station: 19-22.

Gaines, D.A. 1974. A new look at the nesting riparian avifauna of the Sacramento Valley, California. Western Birds. 5: 61-80.

Gaines, D.A., ed. 1976. Abstracts from the conference on the riparian forests of the Sacramento Valley. Sponsored by Davis and Altacal Audubon Societies at Chico, California; 1976 May 22. Unpublished report on file with: California Syllabus, Oakland, CA. 25 p.

Gaines, D.A. 1980. The valley riparian forests of California: Their importance to bird populations. In: Sands, A., ed. Riparian forests in California: Their ecology and conservation: A symposium; 1977 May 14; Davis, CA. Berkeley, CA: University of California, Agricultural Science Publications: $57-85$.

Gatewood, J.S.; Robinson, T.W.; Colby, B.R.; [et al.]. 1950. Use of water by bottom-land vegetation in the lower Safford Valley Arizona. U.S. Geological Survey Water-Supply Paper. 1103. Reston, VA: U.S. Department of the Interior, Geological Survey. 210 p.

Gavin, T.A.; Sowls, L.K. 1975. Avian fauna of a San Pedro Valley mesquite forest. Journal of the Arizona Academy of Science. 10: 33-41. 
Gido, K.B.; Propst, D.L.; Olden, J.D.; [et al.]. 2013. Multidecadal responses of native and introduced fishes to natural and altered flow regimes in the American Southwest. Canadian Journal of Fisheries and Aquatic Sciences. 70: 554-564.

Goodwin, C.N.; Hawkins, C.P.; Kershner, J.L. 1997. Riparian restoration in the western United States: Overview and perspective. Restoration Ecology. 5(4S): 4-14.

Gottfried, G.J.; DeBano, L.F.; Baker, M.B., Jr. 1999. Beginning of watershed studies in the Central Arizona Highlands. Chapter 2. In: Baker, M.B., Jr., comp. History of research in the Central Highlands of Arizona. Gen. Tech. Rep. RMRS-GTR-29. Fort Collins, CO: U.S. Department of Agriculture, Forest Service, Rocky Mountain Research Station: 7-12.

Graf, W.L.; Patten, D.T.; Turner, B. 1984. Issues concerning phreatophyte clearing, revegetation, and water savings along the Gila River, Arizona. Tempe, AZ: Arizona State University. 69 p. http://scholarcommons.sc.edu/cgi/viewcontent.cgi?article=1044\&context=geog_facpub. [Accessed November 21, 2016].

Haney, J.A. 2005, Hydrology and biodiversity conservation on the Lower San Pedro River. In: Gottfried, G.J.; Gebow, G.S.; Eskew, L.G.; [et al.], eds. Connecting mountain islands and desert seas: Biodiversity and management of the Madrean Archipelago II. RMRS-P-36. Proceedings: Fort Collins, CO: U.S. Department of Agriculture, Forest Service, Rocky Mountain Forest and Range Experiment Station: 311-315.

Horton, J.S. 1973. Evapotranspiration and water research as related to riparian and phreatophyte management: An abstract bibliography. Miscell. Publ. 1234. Washington, DC. U.S. Department of Agriculture, Forest Service. 192 p.

Horton, J.S.; Robinson, T.W.; McDonald, H.R. 1964. Guide for surveying phreatophyte vegetation. Agric. Handb. No. 266. Washington, DC: U.S. Department of Agriculture, Forest Service. $37 \mathrm{p}$.

Hubbard, J.P. 1971. The summer birds of the Gila Valley, New Mexico. Occasional Papers of the Delaware Museum of Natural History. Nemouria. 2: 1-35.

Hubbard, J.P. 1977a. Importance of riparian ecosystems: Biotic considerations. In: Johnson, R.R.; Jones, D.A., tech. coords. Importance, preservation, and management of riparian habitat: A symposium. Gen. Tech. Rep. RM-43. Fort Collins, CO: U.S. Department of Agriculture, Forest Service, Rocky Mountain Forest and Range Experiment Station: 14-18.

Hubbard, J.P., ed. 1977b. A biological inventory of the Lower Gila River Valley, New Mexico. Santa Fe, NM: New Mexico Game and Fish. 56 p.

Hunter, W.C.; Ohmart, R.D.; Anderson, B.W. 1988. Use of exotic saltcedar (Tamarix chinensis) by birds in arid riparian systems. Condor. 90: 113-123.

Hynes, H.B.N. 1975. The stream and its valley. Verhandlungen, Internationale Vereinigung fur Theoretische und Augewandte Limnologue. 19: 1-15.

Ingles, L.G. 1950. Nesting birds of the willow-cottonwood community in California. Auk. 67: 325-332.

Johnson, R.R. 1971. Tree removal along southwestern rivers and effects on associated organisms. American Philosophical Society Yearbook. 1970: 321-322.

Johnson, R.R. 1977. Synthesis and management implications of the Colorado River Research Program. Colorado River Technical Report No. 17. Washington, DC: U.S. Department of the Interior, National Park Service. 75 p.

Johnson, R.R. 1991. Historic changes in vegetation along the Colorado River in Grand Canyon. In: Colorado River ecology and dam management: Proceedings of a symposium; 1990 May 24-25; Santa Fe, NM. Washington, DC: National Academies Press: 178-206.

Johnson, R.R.; Carothers, S.W. 1982. Riparian habitats and recreation: Interrelationships and impacts in the Southwest and Rocky Mountain region. Eisenhower Consortium Bulletin No. 12. Fort Collins, CO: Eisenhower Consortium for Western Environmental Forestry Research. $31 \mathrm{p}$.

Johnson, R.R.; Carothers, S.W. 1987. External threats: The dilemma of resource management on the Colorado River in Grand Canyon National Park, USA. Environmental Management. 11: 99-107. 
Johnson, R.R.; Haight, L.T. 1985. Avian use of xeroriparian ecosystems in the North American warm deserts. In: Johnson, R.R.; Ziebell, C.D.; Patton, D.R.; [et al.], tech. coords. Riparian ecosystems and their management: Reconciling conflicting uses. First North American riparian conference; 1985 April 16-18; Tucson, AZ. Gen. Tech. Rep. RMGTR-120. Fort Collins, CO: U.S. Department of Agriculture, Forest Service, Rocky Mountain Forest and Range Experiment Station: 156-160.

Johnson, R.R.; Lowe, C.H. 1985. On the development of riparian ecology. In: Johnson, R.R.; Ziebell, C.D.; Patton, D.R.; [et al.], technical coordinators. Riparian ecosystems and their management: Reconciling conflicting uses. First North American riparian conference; 1985 April 16-18; Tucson, AZ. Gen. Tech. Rep. RM-GTR-120. Fort Collins, CO: U.S. Department of Agriculture, Forest Service, Rocky Mountain Forest and Range Experiment Station: 112-116.

Johnson, R.R.; Simpson, J.M. 1971. Important birds from Blue Point Cottonwoods, Maricopa County, Arizona. Condor. 73: 379-380.

Johnson, R.R.; Carothers, S.W.; Finch, D.M.; [et al.], tech. eds. [In prep.]. Riparian research and management: Past, present, future. Volume 2. Gen. Tech. Rep. RMRS-GTR-XXX. Fort Collins, CO: U.S. Department of Agriculture, Forest Service, Rocky Mountain Research Station.

Johnson, R.R.; Carothers, S.W.; Simpson, J.M. 1984. A riparian classification system. In: Warner, R.E.; Hendrix, K.M., eds. California riparian systems. Berkeley, CA: University of California Press: $375-382$.

Johnson, R.R.; Haight, L.T.; Simpson; J.M. 1977. Endangered species vs. endangered habitat: A concept. In: Johnson, R.R.; Jones, D.A., tech. coords. Importance, preservation, and management of riparian habitat: A symposium. Gen. Tech. Rep. RM-43. Fort Collins, CO: U.S. Department of Agriculture, Forest Service, Rocky Mountain Forest and Range Experiment Station: 68-79.

Johnson, R.R.; Haight, L.T.; Simpson; J.M. 1987. Endangered habitats versus endangered species: A management challenge. In: Laymon, S.A., ed. Management and preservation of endangered birds in riparian ecosystems. Western Birds. 18(1): 89-96.

Johnson, T.D. 2013. Tamarix: Passenger or driver of ecosystem change? In: Sher, A.; Quigley, M.F., eds. 2013. Tamarix: A case study of ecological change in the American west. New York: Oxford University Press: 256-268.

Jones, K.B. 1988. Distribution and habitat associations of herpetofauna in Arizona: Comparisons by habitat type. In: Szaro, R.C.; Severson, K.E.; Patton, D.R., tech. coords. Proceedings of the symposium on the management of amphibians, reptiles, and small mammals in North America: Proceedings of the symposium; 1988 July 19-21; Flagstaff, AZ Gen. Tech. Rep. RM-166. Fort Collins, CO: U.S. Department of Agriculture, Forest Service, Rocky Mountain Forest and Range Experiment Station: 109-128.

Junk, W.J.; Bayley, P.B.; Sparks, R.E. 1989. The flood pulse concept in river floodplain systems. In: Dodge, D.P., eds. Proceedings of the international large river symposium. Canadian Special Publication of Fisheries and Aquatic Science. 106: 110-127.

Knopf, F.L.; Johnson, R.R.; Rich, T.; [et al.]. 1988. Conservation of riparian ecosystems in the United States. Wilson Bulletin. 100: 272-284.

Koehler, D.A.; Thomas, A.E., comps. 2000. Managing for enhancement of riparian and wetland areas of the Western United States: An annotated bibliography. Gen. Tech. Rep. RMRSGTR-54. Ogden, UT: U.S. Department of Agriculture, Forest Service, Rocky Mountain Research Station. 369 p.

Krausman, P.A.; Rautenstrauch, K.R.; Leopold, B.D. 1985. Xeroriparian systems used by desert mule deer in Texas and Arizona. In: Johnson, R.R.; Ziebell, C.D.; Patton, D.R.; [et al.], tech. coords. Riparian ecosystems and their management: Reconciling conflicting uses. Gen. Tech. Rep. RM-120, Fort Collins, CO: U.S. Department of Agriculture, Forest Service, Rocky Mountain Research Station: 144-149. 
Kubly, D.M.; Winstead, R.A.; Allison, L.J.; [et al.]. 1997. Statewide riparian inventory and mapping project: Executive summary. Nongame Technical Reports 111 \& 112. Phoenix, AZ: Arizona Game and Fish Department. 10 p.

Leenhouts, J.M.; Stromberg, J.C.; Scott, R.L. 2006. Hydrologic requirements of and consumptive groundwater use by riparian vegetation along the San Pedro River, Arizona. Scientific Investigations Report 2005-5163. Reston, VA: U.S. Department of the Interior, Geological Survey.

Levick, L.R.; Goodrich, D.C.; Hernandez, M.; [et al.]. 2008. The ecological and hydrological significance of ephemeral and intermittent streams in the arid and semi-arid American southwest. Washington, DC: U.S. Environmental Protection Agency. 116 p.

Lowe, C.H. 1961. Biotic communities in the sub-Mogollon region of the inland Southwest. Journal of the Arizona Academy of Science. 2: 40-49.

Lowe, C.H., ed. 1964. The vertebrates of Arizona. Tucson, AZ: University of Arizona Press. $270 \mathrm{p}$.

Lowe, C.H.; Brown, D.E. 1973. The natural vegetation of Arizona. Publication No. 2. Phoenix: Arizona Resources Information Systems (ARIS).

Mahoney, J.M.; Rood, S.B. 1998. Streamflow requirements for cottonwood seedling recruitment-An integrative model. Wetlands. 18: 634-645.

Meffe, G.K.; Minckley, W.L. 1987. Persistence and stability of fishes and invertebrate assemblages in a repeatedly disturbed Sonoran Desert stream. American Midland Naturalist. 117: 177-191.

Meinzer, O.E. 1923. Outline of ground-water hydrology with definitions. U.S. Geological Survey Water-Supply Paper 494. Reston, VA: U.S. Department of the Interior, Geological Survey. $71 \mathrm{p}$.

Meinzer, O.E. 1927. Plants as indicators of ground water: U.S. Geological Survey Water-Supply Paper 577. Reston, VA: U.S. Department of the Interior, Geological Survey. 95 p.

Merritt, D.M.; Poff, N.L. 2010. Shifting dominance of riparian Populus and Tamarix along gradients of flow alteration in western North American rivers. Ecological Adaptations. 20: $135-152$.

Minckley, W.L. 1981. Ecological studies of Aravaípa Creek, Central Arizona, relative to past, present and future uses. Final Report. Safford, AZ: U.S. Department of the Interior, Bureau of Land Management. 362 p.

Nagler, P.L.; Glenn, E.P.; Jarnevich, C.S.; [et al.]. 2011. Distribution and abundance of saltcedar and Russian olive in the western United States. Critical Reviews in Plant Sciences. 30: 508-523.

National Research Council (NRC). 1987. The Mono Basin ecosystem. Effects of changing lake level. Washington, DC: National Academy Press. 272 p.

National Research Council (NRC). 1991. Colorado River ecology and dam management. Washington, DC: National Academy Press. 276 p.

National Research Council (NRC). 2002. Riparian areas: Functions and strategies for management. Washington, DC: National Academy Press. 436 p. https://www.nap.edu/ catalog/10327/riparian-areas-functions-and-strategies-for-management. [Accessed November $22,2016]$.

National Riparian Service Team (NRST). 2012. Riparian conditions along the San Pedro River: Proper functioning condition riparian assessment report. Washington, DC: U.S Department of the Interior, Bureau of Land Management. $291 \mathrm{p}$.

Ohmart, R.D. 1996. Historical and present impacts of livestock grazing on fish and wildlife resources in western riparian habitats. In: Krausman, P.R., ed. Rangeland wildlife. Denver CO: Society for Range Management: 245-279. 
Ohmart, R.D.; Anderson, B.W. 1977. Vegetation structure and bird use in the Lower Colorado River Valley. In: Johnson, R.R.; Jones, D.A., tech. coords. Importance, preservation, and management of riparian habitat: A symposium. Gen. Tech. Rep. RM-43. Fort Collins, CO: U.S. Department of Agriculture, Forest Service, Rocky Mountain Forest and Range Experiment Station. 23-34.

Patten, D.T. 1998. Riparian ecosystems of semi-arid North America: Diversity and human impacts. Wetlands. 18: 498-512.

Patton, D.R. 1977. Riparian research needs. In: Johnson, R.R.; Jones, D.A., tech. coords. Importance, preservation, and management of riparian habitat: A symposium. Gen. Tech. Rep. RM-43. Fort Collins, CO: U.S. Department of Agriculture, Forest Service, Rocky Mountain Forest and Range Experiment Station: 80-82.

Paxton, E.H.; Theimer, T.C.; Sogge, M.K. 2011. Tamarisk biocontrol using tamarisk beetles: Potential consequences for riparian birds in the southwestern United States. Condor. 113: 255-265.

Platts, W.S. 1979. Livestock grazing and riparian/stream ecosystems. In: Cope, O.B., ed. Forum on grazing and riparian stream ecosystems. Denver, CO: Trout Unlimited, Inc.: 39-45.

Platts, W.S. 1981. Influence of forest and rangeland management on anadromous fish habitat in Western North America: Effects of livestock grazing. Gen. Tech. Rep. PNW-GTR-124. Portland, OR: U.S. Department of Agriculture, Forest Service, Pacific Northwest Research Station. 25 p.

Poff, N.L.; Zimmerman, J.K.H. 2010. Ecological responses to altered flow regimes: A literature review to inform the science and management of environmental flows. Freshwater Biology. 55: 194-205.

Poff, N.L.; Allan, J.D.; Bain, M.B.; [et al.]. 1997. The natural flow regime. BioScience. 47: 769-784.

Propst, D.L.; Gido, K.B.; Stefferud, J.A. 2008. Natural flow regimes, nonnative fishes, and native fish persistence in arid-land river systems. Ecological Applications. 18: 1236-1252.

Rieger, J.; Stanley, J.; Traynor, R. 2014. Project planning and management for ecological restoration. 2nd ed. Washington, DC: Island Press. 300 p.

Robinson, T.W. 1952. Phreatophytes and their relationship to water in western United States. Transactions American Geophysical Union. 33: 57-61.

Robinson, T.W. 1958, Phreatophytes: U.S. Geological Survey Water-Supply Paper 1423. Reston, VA: U.S. Department of the Interior, Geological Survey. $84 \mathrm{p}$.

Rosenberg, K.V.; Ohmart, R.D.; Hunter W.C.; [et al.]. 1991. Birds of the lower Colorado River Valley. Tucson: University of Arizona Press. 416 p.

Sala, A.; Smith, S.D.; Devitt, D.A. 1996. Water use by Tamarix ramosissima and associated phreatophytes in a Mojave Desert floodplain. Ecological Applications. 6: 888-898.

Shafroth P.B.; Auble, G.T.; Stromberg, J.C.; [et al.]. 1998. Establishment of woody riparian vegetation in relation to annual patterns of streamflow, Bill Williams River, Arizona. Wetlands. 18: 577-590.

Shafroth, P.B.; Beauchamp, V.B.; Briggs, M.K.; [et al.]. 2008. Planning riparian restoration in the context of Tamarix control in Western United States, Restoration Ecology. 16: 97-112.

Shafroth, P.B.; Merritt, D.M.; Briggs, M.K.; Beauchamp, V.B.; Lair, K.D.; Scott, M.L.; Sher, A. 2013. Riparian restoration in the context of Tamarix control. In: Sher, A.; Quigley, M.F., eds. Tamarix: A case study of ecological change in the American west. New York: Oxford University Press: $1-18$.

Shafroth, P.B.; Stromberg, J.C.; Patten, D.T. 2000. Woody riparian vegetation responses to different alluvial water table regimes. Western North American Naturalist. 60: 66-76.

Shafroth, P.B.; Wilcox, A.C.; Lytle, D.A.; [et al.]. 2010. Ecosystem effects of environmental flows: Modeling and experimental floods in a dryland river. Freshwater Biology. 55: 68-85. 
Shah, J.J.F.; Dahm. C.N.; Gloss, S.P.; [et al.]. 2007. River and riparian restoration in the Southwest: Results of the National River Restoration Science Project. Restoration Ecology. 15: $550-562$.

Sher, A.; Quigley, M.F., eds. 2013. Tamarix: A case study of ecological change in the American West. New York: Oxford University Press. 488 p.

Siemion, G.M.; Stevens, L.E. 2015. Interactions among Tamarix (Tamaricaceae), Opsius stacto-galus (Cicadellidae), and litter fungi limit riparian plant establishment. Advances in Entomology. 3: 65-81.

Smith, S.D.; Devitt, D.A.; Sala, A.; [et al.]. 1998. Water relations of riparian plants from warm desert regions. Wetlands. 18: 687-696.

Smith, S.D.; Wellington, A.B.; Nachlinger, J.L.; [et al.]. 1991. Functional responses of riparian vegetation to streamflow diversion in the eastern Sierra Nevada. Ecological Applications. 1: 89-97.

Stanley, J; Griggs, T.; Rieger, J. [In prep.]. The development of riparian ecosystem restoration in California. In: Johnson, R. Roy; Carothers, Steven W.; Finch, Deborah M.; [et al.], tech. eds. Riparian research and management: Past, present, future. Volume 2. Gen. Tech. Rep. RMRS-GTR-XXX. Fort Collins, CO: U.S. Department of Agriculture, Forest Service, Rocky Mountain Research Station.

Steiner, F.; McSherry, L.; Brennan, D.; [et aal.]. 1999. Concepts for alternative suburban planning in the northern Phoenix area. Journal of the American Planning Association. 65: 207-222.

Stromberg, J.C. 1997. Growth and survivorship of Fremont cottonwood, Goodding willow, and saltcedar seedlings after large floods in central Arizona. Great Basin Naturalist. 57: 198-208.

Stromberg, J.C. 2001. Restoration of riparian vegetation in the south-western United States: Importance of flow regimes and fluvial dynamism. Journal of Arid Environments. 49: 17-34.

Stromberg, J.C.; Patten, D.T. 1990. Riparian vegetation instream flow requirements: A case study from a diverted stream in the eastern Sierra Nevada, California. Environmental Management. 14: $185-194$.

Stromberg, J.C.; Patten, D.T. 1992. Mortality and age of black cottonwood stands along diverted and undiverted streams in the eastern Sierra Nevada, California. Madroño. 39: 205-223.

Stromberg, J.C.; Rychener, T.J. 2010. Effects of fire on riparian forests along a free-flowing dryland river. Wetlands. 30: 75-86.

Stromberg, J.C.; Tellman, B., eds. 2009. Ecology and conservation of the San Pedro River. Tucson, AZ: University of Arizona Press. 524 p.

Stromberg, J.C.; Bagstad, K.J.; Leenhouts, J.M.; [et al.]. 2005. Effects of stream flow intermittency on riparian vegetation of a semiarid region river (San Pedro River, Arizona). River Research and Applications. 21: 925-938.

Stromberg, J.C.; Beauchamp, V.B.; Dixon, M.D.; [et al.]. 2007. Importance of low-flow and high-flow characteristics to restoration of riparian vegetation along rivers in arid southwestern United States. Freshwater Biology. 52: 651-679.

Stromberg, J.C.; Chew, M.K.; Nagler, P.L.; [et al.]. 2009. Changing perceptions of change: The role of scientists in Tamarix and river management. Restoration Ecology. 17: 177-186.

Stromberg, J.C.; Hazelton, A.F.; White, M.S. 2009. Plant species richness in ephemeral and perennial reaches of a dryland river. Biodiversity Conservation. 18: 663-677.

Stromberg, J.C.; Lite, S.J.; Dixon, M.D. 2010. Effects of stream flow patterns on riparian vegetation of a semiarid river: Implications for a changing climate. River Research Applications. 26: 712-729.

Stromberg, J.C.; Wilkins, S.D.; Tress, J.A. 1993. Vegetation-hydrology models: Implications for management of Prosopis velutina (velvet mesquite) riparian ecosystems. Ecological Applications. 3: 307-314.

Szaro, R.C., 1989. Riparian forest and scrubland community types of Arizona and New Mexico. Desert Plants Special Issue. 9(3-4): 70-139. 
Szaro R.C. 1990. Southwestern riparian plant communities: Site characteristics, tree species distributions, and size-class structures. Forest Ecology and Management. 33-34: 315-334.

Szaro, R.C.; Severson, K.E.; Patton, D.R., tech. cords. 1988. Proceedings of the symposium on the management of amphibians, reptiles, and small mammals in North America: Proceedings of the symposium; 1988 July 19-21; Flagstaff, AZ. Gen. Tech. Rep. RM-166. Fort Collins, CO: U.S. Department of Agriculture, Forest Service, Rocky Mountain Forest and Range Experiment Station. 458 p.

Tellman, B.; Yarde, R.; Wallace, M.G. 1997. Arizona's changing rivers: How people have affected the rivers. Tucson, AZ: University of Arizona, College of Agriculture, Water Resources Research Center. 198 p.

Turner, R.M. 1974. Quantitative and historical evidence of vegetation changes along the Upper Gila River, Arizona. U.S. Geological Survey Professional Paper 655H. Reston, VA: U.S. Department of the Interior, Geological Survey. $19 \mathrm{p}$.

Vannote, R.L.; Minshall, G.W.; Cummins, K.W.; [et al.]. 1980. The river continuum concept. Canadian Journal of Fisheries and Aquatic Science. 37: 130-137.

Wauer, R.H. 1977. Significance of Rio Grande riparian systems upon the avifauna. In: Johnson, R.R.; Jones, D.A., tech. coords. Importance, preservation, and management of riparian habitat: A symposium. Gen. Tech. Rep. RM-43. Fort Collins, CO: U.S. Department of Agriculture, Forest Service, Rocky Mountain Forest and Range Experiment Station: 165-174.

Webb, R.H.; Leake, S.A. 2006. Ground-water surface-water interactions and long-term change in riverine riparian vegetation in the southwestern United States. Journal of Hydrology. 320: 302-323.

Webb R.H.; Betancourt, J.L.; Johnson, R.R.; [et al.]. 2014. Requiem for the Santa Cruz River: An environmental history of an Arizona river. Tucson, AZ: University of Arizona Press. 280 p.

Welch, J. 1997. The heritage stewardship program introducing beaver to a desert stream, Arizona. Wildlife Views. 40: 9-13.

Whitham T.G.; Bailey, J.K.; Schweitzer, J.A.; [et al.]. 2006. A framework for community and ecosystem genetics: From genes to ecosystems. Nature Reviews Genetics. 7: 510-523.

Wikipedia. 2016. Rio Grande Project. Washington, DC: U.S. Department of the Interior, Bureau of Reclamation. https://en.wikipedia.org/wiki/Rio_Grande_Project. [Accessed April 8, 2016].

Zeedyk, B.; Clothier, V., 2012. Let the water do the work: Induced meandering, an evolving method for restoring incised channels, revised. Santa Fe, NM: Quivira Coalition. 239 p.

Zektser, S.; Loáiciga, H.A.; Wolf, J.T. 2005. Environmental impacts of groundwater overdraft: Selected case studies in the southwestern United States. Environmental Geology. 47(3): 396-404.

Zimmerman, D.A. 1970. Birds and bird habitats in the National Forest lands in the Gila River Valley, southwestern New Mexico. Silver City: NM. Unpublished report on file with: U.S. Department of Agriculture, Forest Service, Gila National Forest, Silver City, NM. 50 p. 


\title{
Chapter 2. Development of Riparian Perspectives in the Wet Pacific Northwest Since the 1970s
}

\author{
Frederick J. Swanson and Stanley V. Gregory
}

\section{Introduction}

Streams and riparian zones have been fertile ground for ecosystem science and a battleground for forest policy and management in the wet Pacific Northwest west of the crest of the Cascade Range for many decades. Competing, high-value resources of salmon and big Douglas-fir timber and their iconic places in cultures of the region sharpened the clash of values. Landslides from forestry operations and roads and elevated water temperature in streams where forest cover had been removed were points of physical connection between steep slope forestry and cold-water fishes. Logging slash from harvest operations had dammed streams and depleted dissolved oxygen, leading fisheries agencies and advocates to call for removal of wood from streams in the 1950 s and 1960s.

In the decades since, science has played important roles in characterizing ecosystem components and dynamics and in identifying issues and management options. Social conflicts have propelled the science forward. In this essay, we offer a brief historical overview of steps in the development of concepts about riparian zones in this region and societal context from the perspective of the large, interdisciplinary science team - the Stream Team - based on the Oregon State University campus in Corvallis and at the H.J. Andrews Experimental Forest in the Willamette National Forest east of Eugene. Team members come from the University, Forest Service research and land management branches, and other institutions; and the participants have roots in stream ecology, fisheries and forest science, geomorphology, and other fields. The nucleus of the Stream Team has been large research programs - the International Biological Program in the 1970s and the Long-Term Ecological Research program since 1980, both supported by the National Science Foundation and the Forest Service, and based in Oregon State University. Important work occurred elsewhere in the region, most notably based in Seattle in fisheries and forestry research, and outreach programs based at the University of Washington (e.g., Naiman et al. 2005), but we do not attempt to cover that work in this chapter.

An apparent contrast in the perceptions of riparian zones between the dry interior west and the wet Pacific Northwest west of the crest of the Cascades may stem in part from the contrasts in the stature of vegetation. Riparian zones in many arid lands can be conspicuous as lush stands of shrubs and scattered trees in a sea of knee-high sagebrush. Westside conifer forests, on the other hand, can be $70+\mathrm{m}$ tall, dwarfing streamside willow (Salix spp.) and red alder (Alnus rubra) stands and creating continuous forest canopy from stream banks to ridge. Westside forest ecologists naturally focused their science on the interactions among forests, streams, and riparian zones. In the case of the 
Andrews Forest team, stream ecologists pressured the forest scientists to extend their work down into the riparian zone.

The evolution of thinking about riparian zones in the Andrews Forest team was the gradual awakening to the many interactions between forests and streams. Driven by both science and policy questions, big wood in streams became a pivotal issue in the mid-1970s. The policy question: Should loggers be required to remove wood from streams to provide for fish passage and limit biological oxygen demand? The science question: What does big wood contribute to the geomorphic structure, organic matter and nutrient budgets, and overall functioning of stream ecosystems? The history of logging slash and stream management often is characterized as, "First they told us to take wood out of streams and now they are telling us to put it back. When will those darn scientists change their minds again and tell us to take it out again?"

But, the management history was more nuanced; early rules called for leaving the pre-existing wood in streams and removing only logging debris. The pendulum swung from having too much wood in streams - especially readily mobilized logging slash - to removing too much wood from streams, especially wood of a natural size distribution, including big, stable pieces. The arguments about how much wood is appropriate continues, but the general thread of the story is that wood is a natural part of stream systems so policy now sustains that function through direct intervention in streams and management of riparian forests for future wood supply. The big wood connection between forest and stream turned out to be vital to the interdisciplinary spirit of the science team - the work required integrating the perspectives of stream and forest ecologists and geomorphologists.

By the latter half of the 1970s, the Andrews group had made substantial progress on their studies of nitrogen and organic matter budgeting (Triska et al. 1984), addressing both processes and standing stocks of materials all with attention to how forests affect streams. A succession of papers (in chronological order: Cummins 1975; Meehan et al. 1977; Swanson et al. 1982; Gregory et al. 1991) developed the thinking about forest-stream interactions in terms of regulation of light levels influencing primary productivity, water temperature, fish foraging efficiency, and other processes. Also summarized in figure 1, the roles of forests in supplying organic matter range from fine litter to whole old-growth trees that shape stream channels, provide cover, and provide substrates for biological activity. This evolution led to the notion of defining riparian zones in ecosystem terms as the zone of interaction rather than on the basis of hydrologic, botanical, or soil considerations (Gregory et al. 1991). Unlike lowland fluvial systems with well-defined floodplains, hydrologic criteria do not work well in steep mountain streams with their high levels of topographic complexity imposed by boulders, big wood, and narrow valley floors.

Botanical criteria have limitations in part because the great stature of vegetation means that trees distant from the stream can have important influences. Studies of riparian vegetation have been rather limited in these mountain environments. In the Andrews Forest, for example, in 1979 and 1990 forest ecologists established several large (2-2.4 ha) stem maps straddling streams of different size, but it took some years and a major flood to develop a record of sufficient length to reveal the disturbance dynamics of the riparian system (Acker et al. 2003). Hydric soils criteria for defining riparian 
Figure 1-Foreststream interactions as a basis for defining the riparian zone, as viewed in 1978 (source: Meehan et al. 1977, public domain).

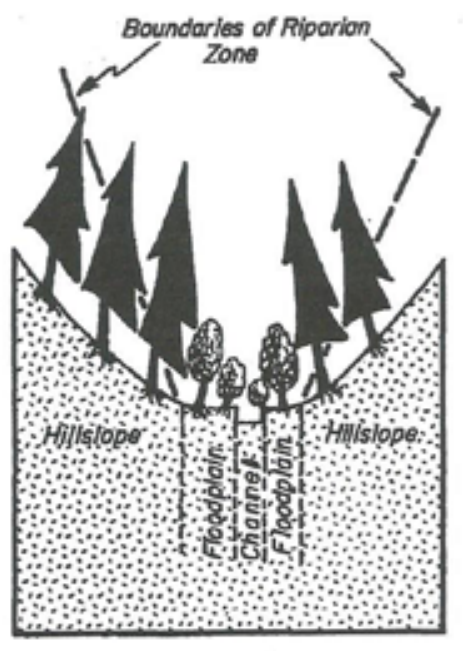

\begin{tabular}{|c|c|c|}
\hline \multirow[b]{2}{*}{ SITE } & \multicolumn{2}{|c|}{ RIPARIAN VEGETATION } \\
\hline & COMPONENT & FUNCTION \\
\hline \multirow[t]{3}{*}{$\begin{array}{l}\text { above ground- } \\
\text { above channel }\end{array}$} & conopy 8 stems & $\begin{array}{l}\text { 1. Shade-controls termperoture } 8 \\
\text { In stream primary production }\end{array}$ \\
\hline & & $\begin{array}{l}\text { 2. Source of large and fine plant } \\
\text { defritus }\end{array}$ \\
\hline & & 3. Source of terrestrial insects \\
\hline \multirow[t]{3}{*}{ in channel } & $\begin{array}{l}\text { large debris } \\
\text { derived from }\end{array}$ & $\begin{array}{l}\text { I. Control routing of water and } \\
\text { sediment }\end{array}$ \\
\hline & riparian veg & $\begin{array}{l}\text { 2. Shape habltat-pools, riffles, } \\
\text { cover }\end{array}$ \\
\hline & & 3. Substrate for biological activity \\
\hline \multirow[t]{2}{*}{ streambanks } & roots & I. Increose bonk stobility \\
\hline & & 2. Create overhanging banks -cover \\
\hline floodploin & $\begin{array}{l}\text { stems } 8 \text { low } \\
\text { lying conopy }\end{array}$ & $\begin{array}{l}\text { L. Retard movement of sediment, } \\
\text { water and floated organic } \\
\text { debris in flood flows }\end{array}$ \\
\hline
\end{tabular}

systems in the forest setting are far too narrow and fail to encompass the terrestrialaquatic interactions that strongly influence stream ecosystems.

Also, during the late 1970s, the highly influential River Continuum Concept (RCC) project was in full swing (Vannote et al. 1980, which had been cited more than 8,300 times as reported in Google Scholar as of 22 March 2017). A national program led by Robin Vannote of the Stroud Water Research Laboratory in southeastern Pennsylvania explored concepts of how forest influences on stream ecosystems varied from small headwater streams to large rivers. As the stream widened downstream, more light reaches the channel, so food resources for aquatic organisms shift from productivity driven dominantly by forest litter to in-stream primary production. A cascade of ecological consequences follows, including shifts in composition of the aquatic invertebrate community from one that processes organic inputs from the surrounding forest to grazers that process algae and diatoms produced in the channel itself. Many other aspects of the stream ecosystem, including big wood, were examined at four stream sizes from first- to seventh-order channels. The Andrews Forest was one of four study areas in the RCC project scattered across the country. This work helped place stream ecosystems in a landscape context by explaining variation along the longitudinal profile of the stream system. The RCC also argued for connectivity through the stream network via the influence of upstream areas as sources of nutritional resources for downstream rivers and floodplains.

A key feature of the Andrews Forest program has been its close partnership with land managers of the Willamette National Forest. Preparation of the forest management plan culminating in 1990 included a prime example of that partnering in the form of a 65-page supplement for stream and riparian management guide authored by two researchers working in collaboration with National Forest personnel (Gregory and Ashkenas 1990). This guide affirms the many important ecological functions of riparian zones, the policy direction to sustain them, and the necessary management standards and guidelines in the context of a full watershed perspective. The collaborative approach has been mutually beneficial; researchers bring the most up-to-date science and the land managers bring a great deal of real-world experience plus exposure to the competing 
values within society. Therefore, the ultimate plan has the best chance to be credible on science, societal, and operational fronts.

This sense for integrating science and land management practices was valuable a few years later during the Forest Ecosystem Management Assessment Team (FEMAT) process convened by President Clinton in April 1993, to move beyond the injunction that Judge Dwyer had leveled on logging on Federal lands in the range of the northern spotted owl-10 million hectares along the Pacific Coast (FEMAT 1993). The FEMAT process set the path to the Northwest Forest Plan (NWFP) signed by the secretaries of Agriculture and Interior in 1994. A synthesis of some of the findings from Andrews Forest science and other sources was encapsulated in a figure that helped shape thinking about width of riparian reserves to maintain many functions of streamside forests within cutting units (fig. 2).

This conceptual framework was a dramatic departure from the policy debates about riparian buffer widths over the previous 20 years. One of the first questions that emerges in riparian zone management is: How wide should buffers be? Most discussions focused on uniform distances from the streams edge based on the operational willingness to forego some or all timber harvest within that distance. The Riparian Reserves of the NWFP designed riparian widths based on site-potential tree heights (the height of an average tree in late succession stage of stand development). As a result, riparian zone widths were conceived as varying among areas with different forest composition and site productivity. Riparian reserve widths could also be variable and shaped to local topography and potential interactions with the stream. As a result, riparian management areas were ecologically defined and based on the overall landscape rather than the tape measure.

The fixed-width riparian reserves prescribed in the Matrix land allocation of the NWFP, where some logging was to be permitted, were expected to be modified after "watershed analysis" provided a comprehensive, watershed-wide view of biotic and geomorphic conditions that might motivate widening or narrowing of the reserve widths. However, these modifications did not occur in most areas for a variety of reasons.

Figure 2-Effectiveness of streamside forest in providing litter fall, root strength in streambanks, shading, and large wood to the channel as a function of distance from the channel as measured in proportion of tree height (source: FEMAT 1993, public domain).

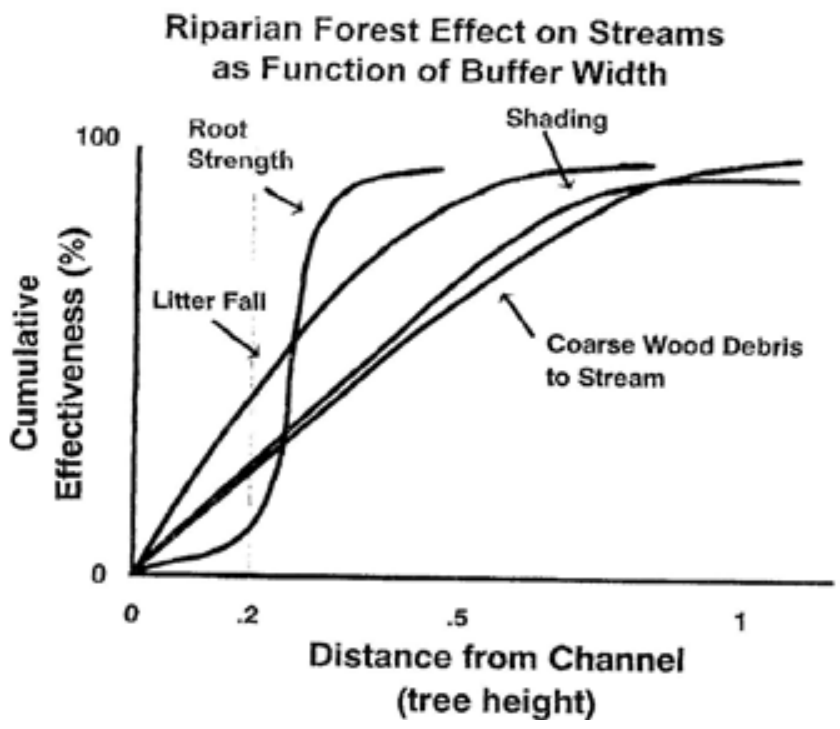


The NWFP also charged the research-management partnership team based at the Andrews Forest with developing a landscape management plan based on the historic wildfire regime. This ecosystem-dynamics approach to landscape planning, developed as the Blue River Landscape Plan, contrasts with the species-specific conservation approach that dominates the NWFP (Cissel et al. 1999). A key part of the Blue River plan is to consider the frequency and severity of disturbance in the uplands as well as the streamside forest when managing for aquatic conservation objectives consistent with the historic disturbance regime. Several timber sales in native, mature-age-class (ca. 150 years) forests that are part of implementing and testing the plan are completed, but further implementation has been stopped with the region-wide cessation of logging accomplished by environmentalists over the past 20-plus years. Despite the management outcomes, the multi-discipline, multi-scale research carried out at the Andrews Forest in past decades proved to be an important part of the foundation for both the local plan and the regional conservation strategy of which stream and riparian networks are a vital part.

Even as input to policy and management proceeded, research efforts were gaining new insights to the complexity of riparian systems. Several decades of study have revealed secrets of the hyporheic system - the down-valley, subsurface flow of water beneath the streambed and within the valley-floor alluvium that experiences periodic exchange with surface waters (Wondzell and Swanson 1996). The hyporheic system facilitates interaction of surface water senwith root systems of riparian vegetation, which in the westside Pacific Northwest often includes red alder, a nitrogen-fixing species. An isotopic nitrogen tracer study revealed that some nitrogen in streamwater can actually flow upward into the terrestrial system via a pathway beginning as hyporheic flow is taken up by riparian plants, which incorporate the dissolved nitrogen in streamwater into foliage, which is then consumed by herbivorous invertebrates fed upon by birds that integrate with the terrestrial food web (Ashkenas et al. 2003).

Given the ever-changing perceptions of riparian systems prompted by new science, new tools, and biophysical and social disturbance events, we are confident that the next generation of students of riparian zones will make many interesting discoveries of forest-stream interactions at micro-site to large watershed scales. We often wonder: What is it that is right in front of us now that we cannot see-just like the fallen logs we tripped over in the early 1970s until recognizing their importance and building much of our science careers around them? Young scientists and land managers beginning their careers have exciting opportunities for discovery in riparian systems.

\section{Acknowledgments}

We write this as a shared, personal essay, with a sense of great gratitude to many wild, wonderful, and too-numerous-to-name colleagues of the Stream Team based on the Oregon State University campus over the decades. Decades of funding and other forms of institutional support of NSF, OSU, and USFS Pacific Northwest Research Station are deeply appreciated. We dedicate this essay to the memory of Jim Sedell, our inspiring friend and colleague whose ashes are now part of biogeochemical system associated with Mack Creek in the Andrews Forest; his ideas live on as well. Jim loved rivers and worked for their betterment in many capacities while working in academia, government research, corporate, and NGO sectors. 


\section{References}

Acker, S.A.; Gregory, S.V.; Lienkaemper, G.; [et al.]. 2003. Composition, complexity, and tree mortality in riparian forests in the central western Cascades of Oregon. Forest Ecology and Management. 173: 293-308. http://andrewsforest.oregonstate.edu/pubs/pdf/pub2740.pdf [Accessed December 6, 2016].

Ashkenas, L.R.; Johnson, S.L.; Gregory, S.V.; [et al.]. 2004. A stable isotope tracer study of nitrogen uptake and transformation in an old-growth forest stream. Ecology. 85(6): 1725-1739. http://andrewsforest.oregonstate.edu/pubs/pdf/pub3605.pdf [Accessed December 6, 2016].

Cissel, J.H.; Swanson, F.J.; Weisberg, P.J. 1999. Landscape management using historical fire regimes: Blue River, Oregon. Ecological Applications. 9(4): 1217-1231. http://andrewsforest. oregonstate.edu/pubs/pdf/pub2502.pdf [Accessed December 6, 2016].

Cummins, K.W. 1976. The ecology of running water: Theory and practice. In: Baker, D.B.; Jackson, W.B.; Prater, B.L., eds. Proceedings of the Sandusky River Basin symposium; 1975 May 2; Tiffin, OH. Washington, DC: U.S. Government Printing Office: 277-393.

Forest Ecosystem Management Assessment Team (FEMAT). 1993. Forest ecosystem management: An ecological, economic, and social assessment. Washington, DC: U.S. Department of Agriculture, Forest Service; U.S. Department of Commerce, National Oceanic and Atmospheric Administration, National Marine Fisheries Service; U.S. Department of the Interior, Bureau of Land Management, Fish and Wildlife Service, National Park Service; U.S. Environmental Protection Agency. https://www.blm.gov/or/plans/nwfpnepa/ FEMAT-1993/1993_percent20FEMAT_Report.pdf [Accessed November 29, 2016].

Gregory, S.; Ashkenas, L. 1990. Field guide for riparian management, Willamette National Forest. U.S. Department of Agriculture, Forest Service, Willamette National Forest. 65 p. http://andrewsforest.oregonstate.edu/pubs/pdf/pub1039.pdf [Accessed December 6, 2016].

Gregory, S.V. 1996. History of management of large woody debris in the Pacific Northwest. In: Cone, J.; Ridlington, S., eds. The Northwest salmon crisis: A documentary history. Corvallis, OR: Oregon State University Press. 384 p.

Gregory, S.V. 1997. Riparian management in the 21 st century. In: Kohm, K.A.; Franklin, J.F., eds. Creating a forestry for the 21 st century: The science of ecosystem management. Covelo, CA: Island Press: 69-85. http://andrewsforest.oregonstate.edu/pubs/pdf/pub2334.pdf [Accessed December 6, 2016].

Gregory, S.V.; Swanson, F.J.; McKee, W.A.; Cummins, K.W. 1991. An ecosystem perspective of riparian zones: Focus on links between land and water. BioScience. 41(8): 540-551. http:// andrewsforest.oregonstate.edu/pubs/pdf/pub954.pdf [Accessed December 6, 2016].

Meehan, W.R.; Swanson, F.J.; Sedell, J.R. 1977. Influences of riparian vegetation on aquatic ecosystems with particular reference to salmonid fishes and their food supply. In: Johnson, R. Roy; Jones, Dale A., tech. coords. Importance, preservation and management of riparian habitat: A symposium; 1977 July 9; Tucson, AZ. Gen. Tech. Rep. RM-43. Fort Collins, CO: U.S. Department of Agriculture, Forest Service, Rocky Mountain Forest and Range Experiment Station: 137-145. http://andrewsforest.oregonstate.edu/pubs/pdf/pub523.pdf [Accessed December 6, 2016].

Naiman R.J.; Decamps, H.; McLain, M.E. 2005. Riparia: Ecology, conservation, and management of streamside communities. New York: Elsevier. 430 p.

Swanson, F.J.; Gregory, S.V.; Sedell, J.R.; [et al.]. 1982. Land-water interactions: The riparian zone, Chapter 9. In: Edmonds, R.L., ed. Analysis of coniferous forest ecosystems in the western United States. US/IBP Synthesis Series. 14. Stroudsburg, PA: Hutchinson Ross Publishing Co.: 267-291. http://andrewsforest.oregonstate.edu/pubs/pdf/pub626.pdf [Accessed December 6, 2016].

Triska, F.J.; Sedell, J.R.; Cromack, K.; [et al.]. 1984. Nitrogen budget for a small coniferous forest stream. Ecological Monographs. 54: 119-140. http://andrewsforest.oregonstate.edu/ pubs/pdf/pub1354.pdf [Accessed December 6, 2016]. 
Vannote, R.L; Minshall, G.W.; Cummins, K.W.; [et al.]. 1980. The river continuum concept. Canadian Journal of Fisheries and Aquatic Sciences. 37(1): 130-137.

Wondzell, S.M.; Swanson, F.J. 1996. Seasonal and storm dynamics of the hyporheic zone of a 4th-order mountain stream. I: Hydrologic processes. Journal of the North American Benthological Society. 15(1): 3-19. http://andrewsforest.oregonstate.edu/pubs/pdf/pub2121. pdf [Accessed December 6, 2016]. 


\title{
Chapter 3. Impacts of Interacting Fire, Climate, and Hydrologic Changes on Riparian Forest Ecosystems in the Southwest
}

\author{
D. Max Smith and Deborah M. Finch
}

\section{Introduction}

Changes in human populations, water use, climate, and related disturbances are impacting riparian ecosystems throughout the western United States. Nowhere is this more pronounced than in the arid American Southwest (Gutzler 2013; Molles et al. 1998; Webb et al. 2007). Changes in southwestern riparian ecosystems are often visible to the casual eye in the form of reduced and channelized water along stream courses, loss or changes in riparian vegetation, fire, and urbanization. To manage these changes and improve ecosystem resiliency for the future, a better understanding of the impacts of stressors and disturbances on southwestern riparian ecosystems, and especially on resources of high value from human and ecological perspectives, is needed. We focus on aridland riparian forests in this chapter owing to their values for recreation, wildlife habitat, and energy and nutrient input.

Aridland riparian forests are composed of species in plant guilds that vary in their response to surface flows and groundwater (fig. 3; Stromberg and Merritt 2015).

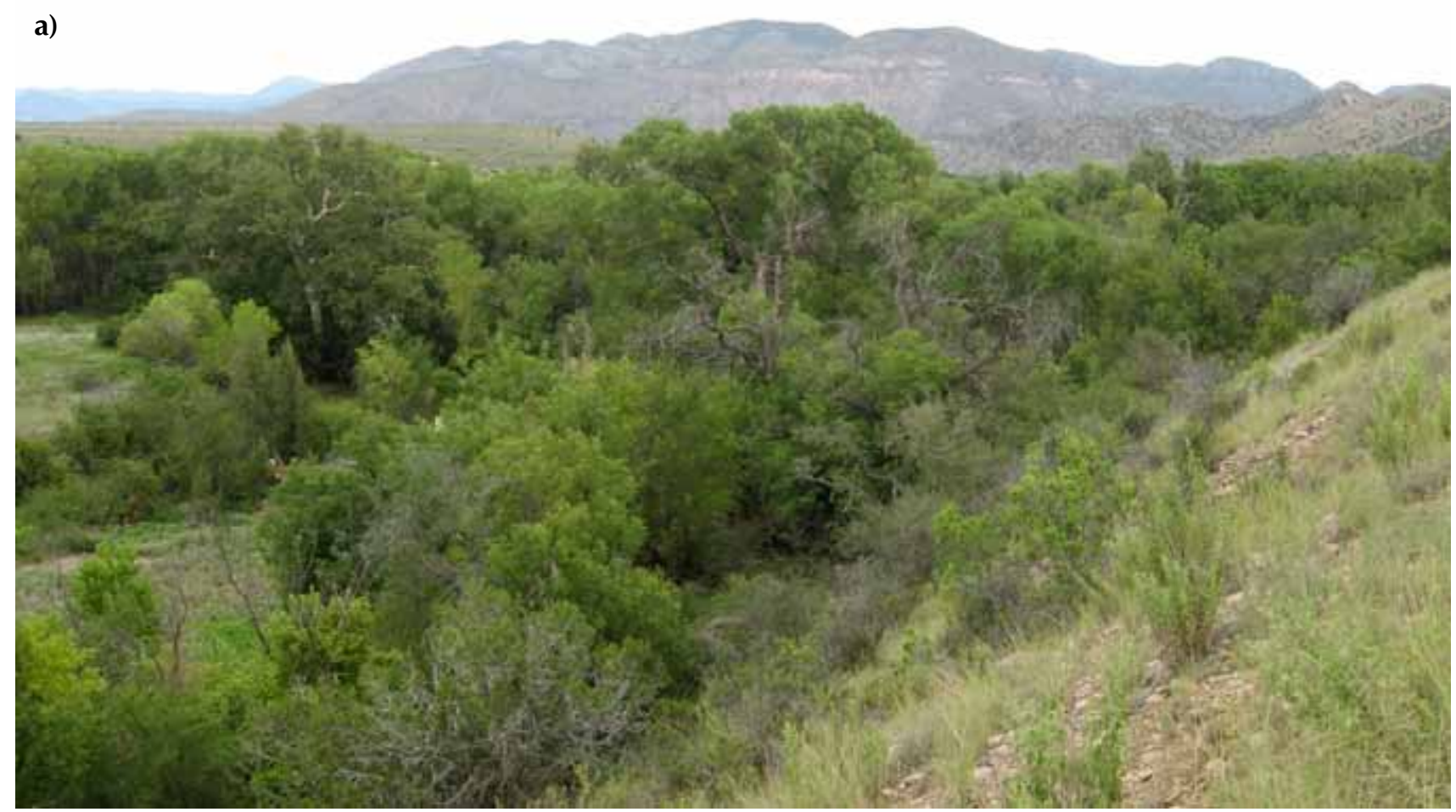

Figure 3-Examples of southwestern riparian forests: (a) along the Gila River in southwestern New Mexico, with a Fremont cottonwood and Arizona sycamore canopy and Goodding's willow, boxelder, and other woody species in the subcanopy; 


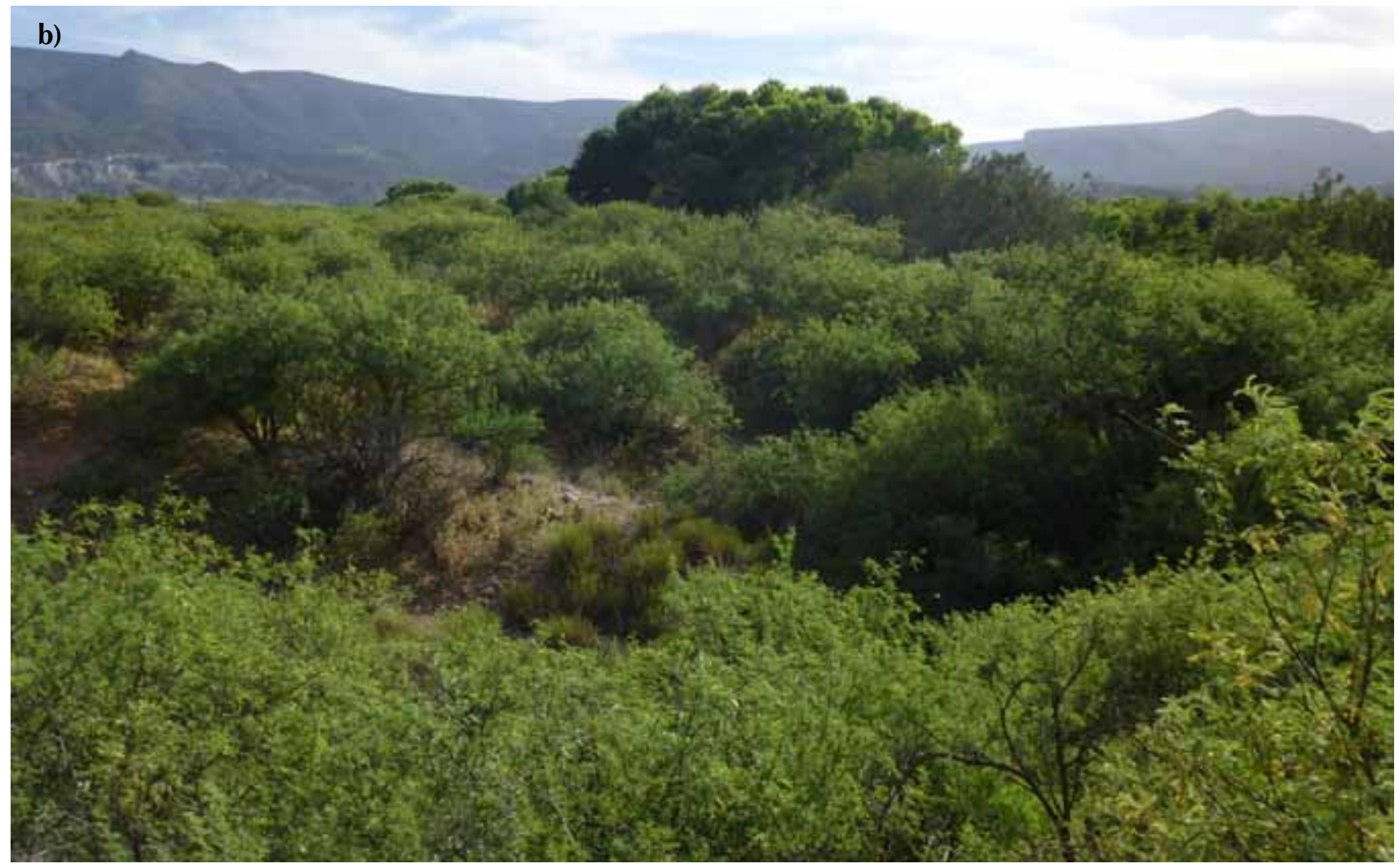

Figure 3-Examples continued. (b) near the Verde River in central Arizona with a mesquite bosque (foreground) and cottonwood canopy (upper center);

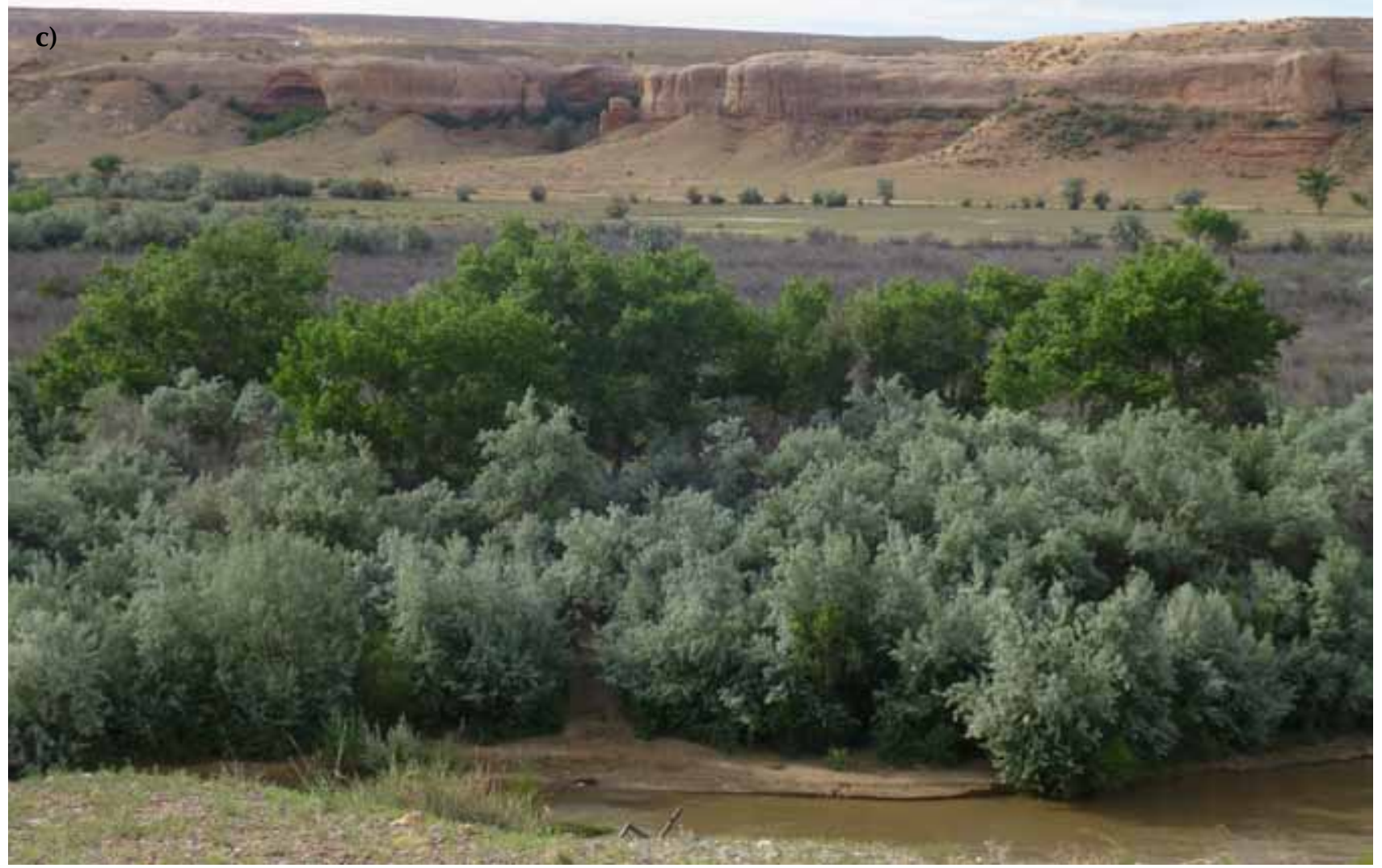

Figure 3-Examples continued. (c) along the San Juan River in southeastern Utah with Fremont cottonwood, Russian olive, and saltcedar (background), which has been defoliated by leaf beetles; 


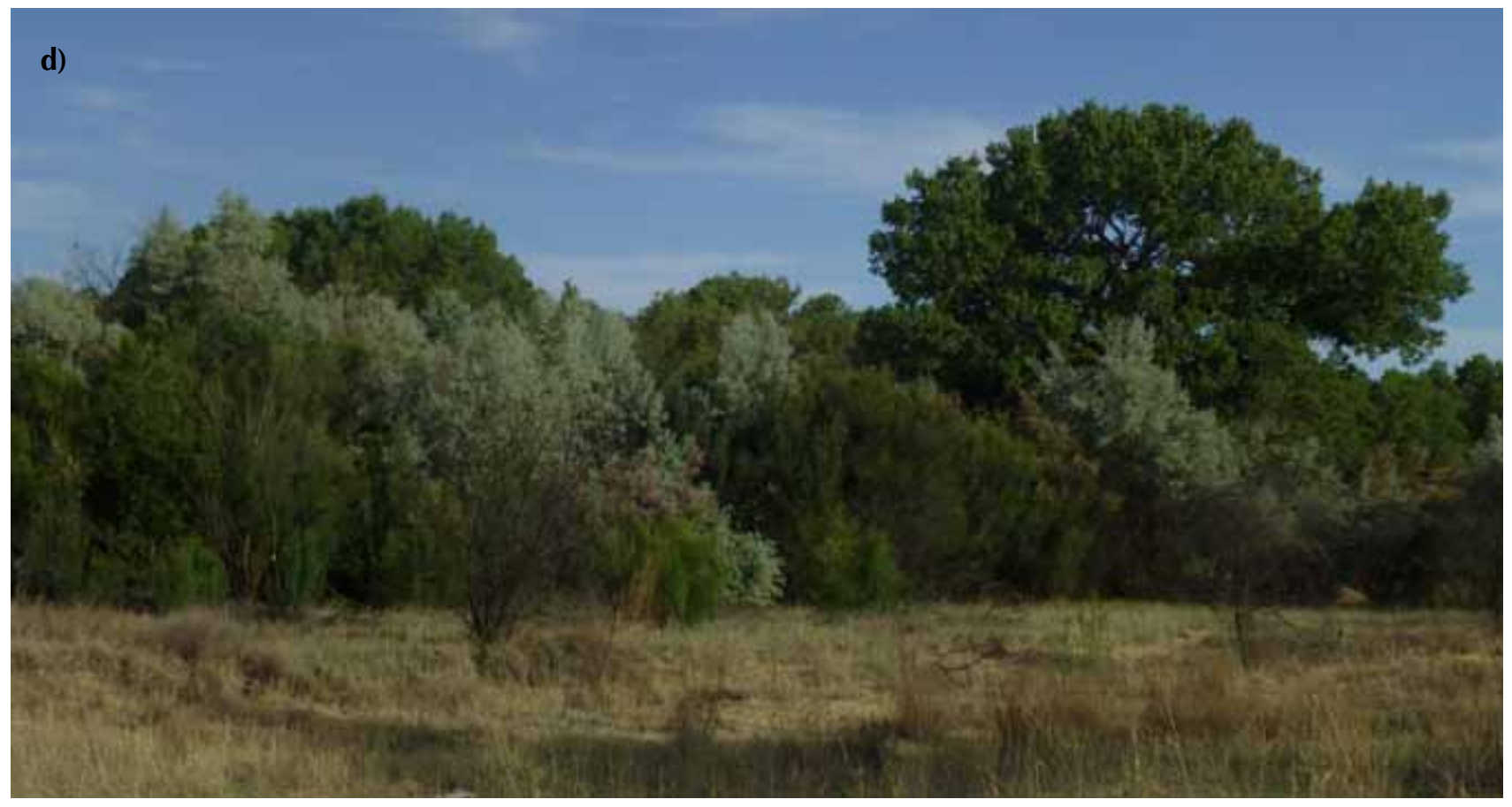

Figure 3-Examples continued. and (d) along the Middle Rio Grande in central New Mexico with Rio Grande cottonwood, saltcedar, and Russian olive.

Taxa in hydroriparian guilds include cottonwoods (Populus spp.) and willows (Salix spp.). Mesoriparian and xeroriparian taxa include boxelder (Acer negundo), mesquites (Prosopis spp.), and invasive, nonnative species such as Russian olive (Elaeagnus angustifolia) and saltcedar (Tamarix spp). The extent of riparian forests is small relative to other southwestern plant communities and is largely determined by complex interactions among human activity, climate, and disturbance processes. Fremont cottonwood (Populus fremontii), Arizona sycamore (Platanus wrightii), and other woody species provide birds and other animals with nesting sites and foraging opportunities that are often absent in upland plant communities (Bock and Bock 1984; Carothers et al. 1974). The structurally diverse, species-rich vegetation along many southwestern streams supports high densities of territories and nest sites for a variety of birds including the Federally endangered southwestern willow flycatcher (Empidonax traillii extimus), the threatened western population of yellow-billed cuckoo (Coccyzus americanus), and other species of high conservation priority such as Lucy's warbler (Oreothlypis luciae) (Finch et al. 2006; Friggens and Finch 2015; Smith and Finch 2014).

Given the acceleration of human influence at local to global scales and changes in climate, fire severity and frequency, and other stressors, it is critical to assess the effects and interactions of natural and altered disturbance regimes on riparian forest ecosystems and species in the Southwest. Such information will help us understand ecosystem vulnerability and develop actions to manage ecosystems for improved resiliency (Friggens et al. 2013). In this chapter we examine these effects through the lens of native and nonnative riparian woody vegetation. The Middle Rio Grande riparian forest, known as the "bosque," is highlighted as a case study. 
Flood, drought, and wildfire are primary components of disturbance regimes affecting aridland riparian forests. These disturbances can be caused by natural climate and hydrological cycles, human activity, or their interactions. To evaluate the state of knowledge on these disturbances, we searched for papers describing the response of native and nonnative woody species to flood, drought, and wildfire. We focused on seven taxa common to these forests: Fremont cottonwood and Rio Grande cottonwood (Populus deltoides ssp. wislizenii), combined hereafter as "cottonwood"; Goodding's willow (Salix gooddingii); velvet mesquite (Prosopis velutina) and honey mesquite (Prosopis glandulosa), combined hereafter as "mesquite"; Arizona sycamore; boxelder; Russian olive; and saltcedar. We found studies of drought and flood effects by searching for the common and scientific names of each species, along with "flood" and "drought" in the online citation service Web of Science. To find studies of wildfire effects we used the same procedure in Web of Science and expanded our search by using Google Scholar.

\section{Effects of Flooding and Flood Reduction}

Flood is the most frequently studied disturbance for all taxa but mesquite (fig. 4). In the Southwest, floods can occur throughout the year, fueled by snowmelt, rain, or a combination of the two. High-magnitude flows occasionally create enough shear stress, erosion, and sedimentation to kill individuals or remove entire stands of shrubs or trees (Bock and Bock 1989; Friedman and Auble 1999; Minkley and Clark 1984). Conversely, floods are in some way instrumental for reproduction of most, if not all woody riparian species. Vegetative reproduction occurs when above- or below-ground portions of woody plants are transported by flood and buried by sediment (Rood et al. 2007). Floods also create opportunities for germination of pioneer species including cottonwood, Goodding's willow, and Arizona sycamore (Stromberg and Merritt 2015) and produce germination sites by delivering damp sediment and removing litter and competing vegetation (Braatne et al. 1996; Stromberg 1997, 2002). By wetting unsaturated

Figure 4-Number of publications reporting effects of flood, drought, and wildfire on seven woody riparian species in North America. Flood and drought papers were found by searching for common and scientific names with "flood" and "drought" in Web of Science; wildfire papers were found using the same procedure in Web of Science and Google Scholar.

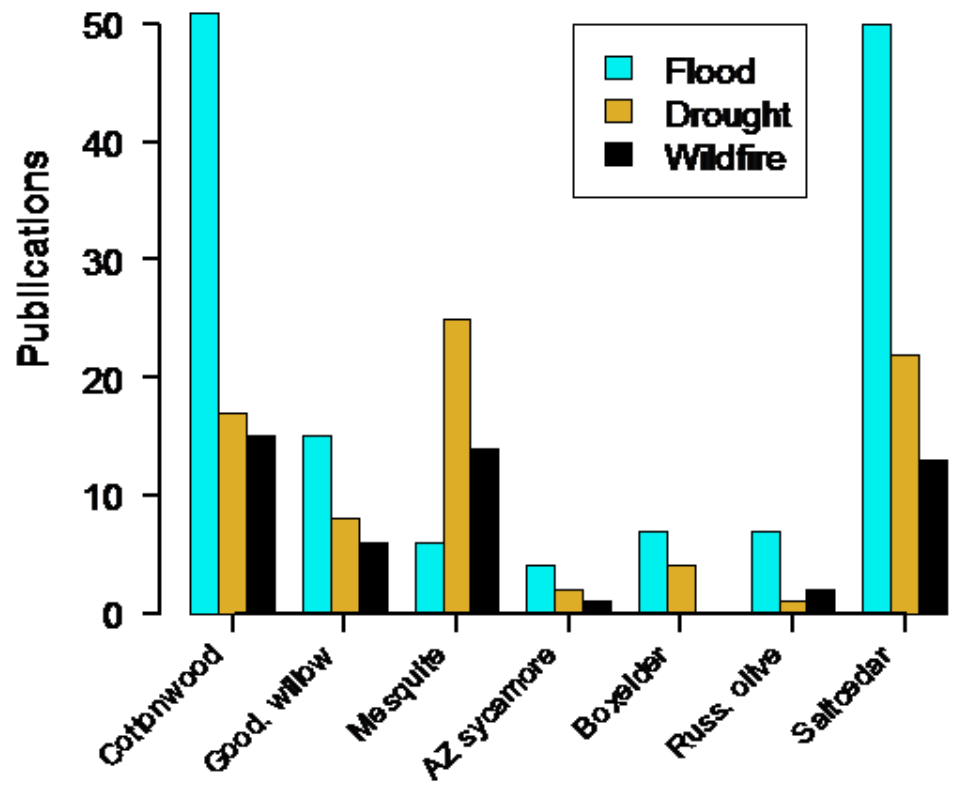


soil layers, flood waters induce germination and support the growth of seedlings until their roots have reached the saturated layer of soil, forming a connection necessary for survival in arid conditions (Bhattacharjee et al. 2006; Horton and Clark 2001; Mahoney and Rood 1998).

Boxelder, mesquites, and Russian olive have relatively large, long-lived seeds that can germinate in the presence of litter and competing vegetation. Though their seeds do not require flood-exposed sites, flood-dampened soil is needed for germination, especially if rainfall is insufficient (Katz and Shafroth 2003; Dewine and Cooper 2007; Stromberg 1993). Mesquite seedlings do not survive well in saturated soil, so mesquite bosques often occupy the outer portions of riparian zones, beyond the area occupied by cottonwood, willow, and sycamore (Stromberg 1993). Where surface flows are intermittent, floods are needed to both replenish groundwater aquifers and deliver nutrients to the soil-processes critical to growth and survival of individuals across guilds and age classes (Stromberg 2001a).

At many streams, frequency, magnitude, and timing of floods have been altered by diversions and dams, with well-documented effects on woody riparian plants (Webb et al. 2007). Though cottonwood and willow recruitment often occurs along narrowed streams following dam construction, opportunities for further reproduction are limited by the reduction of flood scour and sediment deposition (Coble and Kolb 2013; Howe and Knopf 1991; Merritt and Poff 2010; Shafroth et al. 2002). Reduction in magnitude of floods can also limit recruitment of mesoriparian and xeroriparian species that grow at higher elevations of the floodplain (Coble and Kolb 2013; Stromberg 1993). In turn, flow modification encourages establishment of Russian olive, which does not require flood-dampened soil or exposed sites for germination (Katz and Shafroth 2003).

Timing of flow events, such as floods and baseflows, influences reproduction of woody species and riparian forest composition (Beauchamp and Stromberg 2007; Birken and Cooper 2006). A shift in timing of peak discharge away from the dispersal period of pioneer species' short-lived seed will prevent their germination (Fenner et al. 1985). Saltcedar has similar requirements for germination as cottonwood, Goodding's willow, and Arizona sycamore, but it has a longer, more variable period of seed release (Stevens and Siemion 2012). Changes in timing of peak discharge, caused by regulation, can therefore encourage replacement of native species by saltcedar.

\section{Drought Effects}

The water required by riparian trees for reproduction, growth, and survival is accessed from surface flows, groundwater, and precipitation (Kolb et al. 1997; Snyder and Williams 2000). These water sources are also linked to one another through natural hydrological processes (Webb and Leake 2006). Periodic shortages in these sources occur naturally across climatic cycles, but for over a century shortages have been caused or exacerbated by surface flow diversion, groundwater withdrawal, and reservoir storage (Phillips et al. 2011; Summitt 2013). Studies have examined effects of stream drying, both natural and human-induced, in a variety of native and nonnative taxa, with cottonwood, mesquite, and saltcedar receiving the most attention in the literature (fig. 4).

Cottonwood, Goodding's willow, and Arizona sycamore are hydroriparian taxa that can form an extensive forest canopy where groundwater remains accessible to their 
shallow roots (Lite and Stromberg 2005; Stromberg 2001b). Of these taxa, Goodding's willow is the most dependent on shallow depth to groundwater and often establishes closest to the stream channel. Mesquite, boxelder, Russian olive, and saltcedar are mesoriparian and xeroriparian taxa that can establish throughout a floodplain (Dewine and Cooper 2008; Stromberg et al. 2007). Mesquites are capable of attaining large size and forming extensive stands known as bosques. For mature mesquite bosques to form, trees must have access to groundwater at depths of $15 \mathrm{~m}$ or less, though $6 \mathrm{~m}$ or less is ideal (Stromberg 1993).

When depth to groundwater increases, hydroriparian species respond rapidly through reduction of growth, branch dieback, and stem mortality (Coble and Kolb 2012; Stromberg et al. 2007). Mesoriparian and xeroriparian species can therefore gain a competitive advantage over hydroriparian species when moderate drought occurs (Cleverly et al. 1997; Horton et al. 2001a, 2001b; Lite and Stromberg 2005). Severe droughts and flow modification can reduce growth, decrease reproduction, and increase mortality of mesoriparian and xeroriparian species as well, leading to replacement by small-stature upland plants (Coble and Kolb 2012, 2013; Dewine and Cooper 2007; Stromberg 1993).

\section{Fire Effects}

The effects of wildfire on riparian vegetation have received little research attention relative to effects of flood and drought (fig. 4). Fire has long been studied as a method to control the spread of mesquites in rangelands (Blydenstein 1957), but little is known about their response to fire in a riparian setting. Most studies of fire in aridland riparian systems have focused on cottonwoods and saltcedar, largely due to concerns that wildfire will facilitate replacement of the former by the latter (Busch and Smith 1995; Drus 2013; Smith et al. 2009b). Fire effects have been documented infrequently for the other woody taxa (fig. 4). The responses of woody plants to fire in these studies generally include rates of topkill (death of above-ground tissues) and resprouting (production of basal sprouts, epicormic sprouts, and root suckers). Postfire germination has been observed for cottonwoods by Ellis (2001), but direct measurements are not reported in the literature. Boxelder is a widespread and important component of wildlife habitat (Brodhead et al. 2007; Stoleson and Finch 2003), but we did not find reported effects of fire on this species.

Topkill vulnerability varies among taxa, size classes, and fire severity (Bock and Bock 2014; Ellis 2001; Stuever 1997). To our knowledge, all deciduous riparian tree taxa can recover from topkill by producing basal sprouts, epicormic sprouts, or root suckers. The success of vegetative recovery, however, is affected by numerous factors that vary among species and wildfire sites (Eillis 2001; Smith et al. 2009b; Stromberg and Rychener 2010). Examinations of fire that take into account flow modifications, native and nonnative plant responses, and response of animal communities to changes in vegetation are needed. Below we provide an example of this type of study, conducted along the Middle Rio Grande in central New Mexico.

\section{Middle Rio Grande Case Study}

The Middle Rio Grande in central New Mexico is anthropogenically modified, but many stretches still support native trees and shrubs, which provide habitat for wildlife 


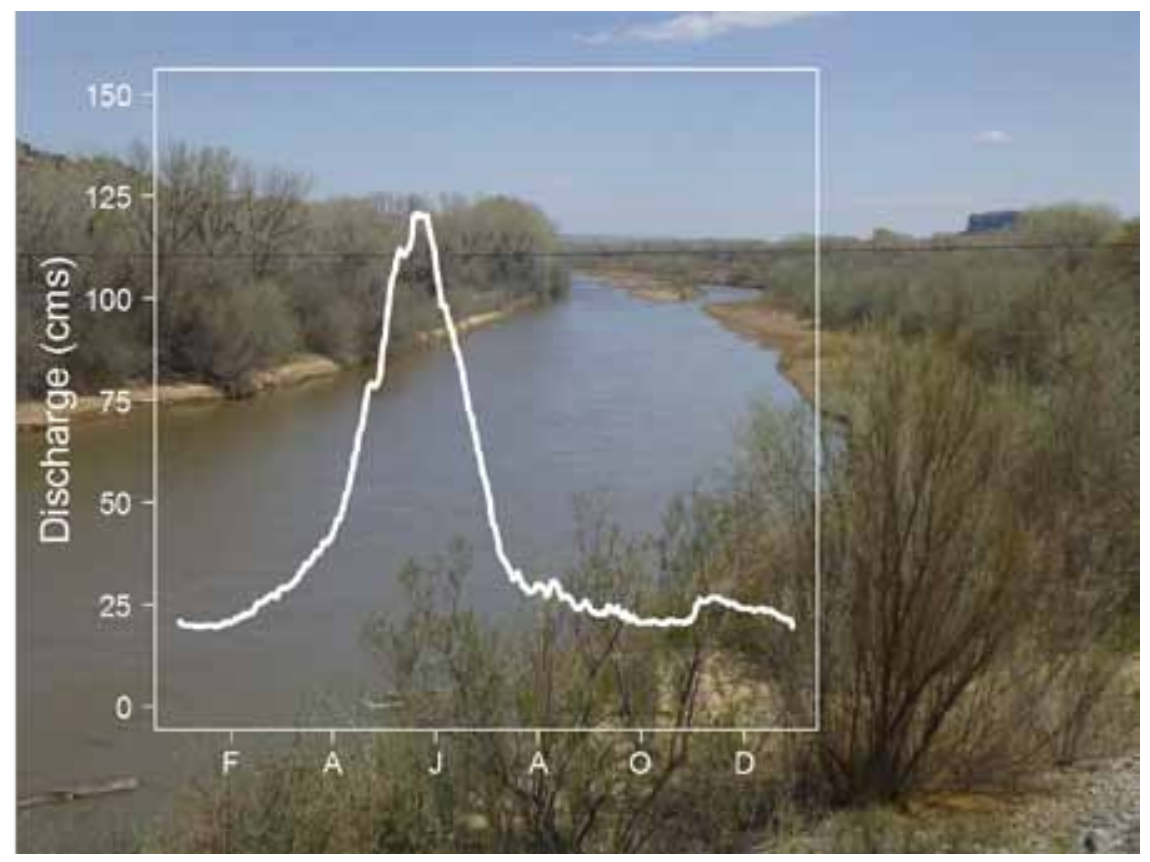

Figure 5-Mean daily discharge hydrograph at the Rio Grande at Otowi, upstream from Cochiti Dam. Line values represent mean daily discharge for each day of the year averaged over the period of 1919 to 2013. Data were obtained from the United State Geological Survey National Water Information System and are available online (http://waterdata.usgs.gov/nwis) (photo by Max Smith).

including riparian obligates and threatened and endangered species (Friggens et al. 2013; Smith and Finch 2014). With several decades of research on hydrology, wildfire, plants, and animals, this area is an ideal case study of changing disturbance regimes and their ecological effects.

\section{Natural Hydrological Regime}

The Middle Rio Grande is the section of the Rio Grande that flows north to south through central New Mexico. The Rio Grande originates in and receives most of its surface flow from the San Juan Mountains of southwestern Colorado (Phillips et al. 2011). Peak flows, resulting from snowmelt runoff, historically occurred during the late spring or early summer (fig. 5). Floods would cause the channel to migrate throughout the broad alluvial valley, leaving a mosaic of wetlands and multi-aged stands of riparian vegetation (Scurlock 1998). Floods also occurred following heavy thunderstorms during the summer monsoon and other times of the year, but spring snowmelt provided the opportunities for pioneer tree establishment.

\section{Changes to the Regime}

Alterations to the Middle Rio Grande have occurred over several centuries, but the stream became profoundly regulated during a period bookended by the formation of the Middle Rio Grande Conservancy District in 1929 and the completion of Cochiti Dam in 1974. To reduce flooding and improve agricultural activity, government agencies constructed a network of diversion dams, levees, irrigation canals, and drains (Phillips et al. 2011; Scurlock 1998). The levees currently prevent the river from meandering across most of the natural floodplain. Within the levees, the stream bank has been stabilized to limit the movement of the active channel. Cochiti Dam, located at the north end of the Middle Rio Grande, has reduced the magnitude of peak flows, but releases from the dam have maintained the seasonal timing of fluctuations (Braun et al. 2015). During years of low runoff, large stretches of the channel become dry as water is diverted for irrigation. 
In years with heavy runoff, flood pulses, released from Cochiti Dam, inundate some portions of the area between the levees.

\section{Effects on Riparian Trees}

Prior to extensive regulation, riparian forests and herbaceous wetlands were scattered throughout the Middle Rio Grande floodplain in a variety of age classes and seral states (Whitney 1996). Midcentury confinement and channelization of the river led to the establishment of Rio Grande cottonwood bosque that is now sandwiched between the stream channel and the levees. During this time, herbaceous wetlands were lost due to the lowering of water tables and the cessation of channel migration (Crawford et al. 1993). Russian olive, saltcedar, and other nonnative woody species have been in the Middle Rio Grande Basin since the 1930s or earlier and are established throughout the bosque (Scurlock 1998). In terms of stem density, saltcedar is now the numerically dominant woody species in the bosque, followed by cottonwood and Russian olive (figure 3d, Smith and Finch 2014). Cottonwoods and other native trees may die during periods of low precipitation and runoff when depth to groundwater increases (Smith et al. 2009b).

As a result of modification and invasives, composition and arrangement of riparian vegetation are very different from conditions prior to Euro-American settlement. Native and nonnative species now grow in narrow, dense stands that extend from Cochiti Dam to Elephant Butte Reservoir. Without management intervention, flood magnitude is not great enough to scour the forest floor of woody vegetation and deposit sediment for establishment of hydroriparian species. In response, cottonwoods and Goodding's willows may be replaced by nonnative trees in the coming decades (Howe and Knopf 1991; Molles et al. 1998).

\section{Historical/Current Wildfire Effects}

As the role of flooding has diminished along the Middle Rio Grande, wildfire has grown from a minor component of the disturbance regime to an increasingly important influence on plants and animals (Crawford et al. 1993; Finch et al. 2006; Stuever et al. 1995; Williams et al. 2007; Bess et al. 2002). Most fires that enter the bosque are accidentally ignited and burn with mixed intensity until they are contained by firefighting crews. The number of ignitions increases with proximity to larger towns and cities, but the size of fires increases with distance from these areas (Williams et al. 2007). Most fires occur in the dry spring and early summer period and the number of fires tends to be greater during years with low precipitation (Stuever et al. 1995). Since the beginning of a long-term drought in 2000, at least 40 percent of a 732-ha study area has burned and some portions have burned multiple times (Smith and Finch 2017). With the lack of high-magnitude flooding, the bosque has accumulated large quantities of litter and woody debris. Nonnative plant species, especially Russian olive and saltcedar, have spread as soil moisture declined, increasing the density of woody plants in the understory (Bateman et al. 2008). These fuels, combined with the spatial arrangement of the forest, have contributed to increasing fire sizes and intensities that are likely outside the natural range of variability in the Middle Rio Grande (Bateman et al. 2008; Ellis 2001; Johnson and Merritt 2009). 


\section{Response of Woody Plants to Wildfire}

Several studies have examined responses of native and nonnative woody vegetation to wildfire in the Middle Rio Grande. Results are varied, indicating that spatial and temporal factors interact with fire in shaping riparian forest composition. Several patterns, however, have emerged with the response of cottonwood and other woody plants.

Cottonwoods are extremely vulnerable to topkill from fires that enter the bosque (table 1). Most, if not all, above-ground mortality occurs immediately after fire. In areas where fire severity is high (all organic matter is consumed on the forest floor), all cottonwoods and other woody species are top-killed. Topkill rates are lower for trees in areas burned with moderate severity ( 78 to 100 percent of trees killed) and light severity (52 to 70 percent of trees killed) (Ellis 2001; Stuever 1997). Managed flooding and mechanical fuel reduction can increase resistance to topkill of cottonwood, but only to a limited extent given their high vulnerability to fire and the difficulty of removing all sources of fuel from the understory (Ellis 2001; Johnson and Merritt 2009). Woody riparian plants recover vegetatively from wildfire through production of basal sprouts, root suckers, and (in the case of cottonwoods) epicormic sprouts. Their production and survival, however, vary among species and study sites (Ellis 2001; Smith et al. 2009b). We observed epicormic sprouting of cottonwoods only at one site that burned with light to moderate severity.

We observed postfire germination of cottonwoods at a site burned in March of 2008 and partially flooded in June of that year. Ellis (2001) also observed saplings in postwildfire sites along the Middle Rio Grande that were flooded within 2 years of being burned. A combination of fire and low-magnitude flooding can therefore act as a replacement for high-magnitude flooding along this heavily regulated stream.

\section{Ecosystem Implications of the Current Disturbance Regime}

Despite its highly regulated state, the Middle Rio Grande supports a unique assemblage of wildlife species. In unburned portions of the bosque, large cottonwoods provide nest sites, shelter, and food for reptiles, birds, and mammals (Finch et al. 2006; Smith and Finch 2014; Smith et al. 2006). Cavities in cottonwood snags and broken branches of live cottonwoods are used for nesting and roosting sites. Smaller woody plants, including Russian olive and saltcedar, provide resources such as nest sites for birds in the shrub and subcanopy nesting guilds (Finch et al. 2006; Smith and Finch 2014; Smith

Table 1-Estimates of top-kill and basal sprouting rates at four sites along the Middle Rio Grande. The San Pedro burn sites were measured by Ellis (2001) in 1996. We measured the 3-4-6 and Sevilleta burn sites in 2013.

\begin{tabular}{|c|c|c|c|c|c|c|c|c|}
\hline & \multicolumn{4}{|c|}{ Topkill } & \multicolumn{4}{|c|}{ Basal sprouting } \\
\hline & $\begin{array}{c}\text { San Pedro } \\
\text { Burn } 1 \\
(1996)\end{array}$ & $\begin{array}{c}\text { San Pedro } \\
\text { Burn } 2 \\
(1996)\end{array}$ & $\begin{array}{c}\text { 3-4-6 } \\
\text { Burn } \\
(2011)\end{array}$ & $\begin{array}{c}\text { Sevilleta } \\
\text { Burn } \\
(2011)\end{array}$ & $\begin{array}{c}\text { San Pedro } \\
\text { Burn } 1 \\
(1996)\end{array}$ & $\begin{array}{c}\text { San Pedro } \\
\text { Burn } 2 \\
(1996)\end{array}$ & $\begin{array}{c}\text { 3-4-6 } \\
\text { Burn } \\
(2011)\end{array}$ & $\begin{array}{c}\text { Sevilleta } \\
\text { Burn } \\
(2011)\end{array}$ \\
\hline Cottonwood & 100 & 97.7 & 100 & 95 & 77 & 81 & 21.2 & 56.8 \\
\hline Saltcedar & 100 & 100 & 95 & NA & 53 & 55 & 84.9 & NA \\
\hline Russian olive & NA & NA & 97 & 100 & NA & NA & 85.7 & 75.7 \\
\hline
\end{tabular}


et al. 2009a). Wildfire removes cottonwood canopy, creates snags and fallen debris, and induces resprouting of woody plants, especially saltcedar. These changes to forest structure and composition create habitat features used by many animal species, but make the bosque unsuitable for others (Smith et al. 2007, 2012). As postfire succession occurs, density of canopy-dependent species will decline if cottonwoods do not recover. In addition, cavity-associated species will lose nest and roosting sites if fallen snags are not replaced by mature trees.

Under the current disturbance regime, mortality of large riparian trees will continue to increase due to wildfire, drought, and senescence (Smith and Finch 2015). Vegetative and sexual reproduction of cottonwood and other native trees may occur under certain circumstances, such as fire and flood events and management intervention that are limited in spatial scale (Howe and Knopf 1991). Nonnative woody species, such as Russian olive and saltcedar, are present throughout the Middle Rio Grande and will likely increase in abundance as cottonwood declines. With high densities of mesoriparian and xeroriparian growth, postwildfire sites are vulnerable to additional high-severity fires and may enter a positive feedback loop, to the detriment of native hydroriparian species (Drus 2013). Postwildfire replacement of cottonwood by Russian olive and saltcedar will change the structure of the Middle Rio Grande riparian forest by increasing the density of low-stature vegetation and decreasing canopy height, in turn affecting habitat quality for wildlife, including riparian-nesting birds.

\section{Implications of Climate Change}

Projected effects of climate change are particularly severe in the Southwest (Gutzler and Robbins 2011; Seager et al. 2007). Increasing temperatures and changes in precipitation will affect characteristics of streams, which in turn shape aridland riparian ecosystems (Seager et al. 2013) and their capacity to support wildlife (Friggens and Finch 2015). For example, global climate models predict that, in the Rio Grande Basin, increasing temperatures will result in decreased snowpack, decreased runoff, and earlier peak discharge (fig. 6). Such changes could further limit reproduction of cottonwoods and willows, increase drought mortality, and decrease their ability to recovery from wildfires relative to Russian olive and saltcedar (Smith et al. 2009b). In addition, storms such as those during monsoons may gain strength in response to warming. Resulting floods could induce late summer germination of mesoriparian and xeroriparian species, to the exclusion of species with narrower windows of seed viability (Dewine and Cooper 2007; Fenner et al. 1985; Katz and Shafroth 2003). Replacement of hydroriparian species by mesoriparian and xeroriparian species would have cascading effects on the riparian forest community.

\section{Conclusions: Disturbance Change and the Future of Aridland Riparian Forests}

Studies of woody riparian plants show that effects of disturbances on survival and reproduction vary among species. As our Middle Rio Grande study shows, native hydroriparian pioneer species are vulnerable to changes in streamflow, which, coupled with wildfire effects, could open doors to invasion by xeroriparian and upland species. As with other aridland rivers, the Middle Rio Grande has created an extensive riparian 

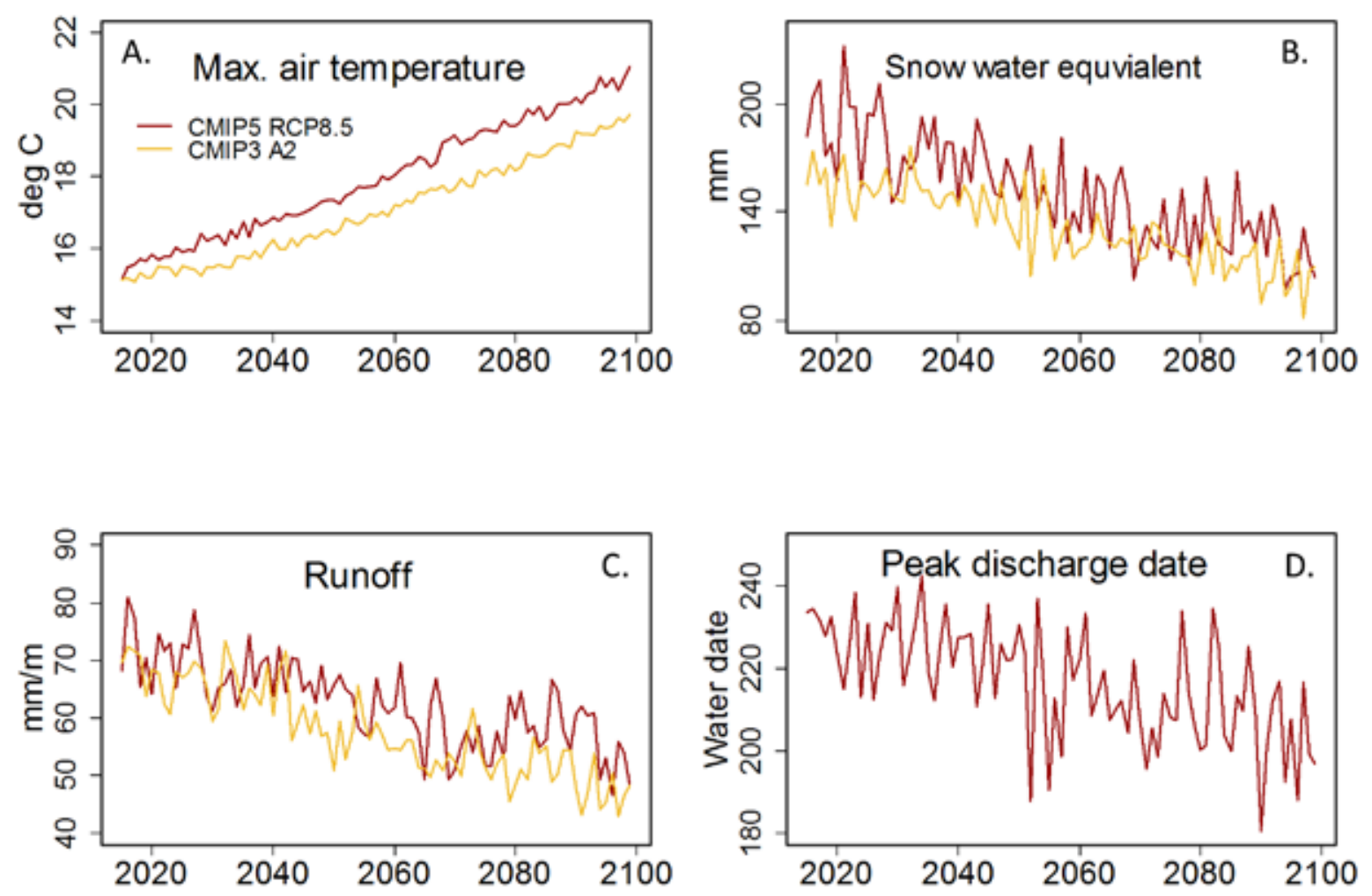

Figure 6-Temperature and hydrological projections for the Rio Grande Basin. Boxes A-C contain projections by 29 models run under the CMIP5 RCP8.5 scenario and 16 models run under the CMIP3 A2 scenario. Box D contains projections of peak discharge date for the Rio Grande at Otowi from 15 models run under the CMIP3 A2 scenario. Projections were made by the U.S. Bureau of Reclamation and are available online (http://gdodcp.ucllnl.org/downscaled_cmip_projections/dcplnterface.html).

corridor critical to the successful migration, reproduction, and overwintering of myriad wildlife species (Carothers et al. 1974; Knopf and Sampson 1994; Bateman et al. 2008). Maintaining the composition of these corridors is necessary to preserve both regional and continental biodiversity.

During the previous decades of riparian research, ecologists have highlighted the importance of woody riparian vegetation to wildlife and have described the response to changes in hydrology. For most riparian taxa, however, response to wildfire, especially in combination with drought, is poorly known or has been examined in only a few locations. As climate changes and wildfire becomes more frequent than flooding, information on how fire, drought, and climate change affect riparian vegetation will be critical for managers in maintaining ecosystem structure and stability, wildlife habitat, and the associated animal populations and communities. Because riparian dynamics, including recovery from wildfire, are coupled with hydrology of regulated streams, we need hydrological projections that incorporate future water use and climate change scenarios. With this information, we can determine which species of plants will naturally sustain themselves and which will require adaptive management in an increasingly arid Southwest. 


\section{Acknowledgments}

We appreciate input from Megan Friggens and comments from multiple reviewers. Funding for this work was provided by the Desert and Southern Rockies Landscape Conservation Cooperatives and the USDA Forest Service Rocky Mountain Research Station.

\section{References}

Bateman, H.L.; Chung-MacCoubrey, A.; Finch, D.M.; [et al.]. 2008. Impacts of non-native plant removal on vertebrates along the Middle Rio Grande (New Mexico). Ecological Restoration. 26: $193-195$.

Beauchamp, V.B.; Stromberg, J.C. 2007. Flow regulation of the Verde River, Arizona encourages Tamarix recruitment but has minimal effect on Populus and Salix stand density. Wetlands. 27(2): 381-389.

Bess, E.C.; Parmenter, R.R.; Mccoy, S.; [et al.]. 2002. Responses of a riparian forestfloor arthropod community to wildfire in the middle Rio Grande Valley, New Mexico. Environmental Entomology. 31: 774-784.

Bhattacharjee, J.; Taylor, J.P.; Smith, L.M. 2006. Controlled flooding and staged drawdown for restoration of native cottonwoods in the Rio Grande Valley, New Mexico. Wetlands. 26: 691-702.

Birken, A.S.; Cooper, D.J. 2006. Processes of Tamarix invasion and floodplain development along the lower Green River, Utah. Ecological applications. 16(3): 1103-1120.

Blydenstein, J. 1957. The survival of velvet mesquite (Prosopis juliflora var. velutina) after fire. Journal of Range Management. 10: 221-223.

Bock, C.E.; Bock, J.H. 1984. Importance of sycamores to riparian birds in southeastern Arizona. Journal of Field Ornithology. 55: 97-103.

Bock, C.E.; Bock, J.H. 2014. Effects of wildfire on riparian trees in southeastern Arizona. Southwestern Naturalist. 59: 568-574.

Bock, J.H.; Bock, C.E. 1989. Factors limiting sexual reproduction in Platanus wrightii in southeastern Arizona. Aliso. 12: 295-301.

Braatne, J.H.; Rood, S.B.; Heilman, P.E. 1996. Life history, ecology, and conservation of riparian cottonwoods in North America. In: Stettler, R.F., Bradshaw, H.D., Jr.; Heilman, P.E.; [et al.], eds. Biology of Populus and its implications for management and conservation. Ottawa, Ontario, Canada: National Research Council of Canada: 57-85.

Braun, C.L.; Pearson, D.K.; Porter, M.D.; [et al.]. 2015. Physical characteristics and fish assemblage composition at site and mesohabitat scales over a range of streamflows in the Middle Rio Grande, New Mexico, winter 2011-12, summer 2012. Scientific Investigations Report 2015-5025. Reston, VA; U.S. Department of the Interior, U.S. Geological Survey. $90 \mathrm{p}$.

Brodhead, K.M.; Stoleson, S.H.; Finch, D.M. 2007. Southwestern willow flycatchers (Empidonax traillii extimus) in a grazed landscape: Factors affecting brood parasitism. Auk. 124: $1213-1228$.

Busch, D.E.; Smith, S.D. 1995. Mechanisms associated with decline of woody species in riparian ecosystems of the southwestern U.S. Ecological Monographs. 65: 347-350.

Carothers, S.W.; Johnson, R.R.; Atchison, S.W. 1974. Population structure and social organization of southwestern riparian birds. American Zoologist. 14: 97-108.

Cleverly, J.R.; Smith, S.D.; Sala, A.; Devitt, D.A. 1997. Invasive capacity of Tamarisk ramosissima in a Mojave Desert floodplain: The role of drought. Oecologia. 111: 12-18.

Coble, A.P.; Kolb, T.E. 2012. Riparian tree growth response to drought and altered streamflow along the Dolores River, Colorado. Western Journal of Applied Forestry. 27: 205-211. 
Coble, A.P.; Kolb, T.E. 2013. Native riparian tree establishment along the regulated Dolores River, Colorado. Western North American Naturalist. 73: 41-53.

Crawford, C.S.; Cully, A.C.; Leutheuser, R.; [et al.]. 1993. Middle Rio Grande ecosystem: Bosque biological management plan. Albuquerque, NM: University of New Mexico, Center for Southwest Research.

Dewine, J.M.; Cooper, D.J. 2007. Effects of river regulation on riparian box elder (Acer negundo) forests in canyons of the upper Colorado River basin, USA. Wetlands. 27: 278-289.

Dewine, J.M.; Cooper, D.J. 2008. Canopy shade and the successional replacement of tamarisk by native boxelder. Journal of Applied Ecology. 45: 505-514.

Drus, G.M. 2013. Tamarisk (Tamarix spp.) and desert riparian ecosystem change. Dissertation. Santa Barbara, CA: University of California, Santa Barbara. 189 p.

Ellis, L.M. 2001. Short-term response of woody plants to fire in a Rio Grande riparian forest, central New Mexico, U.S.A. Biological Conservation. 97: 159-170.

Fenner, P.; Brady, W.W.; Patten, D.R. 1985. Effects of regulated water flows on regeneration of Fremont cottonwood. Journal of Range Management. 38: 135-138.

Finch, D.M.; Galloway, J.; Hawksworth, D. 2006. Monitoring bird populations in relation to fuel loads and fuel treatments in riparian woodlands with tamarisk and Russian olive understories. In: Aguirre-Bravo, C.; Pellicane, P.J.; Burns, D.P.; [et al.], eds. Monitoring science and technology symposium: Unifying knowledge for sustainability in the Western Hemisphere. Proceedings RMRS-P-42CD. Fort Collins, CO: U.S. Department of Agriculture, Forest Service, Rocky Mountain Research Station: 113-120.

Friedman, J.M.; Auble, G.T. 1999. Mortality of riparian boxelder from sediment mobilization and extended inundation. Regulated Rivers: Research \& Management. 15: 463-476.

Friggens, M.M.; Finch, D.M. 2015. Implications of climate change for bird conservation in the southwestern U.S. under three alternative futures. PLoS ONE 10: e0144089.

Friggens, M.M.; Finch, D.M.; Bagne, K.E.; [et al.]. 2013. Vulnerability of species to climate change in the Southwest: Terrestrial species of the Middle Rio Grande. Gen. Tech. Rep. RMRS-GTR-306. Fort Collins, CO: U.S. Department of Agriculture, Forest Service, Rocky Mountain Research Station. 191 p.

Gutzler, D.S. 2013. Regional climatic considerations for borderlands sustainability. Ecosphere. 4: $1-12$.

Gutzler, D.S.; Robbins, T.O. 2011. Climate variability and expected change in the western United States: Regional downscaling and drought statistics. Climate Dynamics. 37: 835-849.

Horton, J.L.; Clark, J.L. 2001. Water table decline alters growth and survival of Salix gooddingii and Tamarix chinensis seedlings. Forest Ecology and Management. 40(2): 239-247.

Horton, J.L.; Kolb, T.E.; Hart, S.C. 2001a. Physiological response to groundwater depth among species and with river flow regulation. Ecological Applications. 11: 1046-1059.

Horton, J.L.; Kolb, T.E.; Hart, S.C. 2001b. Responses of riparian trees to interannual variation in ground water depth in a semi-arid river basin. Plant, Cell and Environment. 24: 293-304.

Howe, W.H.; Knopf, F.L. 1991. On the imminent decline of Rio Grande cottonwoods in central New Mexico. Southwestern Naturalist. 36: 218-224.

Johnson B.; Merritt, D. 2009. The effects of wildfire on native tree species in the Middle Rio Grande bosques of New Mexico. Fort, Collins. CO: Colorado State University. 43 p.

Katz, G.L.; Shafroth, P.B. 2003. Biology, ecology, and management of Elaeagnus angustifolia (Russian olive) in western North America. Wetlands. 23: 763-777.

Knopf, F.L., Sampson, F.B. 1994. Scale perspectives on avian diversity in western riparian ecosystems. Conservation Biology. 8: 669-676.

Kolb, T.E.; Hart, S.C.; Amundson, R. 1997. Boxelder water sources and physiology at perennial and ephemeral stream sites in Arizona. Tree Physiology. 17: 151-160.

Lite, S.J.; Stromberg, J. 2005. Surface water and ground-water thresholds for maintaining Populus-Salix forests, San Pedro River, Arizona. Biological Conservation. 125: 153-167. 
Mahoney, J.M.; Rood, S.B. 1998. Streamflow requirements for cottonwood seedling recruitmentan integrative model. Wetlands. 18: 634-645.

Merritt, D.M.; Poff, N.L.R. 2010. Shifting dominance of riparian Populus and Tamarix along gradients of flow alteration in western North American rivers. Ecological Applications. 20: $135-152$.

Minkley, W.L.; Clark, T.O. 1984. Formation and destruction of a Gila River mesquite bosque community. Desert Plants 6: 23-29.

Molles, M.C., Jr; Crawford, C.S.; Ellis, L.M.; [et al.]. 1998. Managed flooding for riparian ecosystem restoration. Bioscience. 48: 749-756.

Phillips, F.M.; Hall, G.E.; Black, M.E. 2011. Reining in the Rio Grande: People, land, and water. Albuquerque, NM: University of New Mexico Press. 256 p.

Rood, S.B.; Goater, L.A.; Mahoney, J.M.; [et al.] 2007. Floods, fire, and ice: Disturbance ecology of riparian cottonwoods. Canadian Journal of Botany. 85: 1019-1032.

Scurlock, D. 1998. From the Rio to the Sierra: An environmental history of the Middle Rio Grande Basin. Gen. Tech. Rep. RMRS-GTR-5. Fort Collins, Colorado: U.S. Department of Agriculture, Forest Service, Rocky Mountain Research Station. 440 p.

Seager, R.M.; Ting, I.; Held, Y.; [et al.]. 2007. Model projections of an imminent transition to a more arid climate in southwestern North America. Science. 316: 1181-1184.

Seager, R.; Ting, M.; Li, C.; [et al.]. 2013. Projections of declining surface water availability in the southwestern United States. Nature Climate Change. 3: 482-486.

Shafroth, P.B.; Stromberg, J.C.; Patten, D.T. 2002. Riparian vegetation response to altered disturbance and stress regimes. Ecological Applications. 12: 107-123.

Smith, D.M.; Finch, D.M. 2014. Use of native and nonnative nest plants by riparian-nesting birds along two streams in New Mexico. River Research and Applications 30: 1134-1145.

Smith, D.M.; Finch, D.M. 2015. Modeling woody plant regeneration and woody debris accumulation under future streamflow and wildfire scenarios in semi-arid riparian ecosystems. Final performance report for interagency agreement R12PG80470. Washington, DC: U.S. Bureau of Reclamation, Desert and Southern Rockies Landscape Conservation. 72 p.

Smith, D.M.; Finch, D.M. 2017. Climate change and wildfire effects in aridland riparian ecosystems: An examination of current and future conditions. Gen. Tech. Rep. RMRS-GTR364. Fort Collins, CO: U.S. Department of Agriculture, Forest Service, Rocky Mountain Research Station. 65 p. https://www.treesearch.fs.fed.us/pubs/54331

Smith, D.M.; Finch, D.M.; Gunning, C.; [et al.]. 2009b. Post-wildfire recovery of riparian vegetation during a period of water scarcity in the southwestern U.S. Fire Ecology. 5: 38-55.

Smith, D.M., Finch, D.M., Hawksworth, D.L. 2009a. Black-chinned hummingbird nest-site selection and nest survival in response to fuel reduction in a southwestern riparian forest. Condor. 111: 641-652.

Smith, D.M.; Finch, D.M.; Hawksworth, D.L. 2012. Nesting characteristics of mourning doves in central New Mexico: Response to riparian forest change. Journal of Wildlife Management. 76: $382-390$.

Smith, D.M.; Kelly, J.F.; Finch, D.M. 2006. Cicada emergence in southwestern riparian forest: Influences of wildfire and vegetation composition. Ecological Applications. 16: 1608-1618.

Smith, D.M.; Kelly, J.F.; Finch, D.M. 2007. Avian nest box selection and nest success in burned and unburned southwestern riparian forest. Journal of Wildlife Management. 71: 411-421.

Snyder, K.A.; Williams, D.G. 2000. Water sources used by riparian trees varies among stream types on the San Pedro River, Arizona. Journal of Agricultural and Forest Meteorology. 105: $227-240$.

Stevens L.E.; Siemion G. 2012. Tamarisk reproductive phenology and Colorado River hydrography, Southwestern USA. Journal of the Arizona-Nevada Academy of Science. 44: $46-58$.

Stoleson, S.H.; Finch, D.M. 2003. Microhabitat use by breeding southwestern willow flycatchers on the Gila River, New Mexico. Studies in Avian Biology. 26: 91-95. 
Stromberg, J.C. 1993. Riparian mesquite forests: A review of their ecology, threats, and recovery potential. Journal of the Arizona-Nevada Academy of Science 27: 111-124.

Stromberg, J.C. 1997. Growth and survivorship of Fremont cottonwood, Goodding Willow, and saltcedar seedlings after large floods in Arizona. Great Basin Naturalist. 57: 198-208.

Stromberg, J.C. 2001a. Influence of stream flow regime and temperature on growth rate of the riparian tree, Platanus wrightii, in Arizona. Freshwater Biology. 46: 227-239.

Stromberg, J.C. 2001b. Biotic integrity of Platanus wrightii riparian forests in Arizona: First approximation. Forest Ecology and Management. 142: 251-266.

Stromberg, J.C. 2002. Flood flows and population dynamics of Arizona sycamore (Platanus wrightii). Western North American Naturalist. 62: 170-187.

Stromberg, J.C.; Merritt, D.M. 2015. Riparian plant guilds of ephemeral, intermittent and perennial rivers. Freshwater Biology 61: 1259-1275.

Stromberg, J.C.; Rychener, T.J. 2010. Effects of fire on riparian forests along a free-flowing dryland river. Wetlands 30: 75-86.

Stromberg, J.C.; Beuchamp, V.B.; Dixon, M.D.; [et al.]. 2007. Importance of low-flow and highflow characteristics to restoration of riparian vegetation along rivers in arid south-western United States. Freshwater Biology. 52: 651-679.

Stuever, M.C. 1997. Fire induced mortality of Rio Grande cottonwood. Thesis. Albuquerque, NM: University of New Mexico. $170 \mathrm{p}$.

Stuever, M.C.; Crawford, C.S.; Molles, M.C.; [et al.]. 1995. Initial assessment of the role of fire in the middle Rio Grande Bosque. In: Greenlee, J.M., ed. Proceedings: First conference on fire effects on rare and endangered species and habitats; 1995 November 13-15; Coeur d'Alene, ID. Coeur d'Alene, ID: International Association of Wildland Fire: 275-283.

Summitt, A.R. 2013. Contested waters: An environmental history of the Colorado River. Boulder, CO: University Press of Colorado. 248 p.

Webb, R.H.; Leake, S.A. 2006. Ground-water surface-water interactions and long-term change in riverine riparian vegetation in the southwestern United States. Journal of Hydrology. 320: 302-323.

Webb, R.H.; Leake, S.A.; Turner, R.M. 2007. The ribbon of green: Change in riparian vegetation on the southwestern United States. Tucson, AZ: University of Arizona Press. 480 p.

Whitney, J.C. 1996. The Middle Rio Grande: Its ecology and management. In: Shaw, D.W.; Finch, D.M., tech. cords. Desired future conditions for Southwestern riparian ecosystems: Bridging interests and concerns together; 1995 September 18-22; Albuquerque, NM. Gen. Tech. Rep. RM-GTR-272. Fort Collins, CO: US Department of Agriculture, Forest Service, Rocky Mountain Forest and Range Experiment Station: 281-283.

Williams, V.; David, P.; Fluder, J.J., III. 2007. Middle Rio Grande bosque community wildfire protection plan. Albuquerque, NM: SWCA Environmental Consultants. 


\title{
Chapter 4. Invasion and Restoration of Western Rivers Dominated by Tamarix spp.
}

\author{
Hisham N. El Waer, Annie Henry, Katie Merewether, and Anna A. Sher
}

\section{Introduction}

Scientists, land managers, government, and private institutions in the United States have given much attention to invasive control and restoration projects along western rivers; in the West, removal of Tamarix spp. (tamarisk, saltcedar) has been a primary focus of these projects (Dennison et al. 2009; González et al. 2017a; Harms and Hiebert 2006; Shafroth et al. 2008). These trees were first introduced to North America during the 1800s from Eurasia mainly to decrease erosion, to be wind breaks, and to slow down water flow in riparian and agriculture areas (DiTomaso 1998). Since that time, this invasive tree has become the third most common woody species and second highest tree cover in the southwestern United States (Friedman et al. 2005). Despite the fact that invasive plant species removal has long been a priority in restoration of riparian ecosystems (González et al. 2015), we are only beginning to understand the ecological impact of the removal of invasive species from such ecosystems. Here we will provide an overview of Tamarix ecology along rivers in the western United States and the results of our research monitoring plant communities in 25 riparian sites over 3 years, with a particular interest in the results of removal of Tamarix by various methods including biological control by a defoliating beetle.

\section{Tamarix Introduction and Impact}

During the 1800s, eight species of Tamarix were first introduced to the United States from Europe, Asia, and North Africa. In the 1920s, Tamarix spread and occupied about 4,000 ha of riparian habitat in the southwestern United States. By 1987, the area invaded by Tamarix increased to about 600,000 ha (Brock 1994; DiTomaso 1998; Gaskin and Schaal 2002; McDaniel et al. 2005; Nagler et al. 2011) and it now occupies approximately 800,000 ha. The most widely naturalized species are Tamarix ramosissima, Tamarix chinensis, and their hybrid (Friedman et al. 2005; Gaskin and Schaal 2002).

Tamarix is classified as deciduous with either a tree or shrub growth habit. It is also a paradoxical plant from the selection theory perspective as it uses both $\mathrm{r}$ and $\mathrm{K}$ strategies (sensu McArthur and Wilson 1967) with both a large number of offspring and high longevity (Sher 2013). Tamarix individuals can live for more than 100 years, and one large tree produces about 500,000 seeds per year (McDaniel et al. 2005; Stromberg et al. 2007b). It is highly tolerant of drought; its evapotranspiration rates are highly variable and adaptable to water availability, and as a facultative phreatophyte, uses both surface and ground water (Glen and Nagler 2005). Its deep roots can reach declining water tables when other species cannot (Shafroth et al. 2000). Tamarix also has adaptations that allow it to tolerate greater salinities than native vegetation (Shafroth et al. 
1995). Together, these traits have allowed Tamarix to take advantage of the environmental stresses associated with dammed rivers (Sher 2013; Stromberg et al. 2007b).

Under natural river flow conditions, native cottonwoods (Populus spp.) are typically competitive over invasive Tamarix (Huston 2004; Sher et al. 2000, 2002; Stromberg et al. 2007a), suggesting that Tamarix would not thrive under natural conditions. Rather, as a result of widespread flow control, many riparian ecosystems of the Southwest no longer support native vegetation, allowing Tamarix to dominate (Sher 2013).

Thus, Tamarix dominance is the result of ecosystem change, but it can also be the cause (passenger vs. driver, sensu MacDougall and Turkington 2005; Johnson 2013). Like many invasive species, once Tamarix establishes it can also alter the ecosystems in which it occurs, increasing fire risk (Drus 2013), changing the morphology of the stream bank (Auerbach et al. 2013), and increasing the soil salinity (Ohrtman et al. 2012), among other effects (Didham et al. 2005; Johnson 2013; Sher 2006). Such changes add to the inhospitable quality of the riparian area following river flow regulation to native plant communities.

All of these environmental changes mean that Tamarix-dominated stands are associated with lower diversity in plant and animal communities (Sher 2013), making Tamarix removal a high priority for many private and public institutions, despite its considerable cost (de Wall 1994; Zavaleta 2001). However, the dual role of Tamarix as both ecosystem passenger and driver has profound implications for restoration (Bauer 2012). As a driver of ecosystem change, removing Tamarix should solve many of the concerns for conserving riparian areas. No doubt, this was the perspective of early aims to remove Tamarix (see Chapter 1). However, as a passenger of ecosystem change, its removal alone should affect no positive change; recent research suggests at least in some cases without natural flow regimes, native riparian vegetation cannot reestablish (González et al. 2017a; Merritt and Poff 2010). Furthermore, some changes that Tamarix make to riparian ecosystems are difficult to reverse simply by removing Tamarix itself, such as soil salinization (Merritt and Shafroth 2012). Thus it is imperative that we carefully monitor the ecological consequences of Tamarix removal projects.

Since Tamarix removal sites are not selected randomly, monitoring at a single point in time or combining sites with different periods of time since Tamarix removal can prove misleading. Variables such as weather patterns (e.g., dry year coinciding with single time monitoring) or variation in time since removal can confound analyses and lead to misinterpretation of results. Multiple years must therefore be sampled to determine whether patterns of recovery are real or a product of confounding variables such as years since removal, drought years, or flood events at a particular location in a particular year. Because of variability associated with geographic location, it is also imperative that sites of the same age but different treatments be sampled at the same time. Rarely have both been done in a single project.

\section{Vegetation Response to Tamarix Removal}

While invasive plant species removal has long been a priority in the restoration of river systems, relatively little is understood about the ecological impact of the removal of invasive species from the ecosystem (Bay and Sher 2008; Cuevas and Zalba 2010; Ostoja et al. 2014; Shafroth et al. 2005). Previous research on plant community response 
to Tamarix removal is mixed. Harms and Hiebert (2006) surveyed 33 Tamarix removal and non-removal sites where only passive revegetation had been done. They found a decrease in the cover of invasive Tamarix compared to the control sites and a significant increase in native foliar cover in the Mojave region.

However, there was no consistent change in native cover in the two other regions sampled, and when Tamarix was excluded from data analysis, they found no difference regarding species composition across all sites. In contrast, in a similar study but with active revegetation, Bay and Sher (2008) found increases in native cover after tamarisk removal could be explained by several factors, including that the relative cover of planted or native species was greater in the sites when the removal period was greater than 8 years, when there was lower salinity, when there was coarser soil texture, and when closer to a body of water. More recently, Ostoja et al. (2014) examined short-term responses of riparian plant communities to Tamarix removal. They found increased species richness and diversity, but still very low absolute diversity and abundance of native species. Most of these studies did not control for the number of years since Tamarix removal and did not follow the same sites over time. Furthermore, none examined the response of plant communities to Tamarix control using the biological control agent, Diorhabda spp.

Diorhabda spp. is a beetle herbivore that defoliates Tamarix spp. in its native range. After extensive research on host specificity, it was approved for release as a biological control agent in 2001 (DeLoach et al. 2003; also see Chapter 5). Since its release, Diorhabda has moved farther and faster than anticipated (Nagler et al. 2014). Studies so far show that its impact on Tamarix as well as riparian plant communities is variable and difficult to predict (González et al. 2017a; Hultine et al. 2015; Kennard et al. 2016).

In the largest review to date of the consequences of Tamarix removal, González et al. (2017a) compiled monitoring data for plant communities following Tamarix removal across the Southwest in 416 sites, including those with Diorhabda spp. biological control. They found that for most removal methods, native cover significantly increased following Tamarix removal, but the increases were extremely gradual, averaging less than 2 percent per year. Native cover was not consistently increased with active revegetation, and the community did not typically revert to the mesic plant species that had occurred there historically. Exotic species also increased in cover after Tamarix removal ("secondary invasion"), particularly with high disturbance treatment methods, even though exotic cover decreased over time in biocontrol treatment sites (González et al. 2017b). However, the González et al. (2017b) study amassed data from regions all over the western United States, possibly obscuring the importance of regional effects. Nowhere in the literature is there a study that compares regions that were measured at the same times in the same ways with comparable removal dates over time.

In Colorado, biocontrol beetles were released in 2005 on the Western Slope and have become nearly ubiquitous there. At the time of this study (2010-2012), the biocontrol had been released but not yet well-established on the Eastern Slope. This situation provided a unique opportunity to study the impact of Diorhabda spp. alone and in combination with other removal techniques on Tamarix cover, as well as the consequent effect on the rest of the plant community. This is one of the only studies in which multiple sites in different regions have been sampled by the same methods for multiple years 
and multiple seasons within a year, thus representing a unique opportunity to investigate the impact of Tamarix removal on plant communities.

\section{Sampling Methodologies and Invasive Removal Techniques}

We monitored vegetation response after invasive Tamarix removal in sites east and west of the Rocky Mountains in Colorado for 3 and a half years beginning in fall 2009. This project aimed to establish baseline data for long-term monitoring and to develop the best practices to make recommendations for monitoring by land managers.

Our broad interest was understanding the response of plant communities along rivers in Colorado to the removal of a dominant invasive species. Our specific questions were: (1) How do riparian plant communities differ between the Eastern and Western Slope of Colorado that may influence response to restoration? (2) Are removal methods effective in reducing percent cover of Tamarix? (3) Does it matter whether the biological control is present or not? (4) How do exotic and native plants respond to Tamarix spp. removal in each of these regions? Our intent, by measuring the impact of Tamarix removal in the ecosystem via the measurement of vegetation parameters over time, is to help answer some of the controversial questions about the ecological impact of Tamarix removal on these ecosystems, including the presence of the biological control.

\section{Methods and Site Locations}

We monitored vegetation in a total of 25 sites: nine sites in three reaches located in western Colorado (fig. 7a) and 16 sites in 5 reaches located in eastern Colorado (fig. 7b). The western sites, at approximately $38^{\circ} 1^{\prime} 0^{\prime \prime} \mathrm{N} 108^{\circ} 49^{\prime} 26^{\prime \prime} \mathrm{W}$, are located in the Upper Dolores Watershed including Big Gypsum Valley, Disappointment Valley, and Slickrock Canyon. The eastern sites, at approximately $37^{\circ} 33^{\prime} 0^{\prime \prime} \mathrm{N} 103^{\circ} 38^{\prime} 21^{\prime \prime} \mathrm{W}$, are located in the Purgatory Watershed including Chacuaco Creek, Plum Creek, and Apishapa River. These sites were mostly on private land in the East and BLM land in the west, selected by land managers for our group to survey either because they were candidates for tamarisk removal, or they represented an un-invaded ecosystem. Although they were not randomly selected, the sites represent a range of representative riparian ecosystem conditions, from degraded to fairly un-impacted. Native-dominated sites are referred to throughout this chapter as positive reference sites (González et al. 2015). The Society for Restoration International (SERI) Primer states that it is imperative to identify sites that represent the goal (positive references) of restoration (SERI 2004). Sites dominated by Tamarix where there was no active removal are referred to as negative reference sites. Active removal refers to the removal of Tamarix by the following methods: cut stump (chainsaws are used cut down Tamarix and herbicide is applied to the remaining stump); track hoe (Tamarix is removed using large machinery); or lastly, spraying herbicide by helicopter.

By employing both sampling over time and reference sites, we address potential issues of confounding time and space, referred to as a BACI approach: Before vs. After treatment (within the same site) plus Control vs. Impact (comparing sites with versus without active removal within the same point in time) (Bernhardt et al. 2007; Palmer et al. 2005). In this way, we address the shortcomings of most other studies in which results could be attributed to either time or space rather than the treatment itself. 

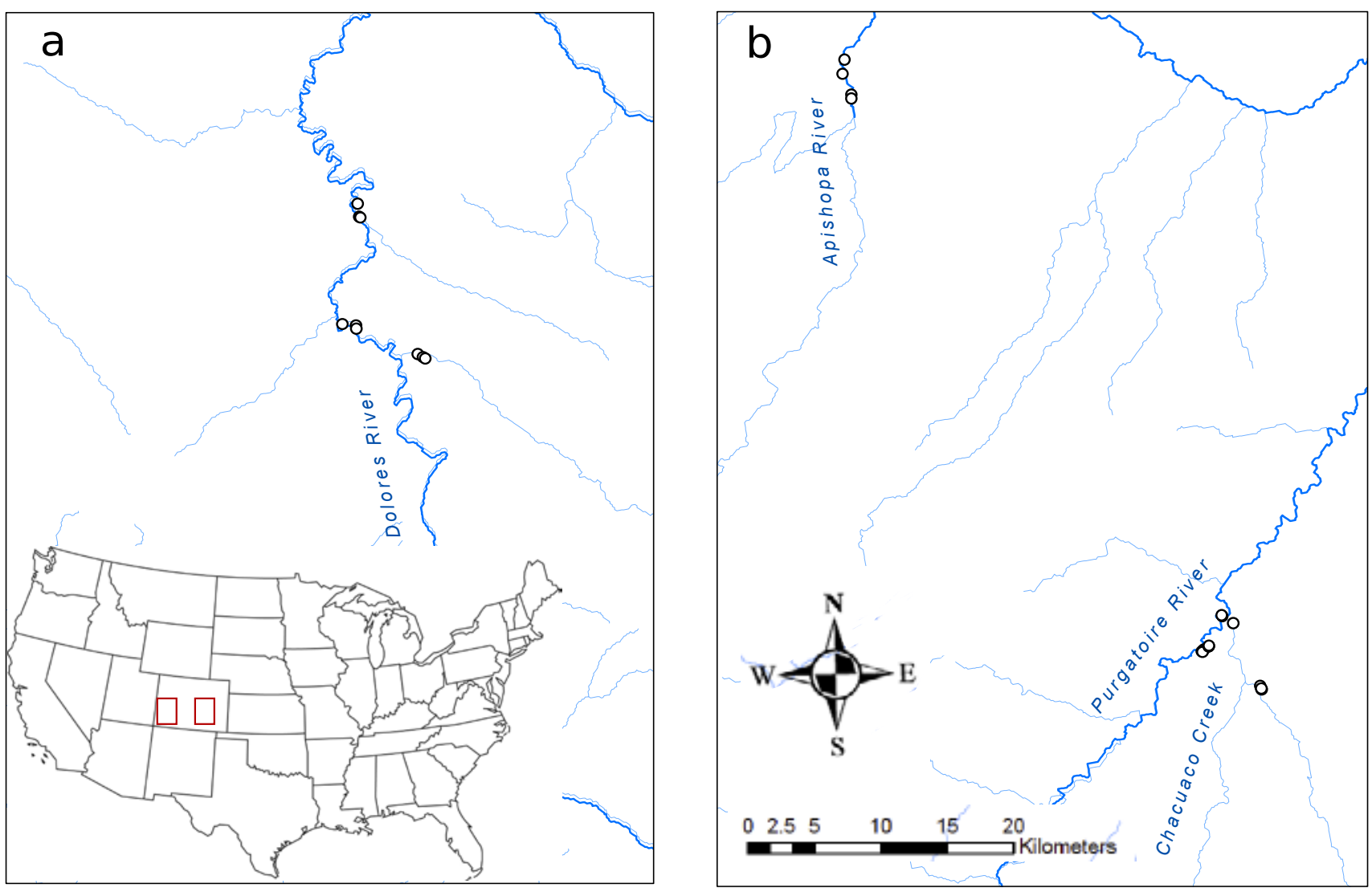

Figure 7-(a) Site locations for west slope of Colorado, a total of 9 sites. (b) Site locations for eastern plains of Colorado, a total of 16 sites (map by Annie Henry).

Within each site, a $20 \mathrm{~m} \times 50 \mathrm{~m}$ plot was established, within which five stratified random transects were established that were sampled at $10 \mathrm{~cm}$ intervals using the line point intercept method. All sites were sampled in this way in spring of 2010 and in spring and summer of 2011 and 2012. Sites in the East were also sampled in the summer of 2010. The Modified Whittaker Plot method was used to record species richness at each sampling period in each site (Stohlgren et al. 1995).

All specimens that could not be positively identified in the field were collected and taken to Denver Botanic Gardens' Kathryn Kalmbach Herbarium (KHD) for identification. A total of 412 specimens were collected by the end of the last season of data collection on August 13, 2012. Pictures were taken of all specimens and stored in a digital form to serve as a backup for the original.

Specimens were identified with the assistance of local plant experts and the following books: Colorado Flora Eastern Slope (Weber et al. 1996a), Colorado Flora Western Slope (Weber et al. 1996b), Illustrated Key to the Grasses of Colorado (Wingate 1994), Shrubs and Trees of the Southwest Uplands (Elmore 1976), and Weeds of the West (Whitson and Burrill 2000). All specimens identified by dichotomous key were doublechecked against stored reference specimens and confirmed by staff at KHD.

Digital plant databases were used to confirm current species information. Geographic distribution, plant morphology, spelling of scientific and common names, nativity status, growth habit, and plant functional group of each specimen were determined using United States Department of Agriculture Plant Database (USDA 2010), 
Colorado State University (CSU Herbarium 2001), and Southwest Environmental Information Network (SWEIN 2012).

\section{Research Findings and Implications}

\section{Regional Differences}

We identified a total of 145 different species in 45 plant families within the 25 sites from 2010-2012. The Eastern Slope sites had greater species richness than the Western Slope sites during this study period; 111 species in 41 families on the Eastern Slope compared to only 53 species in 25 families on the Western Slope. The most important families in the study area as indicated by highest numbers of species, in descending order are: (1) Poaceae-35; (2) Asteraceae-34; (3) Chenopodaceae-10; (4) Fabaceae-7; and (5) Brassicaceae-6.

The plant communities differed in composition between the two areas (fig. 8). Understory vegetation cover in western Colorado was dominated by shrubs (Ericameria nauseosa, Chrysothamnus linifolius Greene, Artemisia tridentate, Atriplex canescens, Sarcobatus vermiculatus, Forestiera pubescens, Rhus trilobata) while exotic herbaceous species (Bromus tectorum, Bromus japonicas, Kochia scoparia) dominated eastern

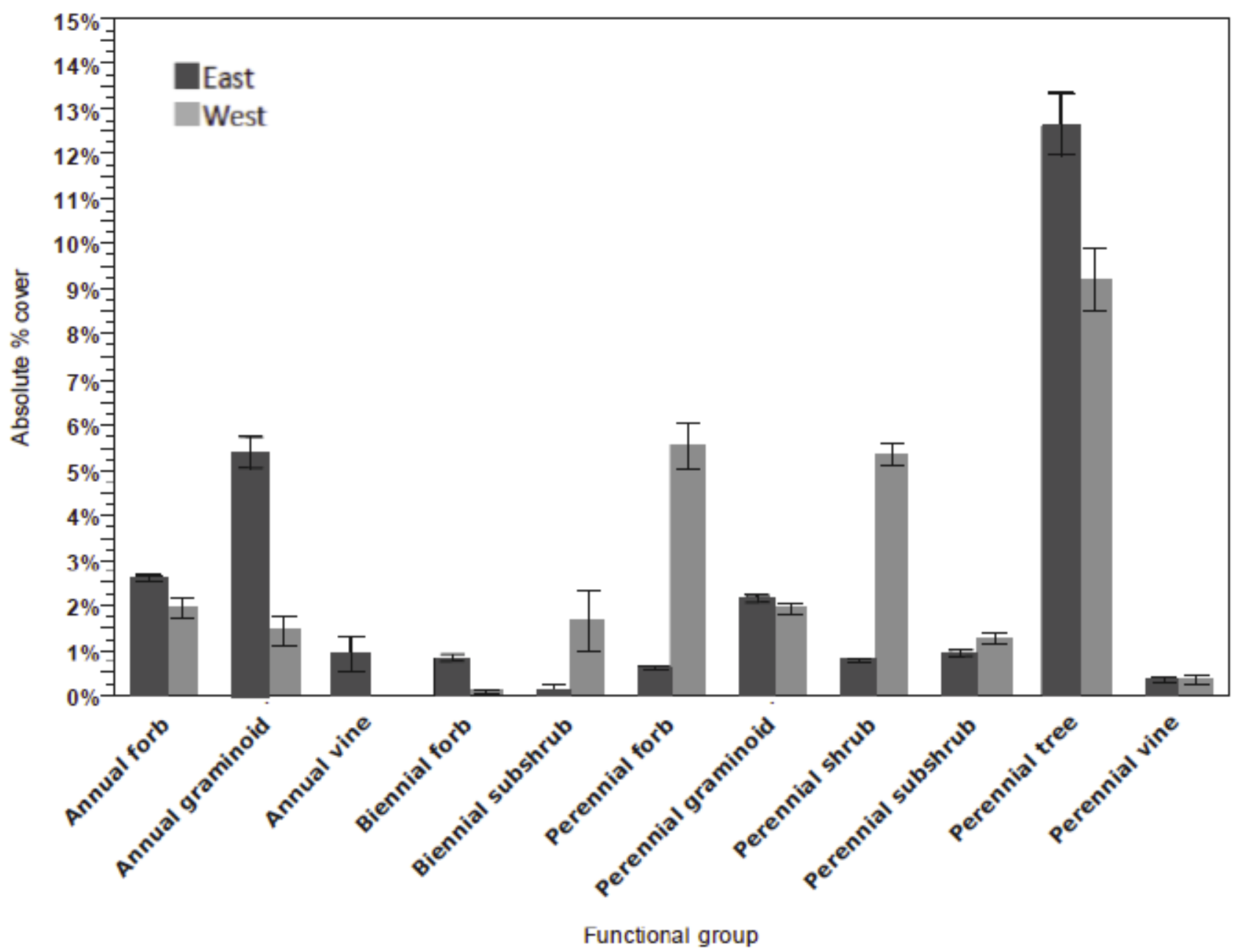

Figure 8-Mean (+/- 1 SE) cover for east and west slope sites by functional group. (Chi-square, Pearson; $N=699$, DF = 8, X2 $=26.34, P<0.0009$.) 
Colorado. With regard to trees, both regions were dominated by Tamarix spp., Populus spp., and Salix exigua, but the eastern sites also contained Juniperus scopulorum and Celtis reticulata, while in the west the only other species was Acer negundo.

The Jaccard Index of similarity indicated that there was 36 percent similarity between eastern and western sites using all vegetation types, and 50 percent similarity in tree and shrub communities. East and west sites differed significantly in frequency of different functional groups (Chi-square, Pearson; $\mathrm{N}=699, \mathrm{DF}=8, \mathrm{X} 2=26.3, \mathrm{P}<$ $0.0009)$. While there were distinct regional differences in the understory plant community by functional group, both regions had similar starting absolute cover of Tamarix at about 30 percent, and less than 10 cover percentage of native woody vegetation, as well as similar cover of understory natives and exotics.

\section{The Response of Tamarix to Removal Efforts}

There was a significant decrease in Tamarix cover after active removal with a more dramatic decrease on the Western Slope (repeated measures ANOVA, before/ after*slope: $\mathrm{F}=4.13, \mathrm{DF}=1 / 83, \mathrm{P}<0.05)$. Over time, we can see the decrease in the total absolute cover of Tamarix immediately following active removal in the spring 2011, but the trajectories differ between east and west sites after that (fig. 9). Western Slope Tamarix cover remained low, whereas Tamarix increased slightly in the eastern

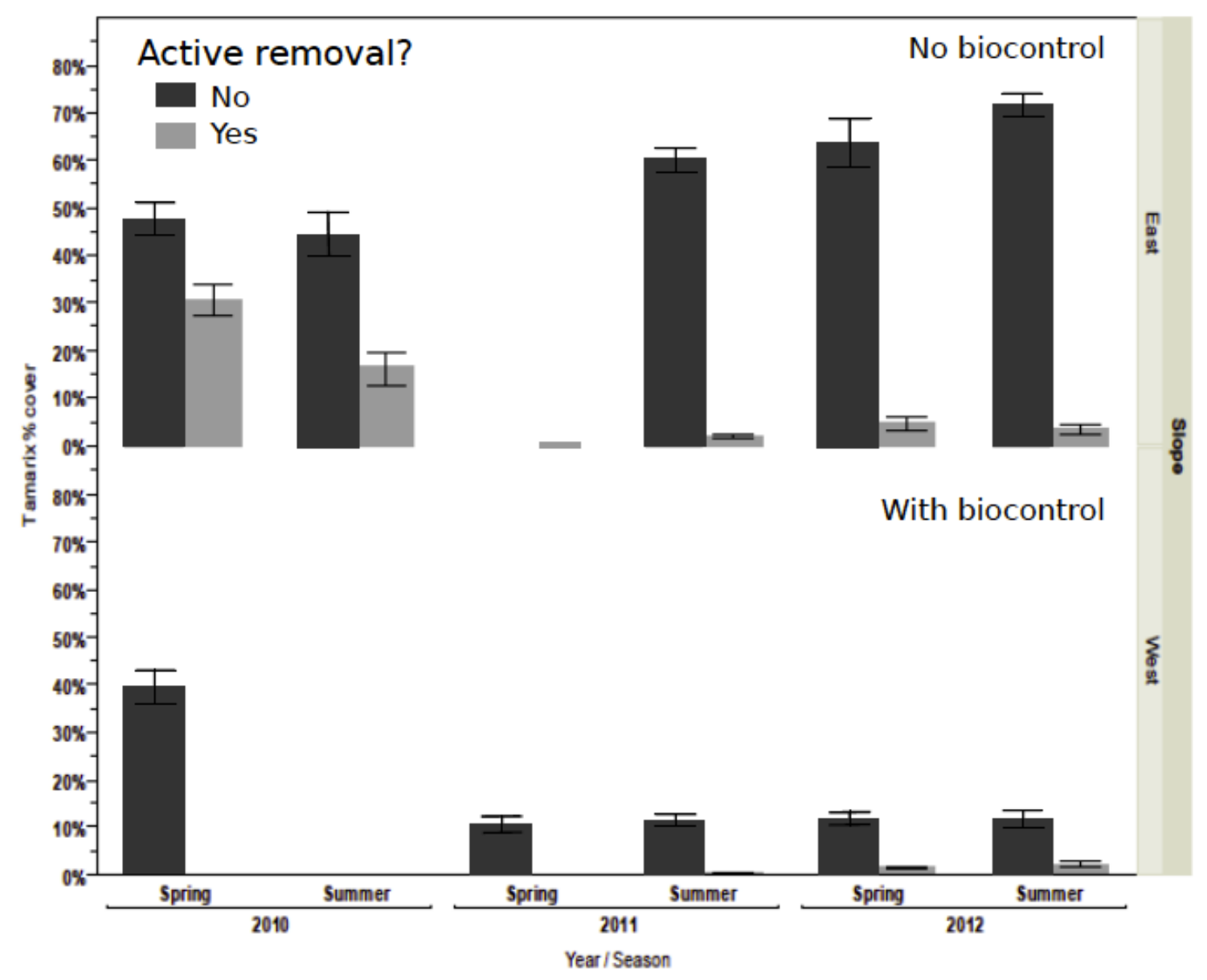

Figure 9-Mean (+/- $1 \mathrm{SE}$ ) cover of Tamarix spp. of active removal (light grey) or no active removal (dark grey). West slope sites have beetles present whereas east slope sites do not. 
sites in non-active removal sites. When we compare active removal sites with non-active removal at the same point in time, we see even more dramatic evidence of the impact of removal. By 2012, however, this difference was much greater in the east sites compared to the west where Diorhabda spp. is known to occur.

There was also a decrease in total density (i.e., number of individuals) of Tamarix in the removal sites compared to non-active removal sites from the first to third year, also with a significant region effect, but the opposite pattern from what was observed with cover (fig. 10). Both regions saw a decrease in Tamarix individuals with active removal, but by 2012 there was an increase in the number of individuals in the west sites.

Differences between regions in successful control of Tamarix are multifaceted. Although Tamarix cover remained low in the Western Slope sites where biological control is ubiquitous, the Tamarix density was almost the same by the end of our 3 years of sampling. This suggests that even though there was new recruitment of Tamarix seedlings after active removal in the Western Slope, defoliation by the beetles was likely keeping overall Tamarix cover lower than in the Eastern Slope. The lower recruitment of seedlings in the east is likely because there was less overbank flooding than in the west, which is generally associated with regeneration by seed for Tamarix; especially high flows were observed by our team in several areas along the Dolores River in 2011, but not in the eastern sites. Water availability is the primary determinant of Tamarix establishment by seed (Sher and Marshall 2003). It is also possible that in the eastern sites new individuals were killed with follow-up treatments or by cattle grazing or trampling, given that all of the eastern sites were on private land and thus subject to more intense use and management.

Figure 10-Mean (+/- $1 \mathrm{SE})$ number of Tamarix (i.e., density) per site of Tamarix spp. on removal vs. non removal sites in the eastern plains and west slope of Colorado before active removal in 2010 and for 2 years following; spring season, cut stump method. ANOVA test $(\mathrm{F}=0.340, \mathrm{DF}=2, P$ value $<$ 0.004).

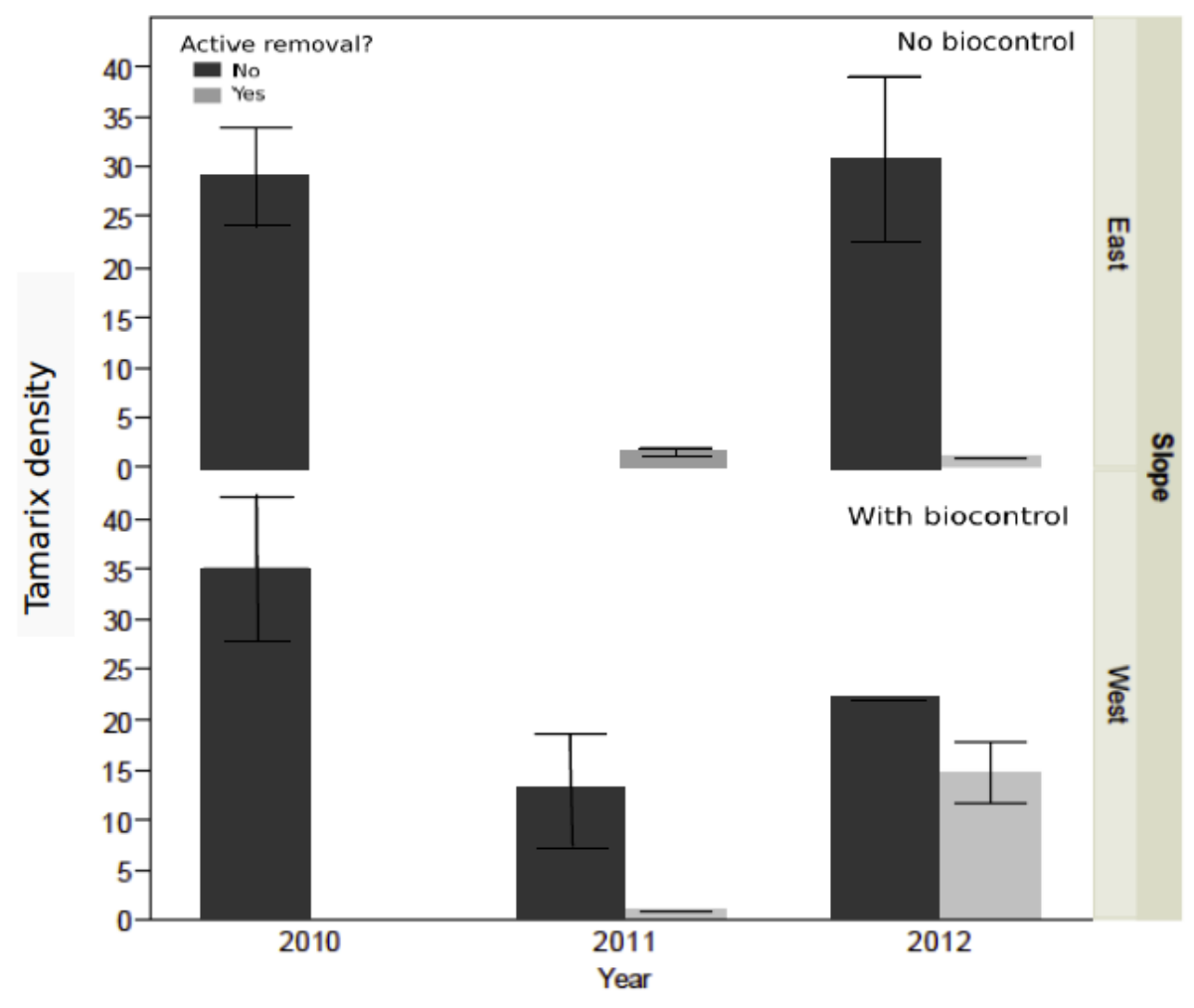




\section{The Response of Plant Communities to Tamarix Removal Efforts}

After Tamarix removal, we observed slightly greater cover of natives and a decrease in introduced species relative to before removal, but with different magnitudes between the two regions (fig. 11). Overall, we observed much more dramatic positive changes to the understory in the western sites.

Removal method mattered as well. Other than the positive reference sites, the highest relative percent cover of native species was found in the cut stump sites (fig. 12). Relative understory native cover decreased over time only in Tamarix control sites and helicopter spray treatment sites, while it dramatically increased in native control, cut stump, and track-hoe treatment.

Species richness was also strongly impacted by Tamarix removal, but a different picture is painted whether we consider before vs. after or control vs. impact. In the east, the number of species decreased after removal, likely due to negative effects of the disturbance of the Tamarix removal methods (fig. 13). This is in contrast with the increase in richness after removal in the west. However, when we compare species richness at the same point in time, east and west active removal sites have very similar species richness, but this is low relative to positive reference sites in the east and high for those in the west (fig. 14). In the west, but not in the east, Tamarix-dominated stands (negative reference sites) were associated with much lower species diversity than positive

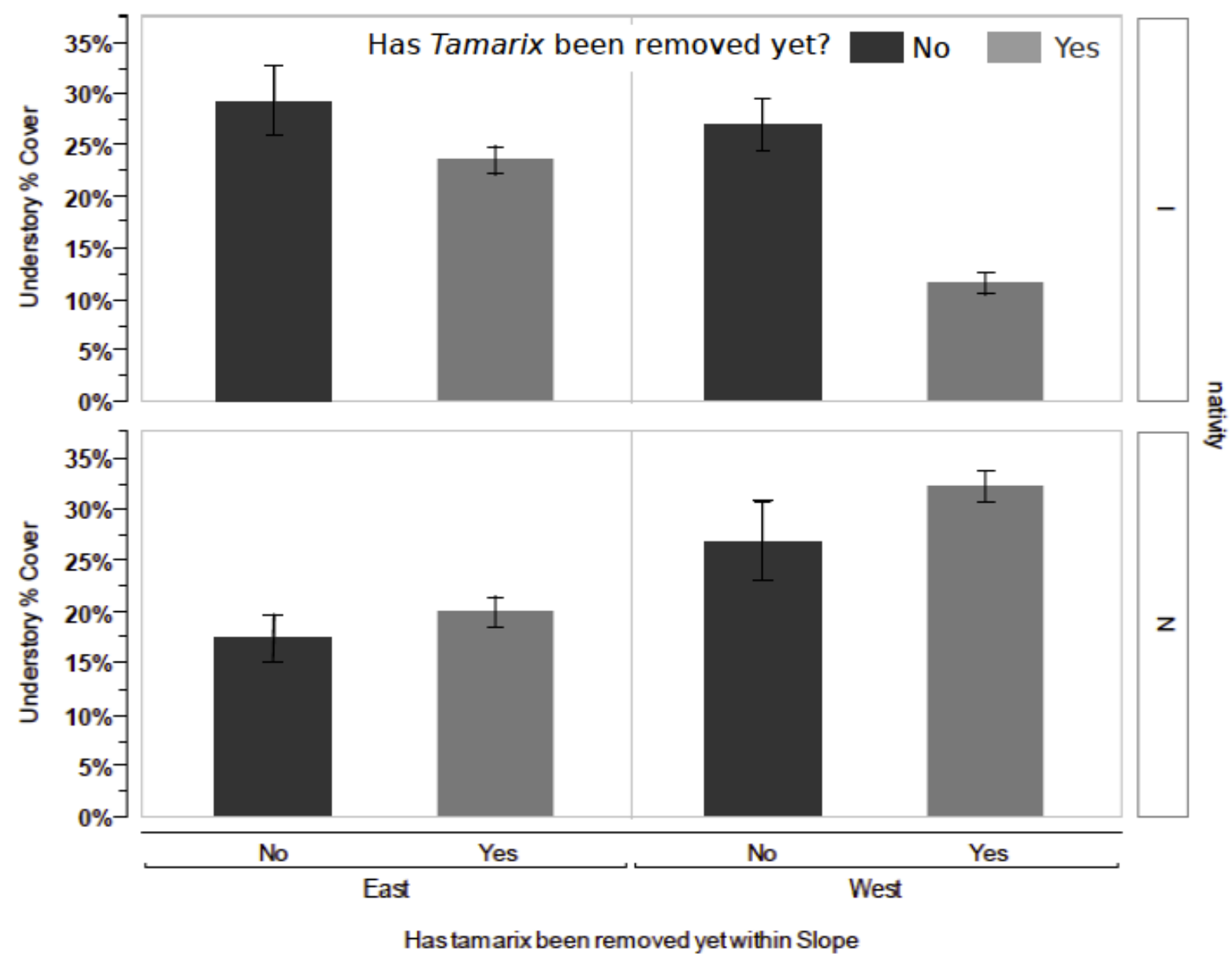

Figure 11-Mean (+/- $1 \mathrm{SE}$ ) cover of understory vegetation by nativity (native "N" and introduced "I") for east and west sites by active removal ("has Tamarix been removed yet"). 
reference sites. The difference between regions in the response to Tamarix removal is likely due to the difference in initial plant communities; most of understory vegetation were shrubs in the Western Slope whereas the Eastern Slope was dominated by herbaceous species. Herbaceous species are much more likely to be killed by the heavy machinery, use of herbicides, and trampling associated with Tamarix removal relative to shrubs. In particular, helicopter-applied herbicides in some of the eastern sites likely negatively affected the plant community.

Given that very different patterns appeared in the sites where helicopter spray was applied, we used another quantitative measurement, the importance value (IV), to investigate the community response in these sites with more detail. The importance value is a combination of the relative cover, density, and frequency, and as such can better explain the change of plant composition than just one parameter (Mueller-Dombois and Ellenberg 1974)3. Results of this analysis showed that the increase in understory exotics in the helicopter spray sites was primarily due to the exotic forb Bassia scoparia (a.k.a. Kochia scoparia, burningbush). This exotic forb, which ranked third in IV before removal, took first place after removal, shifting the community from native dominated (Elymus canadensis) to exotic because of the increase in the relative cover of B. scopar$i a$. This is an exotic species that is considered a nuisance but is not a State-listed weed. It is also known to have resistance to commonly used herbicides. Thus, the primary problem we observed with the aerial application of herbicide was its direct negative effect on the native species, which decreased significantly when this approach was used.

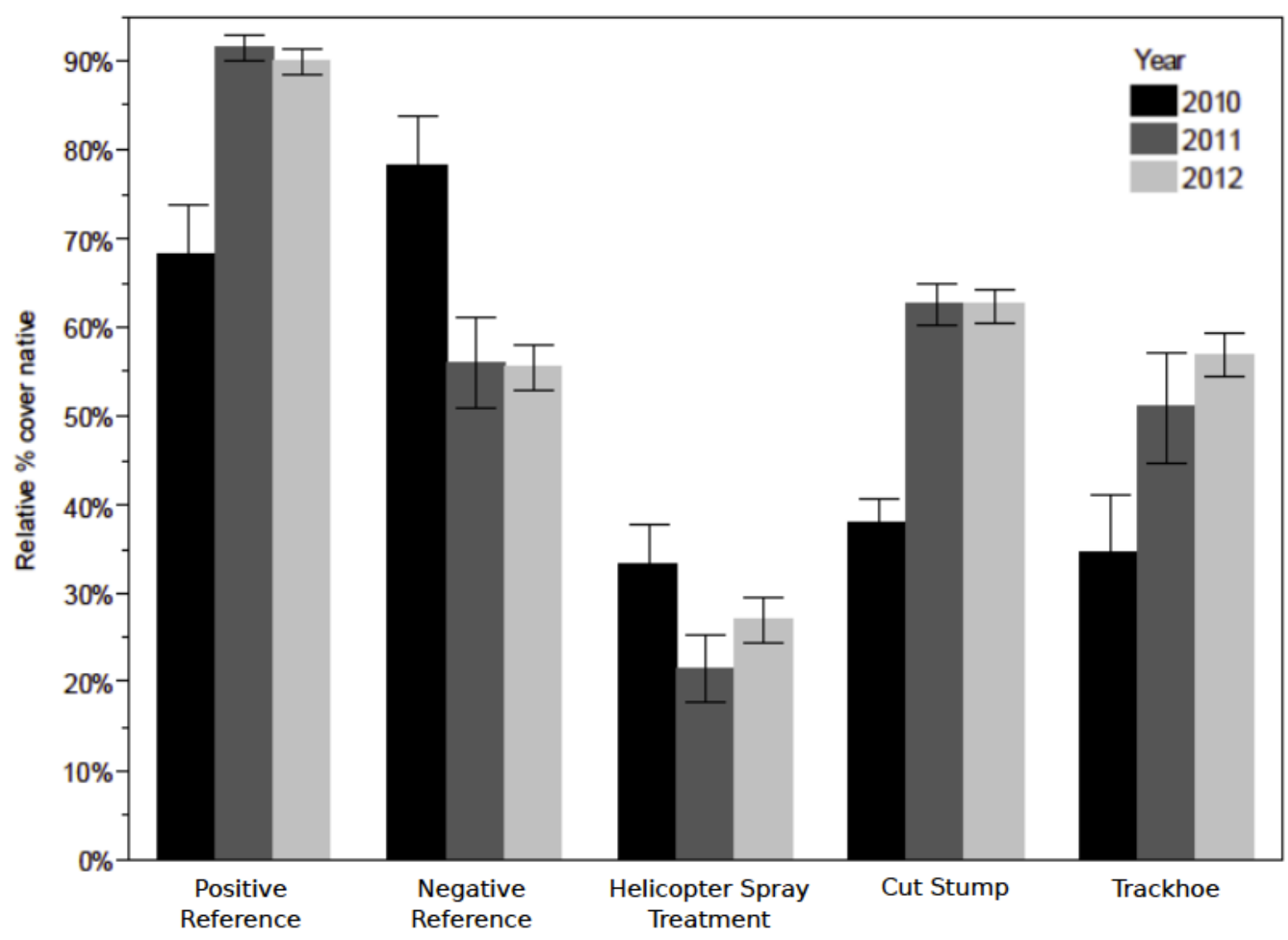

Figure 12-Mean (+/- 1SE) relative native understory cover over time within different removal methods. $(F=55.9$, $\mathrm{DF}=5,599, P<0.0001)$. 
Figure 13-Average richness over time from before treatment to 2 years after treatment, by slope.
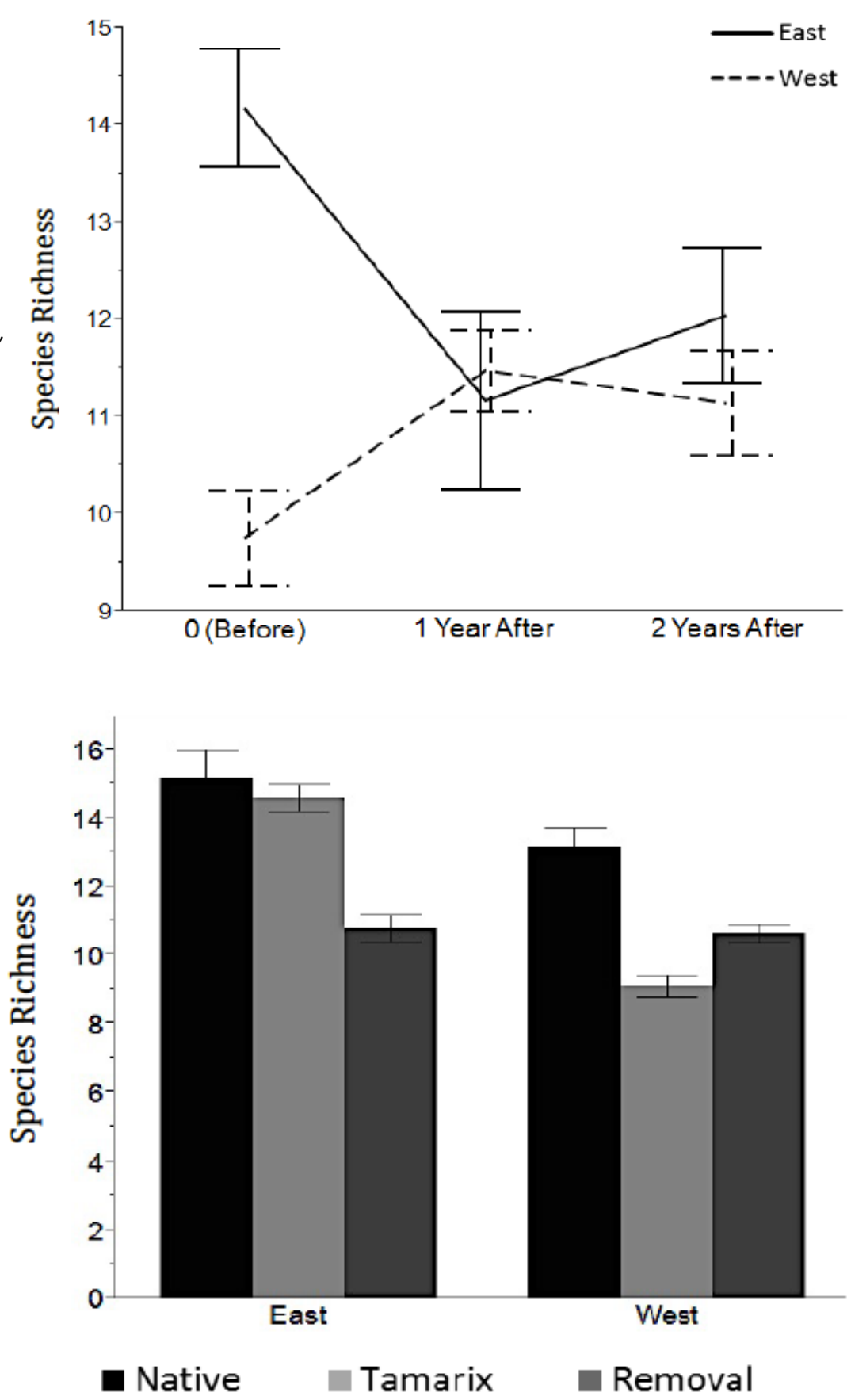

Figure 14-Mean (+/- $1 \mathrm{SE})$ number of species per transect for positive reference sites ("native"), negative reference sites ("Tamarix"), and active removal sites in both east and west slope sites. (ANOVA Treatment*Slope: $F$ $=19.7, \mathrm{DF}=2,380, P<0.0001$.)

\section{Conclusion and Implications}

In summary, active removal of Tamarix was highly successful and had significant effects on the understory that differed by region. In the western sites where the biocontrol beetle Diorhabda spp. was present, Tamarix cover decreased over time in both Tamarix active removal sites and non-active removal sites, and the former was associated with decreases in other exotics while increasing native species. The eastern sites where there was no biological control and no active removal had very high cover of Tamarix, but differences between these sites were not as great for the understory, due to the poor results seen in those sites with aerial application of herbicide. Generally, 
Tamarix removal led to an increase in native understory vegetation except when herbicide was applied by helicopter. Spraying herbicide by helicopter was associated with the increased importance of Bassia scoparia, an understory exotic. These results are consistent with other studies in which secondary invasions were less notable following biocontrol than other treatment methods (González et al. 2017a; Sher et al., in review), particularly B. scoparia (González et al. 2017b).

It is also important to note that we observed positive reference sites to increase in native cover over time, whereas sites with no Tamarix removal decreased in native cover, and when the biocontrol was absent, increased in Tamarix cover. This suggests a risk of site depredation if nothing is done to reduce this exotic tree.

In conclusion, our results suggest that removal of Tamarix by commonly used methods is either neutral or positive for the native plant community. Although 2 years post removal is too short a period to reach any broad conclusions about impact, our results are consistent with those over longer time periods and greater geographic range that suggest that native cover can be promoted through Tamarix removal (González et al. 2017a). Although this should not be confused with a return to the mesic riparian forests associated with pre-invasion and pre-damming, it does bode well for improvement of these communities.

\section{Acknowledgments}

We are indebted to the following partner organizations for their support: Branson Trinchera Conservation District (BTCD), The Nature Conservancy (TNC), the Colorado Water Conservation Board (CWCB), U.S. Fish and Wildlife Service (USFWS), Natural Resources Conservation Service (NRCS), Denver Botanic Garden (DBG), University of Denver (DU), Colorado State Forest Service (CSFS), and the Bureau of Land Management (BLM). Many thanks to all who contributed to data collection and data entry for this project: D. Stahl, R. Anderson, K. Merewether, C. Slattery, B. Peters, S. Coles, R. Whitney, F. Aguirre, E. Jackson, and C. Ballinger. Early drafts of this paper were improved by feedback from M. Quigley, S. Murphy, and R. Powell. Special thanks are directed to all of the landowners and land management agencies, especially the Doherty, Wooten, and Larson families, for permitting their properties to be the locations for this project and for providing guidance and facilities which made the field work and data collection possible.

\section{References}

Auerbach, D.A.; Merritt, D.M.; Shafroth, P.B. 2013. Tamarix, hydrology, and fluvial geomorphology. In: Sher A.A.; Quigley, M.F., eds. Tamarix: A case study of ecological change in the American West. Oxford, United Kingdom: Oxford University Press: 99-121.

Bauer, J.T. 2012. Invasive species: "Backseat drivers" of ecosystem change? Biological Invasions. 14: 1295-1304.

Bay, R.F.; Sher, A.A. 2008. Success of active revegetation after Tamarix removal in riparian ecosystems of the Southwestern United States: A quantitative assessment of past restoration projects. Restoration Ecology. 16: 113-128.

Bernhardt, E.S.; Sudduth, E.B.; Palmer, M.A.; [et al.]. 2007. Restoring rivers one reach at a time: Results from a survey of U.S. river restoration practitioners. Restoration Ecology. 15: 482-493. 
Brock, J.H. 1994. Tamarix spp. (Saltcedar), an invasive exotic woody plant in arid and semiarid riparian habitats of Western USA. In: de Waal, L.C.; Child, L.E.; Wade, P.M.; [et al.], eds. Ecology and management of invasive riverside plants. New York: Wiley: 27-44.

CSU Herbarium. 2001. Colorado State University Herbarium. Database. Fort Collins, CO: Colorado State University, College of Natural Sciences. http://herbarium.biology.colostate. edu. [Accessed April 13, 2017.]

Cuevas, Y.A.; Zalba, S.M. 2010. Recovery of native grasslands after removing invasive pines. Restoration Ecology. 18: 711-719.

DeLoach, C.J.; Lewis, P.A.; Herr, J.C.; [et al.]. 2003. Host specificity of the leaf beetle, Diorhabda elongata deserticola (Coleoptera: Chrysomelidae) from Asia, a biological control agent for saltcedars (Tamarix: Tamaricaceae) in the Western United States. Biological Control. 27(2): 117-147.

Dennison, P.E.; Nagler, P.L.; Hultine, K.R.; [et al.]. 2009. Remote monitoring of tamarisk defoliation and evapotranspiration following saltcedar leaf beetle attack. Remote Sensing of Environment. 113: 1462-1472.

de Waal, L.C.; Child, L.E.; Wade, P.M.; [et al.], eds. 1994. Ecology and management of invasive riverside plants. New York: Wiley. 232 p.

Didham, R.K.; Tylianakis, J.M.; Hutchison, M.A.; [et al.]. 2005. Are invasive species the drivers of ecological change? Trends in Ecology \& Evolution. 20: 470-474.

DiTomaso, J.M. 1998. Impact, biology, and ecology of saltcedar (Tamarix spp.) in the southwestern United States. Weed Technology. 12: 326-336.

Drus, G.M. 2013. Fire ecology of Tamarix. In Sher, A.A; Quigley, M.F., eds. Tamarix: A case study of ecological change in the American West. New York: Oxford University Press: 240-255.

Elmore, F.H. 1976. Shrubs and trees of the Southwest Uplands. Globe, AZ: Southwest Parks and Monuments Association. 214 p.

Friedman, J.M.; Auble, G.T.; Shafroth, P.B.; [et al.]. 2005. Dominance of nonnative riparian trees in western USA. Biological Invasions. 7: 747-751.

Gaskin, J.F.; Schaal, B.A. 2002. Hybrid Tamarix widespread in U.S. invasion and undetected in native Asian range. Proceedings of the National Academy of Sciences. 99: 11256-11259.

Glen, E.P.; Nagler, P.L. 2005. Comparative ecophysiology of Tamarix ramosissima and native trees in western U.S. riparian zones. Journal of Arid Environments. 61: 419-446.

González, E.; Sher, A.A.; Anderson, R.M.; [et al.]. 2017b. Secondary invasions of noxious weeds associated with control of invasive Tamarix are frequent, idiosyncratic and persistent. Biological Conservation. 213 (2017): 106-114.

González, E.; Sher, A.A.; Anderson, R.M.; [et al.]. 2017a. Vegetation response to removal and bioconrol of invasive Tamarix in southwestern U.S. rivers: A collaborative study including 416 sites. Ecological Applications. 27(6): 1789-1804.

González, E.; Sher, A.A.; Tabacchi, E.; [et al.]. 2015. Restoration of riparian vegetation: A global review of implementation and evaluation approaches in the international, peer-reviewed literature. Journal of Environmental Management. 158: 85-94.

Graf, W.L.; Patten, D.T.; Turner, B. 1984. Issues concerning phreatophyte clearing, revegetation, and water savings along the Gila River, Arizona. Army Corps of Engineers Contract DACW09-83-M-2623. Tempe, AZ: Arizona State University. 69 p. Uhttp://scholarcommons. sc.edu/cgi/viewcontent.cgi?article $=1044 \&$ context $=$ geog_facpub [Accessed April 13, 2017].

Harms, R.S.; Hiebert, R.D. 2006. Vegetation response following invasive tamarisk (Tamarix spp.) removal and implications for riparian restoration. Restoration Ecology. 14: 461472.

Hultine, K.R.; Belnap, J.; van Riper, C.; [et al.]. 2010. Tamarisk biocontrol in the western United States: Ecological and societal implications. Frontiers in Ecology and the Environment. 8: $467-474$. 
Hultine, K.R.; Dudley, T.L.; Koepke, D.F.; [et al.]. 2015. Patterns of herbivory-induced mortality of a dominant non-native tree/shrub (Tamarix spp.) in a southwestern US watershed. Biological Invasions. 17: 1729-1742.

Huston, M.A. 2004. Management strategies for plant invasions: Manipulating productivity, disturbance, and competition. Diversity and Distributions.10: 167-178.

Johnson, D.T. 2013. Tamarix: Passenger or driver of ecosystem change. In: Sher, A.A.; Quigley, M.F., eds. Tamarix: A case study of ecological change in the American West. New York: Oxford University Press: 256-268.

Kennard, D.; Louden, N.; Gemoets, D.; [et al.]. 2016. Tamarix dieback and vegetation patterns following release of the northern tamarisk beetle (Diorhabda carinulata) in western Colorado. Biological Control. 101: 114-122.

MacDougall, A.S.; Turkington, R. 2005. Are invasive species the drivers or passengers of change in degraded ecosystems? Ecology. 86: 42-55.

McArthur, R.H.; Wilson, E.O. 1967. The theory of island biogeography. Princeton, NJ: Princeton University Press. (Reprinted 2001). 203 p.

McDaniel, K.C.; DiTomaso, J.M.; Duncan, C.A. 2005. Tamarisk family: Tamaricaeae. Tamarisk or saltcedar, Tamarix spp. In: Duncan, C.A.; Clark, J.K., eds. Invasive plants of range and wildlands and their environmental, economic, and societal impacts. Lawrence, KS: Weed Science Society of America: 198-222.

Merritt, D.M.; Poff, N.L. 2010. Shifting dominance of riparian Populus and Tamarix along gradients of flow alteration in western North American rivers. Ecological Applications. 20: $135-152$.

Merritt, D.M.; Shafroth, P.B. 2012. Edaphic, salinity, and stand structural trends in chronosequences of native and non-native dominated riparian forests along the Colorado River, USA. Biological Invasions. 14: 2665-2685.

Mueller-Dombois, D.; Ellenberg, H. 1974. Aims and methods of vegetation ecology. New York: Wiley. 547 p.

Nagler, P.L.; Glenn, E.P.; Jarnevich, C.S.; [et al.]. 2011. Distribution and abundance of saltcedar and Russian olive in the Western United States. Critical Reviews in Plant Sciences. 30: 508-523.

Nagler, P.L.; Pearlstein, S.; Glenn, E.P.; [et al.]. 2014. Rapid dispersal of saltcedar (Tamarix spp.) biocontrol beetles (Diorhabda carinulata) on a desert river detected by phenocams, MODIS imagery and ground observations. Remote Sensing of Environment 140: 206-219.

Ohrtman, M.K.; Sher, A.A.; Lair, K.D. 2012. Quantifying soil salinity in areas invaded by Tamarix spp. Journal of Arid Environments. 85: 114-121.

Ostoja, S.M.; Brooks, M.L.; Dudley, T.; [et al.]. 2014. Short-term vegetation response following mechanical control of Saltcedar (Tamarix spp.) on the Virgin River, Nevada, USA. Invasive Plant Science and Management. 7: 310-319.

Palmer, M.A.; Bernhardt, E.S.; Allan, J.D.; [et al.]. 2005. Standards for ecologically successful river restoration. Journal of Applied Ecology. 42: 208-217. doi:10.1111/j.1365-2664.2005.01004.x.

Shafroth, P.B.; Briggs, M.K. 2008. Restoration ecology and invasive riparian plants: An introduction to the special section on Tamarix spp. in western North America. Restoration Ecology. 16: 94-96.

Shafroth, P.B.; Cleverly, J.R.; Dudley, T.L.; [et al.]. 2005. Control of Tamarix in the Western United States: Implications for water salvage, wildlife use, and riparian restoration. Environmental Management. 35: 231-246.

Shafroth, P.B.; Friedman, J.M.; Ischinger, L.S. 1995. Effects of salinity on establishment of Populus fremontii (cottonwood) and Tamarix ramosissima (saltcedar) in southwestern United States. The Great Basin Naturalist. 55(1): 58-65.

Shafroth, P.B.; Stromberg, J.C.; Patten, D.T. 2000. Woody riparian vegetation response to different alluvial water table regimes. Western North American Naturalist. 60(1): 66-76. 
Sher, A.A. 2006. Tamarisk: Passengers versus drivers of ecosystem change: Current debate on Tamarix and riparian invasion. In: ESA 91st annual meeting; 2006 August 6-11; Memphis, TN. Washington, DC: Ecological Society of America.

Sher, A.A. 2013. Introduction to the paradox plant. In: Sher, A.; Quigley, M.F., eds. Tamarix: A case study of ecological change in the American west. New York: Oxford University Press: $1-18$.

Sher, A.A.; Marshall, D.L. 2003. Competition between native and exotic floodplain tree species across water regimes and soil textures. American Journal of Botany. 90: 413-422.

Sher, A. A.; Elwaer, H.; González, E.; [et al.]. [In review]. Native species recovery facilitated by the removal of an invasive tree by biological control alone and in combination with active removal.

Sher, A.A.; Gieck, S.; Brown, C.S.; [et al.]. 2008. First year responses of cheatgrass following Tamarix spp. control and restoration related disturbances. Restoration Ecology. 16: 129-135.

Sher, A.A.; Marshall, D.L.; Gilbert, S.A. 2000. Competition between native Populus deltoides and invasive Tamarix ramosissima and the implications for reestablishing flooding disturbance. Conservation Biology. 14: 1744-1754.

Sher, A.A.; Marshall, D.L.; Taylor, J.P. 2002. Establishment patterns of native Populus and Salix in the presence of invasive nonnative Tamarix. Ecological Applications. 12: 760-772.

Society for Ecological Restoration International Science \& Policy Working Group (SERI). 2004. The SER international primer on ecological restoration. Tucson, AZ: Society for Ecological Restoration International. 15 p. http://www.ser.org/page/SERDocuments [Accessed April 13 2017].

Southwest Environmental Information Network (SWEIN). 2012. SEINet—Arizona-New Mexico Chapter. Database. http://swbiodiversity.org/seinet/index.php [Accessed April 13, 2017].

Stohlgren, T.J.; Falkner, M.B.; Schell, L.D. 1995. A modified-Whittaker nested vegetation sampling method. Vegetatio. 117(2): 113-121.

Stromberg, J.C.; Beauchamp, V.B.; Dixon, M.D.; [et al.]. 2007a. Importance of low-flow and high-flow characteristics to restoration of riparian vegetation along rivers in and southwestern United States. Freshwater Biology. 52: 651-679.

Stromberg, J.C.; Lite, S.J.; Marler, R.; [et al.]. 2007b. Altered stream-flow regimes and invasive plant species: The Tamarix case. Global Ecology and Biogeography. 16: 381-393.

USDA. 2010. Plants Database. Washington, DC; U.S. Departmeny of Agriculture. https://plants. usda.gov/java/ [Accessed April 13, 2017].

Weber, W.A.; Wittmann, R.C. 1996a. Colorado flora: Eastern slope. Boulder, CO: University Press of Colorado. $608 \mathrm{p}$.

Weber, W.A.; Wittmann, R.C. 1996b. Colorado flora: Western slope. Boulder, CO: University Press of Colorado. $595 \mathrm{p}$.

Whitson, T.D.; Burrill, L.C. 2000. Weeds of the West. 9th ed. Newark, CA: Western Society of Weed Science; Western United States Land Grant Universities Cooperative Extension Services. $628 \mathrm{p}$.

Wingate, J.L. 1994. Illustrated keys to the grasses of Colorado. Denver, CO: Wingate Consulting. $94 \mathrm{p}$.

Zavaleta, E.S.; Hobbs, R.J.; Money, H.A. 2001. Viewing invasive species removal in a wholeecosystem context. Trends in Ecology and Evolution. 16: 454-459. 


\title{
Chapter 5. Unintended Consequences: Tamarisk Control and Increasing Threats to the Southwestern Willow Flycatcher
}

\author{
Mary Anne McLeod
}

\section{Introduction}

It is well known that nonnative tamarisk (Tamarix parviflora, T. ramosissima, $T$. chinensis, and their hybrids; a.k.a. saltcedar) has replaced native riparian woodland vegetation along many streams in the arid Southwest over the last 100 years. Tamarisk can form extensive, dense monocultures and may alter not only the physical structure of the riparian woodland but also soil salinity and fire frequency (Sher 2013). There is significant debate, however, over whether tamarisk is the driver or a passenger of ecological change (Johnson 2013). The decline in the numbers and range of native riparian wildlife has been concurrent with the spread of tamarisk, and numerous studies show that tamarisk-dominated stands may support a lower density and/or diversity of wildlife than do native habitats (Bateman and Ostoja 2012; Sogge et al. 2008; Strudley and Dalin 2013). Consequently, tamarisk is often portrayed as the primary cause for declines in riparian wildlife (e.g., DeLoach et al. 2003a). Although it is now recognized that water use by native vegetation compared to tamarisk depends on site conditions (Zavaleta 2013), tamarisk was also widely blamed for water consumption in excess of native species (Nagler and Glenn 2013). Tamarisk control efforts, many of which were driven by the desire to make more water available for human use, began in the 1940s (Douglass et al. 2013) and continue to the present day, with improvement of wildlife habitat often cited as a goal of tamarisk removal.

Many wildlife species successfully inhabit tamarisk, however, and evidence mounted in the 1980s and 1990s that tamarisk provides important habitat, particularly for birds, in many southwestern riparian systems (see review in Sogge et al. 2008), especially if a small component of native vegetation remains (van Riper et al. 2008). Perhaps the best known, and most controversial, avian occupant of tamarisk habitats is the southwestern willow flycatcher (Empidonax traillii extimus; hereafter flycatcher), a riparian obligate songbird that was listed as endangered in 1995 by the U.S. Fish and Wildlife Service. In recent decades, an effective biological control for reducing the vigor and reproductive success of tamarisk was found, and biological control agents were released beginning in 2001. As a result of this biocontrol effort, there have been unintended consequences to the flycatcher and other riparian wildlife. This paper addresses the history of the biocontrol effort and the failure of the scientific community and regulatory agencies to accurately predict the impact of biocontrol releases. 


\section{The Search for Biocontrol for Tamarisk}

Tamarisk is difficult to control by mechanical means, as it resprouts vigorously following cutting or fire. Heavy equipment can be used to remove entire plants, but this is expensive, causes extensive soil disruption, and is often impractical in riparian areas that are difficult to access. There are several herbicides that are widely used for tamarisk control; however, aerial applications are non-selective, and cut stump treatments, while very effective, are labor intensive (DiTomaso et al. 2013). Given the difficulty and expense of mechanical and chemical control methods, biological control, which would involve using a natural predator, parasite, or pathogen to suppress the tamarisk population, seemed like an attractive alternative. Tamarisk was an ideal candidate for biocontrol; the Tamaricaceae family has no species that are native to North America, and the prospects were therefore good of finding a biocontrol agent that would act selectively on tamarisk and leave other species untouched. Successful biocontrol was expected to reduce the use of conventional pesticides and provide cost effective, selfsustaining, target-specific suppression for tamarisk (USDA Animal and Plant Health Inspection Service 2015a).

The search for biological control for tamarisk began in the late 1960s, led by personnel at the U.S. Department of Agriculture's Agricultural Research Service (USDA ARS). Researchers gathered information on tamarisk and the insects that feed on it throughout its native range to identify potential biocontrol agents - insects that feed selectively on tamarisk and are capable of reducing the population of the host plant (DeLoach et al. 2003a). In 1989, Jack DeLoach of the USDA ARS and colleagues submitted a petition to the Technical Advisory Group for Introduction of Biological Control Agents of Weeds (TAG), a committee of the USDA Animal and Plant Health Inspection Service (APHIS) that is tasked with "providing guidance to researchers and recommendations to regulating agencies for or against the release of nonindigenous biological control agents" (USDA Animal and Plant Health Inspection Service 2015b), asking the TAG's advice on whether proceeding with a biological control program on tamarisk was in the best national interest (DeLoach et al. 2003b). The TAG recommended that the program could proceed, and the search for suitable biocontrol agents continued, with the assistance of several overseas cooperators.

The tamarisk leaf beetle (Diorhabda spp.) was identified as one of the promising candidates for biocontrol. It was known to occur in high densities and completely defoliate large areas of tamarisk, and beetles were considered a pest in China in areas where tamarisk was planted for sand dune control (DeLoach 1994). The beetle was brought back to the United States where it underwent extensive host-specificity testing starting in 1992. Tests conducted in 1992 and 1993 showed that beetle larvae developed readily on Tamarix hosts and would feed but rarely developed into adults on shrubs in the Frankenia (seaheath) genus, the only plants native to the Western Hemisphere that are in the same order as Tamarix (Lewis et al. 2003a). Larvae failed to develop on all other host species that were tested (DeLoach 1994).

ARS submitted a petition to the TAG requesting approval for the field release of beetles in Texas and Wyoming in May 1994 (DeLoach 1994). Of the 16 TAG members who responded, nine recommended release with no reservations, six recommended release but had reservations, and one did not recommend release. The most common 
concern was the possibility that beetles could feed on Frankenia, some species of which were rare. Other concerns were the impact beetles could have on athel (T. aphylla, a tree form of tamarisk that is far less invasive than the other Tamarix species), which was used as a shade tree in the southwestern United States and Mexico; whether native vegetation would replace tamarisk following biocontrol; and whether there was a means to control Diorhabda, if needed. A letter from Jack DeLoach to APHIS on December 22, 1994, clarified that larvae that developed into adults on Frankenia were unable to reproduce; this was later confirmed by further host testing (Lewis et al. 2003a). The letter cited the relative rarity of athel among ornamental shade trees as evidence of the limited potential effects to athel. ${ }^{1}$ DeLoach conceded in his letter that "Replacement by native vegetation after control ... is circumstantial and not well supported. It is based mostly on biocontrol of other weed species, where native vegetation, desirable range plants, etc., came back strongly after the weed was controlled." As far as beetle control was concerned, DeLoach cited information from China that local beetle populations could be controlled with insecticides. The letter was sufficient to relieve the concerns of the TAG members, and the TAG chairman recommended to APHIS on June 1, 1995, that Diorhabda be approved for release into North America.

Tamarisk leaf beetles feed on the foliage of tamarisk as adults and in each of three larval stages. Beetles overwinter in the leaf litter as adults and emerge in the spring in response to warming temperatures. They aggregate on tamarisk plants to feed, mate, and lay eggs. After progressing through the larval stages, beetles descend to the leaf litter to pupate. The entire life cycle takes 30 to 40 days (Lewis et al. 2003b), and beetles typically go through multiple generations during a growing season. When adult beetles emerge from the leaf litter, they either become reproductively active or are triggered to go into diapause, an overwintering state of suppressed development, by shortening of the photoperiod in late summer (Bean et al. 2007a; Lewis et al. 2003b). If local food resources have been depleted by the previous generation of beetles, adults will disperse, sometimes in large flights, in search of green foliage. Adults that are destined for diapause feed and then descend into the leaf litter instead of becoming reproductively active (Bean et al. 2013).

Tamarisk leaf beetles are sensitive to chemicals released by tamarisk and also to chemicals released by other Diorhabda individuals (Bean et al. 2013). This sensitivity allows beetles to occur in large aggregations that can exceed 1,000 beetles per plant (Bean et al. 2013; Jashenko n.d.), resulting in rapid and complete defoliation. The defoliation period can last for several weeks, but the tamarisk then typically puts on new leaves. An individual plant can be defoliated multiple times within a growing season. The response of tamarisk to multiple defoliation events is variable and is likely influenced by numerous factors, including age of the plant, access by the plant to resources such as water, seasonal timing of defoliation, and plant genetics (Bean et al. 2013). A single defoliation event can result in mortality, but more typically several defoliation events are required, if the plant is killed at all. When plants do refoliate, they often exhibit reduced vigor, with dieback of terminal branches, reduced foliage volume, and

\footnotetext{
${ }^{1}$ Further research suggested that beetles would not affect athel as strongly as they affected other Tamarix species, although the researchers conceded the possibility of "transient but substantial damage" to athel (Moran et al. 2009). Damage to athel in northern Mexico was described as "conspicuous" (Estrada-Muñoz and Sánchez-Peña 2014), and treating individual athel trees with insecticide was recommended for beetle control (Muegge 2010).
} 
reduced flowering. The response of other vegetation to tamarisk dieback and mortality is also variable and is influenced by soil condition, hydrological regime, and local seed sources.

\section{Conflict With the Southwestern Willow Flycatcher}

By the time beetles had been recommended for release by the TAG, another concern had surfaced. The southwestern willow flycatcher was listed as endangered on February 27, 1995 (60 FR 10694-10715). The flycatcher breeds in Arizona, New Mexico, southern California, southern Nevada, southern Utah, and western Texas, placing its nests in dense, wet thickets of trees and shrubs approximately 4-7 $\mathrm{m}$ or more in height. The southwestern willow flycatcher was historically a common species in riparian areas throughout its range, but flycatcher numbers dwindled as southwestern wetlands and riparian habitats, particularly those vegetated by cottonwood and willow, suffered large-scale losses during the 1900s as the result of dams, diversions, livestock grazing, increase in agriculture, urbanization, and wood cutting. By the time the flycatcher was listed, the range-wide population was estimated at around 500 pairs (60 FR 10694-10715). The decline in flycatcher populations coincided with the spread of tamarisk, which proliferated with the modifications in the natural hydrograph caused by dams and diversions. Tamarisk was regarded by some researchers as providing poor habitat in comparison to native vegetation for various bird species because of reduced structural diversity, changes in the arthropod community (Carothers and Brown 1991), and a hotter microclimate (Hunter et al. 1987). At the time of listing, flycatchers were known to nest in thickets dominated by tamarisk, but it was unclear whether the longterm reproductive success of flycatchers nesting in native vegetation differed from the success of those nesting in tamarisk.

Because of the potential effect of beetle-caused defoliation on flycatchers, consultation with the U.S. Fish and Wildlife Service (USFWS) was required prior to release of the beetles. ARS and APHIS submitted a draft Biological Assessment (BA) to the USFWS in October 1997 (DeLoach and Tracy 1997). The action proposed in the draft BA was to release both the leaf beetle and a mealybug, Trabutina mannipara, at sites across seven States. All proposed release sites were at least 100 miles from areas where flycatchers were known to nest in tamarisk. The BA considered direct and indirect effects of biological control agents on flycatchers not only at the release sites themselves but also across the region, after the control agents had resulted in an estimated 75-85 percent reduction in the density and cover of tamarisk.

The analysis of effects in the BA rested on several assumptions: (1) biocontrol agents would not spread more than 2-4 miles each year; (2) the decrease in the density of tamarisk would be gradual and would be accompanied by a "consequent and concurrent increase in the native plant community"; (3) biocontrol agents would provide food for flycatchers; and (4) tamarisk is "only partially suitable as habitat for flycatchers" and was "a major factor in [the flycatcher's] extirpation from ... the lower Colorado and the lower Gila rivers." In particular, the BA proposed that tamarisk provides unsuitable habitat for flycatchers at lower elevations because tamarisk stands are "intrinsically hotter" than cottonwood/willow vegetation, resulting in the exposure of flycatchers to temperatures that are lethal for eggs and nestlings. It then followed that, if biocontrol 
resulted in the replacement of tamarisk with native vegetation, the suitability of formerly tamarisk-dominated areas for nesting flycatchers would increase. The BA concluded that biological control of tamarisk "is not likely to adversely affect the southwestern willow flycatcher."

The authors of the BA overlooked a few key factors about the effects of the beetles on tamarisk. Although mortality of tamarisk might be gradual, defoliation by tamarisk leaf beetles was known to be sudden and complete. If, as the project proponents maintained, exposure of flycatcher nests to lethal temperatures was a cause of extirpation of flycatchers from some areas, surely the removal of shade during the height of flycatcher breeding season should have been a concern.

In addition, there was no evidence, at the time the BA was written, that native vegetation would return to areas where tamarisk had been controlled. The BA did not completely address the role that changes in hydrology (e.g., the construction of Hoover Dam) likely played both in the invasion of tamarisk and in the reduction of habitat suitability for willow flycatchers via stream channelization and the reduction in spring floods that create the dense thickets of young vegetation preferred by flycatchers.

Despite assurances by beetle proponents, some scientists gave unequivocal warnings against beetle releases (see Appendix IV in DeLoach and Tracy 1997). In response to concerns voiced within and outside of the USFWS and APHIS, a meeting was called in June 1998 with the USFWS, ARS, and other Federal agencies to discuss the BA.

As a result of these concerns, ARS and APHIS submitted a revised research proposal to the USFWS in August 1998 (DeLoach and Gould 1998). This proposal requested the release of tamarisk beetles and mealybugs at 13 sites in seven western States, with one of the criteria for site selection being a distance of at least 200 miles from areas where flycatchers nest in tamarisk. The proposal specified two phasesresearch and implementation - of the biocontrol program. The research phase included both cage and field releases and was intended in part to evaluate whether remedial actions, such as manual revegetation, would be needed prior to the arrival of beetles in areas occupied by flycatchers. The proposal stated that biocontrol agents would be contained within the defined release sites; some of these release sites, however, encompassed over 100 miles of river. The implementation phase would entail release of biocontrol agents at additional sites, with the goal of widespread control of tamarisk, but would still exclude releases in areas where flycatchers nest in tamarisk.

The proposal acknowledged, however, that the control insects would eventually disperse to areas occupied by flycatchers, though this was projected to take 10 to 20 years. This estimate of dispersal speed (200 miles in as little as 10 years, or an average of 20 miles in a year) was quite different from the 2-4 miles per year stated in the 1997 BA, but there was no direct acknowledgment in the proposal that the dispersal estimate had changed, and subsequent analysis by the USFWS did not consider this faster dispersal rate. The proposal expressly stated, "Unprecedented safeguards and precautions are herein proposed to insure that biological control does not adversely affect the [flycatcher], especially through the process of reducing its potential breeding habitat (which presently includes saltcedar) before the recovery of its native habitat (willows, cottonwoods and other native trees and shrubs) can occur."

The proposal refers to the BA for these safeguards and precautions, and the BA contains only the very general statement that in the "very improbable" event that beetles 
needed to be controlled, “...the areas of the most dense and most damaging control agents populations will be treated by ground or aerial applications of appropriate insecticides at sub-lethal or borderline lethal rates in order to slow the reproduction and spread, but without exterminating all control agents at the release site." There was no consideration of the possibility that by the time it would become obvious that control was progressing too rapidly, the beetles would occupy too large an area for insecticide to be a reasonable solution.

The Flycatcher Recovery Team reviewed the revised research proposal and submitted a letter to the Southwest Regional Director of the USFWS, expressing its concerns that tamarisk might not be replaced by native vegetation with equal function with respect to the needs of the flycatcher, particularly in areas with site conditions such as altered flooding regimes, high salinity, and grazing. There was also concern that the biocontrol agents might escape the proposed release areas, either by natural dispersal or by transport by humans (USFWS 2014).

Despite the concerns of the Flycatcher Recovery Team and the presence of flycatchers nesting in tamarisk along the Rio Grande (USFWS 2002), the USFWS issued concurrence on December 28, 1998, that the proposed releases at all 13 sites would not adversely affect the flycatcher. It cited safeguards such as the 200-mile distance from areas where flycatchers nested in tamarisk. The concurrence was rescinded the following April, based on "new information" regarding flycatchers nesting in tamarisk along the Rio Grande. An amended concurrence was issued on June 3, 1999, following a meeting between USFWS and USDA personnel and agreement from the project proponents that all sites along the Rio Grande would be removed from consideration.

The concurrence required a separate consultation before the implementation phase of the project could be started, and it also required separate consultation for the addition of any new sites. Despite the prediction in the project proposal that beetles could spread as much as 20 miles per year, the concurrence cited "convincing argument[s]" presented by USDA personnel at the meeting that the geographic isolation of the remaining release sites would prevent the control agents from reaching areas where flycatchers nested in tamarisk, given that "research ... indicates [the control agents] should move on the order of tens of feet per year."

A final draft Environmental Assessment (EA) on the biological control of tamarisk was released by APHIS in July 1999. The EA addressed the release only of the tamarisk leaf beetle, Diorhabda elongata Brulle, and did not include the mealybug. The proposed action included the release of beetles at 10 sites, all of which were at least 185 miles from flycatcher nesting areas, and stated that the spread of beetles would be slowed through chemical or mechanical means if the beetles appeared to "consume saltcedar too rapidly." The EA did not predict a rate of spread for these particular beetles but implied that the rate would be slow, given that other chrysomelid beetles "appeared to spread relatively slowly at a maximum of several tens of meters per year," and stated that invasion of flycatcher nesting areas by beetles and the death of tamarisk faster than native plants could regenerate was "highly improbable." A Finding of No Significant Impact (FONSI) was signed on July 7, 1999, and APHIS immediately began issuing permits for the establishment of field cages. 


\title{
Beetle Releases
}

\author{
Northern Beetles
}

Field cages were established as soon as permits were obtained, but because permits were not issued until mid-July, research at the field cages during 1999 was largely limited to one generation of beetles. Despite having data only from a single generation of beetles in a single year, a report issued later that year (Gould 1999) concluded that "the data ... indicate that D. elongata will require at least several years to reduce even local saltcedar stands to a significant degree." A second summer of cage studies was completed in 2000, and beetle populations at several of the sites increased to very high numbers, resulting in the consumption of all foliage in the cages and causing complete mortality of some large plants (DeLoach et al. 2003b).

In the spring of 2001, APHIS issued permits for the open release of beetles, and beetles were released in May at sites in Texas, Colorado, Wyoming, Utah, Nevada, and California. Little defoliation was seen during the summer of 2001, but the summer of 2002 produced "spectacular defoliation" at some sites (DeLoach et al. 2003b). By September of 2002, beetles had dispersed no farther than approximately $100 \mathrm{~m}$ from the release points.

The beetles that were released into cages in 1999 and then into the field in 2001 all originated either from Fukang, China, or Chilik, Kazakhstan (classified at the time as Diorhabda elongata deserticola and later reclassified as D. carinulata, the northern tamarisk beetle; Tracy and Robbins 2009). The cage and field tests revealed that beetles originating from these northerly latitudes did not overwinter successfully at southerly latitudes (DeLoach et al. 2003b). Laboratory experiments and field observations on the northern tamarisk beetle showed that this ecotype entered diapause at a day length of $\approx 14 \mathrm{~h} 39$ minutes; south of $36^{\circ} 20^{\prime} \mathrm{N}$ (approximately 50 miles south of the northern borders of Arizona and New Mexico), the longest day is shorter than this critical day length. Researchers therefore concluded that this northern ecotype was unlikely to succeed as a biocontrol agent south of $38^{\circ} \mathrm{N}$ (approximately 70 miles north of the northern borders of Arizona and New Mexico) because premature diapause would increase mortality (Bean et al. 2007b).

\section{Other Beetle Species}

Beetle proponents began testing other ecotypes, which were also later reclassified as separate species, originating from Uzbekistan (D. carinata, the larger tamarisk beetle), Crete (D. elongata, the Mediterranean tamarisk beetle), and Tunisia (D. sublineata, the subtropical tamarisk beetle) (Tracy and Robbins 2009) for control of tamarisk at latitudes below $38^{\circ} \mathrm{N}$. By the end of the summer of 2002, all four beetle species had been tested in cages, and a request was submitted on February 14, 2003, to the USFWS for the release of beetles of all four subspecies at the 10 existing sites as well as 20 new sites, many of which were in Texas and New Mexico and included sites on the Rio Grande where flycatchers were known to breed (DeLoach et al. 2003b). Beetle releases at these flycatcher sites were requested as a demonstration that beetles would have no adverse effects on flycatchers that nested in areas with abundant willows. 
Subsequent discussion between ARS and the USFWS resulted in all sites along the Rio Grande that were within 200 miles of occupied flycatcher habitat being removed from consideration, and the USFWS issued a letter on June 13, 2003, concurring that release of beetles at the additional sites "may affect, but is not likely to affect" the flycatcher. This determination relied on distance and geographic barriers (i.e., expanses without tamarisk) to be "effective as a means of keeping the control agents from sites on the Lower Colorado River in Arizona and the Rio Grande in New Mexico where flycatchers are nesting in saltcedar." Concurrence was also given by the USFWS on July 23, 2003, for the release of multiple species of beetle near Kingsville, Texas, and at several sites along the Pecos River. Concurrence for release at sites in western Texas followed on September 1, 2004. Between 2003 and 2009, beetles of all four species were released at about 70 sites in Texas, and the larger, subtropical, and Mediterranean species became established at various sites (DeLoach et al. 2011). Beetles were first released on the Rio Grande in Texas in 2007, and subtropical beetles became established at multiple sites along the Rio Grande in 2009.

\section{Implementation Phase of Biocontrol Program}

While additional release sites were being approved by the USFWS, USDA personnel were also working toward the implementation phase of the biocontrol program. The implementation phase considered only the northern tamarisk beetle, D. carinulata. Under the implementation phase, beetles would be established at "nursery" sites in up to 13 western and midwestern States, north of $38^{\circ} \mathrm{N}$ latitude. Beetles would then be available for distribution anywhere in those States. Utah was excluded from the plan since beetles had already been distributed there.

A BA for the implementation phase was released in March 2005 and an EA followed in June. The effects analysis in both documents determined that there would be no effect to flycatchers, and this determination relied on critical day length for D. carinulata precluding beetles from establishing populations in areas south of $38^{\circ} \mathrm{N}$. The EA did concede that beetles from the northern ecotype could eventually adapt to conditions below $38^{\circ}$ but stated that this adaptation would not be rapid because beetles were documented to disperse only 1.5 miles in 3 years. Later in the same document, however, dispersal was noted as being over an order or magnitude larger than this, 50 miles in 4 years.

In the concurrence letter, the USFWS indicated that APHIS provided additional information and clarification to the USFWS before the concurrence was issued. The USFWS concluded that D. carinulata is "capable of occurring between 36 and 38 degrees north latitude in substantial numbers at some locations" and also acknowledged that the beetles "are expected to eventually adapt to diapause at lower latitudes" but still maintained that beetles were expected to have "little success in reducing saltcedar stands in areas at or south of $38^{\circ}$ north latitude." The concurrence letter also recognized that suppression of tamarisk without active management to restore native vegetation might result in riparian habitat of degraded quality, thereby reducing habitat quality for flycatchers. Despite these apparent misgivings, the USFWS concurred on July 11, 2005 , that the proposed action was not likely to adversely affect the flycatcher, and the FONSI, which predated the concurrence, was issued for the EA in June 2005. 


\title{
Beetles Spread Into Flycatcher Habitat
}

\author{
Virgin, Muddy, and Lower Colorado Rivers
}

The 2005 EA for the implementation phase of the beetle program acknowledged that the eventual outcome of the no action alternative and the proposed action alternative were the same; the only difference was the rapidity with which beetles would spread. As was soon to be demonstrated, however, beetles are capable of rapid spread even without human assistance. In 2004, beetles were released along the Colorado River near Moab, Utah. This release was not done under the USDA program but rather by the Grand County weed management department, which had collected beetles (D. carinulata, from the Chilik, Kazakhstan strain) from Delta, Utah, one of the original 10 test sites, and re-distributed them near Moab. The first major defoliation along the Colorado River was recorded in 2006 and encompassed around 990 acres over approximately 20 miles of river. By the end of the following year, around 10,000 acres were defoliated over approximately 70 miles of the Colorado River, and beetles had spread into the Green and Dolores Rivers (Tamarisk Coalition, n.d.). In subsequent years, these beetles continued to spread in the upper Colorado River Basin.

In 2006, another D. carinulata release occurred, this time by the city of St. George, Utah. St. George lies along the Virgin River just above $37^{\circ} \mathrm{N}$ latitude and has a small population of nesting flycatchers. Although beetle researchers had claimed that D. carinulata was unlikely to do well below $38^{\circ} \mathrm{N}$, widespread defoliation around St. George occurred beginning in August 2008 (Dobbs et al. 2012). As the beetles progressed southward, it became abundantly clear that the assumption that northern beetles would not succeed as a biocontrol agent below $38^{\circ} \mathrm{N}$ was wrong. Further experiments in 2007 and 2008 on D. carinulata showed that critical day length had decreased over the previous 5 years, with the magnitude of the decrease being inversely proportional to latitude (Bean et al. 2012).

The area around St. George was again defoliated in 2009, this time beginning in June, and by the end of that summer, complete defoliation had spread over 25 miles downstream of St. George, to a point between Littlefield, Arizona, and Mesquite, Nevada. Beetles continued to spread downstream on the Virgin River, traveling another 20 miles and encompassing another flycatcher breeding site in 2010, reaching the Gold Butte area by the end of the summer, and extending another 20 miles to reach a third flycatcher breeding site and encompass the entire lower Virgin River to the Overton Arm of Lake Mead (approximately $36.4^{\circ} \mathrm{N}$ ) by the end of 2011. By the end of 2012, beetles occurred all along the Muddy River, including at another flycatcher site, and had reached the lower end of Lake Mohave. By the end of 2013 they were at Big Bend State Park, south of Laughlin, Nevada, at $35.1^{\circ} \mathrm{N}$, having dispersed a straight-line distance of 150 miles in the 7 years since their release in St. George (fig. 15). This was an average dispersal distance of slightly over 20 miles per year, exactly what had been stated in the 1998 project proposal as the maximum likely dispersal rate.

Over the next 2 years, beetles spread very little south of Big Bend State Park. In July 2015, extensive defoliation was apparent at Big Bend State Park (M.A. McLeod, Biologist, SWCA Environmental Consultants, personal observation, Big Bend State Park, July 23, 2015), and a few individual beetles but no defoliation were observed 
Figure 15-Spread of tamarisk beetles along the Virgin and Lower Colorado Rivers in 2008 to 2016 (map by Glenn Dunno, SWCA Environmental Consultants).

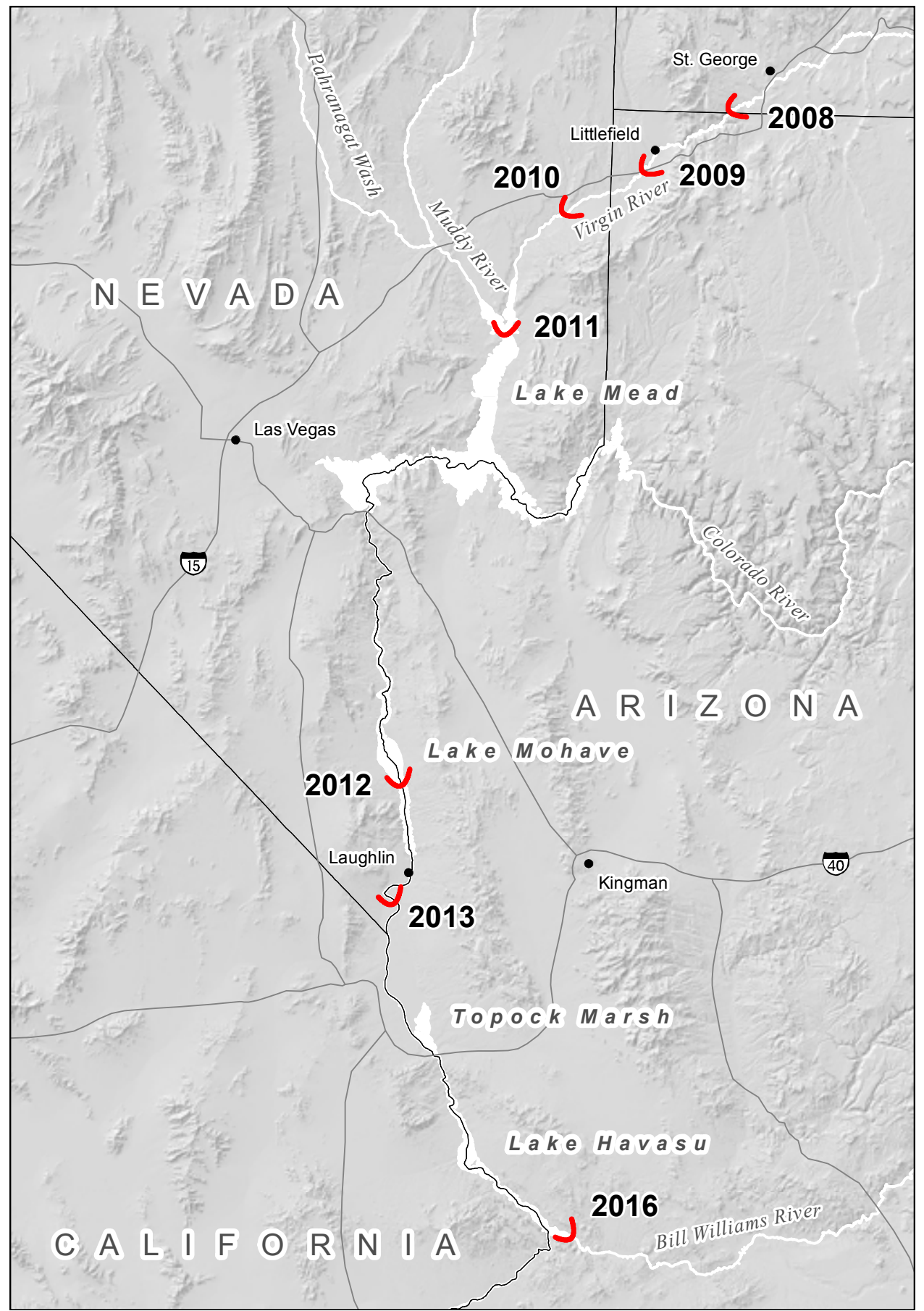

approximately 5 miles south of Big Bend (Tom Dudley, University of California Santa Barbara, personal communication, August 7, 2015). Some people speculated that the northern beetles had finally reached the latitude where southerly dispersal would be limited by critical day length. However, by July 2016, beetles and defoliation were apparent at Topock Marsh, on both sides of Lake Havasu, and at the mouth of the Bill Williams River, over 60 miles from Big Bend and within a quarter mile of nesting flycatchers along the Bill Williams River (M.A. McLeod, Biologist, SWCA Environmental Consultants, personal observation, Lower Colorado River, July 21 and 22, 2016). 


\section{Rio Grande}

While $D$. carinulata were spreading along the Virgin River and downstream along the Lower Colorado River, they were also spreading elsewhere. By the end of 2014, D. carinulata were found throughout much of the upper Colorado River Basin, including the San Juan River, as well as through Grand Canyon and the Little Colorado River as far east as Holbrook, Arizona. D. carinulata were also defoliating tamarisk along the Rio Grande around Albuquerque and as far south as Socorro, New Mexico, near $34^{\circ} \mathrm{N}$ (Tamarisk Coalition 2014). By the end of 2015, northern beetles had moved southward on the Rio Grande almost to Elephant Butte Reservoir. Subtropical beetles expanded northward along the Rio Grande from Texas at the same time as the northern beetles advanced southward. Subtropical beetles were found north of Las Cruces at Rincon, New Mexico, by fall of 2014; in August of 2015 beetles and defoliation were noted at Caballo Reservoir, about 30 miles south of Elephant Butte (James Tracy, Texas A\&M University, College Station, Texas, personal communication, August 6, 2015).

Beetles, presumed to be of the subtropical species but awaiting species verification at the time of this writing, arrived at Elephant Butte during the summer of 2016 and began defoliating tamarisk close to areas with large numbers of flycatchers nesting in tamarisk (Dave Moore, U.S. Department of the Interior, Bureau of Reclamation, Denver, Colorado, personal communication, July 2, 2016). Nesting flycatchers are found along the Rio Grande from north of Albuquerque south to Radium Springs near Las Cruces. The Elephant Butte area hosts one of the largest populations of nesting flycatchers, with over 300 territories documented in 2014 (Moore 2015). Nesting habitat along the Middle Rio Grande was dominated by native vegetation in 2002, but native habitat declined in subsequent years, partly as the result of drought, and by 2014 less than 40 percent of flycatcher nest sites were dominated by native vegetation (Moore 2015).

The subtropical beetle had been projected to reach Elephant Butte Reservoir by fall of 2014 and the middle Gila River in Arizona by the spring of 2017 (Tracy 2014). Given that the arrival of beetles at Elephant Butte was later than initially thought, beetles will likely not arrive on the Gila River as soon as was anticipated. The middle Gila River also hosts a large flycatcher population, and almost all flycatcher breeding sites are dominated by tamarisk (Graber et al. 2012; Heather English, Salt River Project, Phoenix, Arizona, personal communication, April 30, 2013).

\section{Cessation of Biocontrol Releases}

The Center for Biological Diversity (CBD) and Maricopa Audubon Society filed suit against the USFWS and APHIS on March 27, 2009, seeking reinitiation of consultation between APHIS and the USFWS, after beetles defoliated flycatcher habitat around St. George and research showed that northern beetles were adapting to more southerly latitudes. Consultation was reinitiated later that year. In May 2010, APHIS submitted a new BA to the USFWS, asking for concurrence that cessation of the beetle release program would have no adverse impacts to the flycatcher. An official moratorium on the beetle program, cancelling all existing permits for release and interstate transport of all Diorhabda species and discontinuing issuance of new permits, was announced by APHIS on June 15, 2010. However, beetles were already widely established by then, and shutting down the release program had no effect on preventing the spread of the 
beetle. CBD and Maricopa Audubon Society filed a second suit in 2013, seeking, in part, a "mitigation plan to address impacts of the beetle populations on flycatchers and their critical habitat."

\title{
Response by Flycatchers to Tamarisk Defoliation
}

\author{
St. George, Utah
}

Breeding flycatchers and beetle defoliation first overlapped in St. George, Utah, in late July of 2008. This was, coincidentally, also the year that the Utah Division of Wildlife Resources began intensive monitoring of nesting flycatchers in St. George after doing general presence/absence surveys since 2001. Flycatchers along the Virgin River typically arrive on their territories beginning in early May, with late arrivals coming in the middle of June. The average start of incubation is in the middle of June, and the latest nests fledge by the middle of August (Bureau of Reclamation, n.d.; Sogge et al. 2010). Therefore, defoliation that begins in late July has little effect on flycatchers. Eight breeding pairs and 10 nesting attempts were documented in St. George in 2008; seven of the 10 nests were built in areas dominated by tamarisk (Edwards and Woodhouse 2015). The eight pairs produced 17 young (fecundity, or young produced per female, was 2.1; fig. 16) (Fridell et al. 2009).

The following year, defoliation was noted beginning in early June, after territories had been established and when nesting was already underway, and a second defoliation event occurred in late July to August. The Utah Division of Wildlife Resources documented 10 breeding pairs and 18 nests, three of which were abandoned before eggs were laid. As was the case in 2008, the majority of nests (11 of 15 nests with flycatcher eggs) were placed in areas dominated by tamarisk (Edwards and Woodhouse 2015). Defoliation of the tamarisk was complete, leaving nests without shade or concealment (fig. 17). Productivity was markedly lower than in 2008, with a total of two young produced (fecundity $=0.2$ ) (Fridell et al. 2009; fig. 16). Primary causes of nest failure were depredation and failure of the eggs to hatch after at least 18 days of incubation. Six nests (46 percent of nests that failed after eggs were laid) failed to hatch, indicating that embryos died in the egg (Dobbs et al. 2012). Failure to hatch is not typically a common reason for a nest to fail, accounting for less than 9 percent of failures on the lower Virgin River in 2003 to 2010 (McLeod and Pellegrini 2013). The high rate of addled nests in 2009 could have been the result of eggs at unshaded nests being exposed to lethal temperatures.

In 2010, defoliation was again noted in St. George beginning in early June, with a second defoliation in late July to August (Dobbs et al. 2012). Nine breeding pairs of flycatchers were detected in 2010. The marked difference between 2010 and prior years was where the flycatchers established territories. In previous years, flycatchers had nested primarily in tamarisk-dominated sites; in 2010, 16 of 20 nests were built in willow-dominated areas that had been previously either unoccupied or sparsely occupied by flycatchers, including one site where willow planting had occurred following a large flood in 2005. Fecundity in 2010 rose to 1.3 young per female (Dobbs et al. 2012). Tamarisk around St. George has been defoliated each year since 2008, although the timing and number of defoliation events has varied among years. Despite annual defoliation, the tamarisk shows little sign of mortality or reduced vigor (Hultine et al. 2015; 


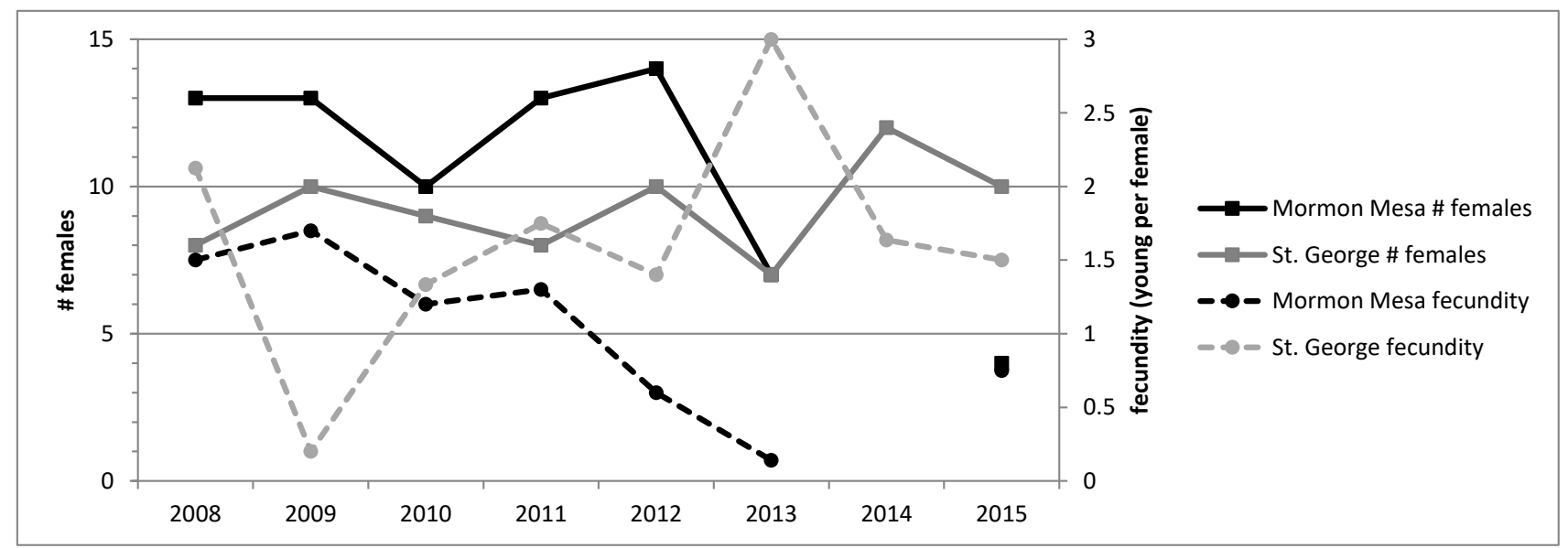

Figure 16-Number of female southwestern willow flycatchers and annual fecundity (young produced per female) documented at St. George, Utah, and Mormon Mesa, Nevada, 2008 to 2015.

Figure 17-Female southwestern willow flycatcher panting as she shades her nest in a defoliated tamarisk stand, St. George, Utah (photo by Pam Wheeler, Utah Division of Wildlife Resources).

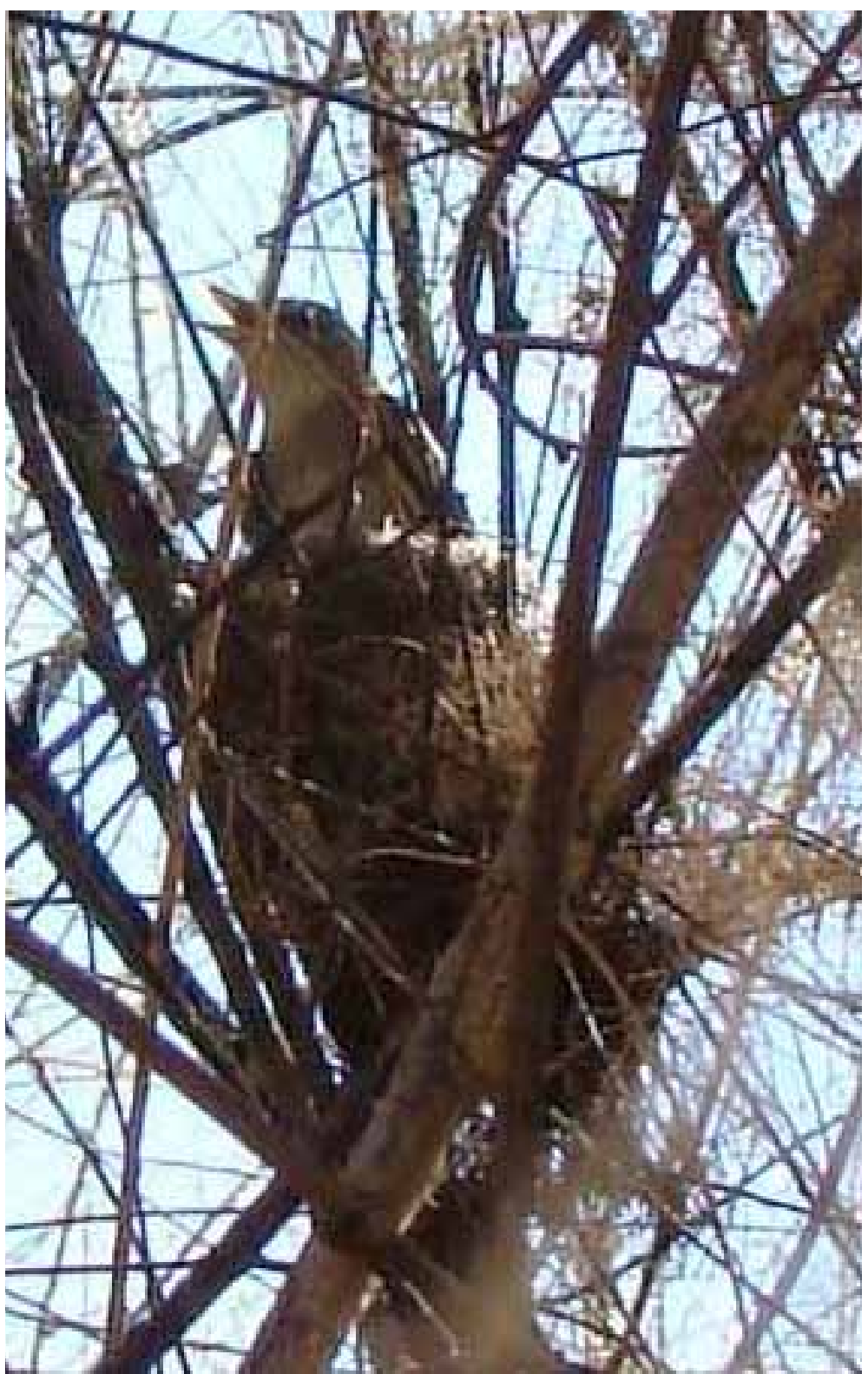


M.A. McLeod, Biologist, SWCA Environmental Consultants, personal observation, St. George, Utah). Flycatchers around St. George continued occupying native-dominated areas in 2011 to 2015, though flycatchers again occupied tamarisk-dominated areas in 2014 and 2015 (Edwards and Woodhouse 2015). The total number of flycatcher pairs fluctuated between 7 and 12, and fecundity varied between 1.4 and 3.0 young per female (fig. 16; Dobbs and Edwards 2012; Dobbs et al. 2012; Edwards and Dobbs 2013; Edwards and Woodhouse 2014, 2015).

Flycatchers typically demonstrate a high degree of site fidelity, with half of all adults that are detected in multiple years returning to nest within $40 \mathrm{~m}$ of the place where they nested the previous year (McLeod and Pellegrini 2013). However, site fidelity is strongly influenced by reproductive success, with flycatchers that fail to produce offspring being far more likely to attempt breeding at a different site in the following year (McLeod and Pellegrini 2013; Paxton et al. 2007). This local plasticity in site selection, as demonstrated by the flycatchers in St. George, is what should be expected from a species that was adapted to the southwestern riparian system, which was characterized by scouring floods and a constantly shifting mosaic of vegetation.

\section{Mormon Mesa, Nevada}

When beetles progressed downstream on the Virgin River in 2009 to 2011, they affected the two flycatcher breeding sites on the lower Virgin River. Flycatchers along the Virgin River in Arizona and Nevada have been monitored annually since 1997 under a contract funded by the Bureau of Reclamation. Two areas, one in the vicinity of the town of Mesquite, Nevada, and the other approximately 19 miles downstream, across Mormon Mesa from Overton, Nevada, have been consistently occupied by breeding flycatchers since monitoring began (McLeod and Pellegrini 2015). Although flycatcher occupancy and nest success at Mesquite declined markedly from 2010 to 2013 (McLeod and Pellegrini 2014), this was likely a response to the site being dry for extended periods in 2011-2013 and the resulting decline in vegetation health.

The flycatcher breeding site at Mormon Mesa contained patches of coyote willow and a few emergent Goodding's willows (Salix gooddingii) surrounded by a sea of tamarisk. Defoliation was first observed at Mormon Mesa in mid-July 2011, and the breeding area was fully defoliated by early August. In 2012, widespread defoliation was observed in late May, and a second defoliation event occurred at the beginning of August. No defoliation events occurred during the flycatcher breeding season in 2013, but defoliation from the previous 2 years had resulted in 84 percent dieback at Mormon Mesa by 2013 (Hultine et al. 2015). This dramatic change in the vegetation is readily apparent on satellite imagery (fig. 18).

As was the case in St. George, the first defoliation event at Mormon Mesa occurred late in the breeding season, after most flycatcher nesting activity was over. The number of female flycatchers (13) and fecundity (1.3 young per female) documented in 2011 were typical of previous years (fig. 16; McLeod and Pellegrini 2013). In the following year, defoliation occurred as flycatchers were establishing territories and choosing nest sites. Fourteen female flycatchers nested at Mormon Mesa in 2012, and every nest found was placed in or on the edge of a willow patch. 


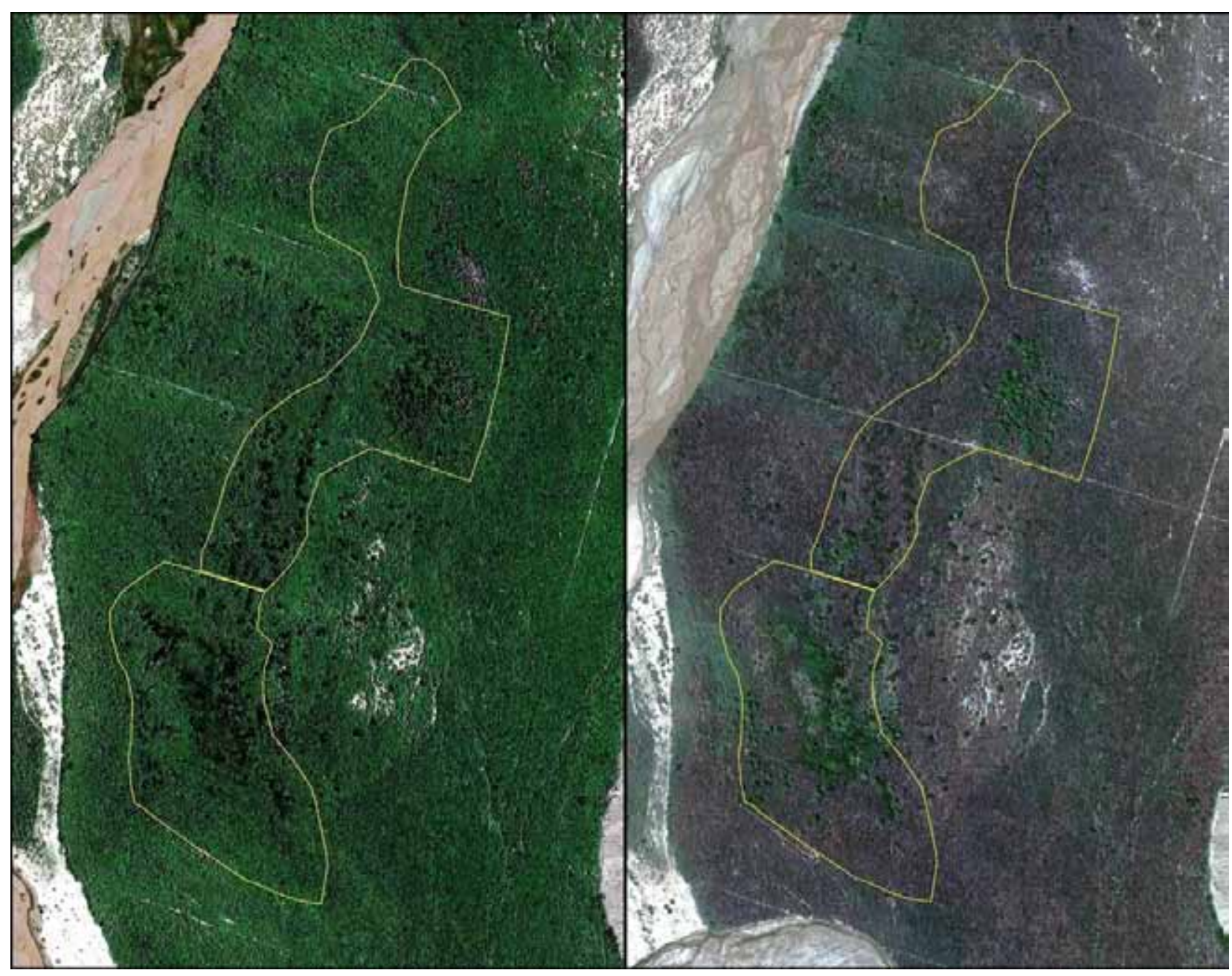

Figure 18-The Mormon Mesa area of the Virgin River in August 2010 before tamarisk beetles arrived (left) and in May 2013, after 2 years of defoliation (right). The 2013 image was not taken during a defoliation event and depicts the mortality and dieback of tamarisk caused by the prior 2 years of defoliation. The areas in the 2013 image that appear grayish-green are vegetated by arrowweed (Pluchea sericea), and the bright green areas are coyote willow (Salix exigua) or Goodding's willow (S. gooddingii). Yellow outline shows the area surveyed for flycatchers (base photo by Google Maps, outlines by SWCA Environmental Consultants).

Despite nests being placed in willow patches, fecundity in 2012 was 0.6 , just half that recorded in the prior year (McLeod and Pellegrini 2013). Nest desertion during the laying phase, without any sign of cowbird parasitism or partial depredation of the clutch, accounted for half (4 of 8) of the nest failures; in 1997 to 2010, only two other instances of this were observed on the lower Virgin River, accounting for 1 percent of nest failures (Bureau of Reclamation, n.d.). Nest desertion may be indicative of poor habitat quality; flycatchers in Arizona were observed to forego nesting altogether under severe drought conditions (Ellis et al. 2008). In 2013, only seven females nested at Mormon Mesa, producing one fledgling among them (fecundity $=0.14$ young per female; fig. 16; McLeod and Pellegrini 2014). Four nests were abandoned before eggs were laid, and two of the four nests (50 percent) that failed after eggs were laid had addled clutches.

Flycatchers at Mormon Mesa were not monitored in 2014 because all Federal agency personnel and their contractors were barred from visiting the lower Virgin River 
because of safety concerns following the Bureau of Land Management's attempt to remove Cliven Bundy's trespass cattle. The Nevada Department of Wildlife (NDOW) completed surveys and intermittent monitoring for flycatchers at Mormon Mesa in 2015. Only two breeding male flycatchers were detected, each of which was confirmed to have one mate and suspected to have two (NDOW, n.d.). Two of the females were confirmed to have produced three fledglings between them, for a minimum fecundity of 0.8 young per female (fig. 16).

It is unlikely that a substantial number of the flycatchers at Mormon Mesa moved to other locations, where they went undetected, in the years following 2012. Estimated annual survival of adult flycatchers along the Virgin River in 1997-2012 was 61 percent (McLeod and Pellegrini 2013). In 2012, 20 adult flycatchers were individually identified, via unique color-bands, at Mormon Mesa. Thirteen (65 percent, essentially what would be expected given annual mortality) of those flycatchers were detected again in 2013, and all 13 were detected at Mormon Mesa; none were detected at other flycatcher sites despite all known flycatcher breeding areas in southern Nevada and western Arizona being monitored as part of various projects. In addition, all of the adult flycatchers detected at Mormon Mesa in 2013 had been there the year before; i.e., for the first time in 17 years of monitoring, no new adults entered the population at Mormon Mesa (McLeod and Pellegrini 2014; Bureau of Reclamation, n.d.).

\section{St. George vs. Mormon Mesa}

Flycatchers at both St. George and Mormon Mesa had a sharp decline in productivity in the first year when defoliation significantly overlapped the flycatcher breeding season. The response after that first year differed dramatically between the two areas, however, and the two populations took very different trajectories. Flycatchers in St. George moved into native-dominated stands in subsequent years, the total number of breeding flycatchers remained the same, and productivity recovered from the low observed in the first year of defoliation; flycatchers at Mormon Mesa continued attempting to breed in the same stands but the number of breeding flycatchers dropped sharply and productivity remained very low through the second year, despite no defoliation events occurring during that breeding season.

There are two key differences between St. George and Mormon Mesa that likely contributed to the differing trajectories of the flycatcher population. One is the response of tamarisk to beetle defoliation. Tamarisk around St. George has experienced little mortality or dieback as a result of repeated defoliation; unless a defoliation event is occurring, the tamarisk still provides shade and concealment. In the Mormon Mesa area, in contrast, two seasons of defoliation resulted in widespread mortality and dieback.

The other striking difference is the overall species composition of the vegetation in the riparian zone. St. George is on the upper Virgin River, where native trees are common. Prior to 2009, St. George had stands of native trees that looked like suitable flycatcher habitat and had been surveyed, but where few or no resident flycatchers were found (Rob Dobbs, Utah Division of Wildlife Resources, Hurricane, Utah, personal communication). Flycatchers moved into these existing native sites in 2010, following defoliation and widespread nest failure at tamarisk-dominated sites in 2009 . The lower Virgin River, in contrast, has relatively little native vegetation; there were 
no sites, consisting of either native vegetation or tamarisk, that looked like they could be suitable flycatcher habitat but were unoccupied (M.A. McLeod, Biologist, SWCA Environmental Consultants, personal observation, lower Virgin River). When tamarisk was defoliated, flycatchers at Mormon Mesa had nowhere nearby to go. The closest flycatcher sites to Mormon Mesa were at Mesquite ( 19 miles away) and at Overton on the Muddy River ( $\sim 7$ miles away). Both were in poor condition; Mesquite had been dry, and Overton was suffering both from changes in streamflow that left a portion of the breeding site dry and from tamarisk defoliation (McLeod and Pellegrini 2015).

\section{Short-Term Consequences}

The proponents of the tamarisk biocontrol program claimed that decline in tamarisk would be gradual and would be accompanied by a concurrent increase in the native plant community. They also cited examples of how quickly native vegetation could become suitable habitat for nesting flycatchers as evidence that no gap in habitat availability would occur. However, beetles can cause complete defoliation that results in greater solar insolation, lower humidity, and higher temperatures (Bateman et al. 2013), which have been associated with low reproductive output in flycatchers (Dobbs et al. 2012; McLeod and Pellegrini 2013). While it is true that riparian vegetation can grow into suitable flycatcher nesting habitat in as little as 2 or 3 years (Paxton et al. 2007; M.A. McLeod, Biologist, SWCA Environmental Consultants, personal observation, Virgin and lower Colorado rivers), this typically occurs in areas that have been scoured by a flood or on sediments that are newly exposed when water levels in a reservoir decline.

A resurgence of willows on the stream margins of areas that have been defoliated by tamarisk beetles has been observed in some areas, such as along the upper Colorado River (S. Carothers, SWCA Environmental Consultants, personal observation, upper Colorado River; Graham et al. 2016), but in other areas, the reduction in canopy cover of tamarisk has allowed weed species to proliferate. At Mormon Mesa, beetles caused rapid dieback and mortality of tamarisk, without concurrent recovery of native vegetation. No expansion of the willows was apparent as of the summer of 2016, 5 years after beetles became established in the area, but whitetop (Lepidium sp.), an invasive weed, had become much more widespread than it was prior to the arrival of beetles (M.A. McLeod, Biologist, SWCA Environmental Consultants, personal observation, Mormon Mesa, June 16, 2016). In short, it is now clear that beetles can cause a gap in habitat availability that lasts for several years, and possibly much longer.

Flycatchers, like most small passerines, are relatively short-lived birds. Estimated juvenile mortality along the Virgin River in 1997-2012 was 68 percent (i.e., only 32 percent of fledglings survive to their second summer; McLeod and Pellegrini 2013), and estimated annual adult mortality over that same period was 39 percent. If flycatchers are unable to reproduce, the flycatcher population experiences a precipitous decline. In the complete absence of reproduction, the adult flycatcher population would decline by 77 percent in just 3 years and 91 percent in 5 years, given the estimated annual mortality rate. Even if each adult female produces, on average, one fledgling per year, the population would decline 73 percent after 5 years. Flycatchers do not have the longevity to be able to wait out several years of poor reproduction if tamarisk defoliation renders entire river reaches unsuitable as breeding habitat. 
In areas where flycatchers nest primarily in tamarisk-dominated habitats, alternative breeding sites are needed so that local populations can persist during the period when tamarisk no longer provides nesting habitat but native vegetation has not recovered. These alternative sites should be close to existing breeding sites; in multiple drainages where flycatchers have been studied, the vast majority of between-year movements by adult flycatchers resulted in distances moved of less than 25 miles (McLeod and Pellegrini 2013; Paxton et al. 2007).

In addition, when a large area of formerly suitable habitat became unsuitable, no large-scale dispersal to other breeding locations was observed (Paxton et al. 2007), illustrating the need for local refugia. Following biocontrol, any areas that recover native vegetation in sufficient density to become flycatcher breeding habitat should be readily colonized by flycatchers if a local population is present. Colonization of new habitats that are adjacent to occupied areas has been observed in multiple flycatcher studies (McLeod and Pellegrini 2014; Moore and Ahlers 2008; Paxton et al. 2007), and flycatcher populations can increase rapidly in response to an increase in suitable habitat (Graber et al. 2012; Moore and Ahlers 2008; Paxton et al. 2007).

\section{Long-Term Prospects}

Beetles are expected to be eventually found in all areas of North America that have tamarisk (Bean et al. 2013), and these areas completely overlap the breeding range of the southwestern willow flycatcher. In the long term, tamarisk biocontrol may have exactly the effect on tamarisk that its proponents advertised: reducing the density of tamarisk by up to 85 percent. The authors of the 1998 biocontrol proposal suggested this would "reduce the abundance of saltcedar to below the level where it causes important damage to western riparian ecosystems." At this level of suppression, however, tamarisk would also no longer provide much ecological value. Recovery of native vegetation is unlikely to occur in many areas that will be affected by the tamarisk beetle, and in these places, biocontrol will result in a long-term reduction in habitat quality.

Tamarisk is a symptom as well as a cause of the degradation of riparian ecosystems, and removing the tamarisk does not address the underlying changes that limit native riparian species and allow tamarisk to proliferate. The Flycatcher Recovery Team identified this concern early on and reiterated it in the letter sent to the Regional Director of the USFWS in 1998 expressing their concerns about the proposed beetle releases, pointing out that without extensive regional changes in the management of water and land, existing conditions would continue to preclude the establishment of native riparian vegetation.

The long-term effects of tamarisk beetles on vegetation conditions are likely to vary widely between river systems and between reaches, depending on the prevalence of tamarisk and on the many factors, such as flood regimes, groundwater levels, and soil and water salinity, that influence whether native riparian vegetation can become established and persist. The fact that some of the largest flycatcher populations occur in sites dominated by tamarisk makes the flycatcher, among riparian obligate wildlife, particularly susceptible to the detrimental effects of tamarisk beetles. Based on the observed responses of flycatchers to tamarisk defoliation, flycatcher productivity will almost certainly decrease immediately following the arrival of beetles in any area 
where flycatchers nest in vegetation with a significant tamarisk component, including at Elephant Butte Reservoir and on the Gila River.

Whether beetles cause a long-term reduction in, or even extirpation of, the flycatcher population in these areas remains to be seen. The health, and possibly persistence, of flycatcher populations in reaches that can still support native vegetation may depend on active restoration of native vegetation prior to and immediately following the arrival of beetles. Even beetle researchers have recently acknowledged that defoliation and subsequent dieback of tamarisk can have adverse effects on flycatchers, including in stands that are not dominated by tamarisk (Tracy et al. 2014). Researchers have advocated restoration efforts in advance of the arrival of beetles (Tracy 2014).

Beetle proponents and opponents differ, often passionately, on whether tamarisk biocontrol was a good idea, but both sides ostensibly have the same goal: the preservation and improvement of riparian health. Now that the beetle has been set loose and is spreading rapidly, the common focus should be on mitigating the detrimental effects and maximizing the beneficial results of the inevitable arrival of beetles. The lawsuit that was filed in 2013 against APHIS and the USFWS by CBD and Maricopa Audubon Society sought, in part, a declaration that the defendants had violated the Endangered Species Act and the development of "an appropriate mitigation plan to address the impacts of the beetle populations on flycatchers and their critical habitat." The District Court found that APHIS was in violation of section 7(a)(1) of the Endangered Species Act, which requires Federal agencies to take actions to preserve endangered species (Center for Biological Diversity et al. v Vilsack et al., Dkt. 87), and issued a remedial order instructing the defendants to take several measures, including considering funding intensive third-party restoration efforts (Center for Biological Diversity et al. v Vilsack et al., Dkt. 104).

Flycatchers have received much attention because of their status as a Federally endangered species, but they are, of course, not the only species affected by tamarisk defoliation. A study of riparian-nesting birds on the Virgin River showed that species richness and abundance were higher in 2009 and 2010, prior to the arrival of beetles, than they were in 2013, after 2 or 3 years of defoliation, with yellow warblers (Setophaga petechia) being particularly affected (Johnson 2015). Similarly, herpetofauna were less abundant after defoliation in both monotypic tamarisk and stands of mixed vegetation (Bateman et al. 2014). No study of riparian-nesting birds has been undertaken to compare the pre- and post-beetle nest success of species other than the flycatcher.

For the sake of all riparian obligate wildlife, restoration of native vegetation is urgently needed wherever tamarisk constitutes a significant portion of the woody riparian vegetation and the arrival of beetles is imminent or has already occurred. Restoration is often costly and labor intensive, and it will likely be prohibitively so in places where soil treatments are needed or depth to groundwater is such that irrigation would be required in perpetuity. Restoring habitat where flycatchers can nest successfully is even more difficult, given their propensity to select dense vegetation close to surface water.

One strategy in places where beetles are already present is to target monotypic or mixed tamarisk stands that supported breeding flycatchers prior to the arrival of beetles. These stands likely still have the same surface water conditions that attracted breeding flycatchers but no longer have suitably dense vegetation. This strategy has been employed around St. George, and two successful flycatcher nests were located in one of the restored areas in 2017 (Christian Edwards, Utah Division of Wildlife Resources, 
personal communication, September 11, 2017). Prior to the arrival of beetles, restoration efforts should target sites that can support dense vegetation in proximity to breeding flycatchers, as nearby sites are the most likely to be colonized. This approach is being used on the Gila River in the Safford Valley. Either approach requires careful planning and close coordination with the USFWS. These strategies represent a change from more traditional flycatcher management, which required avoiding nesting sites and their surroundings, but this kind of proactive management may be critical to the long-term success of the southwestern willow flycatcher.

\section{References}

Bateman, H.L.; Ostoja, S.M. 2012. Invasive woody plants affect the composition of native lizard and small mammal communities in riparian woodlands. Animal Conservation. 15: 294-304.

Bateman, H.L.; Merritt, D.M.; Glenn. E.P.; [et al.]. 2014. Indirect effects of biocontrol of an invasive riparian plant (Tamarix) alters habitat and reduces herpetofauna abundance. Biological Invasions. 17(1): 87-97.

Bateman, H.L.; Nagler, P.L.; Glenn, E.P. 2013. Plot- and landscape-level changes in climate and vegetation following defoliation of exotic saltcedar (Tamarix sp.) from the biocontrol agent Diorhabda carinulata along a stream in the Mojave Desert (USA). Journal of Arid Environments. 89: 16-20.

Bean, D.; Dudley, T.; Hultine, K. 2013. Bring on the beetles! In: Sher, A.; Quigley, M.F., eds. Tamarix: A case study of ecological change in the American west. New York: Oxford University Press: 377-403.

Bean, D.W.; Dalin, P.; Dudley, T.L. 2012. Evolution of critical day length for diapause induction enables range expansion of Diorhabda carinulata, a biological control agent against tamarisk (Tamarix spp.). Evolutionary Applications. 5: 511-523.

Bean, D.W.; Dudley, T.L.; Keller, J.C. 2007b. Seasonal timing and diapause induction limits the effective range of Diorhabda elongata deserticola (Coleoptera: Chrysomelidae) as a biological control agent for tamarisk (Tamarix spp.). Environmental Entomology. 36(1): $15-25$.

Bean, D.W.; Wang, T.; Bartelt, R.J.; [et al.]. 2007a. Diapause in the leaf beetle Diorhabda elongata (Coleoptera: Chrysomelidae), a biological control agent for tamarisk (Tamarix spp.). Environmental Entomology. 36(3): 531-540.

Bureau of Reclamation. [n.d.] Flycatcher nesting data. Unpublished data on file with: Bureau of Reclamation, Lower Colorado Region, Boulder City, NV.

Carothers, S.W.; Brown, B.T. 1991. The Colorado River through Grand Canyon: Natural history and human change. Tucson, AZ: University of Arizona Press. 235 p.

DeLoach, C.J. 1994. Petition to release into the field the leaf beetle Diorhabda elongata from China for biological control of saltcedar, Tamarix ramosissima, a weed of riparian areas of the western United States and northern Mexico. U.S. Department of Agriculture, Animal and Plant Health Inspection Service. $43 \mathrm{p}$.

DeLoach, C.J.; Gould, J. 1998. Biological control of exotic, invading saltcedars (Tamarix spp.) by the introduction of Tamarix-specific control insects from Eurasia. Proposal submitted to U.S. Fish and Wildlife Service, August 28, 1998. 45 p.

DeLoach, C.J.; Tracy, J. 1997. Effects of biological control of saltcedar (Tamarix ramosissima) on endangered species. Draft Biological Assessment submitted by U.S. Department of Agriculture Agricultural Research Service. 459 p.

DeLoach, C.J.; Carruthers, R.I.; Dudley, T.L. 2003b. Request to U.S. Fish and Wildlife Service for additional new sites for release of the leaf beetle, Diorhabda elongata from Eurasia, for biological control of saltcedar (Tamarix spp.) in seven western states. Submitted 14 February 2003. $118 \mathrm{p}$. 
DeLoach, C.J.; Knutson, A.E.; Moran, P.J.; [et al.]. 2011. Progress on biological control of saltcedar in the western U.S.: Emphasis-Texas 1986-2010. Report issued by U.S. Department of Agriculture, 1 March 2011. 53 p.

DeLoach, C.J.; Lewis, P.A.; Herr, J.C.; [et al.]. 2003a. Host specificity of the leaf beetle, Diorhabda elongata deserticola (Coleoptera: Chrysomelidae) from Asia, a biological control agent for saltcedars (Tamarix: Tamaricaceae) in the Western United States. Biological Control. 27: 117-147.

DiTomaso, J.M.; Kyser, G.B.; Oneto, S.R.; [et al.]. 2013. Weed control in natural areas in the Western United States. Davis, CA: University of California, Weed Research and Information Center. 544 p.

Dobbs, R. 2012. Southwestern willow flycatcher habitat use and interactions with tamarisk beetles on the Virgin River, Utah. Hurricane, UT: Utah Division of Wildlife Resources, Washington County Field Office. 22 p.

Dobbs, R; Edwards, C. 2012. Southwestern willow flycatcher monitoring, May-August 2012. Unpublished report on file with: Washington County Field Office, Utah Division of Wildlife Resources, Hurricane, UT. Various pagings.

Dobbs, R.C.; Huizinga, M.; Edwards, C.N.; [et al.]. 2012. Status, reproductive success, and habitat use of southwestern willow flycatchers on the Virgin River, Utah, 2008-2011. Publication Number 12-36. Salt Lake City, UT: Utah Division of Wildlife Resources. 85 p.

Douglass, C.H.; Nissen, S.J.; Hart, C.R. 2013. Tamarisk management. In: Sher, A.; Quigley, M.F., eds. Tamarix: A case study of ecological change in the American west. New York: Oxford University Press: 333-353.

Durst, S.L.; Theimer, T.C.; Paxton, E.H.; [et al.]. 2008. Age, habitat, and yearly variation in the diet of a generalist insectivore, the southwestern willow flycatcher. Condor. 110(3): 514-525.

Edwards, C.; Dobbs, R. 2013. Southwestern willow flycatcher monitoring, May-September 2013. Unpublished report on file with: Washington County Field Office, Utah Division of Wildlife Resources, Hurricane, UT. Various pagings.

Edwards, C.; Woodhouse, E. 2014. Southwestern willow flycatcher monitoring, May-September 2014. Unpublished report on file with: Washington County Field Office, Utah Division of Wildlife Resources, Hurricane, UT. Various pagings.

Edwards, C.; Woodhouse, E. 2015. Southwestern willow flycatcher monitoring, May-September 2015. Unpublished report on file with: Washington County Field Office, Utah Division of Wildlife Resources, Hurricane, UT. Various pagings.

Ellis, L.A.; Weddle, D.M.; Stump, S.D.; [et al.]. 2008. Southwestern willow flycatcher final survey and monitoring report. Research Technical Guidance Bulletin 10. Phoenix, AZ: Arizona Game and Fish Department.

Estrada-Muñoz, G.A.; Sánchez-Peña, S.R. 2014. Imidacloprid drench on athel trees (Tamarix aphylla): Effect on foliage consumption and knock-down of Diorhabda sublineata at Chihuahua, Mexico. Southwestern Entomologist. 39(3): 439-450.

Fridell, R.; Dobbs, R.; Wheeler, P. 2009. 2009 southwestern willow flycatcher nest monitoring study. Unpublished report on file with: Washington County Field Office, Utah Division of Wildlife Resources, Hurricane, UT. 5 p.

Gould, J. 1999. Life-history of Diorhabda elongata in secure field cages: Results of research during stage A of research releases in 1999. Riverdale, MD: U.S. Department of Agriculture, Animal and Plant Health Inspection Service. 22 p.

Graber, A.E.; Koronkiewicz, T.J.; Granger, J.L. 2012. Southwestern willow flycatcher surveys and nest monitoring along the Gila River between Coolidge Dam and South Butte, 2011. Annual summary report to U.S. Bureau of Reclamation, Glendale, AZ. Flagstaff, AZ: SWCA Environmental Consultants. 35 p. plus appendices. 
Graham, T.B.; Robinson, W.; Higgs, T. 2016. Monitoring of spatial and temporal patterns of beetle abundance and tamarisk defoliation in Grand County, Utah, 2004-2015. In: The road to riparian restoration: Innovations for working on public, private, and tribal lands in the arid West; Tamarisk Coalition Research and Management Conference; 2016 February 9-11; Grand Junction, CO. Grand Junction, CO: Tamarisk Coalition.

Hultine, K.R.; Dudley, T.L.; Koepke, D.F.; [et al.]. 2015. Patterns of herbivory-induced mortality of a dominant non-native tree/shrub (Tamarix spp.) in a southwestern US watershed. Biological Invasions. 17(6): 1729-1742.

Hunter, W.C.; Ohmart, R.D.; Anderson, B.W. 1987. Status of breeding riparian-obligate birds in southwestern riverine systems. Western Birds. 18: 10-18.

Jashenko, R. [n.d.]. Biological control of U.S. invasive weeds from Kazakhstan. Washington, DC: U.S. Department of Agriculture, Agricultural Research Service. https://portal.nifa.usda. gov/web/crisprojectpages/0405853-biological-control-of-us-invasive-weeds-from-kazakhstan. html [Accessed January 7, 2017].

Johnson, T.D. 2013. Tamarix: Passenger or driver of ecosystem change? In: Sher, A.; Quigley, M.F., eds. Tamarix: A case study of ecological change in the American west. New York: Oxford University Press: 256-266.

Lewis, P.A.; DeLoach, C.J.; Herr, J.C.; [et al.]. 2003a. Assessment of risk to native Frankenia shrubs from an Asian leaf beetle, Diorhabda elongata deserticola (Coleoptera: Chrysolmelidae), introduced for biological control of saltcedars (Tamarix spp.) in the western United States. Biological Control. 27: 148-166.

Lewis, P.A.; DeLoach, C.J.; Knutson, A.E.; [et al.]. 2003b. Biology of Diorhabda elongata deserticola (Coleoptera: Chrysomelidae), an Asian leaf beetle for biological control of saltcedars (Tamarix spp.) in the United States. Biological Control. 27: 101-116.

McLeod, M.A.; Pellegrini, A.R. 2013. Southwestern willow flycatcher surveys, demography, and ecology along the lower Colorado River and tributaries, 2008-2012. Summary report to U.S. Bureau of Reclamation, Boulder City, NV. Flagstaff, AZ: SWCA Environmental Consultants. 341 p. plus attachments.

McLeod, M.A.; Pellegrini, A.R. 2014. Southwestern willow flycatcher surveys, demography, and ecology along the lower Colorado River and tributaries, 2013. Annual report to U.S. Bureau of Reclamation, Boulder City, NV. Flagstaff, AZ: SWCA Environmental Consultants. 147 p. plus attachments.

McLeod, M.A.; Pellegrini, A.R. 2015. Southwestern willow flycatcher surveys, demography, and ecology along the lower Colorado River and tributaries, 2014. Annual report to U.S. Bureau of Reclamation, Boulder City, NV. Flagstaff, AZ: SWCA Environmental Consultants. 147 p. plus attachments.

Moore, D.; Ahlers, D. 2008. Southwestern willow flycatcher study results: Selected sites along the Rio Grande from Velarde to Elephant Butte Reservoir, New Mexico. Denver, CO: U.S. Bureau of Reclamation, Technical Service Center. 64 p.

Moore, S.D. 2015. Southwestern willow flycatcher studies within the Rio Grande Basin, New Mexico. Washington, DC: U.S. Department of the Interior, Bureau of Reclamation.

Muegge, M. 2010. Controlling saltcedar leaf beetle on athel, E-290. Texas A\&M AgriLife Extension Service. 3 p. http://pecosbasin.tamu.edu/media/327130/e-290._controlling_sc_ beetles_on_athel.pdf [Accessed January 5, 2017].

Nagler, P.L.; Glenn, E.P. 2013. Tamarisk: Ecohydrology of a successful riparian plant. In: Sher, A.; Quigley, M.F., eds. Tamarix: A case study of ecological change in the American west. New York: Oxford University Press: 63-84.

Nevada of Department of Wildlife [NDOW]. [n.d.]. Survey and monitoring data for flycatchers at Mormon Mesa. Unpublished data on file with: Nevada Department of Wildlife, Wildlife Diversity Division, Southern Region, Las Vegas, NV.

Owen, J.C.; Sogge, M.K.; Kern, M.D. 2005. Habitat and sex differences in physiological condition of breeding southwestern willow flycatchers (Empidonax traillii extimus). The Auk. 122(4): 1261-1270. 
Paxton, E.H.; Sogge, M.K.; Durst, S.L.; [et al.]. 2007. The ecology of the southwestern willow flycatcher in central Arizona-A 10-year synthesis report. Open-File Report 2007-1381. Reston, VA: U.S. Department of the Interior, Geological Survey.

Sher, A. 2013. Introduction to the paradox plant. In: Sher, A.; Quigley, M.F., eds. Tamarix: A case study of ecological change in the American west. New York: Oxford University Press: 1-18.

Sogge, M.K.; Ahlers, D.; Sferra, S.J. 2010. A natural history summary and survey protocol for the southwestern willow flycatcher. Techniques and Methods 2A-10. Reston, VA: U.S. Department of the Interior, Geological Survey. $38 \mathrm{p}$.

Sogge, M.K.; Sferra, S.J.; Paxton, E.H. 2008. Tamarix as habitat for birds: Implications for riparian restoration in the southwestern United States. Restoration Ecology. 16(1): 146-154.

Strudley, S.; Dalin. P. 2013. Tamarix as invertebrate habitat. In: Sher, A.; Quigley, M.F., eds. Tamarix: A case study of ecological change in the American west. New York: Oxford University Press: 207-224.

Tamarisk Coalition. 2014. Yearly distribution (2007-2014) of tamarisk beetle (Diorhabda spp.). Grand Junction, CO: Tamarisk Coalition. http://www.tamariskcoalition.org/sites/default/files/ files/2014_Diorhabda_Distribution_Map_Final_v2.pdf. [Accessed January 6, 2017].

Tamarisk Coalition. [n.d.] Tamarisk beetle spread data. Unpublished data on file with: Tamarisk Coalition, Grand Junction, CO.

Theimer, T.C.; Smith, A.D.; Mahoney, S.M.; [et al.]. 2016. Available data support protection of the Southwestern Willow Flycatcher under the Endangered Species Act. The Condor. 118(2): 289-299.

Tracy, J.L.; Robbins, T.O. 2009. Taxonomic revision and biogeography of the Tamarix-feeding Diorhabda elongata (Brullé, 1832) species group (Coleoptera: Chrysomelidae: Galerucinae: Galerucini) and analysis of their potential in biological control of tamarisk. Zootaxa. 2101: $1-152$.

Tracy, J.L. 2014. Projecting dispersal of subtropical tamarisk beetles toward habitat of endangered southwestern willow flycatchers in Arizona. Grand Junction, CO. Tamarisk Coalition.

Tracy, J.L.; Coulson, R.N.; March, R.G. 2014. Southwestern willow flycatcher habitat suitability and connectivity under simulated conditions of tamarisk beetle herbivory and willow restoration. Grand Junction, CO: Tamarisk, Coalition.

USDA Animal and Plant Health Inspection Service. 2015a, July 8-last update. Biological Control Program. https://www.aphis.usda.gov/aphis/ourfocus/planthealth/plant-pest-and-diseaseprograms/biological-control-program [Accessed January 7, 2017].

USDA Animal and Plant Health Inspection Service. 2015b, June 26-last update. TAG Charter. https://www.aphis.usda.gov/aphis/ourfocus/planthealth/import-information/permits/regulatedorganism-and-soil-permits/biological-control-organism-permits/sa_tag/ct_charter [Accessed January 7, 2016].

U.S. Fish and Wildlife Service. 2002. Southwestern willow flycatcher final recovery plan. Albuquerque, NM: U.S. Fish and Wildlife Service. 520 p.

U.S. Fish and Wildlife Service. 2014. Southwestern willow flycatcher (Empidonax traillii extimus) 5-year review: Summary and evaluation. U.S. Fish and Wildlife Service, Arizona Ecological Services: Phoenix, AZ. 104 p. https://www.fws.gov/southwest/es/Documents/ R2ES/SouthwesternWillowFlycatcher_5YrReview_2014.pdf [Accessed 22 August 2018].

van Riper, C., III; Paxton, K.L.; O'Brien, C.; [et al.]. 2008. Rethinking avian response to Tamarix on the Lower Colorado River: A threshold hypothesis. Restoration Ecology. 16(1): 155-167.

Zavaleta, E. 2013. Evapotranspiration by tamarisk in the Colorado River Basin. In: Sher, A.; Quigley, M.F., eds. Tamarix: A case study of ecological change in the American west. New York: Oxford University Press: 44-62.

Zink, R.M. 2015. Genetics, morphology, and ecological niche modeling do not support the subspecies status of the endangered Southwestern Willow Flycatcher (Empidonax traillii extimus). The Condor. 117(1): 76-86. 


\title{
Chapter 6. Beavers, Livestock, and Riparian Synergies: Bringing Small Mammals Into the Picture
}

\author{
Jennifer K. Frey
}

\section{Introduction}

Riparian ecosystems provide the anchor for their associated aquatic habitats and the structure for a unique assemblage of life found in these exceptionally productive ecosystems. Much of upland life also is tied to this zone, particularly in arid regions. For instance, on National Forest lands in the Southwest Region, 57 percent of all vertebrates occur in riparian ecosystems, but these systems make up $<2$ percent of these lands (Rickel 2005a). However, it has been estimated that 90 percent of riparian ecosystems have been lost or degraded in parts of the western United States through human-mediated factors (Ohmart and Anderson 1986). The inception of much of this degradation occurred during the 1800s when trappers flooded into the West exploring each river and tributary in pursuit of the American beaver (Castor canadensis; hereafter beaver). The pelts of these animals were made into felt that was used for the manufacture of gentlemen's top-hats. Trade in the pelts of these and other furbearers constituted a major economic export to Europe, which helped fuel the economy of the young country (Weber 1971). As a consequence, beavers were extirpated from many streams and the population of beavers in North America fell from more than 60 million before the arrival of Europeans to near extinction by 1900 (Naiman et al. 1988). Prior, beavers were an important force that influenced the hydrology and hence overall ecology of streams and rivers. Beavers cut trees to build dams on smaller streams and on side channels of larger rivers. Beaver dams and the coarse woody debris introduced into the waterways due to beaver activities are a strong force that alters the stream planform by spreading the water into a multitude of smaller channels and by creating ponds, pools, and backwaters (Polvi and Wohl 2013). With the loss of beavers, there was a simplification of the complex hydrology maintained by beavers resulting in single channels of water with relatively high stream power and erosive force, as well as reduced storage of water that otherwise would be released to sustain riparian plants during dry periods and droughts. This resulted in the inception of stream channel incision and a narrowing and simplification of the riparian zone (Naiman et al. 1988).

Of course, other factors besides the demise of beaver also have contributed to the loss of riparian habitats. Nearly all western rivers have had natural flow regimes altered by dams and diversions. Free water is an essential limiting factor for human survival and hence most human settlements are located along streams and rivers. Agricultural areas were initially developed in the fertile valleys along low gradient reaches of streams and rivers where water could be harnessed for irrigation. In turn, the larger of these valuable agricultural areas helped to fuel the growth of cities, which in turn are run by a complex infrastructure of water delivery and waste often originating and ending in rivers. Exotic species have been introduced, either intentionally or by accident, some of 
which, such as saltcedar (Tamarix spp.), have nearly wholly displaced native riparian communities in some areas in favor of novel systems consisting of near monotypes of the alien species (Shafroth et al. 2005).

Another agricultural product that exerts an influence on riparian ecosystems is domesticated livestock, such as cattle, horses, sheep, and goats. In the American West, livestock grazing is one of the few economic uses of much of the land and hence they are nearly ubiquitous on larger tracks of private lands and on the extensive tracks of public lands managed for multiple uses (e.g., U.S. Forest Service [USFS]; Bureau of Land Management [BLM]). These exotic animals were introduced into western North America in the late 1500s and hence some areas have been grazed by these animals for over 400 years (Bowling 1941). The behaviors and managed distributions of livestock are substantially different from native ungulates such as elk (Cervus elaphus) and deer (Odocoileus spp.). The long-term and differential use of riparian zones by livestock has substantially changed the composition and structure of riparian plant communities, typically resulting in an overall drying and simplification of the ecosystem (Belsky et al. 1999). And lastly, the world has embarked on a period of rapid climate change that is just beginning to exert its influence. In the American West, the future is expected to bring periods of prolonged drought as well as intense flooding. How riparian zones will respond to these changes is not precisely known, but it is likely to cause the continued deterioration of riparian ecosystems.

Water is vital for human interests and ecosystem function. Consequently, there is increasing interest in restoring riparian ecosystems and their associated aquatic habitats. Regardless of the goal (e.g., restore stream hydrology to improve fish habitat, improve specific riparian habitat elements) and regardless of the mechanics (e.g., use of big machinery to recontour streambeds, installation of instream structures, planting specific species), nearly all such restorations ultimately consider aspects of the riparian plant community. It is the deep-rooted riparian plants that ultimately stabilize the riparian and aquatic habitats and provide habitat for associated animals. However, to a large extent, these efforts focus on woody plants and their associated bird communities. This narrow perspective may fail to result in projects that restore full ecosystem function.

Thus, the ultimate purpose of this chapter is to call attention to an overlooked but vital element of riparian zones: the small mammal community, which is associated with herbaceous vegetation near ground level. I argue that taxonomic biases in the study of riparian ecosystems and frequent goals of riparian restoration have resulted in overlooking one of the most important elements of the riparian zone. Abundant and diverse small mammal communities support a vast array of ecosystem services. However, such communities are only fully expressed when riparian zones support a productive and diverse herbaceous riparian community. This may be maximally expressed through a synergism between healthy native riparian vegetation and beaver activities. However, this synergism can be disrupted, especially by livestock grazing, which ultimately can cause a loss of diversity and function to these ecosystems. I conclude by making recommendations on needed research to help improve understanding of these relationships and the management of these systems. Riparian restorations that fail to consider these aspects are not likely to reap full ecosystem benefits. 


\section{Taxonomic Bias in Riparian Restoration}

There appear to be taxonomic biases in our knowledge about riparian ecosystems and the typical goals and monitoring of riparian restoration. People often seem to assume that birds are the group of animals most impacted by loss and degradation of riparian systems, perhaps with the exception of the impact to fishes by the concomitant degradation of the aquatic systems. Many references on riparian restoration explicitly link vegetation restoration with the needs of birds or use birds as the basis for understanding existing or future conditions (e.g., Eubanks 2004; Gardner et al. 1999). Monitoring the success of riparian restorations typically involves birds, and sometimes other taxa such as reptiles or bats, but rarely includes small mammals (e.g., Bateman et al. 2008; but see Queheillalt and Morrison 2006).

For instance, a USFS riparian restoration guide, while noting the importance of riparian systems for all wildlife, singles out only the analysis of threatened and endangered species and bird communities for establishing existing conditions of a riparian zone (Eubanks 2004). Furthermore, bird communities are often promoted as an index for planning and monitoring riparian condition and restoration, to the exclusion of other taxa (Bryce et al. 2002; Rich 2002; Young et al. 2013). As an example, it has been proposed that evaluation of breeding bird communities should be used as a means to assess "Proper Functioning Condition," which is the main method that Federal land management agencies, including the USFS, BLM, and Natural Resources Conservation Service, use to evaluate riparian health (Rich 2002).

I believe there are numerous reasons for this seeming taxonomic bias, although few have a biological basis. First, birds are viewed as charismatic and valuable animals. Besides the human fascination with flight, most birds are relatively easy to observe due to their flight, diurnal behavior, and repertoire of often loud, beautiful, and distinctive vocalizations. Pronounced morphological and plumage variation in this diverse group allows for relatively easy identification of species and often identification of different genders and ages, allowing even casual observers to understand something a bit deeper about their biology. As a consequence, birds are enormously popular with the public, which has led to formation of powerful lay advocacy groups (e.g., National Audubon Society). Such organizations convey numerous tangible and intangible benefits to birds by bringing attention to issues, garnering resources, and influencing legislation.

Further, the accessibility of birds allows citizens to participate in the collection of biologically meaningful data (e.g., winter bird count, rare bird alert, eBird) that help to expand the knowledge base of these organisms. Just as birds are popular with the public, they also are popular study organisms for scientists. For instance, consider that in North America there is only a single professional society dedicated to the study of mammals (American Society of Mammalogists), while in contrast there are at least four professional societies dedicated to the study of birds (American Ornithologists Union, Cooper Ornithological Society, Association of Field Ornithologists, Wilson Ornithological Society). One important consequence of this heightened attention and knowledge is that birds might be more likely to be listed as threatened or endangered than other taxonomic groups, and the perceived bar for "endangerment" might be lower. In turn, threatened or endangered listing can stimulate research and management focuses. 
While there is no doubt that birds can be impacted by changes to riparian habitats and that they provide ecosystem services (Whelan et al. 2015), the taxonomic bias focuses attention on a suite of species that are primarily associated with the woody components of riparian ecosystems. This approach parallels another apparent bias in how humans tend to perceive ecosystems. Although trees and shrubs are usually a minor component of the diversity of riparian zones, they are usually the largest species present and hence they receive our differential attention. As an example, most vegetation classification schemes are based, in large part, on the woody species present (e.g., U.S. National Vegetation Classification). In addition, because these plants are relatively longlived, they are used as a benchmark or proxy for assessing the "health" of a riparian system or success of a restoration project. The main focus of many riparian restoration projects is planting woody species or adjusting hydrology to encourage their natural regeneration (e.g., Dreesen et al. 2002). Thus, a focus on avian species seems to dovetail nicely with a corresponding viewpoint of the importance of the woody component of riparian habitats.

Although birds are diverse, their influence on the structure and function of riparian ecosystems may be relatively weak compared to other taxonomic groups. There are several reasons for this. First, due to territoriality and high vagility, birds tend to be relatively sparsely distributed. As a result of this rarity, and in combination with their relatively small body size, birds usually account for but a minor proportion of the animal biomass in a given area (Turner and Chew 1981). Consequently, birds have relatively little influence on higher trophic levels. On the other hand, due to the relatively high diversity of birds, their greatest ecosystem influence might be a consequence of some foraging behaviors (Whelan et al. 2015). For instance, granivores are considered important agents of seed predation and dispersal, even though when compared directly with rodents, the impacts of birds are relatively weak (e.g., Hulme and Benkman 2002; Mares and Rosenzweig 1978). Some birds, such as hummingbirds, transfer pollen that benefits some plants. Insectivores may help regulate invertebrate communities, while raptors may help regulate some rodent communities (Whelan et al. 2015). Other services provided by some kinds of birds, such as creating cavity holes in trees by woodpeckers, while important, are of more minor impact to the overall ecosystem.

Although the restoration of riparian habitats is considered important for the maintenance of bird diversity (Gardner et al. 1999), the taxonomic bias on birds focuses attention on species that may be only weakly linked to overall ecosystem function or may cause other important aspects of ecosystem function to be missed. In contrast, other elements of the riparian zone, in particular small mammals, have been mostly overlooked and yet they may have more strong influence on overall ecosystem structure and function. Consequently, riparian habitat restorations without consideration of small mammals, and the riparian habitat elements they require, will be incomplete and may not provide the full range of ecosystem services.

\section{Terrestrial Small Mammal Riparian Communities}

In western North America, terrestrial small mammals strongly associated with riparian zones include members of the order Eulipotyphla (e.g., shrews [Soricidae], moles [Talpidae]); Rodentia (e.g., deer mice [Cricetidae], cotton rats [Sigmodontidae], 
voles [Arvicolidae], jumping mice [Zapodidae]); and some small members of the orders Carnivora (e.g., short-tailed weasel [Mustela erminea; Mustelidae]) and Lagomorpha (e.g., some Sylvilagus). These species can be categorized into two groups: those that are relatively specialized on riparian ecosystems and those that become disproportionately abundant within riparian ecosystems. Examples of species in the first category, the riparian specialists, include: marsh shrew (Sorex bendirii), cordilleran water shrew (Sorex navigator), water vole (Microtus richardsoni), muskrat (Ondatra zibethicus), and some jumping mice (e.g., Zapus luteus luteus and Z. hudsonius preblei). Examples of species in the much larger second category include: montane shrew (Sorex monticola), Townsend's mole (Scapanus townsendii), white-footed deermouse (Peromyscus leucopus), North American deermouse (Peromyscus maniculatus), western harvest mouse (Reithrodontomys megalotis), hispid cotton rat (Sigmodon hispidus), tawny-bellied cotton rat (S. fulviventer), California vole (Microtus californicus), long-tailed vole (Microtus longicaudus), montane vole (Microtus montanus), meadow vole (M. pennsylvanicus), white-footed vole (Phenacomys albipes), western heather vole (Phenacomys intermedius), western jumping mouse (Zapus princeps), Pacific jumping mouse (Zapus trinotatus), brush rabbit (Sylvilagus bachmani), and short-tailed weasel.

In addition, other species that are more typical of other vegetation types may also occur in the riparian zone when the communities closely abut (e.g., small order stream in coniferous forest), such as the cinereus shrew (Sorex cinereus), mountain cottontail (Sylvilagus nuttalii), least chipmunk (Neotamias minimus), red squirrel (Tamiasciurus hudsonicus), Botta's pocket gopher (Thomomys bottae), northern pocket gopher (T. talpoides), Mexican woodrat (Neotoma mexicana), and southern red-backed vole (Myodes gapperi). In the Mountain West, riparian small mammal communities become more unique in comparison with uplands as elevation increases (Olson and Knopf 1988). Finally, it should be recognized that many species exhibit geographic variation in their habitat associations such that a species may be a riparian associate in a more mesic region, but become more of a riparian specialist in a more xeric region (e.g., California vole; Conroy et al. 2016).

Although terrestrial small mammals are important members of riparian communities, they have been mostly overlooked both in terms of knowledge of their ecology and focus in riparian restorations (but see for example Rickel 2005b and Golet et al. 2008). There are a number of reasons for this. First, small mammals tend to be relatively difficult to study. Most are nocturnal and live in burrows or other hidden places such that they are not easily observed. Study usually requires capturing individuals, which is labor intensive and necessitates specialized equipment, permits, and expertise. Because most small mammals have generalized, nondescript body plans, accurate identifications can be difficult, often requiring examination of cranial characters (necessitating collection and preparation of series of museum specimens) or DNA (which is expensive and requires specialized equipment).

These difficulties largely preclude the public, and even many scientists, from informal or formal study of these organisms. Thus, relative to some other taxonomic groups, such as birds, fishes, and big game mammals, there are relatively few scientists that specialize on studying small mammals. Perhaps more importantly, most of these species, with the exception perhaps of some squirrels, simply lack charisma or perceived value (e.g., few are considered game species). To many people, these "rats and mice" 
are simply vermin. Consequently, no public organizations that promote these species exist and there is limited funding and political will. Taken together, these factors cause knowledge about riparian small mammals to lag far behind other species. For instance, the recent comprehensive Beaver Restoration Guidelines reference manual (Pollock et al. 2015), which reviewed the ecological impacts of beavers on other organisms, included sections on birds, fishes, and invertebrates, but did not include mention of ecological impacts to other mammals.

\section{Ecological Roles of Riparian Small Mammals}

The ecological roles of most small mammals have been poorly studied. Yet, limited research indicates that the ecosystem services provided by small mammals are strong and important to diverse ecosystems, including riparian zones. By way of example, I highlight four essential aspects of the role of small mammals in riparian ecosystems, including: (1) dominance of animal biomass, (2) prey base for diverse carnivore communities, (3) influence on soil condition, and (4) influence on plant composition and succession.

\section{Animal Production and Biomass}

Although data are limited, small mammals likely constitute the dominant proportion of vertebrate animal production and biomass in healthy riparian systems. For instance, Turner and Chew (1981) found that production of terrestrial small mammals in arid environments of southwestern North America far outweighed production by other groups of animals (in contrast, birds were among the lowest). In part, this is because small mammals, while having small body size compared with other mammals, are on average larger than most other kinds of organisms. In addition, terrestrial small mammals are year-round residents and they have relatively small and overlapping home ranges. For example, home ranges of the meadow vole may be as little as $160 \mathrm{~m}^{2}$ (Van Vleck 1969).

Further, small mammals are prone to population irruptions that can produce extremely high densities and biomass. Generation of exceptionally high biomass is particularly true for the graminivorous (grass eating) riparian species, including the cotton rats at lower latitudes and elevations and the voles at higher latitudes and elevations; both groups may display population cycles or strong annual variation in population densities (Fagerstone and Ramey 1996; Grant et al. 1982; Rickel 2005b; Taitt and Krebs 1985). For instance, densities during population highs for these species can exceed 369 cotton rats/ha (Guthery et al. 1979) and 7,400 voles/ha (Spencer 1958). Production of small mammals in vole-dominated communities can exceed 5,000 kcal/ha in high quality habitats (Grant et al. 1982).

Small mammal populations are renowned for their volatility (Witmer and Proulx. 2010). Whitford (2002) identified episodic species as those that respond to periods of high primary production with high rates of reproduction and population growth, and hence driving high rates of secondary production. Riparian zones may serve as important refugia for episodic species in arid environments. During wet periods, episodic species experience population growth and immigration into marginal habitats, where they can exhibit explosive growth relative to corresponding dry periods. Thus, 
population dynamics of small mammals in riparian ecosystems can have far reaching and direct impacts on adjacent terrestrial ecosystems.

\section{Fuel for Predator Communities}

The high density and biomass of small mammals that concentrates in healthy riparian zones provides fuel for supporting a diverse predator community that includes hawks, owls, snakes, and myriad mammalian carnivores such as weasels, minks, bobcats, foxes, and coyotes (Hamilton et al. 2015). Starvation is a real and constant threat for many kinds of predators. Consequently, a high threshold of prey abundance is required for many kinds of predators to persist in an area. For instance, weasels have particularly high energy demands due to their active lifestyle and their lean, narrow body plan. Meals pass through their short digestive tracks in just a few hours, meaning they must eat frequently. It has been estimated that long-tailed weasels (Mustela frenata) must consume 20-40 percent of their body weight in small mammal prey every day. However, the energetic demands for smaller weasels are even more extreme. For instance, captive least weasels had to eat meals every 2.5 to 3 hours, totaling 5-10 meals per day. Small weasels are not likely to be able to survive more than 24 hours without eating (Gillingham 1984). The energetic demands of females that successfully raise young are even higher. Voles are the main group of small mammals in the temperate zone that can generate the densities and biomass of animal flesh required to support predators that have high energy demands (Frey and Calkins 2013; Rickel 2005b). Thus, it is no surprise that many species of owls also specialize on voles preferential to other kinds of small mammals (e.g., Colvin and McLean 1986).

Exceptionally high abundance of suitable prey is thought to be necessary to permit coexistence of some predators. For instance, short-tailed weasels and long-tailed weasels are sympatric across much of the western United States. However, models indicate that it might not be possible for both species to coexist in a local habitat unless the prey populations are high and diverse (Powell and Zielinski 1983). Riparian zones also provide an important source of alternate prey for more specialized predators such as Canada lynx (Lynx canadensis), river otters (Lontra canadensis), martens (Martes spp.), fishers (Pekania pennati), wolverines (Gulo gulo), and wolves (Canis lupus). Alternate prey serves as a critical resource for these predators during certain seasons or years or by certain demographic groups (e.g., nursing mothers). Thus, small mammals contribute to the diversity of riparian zones, not only through the presence of a unique assemblage of riparian small mammals, but also by supporting diverse predator communities. By supporting diverse predator communities, riparian small mammals provide an important link between the riparian zone and adjacent upland communities.

\section{Soil Condition}

Soil is formed over time primarily through the interactions of the parent material, topography, climate, vegetation, and invertebrate animals. However, small mammals also play an important role in the structure and function of soils through their burrowing activities, underground caching of seeds and other plant parts, and decomposition of latrines and carcasses. Most terrestrial small mammals construct subterranean burrows or modify and utilize the burrows constructed by other species of small mammals, at 
least for some aspects of their life cycle (e.g., hibernacula, maternal nest chambers). Some species, such as the pocket gophers and moles, spend most of their lives within these burrows. Burrowing activity has an important role in improving soil structure by loosening soil particles and in mixing soils by bringing soils from lower strata to the surface, to the extent that sometimes this mixing can obliterate the upper soil horizons (Hendricks 1985). For instance, estimates of soil excavated by pocket gophers can exceed more than $100 \mathrm{Mg}$ /ha (Cox 1990; Grinnell 1923).

Burrow systems also affect the soil climate by enhancing infiltration of oxygen and water. Subterranean chambers made by small mammals to store food caches, or serve as nest sites or latrines, create local concentrations of key limiting nutrients such as salts, nitrogen, phosphorus, and potassium (Hendricks 1985). Finally, like woodpeckers creating tree cavities that may be used by other species, the burrows constructed by small mammals can harbor an array of non-burrowing organisms such as fungi, spiders, amphibians, and snakes, thus supporting overall biodiversity (Scheffer 1945).

\section{Plant Community Composition and Succession}

Although understudied, terrestrial small mammals may have a profound impact on the structure and function of plant communities. For instance, Bryce et al. (2013) demonstrated that the long-term impacts of vole burrowing activities and herbivory result in a patchwork of different plant successional stages in riparian systems. Further, small mammals impact the structure and function of plant communities through their predation on seeds and seedlings and concomitantly through the dispersal of seeds and mycorrhizal fungi. Seeds are an important part of the diet of most small mammals, including species such as shrews, which are normally thought of as strictly insectivorous (Hallett et al. 2003). Small mammal seed predators include species such as harvest mice and jumping mice that specialize on harvesting seeds from grasses and other herbaceous plants prior to seed dispersal (e.g., Wright and Frey 2014), as well as species such as chipmunks, pocket mice (e.g., Chaetodipus spp.), and deer mice that forage on a wide range of seed types from both herbaceous and woody plants in the seed rain or seedbank.

In the temperate zone, most seed removal is due to small mammals (Hulme and Benkman 2002; Mares and Rosenzweig 1978). Thus, granivory by small mammals can have a profound impact on seed populations, and hence plant communities (Hulme and Benkman 2002). For instance, the extent of small mammal seed predation can be so high ( $>95$ percent of seeds sown) that it can hamper efforts to restore forests and other ecosystems via direct seeding (Hallett et al. 2003). Similarly, seedlings and saplings are also vulnerable to predation by rodents, including those of conifer trees that are especially vulnerable under cover of snow when herbaceous plants are less available (Hallett et al. 2003). Thus, small mammal herbivory tends to impede succession, thereby maintaining early successional habitats that provide favorable food and cover (Davidson 1993).

Few studies have examined the role of mammals in seed dispersal. However, the number of fruit seeds dispersed into a plant population by medium-sized mammals, such as foxes, may be twice that mediated by frugivorous birds (Jordano et al. 2007). Further, although small mammals are efficient predators on some seeds, many also gather, move, and store these seeds in underground burrows. Unrecovered seeds cached by these 
rodents may be essential to the establishment of some plants (e.g., Hallett et al. 2003; Longland and Ostoja 2013).

Perhaps even more important than the role mammals play in seed dispersal and germination is their crucial relationship with mycorrhizal fungi. Mycorrhizal fungi form symbiotic relationships with the roots of most vascular plants. Growth and survival of many plants is dependent on this relationship, which provides for the uptake of water and nutrients (Molina 1994). Concurrently, mycorrhizal fungi are an important component of the diet for many small mammals, but the spores of these fungi pass through the digestive tracts of the small mammals with no loss in viability (Maser et al. 1978). Thus, small mammals have been implicated as the dominant means for dispersal of mycorrhizal inocula, which in turn must be present to support plants. Small mammals, therefore, may control some aspects of succession.

For instance, an interesting study by Terwilliger and Pastor (1999) concluded that small mammals regulated the succession of trees into "beaver meadows." Beaver meadows are herbaceous dominated ecosystems that form in the silt that is left behind after a beaver dam has been breached and the pond drained. These are exceptionally important habitats, especially in coniferous forest dominated regions, and they can persist for many decades, although an explanation for their longevity was lacking. Terwilliger and Pastor (1999) found that the soils of beaver meadows lacked the mycorrhizal fungi necessary for the growth of conifers and attributed that to long-term inundation of the soils by the former pond. In their study system, the primary consumer of mycorrhizal fungi associated with conifers was the red-backed vole (Myodes gapperi), which mostly occurs in forested habitat. In contrast, they speculated that meadow voles, which are associated with the graminoid habitats of the beaver meadows, competitively excluded red-backed voles and their spore containing feces from the meadows. Thus, it was speculated that reestablishment of conifers in the beaver meadows was limited both by patterns of mycorrhizal fungal distribution and by use by small mammals and the competitive interactions among them.

\section{Terrestrial Small Mammal Community Habitat Relationships}

Terrestrial small mammals serve as prey for a host of predators, such as snakes, hawks, owls, minks, foxes, bobcats, and bears. Consequently, appropriate concealment cover from predators is one of the most important overriding microhabitat component required for the production of abundant and diverse small mammal communities (e.g., Longland and Price 1991). In riparian ecosystems, these communities are mainly associated with early seral plant communities typified by tall, dense herbaceous ground cover, often in conjunction with riparian shrubs such as willow and alders (e.g., Dickson and Williamson 1988; Golet et al. 2008).

Because these communities are often associated with riparian shrubs, vegetation maps are likely to underestimate the extent of this vegetation type and there are no estimates for the proportion of riparian systems that support herbaceous riparian vegetation. These herbaceous plant communities also provide necessary food for small mammals. Small mammals have high energetic demands and utilize a wide range of foods. Many small mammals eat the seeds of grasses and forbs. Other small mammals, such as the 
voles and cotton rats, eat the vegetative parts of graminoids, while pocket gophers utilize the roots of herbaceous plants.

In well-developed herbaceous riparian habitats, graminoid food is not limiting, which contributes to potential for exceptionally high biomass of voles and cotton rats. Invertebrates are supported by diverse and abundant riparian vegetation and these are utilized as food by shrews and moles, and to a lesser extent by many rodents. In contrast, late seral riparian vegetation types are dominated by trees (e.g., cottonwood gallery forest) and consequently may have lower densities and diversity of mammals due to the drier soils and lack of adequate ground cover (Andersen and Nelson 1999). Furthermore, in late seral riparian habitats that have been substantially degraded, such as via conversion to monotypes of saltcedar, small mammal communities may be indistinguishable from upland communities (i.e., due to loss of riparian adapted species and invasion by upland species) or become dominated by disturbance adapted species such as deer mice (e.g., Ellis et al. 1997).

Riparian habitats that offer tall, dense, diverse herbaceous vegetation are maximally developed in locations with relatively low topographic relief, low gradient, broad floodplains, high soil moisture, and high exposure to solar radiation (low tree canopy cover or lack of shading by adjacent mountainsides; Dickson and Williamson 1988). To a large extent these characteristics are determined by local landscape features. However, beavers are unique in that their activities can increase the distribution and abundance of riparian characteristics that support early seral stage herbaceous communities. Beavers increase these habitats through a variety of mechanisms, including felling trees, creating dams that retain sediments, creating ponds that kill trees (due to submergence), increasing the area of sub-irrigated soils, storing water that is released as base flows during dry periods or drought, and creation of beaver meadows following abandonment of ponds (McMaster and McMaster 2000; Naiman et al. 1986, 1988; Rosell et al. 2005). For instance, Naiman et al. (1986) found that beaver dams increased the wetted surface area of the channel by several hundred-fold, while in Wyoming the width of riparian zones was $33.9 \mathrm{~m}$ in streams with beaver ponds but only $10.5 \mathrm{~m}$ in streams without such ponds (McKinstry et al. 2001).

Although research is limited, studies indicate that beaver activities can have a profound impact on small mammal communities. For instance, in Idaho, Medin and Clary (1991) compared riparian small mammal communities in an area within a complex of beaver ponds versus a control reach that did not have beaver ponds. They found that the standing crop biomass $(\mathrm{g} / \mathrm{ha}$ ) of small mammals was about 2.7 times higher at the beaver complex. This was due to exceptionally higher density of shrews and voles in the beaver modified habitats. In addition, the western jumping mouse was only found in the beaver modified habitat. Medin and Clary (1991) attributed differences in small mammal communities to the dense and structurally complex vegetation created by beavers, which provide food and cover. Similarly, in Oregon, Suzuki (1992) found significantly more deer mice (Peromyscus), voles in genus Microtus, Pacific jumping mice, and certain species of shrews (Sorex) on stream reaches occupied by beavers compared to stream reaches lacking beavers. In the American Southwest, beaver dams were implicated as important for the occurrence of the short-tailed weasel, which is of conservation concern (Frey and Calkins 2013), and the Federally endangered New Mexico meadow jumping mouse (Z. l. luteus), which is a riparian obligate (Frey and Malaney 2009). 
In contrast to the positive influence of beavers on herbaceous habitat and small mammal communities, livestock (and sometimes overabundant native ungulates such as elk [Cervus elaphus]) can have a deleterious influence on herbaceous riparian habitats. Although the specific impacts of livestock grazing on riparian ecosystems are dependent on a number of variables and some studies have been based on poorly designed methods (Milchunas and Lauenroth 1999; Sarr 2002), the vast majority of evidence indicates that riparian systems are especially prone to excessive grazing that can lead to a disruption of ecosystem structure and function (e.g., Belsky et al. 1999; Fleischner 2002; Trimble and Mendel 1995). As large-bodied nonnative grazers and browsers, livestock can negatively impact or obliterate herbaceous riparian vegetation through herbage removal, soil compaction, and trampling (Giuliano and Homyack 2004; Johnston and Anthony 2008; Kauffman and Krueger 1984). Once deep-rooted riparian plants have been reduced or eliminated from riparian communities, stream banks can erode and channels can downcut, further exacerbating changes to the riparian plant and animal communities.

Small mammals are sensitive indicators of disturbances and changes to plant communities, particularly changes that impact the herbaceous layer (Fagerstone and Ramey 1996). For instance, in Oregon Moser and Witmer (2000) found significantly higher abundance, species richness, and species diversity of small mammals in ungrazed areas versus areas grazed by elk and cattle, while no differences were exhibited in similar metrics of the bird or plant community. While abundance of some upland or generalist mammal species, such as the North American deermouse, can increase in riparian areas that are grazed, most studies show a marked decrease in diversity and abundance of small mammals in grazed riparian areas. This pattern is especially pronounced for species that are more restricted to these areas such as shrews, voles, cotton rats, harvest mice, and jumping mice (e.g., Fagerstone and Ramey 1996; Frey and Malaney 2009; Medin and Clary 1989; Schulz and Leininger 1991).

For instance, voles select areas with high vegetation cover, which provides concealment from predators, reduces antagonistic interactions among individuals, provides food, facilitates subnivean spaces during winter, and moderates temperature and humidity. A threshold of vegetative cover may be necessary to support a population and allow for population buildups (Fagerstone and Ramey 1996). Consequently, voles tend to be relatively intolerant of livestock grazing that reduces cover, and their populations may be greatly depressed or extirpated in locations where grazing has greatly reduced herbaceous cover (Sullivan and Sullivan 2013).

Besides causing changes to riparian habitats that directly impact small mammal communities, livestock grazing can also influence suitability of riparian habitats for beavers. Beavers prefer herbaceous plants for food, but will use certain deciduous trees and shrubs for food when herbaceous plants are not available, such as under ice in winter (Müller-Schwarze and Sun 2003). In western North America where there are relatively few species of deciduous trees and shrubs to choose from, beavers exhibit a mutualistic relationship with willows, wherein beavers benefit from willows for food and building material, while willows benefit from beavers via the increased area of wetted soil created by their dams and asexual reproduction by resprouting of cut limbs (Kindschy 1989; Peinetti et al. 2009).

As strict herbivores, beavers enter into direct competition with livestock and native ungulates for food. Livestock preferentially graze on herbaceous vegetation during 
the early part of the growing season but then switch to browsing on willows during the latter part of the growing season (Pelster et al. 2004). Thus, excessive livestock grazing can result in loss of both herbaceous vegetation and willows, creating depauperate riparian zones that resemble upland communities (e.g., Small et al. 2016). A similar process can occur due to abundant native ungulates when top predators have been removed from an ecosystem. For instance, in Yellowstone National Park an increase in beavers occurred after restoration of wolves, likely due to decreased use of riparian zones by elk, which allowed for increased growth of willows and other riparian plants (Ripple and Beschta 2012).

Beavers are sometimes able to exist, at least temporarily, in marginal habitats that appear to offer scant resources for food and building material. In New Mexico for instance, I have observed beavers building dams and living on small order streams at the opening of a narrow sheer-sided canyon in the Chihuahuan Desert, and occurring in other locations where the only available dam building material was saltcedar, sagebrush (Artemisia), or cattails (Typha). On the Rio Grande in the Chihuahuan Desert, beavers can persist in small isolated pools of water after river flows are shut off by upstream dams (Barela and Frey 2016).

Given that beavers can exist in marginal environments, if conditions are inadequate for beavers, they also are likely inadequate to support healthy small mammal communities. Thus, the status of beavers may suggest the concomitant status of small mammal communities. For example, in New Mexico, Small et al. (2016) found only 38 active primary beaver dams on Federal public lands throughout the State, despite historical efforts to restore the species. The near absence of beavers was attributed to the loss of riparian habitat as a consequence of nearly ubiquitous cattle grazing. Given that riparian habitat conditions are mostly not adequate to support beavers, this suggests that riparian habitats are also mostly not capable of supporting diverse and abundant small mammal communities. The recent listing of a riparian habitat specialist, the New Mexico meadow jumping mouse, as endangered supports this idea and suggests the need for managers to more carefully consider the needs of riparian small mammals (and beavers) in management plans.

\section{Conclusions}

Small mammals are an often overlooked but vitally important component of healthy riparian ecosystems. These species provide critical ecosystem services to riparian zones by virtue of their high biomass, support of diverse predator communities, physical alterations of the soil, and regulation of plant communities. Small mammal communities are best developed in riparian systems that provide an abundance of tall, dense, and diverse herbaceous vegetation. Beavers are capable of increasing the capacity of riparian systems to produce these early seral plant communities and hence benefit small mammal communities. In contrast, excessive livestock grazing can disrupt small mammal communities by causing loss of tall, dense, and diverse herbaceous vegetation, and can also limit the capacity of riparian systems to support beavers. This negative synergism can result in riparian ecosystems that are depleted and fail to support critical ecosystem services. 
Thus, restoration of full ecosystem services of riparian zones requires consideration of the herbaceous plant and small mammal communities. In contrast, riparian restoration that focuses mainly on woody plants might restore habitats for birds and stabilize stream banks, but may fail to provide full restoration of crucial ecosystem function. Additional research is needed on livestock grazing management that can enhance herbaceous riparian vegetation and thereby support beavers and healthy small mammal communities. In addition, there is need for more research on the roles of small mammals in riparian ecosystem function and the patterns of riparian mammal diversity and abundance in relation to various disturbances and management actions.

\section{Acknowledgments}

I thank T.C. Frey, R. Goljani, I. Perkins-Taylor, and several peer-reviewers for comments on previous versions of this manuscript.

\section{References}

Andersen, D.C.; Nelson, S.M. 1999. Rodent use of anthropogenic and "natural" desert riparian habitat, Lower Colorado River, Arizona. Regulated Rivers: Research and Management. 15: $377 \mathrm{c} 393$.

Barela, I.A.; Frey, J.K. 2016. Habitat and forage selection by the American beaver (Castor canadensis) on a regulated river in the Chihuahuan Desert. Southwestern Naturalist. 61: 286-293.

Bateman, H.L.; Chung-MacCoubrey, A; Finch, D.M.; [et al.]. 2008. Impacts of non-native plant removal on vertebrates along the Middle Rio Grande (New Mexico). Ecological Restoration. 26: 193-195.

Belsky, J.A; Matzke, A; Uselman, S. 1999. Survey of livestock influences on stream and riparian ecosystems in the western United States. Journal of Soil and Water Conservation. 54: 419-431.

Bowling, G.A. 1941. The introduction of cattle into colonial North America. Journal of Dairy Science. 25: 129-154.

Bryce, S.A.; Hughes, R.M.; Kaufmann, P.R. 2002. Development of a bird integrity index: Using bird assemblages as indicators of riparian condition. Environmental Management. 30: 294-310.

Bryce, R.; van der Wal, R.; Mitchell, R.; [et al.]. 2013. Metapopulation dynamics of a burrowing herbivore drive spatio-temporal dynamics of riparian plant communities. Ecosystems. 16: 1165-1177.

Colvin, B.A.; McLean, E.B. 1986. Food habits and prey specificity of the common barn owls in Ohio. The Ohio Journal of Science. 86: 76-80.

Conroy, C.J.; Patton, J.L.; Lim, M.C.W.; [et al.]. 2016. Following the rivers: Historical reconstruction of California voles Microtus californicus (Rodentia: Cricetidae) in the deserts of eastern California. Biological Journal of the Linnean Society. doi: 10.1111/bij.12808.

Cox, G.W. 1990. Soil mining by pocket gophers along topographic gradients in a Mima moundfield. Ecology. 71: 837-843.

Davidson, D.W. 1993. The effect of herbivory and granivory on terrestrial plant succession. Oikos. 68: 23-35.

Dickson, J.G.; Williamson, J.H. 1988. Small mammals in streamside management zones in pine plantations. In: Szaro, R.C.; Severson, K.E.; Patton, D.R., tech. coords. Management of amphibians, and small mammals in North America: Proceedings of the symposium. Gen. Tech. Rep. RM-166. Fort Collins, CO: U.S. Department of Agriculture, Forest Service, Rocky Mountain Forest and Range Experiment Station: 375-378. 
Dreesen, D.; Harrington, J.; Subirge, T.; [et al.]. 2002. Riparian restoration in the SouthwestSpecies selection, propagation, planting methods, and case studies. In: Dumrose, R.K.; Riley, L.E.; Landis, T. D., eds. National nursery proceedings-1999, 2000, and 2001. Proc. RMRS-P-24. Fort Collins, CO: U.S. Department of Agriculture, Forest Service, Rocky Mountain Research Station, 370 p. http://www.nm.nrcs.usda.gov/Programs/pmc/symposium/ nmpmcsy03852.pdf

Ellis, L.M.; Crawford, C.S.; Molles, M.C. 1997. Rodent communities in native and exotic riparian vegetation in the Middle Rio Grande Valley of central New Mexico. Southwestern Naturalist. 42: 13-19.

Eubanks, E. 2004. Riparian restoration. Tech. Devel. Prog. 0423 1201-SDTDC. San Dimas, CA: U.S. Department of Agriculture, Forest Service, Technology and Development Program. 136 p. https://wildlife.utah.gov/pdf/riparian.pdf

Fagerstone, K.A.; Ramey, C.A. 1996. Rodents and lagomorphs. In: Rangeland wildlife. Krausman, P.R., ed. Denver, CO: The Society of Range Management. 440 p.

Fleischner, T.L. 2002. Ecological costs of livestock grazing in western North America. Conservation Biology. 8: 629-644.

Frey, J.K.; Calkins, M.T. 2013. Snow cover and riparian habitat determines distribution of the short-tailed weasel (Mustela erminea) at its southern range limits in western North America. Mammalia. 78: 45-56.

Frey, J.K.; Malaney, J.L. 2009. Decline of the meadow jumping mouse (Zapus hudsonius luteus) in two mountain ranges in New Mexico. Southwestern Naturalist. 54: 31-44.

Gardner, P.A; Stevens, R.; Howe, F.P. 1999. A handbook of riparian restoration and revegetation for the conservation of land birds in Utah with emphasis on habitat types in middle and lower elevations. Publication Number 99-38. Salt Lake City, UT: Utah Division of Wildlife Resources. 48 p.

Gillingham, B.J. 1984. Meal size and feeding rate in the least weasel (Mustela nivalis). Journal of Mammalogy. 65: 517-519.

Giullano, W.M.; Homyack, J.D. 2004. Short-term grazing exclusion effects on riparian small mammal communities. Journal of Range Management. 57: 346-350.

Golet, G.H.; Gardali, T.; Howell, C.A; [et al.]. 2008. Wildlife response to riparian restoration on the Sacramento River. San Francisco Estuary and Watershed Science. 6(2) 1-26. http:// escholarship.org/uc/item/4z17h9qm.

Grant, W.E.; Birney, E.C.; French, N.R.; [et al.]. 1982. Structure and productivity of grassland small mammal communities related to grazing-induced changes in vegetative cover. Journal of Mammalogy. 63: 248-260.

Grinnell, J. 1923. The burrowing rodents of California as agents in soil formation. Journal of Mammalogy. 4: 137-149.

Guthery, F.S.; Anderson, T.E.; Lehmann, V.W. 1979. Range rehabilitation enhances cotton rats in South Texas. Journal of Range Management. 32: 354-356.

Hallett, J.G.; O'Connell, M.A.; Maguire, C.C. 2003. Ecological relationships of terrestrial small mammals in western coniferous forests. In: Zabel, C.J.; Anthony, R.G., eds. Mammal community dynamics: Management and conservation in the coniferous forests of western North America. New York: Cambridge University Press: 120-156

Hamilton, B.T.; Roeder, B.L.; Hatch, K.A.; [et al.]. 2015. Why is small mammal diversity higher in riparian areas than in uplands? Journal of Arid Environments. 119: 41-50.

Hendricks, D. 1985. Arizona soils. Tucson, AZ: University of Arizona, College of Agriculture. http://www.library.arizona.edu/exhibits/swetc/azso/index.html.

Hulme, P.; Benkman, C.W. 2002. Granivory. In: Herrera C.; Pellmyr, O., eds. Plant-animal interactions: An evolutionary approach. New York: Blackwell Scientific Publications: $132-154$.

Johnston, A.N.; Anthony, R.G. 2008. Small-mammal microhabitat associations and response to grazing in Oregon. Journal of Wildlife Management. 72: 1736-1746. 
Jordano, P.; Garcia, C.; Godoy, J.A.; [et al.]. 2009. Differential contribution of frugivores to complex seed dispersal patterns. Proceedings of the National Academy of Science. 104: $3278-3282$.

Kauffman, J.B.; Krueger, W.C. 1984. Livestock impacts on riparian ecosystems and streamside management implications...A review. Journal of Range Management. 37: 430-438.

Kindschy, R.R. 1989. Regrowth of willow following simulated beaver cutting. Wildlife Society Bulletin. 17: 290-294.

Longland, W.S.; Price, M.V. 1991. Direct observations of owls and heteromyid rodents: Can predation risk explain microhabitat use? Ecology. 72: 2261-2273.

Longland, W.S.; Ostoja, S.M. 2013. Ecosystem services from keystone species: Diversionary seeding and seed-caching desert rodents can enhance Indian ricegrass seedling establishment. Restoration Ecology. 21: 285-291.

Mares, M.A.; Rosenzweig, M.L. 1978. Granivory in North and South American deserts: Rodents, birds, and ants. Ecology. 59: 235-241.

Maser, C.; Trappe, J.M.; Nussbaum, R.A. 1978. Fungal-small mammal interrelationships with emphasis on Oregon coniferous forests. Ecology. 59: 799-809.

McKinstry, M.C.; Caffrey, P.; Anderson, S.H. 2001. The importance of beaver to wetland habitats and waterfowl in Wyoming. Journal of the American Water Resources Association. 37: 1571-1577.

McMaster, R.T.; McMaster, N.D. 2000. Vascular flora of beaver wetlands in western Massachusetts. Rhodora. 102: 175-197.

Medin, D.E.; Clary, W.P. 1989. Small mammal populations in grazed and ungrazed riparian habitat in Nevada. Res. Pap. INT-413. Ogden, UT: U.S. Department of Agriculture, Forest Service, Intermountain Research Station. 6 p.

Medin, D.E.; Clary, W.P. 1991. Small mammals of a beaver pond ecosystem and adjacent riparian habitat in Idaho. Res. Pap. INT-445. Ogden, UT: U.S. Department of Agriculture, Forest Service, Intermountain Research Station. 4 p.

Milchunas, D.G.; Lauenroth, W.K. 1999. Quantitative effects of grazing on vegetation and soils over a global range of environments. Ecological Monographs. 63: 327-366.

Molina, R. 1994. The role of mycorrhizal symbioses in the health of giant redwoods and other forest ecosystems. In: Aune, Philip S., tech. coord. Proceedings of the symposium on Giant Sequoias: Their place in the ecosystem and society; 1992 June 23-25, 1992; Visalia, CA. Gen. Tech. Rep. PSW-GTR-151. Albany, CA: U.S. Department of Agriculture, Forest Service, Pacific Southwest Research Station: 78-81.

Moser, B.W.; Witmer, G.W. 2000. The effects of elk and cattle foraging on the vegetation, birds, and small mammals of the Bridge Creek Wildlife Area, Oregon. International Biodeterioration and Biodegradation. 45: 151-157.

Müller-Schwarze, D.; Sun, L. 2003. The beaver: Natural history of a wetlands engineer. Ithaca, NY: Cornell University Press. $190 \mathrm{p}$.

Naiman, R.J.; Johnston, C.A.; Kelley, J.C. 1988. Alteration of North American streams by beaver. Bioscience. 38: 753-762.

Naiman, R.J.; Melillo, J.M.; Hobbie, J.E. 1986. Ecosystem alteration of boreal forest streams by beaver (Castor canadensis). Ecology. 67: 1254-1269.

Ohmart, R.D.; Anderson, B.W. 1986. Riparian habitats. In: Cooperrider A.Y.; Boyd R.J., Stuart, H.R., eds. Inventory and monitoring of wildlife habitat. Denver, CO: U.S. Department of the Interior, Bureau of Land Management: 169-199.

Olson, T.E.; Knopf, F.L. 1988. Patterns of relative diversity within riparian small mammal communities, Platte River Watershed, Colorado. In: Szaro, R.C.; Severson, K.E.; Patton, D.R., tech. coords. Management of amphibians, and small mammals in North America: Proceedings of the symposium. Gen. Tech. Rep. RM-166. Fort Collins, CO: U.S. Department of Agriculture, Forest Service, Rocky Mountain Forest and Range Experiment Station, 379-386. 
Peinetti, H.R.; Baker, B.W.; Coughenour, M.B. 2009. Simulation modeling to understand how selective foraging by beaver can drive the structure and function of a willow community. Ecological Modelling. 220: 998-1012.

Pelster, A.J.; Evans, S.; Leininger, W.C.; [et al.]. 2004. Steer diets in a montane riparian community. Journal of Range Management. 57: 546-552.

Pollock, M.M.; Lewallen, G.; Woodruff, K.; [et al.], eds. 2015. The beaver restoration guidebook: Working with beaver to restore streams, wetlands, and floodplains. Version 1.0. Portland, OR: United States Fish and Wildlife Service. 199 p. http://www.fws.gov/oregonfwo/ ToolsForLandowners/RiverScience/Beaver.asp

Polvi, L.E.; Wohl, E. 2013. Biotic drivers of stream planform: Implications for understanding the past and restoring the future. BioScience. 63: 439-452.

Powell, R.A.; Zielinski, W.J. 1983. Competition and coexistence in mustelid communities. Acta Zoologica Fennica. 174: 223-227.

Queheillalt, D.M.; Morrison, M.L. 2006. Vertebrate use of a restored riparian site: A case study on the Central Coast of California. Journal of Wildlife Management. 70: 859-866.

Rich, T.D. 2002. Using breeding land birds in the assessment of western riparian systems. Wildlife Society Bulletin. 30: 1128-1139.

Rickel, B. 2005a. Wildlife. In: Finch, D.M., ed. Assessment of grassland ecosystem conditions in the Southwestern United States: Wildlife and fish, volume 2. Gen. Tech. Rep. RMRSGTR-135-vol. 2. Fort Collins, CO: U.S. Department of Agriculture, Forest Service, Rocky Mountain Research Station: 1-12.

Rickel, B. 2005b. Small mammals, reptiles, and amphibians. In: Finch, D.M., ed. Assessment of grassland ecosystem conditions in the Southwestern United States: Wildlife and fish, volume 2. Gen. Tech. Rep. RMRS-GTR-135-vol. 2. Fort Collins, CO: U.S. Department of Agriculture, Forest Service, Rocky Mountain Research Station: 35-70.

Ripple, W.J.; Beschta, R.L. 2012. Trophic cascades in Yellowstone: The first 15 years after wolf reintroduction. Biological Conservation. 145: 205-213.

Rosell, F.; Bozser, O.; Collen, P.; Parker, H. 2005. Ecological impact of beavers Castor fiber and Castor canadensis and their ability to modify ecosystems. Mammal Review. 35: 248-276.

Sarr, D.A. 2002. Riparian livestock exclosure research in the western United States: A critique and some recommendations. Environmental Management. 30: 516-526.

Scheffer, T.H. 1945. Burrow associations of small mammals. The Murrelet. 26: 24-26.

Schultz, T.T.; Leininger, W.C. 1991. Nongame wildlife communities in grazed and ungrazed montane riparian sites. Great Basin Naturalist. 51: 286-292.

Shafroth, P.B.; Cleverly, J.R.; Dudley, T.L.; [et al.]. 2005. Control of Tamarix in the western United States: Implications for water salvage, wildlife use, and riparian restoration. Environmental Management. 35: 231-246.

Small, B.A.; Frey, J.K.; Gard, C.C. 2016. Livestock grazing limits beaver restoration in northern New Mexico. Restoration Ecology. 24: 646-655.

Spencer, D.A. 1958. Biological aspects of the 1957-58 meadow vole irruption in the Pacific Northwest. Special Report. Denver, CO: U.S. Fish and Wildlife Service, Denver Wildlife Research Laboratory. 9 p.

Sullivan, T.P.; Sullivan, D.S. 2013. Fertilisation, cattle grazing and voles: Collapse of meadow vole populations in young forests? Wildlife Research. 41: 367-378.

Suzuki, N. 1992. Habitat classification and characteristics of small mammals and amphibian communities in beaver-pond habitats of the Oregon Coast Range. Thesis. Corvallis, OR: Oregon State University. 91 p.

Taitt, M.J.; Krebs, C.J. 1985. Population dynamics and cycles. In: Tamarin, R.H., ed. Biology of New World Microtus. American Society of Mammalogists Special Publication. 8: 567-620.

Terwilliger, J.; Pastor, J. 1999. Small mammals, ectomycorrhizae, and conifer succession in beaver meadows. Oikos. 85: 83-94. 
Trimble, S.W.; Mendel, A.C. 1995. The cow as a geomorphic agent-A critical review. Geomorphology. 13: 233-253.

Turner, F.B.; Chew, R.M. 1981. Production by desert animals. In: Goodall, D.W.; Perry, R.A., eds. Arid-land ecosystems: Volume 2, structure, functioning and management. New York, NY: Cambridge University Press: 199-260.

Van Vleck, D.B. 1969. Standardization of Microtus home range calculation. Journal of Mammalogy. 50: 69-80.

Weber, D.J. 1971. The Taos trappers: The fur trade in the far Southwest, 1540-1846. Norman, OK: University of Oklahoma Press. 228 p.

Whelan, C.J.; Şekercoiğulu, Ç; Wenny, D.G. 2015. Why birds matter: From economic ornithology to ecosystem services. Journal of Ornithology. 156(1): 227-238. doi: 10.1007/ s10336-015-1229-y.

Whitford, W.G. 2002. Ecology of desert systems. San Diego, CA: Academic Press. 343 p.

Witmer, G.; Proulx, G. 2010. Rodent outbreaks in North America. In: Singleton, G.R; Belmain, R., Brown, P.R.; [et al.], eds. Rodent outbreaks: Ecology and impacts. Los Banos, Philippines: International Ride Research Institute: 253-267.

Wright, G.D.; Frey, J.K. 2014. Herbeal feeding behavior of the New Mexico meadow jumping mouse (Zapus hudsonius luteus). Western North American Naturalist. 74: 231-235.

Young, J.S.; Ammon, E.M.; Weisberg, P.J.; [et al.]. 2013. Comparison of bird community indices for riparian restoration planning and monitoring. Ecological Indicators. 34: 159-167. 


\title{
Chapter 7. Euro-American Beaver Trapping and Its Long- Term Impact on Drainage Network Form and Function, Water Abundance, Delivery, and System Stability
}

\author{
Suzanne C. Fouty
}

Introduction

Euro-American (EA) beaver trapping was a regional and watershed-scale disturbance that occurred across the North American continent. This concentrated removal of beavers altered drainages by creating thousands of localized base-level drops as beaver dams failed and were not repaired. These base-level drops led to the development of channels as ponds drained and water eroded the fine sediment trapped behind the dams (Dobyns 1981; Fouty 1996, 2003; Parker et al. 1985). The speed at which drainages transformed from beaver-dominated to channel-dominated varied as a function of climate, upland and riparian vegetation, and the subsequent land uses. As the drainage network pattern changed, flood magnitudes and frequencies increased and base flows decreased, creating stream systems much more sensitive to climatic variability.

In most places, trapping predates EA settlement. The one exception is New England in the 1600s where settlement and trapping co-existed in time. The journals from this time period provide intriguing but limited references to vegetative and ecological changes as a result of beaver removal (Cronon 1983). This limited historic documentation of system response to the widespread removal of beavers resulted in our missing the significance of early EA beaver trapping on drainage network development, water abundance, delivery, and system stability. However, the abundant and high quality written records left by the early General Land Office (GLO) surveyors and scientific and military expeditions of their observations of the Southwest and Intermountain West hold promise because they entered these areas only 10 to 30 years post-trapping. Their observations when combined with later research suggest that EA trapping and grazing, though temporally and spatially separated, led to extensive drainage network development in the West and an increase in the sensitivity of stream ecosystems to climate variability. This transformation pre-dates the installation of stream gages and the data collection that forms the basis of our understanding of hydraulic geometry, channel form, and fluvial processes. Consequently, current fluvial geomorphic relationships and our understanding of stream sensitivity to climatic variability reflect highly disturbed watersheds and ecosystems, not healthy intact systems. Without realizing it, the GLO surveyors and the early military and scientific expeditions had captured not virgin territory, but a landscape in transition.

Using current research and historic observations, I developed a conceptual model describing the geomorphic and hydrologic response of a drainage basin to the entry of beavers and then their removal or abandonment (Fouty 2003). The conceptual model is similar in structure to Cooke and Reeves' (1976) deductive model of arroyo formation in the Southwest in that both models examine the hydrologic and geomorphic response 
of streams to EA disturbances. Cooke and Reeves (1976) focused on post-settlement EA disturbances such as livestock grazing, logging, agriculture, and road building. The conceptual model presented here steps further back in time to examine the impact of EA beaver trapping on drainage systems.

Currently, the most visible impact of beavers would occur on first- through fourthorder streams because beavers can build their dams across these stream sizes (Naiman et al. 1986; 1988) and thus have a direct effect on the physical appearance and hydrologic behavior of the drainage network in these areas. However, historically beaver dams would have occurred on higher order streams. The current widths and depths we see for larger order streams is an artifact of and response to the magnitude and abundance of disturbances that have occurred. Prior to trapping and subsequent EA disturbances, streams in many places were anabranching, narrower and had high stream-valley floor connectivity (Sedell and Froggatt 1984; Walter and Merritts 2008).

With the conceptual model as the framework for analysis, this paper then (1) explores why EA beaver trapping as a major disturbance was missed and absent from the discipline of fluvial geomorphology until recently, (2) reexamines the early observations in the Southwest and Intermountain West in the context of EA beaver trapping, and (3) concludes with a brief discussion of Leopold and Maddock's (1953) hydraulic geometry relationships, one of the foundations of fluvial geomorphology. When these relationships are put into their historic disturbance context, one that includes beaver trapping and later land uses, the magnitude and longevity of the impact of EA beaver trapping on drainage networks, water abundance, and system resiliency becomes clear.

\section{Conceptual Model Part 1: Watershed Response to Long-Term Beaver Presence}

The fluvial processes and sequence of events that occur when beavers enter a drainage area and establish a long-term stable presence are shown in figure 19. An excellent discussion of the changes in more detail can be found in Naiman et al. (1988) and so are only briefly discussed here. Changes begin with dam building and foraging for vegetation around the pond area. As beaver dam complexes expand, changes occur to (1) water abundance and vegetation, (2) local and downstream hydrographs, and (3) the character of the drainage network. In figure 19, the local effects are broken down into low-energy environments and high-energy environments. The distinction is made because dams in low-energy environments tend to be stable, allowing wetlands to form and evolve into meadows (if sediment is abundant), while dams in high-energy environments (i.e., steeper gradient streams, higher discharge streams) are more prone to periodic failure and wetlands and meadows less likely to form (Meentemeyer and Butler 1999).

In terms of conceptual models, there are key differences between beaver-dominated and channel-dominated systems. In beaver-dominated systems, stream channels are interrupted by dams that develop ponds across the channel and valley floor and lead to the creation of wetlands. In contrast, the conceptual model of a channelized drainage network is visualized as a set of interconnected channels "where physical variables present a continuous gradient of physical conditions from the headwaters to the mouth" (Naiman et al. 1986). This conceptual model of a watershed of interconnected channels is implied in the hydraulic geometry relationships of Leopold and Maddock (1953) and other researchers 


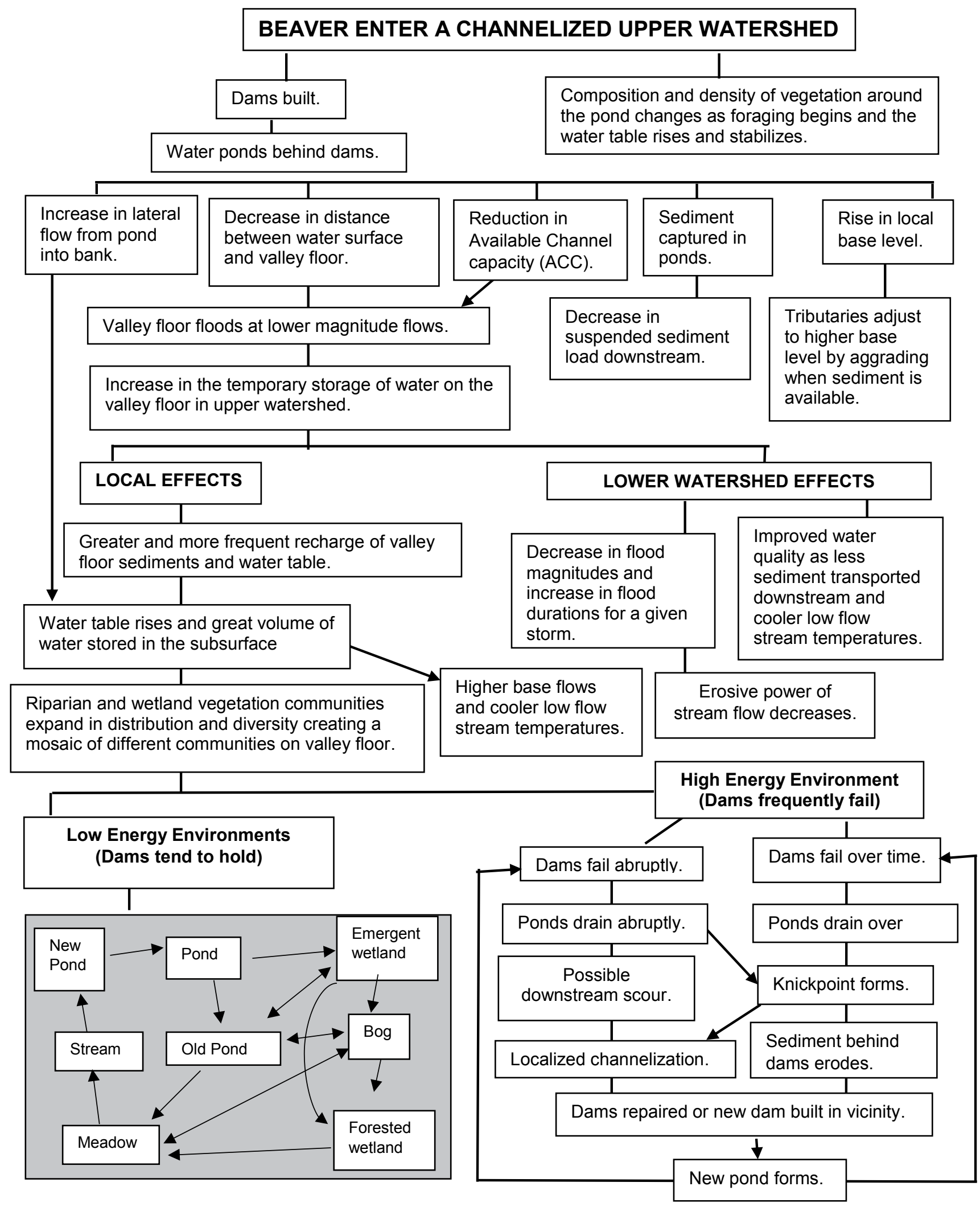

Figure 19-Conceptual model of how beavers influence fluvial systems at the watershed scale (source: Fouty 2003; portion in the shaded box is from Naiman et al. 1998). 
(Knighton 1998). It is also an assumption in the discharge-drainage area relationships that have been developed and used to guide and inform stream restoration efforts.

The most visible change once beaver dams are built is the increase in the amount of surface water stored within a given section of stream, but the increase extends beyond surface water to include groundwater. I modeled the potential increase in the total amount of water that would be stored in a 29 acre meadow with 0.76 miles of stream, and available to the river, using a point-in-time volume estimate of the amount of water held in the channel during the summer as baseline conditions. The reach occurs on Camp Creek, a tributary to the North Fork Burnt River (NFBR), located in eastern Oregon. The goal was to predict potential water-related benefits if beaver returned to the creek. Beavers are currently present in the NFBR but not in Camp Creek, though past signs of their presence exist and beaver habitat restoration efforts are underway. Commercial and recreational trapping currently occur in the NFBR watershed and the area is a mix of public and private land.

The calculations used existing cross-section data, information about summer water levels, an average bank height of $5 \mathrm{ft}$, and expected soil types (silt loam and sandy loam). The meadow was assumed to be one or the other soil type resulting in a range in values. Using information from Dunne and Leopold (1978), the soil porosity values used were 0.46 for silt loam and 0.44 for sandy loam and the field capacity values used were 0.31 for silt loam and 0.15 for sandy loam. These values were used to estimate the amount of groundwater that could be stored in the meadow under saturated conditions and capable of draining freely to the river. The calculations assumed that the dam heights equaled the average bank height.

Without beaver dams (baseline condition), the estimate of in-channel surface water was 0.4 acre-ft for the 0.76 miles of stream. Summer contributions from groundwater to base flows are limited because the channel is incised and over-wide. With beaver dams, the volume of in-channel surface water would increase from 0.4 acre-ft to 9 acre-ft. A saturated meadow could contribute an additional 22 acre-ft (if silt loam) to 42 acre-ft (if sandy loam) of groundwater to the river, contributing to summer baseflows. If the dams extended across the valley floor and were a foot tall, an additional 29 acre-ft of surface water would be held in temporary storage. When all the values are totaled, the amount of water that could be stored within this 29 -acre meadow and available to drain freely into Camp Creek if beaver dams were present increases from 0.4 to as much as 80 acre-ft of water.

A landscape-scale example of actual change in response to beavers expanding their range occurred between 1940 and 1986 on the Kabetogama Peninsula, a 17.4 mile $^{2}$ area in Minnesota. Using aerial photos, Naiman et al. (1988) counted 71 beaver dams in 1940 and 835 dams in 1986. The cover types were lumped into four categories (forest, wet, moist, ponds). In 1940, acres in the moist, wet, and pond categories were 640. By 1986 the number had increased to 9,308 acres with a large portion of that change achieved by 1961 . Ponds increased from 40 acres to 3,388 acres reflecting large increases in surface water. The moist and wet categories increased from 600 to 5,921 acres reflecting a large increase in groundwater stored. Other examples exist within the literature that capture the water storing capability of beavers (Beedle 1991; Hood and Bayley 2008; Demmer and Beschta 2008), leaving little doubt about the ability of abundant beaver populations to effectively help mitigate the effects of climate variability. 


\section{Reductions in Downstream Flood Magnitudes}

Beaver ponds have long been credited with reducing flood magnitudes and stream power through pond storage, valley-floor storage, or both (Dobyns 1981; Naiman et al. 1988; Parker et al. 1985) - assumptions that have been "based primarily on qualitative observations in the literature from the first half of the century" (Meentemeyer and Butler 1999). Actual studies quantifying the influence of beavers on flood magnitudes are few, have focused on small headwater streams, and have only considered the role of pond storage in flood peak reductions. Burns and McDonnell (1998) compared two stream hydrographs. One hydrograph captured flows in a 102 acre drainage containing a perennial stream and a single 3.2 acre beaver pond at its downstream end. The other hydrograph captured flows for a 151.2 acre watershed containing an ephemeral stream and no beaver pond. They found that the single pond provided minimal retention during several large runoff events. Beedle (1991) explored how storm hydrographs responded to increasing amounts of pond storage as the size and numbers of ponds in series increased. The drainages studied were 1,532 acres or less and his maximum pond size was 1.48 acres. He found that the amount of reductions varied with storm size, pond size, pond numbers, and available storage capacity of the ponds prior to the flow event.

A single full beaver pond was found to theoretically reduce peak flows by no more than 5.3 percent regardless of the return interval or watershed size. The shape of the outflow hydrographs were the same as the inflow hydrographs, with only a 10 or 15 minute delay in the time to peak and slightly increased duration. Reductions in peak flows became increasingly large as the number of ponds in a series increased. Five large-sized beaver ponds in series reduced the storm peak flow by 14 percent for a 2 -year event, but only 4 percent for a 50-year event (Beedle 1991).

However, the greater contribution of in-channel ponds as it pertains to reducing flood magnitudes is that they reduce the available channel capacity (ACC). This causes streams to overtop their stream banks at lower flows allowing flood waters to access the valley-floor where temporary flood storage is greater.

The degree to which overbank flooding decreases flood magnitudes and increases flood durations varies as a function of valley-floor roughness (Campbell et al. 1972; Leopold and Maddock 1954; Shankman and Pugh 1992), the amount of storage area (Campbell et al. 1972; Osterkamp and Costa 1987), and the location of unmodified sections of river with respect to the flood wave (Campbell et al. 1972; Hillman 1998). The mix of channelized and nonchannelized reaches results in a discontinuity in flood magnitudes, durations, and frequencies as a flow moves downstream. Some areas will experience increased flooding while others (e.g., downstream of a wetland) will show minimal changes for the same precipitation or dam-bursting event (Campbell et al. 1972; Hillman 1998).

Reductions of flood magnitudes as a result of valley-floor storage in systems where the streams are hydrologically connected to their valley floors but without beavers have been documented by a number of researchers. Osterkamp and Costa (1987) estimated water depths at three valley cross-sections on Plum Creek in Colorado, which drains 328.2 miles $^{2}$. During a 900 to 1,600-year recurrence interval, flood water depths averaged from 7.9 to $9.5 \mathrm{ft}$ but were as great as $19 \mathrm{ft}$. Dunne and Leopold (1978) examined runoff from four large drainage basins ranging in size from 7,411 to 203,000 miles ${ }^{2}$. They found 
that the channel and valley floor stored 57 to 80 percent of the runoff generated by large storms. Campbell et al. (1972) used two flood-routing methods to determine the effect of channel straightening on flood magnitudes, durations, and attenuation of the flood peak for 58 miles of the Boyer River in Tennessee. The river drains 1,188 miles $^{2}$. Channel straightening and the building of dikes increased discharge downstream by limiting access to the valley floor and increasing the stream gradient. In contrast, under partial straightening they found that the unmodified sections of the stream substantially reduced the magnitude of flood peaks because the flood waters overflowed onto the valley floor. The floodplain in the unmodified section averaged 1.3 miles wide.

Campbell et al. (1972) reported the following results of their modeling: "The unmodified reach, even though short, provides tremendous storage, which can nullify the effects produced by the upstream straightening. As indicated in figure $8 \mathrm{c}, 16$ miles of unmodified river reduced the increase in peak discharge from 90 percent to 15 pecent for the condition of high flood plain roughness coefficient. The increase in peak discharge at section 30 [the most downstream section and below the unmodified section] is 35 percent with high $\mathrm{n}$ [0.10] and 30 percent with low $\mathrm{n}$ [0.04] as compared with 190 percent and 90 percent respectively for complete straightening."

A smaller scale example comes from Rocky Creek in central Alberta. It drains an area of 4,621 acres. Hillman (1998) observed the influence of a 222.4-acre wetland on downstream flood flows after a beaver dam failed. The wetland contained a sedge meadow, willows, a small lake, and several beaver ponds. By the time the flood waters had passed through the wetland and reached the main gage, about 4 miles downstream of the dam failure, the flood peak was only 6 percent of the peak estimated to have entered the wetland. He concluded that wetlands, especially when large, are very effective at regulating high flows, even more so than beaver ponds because the dams often wash out during high floods.

These examples show that valley-floor storage, beaver ponds, and wetlands can significantly reduce flood peaks at all scales of drainage area and storm size. As such, the loss of wetlands and beaver ponds and the severing of stream-valley floor hydrologic connections has the reverse effect, increasing flood peaks for all sizes of storms and drainage areas. Nowhere has the impact of lost storage potential been more frequently on display than in the Mississippi River Basin. Hey and Philippi (1995) estimate that beaver ponds and wetlands historically made up 11 percent and 10 percent respectively of the 450 million acres of the Missouri and Upper Mississippi River Basins. They currently make up 1 percent and 4 percent. The reduction of these features, along with the development of a channelized drainage network and levee system, has led to increases in the magnitude and frequency of downstream flooding with large economic and social costs.

\section{Conceptual Model Part 2: Watershed Response to Beaver Trapping After a Long-Term Presence}

The fluvial processes and sequence of events that occur when beavers are removed after a long-term presence, but prior to another large-scale disturbance, are shown in figure 20. Decreases or elimination of beavers from drainages means that dam failures are not repaired. The lack of dam maintenance at multiple sites within a drainage and across a region sets in motion changes that allow the channels to expand beyond the point of 


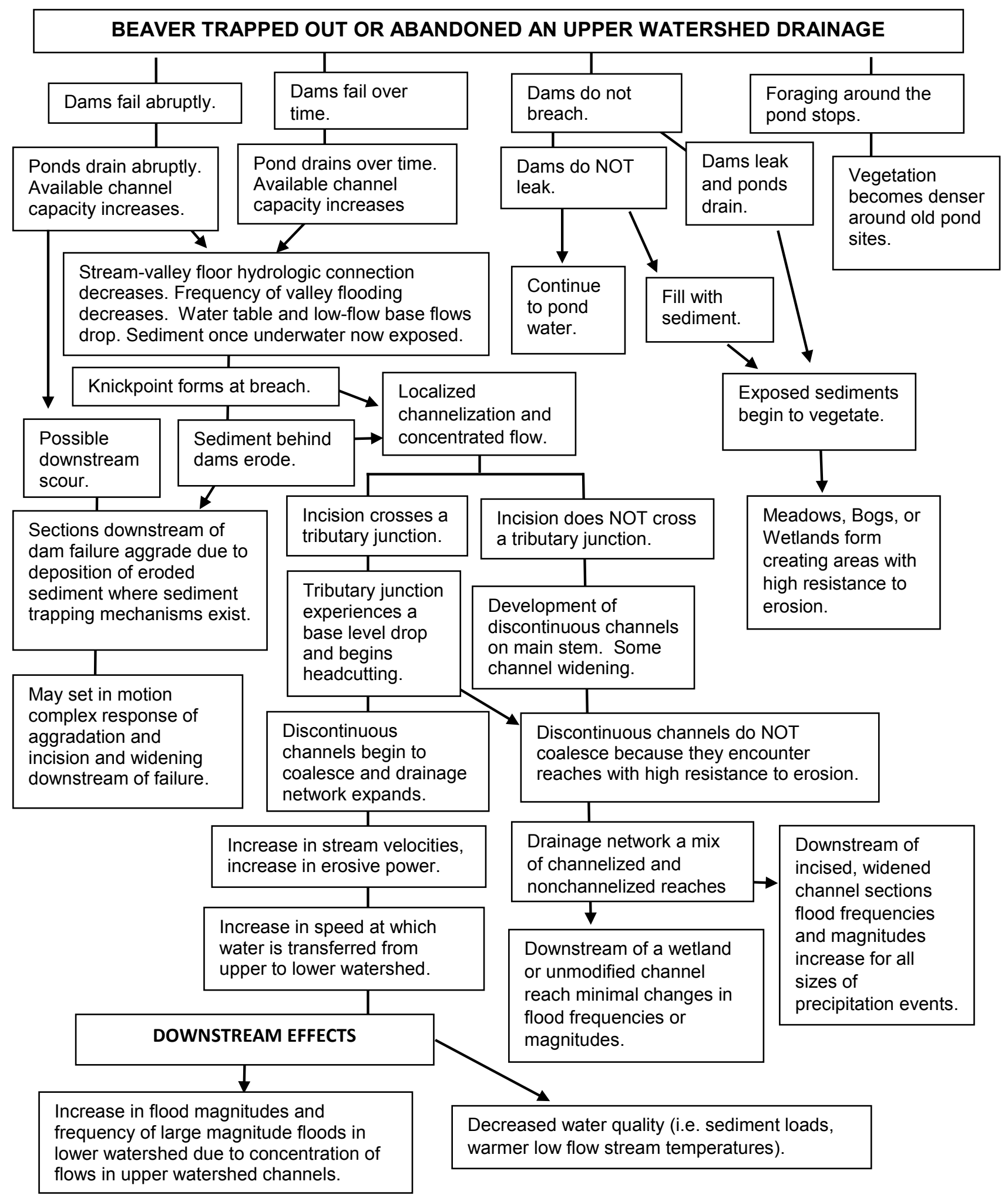

Figure 20-Conceptual model of how beaver trapping or site abandonment influence fluvial systems (source: Fouty 2003). 
dam failure. With failures, (1) ponds drain and sediment erodes, (2) available channel capacity (ACC) increases, (3) local base-levels drop, (4) knickpoints form, and (5) the stream-valley floor hydrologic connection becomes increasingly disconnected.

The impact of beaver trapping and subsequent dam failures on ACC and thus the stream-valley floor hydrologic connection was captured at Price Creek in southwestern Montana (Fouty 2003). Fourteen monumented cross-sections were established in 1995. Twelve occurred inside a cattle exclosure that contained beaver dams. Two occurred downstream of the exclosure in a section without beaver dams. In 1995, the percent $\mathrm{ACC}$ at the dam-controlled cross-sections ranged from 0 percent (channel full) to 62 percent depending on dam integrity (table 2), which was already varying as a result of beaver being trapped out between 1994 and 1995. By 1998 all dams were failing or gone and the percent ACC had increased at all sites.

Table 2-Changes in available channel capacity (ACC) as a result of dam failure and pond drainage, Price Creek, Montana. Cross-sections 17 and 18 were downstream of the beaver dam controlled reaches (source: Fouty 2003.)

\begin{tabular}{|c|c|c|c|c|}
\hline \multirow[t]{2}{*}{$\begin{array}{l}\text { Cross-section } \\
\text { number }\end{array}$} & \multicolumn{2}{|c|}{$\begin{array}{l}\text { \% Available channel } \\
\text { capacity }^{\mathrm{a}}\end{array}$} & \multirow[t]{2}{*}{$\begin{array}{l}\text { Dominant reason for } \\
\text { the change in available } \\
\text { channel capacity }\end{array}$} & \multirow[t]{2}{*}{$\begin{array}{l}\text { Distance upstream of a beaver dam (ft) } \\
\text { and timing of dam failure }\end{array}$} \\
\hline & 1995 & 1998 & & \\
\hline 19 & 0 & 69 & Pond drains & $\begin{array}{l}115 \mathrm{ft} . \text { Begins breaching post } 1995 \text { but still exerting } \\
\text { some influence in } 1997 \text { and } 1998 .\end{array}$ \\
\hline 20 & 0 & 84 & $\begin{array}{l}\text { Pond drains and } \\
\text { sediment erodes }\end{array}$ & $\begin{array}{l}30 \mathrm{ft} \text {. Begins breaching post } 1997 \text { but still exerting some } \\
\text { influence in } 1998 .\end{array}$ \\
\hline 21 & 38 & 81 & Pond drains & $\begin{array}{l}39 \mathrm{ft} \text {. Begins breaching post } 1997 \text { but still exerting some } \\
\text { influence in } 1998 .\end{array}$ \\
\hline 22 & 39 & 91 & Pond drains & $52 \mathrm{ft}$. Begins breaching post 1997 and gone by 1998 . \\
\hline 23 & 17 & 68 & $\begin{array}{l}\text { Pond drains and } \\
\text { sediment erodes }\end{array}$ & $\begin{array}{l}49 \mathrm{ft} \text {. Begins breaching post } 1997 \text { but still exerting some } \\
\text { influence in } 1998 .\end{array}$ \\
\hline 24 & 26 & 72 & $\begin{array}{l}\text { Pond drains and } \\
\text { sediment erodes }\end{array}$ & $\begin{array}{l}10 \mathrm{ft} \text {. Begins breaching post } 1995 \text {. Completely breached } \\
\text { by } 1998 .\end{array}$ \\
\hline 25 & 66 & 84 & Pond drains & $62 \mathrm{ft}$. Intact in 1997, gone by 1998. \\
\hline 26 & 63 & 80 & Pond drains & $\begin{array}{l}89 \mathrm{ft} \text {. Begins breaching post- } 1997 \text { but still exerting some } \\
\text { influence by } 1998 .\end{array}$ \\
\hline 27 & 35 & 71 & Pond drains & $\begin{array}{l}36 \mathrm{ft} \text {. Begins breaching post- } 1997 \text { but still exerting some } \\
\text { influence by } 1998 .\end{array}$ \\
\hline 28 & 62 & 84 & Pond drains & $\begin{array}{l}72 \mathrm{ft} \text {. Begins breaching post } 1995 \text { but still exerting } \\
\text { influence in } 1997 \text { and } 1998 \text {. Below this dam was a } \\
\text { submerged dam acted as a base-level control. }\end{array}$ \\
\hline 29 & 62 & 94 & $\begin{array}{l}\text { Pond drains and } \\
\text { sediment erodes }\end{array}$ & $10 \mathrm{ft}$. Begins breaching post 1995. Gone by 1998 . \\
\hline 30 & 69 & 95 & $\begin{array}{l}\text { Pond drains and } \\
\text { sediment erodes }\end{array}$ & $\begin{array}{l}10 \mathrm{ft} \text {. Begins breaching post } 1995 \text {. Some influence still in } \\
1997 \text { but gone by } 1998 \text {. }\end{array}$ \\
\hline \multicolumn{5}{|c|}{ No beaver dam influence } \\
\hline 17 & 94 & 94 & $\begin{array}{l}\text { Minimal changes in } \\
\text { sediment or water levels }\end{array}$ & $\mathrm{n} / \mathrm{a}$ \\
\hline 18 & 87 & 89 & $\begin{array}{l}\text { Minimal changes in } \\
\text { sediment or water levels }\end{array}$ & $\mathrm{n} / \mathrm{a}$ \\
\hline
\end{tabular}

a \% Available channel capacity $=(1-($ water XS area/channel XS area $)) * 100$. 
Changes in ACC between 1995 and 1998 inside the cattle exclosure varied as a function of proximity to a dam, dam integrity, and the length of time the dam had been in place prior to the building of upstream dams (Fouty 2003). ACC increased at all 12 cross-sections. Seven cross-sections had increases due to pond drainage, and five cross-sections due to sediment erosion and pond drainage. In contrast, the ACC at the two downstream cross-sections $(17,18)$ changed very little despite the large influx of sediment from upstream sites as dams failed and the sediment previously trapped behind them eroded. The lack of sediment trapping mechanisms at these two cross-sections resulted in sediment moving through the system as suspended load, giving the appearance of a sediment-starved system rather than one simply lacking sediment trapping mechanisms.

Unlike Price Creek where repeated beaver trapping has prevented the development of wetlands, streams with a long-term beaver presence and abundant sediment inputs would in time develop complex wetland vegetation communities (Johnston and Naiman 1990). Post-trapping but in the absence of another disturbance, these well-established wetlands would persist after the loss of beavers and impede the headward migration of the knickpoints initiated when the dams failed. Their location, characteristics, and stability would prevent the channels from coalescing into a single interconnected system. The resulting drainage pattern would be one in which channelized reaches are spatially separated by wetlands. The hydrologic impact of this drainage pattern would be a discontinuity in flow magnitudes and durations, similar to that described by Campbell et al. (1972) and Hillman (1998).

The effectiveness of the wetlands at impeding channel development comes from (1) their enhanced roughness that reduces flow velocities (Cooke and Reeves 1976; Hendrickson and Minckley 1984), (2) temporary storage potential that reduces flood peaks (Campbell et al. 1972; Dunne and Leopold 1978; Hillman 1998; Osterkamp and Costa 1987), and (3) their enhanced subsurface cohesion (Cooke and Reeves 1976; Finch et al. 2003; Hendrickson and Minckley 1984; Smith 1976). If, on the other hand, the wetlands develop channels or are eliminated by human activity, the drainage pattern becomes increasingly channelized (fig. 20). Examples of the amount and speed at which channelization can occur are found in table 3.

As a drainage becomes channelized, vegetation shifts from water-dependent to drought-tolerant species. This shift occurs as a result of decreased soil moisture. As a channel incises, widens, or both, the increased ACC leads to a reduction in the frequency of valley-floor flooding (Campbell et al. 1972; Schumm et al. 1984; Shankman and Pugh 1992) and enhances the flow of groundwater toward the channel by steepening the hydraulic gradient between the water table and stream (Knighton 1998 referencing Dunne 1980, 1990). The result is a lowering of the water table.

The speed at which vegetation changes varies as a function of climate, land use, incision depth, groundwater depth, subsurface stratigraphy, and vegetation requirements (Cooke and Reeves 1976). In areas where precipitation is distributed throughout the growing season, it may partially compensate for a decline in water tables if its abundance and distribution are sufficient to maintain soil moisture levels. In areas where precipitation is strongly seasonal, declines in water tables are not compensated for by precipitation, and vegetation responds more quickly to channelization and the lowering of the water table (Bryan 1928b). The speed at which vegetative communities 
Table 3-Examples of the speed at which channelization occurs, and the depth, width, and length of the channelization when known (source: Fouty 2003.)

\begin{tabular}{|c|c|c|c|c|}
\hline Location & Dates & Type and amount of change & Time interval & Source \\
\hline Rio Salado, NM & $\begin{array}{l}\text { Between } 1882 \\
\text { and } 1918\end{array}$ & $\begin{array}{l}\text { Channel widens from } 11.88 \text { to } 48.84 \mathrm{ft} \text { wide to } \\
330.1 \text { to } 550 \mathrm{ft} \text { wide. }\end{array}$ & $<36$ years & Bryan 1927 \\
\hline $\begin{array}{l}\text { Felipe Gilbert } \\
\text { Creek, NM }\end{array}$ & One storm event & Channel headcuts for a distance of 40 to $75 \mathrm{ft}$. & 1 day & Bryan 1927 \\
\hline $\begin{array}{l}\text { Whitewater Draw, } \\
\text { AZ }\end{array}$ & $\begin{array}{l}\text { The rainy season } \\
\text { in } 1910\end{array}$ & Channel headcuts for a distance of 0.25 miles. & $\begin{array}{l}\text { Up to a } \\
\text { couple of } \\
\text { months }\end{array}$ & $\begin{array}{l}\text { Cooke and } \\
\text { Reeves } 1976\end{array}$ \\
\hline Kanab Creek, UT & $\begin{array}{l}\text { Between } 1883 \\
\text { and } 1885\end{array}$ & $\begin{array}{l}\text { Channel incises } 60 \mathrm{ft} \text { and widens nearly } 70 \mathrm{ft} \text { for a } \\
\text { distance of } 15 \text { miles. }\end{array}$ & $<2$ years & Gregory 1917 \\
\hline Walker Creek, AZ & $\begin{array}{l}\text { Between } 1894 \\
\text { and } 1913\end{array}$ & Channel incises $80 \mathrm{ft}$ deep. & $<19$ years & Gregory 1917 \\
\hline Chinle Creek, AZ & $\begin{array}{l}\text { Between } 1894 \\
\text { and } 1913\end{array}$ & Channel incises $100 \mathrm{ft}$ deep. & $<19$ years & Gregory 1917 \\
\hline $\begin{array}{l}\text { Mountain } \\
\text { Meadows, UT }\end{array}$ & $\begin{array}{l}1884 \text { - in one } \\
\text { series of storms }\end{array}$ & $\begin{array}{l}\text { Channel incises into what was once a wet } \\
\text { meadow during a series of storms and continued } \\
\text { to widen after } 1884 \text {. Gullies fingering out to } \\
\text { nearly all parts of meadow. No numbers given. }\end{array}$ & $\begin{array}{l}\text { Up to one } \\
\text { month } \\
\text { for initial } \\
\text { incisions }\end{array}$ & $\begin{array}{l}\text { Cottam and } \\
\text { Stewart } 1940\end{array}$ \\
\hline Crane Creek, OR & $\begin{array}{l}\text { Between } 1925 \\
\text { and } 1930\end{array}$ & Channel incises to a depth of $10 \mathrm{ft}$. & 5 years & Schaffer 1941 \\
\hline $\begin{array}{l}\text { Santa Cruz River } \\
\text { near Tucson, AZ }\end{array}$ & $\begin{array}{l}\text { Between Aug } 5 \\
\text { and } 9,1890\end{array}$ & $\begin{array}{l}\text { Channel incises some unknown depth for } 1.5 \\
\text { miles between August } 5 \text { and } 7 \text {. Between August } \\
7 \text { and } 9 \text { channel begins to fork and headcut in } \\
\text { multiple directions. }\end{array}$ & 4 days & $\begin{array}{l}\text { Cooke and } \\
\text { Reeves } 1976 \\
\text { (p. 51) }\end{array}$ \\
\hline Sonoita Creek, AZ & $\begin{array}{l}\text { Between } 1891 \\
\text { and } 1912\end{array}$ & $\begin{array}{l}\text { Channel incises } 18 \text { to } 20 \mathrm{ft} \text { deep and widens to } \\
250 \mathrm{ft} \text {. }\end{array}$ & $<21$ years & Bryan 1928b \\
\hline $\begin{array}{l}\text { Gila River near } \\
\text { Safford, AZ }\end{array}$ & $\begin{array}{l}\text { Between } 1905 \\
\text { and } 1917\end{array}$ & $\begin{array}{l}\text { Channel widens from an average of less than } 330 \\
\text { to } 2000 \mathrm{ft} \text { for about } 45 \text { miles. }\end{array}$ & $<12$ years & Burkham 1972 \\
\hline $\begin{array}{l}\text { Cimarron River } \\
\text { in southwestern } \\
\text { Kansas }\end{array}$ & $\begin{array}{l}\text { Between } 1874 \\
\text { and } 1939\end{array}$ & $\begin{array}{l}\text { Channel widens from average of } 50 \text { to } 1200 \mathrm{ft} \text { for } \\
\text { about } 175 \text { miles. }\end{array}$ & $<65$ years & $\begin{array}{l}\text { Schumm and } \\
\text { Lichty } 1963\end{array}$ \\
\hline $\begin{array}{l}\text { Rio Puerco, NM } \\
\text { (between mouth } \\
\text { and Cabezon) }\end{array}$ & $\begin{array}{l}\text { Between about } \\
1885 \text { and } 1892\end{array}$ & $\begin{array}{l}\text { Channel incises and the incision migrates } \\
\text { upstream for } 110 \text { miles Discontinuous incision } \\
\text { existed prior to } 1885 \text { and this may have facilitated } \\
\text { rapid headward migration of the incision. }\end{array}$ & $<7$ years & Bryan 1928a \\
\hline $\begin{array}{l}\text { Douglas Creek, CO } \\
\text { (East Fork) }\end{array}$ & $\begin{array}{l}\text { Between } 1882 \\
\text { and } 1900\end{array}$ & Channel has incised $16.4 \mathrm{ft}$. & $<18$ years & $\begin{array}{l}\text { Womack and } \\
\text { Schumm } 1977\end{array}$ \\
\hline $\begin{array}{l}\text { Wolf River near } \\
\text { Memphis, TN }\end{array}$ & $\begin{array}{l}\text { Between } 1964 \\
\text { and } 1999\end{array}$ & $\begin{array}{l}\text { Channel incises migrates upstream for } 10.6 \text { miles. } \\
\text { Headcutting is episodic in nature with an average } \\
\text { rate of headward migration of } 0.37 \text { miles/yr. Some } \\
\text { areas have had a } 19.7 \mathrm{ft} \text { drop in bed level and the } \\
\text { channel has widened to twice its original width. }\end{array}$ & $<35$ years & Wiens 2001 \\
\hline Price Creek, MT & 1995 and 1998 & $\begin{array}{l}\text { Channel incises } 0 \text { to } 2.6 \mathrm{ft} \text { deep for sites less than } \\
50 \mathrm{ft} \text { upstream of beaver dams as a result of dam } \\
\text { failures. }\end{array}$ & 1 to 3 years & Fouty 2003 \\
\hline Obion River, TN & Post 1960s & $\begin{array}{l}\text { Channel has undergone headward migration } \\
\text { of knickpoints as much as } 0.62 \mathrm{miles} / \mathrm{yr} \text { and } \\
\text { channel widening as much as } 3.28 \mathrm{ft} / \mathrm{yr} \text { due to } \\
\text { channelization of the river by U.S. Army Corps of } \\
\text { Engineers in the } 1960 \mathrm{~s} \text {. }\end{array}$ & 1 year & $\begin{array}{l}\text { Shankman and } \\
\text { Pugh } 1992\end{array}$ \\
\hline
\end{tabular}


change further accelerates where land uses increase runoff rates, decrease infiltration rates, surface roughness, and stream-bank vegetation, and damage soil structure. A self-enhancing feedback loop is triggered as increased runoff and loss of bank stability and floodplain roughness facilitate channel enlargement during high flows furthering a lowering of the water table and a shift to more drought tolerant, less densely rooted vegetation. This change to more drought-tolerant species in turn sets another feedback loop in motion by decreasing the water-holding capability of the soil as below-ground root biomass declines (Fitch et al. 2003). In the examples presented in table 4, major changes occurred between 4 to less than 50 years, the time frames constrained by the next observation.

The conceptual model represented by figures 19 and 20 is the backdrop for the remaining sections that explore why beaver trapping as a regional EA disturbance, and beavers as a major component of stream systems, were missed by early researchers and remained absent from the discipline of fluvial geomorphology until recently. This chapter concludes with a discussion of how adding beavers and EA beaver trapping back into the story of EA disturbances changes the discipline of fluvial geomorphology and current stream restoration efforts.

Table 4-Examples of the speed and character of vegetation changes as a result of channel incision. Unless beaver trapping or area abandonment is explicitly mentioned, the cause of the incision is Euro-American settlement activities (source: Fouty 2003.)

\begin{tabular}{|c|c|c|c|c|}
\hline Location & $\begin{array}{c}\text { Time } \\
\text { interval }\end{array}$ & Vegetation change & Total time & Source \\
\hline $\begin{array}{l}\text { Santa Cruz } \\
\text { River near } \\
\text { Tucson }\end{array}$ & $\begin{array}{l}1880 \text { to } \\
1928\end{array}$ & $\begin{array}{l}\text { From area covered by sacaton grass with groves of mesquite and } \\
\text { swampy areas of tule (bulrushes) prior to } 1880 \text { to dense mesquite } \\
\text { forest by } 1928 \text {. Arroyo forms in } 1880 \text {. }\end{array}$ & $\begin{array}{l}\text { Less than } 48 \\
\text { years }\end{array}$ & $\begin{array}{l}\text { Bryan } \\
1928 b\end{array}$ \\
\hline $\begin{array}{l}\text { Sonoita River } \\
\text { of Sonora }\end{array}$ & $\begin{array}{l}\text { pre-Aug 6, } \\
1891, \text { to } \\
1928\end{array}$ & $\begin{array}{l}\text { From swampy area prior to August } 6,1891 \text {, to a dense mesquite } \\
\text { forest by } 1928 \text {. Arroyo forms in August } 6,1891 \text {. }\end{array}$ & $\begin{array}{l}\text { Less than } 37 \\
\text { years }\end{array}$ & $\begin{array}{l}\text { Bryan } \\
1928 b\end{array}$ \\
\hline $\begin{array}{l}\text { Yancy } \\
\text { Meadows, } \\
\text { Yellowstone } \\
\text { NP }\end{array}$ & $\begin{array}{l}1903 \text { or } \\
1904 \text { to } \\
1921\end{array}$ & $\begin{array}{l}\text { Beavers began to desert area in } 1903 \text { or } 1904 \text {. By } 1912 \text { the colony } \\
\text { was abandoned. Changes from ponds to well-formed meadows } \\
\text { to solid ground by } 1921 \text { with little evidence of the earlier beaver } \\
\text { ponds. }\end{array}$ & $\begin{array}{l}17 \text { or } 18 \\
\text { years }\end{array}$ & $\begin{array}{l}\text { Warren } \\
1926\end{array}$ \\
\hline $\begin{array}{l}\text { Crane Creek, } \\
\text { OR }\end{array}$ & $\begin{array}{l}1925 \text { to } \\
1936\end{array}$ & $\begin{array}{l}\text { Beavers trapped out in } 1924 \text {. Channel incises in } 1925 \text { and } \\
\text { vegetation changes from meadows of "stirrup-high native" grasses } \\
\text { subirrigated by beaver ponds to meadows nearly gone, with } \\
\text { clumps of new sagebrush and sparse remnants of the original } \\
\text { grasses by } 1936 .\end{array}$ & 11 years & $\begin{array}{c}\text { Schaffer } \\
1941\end{array}$ \\
\hline $\begin{array}{l}\text { Near Little } \\
\text { Summit } \\
\text { Ranger } \\
\text { Station area, } \\
\text { OR }\end{array}$ & $\begin{array}{l}1925 \text { to } \\
1929\end{array}$ & $\begin{array}{l}\text { Area was formerly full of beavers, but the last appear trapped out } \\
\text { by } 1925 \text {. "From that date to } 1929 \text { ( } 4 \text { years) the old ditch and the } \\
\text { entire meadow were fast becoming a dust bed. During } 1928 \text { and } \\
1929 \text { no water ran out at the lower end of the station" }\end{array}$ & 4 years & $\begin{array}{c}\text { Bailey } \\
1936\end{array}$ \\
\hline $\begin{array}{l}\text { Mountain } \\
\text { Meadows, } \\
\text { southern UT }\end{array}$ & $\begin{array}{l}1884 \text { to } \\
\text { sometime } \\
\text { prior to } 1900\end{array}$ & $\begin{array}{l}\text { Channel incises into what was once a wet meadow during a series } \\
\text { of storms and continues to widen since } 1884 \text {. Gullies fingering } \\
\text { out to nearly all parts of meadow. Shift in vegetation from a wet } \\
\text { wiregrass meadow surrounded by numerous springs and a dry } \\
\text { grass meadow as meadows drain to desert shrub. }\end{array}$ & $<16$ years & $\begin{array}{c}\begin{array}{c}\text { Cottam } \\
\text { and } \\
\text { Stewart } \\
1940\end{array}\end{array}$ \\
\hline
\end{tabular}




\section{The Geographies of Euro-American Beaver Trapping, General Land Office Surveys, and Early Expeditions}

Euro-American (EA) beaver trapping was temporally and spatially concentrated. It began in the 1600s on the East Coast and along the Mississippi and Missouri Rivers, in the early 1700s on the West Coast, and into the Interior United States in the late 1700s and early 1800s (Phillips 1961). The arrival of trappers in an area predated most settlement and scientific and military surveys by at least several decades, with a few exceptions. One exception is the East Coast where settlement and trapping co-existed in time (Cronon 1983) and numerous writings exist from the 1600s and 1700s on the local natural history of those areas (Meisel 1924). Other exceptions are the Lewis and Clark (1804 to 1806), Long (1819 to 1820), and Pike (1805 to 1807) expeditions in the West (Phillips 1961). These written observations, combined with later trappers' journals and records from fur companies, reveal complex, multi-channeled rivers abundant with beavers and beaver dams.

Yet, it was not these early records but those of the later GLO surveys and scientific and military expeditions that have been used to reconstruct the geomorphic and ecological characteristics of watersheds prior to settlement. Embedded in this reliance on the GLO notes for pre-settlement conditions has been an unspoken assumption that "the public land surveys were carried forward in virgin territory - unexplored and unmapped-in advance of settlement" (Clements 1985). However, regardless of the area examined, changes to the drainage network were well underway by the time the GLO surveys and various expeditions arrived, with the degree of change observed influenced by the number and type of EA disturbances that had occurred post-trapping.

The GLO surveys began in 1785 with the passage of the Land Ordinance. The first survey took place in Ohio in 1785 with subsequent surveys proceeding westward in response to pending EA settlement (Clements 1985; White 1996). It was a formalized gathering and storing of information. However, even by 1785 the area east of the Missouri and lower Mississippi Rivers had already been heavily trapped (Phillips 1961). In the New England landscape, beavers had ceased to be a dominant feature as early as the late 1600s (Cronon 1983). By the late 1700s to early to mid-1800s the beaver dams had been replaced by thousands of water-powered mill dams in New England and the Mid-Atlantic States. The mill dams trapped sediments eroding off the valley and hillslope in response to agriculture and logging, burying the beaver-created wetlands (Walter and Merritts 2008). In the Southwest and Intermountain West, trapping and the GLO surveys were more coincident in time but still separated by a decade or more (table 5). Some early researchers in the West acknowledge the occurrence of beaver trapping in their study areas and its implications (Dobyns 1981; Gregory 1917; Gregory and Moore 1931; Hendrickson and Minckley 1984; Leopold 1951), but the loss of beavers as a regional disturbance with major geomorphic and hydrologic significance was missed.

The temporal differences between when trapping occurred versus the GLO surveys and early expeditions was compounded by differences in their spatial geographies. Trappers followed streams in their search for beavers. In contrast, the GLO surveys recorded information about the land and its resources along linear grid lines spaced 
Table 5-Estimated timing of beaver trapping, observations of discontinuous arroyos and incised tributaries, and baseline GLO survey (Source: Fouty 2003.)

Site: San Pedro River, AZ

Dates trapped: 1826-1827 (Pattie 1831)

Pattie and his party trap the river in March 1826 and take 200 beavers. They trap the river again in October 1827. No numbers given for the second time.

Next observation: Military expeditions: 1846, 1852, 1859 (Leopold 1951).

1846 - Description of vegetation patterns in area (Johnston 1847).

1852 near Pomerene: The stream banks not less than 8 to 10 feet high (Bartlett 1854).

1859 - There is a discontinuous gully near Pomerene. The river has a "width of about twelve feet and a depth of twelve inches [water depth], flowing between clay banks ten or twelve feet deep, but below it widens out and from beaver dams and other obstructions overflows a large extent of bottom land, forming marshes densely timbered with cottonwood and ash Hutton (1859)."

Estimated time between trapping and next observation: 19 to 20 years.

Baseline GLO surveys: 1851, 1865, 1867 (White 1996).

Site: Diablo Range, CA about 10.6 to 15.5 miles west of the San Joaquin River (Bull 1964)

Dates trapped: 1829 to 1843 (Phillips 1961).

Hudson's Bay Company trapped in California beginning in 1829 until 1843, returning "every year to trap the Sacramento-San Joaquin River systems and the area around the San Francisco Bay (p. 544)." The company took from the Bay area alone 10,860 beaver between 1830 and 1839.

Next observation: GLO surveys in early 1850s (Bull 1964).

GLO surveyors noted the existence of "traces of older gullies on some of [alluvial] fans indicate that entrenched channels existed before sheep were brought into California in 1853 and before large-scale cattle ranching was introduced in western Fresno County."

Estimated time between trapping and next observation: 9 to 25 years

Baseline GLO surveys: 1852 to 1854 (Cooke and Reeves 1976).

\section{Site: Rio Puerco, NM, a tributary to the Rio Grande (Bryan 1928a)}

Dates trapped: 1823 to about 1838 (Weber 1971).

"In 1823, however the fur trade from New Mexico had scarcely begun....most trappers certainly centered their operations on the virgin streams of the Pecos and Rio Grande valleys. The beaver supply in this convenient area was already being depleted" and by 1824 trappers were heading west. In 1827 American fur trappers were floating down the Rio Grande trapping as they went. 1832 to 1838 trapping occurs around the settlements along the Rio Grande valley.

Next observation: Military expedition 1846 to 1847, 1849 (Bryan 1928a).

Abert (1847): banks were 10 or 12 feet high and vertical at a point west of Albuquerque. Banks were 30 feet further upstream near a ruined town. Simpson (1849): channel was 100 feet wide, contained stagnant pools of water; banks were 20 to 30 feet high about 5 miles above Cabezon (small village on the river). Late 1880s: many settlers testify that in many places the river had no banks or only small ones and in flood the river spread out over the entire valley floor.

Estimated time between trapping and next observation: 9 to 23 years

Baseline GLO surveys: 1855 (Bryan 1928a).

\section{Site: Non-specified tributaries in the Colorado River region (Dellenbaugh (1912)}

Dates trapped: 1824 to probably late 1830s (Chittenden 1954; Phillips 1961).

All the major tributaries of the Colorado River were trapped.

Next observation: The Powell expedition of 1871 or 1872 (Gregory and Moore 1931).

"I noted the same characteristics [trenching of stream beds] (and others probably also noted) years ago in places where there were no cattle and never had been".... "I have seen earth-cliffs 30 to 40 feet high with all the characteristics of a rock-cliff erosion" (Dellenbaugh 1912).

Estimated time between trapping and next observation: 33 to 47 years.

Baseline GLO surveys: New Mexico: 1869; Arizona: post-1867; Utah: post 1855; Colorado: post 1880 (White 1996). 
1 mile apart. The GLO surveys focused first on those areas that were about to be settled or were in the process of being settled by Euro-Americans, leaving large portions of each State unsurveyed until later (Clements 1985; White 1996).

An example is the early military expeditions into Arizona and New Mexico. They entered the Gila River drainage from southern New Mexico via the Lordsburg Plain (Leopold 1951) making their observations of pre-settlement channel incision restricted to the middle and lower Gila River Basin (e.g., San Pedro River, the Santa Cruz River). The upper tributaries (e.g., San Francisco River, East and West Forks of the Gila River) were bypassed and changes unrecorded. Yet references to discontinuous arroyos ending at wetlands on the San Pedro River in 1846 (Cooke and Reeves 1976; Hastings and Turner 1965) suggest that these features would have existed in the upper watershed as well because the entire basin had been trapped between 1826 and 1834 (Pattie 1831; Weber 1971).

I am familiar with the upper Gila watershed, having collected stream data on several of its tributaries in the 1990s. These tributaries contain the appropriate valley characteristics for beaver dam complexes and beavers and I observed beaver sign on the East Fork of the Gila in 1993, 1994, and 1995. Therefore, had the GLO surveyors and early military and scientific expeditions explored the upper watershed, they likely would have observed areas where abundant beaver dam complexes and their relationship to wet meadows persisted. These observations would have led future researchers to ask different questions and come to different conclusions about the causal mechanisms leading to arroyo development.

The limited and selective exploration of the Southwest prior to EA settlement is an example of what Graf (1984) referred to as a "spatial bias." He saw this bias as "a major hazard in geomorphic theory development because of the relatively small size of the geomorphic research community." The limited number of researchers means that "individual scientists can affect the development of theory with relatively few publications, and therefore the field origins [emphasis added] of those few publications [or observations] assume disproportionate importance" (Graf 1984). This is what happened in the case of the spatially limited but high quality GLO surveys and early expedition records in these areas post-trapping. The fragmented but still visible influence of a once-abundant beaver population and the impact of recent trapping on drainage stability appeared localized. Thus their significance at a regional scale was missed by later researchers who would utilize these records.

\section{Arroyo Formation in the Southwest and Intermountain West}

\section{The Role of Beaver Trapping}

The presence of pre-historic arroyos and pre-EA settlement arroyos in the Southwest and Intermountain West (Balling and Wells 1990; Love 1979) has been central to the question about whether EA livestock grazing, climate change, randomfrequency events, or some combination was the dominant causal mechanism that led to widespread arroyo development after EA settlement (Cooke and Reeves 1976). Their presence led some early researchers to suggest that climate was the dominant causal mechanism and EA livestock grazing merely a "trigger pull which timed a change about 
to take place" (Bryan 1928a). This perspective suggested that streams in these regions were inherently sensitive to climatic variability.

The GLO surveys and early expeditions recorded two categories of features: one indicative of a stable fluvial system (wetlands, wet meadows), the other indicative of a destabilized fluvial system (discontinuous arroyos, actively incising tributaries), often within the same drainage (Cooke and Reeves 1976; Hastings and Turner 1965; Hendrickson and Minckley 1984). The active nature of the channel incision suggested that the destabilization had been fairly recent. Determining whether a long-term beaver presence followed by trapping could explain this mix of observations, a direct relationship between EA trapping and arroyo formation was considered supported if (1) trapping occurred in the area, (2) the time interval between trapping and the next observation (i.e., 15 years) was longer than the time needed for substantial channel incision to occur (i.e., $<10$ years), and (3) the magnitude of the observed channelization could have occurred within the intervening time (Fouty 2003). In this case, beaver dam failures and non-repair would explain the channelization observed. When the interval between trapping and the next observation was shorter than 10 years, this suggested that large precipitation events and localized dam failures may have interacted synergistically to enhance large floods, thereby accelerating the rate of dam failures and channel incision. A literature review found that the features observed by the surveys and expeditions in the Southwest and Intermountain West occurred either in areas directly mentioned as being trapped or in the general area. The temporal separation between trapping and the next observations of stream conditions and site characteristics was 9 to 47 years (table 5).

The widespread and rapid removal of beavers throughout these areas led to the development of multiple base-level drops within individual drainages as dams failed and were not repaired. The impact of multiple base-level drops on channel development and drainage network expansion would have been amplified by the period of above-average precipitation from 1835 to 1849 observed in the tree-ring data (D'Arrigo and Jacoby 1991; Meko 1990; Meko et al. 1991). This period occurs shortly after trapping ceased in these areas but before the GLO surveys and early expeditions arrived. A second period of above-average winter precipitation, also identified in the tree-ring data, occurred from 1905 to 1920, or 1928 depending on the tree-ring chronology (D'Arrigo and Jacoby 1991; Meko 1990). This second wet period post-dated not only beaver trapping but settlement, widespread livestock grazing, and other land use activities. It is this second period of above-average precipitation that contributed to the large floods that widened and incised many streams in the West (Burkham 1972; Cooke and Reeves 1976), leading to a further expansion of the channelized network.

The early researchers who sought a causal mechanism to explain the pre- and post-settlement arroyos and changes in watershed hydrology did not understand the significance of the remnant populations of beaver and their scattered dams. Nor were they aware of the period of above-average precipitation that had occurred from 1835 to 1849. When impacts of the two events are combined, a different, more complex causal mechanism for the observations recorded by the GLO surveys and early expeditions and the later increase in flood frequencies and magnitudes appears. The causal mechanisms expand to include a long-term beaver presence followed by beaver trapping followed by above-average precipitation. These series of events explain not only the discontinuous 
arroyos and actively incising tributaries, but the occurrence of drainages in which the arroyos terminated at the base of a wetland.

A long-term beaver presence as an explanation for the wetlands (or cienégas) found in the Southwest is supported by Hendrickson and Minckley (1984). They found that mid-elevation wetlands characterized by permanently saturated, highly organic reducing soils occurred where (1) groundwater intersected the surface, (2) discharges were stable, and (3) flood peaks were low, minimizing the potential for scouring flows and channel incision. The features they identified causing groundwater to intersect the surface included upfaulted bedrock, changes in base level of the receiving stream, stream impoundments by landslides, and the development of a convex-concave profile. In their discussion of the convex-concave profile, they identified two mechanisms leading to its development: the deposition of coarse sediments and the placement of beaver dams along the stream. However, the influence of beaver dams extends beyond the profile. Similar to landslides, though on a smaller scale, beaver dams impound streams, provide local base-level control, and raise the base level of the channel by reducing ACC as they pond water and trap sediment. Though not as stable as bedrock, as long as beavers are present in the system to repair the dams, the dams will operate as a "continuously renewed, erosionally resistant substrate" (Parker et al. 1985).

The long-term presence of beaver dam complexes also creates stable wetlands. These wetlands are highly resistant to climatic variability and disturbance (Ives 1942; Naiman et al. 1986, 1988), and can have long residence times on the landscape when undisturbed (Hendrickson and Minckley 1984; Ives 1942; Naiman et al. 1988; Warren 1926). The dam complexes provide the two other requirements identified by Hendrickson and Minckley for wetland development (low flood peaks and stable discharge). Large ponds and wetlands in headwater streams have been observed to effectively dampen the effects of both large runoff events and prolonged drought (Grasse and Putman 1956; Hillman 1998; Hood and Bayley 2008). Beaver dams decrease flood peaks by storing water in the ponds and reducing ACC such that during high-flow events there is rapid access to the valley floor where potential flood storage and roughness are greater. In turn, the increased frequency of valley-floor flooding leads to higher water tables that stabilize base flows, minimizing the impacts of drought.

Once trapping occurred, the dams were no longer maintained and they ceased to act as "continuously renewed, erosionally resistant substrate" akin to bedrock. Instead they became points of base-level drop and knickpoint initiation. However, the greater resistance of wetlands to incision, compared to the dam sediments, would have effectively halted the headward migration of a knickpoint generated by a base-level drop downstream. The result was the development of the observed discontinuous channels interspersed with wetlands. It is possible that these drainages may have remained a mix of channels, ponds and wetlands without further EA disturbances. The wetlands and lush grasses and willows along channels would have maintained channel and stream bank stability and thus kept channels narrow, the stream-valley floor hydrologic connection high, and downstream flood peaks dampened.

Other areas within the West showed patterns and sequencing of change similar to that found in the Southwest. An example is the work done by Buckley (1992) on Camp Creek, a tributary to the Crooked River, and located in central Oregon. He found that the area had been trapped between 1824 and 1830 by Peter Skeen Ogden and his party 
and his journals reference plentiful beavers, willows, and aspen (Buckley 1992). Later records from military expeditions between 1858 and 1864 note lush grasses, willows, swampy areas, and abundant beavers and beaver dams along Camp Creek. By 1876, references to beavers are absent in the GLO notes, though they still mentioned the presence of large swampy areas along Camp Creek and narrow channel widths (10 to $33 \mathrm{ft}$ ). However, the GLO notes also mention that several homesteaders had been living along Camp Creek and its tributaries since 1871, which may account for the lack of beavers. Livestock were in the area by 1876 with numbers increasing into the early 1900s. By 1905 Camp Creek had incised $25 \mathrm{ft}$ and widths had increased to 60 to $100 \mathrm{ft}$ wide (Buckley 1992).

Not all areas had wetlands mixed with arroyos and incising tributaries. Places where the GLO notes or early expeditions mention arroyos but not wetlands include the Colorado Plateau (Dellenbaugh 1912), the Zuni River in Arizona (Balling and Wells 1990), the Rio Puerco in New Mexico (Bryan 1928a), and the Diablo Mountains in California (Bull 1964). F.S. Dellenbaugh, a topographer on the Powell expedition of the Colorado River area in the 1870s (Gregory and Moore 1931), mentioned seeing earth-cliffs bordering unnamed tributaries in this area in the 1870s that were 30 to $40 \mathrm{ft}$ high. He observed these in areas where EA livestock grazing had not yet reached. He suggested that the tributaries were responding to a drop in base level on the main stem that had occurred for some unknown reason (Dellenbaugh 1912). The Colorado Plateau had been trapped in the 1820 s and perhaps as late as the $1840 \mathrm{~s}$ (Phillips 1961). Dellenbaugh's observations in the 1870s (30 years later) would be consistent with beaver-dam failures on tributary streams triggering multiple points of base-level lowering. It is possible that wetlands were present, but not observed. It is also possible that topography, the presence of Native Peoples and their villages, or both, eliminated wetlands prior to the next EA observation.

\section{The Role of Native Peoples}

The influence of Native Peoples on arroyo development and the presence or absence of wetlands cannot be ignored. The difference between the impacts of beavers and beaver trapping versus Native Peoples' efforts may simply be one of aerial extent. Native Peoples would have influenced the areas around their villages creating localized changes (Dobyns 1981) while beavers would have had a wider distribution. Reagan (1924) observed that "every side-wash, canyon and flat had its village or villages, its dams, ditches and reservoirs, as is readily seen by examining the region." He argued that irrigation systems and check dams built by Native Peoples were responsible for the development of ponds, wetlands, and aggrading surfaces. Reagan's (1924) descriptions of height, composition and locations of the check dams are similar to beaver dams. The check dams were composed of earth, about $5 \mathrm{ft}$ tall and, like beaver dams, would have required constant maintenance. Dobyns (1981) also supported the hypothesis that Native Peoples played a large role in reducing erosion via their check dams. He felt that their reduction in numbers due to contact with EA diseases and conflicts would have led to decreased dam maintenance and renewed erosion as the dams failed. The changes in the drainage network and hydrology would have been similar to those that occurred due 
to widespread beaver dam failures. Some of the dams attributed to Native Peoples may thus have been beaver dams given their wide distribution prior to EA trapping.

The Zuni River, located in Arizona and a tributary to the Little Colorado River, provides possible insight into this question of Native Peoples' influence because documentation exists of arroyos that pre-date both Spanish and EA activity. These early arroyos date from about 1680. Tree-ring dates indicate that the Zuni River had eroded to its present level by 1776 when Fray Dominguez observed an arroyo adjacent to the Zuni Pueblo as well as arroyos upstream of the pueblo (Balling and Wells 1990). Balling and Wells (1990) used modern precipitation records (1897 to 1985) and post-settlement arroyo development to analyze potential causes of early arroyo formation. They suggested links between arroyo formation and changes in local precipitation patterns, particularly precipitation intensities. However, these very early arroyos were in the vicinity of a pueblo, complicating the direct link to precipitation. The Native Peoples may have deliberately or unintentionally altered some feature of the landscape that caused arroyos to form, such as the digging of an irrigation trench, failure of a check dam, or removing beavers from an area. Grazing by Native Peoples' sheep and horses, which had arrived with the Spanish (Love 1916), may have also contributed to arroyo formation by reducing upland vegetation around the pueblo. References from the 1847, 1849, and 1852 expeditions into this area and elsewhere in eastern Arizona mention the presence of numerous Indian horses and sheep and areas with limited forage for their mules (Leopold 1951). The link between arroyo expansion in the Zuni River area and EA beaver trapping after 1849 is clearer because the timing of trapping in the area and the period of above-average precipitation (1835 to 1849) are known.

The Little Colorado River Basin where the Zuni River occurs was trapped for beavers in the 1820s and 1830s (Gregory and Moore 1931; Phillips 1961). Leopold (1951) cites references to the presence of beaver lodges in 1852 on the Little Colorado River

slightly upstream from the town of Holbrook. This would place the lodges roughly 36 linear miles downstream of the confluence of the Zuni River and the Little Colorado River. In addition, the 1852 expedition observed in one place on the Zuni River below the village of Zuni (now a dry wash) "a few populars... and near these trees was a beaver-dam" (Leopold 1951). While the observation of populars [poplars] and beaver dams in this area may have been a rare sight in 1852, it indicates that beaver were present in the area. Their loss would have made streams more susceptible to channelization during the wet period that followed their removal especially in those areas where vegetation had been altered by Native Peoples' livestock or agriculture. Beaver dam failures likely combined with human check dam failures, their similar appearance and function triggering similar effects. The lack of references to wetlands in the area around the Zuni Pueblo by the early military expeditions suggests that the long-term presence of Native People may have already modified conditions such that wetlands had been lost in response to earlier activities.

\section{Reexamining Changes on the Gila River in Light of Beaver Trapping}

This analysis of changes on the Gila River builds on an earlier study by Burkham (1972) in which he assessed the likely causes of the channel widening between 1905 and 1917 on the Gila where it flowed through the Safford Valley of Arizona. This river 
basin, in southwestern New Mexico and southeastern Arizona, is a watershed scale example of how interpretations of causal mechanisms of change can vary once placed in a historical context that includes beaver trapping and more climate information.

The drainage area contributing to the Gila where it flows through the Safford Valley is about 7,900 miles $^{2}$. In 1875 , the average channel width was less than $150 \mathrm{ft}$. Between 1905 and 1917 the average width increased to about 2,000 ft during several large magnitude winter floods (Burkham 1972). The bulk of the widening occurred in 1905 and 1906 and the source of the large floods was the mountainous headwaters of the Gila River. Examination of stream discharge and precipitation data available after 1910 shows a strong correlation between large magnitude floods in the Gila River and rainon-snow events or high-intensity, long-duration storm events (Burkham 1970). Based on this correlation, Burkham (1972) concluded that the large flood magnitudes in 1905 and 1906 were the result of precipitation events in the headwaters. His conclusions relied on the tree-ring data of Stockton and Fritts (1968) for Arizona, which identified 1907-1926 as the wettest 20-year period since 1650 .

Burkham (1972) also considered whether livestock grazing, rather than precipitation, could have been responsible for the large magnitude floods that occurred between 1905 and 1917. He concluded that livestock grazing was not a factor based on his understanding that livestock appeared to be largely restricted to the lower watershed while the floodwaters had their source in the upper watershed. However, livestock grazing had occurred in the upper watershed. Swift (1926) noted livestock grazing on Bonita Creek, a tributary to the Gila River upstream of the Safford Valley, as early as 1884 . Winn (1926) noted livestock grazing on the West Fork of the Gila River in the 1880s. A 1993 environmental impact statement for a cattle allotment on the East Fork of the Gila River stated that the area was severely overgrazed by 1908 (USDA Forest Service 1993). The reference to overgrazing indicates that livestock were using the East Fork drainage prior to 1908. There is no reason to assume that the West Fork of the Gila and Bonita Creek would have been grazed in the 1880s while the East Fork of the Gila, San Francisco River, and other tributaries would have been ignored by early livestock owners.

In this arid landscape, the impact of livestock in the tributaries would have been high around the streams. Hendrickson and Minckley (1984) concluded that grazing in the 1880 s would have been concentrated within a 3-mile radius of streams because livestock rarely travel more than 3 miles from a water source and only lightly graze areas greater than 1.8 miles from water. The result would be concentrated use along the tributary stream corridors accelerating the rate at which riparian vegetation and bank resistance to erosion decreased. Livestock grazing in the upper watershed would have also decreased upland vegetation, decreasing surface roughness. The reduced roughness and resistance to erosion would have resulted in gully development in the uplands, thus facilitating the increase in storm runoff reaching the stream channels. The changes that occurred in Mountain Meadows, Utah, in 1884 is an example of this gully development and captures the speed at which it could occur (Cottam and Stewart 1940, table 3).

Increases in runoff leading to elevated streamflows would have enhanced and accelerated changes triggered by the earlier beaver trapping. The Verde, Salt, San Pedro, San Francisco Rivers (tributaries to the Gila), as well as the Gila itself are all mentioned by name as being trapped between 1826 and 1834 (Pattie 1831; Weber 1971). While not specifically mentioned, the smaller tributaries would have also been trapped as trappers 
systematically moved through the area. Thus, EA livestock grazing in the Gila River basin becomes the second, not first, large-scale regional disturbance in the area.

While Burkham (1972) focused on the 20-year period from 1907 to 1926 identified in Stockton and Fritts (1968), they also examined 10-year intervals. In this interval set, 1831 to 1840 showed up as having a relatively high probability of above normal precipitation. This time interval is close to the 1835-1849 interval identified by later researchers (D’Arrigo and Jacoby 1991; Meko 1990; Meko et al. 1991), both intervals post-dating intensive trapping. Thus, effects of beaver trapping (1826-1834), followed by a wet period (1831-1840 or 1835-1849), and then by intensive grazing in the upper watershed (early 1880s) would have interacted synergistically to accelerate drainage network development in the headwaters. The result would be more rapid transfer of water from the upper to the lower watershed, increasing flood frequencies, and amplifying flood magnitudes for precipitation events of all sizes.

The above scenario of a watershed that had recently undergone changes of such a nature that it was now responding to precipitation events differently is supported by the oral history of the Gila River Pima Indians and historical newspaper accounts that predate the 1910 installation of stream gages in the watershed. Floods occurred in 1833, 1869, 1880, 1884, 1889, 1891, 1895, and 1896 (Dobyns 1981; Burkham 1970). The floods of 1833, 1895, and 1896 are of particular interest. The 1833 flood was the first major downstream flood recorded in Gila River Pima Indian oral history (Dobyns 1981). Since trapping had been ongoing in the upper watershed since 1826 and mostly done by 1831 (Pattie 1831), Dobyns (1981) suggests that this flood may have been the result of the abrupt collapse of beaver dams destroyed in the preceding decade. This scenario is reasonable given that large discharges have been documented occurring in response to abrupt dam failures (Butler 1989; Hillman 1998) and the tree-ring data that recorded a period of above-average precipitation around that time (1830-1841 or 1835-1849). The floods of 1895 and 1896 were unusual because they occurred during the Southwest's third most severe drought in the last 1,000 years (D'Arrigo and Jacoby 1990). These floods are a strong indication that the drainages in the upper watershed had changed.

The timing of the GLO surveys and early expeditions and their spatial geographies influenced the direction that future researchers went as they sought to explain arroyo formation and large magnitude flood events post-EA settlement. When the surveys and expeditions arrived in the Southwest in the 1850s, beavers had somewhat recovered from near extinction. There would have been little awareness of how much their numbers have been reduced or of the precipitation events that followed. Beavers were observed on the San Carlos River in 1846 (Leopold 1951), on the Little Colorado River in 1884 (Colton 1937), and on the San Pedro River in 1858 and as late as 1882 (Hastings and Turner 1965).

The 1858 observation on the San Pedro River is of interest because it notes the following spacing of beaver dams:

The San pedro river as they Call it — is a stream one foot deep six ft wide and runs a mile and half an hour and in ten minutes fishing we Could Catch as many fish as we Could use and about every 5 miles is a beaver dam this is a great Country for them (Hastings and Turner 1965). 
Comparing the 1858 dam spacing to the numbers of beavers taken by trappers in 1826 from the San Pedro and to dam spacing found today in basins with relatively unexploited beaver populations makes clear the magnitude of change that had occurred. In 1826, trappers took 200 beavers from the San Pedro River and found beavers so abundant that they named it the Beaver River (Pattie 1831). Examples of average dam frequencies include 17 dams/mile in two drainage basins in Quebec (Naiman et al. 1986), 4 dams/ mile in the Kabetogama Peninsula in Northern Minnesota (Naiman et al. 1988), and up to 6.5 dams/mile in Bridge Creek in eastern Oregon (Demmer and Beschta 2008)—all much greater than the 5 mile per dam spacing noted on the San Pedro River in 1858.

\section{Explaining the Absence of Arroyo Formation From 1750 to 1825 Despite Large Herds of Spanish and Mexican Livestock}

The relative contributions of livestock grazing versus climate as the cause of widespread arroyo formation in the Southwest post-EA settlement has been in question for nearly a century. Part of the reason for the uncertainty is that large livestock herds existed twice in the Southwest (1750-1825 and 1870-1905) but widespread arroyo formation occurred only once, from 1870 to 1905 (Cooke and Reeves 1976; Denevan 1967). Both periods of large herds had below-normal seasonal precipitation. Possible explanations for this discrepancy in landscape response to livestock grazing have included: (1) a gradual, long period of change in climate that altered vegetation to the point that watersheds in the late 1800 s were more sensitive to livestock grazing than in the late 1700 s to early $1800 \mathrm{~s}$;

(2) the combination of overstocking the range and severe summer drought that occurred in the late 1800s but not in the prior period; and (3) some combination of the two (Cooke and Reeves 1976; Denevan 1967). Another explanation involves the change in beaver numbers and distributions between the two periods of intensive grazing.

Beavers were abundant in the late 1700 s and early 1800 s but greatly reduced by the late 1800 s due to EA trapping in the 1820s and 1830s. Therefore, Spanish and Mexican herds would have grazed on landscapes that pre-date EA beaver trapping while the EA livestock herds grazed on landscapes that post-date trapping. The presence of abundant beavers during the time of Spanish and Mexican livestock grazing would have minimized any impacts that reduced upland vegetation had on runoff and potential flood magnitudes. Beaver-created wetlands and ponds would have provided stability to the fluvial systems during periods of drought and heavy rainfall (Bailey 1936; Grasse and Putman 1950; Hendrickson and Minckley 1984; Hillman 1998; Hood and Bayley 2008; Johnston and Naiman 1990). Despite the heavy sheep and cattle grazing, the dams would have kept ACC low, causing the additional water to be distributed onto the valley floor where its erosive power was less. When dam failures did occur, they would have been repaired or only localized, preventing the development of permanent arroyos or a channelized drainage network. In addition, use of the upper watershed for livestock grazing was likely much more limited during the earlier period than after the EA heads arrived (Love 1916).

When the large EA livestock herds arrived in the 1870s and began moving into the headwaters (Love 1916), the buffering effect of beavers and intact beaver dams had been gone for 30 to 40 years. The period of above-average precipitation, post-trapping but prior to EA settlement and grazing, would have accelerated dam failures and channel development. While agriculture increased in the lower watershed and other activities such as road 
building and logging contributed to changes on the land, it would be livestock grazing in the upper watershed that made the next large contribution to channel changes because it was the most widely dispersed and use would have been concentrated along the stream corridors. Thus the extensive arroyo development from 1870 to 1905 was the response of an increasingly destabilized system in which one regional EA disturbance (trapping) was overlain by another regional disturbance (grazing), along with other localized EA impacts. As a result, even small climate events were now capable of increasing the channel network (table 3) and flood magnitudes as demonstrated by the frequent pre-1900 floods despite periods of drought.

\section{The Question of Stream Sensitivity to Climate Variability}

Adding beaver trapping into the story with the addition of newer tree-ring data helps answer the question: Are Southwestern streams and riparian zones inherently sensitive to climatic variability? The answer to the question is "no," as long as stabilizing influences, such as abundant beavers and well-vegetated landscapes, are maintained because climatic variability is the norm. Using tree-ring data from northern New Mexico, D'Arrigo and Jacoby (1991) identified five periods of substantial drought and five periods of above-average winter precipitation over the last 1,000 years. Therefore, neither the drought nor the above-average precipitation in the late 1800s and early 1900 s is unique, though the abruptness of the shift from severe sustained drought to above-average precipitation in the early 1900s does not appear to have a match in the tree-ring data (D'Arrigo and Jacoby 1991). Regardless, abundant research supports the ability of beaver ponds and wetlands to mitigate the effects of both drought and abundant precipitation on streamflow and stream systems (Bailey 1936; Beedle 1991; Grasse and Putman 1950; Hey and Philippi 1995; Hillman 1998; Hood and Bayley 2008; Schaffer 1940). Thus, rather than instability and sensitivity to climatic variability being an inherent characteristic of streams in the Southwest and elsewhere, this responsiveness is the result of EA beaver trapping with impacts compounded as subsequent EA disturbances occurred.

\section{From Past to Present: Placing Hydraulic Geometry Relationships in Their Historic Disturbance Context}

The early GLO surveys and expeditions lacked information on numbers and distributions of beavers and the appearance of stream ecosystems pre-trapping. The speed of the changes, the timing, and the spatial geographies of the surveys and early expeditions versus trapping, and the continued presence and perceived abundance of beaver post-EA trapping, gave the impression that the significance of beaver trapping at the watershed and regional scale was minimal. It was into this post-trapping, changing landscape that the field of geomorphology emerged in the 1870s. However, it was not until the 1940s that fieldwork and quantification of field data took hold in the discipline (Morisawa 1985). By then most streams in the lower 48 States had undergone multiple adjustments in channel morphology and hydrology in response to various land uses and climatic events. Evidence of beavers as a defining influence on stream ecosystems had become lost by the late 1700s to early 1800s in the East as other land uses buried beaver-created wetlands beneath feet of sediment (Walter and Merritts 2008). It had become fragmented by the 1850s in the 
Southwest and Intermountain West by the time the GLO surveys and expeditions arrived, and invisible everywhere by the 1940s.

Using the limited tools and information at their disposal, the early geomorphologists developed relationships that continue to define the discipline and influence stream restoration efforts. However, new information and the development of new tools require that the relationships and observations found in early publications - publications covering such topics as hydraulic geometry (Leopold and Maddock 1953), formation of river floodplains (Wolman and Leopold 1957), and channel patterns (Leopold and Wolman 1957) — be reevaluated as to their meaning and appropriateness as guiding principles in stream restoration. Leopold and Maddock's (1953) hydraulic geometry relationships serve as an example of how the interpretation of data and observations change once new information is incorporated into the analysis.

Leopold and Maddock used data from 112 stream gages to develop their hydraulic geometry relationships. They chose data from a diversity of geographic locations (fig. 21a), physiographic and geologic types, and sizes because their intent was to examine channel morphology, stream velocity, suspended sediment loads, and discharge information for general trends. The author found gage installation dates for 104 of their 112 gages (http://water.usgs.gov). Ninety-four percent of these gages were installed after 1900 (fig. $21 \mathrm{~b}$ ) and after two waves of regional, large magnitude EA disturbances (table 6). When their data are placed within this historic disturbance context, it becomes clear that the hydraulic geometry relationships they developed, and the processes and rates of change they observed, reflected highly altered fluvial systems. By the time the gages were installed, the drainages had become interconnected systems of channels, the streams had become entrenched, over-wide, and hydrologically disconnected from their valley floors, and beavers no longer played their once defining role.

The first regional disturbance that influenced all their stream gages was beaver trapping. The second regional disturbance varied depending on location. For the stream gages east of the Mississippi River, the next regional disturbance was the building of thousands of water-powered mill dams. These dams trapped the sediment eroding off hillslopes and valley bottoms due to logging and agriculture. As time went on, the mill dams failed and new channels developed (Walter and Merritts 2008). For the lower Midwest stream gages (Kansas, Nebraska, and Missouri), the next regional disturbance was intensive agriculture in which abundant wetlands and beaver ponds were drained (Hey and Philippi 1995). The magnitude of stream changes in this area was captured by Schumm and Lichty (1963) in their work on the Cimarron River in southern Kansas. The Cimarron River increased in average width from 50 to $1,200 \mathrm{ft}$ between 1874 and 1939 over roughly 175 miles with the variability in magnitude reflecting differences in bank composition and cohesiveness once the stabilizing vegetation had been removed (fig. 22).

Finally, for the Northern Rockies/Rockies stream gages (Montana, North Dakota, South Dakota, and Wyoming), it is livestock grazing that is the next regional disturbance. Leopold and Miller (1954), in their work on alluvial valleys in Wyoming, discuss the amount of channel incision that had occurred in this area. They specifically reference some of the same streams used by Leopold and Maddock (1953) in their hydraulic geometry paper. Thus by the time their stream gages were installed, the drainages conveyed water and sediment very differently than they once had. 
a)

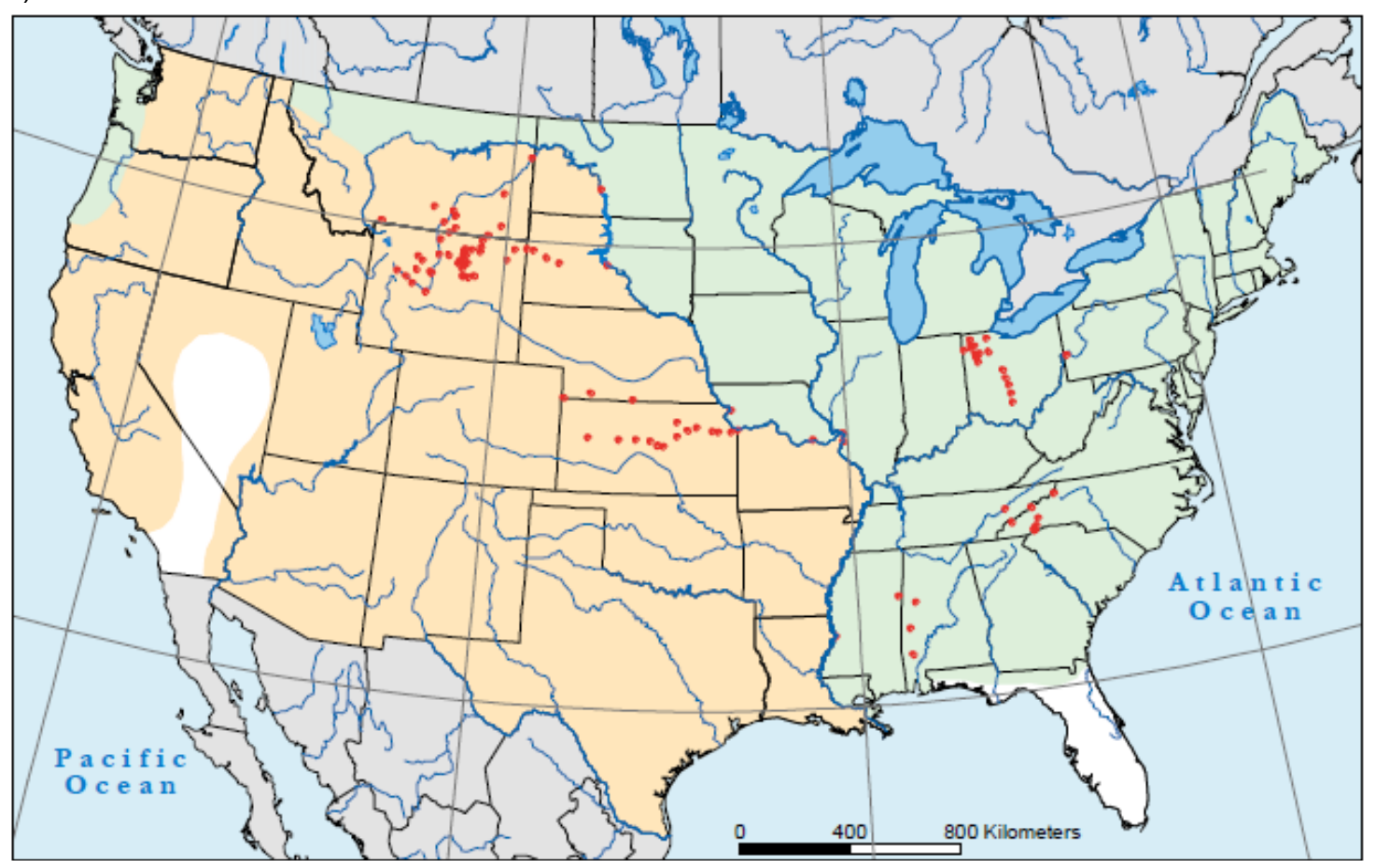

b)

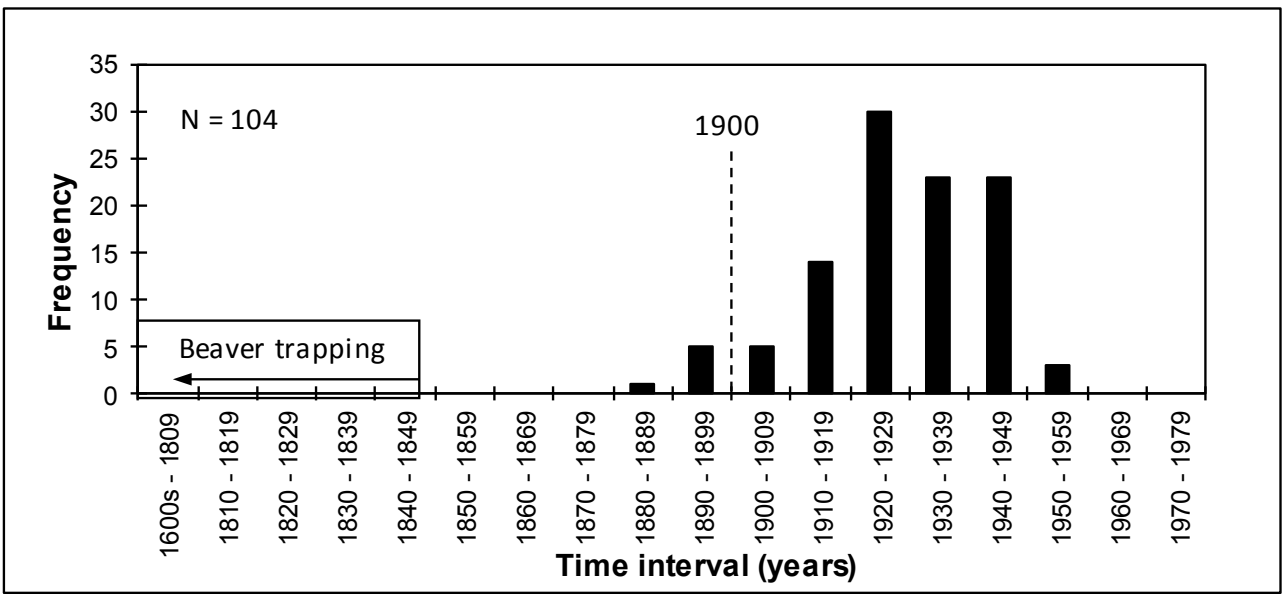

Figure 21-Spatial and temporal distribution of the stream gages used by Leopold and Maddock (1953) and the generalized timing of beaver trapping in the lower 48 States (source: Fouty 2003). (a) Spatial distribution of the stream gages. Gages are represented by the RED dots $(N=104)$, GREEN = beaver trapping from 1600s to 1785 , ORANGE = beaver trapping from 1810 to 1850, WHITE $=$ no known beaver trapping. (b) Installation dates for stream gages (sources: Installation dates U.S. Geological Survey website http://water.usgs.gov. Eight of the gages listed in Leopold and Maddock 1953 were not listed on the website; beaver trapping dates Phillips 1961).

Leopold and Maddock's hydraulic geometry relationships have become one of the guiding principles of fluvial geomorphology. While their relationships have been refined and made more place-specific since 1953, the conceptual model of drainages being interconnected channels remains. The continued use of these and other relationships developed from highly altered stream systems means that restoration efforts end up reinforcing the damage and loss of system resiliency that began with the fur trade in the 1600s. 
Table 6-Relative temporal relationships of Euro-American disturbances and their impact on watershed hydrology and geomorphology (source: Fouty 2003.)

\section{Beaver establish a long-term presence}

Upper watershed: Drainage network pattern a mix of ponds, wetlands and channels. Complex mosaic of riparian vegetation. Stream-valley floor hydrologic connection high and the valley floors frequently flooded. Stream ecosystem has low sensitivity to climatic variability, high resistance to disturbance and recovers rapidly after a disturbance.

Lower watershed: Flood magnitudes and the frequency of large magnitude floods decreases and flood durations increase.

\section{First large-scale Euro-American disturbance: Beaver trapping}

Widespread, temporally concentrated, and systematic removal of beaver from watersheds.

\section{Drainage network transition I}

Upper watershed: Dams fail, ponds drain and stream incises into fine sediments trapped behind the dams. Drainage network shifts to an increasingly channel-dominated network. Stream-valley floor hydrologic connection decreases as channels incise and widen. Wetland and riparian vegetation patterns begin to change in location and abundance in response to localized channelization, dropping water table, decreased valley floor flooding and beaver forage, and exposure of pond sediments. Reaches with intact wetlands continue to have low sensitivity to climatic variability but other areas have increased sensitivity due to channelization. Decreasing resistance to climatic variability and disturbance. Increased channelization in the upper watershed results in more rapid transfer of water from the upper to lower watershed. Drainage network a mix of channelized and nonchannelized reaches.

Lower watershed: Channel morphology may remain unchanged as valley floor and stream bank vegetation still abundant and dams were located on the floodplains and backwater areas. However, complexity of vegetation communities changing as a result of beaver removal. Possible increases in flood peaks and decreases in flood durations due to greater channelization in upper watershed and periodic abrupt dam failures.

Second wave of large-scale Euro-American disturbances (i.e. grazing, agriculture, logging, milldams, ditches)

Upper and lower watershed: Vegetation removed from uplands, valley floor and stream banks. Wetlands drained deliberately or incise due to land use activities. Creation of points of flow convergence (roads, canals). Result is large increases in runoff and decreases the resistance of uplands, valley floors, and stream banks to erosion.

Upper watershed: Channelization expands and discontinuous channels begin to coalesce.

\section{Drainage network transition II}

Upper and lower watershed: Increases in available channel capacity as channels incise and widen. Water routed from upper to lower watershed during a storm event more rapidly. Streams and valley floors hydrologically disconnecting. Frequency of valley floor flooding in upper watershed decreases while the magnitude and frequency of flooding in the lower watershed increases. Stream ecosystem sensitivity to climatic variability increases, resistance to disturbance decreases and recovery rates after a disturbance slower

Current conditions (stream gages install during this period)

Upper and lower watershed: Channel-dominated. Streams and valley floors hydrologically disconnected. Reduced complexity, abundance and extent of the riparian zone. Loss of wetlands. Stream ecosystem sensitivity to climatic variability high, resistance to disturbance low and recovery after disturbance low.

Lower watershed: Increased frequency of higher magnitude floods. 
Figure 22-Changes in channel widths and variability along the Cimarron River in southwestern Kansas between 1874 and 1939. Open circles $=1874$ widths. Solid circles $=1939$ widths (figure generated using data found in Schumm and Lichty 1963).

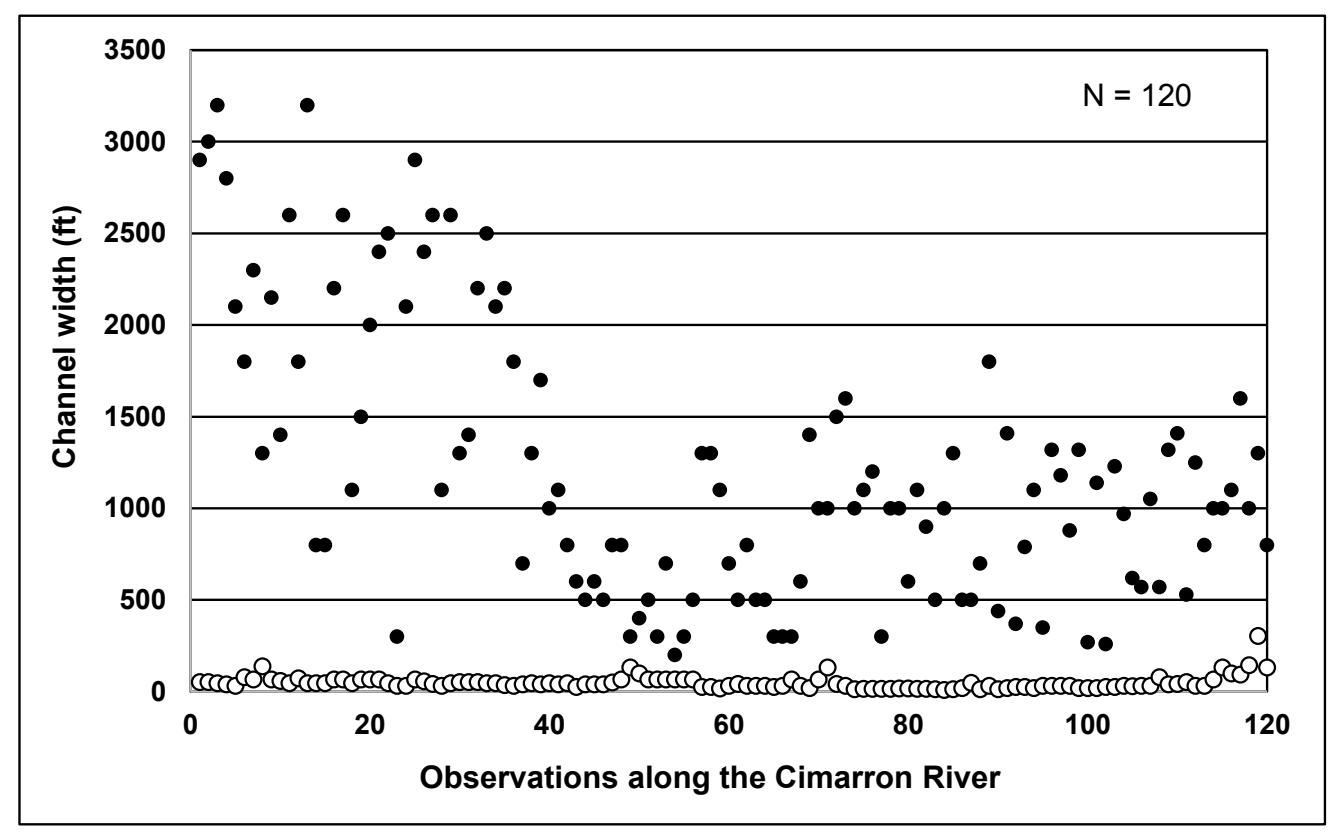

\section{From Present to Future}

Climate change is bringing increased variability. The impacts on wild and human communities are already large and will only increase. As water is essential to all communities, we need to shift our landscapes from "water-sheds" to "water-stores" by allowing the missing parts to return and take up their places and functions on the landscape. Public lands are the ideal place to start beaver-driven stream system restoration. Public lands provide large contiguous areas where beavers can rapidly create vast ecologically complex water storage zones and diverse habitat with limited infrastructure conflicts. Large portions of these lands occur in the headwaters, making them uniquely situated to store water during times of abundance and then release it during times of drought. Because many of the streams are first- through fourth-order streams, they are the appropriate size for beavers and their dam complexes to rapidly restore stream processes and form in these areas.

The challenges inherent in recovering at least some of the stream-valley floor hydrologic connections and the water storage capability of stream systems without beavers become clear when examining the amount of channel incision and/or widening that has occurred (table 3) and volume of stream sediment eroded post-EA trapping. Bryan (1928a) estimated that the Rio Puerco in New Mexico, with a drainage area of roughly $6,220 \mathrm{mi}^{2}$ (USGS stream gage), had lost more than 394,882 acre-ft of sediment over a 42 -year period as a result of channel incision and widening. On a smaller scale, an estimate of 7.2 acre-ft of sediment has been eroded from the 3.4 miles of headwater stream reaches studied by Fouty (2003). These drainages are located in southwest Montana and east-central Arizona and range from 692 to 18,775 acres.

The channelization of drainages across the North American continent resulted in the permanent removal of large volumes of sediment. Therefore, restoration of the stream-valley floor hydrologic connection, and the processes that result from that connection, requires abundant beaver dam complexes with their ponds in order to fill the 
void left by the eroded sediment. Where the amount of erosion prevents recovering the original stream-valley floor hydrologic connection, beaver dam complexes are still required to restore stream processes. However, in these cases these new beaver-dominated systems will be inset into the larger channels as is the case at Bridge Creek in eastern Oregon (Demmer and Beschta 2008; Pollock et al. 2007) and streams near Elko, Nevada (Swanson et al. 2015).

Two key factors prevent beavers from expanding in numbers and distribution. The first is recreational and commercial beaver trapping (Muller-Schwarze and Sun 2003), which removes not only existing beavers but their future progeny. An example of the cumulative effect of trapping on numbers is found in the data collected by Oregon Department of Fish and Wildlife and USDA Wildlife Services for the State of Oregon. The data listed 54,034 beavers reported killed between 2000 and 2015. Of this number, 83 percent $(44,784)$ of the beavers killed were due to hunting and trapping with the vast majority from trapping (about 97 percent).

The second factor is insufficient food and building material due to past and current land uses, with browse pressure on riparian woody vegetation by livestock and wild ungulates being a key contributor on public lands. When livestock are the dominant browser, as was the case for streams near Elko, Nevada, changes in livestock management resulted in rapid improvements in the quality of riparian habitat (Swanson et al. 2015). The expansion of riparian vegetation and the absence of trapping allowed beavers in this area to expand their range such that during an extreme drought in 2012 the rivers with beavers still had water (Fouty, personal observation, July 15, 2012). Where wild ungulates are the browsers, work by Beschta and Ripple $(2009,2010)$ in Yellowstone National Park has shown the role that wolves play in decreasing elk and deer use of riparian areas leading to increased willows, aspen and cottonwoods. Here too beavers have expanded their range in response to improved habitat and no trapping (Smith and Tyers 2008). These studies show that sufficient food and building materials and the absence of trapping are required for beaver populations and their water storage benefits to expand. On public lands where both wild and domestic ungulates graze, changes in livestock management and expansion of wolf populations will be needed to reduce the browse pressure on key beaver food and building materials, along with the elimination of commercial and recreational trapping.

\section{Conclusions}

Separating out cause-and-effect relationships in fluvial systems is challenging because changes to their form and function are the result of many factors interacting over time and space. This chapter explored some of those factors in its examination of how EA beaver trapping altered the appearance and hydrologic behavior of stream systems and why the influence of beavers and beaver trapping were missed in the discipline of fluvial geomorphology until recently. It also examined how information gaps led to the development of relationships of process and form based on observations and measurements of channelized drainages and altered uplands that created conditions whereby water was rapidly shed from the landscape rather than stored and released slowly.

Given the magnitude of the historic changes and their hydrologic consequences, the scale of restoration and the rate at which it must occur is enormous if the impact of 
climate change on water availability, and the systems that depend on water, are to be minimized. Partnering with beavers to restore the water-holding capability of our stream corridors would rapidly dampen fluctuations in the abundance and scarcity of water and leave wild and human communities less vulnerable. Efforts will require broad public support and an integrated approach by State and Federal agencies given their respective areas of influence and impact. Scientists are in a position to help inform the discussions by sharing what we have learned about how past and current land uses affect the ability of the landscape to naturally store water for future use; however, our effectiveness will first require that we change the lens we have been looking through. Because the discipline of fluvial geomorphology has internalized and codified degraded systems as normal, our stream restoration efforts fall short. By placing these fluvial geomorphic relationships within their historic disturbance context, one that includes EA beaver trapping, new strategies, approaches, and partnerships emerge that are essential for restoration to successfully occur. This new lens reveals the essential role beavers play in this recovery process.

\section{Acknowledgments}

My thanks to R. Roy Johnson and Richard W. Reeves for an early review of this paper and to Ken Kingsley for his suggestions and review of figures and tables. Thanks also to Katelyn P. Driscoll, R.H. Hamre, Dale A. Jones, Harley Shaw, and Patty Woodruff for their later reviews of this manuscript that improved it. Finally, a special thanks to Oz, Mariah, and Lily for their field assistance and to R. Roy Johnson (again) for helping to shepherd this manuscript through.

\section{References}

Bailey, V. 1936. The mammal and life zones of Oregon. North American Fauna. 55: 218-222.

Balling, R.C.; Wells, S.G. 1990. Historical rainfall patterns and arroyo activity within the Zuni River drainage basin, New Mexico. Annals of the Association of American Geographers. 80(4): 603-617.

Beedle, D.L. 1991. Physical dimensions and hydrologic effects of beaver ponds on Kuiu Island in southeast Alaska. Thesis. Corvallis, OR: Oregon State University. 94 p.

Bryan, K. 1927. Channel erosion of the Rio Salado, Socorro County, New Mexico. U.S. Geological Survey Bulletin. 790: 17-19.

Bryan, K. 1928a. Historic evidence on changes in the channel of Rio Puerco, a tributary of the Rio Grande in New Mexico. Journal of Geology. 36: 265-282.

Bryan, K. 1928b. Change in plant associations by change in ground water level. Ecology 9: 474-478.

Buckley, G.L. 1992. Desertification of the Camp Creek drainage in central Oregon. Thesis. Eugene, OR: University of Oregon. $136 \mathrm{p}$.

Bull, W.B. 1964. History and causes of channel trenching in western Fresno County, California. American Journal of Science. 262: 249-258.

Burkham, D.E. 1970. Precipitation, streamflow, and major floods at selected sites in the Gila River drainage basin above Coolidge Dam, Arizona. Geological Survey Professional Paper. 655-B. Reston, VA: U.S. Department of the Interior, Geological Survey. 33 p.

Burkham, D.E. 1972. Channel changes of the Gila River in Safford Valley, Arizona 1846-1970. Geological Survey Professional Paper. 655-G. Reston, VA: U.S. Department of the Interior, Geological Survey. 24 p. 
Burns, D.A.; McDonnell, J.J. 1998. Effects of a beaver pond on runoff processes: Comparison of two headwater catchments. Journal of Hydrology 205: 248-264.

Butler, D.R. 1989. The failure of beaver dams and resulting outburst flooding: A geomorphic hazard of the Southeastern piedmont. Geographical Bulletin - Gamma Theta Upsilon. 31(1): 29-38.

Campbell, K.L.; Kumar, S.; Johnson, H.P. 1972. Stream straightening effects on flood-runoff characteristics. American Society of Agricultural Engineering Transactions. 15: 94-98.

Chittenden, H.M. 1954. The American fur trade of the Far West: A history of the pioneer trading posts and early fur companies of the Missouri Valley and the Rocky Mountains and of the overland commerce with Santa Fe. Stanford, CA: Academic Reprints. 1,029 p.

Clements, D.B. 1985. Public land surveys-History and accomplishments. In: Minnick, R. Plotters and patterns of American land surveying: A collection of articles from the archives of the American Congress on Surveying and Mappizng (sic). Rancho Cordova, CA: Landmark Enterprises: 102-108.

Colton, H.S. 1937. Some notes on the original condition of the Little Colorado River: A side light on the problems of erosion. Flagstaff, AZ: Northern Arizona Society of Science and Art, Inc. Museum Notes. 10(6): 17-20.

Cooke, R.U.; Reeves, R.W. 1976. Arroyos and environmental change in the American Southwest. Oxford, UK: Clarendon Press. 226 p.

Cottam, W.P.; Stewart, G. 1940. Plant succession as a result of grazing and of meadow desiccation by erosion since settlement in 1862. Journal of Forestry. 38: 613-626.

Cronon, W. 1983. Changes in the land: Indians, colonists, and the ecology of New England. New York: Hill and Wang. 288 p.

D’Arrigo, R.D.; Jacoby, G.C. 1991. A 1,000-year record of winter precipitation from northwestern New Mexico, USA: A reconstruction from tree-rings and its relation to El Niño and the Southern Oscillation. The Holocene. 1(2): 95-101.

Dellenbaugh, F.S. 1912. Cross cutting and retrograding of stream beds. Science. 35(904): 656-658.

Demmer, R.; Beschta, R.L. 2008. Recent history (1988-2004) of beaver dams along Bridge Creek in Central Oregon. Northwest Science. 83(4): 309-318.

Denevan, W.M. 1967. Livestock numbers in nineteenth-century New Mexico, and the problem of gullying in the Southwest. Annals of the Association of American Geographers. 57(4): 691-703.

Dobyns, H.F. 1981. From fire to flood: Historic human destruction of Sonoran Desert riverine oases. Socorro, NM: Ballena Press. 222 p.

Dunne, T. 1980. Formation and controls of channel networks. Progress in Physical Geography. 4: 211-239.

Dunne, T. 1990. Hydrology, mechanics and geomorphic implications of erosion by subsurface flow. In: Higgens, C.G.; Coates, D.R., eds. Groundwater geomorphology: The role of subsurface water in earth-surface processes and landforms. Special Paper 252. Boulder, CO: Geological Society of America: 1-28.

Dunne, T.; Leopold, L. 1978. Water in environmental planning. New York: W.H. Freeman and Company. 818 p.

Fitch, L.; Adams, B.; O’Shaughnessy, K. 2003. Caring for the green zone: Riparian areas and grazing management. Third edition. Lethbridge, Alberta: Alberta Riparian Habitat Management Society, Cows and Fish Program. 51 p.

Fouty, S.C. 1996. Beaver trapping in the southwest in the early 1800 s as a cause of arroyo formation in the late 1800s and early 1900s (abs.). Geological Society of America Abstracts with Programs, Cordilleran Section Meeting. Boulder, CO: Geological Society of America.

Fouty, S.C. 2003. Current and historic stream channel response to changes in cattle and elk grazing pressure and beaver activity: Southwest Montana and east-central Arizona. Dissertation. Eugene, OR: University of Oregon. 
Graf, W.L. 1984. The geography of American field geomorphology. Professional Geographer. 36(1): 78-82.

Grasse, J.E.; Putman, E.F. 1950. Beaver: Management and ecology in Wyoming. Bulletin 6. Cheyenne, WY: Wyoming Game and Fish Commission. 75 p.

Gregory, H.E. 1917. Geology of the Navajo country: A reconnaissance of parts of Arizona, New Mexico, and Utah. Geological Survey Professional Paper 93. Reston, VA: U.S. Department of the Interior, Geological Survey. $161 \mathrm{p}$.

Gregory, H.E.; Moore, R.C. 1931. The Kaiparowits Region: A geographic and geologic reconnaissance of parts of Utah and Arizona. Geological Survey Professional Paper 164. Reston, VA: U.S. Department of the Interior, Geological Survey. 161 p.

Hastings, J.R.; Turner, R.M. 1965. The changing mile. Tucson: The University of Arizona Press. $317 \mathrm{p}$.

Hendrickson, D.A.; Minckley, W.L. 1984. Cienegas-Vanishing climax communities of the American Southwest. Desert Plants. 6(3): 131-175.

Hey, D.L; Philippi, N.S. 1995. Flood reduction through wetland restoration: The upper Mississippi River basin as a case history. Restoration Ecology. 3(1): 4-17.

Hillman, G.R. 1998. Flood wave attenuation by a wetland following a beaver dam failure on a second order boreal stream. Wetlands. 18(1): 21-34.

Hood, G.A.; Bayley, S.E. 2008. Beaver (Castor canadensis) mitigate the effects of climate on the area of open water in boreal wetlands in western Canada. Biological Conservation. 141: $556-567$.

Ives, R.L. 1942. The beaver-meadow complex. Journal of Geomorphology. 5: 19-25.

Johnston, C.A.; Naiman, R.J. 1990. The use of a geographic information system to analyze longterm landscape alteration by beaver. Landscape Ecology. 4(1): 5-19.

Knighton, D. 1998. Fluvial forms and processes: A new perspective. New York: John Wiley and Sons, Inc. 383 p.

Leopold, L.B. 1951. Vegetation of southwest watersheds in the nineteenth century. Geographical Review. 41: 295-316.

Leopold, L.B.; Maddock, T., Jr. 1953. The hydraulic geometry of stream channels and some physiographic implications. Geological Survey Professional Paper 252. Reston, VA: U.S. Department of the Interior, Geological Surey. 57 p.

Leopold, L.B.; Maddock, T., Jr. 1954. The flood control controversy: Big dams, little dams and land management. New York: The Ronald Press Company. 278 p.

Leopold, L.B.; Miller, J.P. 1954. A postglacial chronology for some alluvial valleys in Wyoming. Water-Supply Paper 1261. Reston, VA: U.S. Department of the Interior, Geological Survey.

Leopold, L.B.; Wolman, M.G. 1957. River channel patterns: Braided, meandering and straight. Geological Survey Professional Paper 282-B. Reston, VA: U.S. Department of the Interior, Geological Survey.

Love, C. 1916. The history of the cattle industry in the Southwest. The Southwestern Historical Quarterly. 19(4): 370-399.

Love, D.W. 1979. Quaternary fluvial geomorphic adjustments in Chaco Canyon, New Mexico. In: Rhodes, D.D; Williams, G.P., eds. Adjustments of the fluvial system. Dubuque, IA: Kendall-Hunt Publishing Company: 277-308.

Meentemeyer, R.K.; Butler, D.R. 1999. Hydrogeomorphic effects of beaver dams in Glacier National Park, Montana. Physical Geography. 20(5): 436-446.

Meisel, M. 1924. A bibliography of American natural history—The pioneer century, 1769-1865. Brooklyn: The Premier Publishing Company. 253 p.

Meko, D.; Hughes, M.; Stockton, C. 1991. Climate change and climate variability: The paleo record. In: Managing water resources in the west under conditions of climate uncertainty: A proceedings. Washington, DC: The National Academy Press: 71-100. 
Meko, D.M. 1990. Inferences from tree rings on low frequency variations in runoff in the interior western United States. Proceedings of the sixth annual Pacific Climate (PACLIM) workshop; 1989 March 5-8; Pacific Grove, CA: 123-127.

Morisawa, M. 1985. Development of quantitative geomorphology. Geological Society of America Centennial Special. 1: 79-107.

Muller-Schwarze, D.; Sun, L. 2003. The beaver: Natural history of a wetlands engineer. Cornell University Press. 190 p.

Naiman, R.J.; Johnston, C.A.; Kelley, J.C. 1988. Alteration of North American streams by beaver. BioScience. 38(11): 753-762.

Naiman, R.J.; Mellillo, J.M.; Hobbie, J.E. 1986. Ecosystem alteration of a boreal forest stream by beaver (Castor canadensis). Ecology. 67: 1254-1269.

Osterkamp, W.R.; Costa, J.E. 1987. Changes accompanying an extraordinary flood on a sandbed stream. In: Mayer, L.; Nash, D., eds. Catastrophic flooding. Boston: Allen and Unwin: 201-224.

Parker, M.; Wood, F.J.; Smith, B.H.; [et al.]. 1985. Erosional downcutting in lower order riparian ecosystems: Have historical changes been caused by removal of beaver? In: Johnson, R.R.; Ziebell, C.D.; Patton, D.R.; [et al.], tech. cords. Riparian ecosystems and their management: Reconciling conflicting uses. First North American riparian conference; 1985 April 16-18; Tucson, AZ. Gen. Tech. Rep. RM-120. Fort Collins, CO: U.S. Department of Agriculture, Forest Service, Rocky Mountain Forest and Range Experiment Station: 35-38.

Pattie, J.O. 1831. The personal narrative of James O. Pattie: The 1831 edition. Lincoln, NE: University of Nebraska Press. 324 p.

Phillips, P.C. 1961. The fur trade. Norman, OK: University of Oklahoma Press. 1,382 p.

Pollock, M.M.; Beechie, T.J.; Jorden, C.E. 2007. Geomorphic changes upstream of beaver dams in Bridge Creek, an incised stream channel in the interior Columbia River basin, eastern Oregon. Earth Surface Processes and Landforms. 32: 1174-1185.

Reagan, A.B. 1924. Stream aggradation through irrigation. The Pan-American Geologist. 42: 335-344.

Schaffer, P.W. 1941. Beaver on trial. Washington, DC: U.S. Department of Agriculture, Soil Conservation Service.

Schumm, S.A.; Harvey, M.D.; Watson, C.C. 1996. Incised channels: Morphology, dynamics and control. Littleton, CO: Water Resources Publications. 200 p.

Schumm, S.A.; Lichty, R.W. 1963. Channel widening and flood-plain construction along Cimarron River in southwestern Kansas. Geological Survey Professional Paper 352-D. Alexandria, VA: U.S. Department of the Interior, Geological Survey.

Sedell, J.R.; Froggatt, J.L. 1984. Importance of streamside forests to large rivers: The isolation of the Willamette River, Oregon, U.S.A., from its floodplain by snagging and streamside forest removal. In: Schwiezerbart, ed. Verhandlungen: Congress in France 1983 of the International Association for Theoretical and Applied Limnology: 1828-1834.

Shankman, D.: Pugh, Y.B. 1992. Discharge response to channelization of a coastal plain stream. Wetlands. 12(3): 157-162.

Smith, D.G. 1976. Effect of vegetation on lateral migration of anastomosed channels of a glacier meltwater river. Geological Society of America Bulletin. 87: 857-860.

Stockton, C.W.; Fritts, H.C. 1968. Conditional probability of occurrence for variations in climate based on widths of annual tree rings in Arizona. Tree-ring Bulletin. 31: 3-24.

Swift, T.T. 1926. Date of channel trenching in the Southwest. Science. 63(1620): 70-71.

USDA Animal and Plant Health Inspection Service (APHIS). 2000-2015. Number of animals taken by WS [Wildlife Services] and methods used from 2000 to 2015. Database. [Data retrieved from each year.] Washington, DC: U.S. Department of Agriculture, Animal and Plant Health Inspection Service, Wildlife Services. https://www.aphis.usda.gov/aphis/ourfocus/ wildlifedamage/SA_Reports/SA_PDRs. 
USDA Forest Service 1993. Draft environmental impact statement for Diamond Bar allotment management plan: Mimbres Ranger District, Gila National Forest. Albuquerque, NM: U.S. Department of Agriculture, Forest Service, Southwestern Region. 233 p.

Walter, R.C.; Merritts, D.J. 2008. Natural streams and the legacy of water-powered mills. Science. 18. 319(5861): 299-304.

Warren, E.R. 1926. A study of the beaver in the Yancey region of Yellowstone National Park. Roosevelt Wild Life Annals of the Roosevelt Wild Life Forest Experiment Station 1(1 and 2): 191.

Weber, D.J. 1971. The Taos trappers: The fur trade in the Far Southwest, 1540-1846. Norman, OK: University of Oklahoma Press. 228 p.

White, C.A. 1996. Initial points of the rectangular survey system. Westminster, CO: The Publishing House. 560 p.

Wiens, K.C. 2001. The effects of headcutting on the bottomland hardwood wetlands of the Wolf River near Memphis, Tennessee. Thesis. Cookeville, TN: Tennessee Technological University: $91 \mathrm{p}$.

Winn, F. 1926. The West Fork of the Gila River. Science, Issue 1644. 64: 16-17.

Wolman, M.G.; Leopold, L.B. 1957. River flood plains: Some observations on their formation. Geologicl Survey Professional Paper 282-C. Reston, VA: U.S. Department of the Interior, Geological Survey.

Womack, W.R.; Schumm, S.A. 1977. Terraces of Douglas Creek, northwestern Colorado: An example off episodic erosion. Geology. 5: 72-76. 


\title{
Chapter 8. Arizona as a Watershed-Then and Now: Case Studies of Changed Management of Rivers and Habitat in the Lower Colorado River System
}

\author{
William E. Werner
}

\section{Introduction}

Prior to human development in the West, rivers flowed freely. Flows in the Colorado River varied greatly with season, with snowmelt runoff from the Rocky Mountains resulting in annual high flows (Topping et al. 2003). The large sediment loads historically found in the Colorado River, estimated to average 160,000,000 tons passing Yuma annually (LaRue 1916), have since caused Laguna Dam (fig. 23) near Yuma, Arizona, completed in 1905, to silt in almost immediately. Even in a managed system, unpredictable unmeasured tributary inflow into the Colorado River below Hoover Dam accounts for approximately 96,000 acre-ft of water annually, with about 62 percent of that flow from Arizona tributaries, including Sacramento Wash, the Bill Williams River area, Bouse Wash, Tyson Wash, the Dome Rock-Trigo-Chocolate Mountains area, and the Gila River area (Owen-Joyce 1987). Grinnell (1914) provided an account of mammals and birds of the Lower Colorado River Valley, which provides a benchmark from early in the development of the river. Riparian habitat became established following seed deposition on surfaces where sufficient soil moisture maintained the vegetation to maturity. As we see today, large numbers of seeds germinate but few plants survive to maturity to provide seed to repeat the cycle.

Human development of the American West included construction of large dams to retain water from high flow periods for later use and clearing of floodplains for agriculture and urban development, impacting riparian habitat (table 7). Dam construction not only changed the pattern of water flow in rivers, but the pattern of sediment movement as well. Fine textured sediment, such as silt, often drops out of water flow in deltaic deposits at the upper end of reservoirs so that the fine sediment is no longer deposited along rivers to form surfaces where seeds collect and vegetation becomes established as described by Brady et al. (1985).

The effect is that, while the processes that perpetuate riparian vegetation persist, the pattern and location on the landscape have changed in many areas. Vegetation on sediment deposits forming deltas in reservoir pool space is often temporary, depending on water and soil moisture conditions suitable for maintaining the vegetation. Conditions change through time, being suitable — following a high flow-with sufficient groundwater in streamside alluvium that is supported by baseflow in the stream in the upper portions of the delta, or by stable reservoir water levels saturating alluvium in the lower portions of the delta. However, more extreme conditions result from either (1) complete inundation of vegetation, if a reservoir fills to capacity, or (2) contrastingly, drying conditions resulting from inadequate water supply to the vegetation if a reservoir is drawn down, resulting in groundwater levels dropping. 


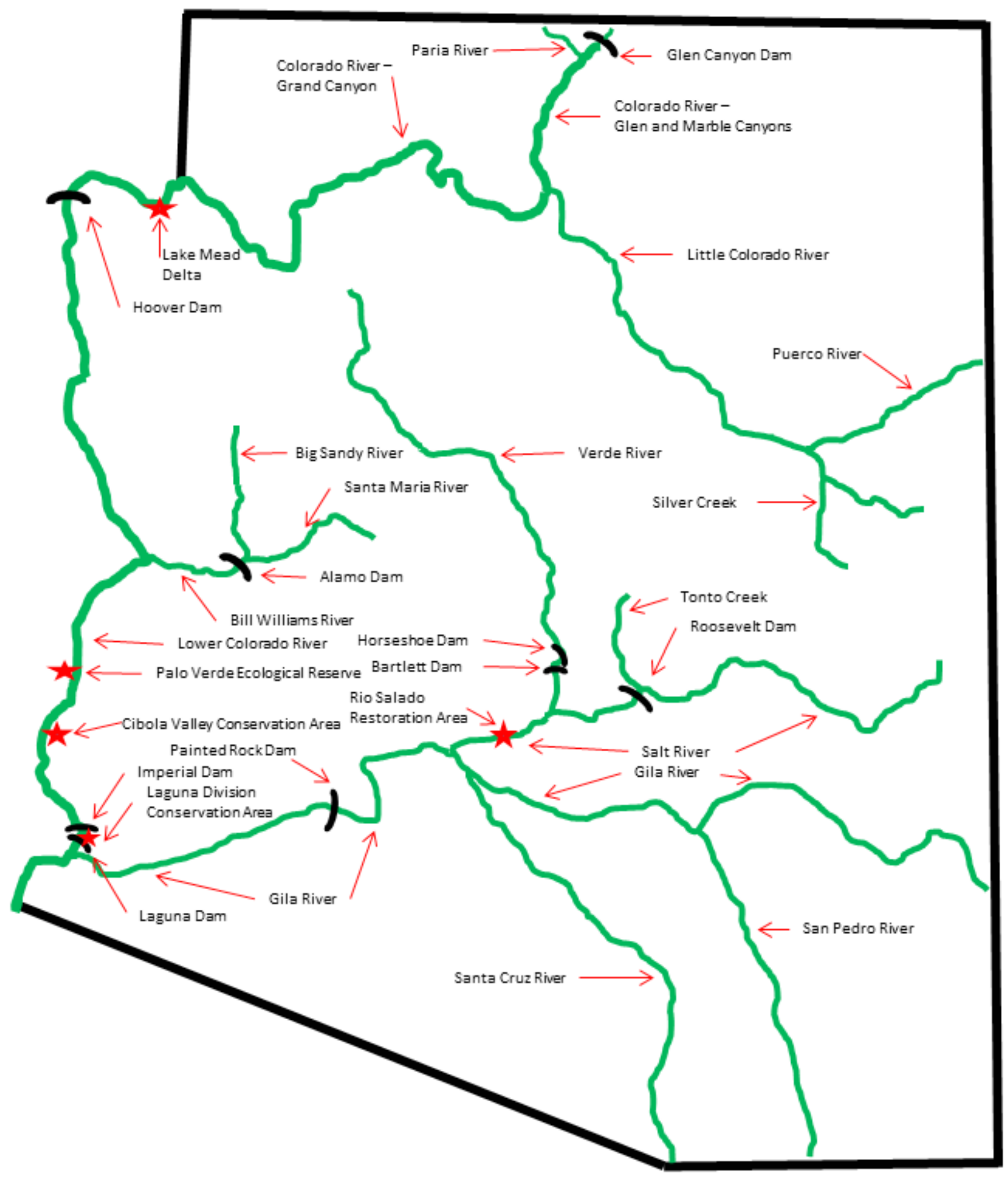

Figure 23-Select Arizona rivers and conservation areas (map by W.E. Werner). 
Table 7-Arizona streams and riparian status.

\begin{tabular}{lll}
\hline Stream reach & $\begin{array}{c}\text { Dams, irrigation project diversions, } \\
\text { and flood control }\end{array}$ & \multicolumn{1}{c}{ Current status of riparian ecosystems } \\
\hline $\begin{array}{l}\text { Summary of } \\
\text { Arizona streams and } \\
\text { watersheds }\end{array}$ & $\begin{array}{l}\text { Numerous "water projects" throughout } \\
\text { Arizona (see below). }\end{array}$ & $\begin{array}{l}\text { Much of riparian habitat at time of Euro-American } \\
\text { settlement lost to agriculture, urbanization, and } \\
\text { water projects (Dobyns 1981). Cottonwood-willow } \\
\text { (Populus-Salix) and mesquite (Prosopis spp.) replaced } \\
\text { by tamarisk (Tamarix spp.) along much of perennial } \\
\text { reaches. }\end{array}$
\end{tabular}

Colorado River below Glen Canyon Dam and tributaries

Bill Williams River

Salt River in Salt River Valley (Phoenix, AZ)

Gila River below Painted Rock Dam

Colorado River below Hoover Dam
None, Grand Canyon National Park most of river length to Lake Mead National Recreation Area.
Prior to Glen Canyon Dam, annual high flows from snowmelt in Rocky Mountains scoured vegetation from sides of the river. After Dam, tamarisk major woody vegetation, with scattered Goodding's willow (Salix gooddingii), coyote willow (S. exigua), seep willow (Baccharis spp.). Willow flycatcher habitat occurs in lower Grand Canyon/Lake Mead Delta area depending on hydrologic conditions and pool elevation at Lake Mead.

Large tamarisk stands; dam releases planned to benefit native trees, e.g., cottonwood-willows. Beaver dams established. Large stands of cottonwood and willow habitat following improved water management. Large numbers of western yellow-billed cuckoo (Coccyzus americanus occidentalis) in new habitat.

Original stands of cottonwood-willow gallery forests killed when Roosevelt Dam constructed upstream. Tamarisk minimal; cottonwood, Goodding's willow, and mesquite. Beavers established; overwintering monarch butterflies (Danaus plexippus) in willows.

Large tamarisk stands, cattail (Typha) marshes; following high flows in 1993, seedling cottonwood and willow trees were observed in the WMIDD area and downstream. Lower reaches of the Gila River have supported habitat used by migrant southwestern willow flycatcher (McLeod 2008).

National Wildlife Refuges created to provide wildlife conservation at the time of dam construction but were not enough to address effects of river operation to habitat. Cottonwood and willow habitat largely lost along the Colorado River, replaced by salt cedar. Lower Colorado River Multi-Species Conservation Program implemented to conserve threatened, endangered, and sensitive species and to provide ongoing Endangered Species Act compliance for operation and maintenance of the river.

If the conditions that support riparian vegetation are temporary at many locations in many watersheds without man's intervention, better understanding of those conditions can help us better manage systems to maintain riparian vegetation in managed watersheds. There are opportunities to manage, to a greater or lesser degree, flow of water, sediment, stream morphology, and suitable surfaces for establishment of vegetation in flow-regulated systems. Examples include the Colorado River below Glen Canyon 
Dam, the Bill Williams River, the Salt River in the Salt River Valley, the Gila River below Painted Rock Dam, and the Colorado River below Hoover Dam (fig. 23, table 7). Success has been variable. One of the challenges managers face is developing appropriate expectations and objectives in systems with variables beyond their control. It may be possible to maintain, as an example, a patch of cottonwood trees that can provide a seed source downstream when conditions are right to establish cottonwood trees after a large flow event. Whether new seedlings persist is constrained by many variables, but without the seeds from seed bearing trees there is little or no opportunity. The species composition of riparian vegetation on a managed stream below a dam may be quite different from unmanaged streams above the dam (Stromberg et al. 2012).

\section{Colorado River Below Glen Canyon Dam and the Role of Tributaries}

Much has been written about riparian vegetation and management of the Colorado River downstream from Glen Canyon Dam (fig. 23; e.g., Carothers and Dolan 1982 and Sankey et al. 2015). Glen Canyon Dam, forming Lake Powell, not only stops and stores snowmelt water from the upper Colorado River watershed, but also traps sediment that once flowed downstream. Downstream from Glen Canyon Dam, the Paria River discharges water and sediment into the Colorado at Lees Ferry, with a mean sediment contribution of approximately 3 million tons/year (Andrews 1991). While surface water flow in the Paria River watershed is not managed to a large degree, the watershed is desert and significant flow of water and sediment depends on episodic storm events. Farther downstream, the Little Colorado River discharges water and sediment from a larger watershed with a mean sediment contribution of approximately 9 million tons/year (Andrews 1991). Many streams in the Little Colorado River watershed have been dammed for consumptive use or recreation, changing the frequency of significant flow events. The Puerco River, a tributary to the Little Colorado River, is largely unregulated and can produce a large volume of sediment under intense runoff conditions (Wirt et al. 1991).

Sediment inflow into the Colorado River from the Paria and Little Colorado Rivers is monitored by the Grand Canyon Monitoring and Research Center as part of the Glen Canyon Dam Adaptive Management Program pursuant to the Grand Canyon Protection Act. When sediment accumulation in the Colorado River has reached an appropriate level, recommendations for higher water releases from Glen Canyon Dam are made to the Secretary of the Interior with goals generally to benefit resources along the river by re-depositing the sediment at higher elevations to benefit riparian vegetation and to create bars to form backwater aquatic habitats (Salazar 2012).

Research into the effects of efforts to manage water and sediment below Glen Canyon Dam conducted by the Grand Canyon Monitoring and Research Center and others in association with the Glen Canyon Dam Adaptive Management Workgroup is ongoing. As described by Johnson and Carothers (1987) and as a former participant in the Workgroup, one of the challenges is identifying management objectives appropriate for the changed system. Water resource development in the watershed above Glen Canyon Dam has resulted in large changes to the pattern and magnitude of movement of both water and sediment. Yet there are opportunities to do the best we can with circumstances as they are today. 
Sediment from the Colorado River below the Grand Canyon has formed deltaic deposits within the reservoir pool area of Lake Mead, providing seed beds suitable for native riparian tree species (McLeod et al. 2008). Depending on reservoir operating conditions, namely the amount of water entering the system versus releases for downstream use, native trees such as Goodding's willow (Salix gooddingii) have provided habitat for the southwestern willow flycatcher (Empidonax traillii extimus; McLeod et al. 2008) as long as moisture remained to support the trees in a stable or falling reservoir condition and water did not completely inundate them in a rising reservoir condition (1996 condition). Flooded vegetation can apparently provide protective cover for young native fish, including razorback sucker (Xyrauchen texanus) increasing survival and recruitment into the adult population (Albrecht et al. 2008). Thus, although within the pool of a reservoir, the natural processes facilitating recruitment of native trees and birds, as well as native fish, can occur in a managed system, although perhaps more accidental than planned.

\section{Alamo Dam and the Bill Williams River}

The Bill Williams River is a major tributary of the Colorado River (fig. 23) beginning at the confluence of the Big Sandy and Santa Maria Rivers in west central Arizona. Alamo Dam, completed in 1969, was constructed to manage flood flows from the Bill Williams River that would otherwise cause flooding along the Lower Colorado River in the vicinity of Parker and Yuma, Arizona. Hunter et al. (1987) describe changes in habitat below Alamo Dam following flooding from high-water releases. Beginning in 1989 the Bill Williams River Corridor Steering Committee, a multi-agency effort, began planning for improved management of flows from Alamo Dam. We sought to benefit native tree species and avoid benefitting nonnative saltcedar (Tamarix spp.) both downstream of the dam and in the reservoir pool, through recommendations to the Corps of Engineers (Werner 2010). Saltcedar is well established in the Bill Williams River watershed, and shoreline deposition of seeds at high reservoir conditions in the late 1970s and early 1980s resulted in establishment of plants around the shoreline of Alamo Lake and where the lake inundated the lower ends of the Santa Maria and Big Sandy Rivers. In analyzing an optimal operating range for Alamo Lake, working with all existing flow data, we sought to minimize the probability of pushing the "bathtub ring" of saltcedar further up the rivers. In addition we attempted to mimic natural timing of downstream high releases from Alamo Dam to benefit native trees and tried to avoid releases that would favor saltcedar. We also recommended base flow releases that would vary seasonally to sustain trees. This planning was informed by research on the Hassayampa River by Stromberg et al. (1991) who found that recruitment of cottonwood and willow trees occurred approximately every 7 to 10 years on that unmanaged system. The Bill Williams River Corridor Steering Committee was concerned that dam operation and flow recommendations not result in a rigid management regime, as had occurred with previous recommendations responding to a planned drawdown that resulted in management of the reservoir with a fixed target elevation, and included a recommendation for development of a monitoring program and an outline of information and data needs to facilitate improvement of recommendations, or adaptive management, in the future. During the period of planning by the Bill Williams River Corridor Steering Committee, 
heavy winter rains occurred in 1993 in the Bill Williams River watershed, resulting in a need for high releases from Alamo Dam. The Corps of Engineers was able to incorporate draft recommendations, based on the existing Water Control Manual, into the schedule for high releases in an attempt to avoid detrimental effects documented previously by Hunter et al. (1987). The Corps of Engineers funded aerial photography during the high releases to document the inundated area along the river.

Operating a reservoir to benefit downstream riparian habitat is like using a debit card drawn from a checking account. There is a finite amount of water in the "account" from which to make baseflow releases. If there is inflow, "income," withdrawals can be sustained to the extent that the volume released doesn't exceed the volume available. If withdrawals are larger than income, the balance in volume goes down. If inflows go down due to reduced precipitation in the watershed, releases must be reduced to maintain a "balance" in the system. Reduced baseflow releases may result in a reduction of the total acreage of riparian habitat maintained downstream from the dam, with some reaches more susceptible to change than others based on geology and landform (Wolcott et al. 1956; House et al. 1999). Maintaining releases to maintain the acreage of riparian habitat downstream will reduce the balance available to make future releases, to the eventual point that releases cannot be made until inflow occurs. The quandary is how much releases should be reduced to be able to make any releases in the future or how much downstream habitat acreage we are reluctantly willing to give up, assuming that future inflows will occur in the nick of time. There are no right or wrong answers to these questions. Decisions can be informed, however, by better understanding the variables that control the system and consequences of decisions. Ultimately, we don't control nature, and precipitation may not be as we desire and the acreage of riparian habitat will adjust downward.

Similar to Lake Mead, deltaic sediment deposits at the upper end of Alamo Lake have provided suitable surfaces and conditions for establishment of native riparian vegetation. Goodding's willow trees in that area have provided nesting habitat for southwestern willow flycatcher (McLeod and Pelligrini 2013). While conditions may remain to support this vegetation, suitable nesting habitat conditions may change through time as vegetation matures and stands thin. The stands of cottonwood and willow trees that became established (fig. 24) following implementation of management recommendations for Alamo Dam downstream from Alamo Dam on the Bill Williams River have supported large numbers of western yellow-billed cuckoo (Coccyzus americanus occidentalis) with 139 detections in 2007 (Johnson et al. 2008).

Subsequent to the original recommendations of the Bill Williams River Corridor Steering Committee, changes to the authorizing legislation for Alamo Dam, and formal revision of the dam Water Control Manual, there has been additional analysis of flow recommendations and research and monitoring of flow effects. Monitoring and evaluation of flow prescriptions is reported by Konrad (2010). Flow effects to vegetation have been studied by Shafroth et al. (2006, 2010) and Wilcox and Shafroth (2013). Reynolds et al. (2014) report changes to vegetation on abandoned floodplain surfaces. Stromberg et al. (2012) describe vegetation on the lower Santa Maria River, above Alamo Dam, compared to vegetation below Alamo Dam on the Bill Williams River, finding the latter less diverse. Vegetation response to water table changes was the subject of research by Shafroth et al. (2000). Anderson et al. $(2010,2011)$ researched beaver dams and effects 


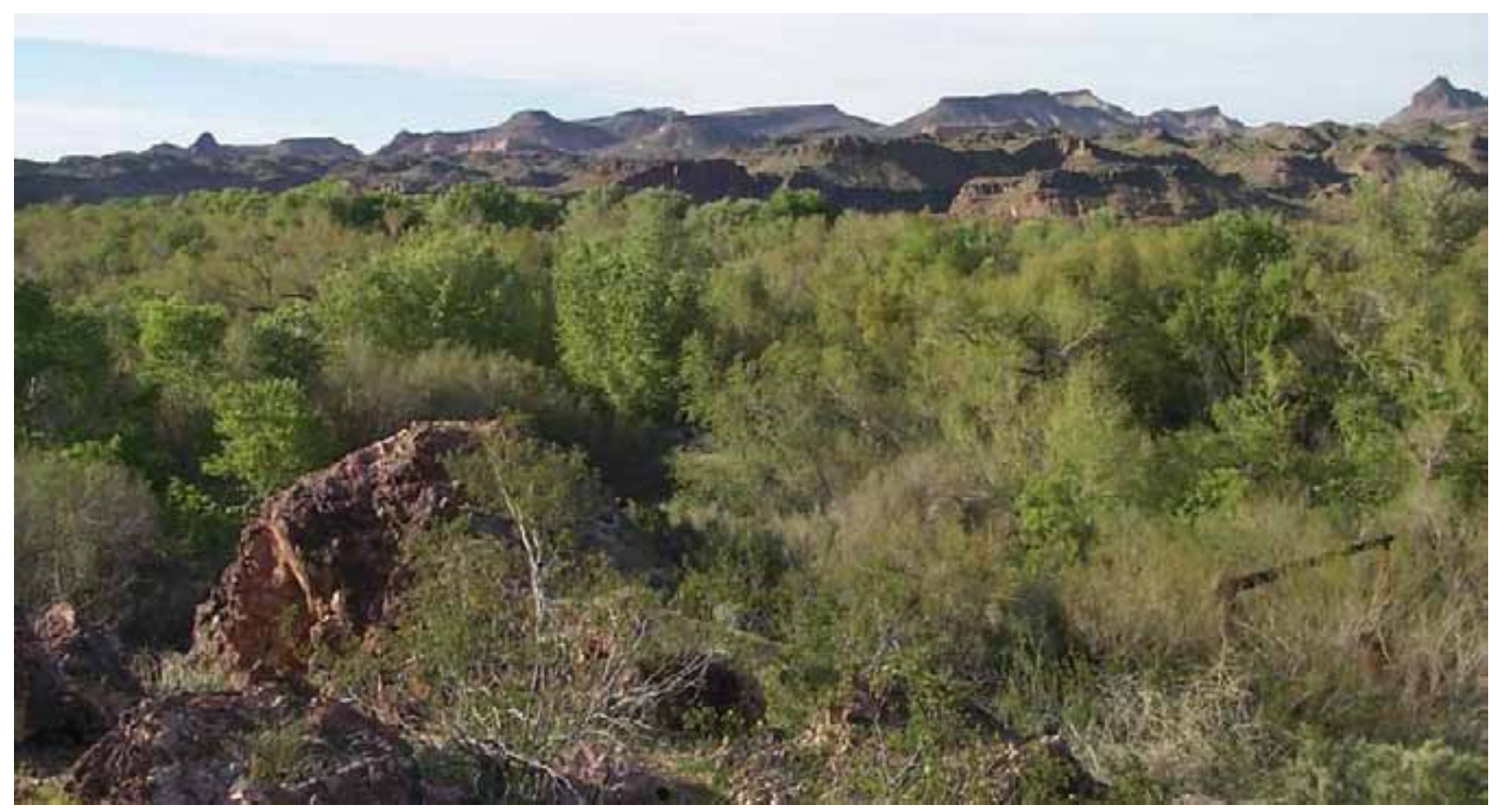

Figure 24-Riparian vegetation on Bill Williams River near Narrows on Bill Williams River NWR (photo by W.E. Werner).

associated with controlled flooding. Anderson et al. (2016) researched wood decay on the Bill Williams River. Ellington and Anderson (2002) researched spatial correlation of Apache cicada (Diceroprocta apache), and Tamarix on the Bill Williams River. Nelson and Anderson (1999) researched butterfly assemblages in natural and restored habitats, including on the Bill Williams River. Wilson and Owen-Joyce (2002) describe hydrologic conditions on the lower Bill Williams River. Wiele et al. $(2009,2011)$ report on sediment discharge from the Bill Williams River and sediment concentration in downstream Lake Havasu associated with high flow releases designed to benefit riparian vegetation.

\section{Salt River in Salt River Valley}

Following flooding on the Salt River in 1993, the U.S. Army Corps of Engineers conducted studies at the request of local sponsors to determine if a Federal project was justified to address flood control, water conservation, recreation, and environmental restoration on the Salt River in the vicinity of Tempe and Phoenix (fig. 23). Review of environmental restoration was based on authority in the Water Resources Development Act of 1986 to address environmental effects of existing projects, in this case upstream dams. As a result of these studies, the Congress of the United States authorized the Corps of Engineers Rio Salado Environmental Restoration Project on the Salt River between Interstate 10 and 19th Avenue to address flood control, environmental restoration, and incidental recreation with the City of Phoenix as the non-Federal sponsor.

In designing the cross section for the Rio Salado Environmental Restoration Project, the Corps of Engineers created a "channel within a channel" with dimensions such that flows that would be expected every 7 to 10 years would overtop the low-flow channel, based on research on the Hassayampa River of the flood frequency maintaining 
riparian trees (Stromberg et al. 1991), but would be contained within dimensions of a flood channel designed to protect adjacent infrastructure. The watershed above the Rio Salado Environmental Restoration Project includes the Salt and Verde River watersheds. There are four large dams on the Salt River, and flood flows are much less likely to completely fill the Salt River reservoir system than to fill the two reservoirs on the Verde formed by two relatively smaller dams. Because of this, flood flows on the Salt River through Phoenix typically originate in the Verde River watershed.

Within the Rio Salado Environmental Restoration Project water to sustain riparian vegetation (fig. 25) is either pumped to higher areas or is drainage water entering the Salt River from the local storm drain system. While storm drain flow isn't predictable it has been consistent and supports habitat in the low-flow channel. Apparently sump pumps pumping high groundwater from the basement levels of some high rise buildings in downtown Phoenix discharge into the storm drain system, providing some of the consistent flow. Efficacy of managing channel size to benefit riparian resources through time will depend on the frequency of flood flows and availability of water to sustain vegetation. An unanticipated high flow through the Rio Salado Environmental Restoration Project occurred in July 2010 when one of the bladders of the inflatable dam at the downstream end of Tempe Town Lake failed, releasing a flood down the Salt River. The low-flow channel through the Rio Salado reach appeared to perform as intended based on high-water marks and flood deposits.

Vegetation within the Rio Salado Environmental Restoration Project includes native Fremont cottonwood (Populus fremontii), Goodding's willow, and mesquite (Prosopis spp). Overwintering of monarch butterflies (Danaus plexippus) has been

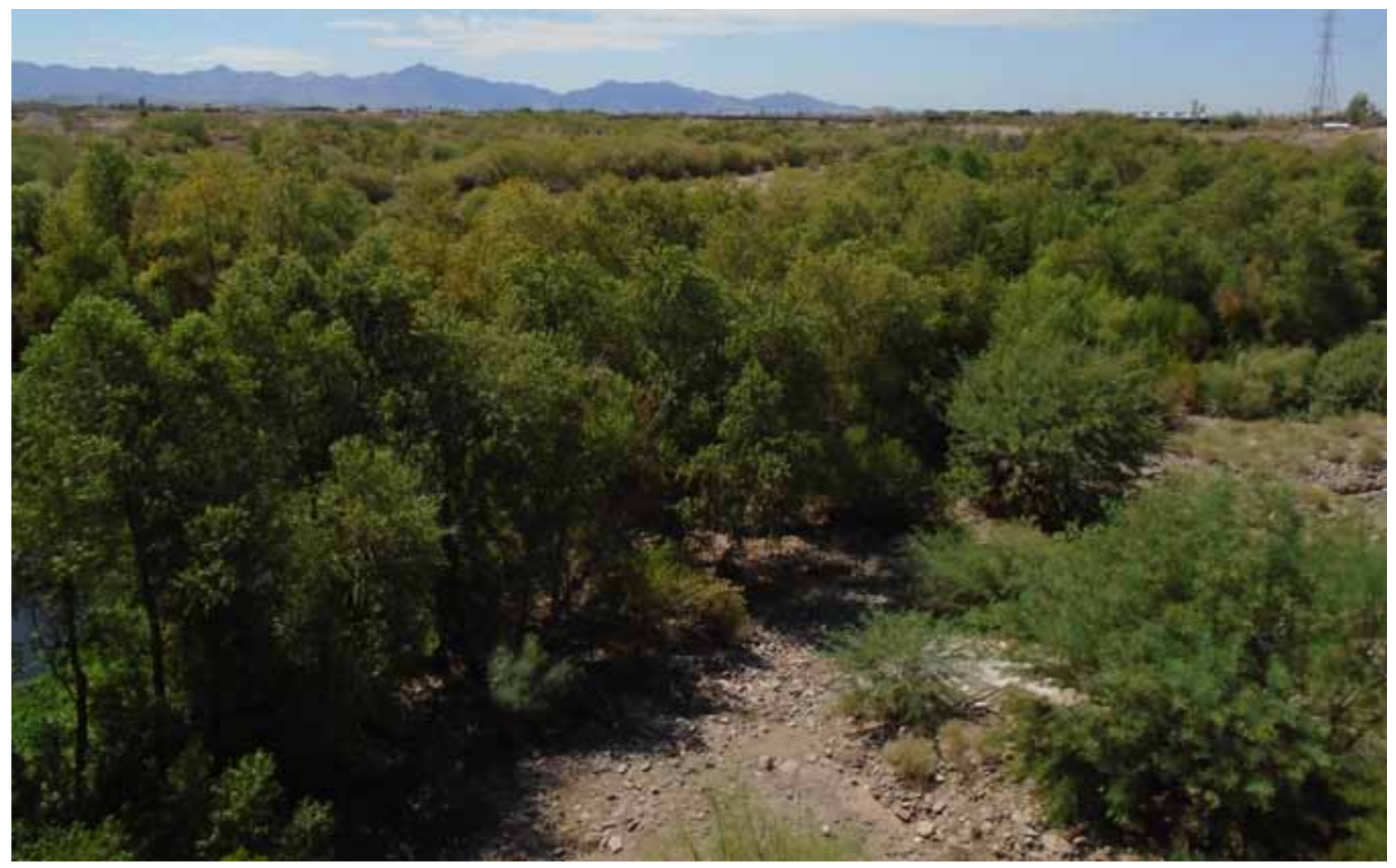

Figure 25-Riparian vegetation on Salt River at Central Avenue, Phoenix Arizona (photo by W.E. Werner). 
documented in a dense stand of Goodding's willow in the Rio Salado Environmental Restoration Project area (Morris et al. 2015) although suitability of conditions may depend on water management in areas higher in elevation than the low-flow channel (Gail Morris, Southwest Monarch Study, Chandler, AZ, personal communication, October 15, 2016). Beavers have become established in the area with evidence of tree gnawing and dam construction.

\section{Gila River Below Painted Rock Dam}

Flow events in central Arizona that exceed the storage capacity of the Salt River Project system on the Salt and Verde Rivers - Lake Pleasant on the Agua Fria River, or San Carlos Reservoir on the Gila River-flow down the Gila River into Painted Rock Reservoir, impounded by the Corps of Engineers Painted Rock Dam. As indicated in the discussion of the Salt River, many of these events are associated with flows on the Verde River but can also result from storm flows from southeastern Arizona flowing into the Gila from the Santa Cruz or San Pedro Rivers. Downstream from Painted Rock Dam, the Wellton-Mohawk Irrigation and Drainage District (WMIDD) was developed as an element of the Gila Project by the Bureau of Reclamation to irrigate floodplain farmland. Irrigation water is diverted from the Colorado River at Imperial Dam and is delivered to the WMIDD area along the lower Gila River through a canal system and pump plants. Flood flows past Painted Rock Dam exceeded the capacity of the Gila River channel through the WMIDD in 1993.

Following high flows in 1993, seedling cottonwood and willow trees were observed in the WMIDD area and downstream. Trees that became established typically were on first terrace silty soils that would retain soil moisture more than river bottom sandy soils. Efforts to restore a channel after the high flows included plans to maintain cutoff meander bends and low-lying areas. In addition, the invert elevation of the channel was raised one foot to increase the probability that future flood flows would overtop the low-flow channel every 7 to 10 years, again based on research on the Hassayampa (Stromberg et al. 1991) to facilitate regeneration of native riparian trees, including cottonwood and willow. This is an example of attempting to shape the channel such that natural processes will maintain riparian habitat.

Groundwater or soil moisture to support riparian habitat along the Gila River downstream from Texas Hill, the upstream end of the WMIDD, is either high groundwater resulting from irrigation with imported Colorado River water or from lateral movement of irrigation water toward lower elevations in the river channel. The first circumstance can change with groundwater pumping patterns and the second can change with cropping patterns and irrigation of agricultural fields adjacent to riparian habitat. Another complicating variable is that groundwater in the WMIDD is often saline, which can vary with mixing with irrigation water from above or less saline water from the river channel during flow events.

Following flood flows in 1993 cottonwood and willow seedlings were observed downstream from mature trees that were apparently supported by water released at ends of the canal system or wasteways. Since a canal system operates on gravity, excess water that is not diverted as planned by a farmer must go somewhere and is sometimes dumped from the canal system into the river floodplain. Sometimes water is flushed into 
the river to clean wind borne sand from the canal system. In addition, in some systems, leaky gates account for additional water into the river. This results in areas that support mature native trees that can provide seeds during high-flow events on the otherwise dry river. There were flood flows on the Gila downstream from Painted Rock Dam in 1993-1995, and smaller high flows in 2005 and 2010. In many areas cottonwood trees that became established following the 1993-1995 high flows have died back. Survival of cottonwood and willow trees appears to have been better on silty soils of the Gila River floodplain than in coarser texture sands in the river channel itself. The silty floodplain soils are also desirable for agriculture as water is better retained to provide moisture to plants. Lower reaches of the Gila River have supported habitat used by migrant southwestern willow flycatcher (McLeod 2008).

\section{Colorado River Below Hoover Dam}

The Lower Colorado River Multi-Species Conservation Program (LCRMSCP) is designed to create habitat and support programs for the benefit of native fish and wildlife affected by operation and maintenance of the Lower Colorado River Dam system from the upper end of Lake Mead above Hoover Dam to the Southerly International Border with Mexico at San Luis, Arizona (Werner 2006). State and Federal water, power, and fish and wildlife agencies worked together to develop the program with a focus on ensuring long-term compliance with the Endangered Species Act and to avoid listing of additional species (a total of 26 covered species). The program includes creation and management of 8,132 acres of habitat, including 5,940 acres of cottonwood-willow habitat with characteristics suitable for southwestern willow flycatcher and western yellow-billed cuckoo, 1,320 acres of honey mesquite, 512 acres of marsh, and 360 acres of backwater, plus specific measures for certain species (LCR MSCP 2004).

Along the Colorado River below Hoover Dam efforts to maintain riparian habitat include channel shaping and water management at the Laguna Division Project between Imperial and Laguna Dams (LCR MSCP 2012) and planting on silty floodplain soils. Water supporting trees at planting sites is either: (1) surface flow irrigation from the Colorado River either by diversion at Palo Verde Diversion Dam for Palo Verde Ecological Reserve (fig. 23) in California or (2) pumping from the river at Cibola Valley Conservation Area (fig. 23) and Cibola National Wildlife Refuge in Arizona. Because of post-dam changes to the Colorado River, the water surface elevation is too low to overtop the banks to flood silty floodplain soils.

Opportunities to take advantage of natural flooding of low-lying areas have been investigated, but the acreage that can be accomplished through this means is limited, often because sediment in the Colorado River is trapped in reservoirs and is no longer available for building bars that provide sites for seed germination. In addition, the channel of the Colorado River has been simplified through human development of the area such that water does not spread across the floodplain.

Habitat creation targeting western yellow-billed cuckoo and southwestern willow flycatcher has included creation of large blocks of intermixed cottonwood, willow, and mesquite habitat. Hunter et al. (1987) reported that the yellow-billed cuckoo was declining and the willow flycatcher had disappeared from most of its historical range in Arizona. There is an extensive monitoring program associated with the LCRMSCP. 
Western yellow-billed cuckoo began nesting in new stands of vegetation within a few years of establishment (Johnson et al. 2008) and there may be bird response and interaction between blocks of mainstem and tributary habitat, including recent habitat on the Bill Williams River discussed earlier, as well as response to decrease in irrigation once trees are established (Tracy and McNeil 2016), a pattern similar to patterns reported by Wallace et al. (2013).

\section{Discussion}

Riparian ecosystems are dynamic by their nature and riparian habitat is dynamic as stands of vegetation progress through natural succession and mature. Maintaining sufficient habitat on the landscape involves more than simply maintaining stands of vegetation. Maintaining conditions suitable to support an adequate prey base for birds, for example, is an element of maintaining habitat. Doing so may require more water than is needed simply for survival of trees. In some circumstances, our ability to control variables limits our ability to manage for riparian habitat. In other circumstances, we can set the stage, to the best of our ability, within constraints, such as on the Salt River in Phoenix where we can manage the landform and can create baseflows but have little control on high flows. In further circumstances, such as the operation of Alamo Dam, we can manage flow constraint by managing both high flows and baseflows, to a greater or lesser degree, within physical constraints of dam design and available water upstream in the system.

In the case of operating Alamo Dam to benefit riparian habitat on the Bill Williams River, we can develop contingency plans to exploit opportunities, if and when those opportunities arise. On the lower Gila River below Painted Rock Dam, we can set the stage by creating suitable landform but have no control on the frequency of high flows, which were more frequent during our planning efforts than since. On the Lower Colorado River, we can create functional habitat in floodplain settings where it once occurred naturally although our ability to manage river flows and sediment movement is very low. By doing the best we can in a variety of circumstances in managed systems, we can create a patchwork quilt of habitat.

\section{References}

Albrecht, B.; Sanderson, T.; Holden, P.B. 2008. Razorback sucker studies on Lake Mead, Nevada and Arizona 1996-2007. PR-1093-2. Logan, UT: BIO-WEST, Inc. 133 p. http://www.lcrmscp. gov/reports/2008/c13_comp_rep_96-07.pdf. [Accessed Aug. 14, 2016].

Andersen, D.C.; Shafroth, P.B. 2010. Beaver dams, hydrological thresholds, and controlled floods as a management tool in a desert riverine ecosystem, Bill Williams River, Arizona. Ecohydrology. 3(3): 325-338.

Andersen, D.C.; Shafroth, P.B.; Pritekel, C.M.; [et al.]. 2011. Managed flood effects on beaver pond habitat in a desert riverine ecosystem, Bill Williams River, Arizona, USA. Wetlands. 31(2): 195-206.

Andersen, D.C.; Stricker, C.A.; Nelson, S.M. 2016. Wood decay in desert riverine environments. Forest Ecology and Management. 365: 83-95. 
Andrews, E.D. 1991. Sediment transport in the Colorado River Basin. In: Colorado River ecology and dam management: Proceedings of a symposium; 1990 May 24-25, 1990; Santa Fe, NM. Washington, DC: National Academies Press. 54-74. http://www.nap.edu/ catalog/1832/colorado-river-ecology-and-dam-management-proceedings-of-a-symposium. [Accessed August 14, 2016].

Brady, W.; Patton, D.R.; Paxson, J. 1985. The development of southwestern riparian gallery forests. In: Johnson, R.R.; Ziebell, C.D.; Patton, D.R.; [et al.], tech. coords. Riparian ecosystems and their management: Reconciling conflicting uses. First North American riparian conference; 1985 April 16-18; Tucson, AZ. Gen. Tech. Rep. RM-GTR-120. Fort Collins, CO: U.S. Department of Agriculture, Forest Service, Rocky Mountain Forest and Range Experiment Station: 39-43. http://www.treesearch.fs.fed.us/pubs/41622. [Accessed August 14, 2016].

Carothers, S.W.; Dolan, R. 1982. Dam changes on the Colorado River. Natural History. 91(1): 74-83.

Dobyns, H.F. 1981. From fire to flood: Historic human destruction of Sonoran Desert river oases. Socorro, NM: Ballena Press: 222 p.

Ellington, A.R.; Anderson, D.C. 2002. Spatial correlations of Diceroprocta apache and its host plants: Evidence for a negative impact from Tamarix invasion. Ecological Entomology. 27(1): $16-24$.

Grinnell, J. 1914. An account of the mammals and birds of the Lower Colorado Valley with special reference to the distributional problems presented. University of California Publications in Zoology. 12(4): 51-294.

House, P.K.; Wood, M.L.; Pearthree, P.A. 1999. Hydrologic and geomorphic characteristics of the Bill Williams River, Arizona. Open-File Report 99-4. Tucson, AZ: Arizona Geological Survey. 46 p. http://repository.azgs.az.gov/sites/default/files/dlio/files/nid1039/ofr-99-04_ billwilliamsriver_report.pdf. [Accessed August 14, 2016].

Hunter, W.C.; Anderson, B.W.; Ohmart, R.D. 1987. Avian community structure changes in a mature floodplain forest after extensive flooding. Journal of Wildlife Management. 51(2): 495-502.

Hunter, W.C.; Ohmart, R.D.; Anderson, B.W. 1987. Status of breeding riparian-obligate birds in southwestern riverine systems. Western Birds. 18(1): 10-18. https://www. westernfieldornithologists.org/archive/V18/18(1) percent20p0010-p0018.pdf. [Accessed August 17, 2016].

Johnson, M.J.; Durst, S.L.; Calvo, C.M.; [et al.]. 2008. Yellow-billed Cuckoo distribution, abundance, and habitat use along the lower Colorado River and its tributaries, 2007 Annual Report. U.S. Geological Survey Open-File Report 2008-1177. Reston, VA: U.S. Department of the Interior, U.S. Geological Survey. 274 p. https://pubs.usgs.gov/of/2008/1177. [Accessed August 14, 2016].

Johnson, R.R.; Carothers, S.W. 1987. External threats: The dilemma of resource management on the Colorado River in Grand Canyon National Park, USA. Environmental Management. 11(1): 99-107.

Konrad, C.P. 2010. Monitoring and evaluation of environmental flow prescriptions for five demonstration sites of the Sustainable Rivers Project. U.S. Geological Survey Open-File Report 2010-1065. Reston, VA: U.S. Department of the Interior, U.S. Geological Survey. 22 p. https://pubs.usgs.gov/of/2010/1065/pdf/of20101065.pdf. [Accessed August 14, 2016].

LaRue, E.C. 1916. Colorado River and its utilization. Water-Supply Paper Number 395. Reston, VA: U.S. Department of the Interior, U.S. Geological Survey. 231p. https://pubs.er.usgs.gov/ publication/wsp395. [Accessed August 14, 2016].

Lower Colorado River Multi-Species Conservation Program (LCR MSCP). 2004. Lower Colorado River Multi-Species Conservation Program, Volume II: Habitat Conservation Plan. Final. December 17. (J\&S 00450.00.) Sacramento, CA: Lower Colorado River Multi-Species Conservation Program. 506 p. https://www.lcrmscp.gov/publications/hcp_volii_dec04.pdf. [Accessed August 14, 2016]. 
Lower Colorado River Multi-Species Conservation Program (LCR MSCP). 2012. Laguna Division Conservation Area Restoration Development and Monitoring Plan. Boulder City, NV: Bureau of Reclamation. 32 p. http://www.lcrmscp.gov/reports/2011/e27_laguna_dev_ mon_plan_aug12.pdf. [Accessed August 14, 2016].

McLeod, M.A.; Koronkiewicz, T.J.; Brown, B.T.; [et al.]. 2008. Southwestern willow flycatcher surveys, demography, and ecology along the lower Colorado River and tributaries, 2003-2007. Five-year summary report. SWCA Project No. 6595-133. Flagstaff, AZ: SWCA Environmental Consultants. 206 p. https://www.lcrmscp.gov/reports/2008/d2_5yr_03-07_ mar08.pdf. [Accessed August 12, 2016].

McLeod, M.A.; Pellegrini, A.R. 2013. Southwestern Willow Flycatcher surveys, demography, and ecology along the lower Colorado River and tributaries, 2008-2012. Summary report. Flagstaff, AZ: SWCA Environmental Consultants. 341 p. http://www.lcrmscp.gov/ reports/2012/d2_sumrep_08-12.pdf. [Accessed August 14, 2016].

Morris, G.M.; Kline, C.; Morris, S.M. 2015. Status of Denaus plexippus population in Arizona. Journal of the Lepidopterists' Society. 69(2): 91-107.

Nelson, S.M.; Anderson, D.C. 1999. Butterfly (Pappilionoidea and Hesperioidea) assemblages associated with natural, exotic, and restored riparian habitats along the lower Colorado River, USA. Regulated River Research and Management. 15(6): 485-504.

Owen-Joyce, S.J. 1987. Estimates of average annual tributary inflow to the lower Colorado River, Hoover Dam to Mexico. Water-Resources Investigations Report 87-4078. Reston, VA: U.S. Department of the Interior, U.S. Geological Survey. 1 sheet. http://pubs.usgs.gov/ wri/1987/4078/report.pdf. [Accessed August 14, 2016].

Reynolds, L.V.; Shafroth, P.B.; House, P.K. 2014. Abandoned floodplain plant communities along a regulated dryland river. River Research and Applications. 30(9): 1084-1098.

Salazar, K. 2012. Memorandum: Report and recommendations from the Glen Canyon Dam Adaptive Management Work Group Federal advisory committee meeting, February 22-23, 2012. Washington, DC: U.S. Department of the Interior. 58 p. http://www.usbr.gov/uc/rm/ amp/amwg/pdfs/recltr_12April30.pdf. [Accessed August 12, 2016].

Sankey, J.B.; Ralston, B.E.; Grams, P.E.; [et al.]. 2015. Riparian vegetation, Colorado River, and climate: Five decades of spatiotemporal dynamics in the Grand Canyon with river regulation. Journal of Geophysical Research: Biogeosciences. 120(8): 1532-1547.

Shafroth, P.B.; Stromberg, J.C.; Patten, D.T. 2000. Woody riparian vegetation response to different alluvial water table regimes. Western North American Naturalist. 60(1): 66-76.

Shafroth, P.B.; Beauchamp, V.B. 2006. Defining ecosystem flow requirements for the Bill Williams River, Arizona. U.S. Geological Survey Open File Report 2006-1314. Reston, VA: U.S. Department of the Interior, U.S. Geological Survey. 135 p. http://www.fort.usgs.gov/ products/publications/21745/21745.pdf. [Accessed August 14, 2016].

Shafroth, P.B.; Wilcox, A. C.; Lytle, D.A.; [et al.]. 2010. Ecosystem effects of environmental flows: Modelling and experimental floods in a dryland river. Freshwater Biology. 55(1): 68-85.

Stromberg, J.C.; Patten, D.T.; Richter, B.D. 1991. Flood flows and dynamics of Sonoran riparian forests. Rivers. 2(3): 221-235.

Stromberg, J.C.; Shafroth, P.B.; Hazelton, A.F. 2012. Legacies of flood reduction on a dryland river. River Research and Applications. 28(2): 143-159.

Topping, D. J.; Schmidt, J.C.; Vierra, L.E., Jr. 2003. Computation and analysis of the instantaneous-discharge record for the Colorado River at Lees Ferry, Arizona-May 8, 1921, through September 30, 2000. U.S. Geological Survey Professional Paper 1677. Reston, VA: U.S. Department of the Interior, U.S. Geological Survey. 118 p. http://pubs.usgs.gov/pp/ pp1677/pdf/pp1677.pdf. [Accessed August 14, 2016] 
Tracy, D.; McNeil, S.E. 2016. Yellow-billed cuckoo surveys and population monitoring on the Lower Colorado River and tributaries, 2015 annual report. Boulder City, NV: U.S. Deparment of the Interior, Bureau of Reclamation, Lower Colorado River Multi-Species Conservation Program. 83 p. http://www.lcrmscp.gov/reports/2015/d7_annrep_2015.pdf. [Accessed August 14, 2016].

Wallace, C.S.A.; Villareal, M.L.; van Riper, C., III. 2013. Influence of monsoon-related riparian phenology on yellow-billed cuckoo habitat selection in Arizona. Journal of Biogeography. 40(11): 2094-2107.

Werner, W.E. 2006. Managing conflict through conservation: The Lower Colorado River multispecies conservation program. In: Zimbelman, D.; Loehlein, W.C., eds. Operating reservoirs in changing conditions. Reston, VA: American Society of Civil Engineers: 176-185.

Werner, W.E. 2010. Ecosystem restoration-Alamo Lake and the Bill Williams River. In: Melis, T.S.; Hamill, J.F.; Bennett, G.E.; [et al.], eds. Proceedings of the Colorado River Basin science and resource management symposium; 2008 November 18-20; Scottsdale, AZ. U.S. Geological Survey Scientific Investigations Report 2010-5135. Reston, VA: U.S. Department of the Interior, U.S. Geological Survey. 6 p. http://pubs.usgs.gov/sir/2010/5135/. [Accessed August 14, 2016].

Wiele, S.M.; Hart, R.J.; Darling, H.L.; Hautzinger, A.B. 2009. Sediment transport in the Bill Williams River and turbidity in Lake Havasu during and following two high releases from Alamo Dam, Arizona, in 2005 and 2006. U.S. Geological Survey Scientific Investigations Report 2009-5195. Reston, VA: U.S. Department of the Interior, U.S. Geological Survey. 22 p. http://pubs.usgs.gov/sir/2009/5195/. [Accessed August 14, 2016].

Wiele, S.M.; Macy, J.P.; Darling, H.L.; [et al.]. 2011. Discharge and sediment concentration in the Bill Williams River and turbidity in Lake Havasu during and following high releases from Alamo Dam, Arizona, in March and April 2010. U.S. Geological Survey Open-File Report 2011-1129. Reston, VA: U.S. Department of the Interior, U.S. Geological Survey. 10 p. http:// pubs.usgs.gov/of/2011/1129. [Accessed August 14, 2016].

Wilson, R.P.; Owen-Joyce, S.J. 2002. Hydrologic conditions in the Bill Williams River National Wildlife Refuge and Planet Valley, Arizona, 2000. Water-Resources Investigations Report 2002-4214. Reston, VA: U.S. Department of the Interior, U.S. Geological Survey. 16 p. https://pubs.er.usgs.gov/publication/wri024214. [Accessed August 14, 2016].

Wilcox, A.C.; Shafroth, P.B. 2013. Coupled hydrogeomorphic and woody-seedling responses to controlled flood releases in a dryland river. Water Resources Research. 49(5): 2843-2860.

Wirt, L.; Van Metre, P.C.; Favor, B. 1991. Historical water quality data, Puerco River Basin, Arizona and New Mexico. U.S. Geological Survey Open-File Report 91-196. Reston, VA: U.S. Department of the Interior, U.S. Geological Survey. 339 p. https://pubs.er.usgs.gov/ publication/ofr91196. [Accessed August 14, 2016].

Wolcott, H.N.; Skibitzke, H.E.; Halpenny, L.C. 1956. Water resources of Bill Williams River Valley near Alamo, Arizona. Geological Survey Water Supply 1360-D. Reston, VA: U.S. Department of the Interior, U.S. Geological Survey. 319 p. http://pubs.usgs.gov/wsp/1360d/ report.pdf. [Accessed August 14, 2016]. 


\title{
Chapter 9. Evaluating Riparian Vegetation Change in Canyon-Bound Reaches of the Colorado River Using Spatially Extensive Matched Photo Sets
}

\author{
Michael L. Scott, Robert H. Webb, R. Roy Johnson, Raymond M. Turner, \\ Jonathan M. Friedman, and Helen C. Fairley
}

\section{Introduction}

Much of what we know about the functional ecology of aquatic and riparian ecosystems comes from work on regulated rivers (Johnson et al. 2012). What little we know about unregulated conditions on many of our larger rivers is often inferred from recollections of individuals, personal diaries, notes, maps, and collections from early scientific surveys (Webb et al. 2007) and from repeat photography (Turner and Karpiscak 1980; Webb 1996). Later surveys often included photographs typically taken at specific and relatively few locations. Because rivers and their related riparian ecosystems vary in both longitudinal and lateral dimensions, such records provide relatively general and incomplete information about historical resource conditions, especially at large spatial scales and over long spans of time.

Pre-development conditions have been more extensively documented along the canyon-bound sections of the Colorado River than along any other river in the western United States (Powell 1961; Smith and Crampton 1987; Wheeler 1872). Unique to this reach of the Colorado River are the existence of photographs taken systematically by the Stanton expedition of 1889-1890 as part of a survey for the route of a railway through the canyons of the Colorado and matched originally in the 1990s (Webb 1996). This work includes a total of 445 photographs, which were taken between what is now Glen Canyon Dam and the upper end of Lake Mead, a distance of 485 river kilometers (rkms). The unparalleled spatial coverage of these photos provides a broad-scale and comprehensive visual record of pre-development conditions along this reach of the Colorado River. As such, this photographic record has and may continue to serve as a basis for monitoring change in the condition of desert and riparian resources in these remote canyons (Webb et al. 2011).

In this investigation, based on both original matches made in the 1990s and a second set taken between 2010 and 2012, repeat photography in Grand Canyon was used to detect and evaluate changes in riparian vegetation over time, relative to distinct changes in flow regime downstream of Glen Canyon Dam in Glen, Marble, and Grand Canyons (fig. 26). All Stanton original photographs are from the National Archives and are public domain. All the matches were done by USGS and are public domain. Our analyses are compatible with evaluations based on aerial imagery (Sankey et al. 2015) with the additional benefit of species-specific assessments. We evaluated change in riparian vegetation relative to earlier descriptions of change and predictions of future condition following completion of Glen Canyon Dam (Johnson 1991; Turner and Karpiscak 1980; Webb 1996). Finally, we examine on-the-ground response of riparian vegetation in 


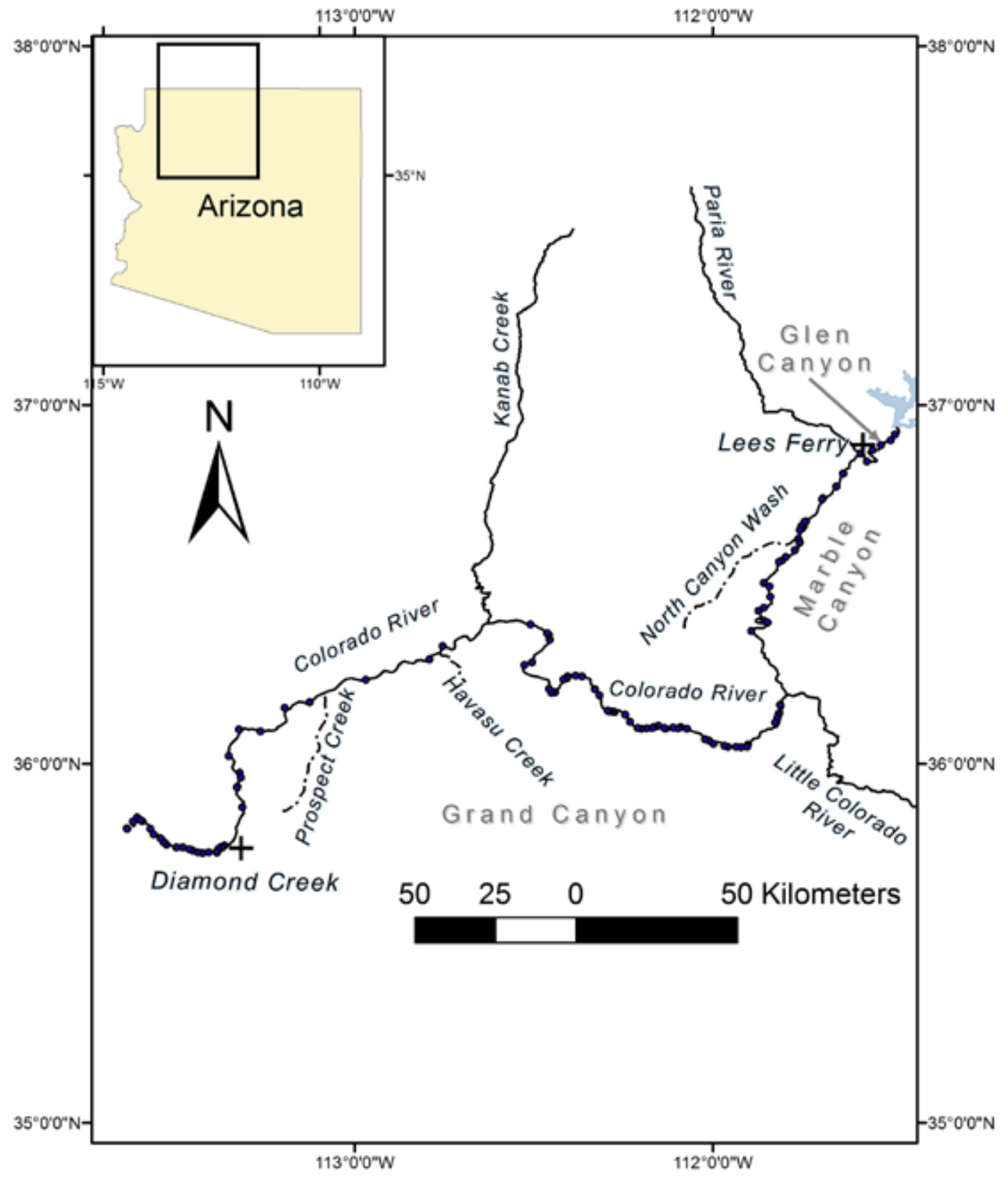

Figure 26-Study area map, including 25 river kilometers of Glen Canyon between Glen Canyon Dam and Lees Ferry (cross). Marble Canyon extends from the Paria River to the Little Colorado River and Grand Canyon, from the Little Colorado River to approximately 50 river kilometers below Diamond Creek (cross). The solid circles are locations of the 160 original Stanton Expedition photos matched and analyzed for this study (figure by M.L. Scott).

relation to recent work that explicitly links flow and climate variables to riparian vegetation change at a broader scale in the post-dam era (Sankey et al. 2015).

\section{Hydrologic and Climatic Context}

Pattern in the occurrence, composition, and productivity of riparian vegetation is structured by transverse (lateral) and longitudinal physical gradients related to the river. Transverse gradients, particularly in arid regions and along physically constrained channels, change sharply over relatively short distances, and riparian vegetation is 
Figure 27-Annual peak discharge, in cubic meters per second, for the period of record at the Lees Ferry gage (U.S. Geological Survey gage 09380000). Horizontal lines and associated values indicate the average 2-year return peak flow for the pre-dam and two post-dam periods. Discharge estimated. Relatively wet or dry periods, based on regional precipitation, are indicated. of the 1884 flood was

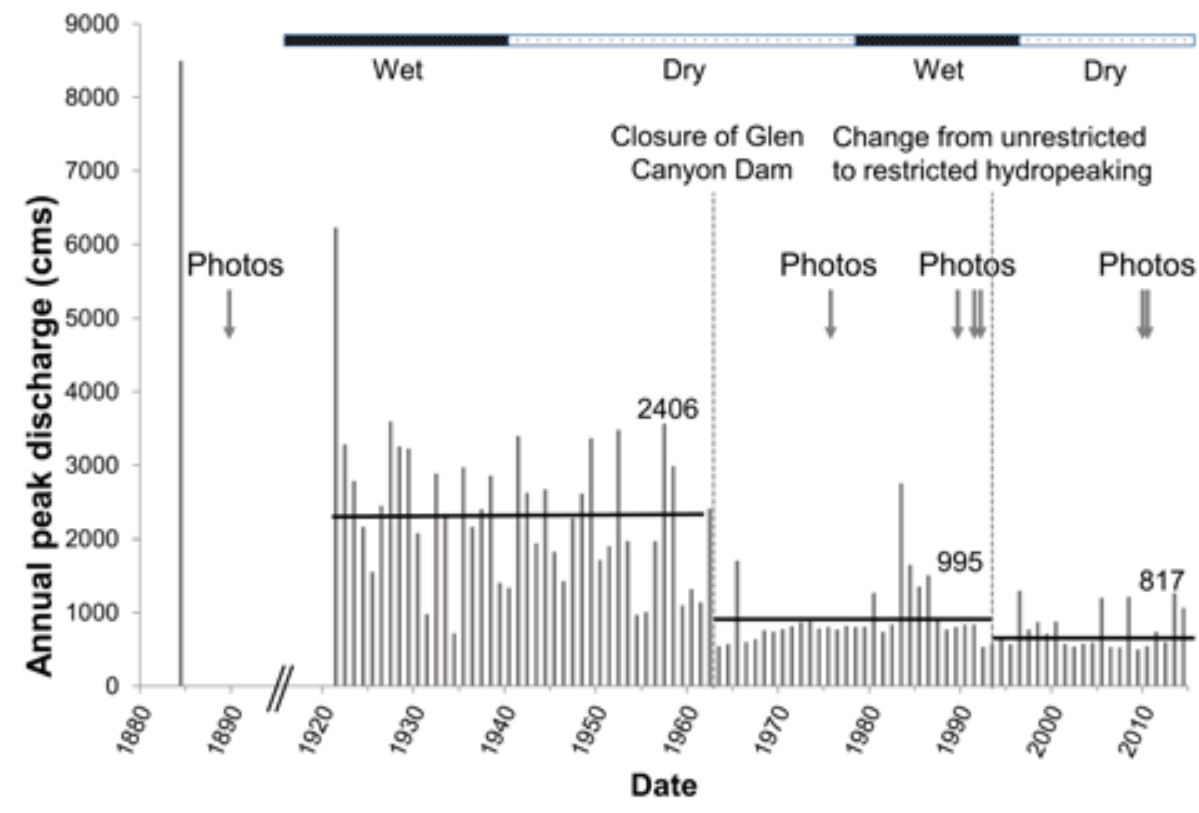

primarily arrayed along a hydrologic gradient (Friedman et al. 2006). Variation in riparian vegetation away from the channel correlates with several interrelated factors that include decreasing fluvial disturbance and inundation (Auble et al. 1994, 2005), change in fluvial landforms (Hupp and Osterkamp 1985), groundwater availability (Webb and Leake 2006), and increasing drought stress (Zimmerman 1969). Longitudinal gradients range from the scale of local hydrologic controls like debris fans to the watershed, where along most western rivers, factors such as temperature, discharge, and floodplain area tend to increase predictably in the downstream direction (Ward et al. 2002).

Streamflow and sediment transport in the Grand Canyon were completely altered by construction of Glen Canyon Dam. Paleoflood records near Lees Ferry, spanning the past 4,500 years, indicate that prior to the dam, the long-term discharge of a common flood (2-year recurrence interval) was 2,133 cubic meters per second (cms) or 75,326 cubic feet per second (cfs) (O'Connor et al. 1994). More recent estimates give a revised value of 2,406 cms (85,000 cfs) for the 2-year return flood (Topping et al. 2003; fig. 27). The post-dam period includes two contrasting periods of stream discharge, primarily the result of changing reservoir operations. From 1963 to 1993, Glen Canyon Dam released water in response to power demands (hydropeaking) with daily highs as high as $878 \mathrm{cms}(31,005 \mathrm{cfs})$ and lows averaging $140 \mathrm{cms}(4,944 \mathrm{cfs})$. This period also featured three large, long-duration floods in 1983, 1984, and 1986 (fig. 28). From 1993 to the present, hydropeaking releases were limited to a narrower range of high and low flows (US DOI 1996) and six, short duration, high-flow experiments occurred in 1996 (Collier et al. 1997; Webb et al. 1999), 2004, 2008, 2012, 2013, and 2014 (Grams et al. 2015; fig. 28).

\section{Riparian Vegetation in the Grand Canyon}

Understanding riparian vegetation in the canyons of the Colorado River begins with the dynamics and distribution of fine-grained sediment. The most conspicuous pre-dam riparian vegetation, termed the old high-water zone (Johnson 1991), consisted of discontinuous bands of woody plants associated with alluvial deposits emplaced by 


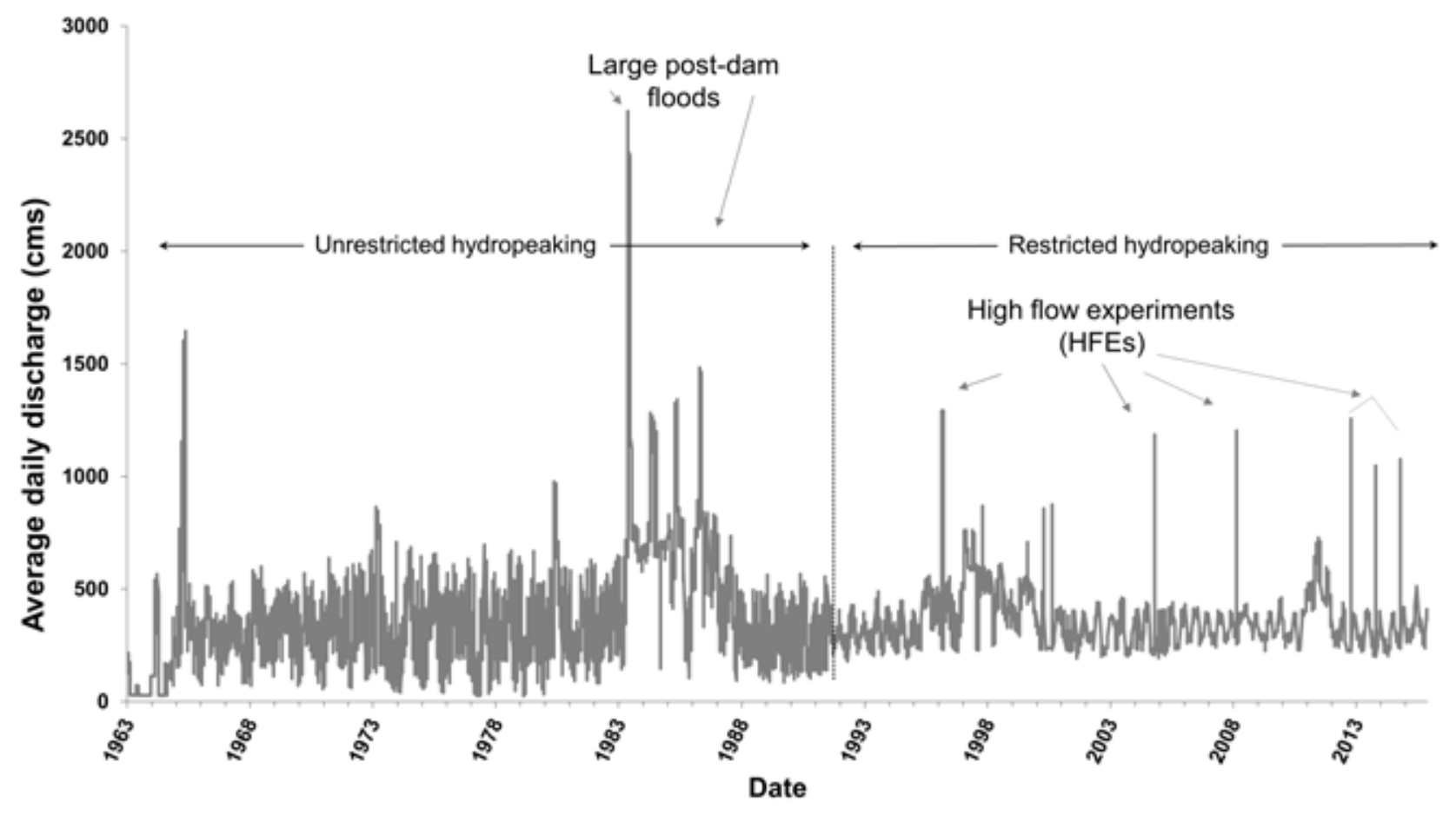

Figure 28-Average daily discharge at Lees Ferry for the post-dam period. The effects of two different hydropower peaking release patterns on peak and base flows are evident, as are the series of large, long-duration floods in the mid-1980s. Three short duration, high flow experiments occurred in 1996, 2004, and 2008, followed by three high flow experiments in 2012, 2013, and 2014.

relatively common pre-dam floods up to $2,800 \mathrm{cms}$. The vegetation in this zone consists of an ensemble of species whose composition shifts upstream to downstream. Netleaf hackberry (Celtis reticulata) is a common tree of this zone through Cataract, Glen, and Marble Canyons. The old high-water zone in Marble Canyon (fig. 26) includes Redbud (Cercis orbiculata) and Apache plume (Fallugia paradoxa), a shrub, present to about river kilometer (rkm) 65. Below rkm 65 and where the canyon widens, catclaw acacia (Acacia greggii) and honey mesquite (Prosopis glandulosa) dominate this zone. Throughout most of their range, neither of these warm desert species is restricted to riparian habitats, but in the Grand Canyon, mesquite is an obligate riparian species and is limited to alluvial terraces and talus slopes adjacent to the river (Warren et al. 1982). Honey mesquite is largely absent in the narrow inner gorges ( $\sim \mathrm{rkm} 120-270)$ where alluvial terraces are rare and the old high-water zone is absent or discontinuous. Here, catclaw grows along the canyon walls and on talus slopes. Below rkm 270, mesquite reappears and becomes abundant on alluvial deposits (Anderson and Ruffner 1987).

The species in the old high-water zone are largely native and have been termed facultative riparian species (Johnson and Lowe 1985) and with the exception of honey mesquite, they do not strictly require riverine disturbance or moisture subsidies to establish and persist. However, species like catclaw reach their greatest densities and sizes along tributaries or in the main canyons, within influence of the river (Anderson and Ruffner 1987). In the case of honey mesquite in Grand Canyon, and other riparian settings, flooding likely serves as an important agent in seed dispersal and germination (Stromberg 1993). 
To establish and persist, early successional, woody riparian plants require bare, moist, and typically fine-grained alluvium that remains relatively safe from subsequent fluvial disturbance (McBride and Strahan 1984; Scott et al. 1997). Pre-dam photographs (Turner and Karpiscak 1980; Webb 1996) and systematic plant collections (Clover and Jotter 1944) in the canyons of the Colorado River suggest that these conditions were infrequently met. Canyon width and the occurrence of debris fans provide the primary structural controls on fine sediment deposition in these canyons (Howard and Dolan 1981; Schmidt 1990). Most fine-grained alluvial surfaces below the high flood line occurred as eddy sand bars and discontinuous channel margin deposits associated with debris-fan channel constrictions. These surfaces, particularly in narrow canyon settings, were apparently reworked frequently enough by pre-dam flows that they were largely devoid of vegetation.

Species, including sandbar willow (Salix exigua), seep-willows (Baccharis emoryi and B. salicifolia), Fremont cottonwood (Populus fremontii), and arrow-weed (Pluchea sericea), are riparian obligates, requiring connection with the river for moisture throughout the growing season. These and other obligate riparian species were found at the mouths of or upstream on some of the perennial tributaries or in wider canyon reaches like Lees Ferry (Clover and Jotter 1944). In western Grand Canyon, where wider canyon reaches allow for reduced flood power and more extensive deposition of fine sediment (Schmidt and Grams 2011), riparian trees survived in some locations. A Fremont cottonwood tree can be seen below the high-water line at rkm 313.6 in a 1923 photo (Turner and Karpiscak 1980). Clover and Jotter (1944) note the occurrence of large tree willows (Salix gooddingii), which also can be seen in pre-dam photos from Granite Park (Turner and Karpiscak 1980) and other locations in western Grand Canyon as documented in written records (Webb 2005) and photos. As with species in the old high-water zone, some obligate riparian species show longitudinal trends in occurrence. For example, desert broom (Baccharis sarothroides) first appears around rkm 200 and becomes very common below National Canyon. In the late 1930s, the nonnative riparian tree tamarisk (Tamarix ramosissima) was reported to be relatively common from Green River, Utah, to the confluence of the Colorado River. It also was common in the approaches to Cataract Canyon, in wide reaches of Glen Canyon, and downstream from Grand Canyon. It was found above and at Lees Ferry but reported only below Vaseys Paradise and at the mouth of Saddle Canyon in Marble Canyon. In lower Grand Canyon, it was found above Lava Falls, near the mouth of Spring Canyon and at Separation Rapid (Clover and Jotter 1944; Webb 2005).

The closing of Glen Canyon Dam in March 1963 fundamentally altered the downstream aquatic and riparian ecosystems in Glen, Marble, and Grand Canyons (Dolan et al. 1974; Johnson et al. 1977; Johnson 1987). The pre-dam floods that reworked alluvial sediments were abruptly reduced (fig. 27), as was the annual pulse of fine sediment, by approximately 80 percent, which came from the Colorado River watershed upstream of Lees Ferry (Topping et al. 2000; Rubin et al. 2002). Riparian vegetation along the former high flood line was disconnected from the river and formerly active channel bedforms suddenly became ideal sites for successful establishment of riparian vegetation, both native and nonnative. 
Accounts in the late 1960s by P.S. Martin (as cited in Johnson 1991 and Webb 1996) attest to the "explosive spread" of tamarisk through Grand Canyon. No doubt there was competition among tamarisk and various native riparian species including sandbar willow, Goodding's willow, Fremont cottonwood, and several shrub species that rapidly colonized newly available establishment sites (Webb 1996). Photos from the mid-1970s show the encroachment of dense stands of riparian vegetation onto formerly scoured alluvial surfaces (Turner and Karpiscak 1980; Webb 1996). Although many newly established stands of riparian vegetation were dominated by tamarisk, mixed stands of tamarisk, sandbar willow, and seep-willow also were present. In certain settings, riverine marsh vegetation became established (Stevens et al. 1995). As has been documented downstream of dams on other rivers (Williams and Wolman 1984), the channel of the Colorado River canyons below Glen Canyon Dam narrowed. The rapid establishment of riparian vegetation created new habitat for a variety of wildlife species, including birds (Willson and Carothers 1979). These dramatic transformations in downstream aquatic and riparian ecosystems, coupled with rapidly escalating human use of the river corridor, raised concerns (Dolan et al. 1974). Efforts were soon underway to understand the nature of these changes with the hope that improved understanding would lead to anticipation of future change and improved resource management in Grand Canyon National Park immediately downstream of Glen Canyon Dam (Johnson 1991; Schmidt et al. 1998).

\section{First Predictions of Change}

After completion of Glen Canyon Dam, Turner and Karpiscak (1980) matched photos taken before the dam with those taken in the early to mid-1970s. The most striking change was the widespread and rapid establishment of new riparian plant assemblages. Dense stands were often dominated by tamarisk but included many native riparian and riverine marsh species. They speculated that the new riparian community was still assembling and, based on the recent spread of camelthorn (Alhagi maurorum) from the Little Colorado River and observed occurrences of both Russian olive (Elaeagnus angustifolia) and Siberian elm (Ulmus pumila), predicted an increased importance for these nonnative species in the riparian vegetation community.

Turner and Karpiscak (1980) observed local declines in the density of plants in the old high-water zone. Based on the fact that flooding would no longer directly inundate these zones, they predicted a more generalized decline of species from the old high-water zone. At the same time, they noted species like catclaw and honey mesquite establishing with tamarisk and sandbar willow in the newly established riparian communities and predicted that they would become a minor but important component of the post-dam riparian community known as the "new high-water zone." Finally, they concluded that prediction of future conditions was not possible given the apparent rapid flux in the new riparian communities and key unknowns like streamflow, which was now determined by power and water-supply demands, as well as water availability. Acknowledging the unpredictability of regional climate, they pointed to the possible effects of drought and excess moisture on release patterns from the dam and the effects of prolonged low flows or inundation on the newly formed communities. Only the passage of time would refine our understanding of these relationships. 
Following the largest post-dam floods on record in the mid-1980s (figs. 27 and 28), Stevens and Waring (1985) recorded high mortality in the new high-water zone riparian vegetation. They also noted significant differences in post-flood establishment. Tamarisk was five times more abundant than any other species on reworked flood surfaces, and clonal species like arrow-weed, sandbar willow, and common reed (Phragmites australis) rapidly colonized disturbed surfaces. They suggested that given different mortality rates and colonization patterns across species, longer-term compositional shifts in riparian vegetation were likely to result from large, long-duration post-dam floods. These results illustrate the points made earlier by Turner and Karpiscak (1980) that only by understanding the response of the new riparian ecosystem to the range of possible postdam flows over time can we begin to predict future conditions.

From 1989-1992, Webb (1996) matched all of the 445 original Stanton expedition photos from 1889-1890 in what remained of Glen Canyon as well as Marble and Grand Canyons. Among other things, Webb's work with his colleagues provides a spatially comprehensive and quantitative assessment of change in riparian vegetation against pre-dam conditions and serves to evaluate trends detected by Turner and Karpiscak (1980) 20 years earlier. Despite high mortality recorded for riparian vegetation in 19831984 below the 1,400 cms (49,440 cfs) stage, these photos document the pervasive presence of post-dam riparian vegetation assemblages in the new high-water zone, including stands of riverine marsh habitat in wider canyon settings (Stevens et al. 1995). Vegetation was sparse only in settings where currents were swift and there was limited availability of fine sediment (Webb 1996). He argues that the rapid spread of tamarisk following dam closure was facilitated by source populations in major tributaries where it had long been established (Clover and Jotter 1944; Dodge 1936). However, Stevens (1989) observed that sandbar willow's ability to spread from root sprouts could ultimately lead to a gradual replacement of tamarisk by willow in the post-dam setting.

Establishment of old high-water zone species like honey mesquite and catclaw in the new high-water zone, noted by Turner and Karpiscak (1980), was confirmed by Webb (1996). He also documented the loss of desert broom from the old high-water community and new occurrences in the new high-water zone in the lower canyon. Because of relatively slow establishment and growth rates of species like honey mesquite and catclaw, mature stands of these trees in the new riparian assemblage could take decades to develop (Webb 1996). Finally, Webb found no clear evidence suggesting a decrease in honey mesquite densities in the old high-water zone over the preceding century but noted crown dieback in many individuals.

\section{Methods}

Repeat photography is the art and science of using ground-based photography to match historical images of landscapes. This approach has long been used to qualitatively and quantitatively assess landscape change (Webb et al. 2010), including in Grand Canyon (Turner and Karpiscak 1980; Webb 1996). Repeat photographs where views are a century or even a few decades apart are not suitable for resolving features or processes that respond on shorter time steps. However, the intervals of our photos are appropriate for examining increases in the number or size of long-lived individual plants in the riparian zone like catclaw acacia or changes in the distribution and size of riparian species 
that tend to grow in dense clumps like sandbar willow where individuals are difficult to identify. Our goal was to quantify change in the abundance of key riparian species and the overall cover or biomass of riparian vegetation resulting from long-term, nonperiodic change in streamflow and precipitation.

Photographs produced by the Stanton railroad survey expeditions of 1889 and 1890 through Marble and Grand Canyons were matched in 1989-1992 (Webb 1996). In 2010-2012, all photographs were again matched approximately 20 years following the first match using the same cameras and techniques described in Boyer et al. (2010). At each camera station, plants were identified and changes in riparian vegetation between the original and first matched photos, compared to the present, were interpreted in the field and recorded as annotations on hard copies of those images. High-resolution digital scans of these images were used in conjunction with field annotations to quantify changes in riparian vegetation.

We examined in detail 160 sets of matches for a total of 492 individual photos (an online Appendix table and all photos are available at: http://dx.doi.org/10.5066/ F76W988R). These included eight matched photo sets with additional dates (e.g., 1975 and 1989) that bracketed the high, post-dam flows (1983 to 1986), allowing us to make inferences about riparian vegetation dynamics over shorter time steps and in response to relatively large post-dam flows. We selected this subset of matched photos to analyze because the images generally featured clear views of riparian vegetation along canyonbound portions of the Colorado River through Glen, Marble, and Grand Canyons. Our selected photo points provide a broad representation of physical settings in the canyons examined (fig. 26). We focused our analysis on changes in the number of individuals and cover of key riparian species, which could be reliably identified in the imagery as well as general changes in the cover or biomass of riparian vegetation in the field of view. Change in number of individuals and biomass were assessed visually as a categorical increase, no change, or a decrease. Because the photo match comparisons between 1989-1992 and 2010-2012 were made between leaf-off and leaf-on conditions, changes in state had to be unambiguous and typically involved the loss or addition of individual plants or groups of plants. We include photo matches as figures that illustrate changes in riparian vegetation across a wide range of fluvial geomorphic settings.

\section{Results and Discussion}

Our photographic images fall within three distinct regimes relative to flow regulation in Grand Canyon (fig. 28). The original Stanton photos were from the period of largely unregulated flow prior to construction of Glen Canyon Dam. Photos from the 1970s and 1980s and the first full set of repeat photos (Webb 1996) were taken during the period of unrestricted hydropeaking (figs. 27 and 28). The second set of repeat photos was taken during the period of restricted hydropeaking and prescribed experimental floods (fig. 28). Of note is the fact that the original Stanton photos were taken 5 to 6 years following the occurrence in 1884 of the largest historical flood known on the Colorado River, with an estimated discharge of about 5,946 $\pm 850 \mathrm{cms}$ $(210,000 \pm 30,000 \mathrm{cfs})$ at Lees Ferry (Topping et al. 2003). The views in $1990 \mathrm{oc}-$ curred at the end of a regionally wet period and the 1983 flood with a peak discharge of 2,621 cms $(92,560 \mathrm{cfs})$, whereas the views in 2010-2012 followed a period referred 
Table 8-The percentage and number of photos, for the periods 1989-1992 and 2010-2012, in which tamarisk was present in the matched view. A total of 160 original photos were examined. Categorical state changes in cover (percentage increase, decrease, no change) for all woody riparian vegetation; all native woody riparian species; and all old high waterzone (OHWZ) species, are compared over the period 1989-1992 to 2010-2012, based on the number of views in which the vegetation category occurred $(n)$.

\begin{tabular}{|c|c|c|c|c|c|c|c|c|}
\hline & \multirow[b]{2}{*}{$\begin{array}{c}\text { Tamarisk } \\
\text { presence in } \\
1989-1992 \\
\text { views } \\
(n=160)\end{array}$} & \multirow[b]{2}{*}{$\begin{array}{c}\text { Tamarisk } \\
\text { presence in } \\
2010-2012 \\
\text { views } \\
(n=160)\end{array}$} & \multicolumn{6}{|c|}{$\begin{array}{c}\text { Changes in matched views for the interval: } 1989-1992 \text { to } 2010-2012 \\
\text { (number of views in which the vegetation category occurred) }\end{array}$} \\
\hline & & & $\begin{array}{l}\text { Increase } \\
\text { in woody } \\
\text { riparian } \\
\text { vegetation } \\
(n=159) \\
\end{array}$ & $\begin{array}{c}\text { No change } \\
\text { in woody } \\
\text { riparian } \\
\text { vegetation } \\
(n=159) \\
\end{array}$ & $\begin{array}{c}\text { Increase } \\
\text { in woody } \\
\text { riparian } \\
\text { natives } \\
(n=157) \\
\end{array}$ & $\begin{array}{c}\text { No change } \\
\text { in woody } \\
\text { riparian } \\
\text { natives } \\
(n=157) \\
\end{array}$ & $\begin{array}{c}\text { No change } \\
\text { in OHWZ } \\
\text { species } \\
(\mathbf{n}=\mathbf{4 8}) \\
\end{array}$ & $\begin{array}{c}\text { Decrease } \\
\text { in OHWZ } \\
\text { species } \\
(\mathbf{n}=48) \\
\end{array}$ \\
\hline$\%$ & 79.5 & 96.9 & 89.3 & 9.4 & 87.3 & 11.5 & $43.8^{a}$ & $18.8^{\mathrm{a}}$ \\
\hline $\mathrm{n}$ & 128 & 156 & 142 & 15 & 137 & 18 & 21 & 9 \\
\hline
\end{tabular}

Table 9-The number and percentage of views in which key riparian species increased in cover during the interval: 1989-1992 to 2010-2012. A total of 160 original photos were examined.

\begin{tabular}{cccccc}
\hline & \multicolumn{4}{c}{ Increases in riparian species during the interval: 1989-1992 to 2010-2012 } \\
\cline { 2 - 6 } & Baccharis spp. & Salix exigua & Pluchea sericea & Acacia gregii & Prosopis glandulosa \\
\hline \% & 53.4 & 1.9 & 13 & 10.6 & 6.8 \\
$\mathrm{n}$ & 86 & 3 & 21 & 17 & 11 \\
\hline
\end{tabular}

to as the early 21 st century drought (Woodhouse et al. 2010). Finally, the 2010-2012 views were taken following a controlled flood with a discharge of $1,175 \mathrm{cms}(41,500$ cfs). Results of our photo matches summarizing overall change in riparian vegetation over the past 20 years are presented in table 8 . Corresponding changes for key riparian species are included in table 9. An online Appendix (http://dx.doi.org/10.5066/ F76W988R) provides a table listing information and the interpretation results for each photo station along with all the photos examined.

Turner and Karpiscak (1980) predicted increases in the invasive species Russian olive and Siberian elm along the Lower Colorado River. Such increases have been large elsewhere, and Russian olive is now the fourth-most frequently occurring woody riparian species in the western United States (Friedman et al. 2005). However, neither of these species appeared in our photo matches and only a few Russian olive stems were observed upstream of Lees Ferry in 2011. These species do not appear to have spread. In the case of Russian olive, the National Park Service (NPS) in Grand Canyon began removing Russian olive in the 1990s and continues to remove them when observed (Hahn 2011). The removal efforts by NPS appear to have been successful given the rapid spread of Russian olive along smaller, regional streams like the Escalante River and at Canyon de Chelly, coinciding with a wet episode beginning about 1980 and extending through the 1990s (Reynolds et al. 2014; Webb et al. 2007). 
The original Stanton photos show little or no vegetation below the old high-water zone. These surfaces, particularly in narrow canyon settings, were apparently reworked frequently enough by pre-dam flows that they were largely devoid of vegetation, except in a few protected settings (see figs. 29-33). Turner and Karpiscak (1980) qualitatively described widespread establishment of riparian vegetation on formerly active channel deposits in the mid-1970s below Glen Canyon Dam. By 1973, the greatest increase in vegetated area (up to 20 percent) occurred in those areas of the channel above the $878 \mathrm{cms}$ ( $\sim 31,000 \mathrm{cfs})$ stage, or the maximum hydropower peaking flows, and remained 10 percent or less below this stage (Sankey et al. 2015). As predicted by Turner and Karpiscak (1980), the vegetation established below the old high-water zone following flow regulation was susceptible to removal by subsequent high flows. It would not take long for the effects of flooding and prolonged inundation on the newly formed riparian ecosystem to be realized.

The largest flood in the post-dam record occurred in 1983, resulting from a series of late snow and rainstorms and rapid runoff in the basin. The flood peaked at 2,621 cms (92,560 cfs) and was of unusually long duration. Comparatively large, long-duration floods followed in 1984 and 1986 (fig. 28). Mortality, resulting from physical removal or prolonged inundation, exceeded 45 percent at some locations for tamarisk, honey mesquite, and catclaw, which had established below the $1,700 \mathrm{cms}(\sim 60,000 \mathrm{cfs})$ stage in the new high-water zone (fig. 29). Clonal species like sandbar willow and arrow-weed had lower mortality rates of 7 percent and 33 percent respectively. Shallowly rooted species like the seep-willow (Baccharis spp.) suffered 90 percent mortality (Johnson 1991; Stevens and Waring 1985).

The flooding in 1983-1986 killed or removed up to 10 percent of all riparian vegetation (Waring 1996), particularly at lower river stages (fig. 29), and vegetated cover below 1,274 cms ( $45,000 \mathrm{cfs})$ showed little or no increase over the interval from 1973 to 1984. Presumably, any increases prior to the flood were offset by mortality from the flood (Sankey et al. 2015). Because of species-specific differences in flood mortality and early differences in post-flood reestablishment patterns, Stevens and Waring (1985) suggested that post-dam flooding from 1983 to 1985 had the potential to shift composition in favor of species like tamarisk and catclaw acacia and away from species like seep-willows and longleaf brickellbush (Brickellia longifolia). By the 1990s, tamarisk remained a prominent component of the new riparian assemblage and it appeared in 71 percent of the views of the river corridor taken by Webb (1996).

In August 1991, operating rules for power generation at Glen Canyon Dam changed and maximum releases were limited to $708 \mathrm{cms}$ ( 25,000 cfs) (US DOI 1996; fig. 28) and by 1992 , vegetated cover values above this stage and below the maximum stage of the 1983 flood increased to between 25 and 30 percent. Values remained at about 10 percent below the new hydropower maximum (Sankey et al. 2015). Three short-duration, highflow experiments (HFEs) occurred in 1996, 2004, and 2008 (fig. 28). By 2002, cover had declined in the zone between the maximum HFE flood and the 1983 flood and remained low through 2009. In contrast, cover increased from 5 to 15 percent below the peak stage of the HFE floods, particularly between 2005 and 2009 (Sankey et al. 2015). Our photo matches in 2010-2012 are consistent with the aerial imagery analysis results of Sankey et 
Figure 29-Tamarisk in Glen Canyon (photo 751; online Appendix, http:// dx.doi.org/10.5066/F76W988R). (a) (top) (1889) This downstream view, 11 river kilometers above Lees Ferry, shows a remarkably clear view of fine-grained alluvium draped over talus. Except for a few scattered plants near the top of the bank, the deposit is largely free of vegetation. (b) (bottom) (1975) Within 12 years following closure of Glen Canyon dam, the bank is heavily vegetated with primarily tamarisk and sand-bar willow. The large tamarisk stem, high on the bank, may have established during high flows before the dam. (c) (next page) (1989) Near-shore stands of tamarisk and willow appear to have been removed or killed-back by flooding a few years preceding this view. (d) (next page) (2011) Woody riparian vegetation, including tamarisk, seep-willow, and sand-bar willow, have reestablished near shore and a diversity of grasses, herbs, and small shrubs fill spaces in between. The large tamarisk on the high bank is still alive but has many dead branches in the crown.
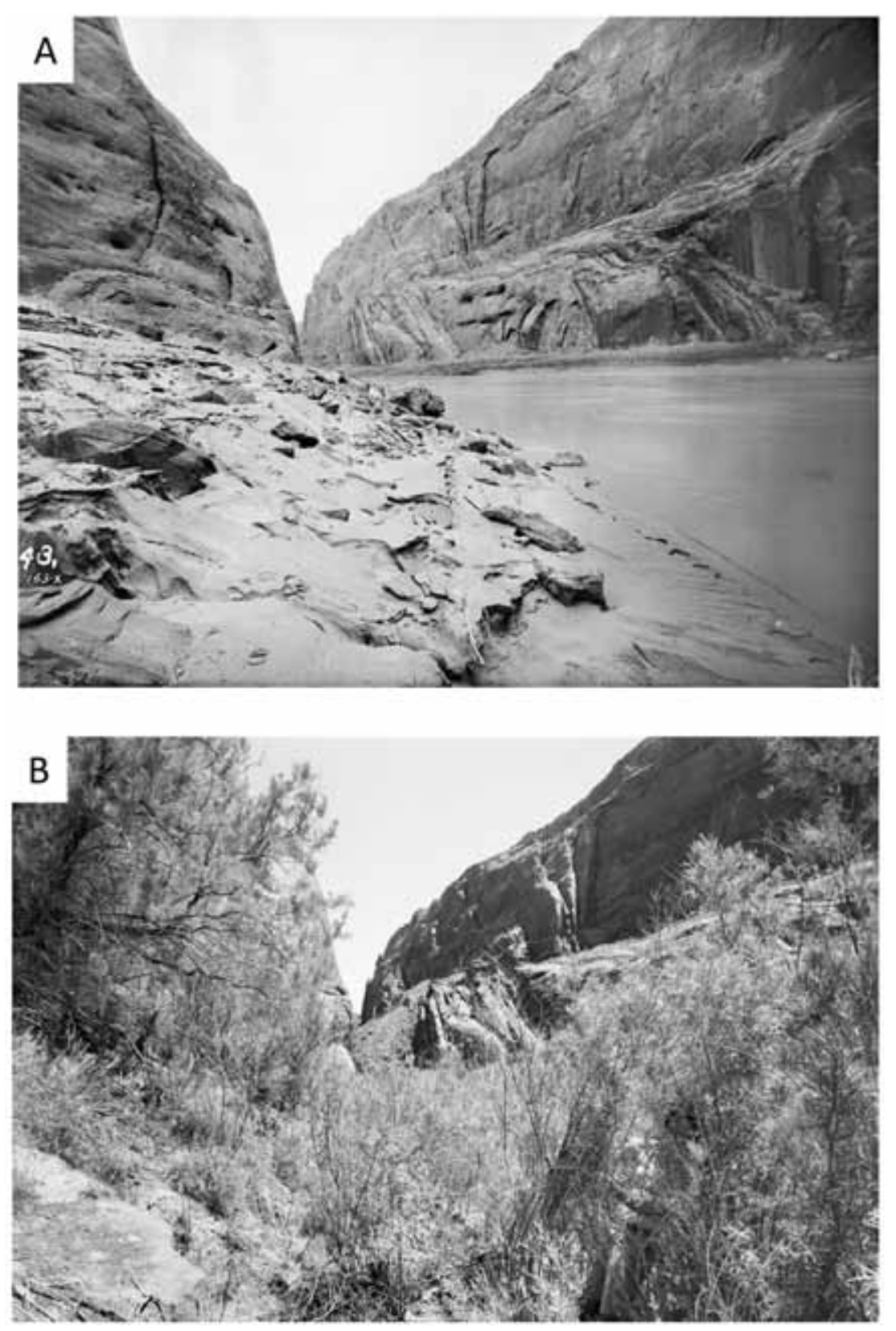

al. (2015) and show increases in riparian vegetation in 90 percent of the views compared with 1989-1992. Tamarisk was present in 79.5 percent of the 1989-1992 views we examined (compared with 71 percent of the total matched population examined by Webb 1996) and increased to a presence of 96.9 percent by 2010-2012 (table 8).

There was no indication that sandbar willow was replacing tamarisk, as it increased in only 1.9 percent of the views (table 9). This contrasts with earlier speculation that sandbar willow might gradually replace tamarisk under the post-dam flow regime (Stevens 1989). Conversely, our data suggest that the recent increases in riparian vegetation at lower stages reported by Sankey et al. (2015) involve a number of other native species such as seep-willow. Overall, native woody species increased in 87.3 percent of our views, with seep-willow increasing in 53.4 percent of the views over the past 20 years (tables 8 and 9). Seep-willow suffered high flood mortality in the mid-1980s and had lower representation in 1990 matched photos. Much of the increase in tamarisk, seep-willow, and arrow-weed 

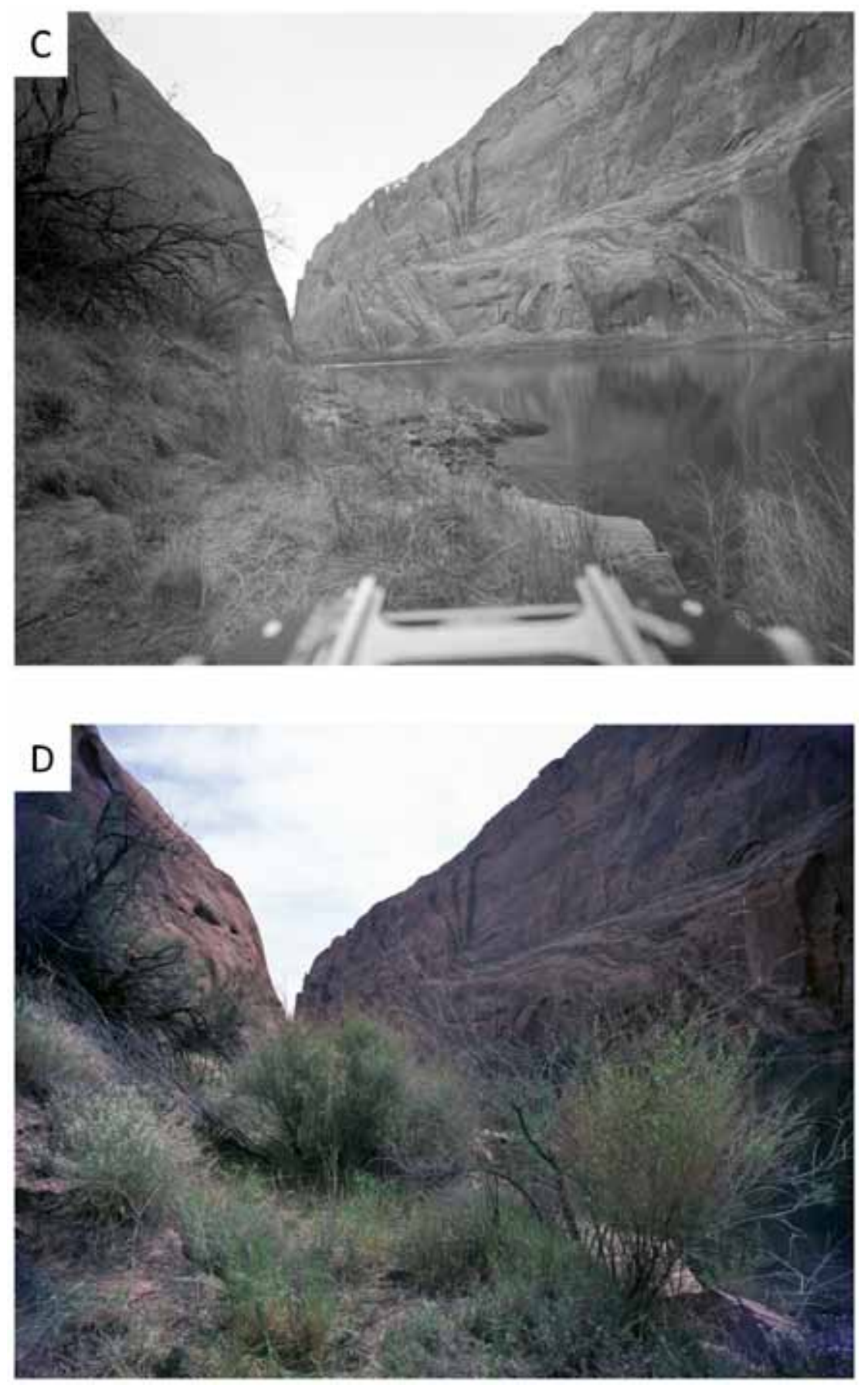

occurred in near-shore locations (figs. 30 and 31). Sankey et al. (2015) found that vegetation expansion into lower elevations of the riparian zone occurred during periods when peak flows were lower and base flows higher and when inundation duration fell below about 5 percent.

Any role that HFEs (fig. 28) may have played in the recent encroachment of riparian vegetation is unclear. A more explicit linkage between the increase in native and nonnative woody shrubs and specific flow events is difficult to make without much shorter time steps between photo matches that tightly bracket the events. Data presented by Sankey et al. (2015) suggest an increase in near-shore vegetation sometime between 2005 and 2009 (see his figure 6). However, whether this was an event-specific response 
Figure 30-Channel narrowing in Marble Canyon (photo 2526; online Appendix, http://dx.doi.org/10.5066/ F76W988R).

(a) (top) (1889) View upstream into still water from the upstream edge of the South Canyon debris fan (river kilometer 51). A channel margin deposit of fine alluvium along the near wall is devoid of vegetation and is marked by a series of flow recession lines. (b) (bottom) (1992) The channel margin deposit has expanded and is now stabilized by tamarisk, sandbar willows and grasses. Leafless, small stems of what may be sand-bar willow or tamarisk grow along the edge of a secondary channel adjacent to a cobble bar with small tamarisk lining the stream ward edge. (c) (next page) (2010) A dense stand of tamarisk, sand-bar willow, and seep-willow now flank the narrowing secondary channel and the cobble bar is largely covered by vegetation and fine sediment.
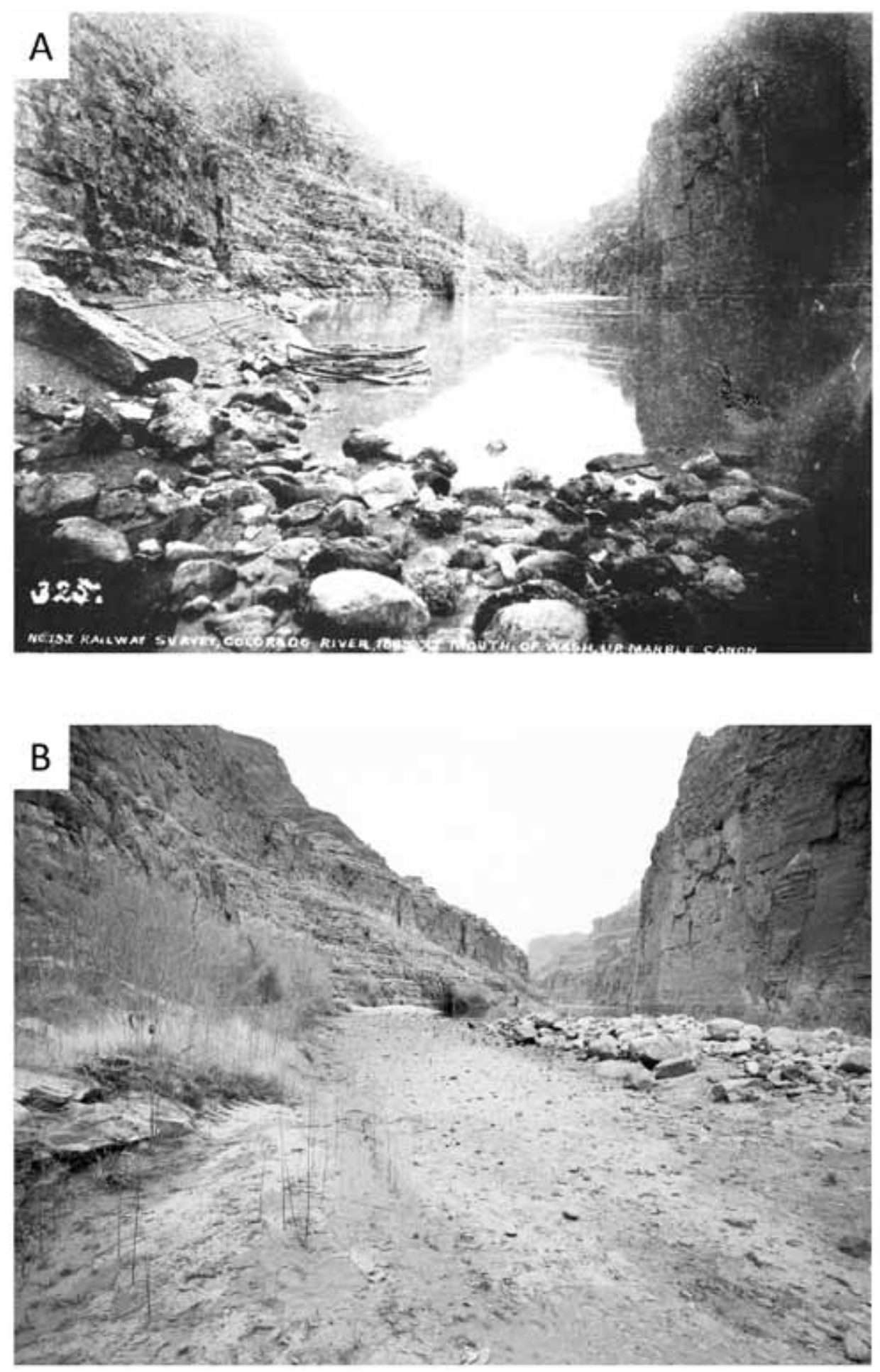

to the $2008 \mathrm{HFE}$ or simply subtle shifts in inundation duration during the period can only be answered by detailed vegetation monitoring in real time or by aging encroaching vegetation retrospectively.

The Glen Canyon Dam Adaptive Management Program (www.gcdamp.gov) conducted three HFEs in 1996, 2004, and 2008. Results from the 1996 and 2008 HFEs indicate that some near-shore wetland plants were removed by these flows and woody riparian plants were buried by sediment, which temporarily reduced vegetation cover. Losses, however, were short-lived (12 months or less). Recovery favored 


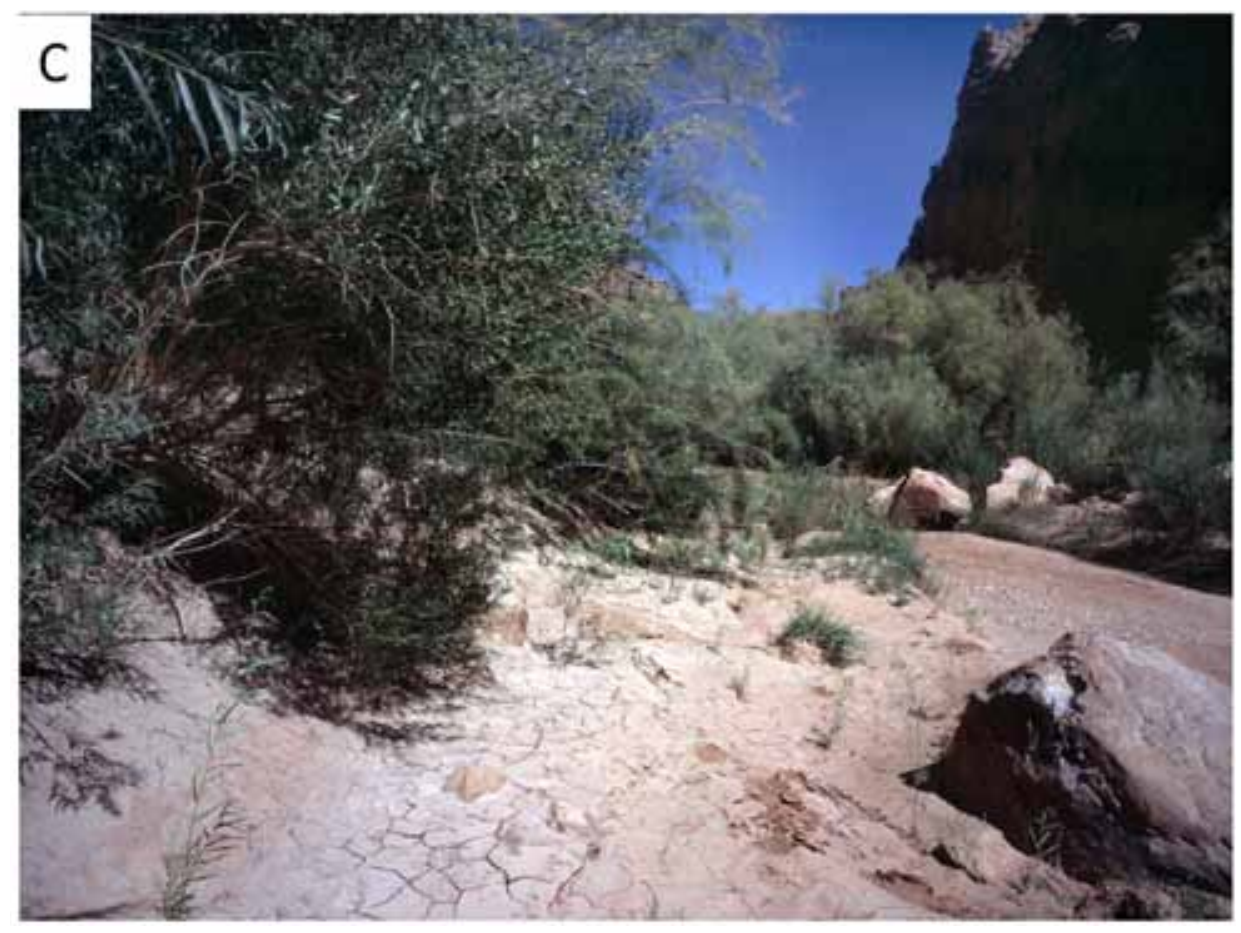

woody and herbaceous species that were able to reproduce vegetatively, like sandbar willow. Because the timing of these flows occurred predominantly before the seed dispersal window for tamarisk, the establishment of this species following the releases was comparatively low (Kennedy and Ralston 2011). Strategies for subsequent HFEs have focused on building and maintaining sandbars from tributary-derived sand and balancing the effects of releases in order to limit competition between nonnative trout (Oncorhynchus mykiss) and native humpback chub (Gila cypha) populations (Wright and Kennedy 2011). The timing of HFEs, which is largely driven by sediment inputs from tributary sources and competitive interactions between fish, could have important implications for riparian plant species that reproduce by seed. This is especially true for woody riparian pioneer species like native cottonwood, willow, and nonnative tamarisk. Because these species have partially non-overlapping seed dispersal periods, subtle differences in flood timing within these seed release periods can have profound influences on the composition of newly established seedling cohorts (Shafroth et al. 2010). Continued monitoring of wetland and riparian vegetation relative to HFEs is important to understanding ecosystem level responses to flow management in the Grand Canyon.

Only $\sim 1$ percent of the views showed a decrease in woody native riparian species, whereas 11.5 percent of the views showed no change in cover and density of these species (table 8). The images reveal that in certain narrow canyon settings, shear stresses are likely to remain high enough under the current flow regime to preclude colonization and persistence of native riparian vegetation (fig. 32). Thus, unless the flow regime changes in the future, certain channel locations should remain free of persistent vegetation. Finally, catclaw acacia and honey mesquite increased in the new high-water zone in 10.6 percent and 6.8 percent of our views, respectively (table 9). For both species, this pattern was especially pronounced beginning at about rkm 105 and some stands are now several meters tall (fig. 33). The widespread occurrence of tamarisk, honey mesquite, catclaw acacia, and a number of other native and nonnative riparian plants in 

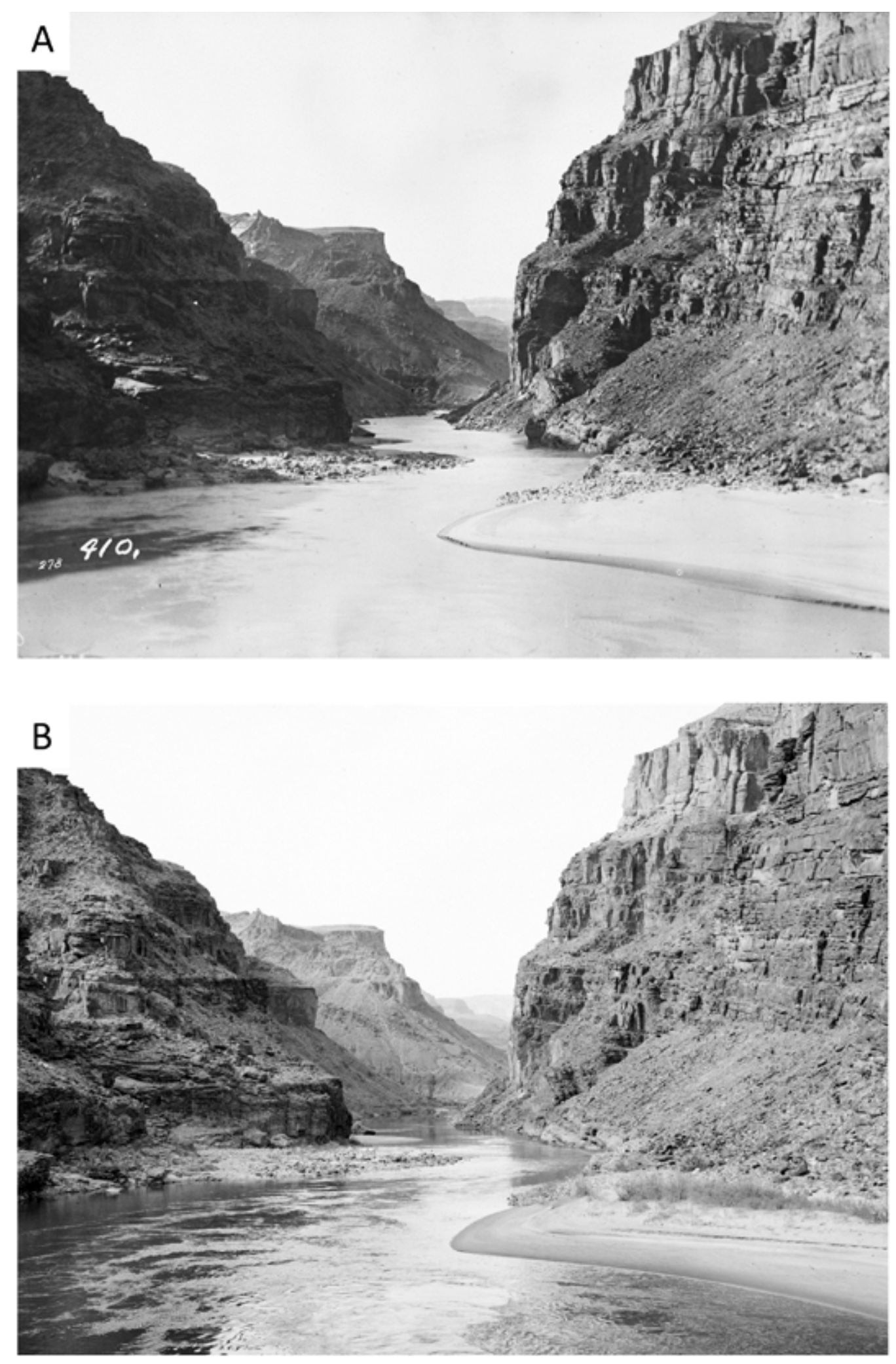


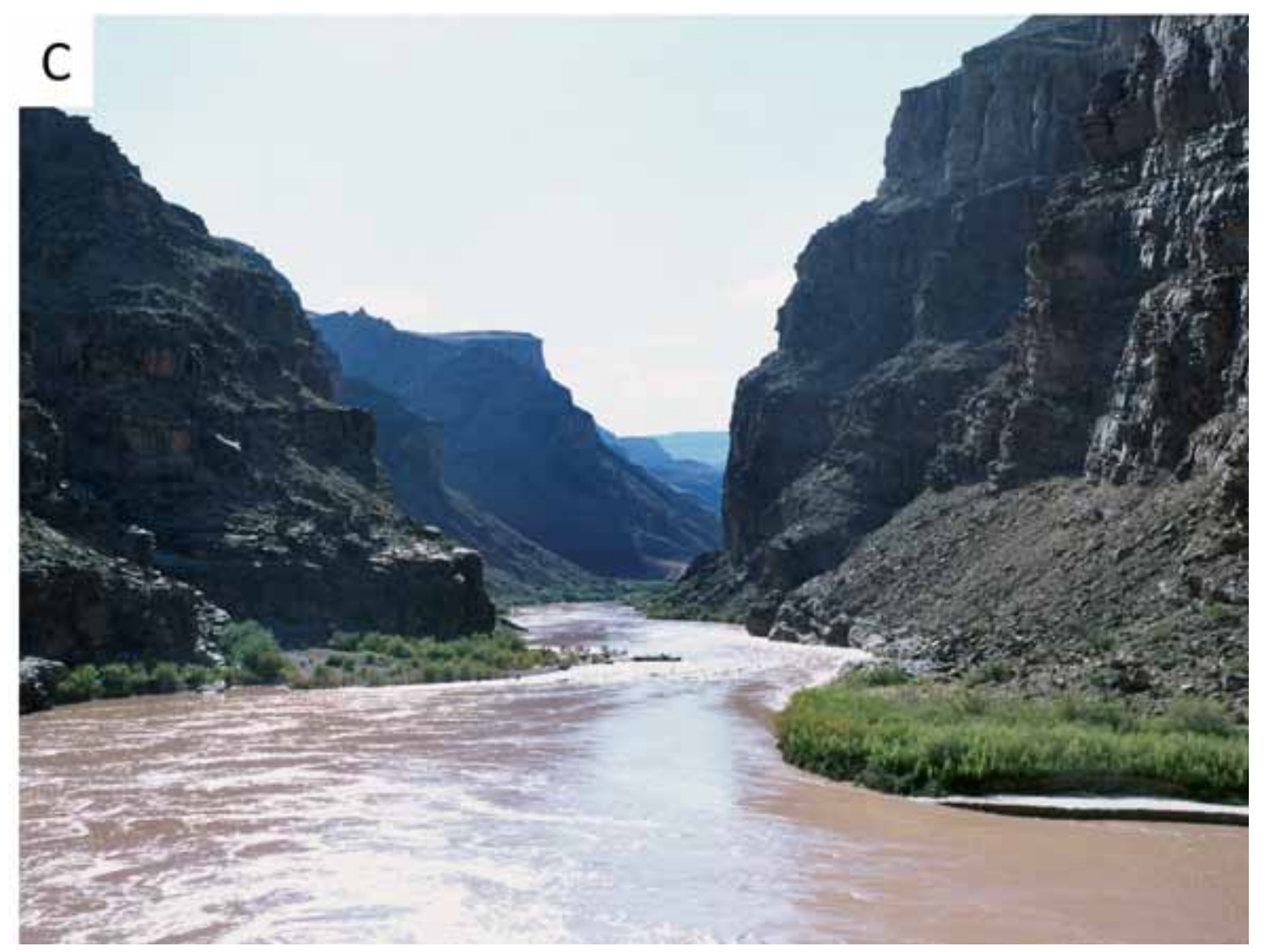

Figure 31-Vegetation encroachment, upper Grand Canyon (photo 1749 b; online Appendix, http://dx.doi.org/10.5066/ F76W988R).

(a) (1890) Looking downstream to a sand and gravel bar on river right, upstream of the Papago Creek debris fan, upper Grand Canyon (river kilometer 123). Both fan and bar features are low and devoid of vegetation. (b) (1991) Tamarisk has colonized the higher portions of the sand bar and the Papago Creek fan, which appears to have increased slightly in elevation. (c) (2011) Tamarisk has increased in size and number on both the bar and debris fan. On the bar, dense stands of tamarisk, sand-bar willow, arrow-weed, and seep-willow have filled in between the older, higher tamarisk and the channel bank. Tamarisk and seep-willow also line the channel margin upstream of the fan as well as the upstream edge of the debris fan.

the new high-water zone predominantly reflect natural establishment and survival in the post-dam period. However, nonnative Russian olive and tamarisk have and are being removed within Grand Canyon National Park.

At the same time, native plants have been planted in various locations, including cottonwoods at Lees Ferry (rkm 0) (Stevens and Burke 2001), various native plants at Soap Creek Camp (rkm 18.5) (Theobald 2001), and honey mesquite and catclaw acacia at Nankoweap (rkm 85) and Granite Park (rkm 336) (Anderson and Ruffner 1987). Additionally, in 2012-2013, the NPS initiated a riparian restoration project at Granite Camp, upstream of Monument Creek (rkm 151) (McMaster 2012). This effort included removing tamarisk and planting honey mesquite, along with other woody native species (https://www.nps.gov/grca/learn/nature/granite.htm). Similar restoration efforts are being planned as part of the Long-term Experimental Management Plan for the operation of Glen Canyon Dam (https://tempeis.anl.gov). The presence of sites in the new high-water zone, where vegetation has been established and maintained artificially, or removed, could potentially muddle future interpretations of vegetation responses to flow management, particularly if the increasing number of restoration activities are not systematically tracked into the future. 

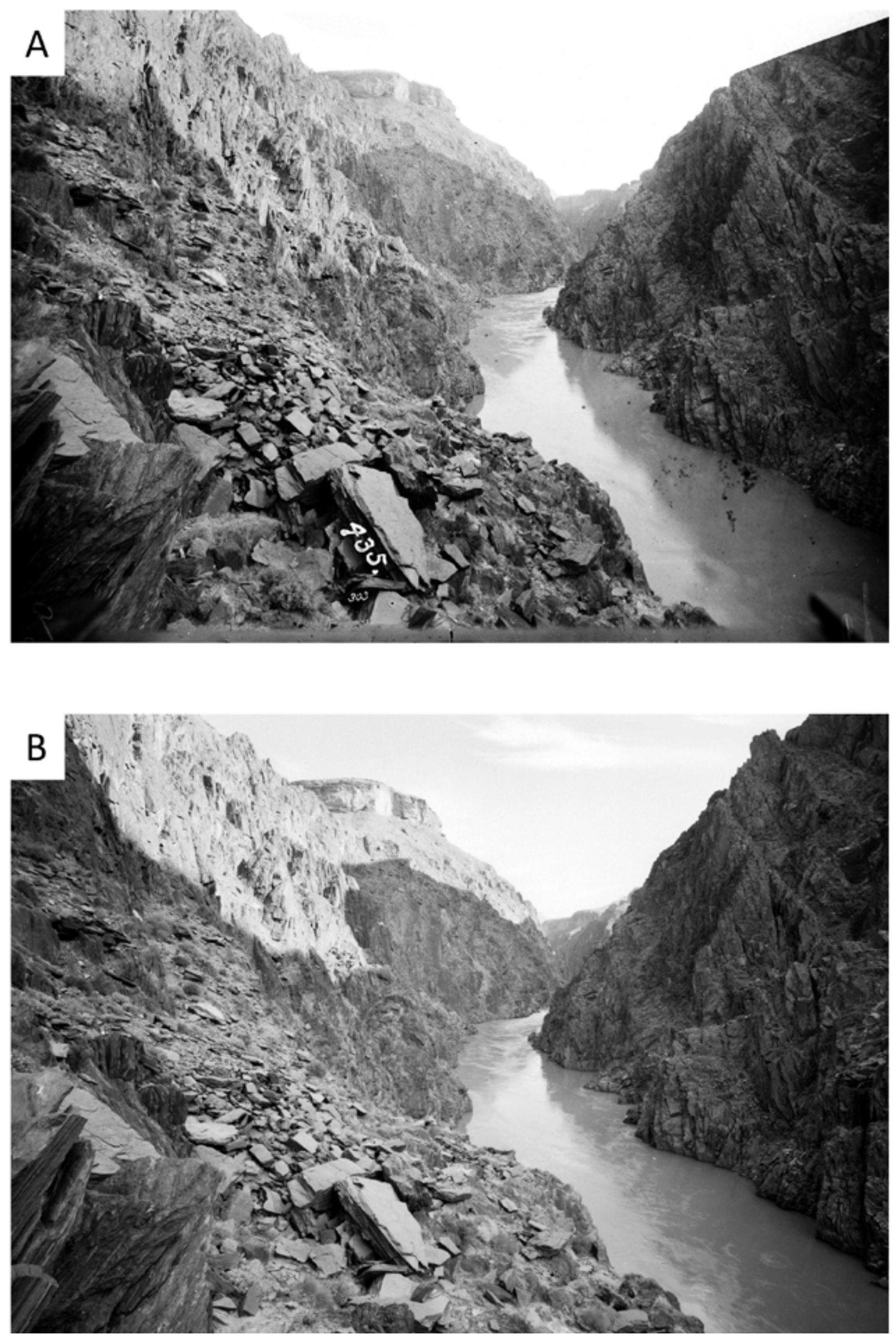


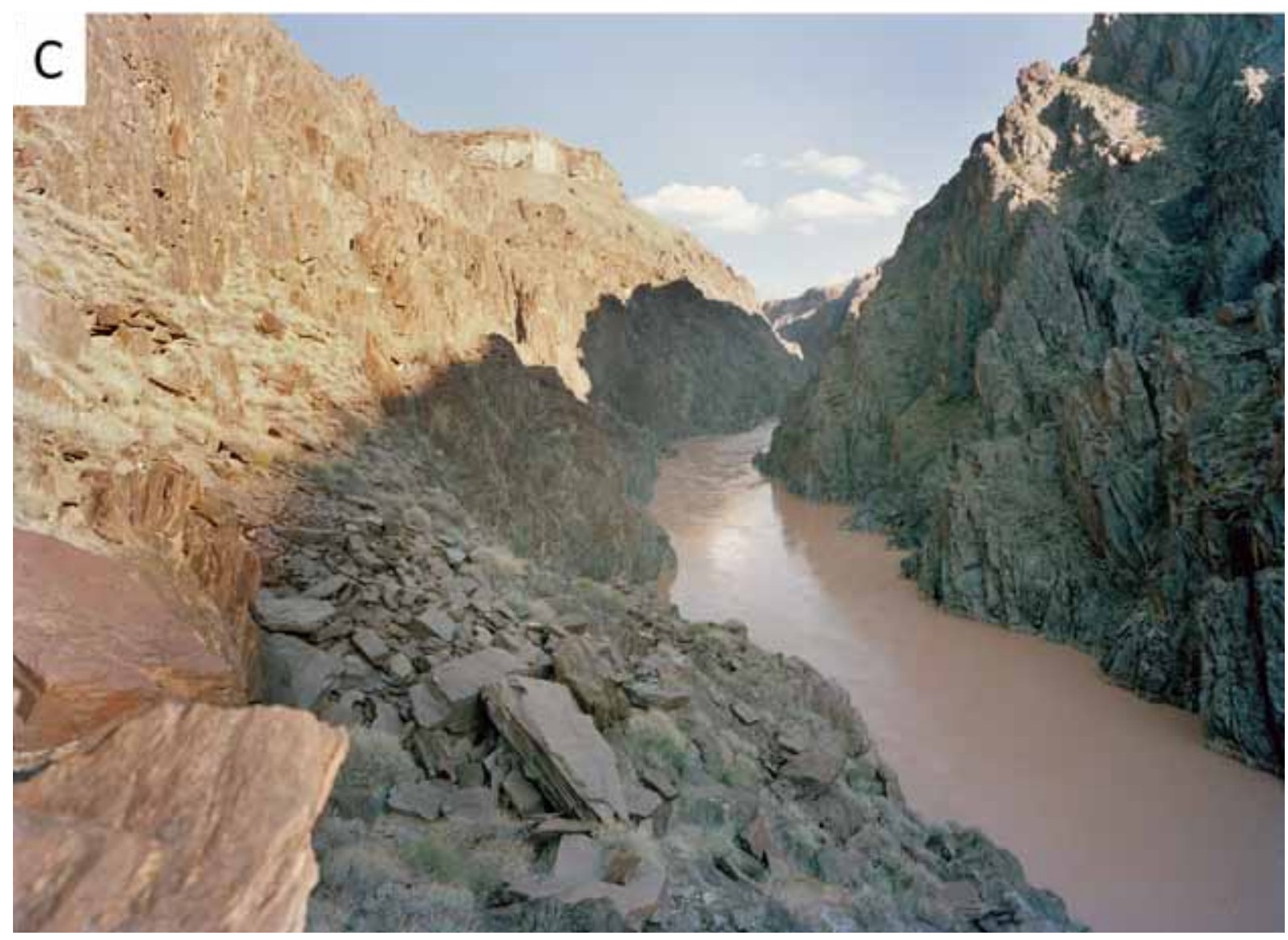

Figure 32-Stasis in upper Granite Gorge (photo 2319; online Appendix, http://dx.doi.org/10.5066/F76W988R).

(a) (1890) Upstream view of the Granite Gorge from Clear Creek (river kilometer 136). The walls of Vishnu schist and Zoroaster granite are too steep and narrow to support any riparian vegetation. (b) (1991) After a century and the closing of Glen Canyon dam, the inner gorge appears little changed. (c) (2011) In spite of large increases in riparian vegetation in wider canyon reaches, some steep, narrow canyon settings are not likely to provide conditions for establishment and persistence, even under current regulated flow conditions.

\section{Old High-Water Zone}

In 1973, Turner and Karpiscak (1980) saw limited evidence for declines in trees in the old high-water zone. Aside from crown dieback and increases in density for honey mesquite, Webb (1996) found little compelling evidence suggesting widespread declines in the old high-water stands; catclaw acacia, for example, seemed little affected. Similarly, results of Sankey et al. (2015) show little directional change in vegetated cover in this zone from 1965 through 1992 but sustained decreases starting in 2002. They point to the early 21 st century drought, beginning in the late 1990 s, as a likely cause. This is consistent with Webb's predictions that following flow regulation species like honey mesquite would be susceptible to drought and undergo slow structural decline (Webb 1996).

In 72 percent of the initial matched views by Webb (1996) containing honey mesquite $(\mathrm{n}=58)$, the trees either increased or showed no change in density. In 10 percent of the views with density increases, there were corresponding decreases in plant stature, suggesting possible climate-related factors like drought and frost. Decreases in severe frosts after 1890 may have spurred new establishment in some settings. Increases in precipitation and streamflow in the early 20th century (Hereford et al. 2006; fig. 27) could 

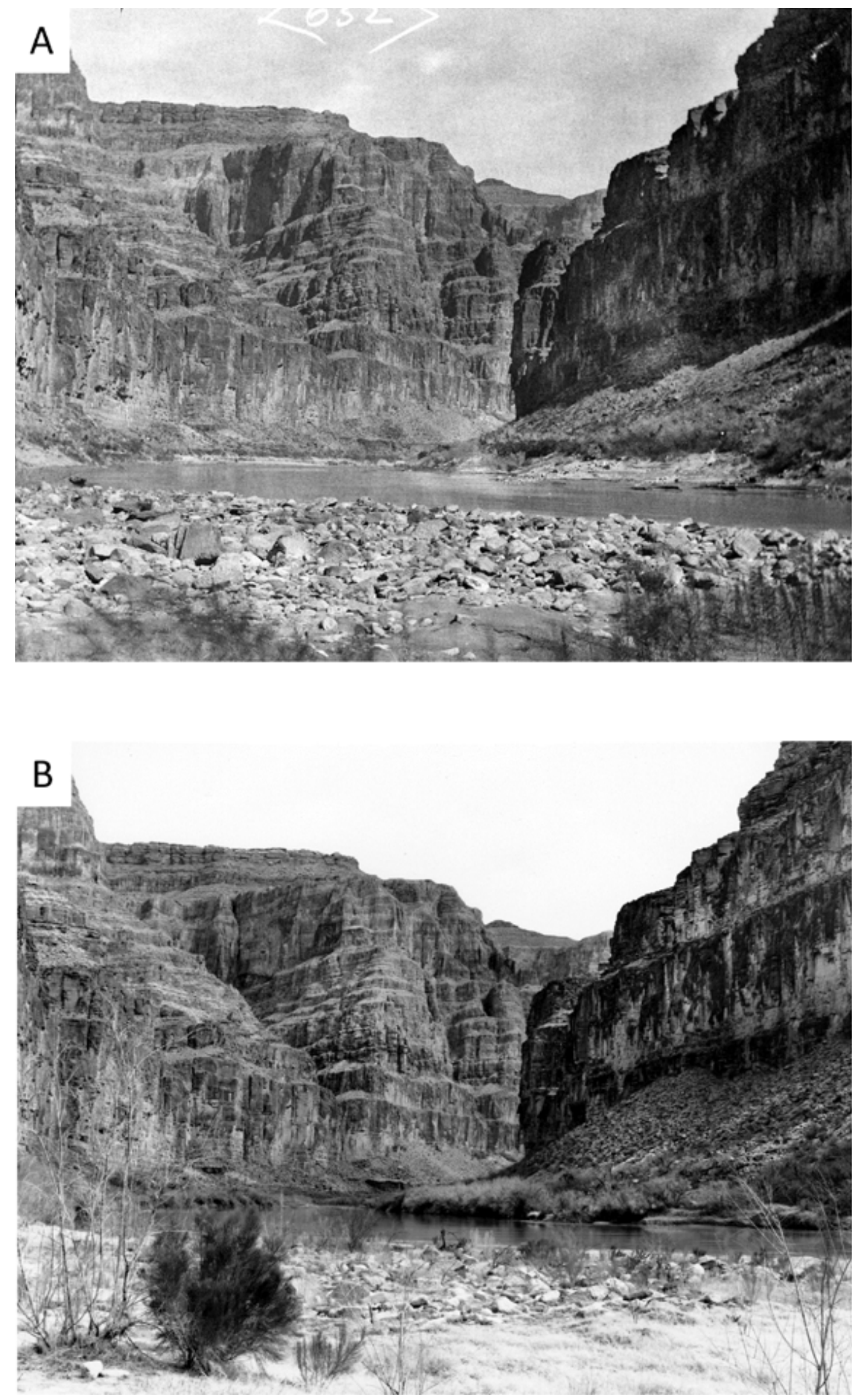


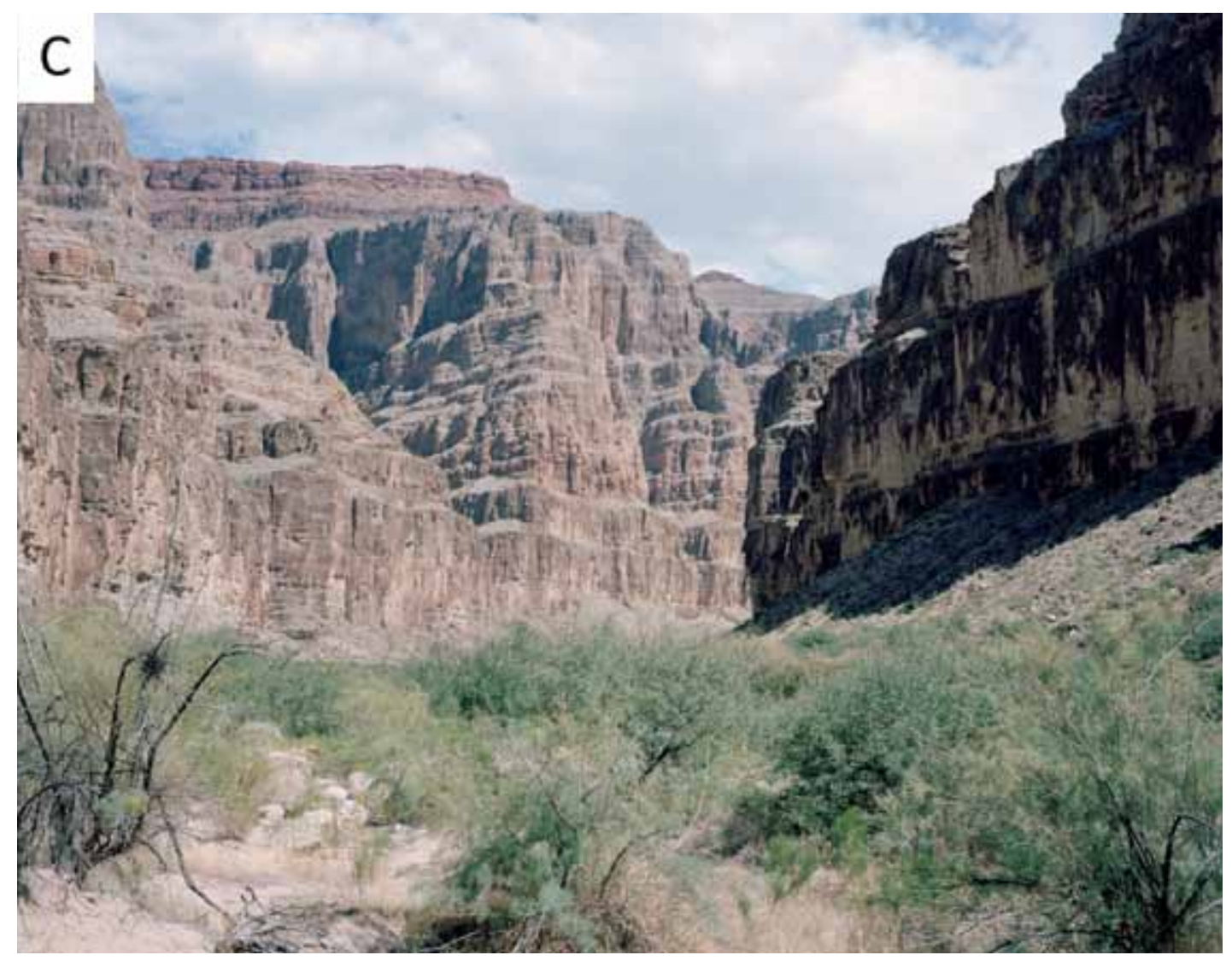

Figure 33-(left and above) A new high water line in lower Grand Canyon (photo 1772 a; online Appendix, http://dx.doi. org/10.5066/F76W988R).

(a) (1890) Looking upstream and across the upper portion of the fan at Parashant Wash (river kilometer 320). A depression filled with fine sediment at the lower right of the image has a patch of sizable vegetation, which is not identifiable. Upstream, and on both sides of the river, a distinct and largely continuous band of woody vegetation can be seen above the old high water line. (b) (1991) Bermuda grass dominates that portion of the fan, which contained fine sediment and vegetation in the previous image. Scattered, taller tamarisk and desert broom occur on the upper portion of the fan. Stunted and dead tamarisk occupy lower portions of the fan, possibly reflecting flood mortality from the mid-1980s floods. Across the river, a dense line of tamarisk occurs below the band of old high water vegetation, which appears to have thinned and some dead stems are apparent. (c) (2011) Tamarisk higher on the bar appears stressed and is dying back and the desert broom is gone. Closer to the river, a dense band of woody vegetation, dominated by mesquite, is tall enough to obscure the river.

have contributed to height growth, which might then have been lost to drought-pruning following dam closure (Webb 1996). Although Webb thought it unlikely that honey mesquite would be lost from this relict riparian assemblage over the short-term, he suggested disconnection from the river in the post-dam era might lead to long-term reproductive failure and that future meteorological drought could reduce existing honey mesquite stands to scattered individuals.

In the 2010-2012 matches that we examined, the old high-water zone occurred in 30 percent $(n=48)$ of our views (table 8$)$. In 18 of those views, an evaluation of change in this pre-dam riparian plant assemblage was not possible, primarily because plant growth in the new high-water zone over the past 20 years obscured the view of the old high-water zone (see fig. 33). In spite of a relatively small number of unobstructed views of the old high-water zone $(n=30)$, our results generally support the observations of Sankey et al. (2015) that this zone showed declines in overall cover beginning in 2002. In our 2010-2012 matches, none showed increase in cover 
of this vegetation. Rather, cover declined in 19 percent of our views and showed no discernable change in 44 percent of our views (table 8 ). This suggests that in spite of generalized regional drought over the past decade (Hereford et al. 2002), factors such as aspect, microclimate, and side-slope drainage in high-relief canyons may buffer some stands of old high-water zone vegetation from the effects of drought. Some of these stands may in fact have become established because of the presence of shallow groundwater of local origin (e.g., the stands at Ledges Camp, rkm 245) and may therefore be largely unaffected by river flows.

Plant pathogens and unintended introductions of insect pests have had unexpected and profound influences on long-term compositional changes in riparian forest ecosystems (Johnson et al. 2012). A new factor potentially influencing the long-term distribution and importance of tamarisk in riparian systems throughout the western United States is the purposefully introduced tamarisk leaf beetle (Diorhabda spp.; see Chapter 5). Monitoring data from the Colorado River Basin show that the beetle was present throughout Marble and middle and lower Grand Canyon by 2011 and 2012 (http://www.tamariskcoalition.org/sites/default/files/files/2014 percent20Distribution percent20Map percent20CRB.pdf). We observed tamarisk defoliation and premature leaf senescence related to beetle activity in 3.7 percent of our views. Anticipating the effects of the beetle on the structure and composition of riparian vegetation assemblages in the Grand Canyon is not yet possible and, as stated earlier by Turner and Karpiscak (1980), will require the passage of time.

Our recent work provides another point-in-time assessment of riparian vegetation change in canyons of the Colorado River influenced by Glen Canyon Dam. This is an effective way to monitor changes that unfold slowly but is inadequate for capturing the details of processes that occur more rapidly, such as event-specific mortality or establishment and removal processes on dynamic geomorphic surfaces. Such refinements require a more mechanistic understanding that explicitly links vegetation with hydrology and climate. Relationships between vegetation and streamflow have been used to predict vegetation response to flow alterations (Auble et al. 1994; Primack 2000). Using surveyed vegetation plots and a hydrologic model, Auble et al. (2005) modeled individualistic plant responses to inundation duration. This relation was used to predict changes in vegetation patterns away from the channel following changes in flow. Because of limits to the amount of topographic data that Auble et al. (2005) could collect, their work was limited to a short reach and could not account for longitudinal variation in the flow-vegetation relationship. However, Sankey et al. (2015) have recently developed fine-resolution spatial and temporal relationships between variations in riparian vegetation cover relative to streamflow and climate. They accomplished this using aerial imagery, instantaneous flow and topographic data, and a spatially extensive hydrologic model of Marble and Grand Canyons. These data provide the basis for predicting future vegetation change in this system. Thus, we examine our findings and earlier predictions in the context of these new results. We used photographic data at a scale fine enough to identify changes in numbers of individuals of particular species. This complements the analysis of Sankey et al. (2015), which was based largely on aerial imagery that was spatially more extensive but lower in resolution. 


\section{Management Implications}

1. Tamarisk was present in Glen, Marble, and Grand Canyons in the pre-dam period (Clover and Jotter 1944). With other native riparian species, it spread rapidly, likely from both tributary sources and existing stands along the Colorado, throughout the Grand Canyon following dam closure. Despite extensive mortality following flooding from 1983-1986, tamarisk is still a dominant riparian species. Based on photographic evidence, it was widespread by 1989-1992 and was found in 71 percent of the views examined by Webb (1996) and in 79.5 percent of the views we examined for the same time period.

2. Woody riparian vegetation has increased throughout the river corridor in Grand Canyon between the 1990s and 2012. In general, total woody riparian vegetation, including tamarisk, showed increased cover and density during this period in 89.3 percent of the matched images in 2010-2012. Recent work shows that vegetation expansion into lower topographic position in the riparian zone occurred during periods when peak flows were lower and base flows higher and when inundation duration fell below about 5 percent (Sankey et al. 2015). There was no evidence that brief, pulsed inundation during HFEs limited vegetation expansion. Gains in riparian vegetation cover over the past two decades were primarily below the maximum stage of post-dam controlled floods $(1,274 \mathrm{cms}[\sim 45,000 \mathrm{cfs}])$, especially in near-shore locations for species like tamarisk, seep-willow, and arrow-weed.

3. Whether HFEs have been a factor in the recent expansion of riparian vegetation is unknown and will require careful, real time monitoring of vegetation following HFEs or retrospective analyses examining the age structure of encroaching vegetation. The seasonal timing of HFEs also warrants further study as they could preferentially shift the structure and composition of riparian vegetation.

4. In contrast to observed vegetation increases, 9.4 percent of the rematches in 2010-2012 show no apparent change, and $<2$ percent of the views show a decrease in woody riparian vegetation cover and density. Under the current flow regime, some narrow canyon settings are likely to remain free of persistent riparian vegetation.

5. Some of the increase in riparian vegetation results from continued spread and growth of tamarisk, but an important component of the increase includes the establishment of native woody riparian species, including old high-water line species, such as catclaw acacia, honey mesquite, and desert broom, in the new high-water zone or below the stage of the 1983 flood $(2,747 \mathrm{cms}[\sim 97,000 \mathrm{cfs}])$.

6. In addition to the natural establishment of riparian vegetation in the new high-water zone, nonnative species like tamarisk and Russian olive have been removed and native vegetation planted as part of experiments or restoration efforts in Marble and Grand Canyons. Artificial manipulation of vegetation should be tracked, actions and locations clearly documented, and the information easily accessible, so that cause-and-effect relationships between flow management and vegetation response can be assessed as accurately as possible.

7. Disconnection of the old high-water assemblage from river flows has left species, like honey mesquite, vulnerable to drought stress, and recent evidence suggests that 
vegetated cover has declined during the period of early 21 st century drought, beginning in the early 1990s. The work of Webb (1996) suggests species like catclaw acacia may be less affected. Some stands may be buffered against drought by factors such as aspect and local ground-water sources.

8. The effects of the recently introduced tamarisk leaf beetle on long-term structure and composition of riparian assemblages in Glen, Marble, and Grand Canyons remain uncertain.

\section{Acknowledgments}

We thank the many individuals who helped with the field work on this project. Diane Boyer and Helen Raichle both supervised student workers and scanned negatives themselves to create a fully digital photographic archive used in our analyses. Grand Canyon National Park provided logistical support for our river trip in 2010, and Grand Canyon Monitoring and Research Center provided additional funding for logistics and salaries. Additional funding was provided by the U.S. Geological Survey. Ryan Morrison, USGS, provided helpful review comments. Any use of trade, firm, or product names is for descriptive purposes only and does not imply endorsement by the U.S. Government.

\section{References}

Anderson, L.S.; Ruffner G.A. 1987. Effects of post Glen Canyon Dam flow regime on the old high water line plant community along the Colorado River in Grand Canyon. Glen Canyon Environmental Studies, Report number GCES/22/87. Grand Canyon, AZ: U.S. Department of the Interior, National Park Service, Grand Canyon National Park.

Auble, G.T.; Friedman, J.M.; Scott, M.L. 1994. Relating riparian vegetation to present and future streamflows. Ecological Applications. 4(3): 544-554.

Auble, G.T.; Scott, M.L.; Friedman, J.M. 2005. Use of individualistic streamflow-vegetation relations along the Fremont River, Utah, USA to assess impacts of flow alteration on wetland and riparian areas. Wetlands. 25(1): 143-154.

Boyer, D.E.; Webb, R.H.; Turner, R.M. 2010. Techniques of matching and archiving repeat photography used in the Desert Laboratory Collection. In: Webb, R.H.; Boyer, D.E.; Turner, R.M., eds. Repeat photography: Methods and applications in the natural sciences. Washington, DC: Island Press: 12-23.

Clover, E.U.; Jotter, L. 1944. Floristic studies in the Canyon of the Colorado and tributaries. American Midland Naturalist. 32(3): 591-642.

Collier, M.P.; Webb, R.H.; Andrews, E.D. 1997. Experimental flooding in Grand Canyon. Scientific American. 276: 82-89.

Dodge, N.N. 1936. Trees of Grand Canyon National Park. Natural History Association Bulletin 3. $69 \mathrm{p}$.

Dolan, R.; Howard, A.; Gallenson, A. 1974. Man's impact on the Colorado River in the Grand Canyon. American Scientist. 62(4): 392-401. http://erode.evsc.virginia.edu/papers/dolan_ GrCyn_impact_74.pdf.

Friedman, J.M.; Auble, G.T.; Andrews, E.D.; [et al.]. 2006. Transverse and longitudinal variation in woody riparian vegetation along a montane river. Western North American Naturalist. 66(1): 78-91.

Friedman, J.M.; Auble, G.T.; Shafroth, P.B.; [et al.]. 2005. Dominance of non-native riparian trees in western USA. Biological Invasions. 7(4): 747-751.

Grams, P.E.; Schmidt, J.C.; Wright, S.A.; [et al.]. 2015. Building sandbars in the Grand Canyon. EOS, Transactions of the American Geophysical Union. 96: 1-11. 
Hahn, M. 2011. National Park Service Colorado River Resource Monitoring and Mitigation Report. Oral presentation to the Glen Canyon Dam Adaptive Management Program, August 24, 2011. http://www.usbr.gov/uc/rm/amp/amwg/mtgs/11aug24/Attach_07.pdf

Hereford, R.; Webb, R.H.; Longpré, C.I. 2006. Precipitation history and ecosystem response to multidecadal precipitation variability in the Mojave Desert region, 1893-2001. Journal of Arid Environments. 67: 13-34.

Howard, J.; Dolan, R. 1981. Geomorphology of the Colorado River in the Grand Canyon. The Journal of Geology. 89(3): 269-298.

Hupp, C.R.; Osterkamp, W.R. 1985. Bottomland vegetation distribution along Passage Creek, Virginia, in relation to fluvial landforms. Ecology. 66(3): 670-681. http://onlinelibrary.wiley. com/doi/10.2307/1940528/epdf.

Johnson, R.R. 1991. Historic changes in vegetation along the Colorado River in Grand Canyon. In: Committee to Review the Glen Canyon Environmental Studies, Water Science and Technology Board, Commission on Geosciences, Environment and Resources, Division of Earth and Life Sciences, National Research Council. Colorado River ecology and dam management. Washington, DC: National Academies Press: 178-206.

Johnson, R.R.; Lowe, C.H. 1985. On the development of riparian ecology. In: Johnson, R.R.; Ziebell, C.D.; Patton, D.R.; Ffolliott, P.F.; [et al.], tech. coords. Riparian ecosystems and their management: Reconciling conflicting uses. First North American riparian conference; 1985 April 16-18; Tucson, AZ. Gen. Tech. Rep. RM-GTR-120. Fort Collins, CO: U.S. Department of Agriculture, Forest Service, Rocky Mountain Forest and Range Experiment Station: 112-116.

Johnson, R.R.; Haight, L.T.; Simpson; J.M. 1977. Endangered species vs. endangered habitat: A concept. In: Johnson, R.R.; Jones, D.A., tech. coords. Proceedings: Symposium on importance, preservation, and management of riparian habitat. Gen. Tech. Rep. RM-43, Fort Collins, CO: U.S. Department of Agriculture, Forest Service, Rocky Mountain Research Station: 68-79.

Johnson, R.R.; Haight, L.T.; Simpson, J.M. 1987. Endangered habitats versus endangered species: A management challenge. In: Laymon, S.A., ed. Management and preservation of endangered birds in riparian ecosystems. Western Birds. 18(1): 89-96.

Johnson, W.C.; Dixon, M.D.; Scott, M.L.; [et al.]. 2012. Forty years of vegetation change on the Missouri River floodplain. Bioscience. 62(2): 123-135. http://www.bioone.org/doi/abs/10.1525/ bio.2012.62.2.6.

Kennedy, T.A.; Ralston, B.E. 2011. Biological responses to high-flow experiments at Glen Canyon. In: Melis, T.S., ed. Effects of three high-flow experiments on the Colorado River ecosystem downstream from Glen Canyon Dam, Arizona. U.S. Geological Survey Circular 1366. Reston, VA: U.S. Department of the Interior, U.S. Geological Survey: 93-125.

McBride, J.R.; Strahan, J. 1984. Establishment and survival of woody riparian species on gravel bars of an intermittent stream. American Midland Naturalist. 112(2): 235-245.

McMaster, M.; Chaudhry, T.; Mathis, A.; [et al.]. 2012. Granite Camp-Monument Creek pilot stewardship project. Boatman's Quarterly Review. 25(3): 14-15, 43.

O'Connor, J.E.; Ely, L.L.; Wohl, E.E.; [et al.]. 1994. A 4500-year record of large floods on the Colorado River in the Grand Canyon, Arizona. The Journal of Geology. 102(1): 1-9.

Powell, J.W. 1961. Exploration of the Colorado River and its canyons. New York: Dover Publications, Inc. $400 \mathrm{p}$.

Primack, A.G.B. 2000. Simulation of climate-change effects on riparian vegetation in the Pere Marquette River, Michigan. Wetlands. 20(3): 538-547.

Reynolds, L.V.; Cooper, D.J.; Hobbs N.T. 2014. Drivers of riparian tree invasion on a desert stream. River Research and Applications. 30(1): 60-70.

Rubin, D.M.; Topping, D.J.; Schmidt, J.C.; [et al.]. 2002. Recent sediment studies refute Glen Canyon Dam hypothesis. EOS. 83(25): 273-278.

Sankey, J.B.; Ralston, B.E.; Grams, P.E.; [et al.]. 2015. Riparian vegetation, Colorado River, and climate: Five decades of spatiotemporal dynamics in the Grand Canyon with river regulation. Journal of Geophysical Research: Biogeosciences. 120: 1532-1547. 
Schmidt, J.C. 1990. Recirculating flow and sedimentation in the Colorado River in Grand Canyon, Arizona. The Journal of Geology. 98(5): 709-724.

Schmidt, J.C.; Webb, R.H.; Valdez, R.A.; [et al.]. 1998. Science and values in river restoration the Grand Canyon. Bioscience. 48(9): 735-747.

Schmidt, J.C.; Grams, P.E. 2011. Understanding physical processes of the Colorado River In: Melis, T.S., ed. Effects of three high-flow experiments on the Colorado River ecosystem downstream from Glen Canyon Dam, Arizona. U.S. Geological Survey Circular 1366. Reston, VA: U.S. Department of the Interior, U.S. Geological Survey: 17-55.

Scott, M.L.; Auble, G.T.; Friedman, J.M. 1997. Flood dependency of cottonwood establishment along the Missouri River, Montana, USA. Ecological Applications. 72(2): 677-690. Available at: http://www.mesc.usgs.gov/products/Publications/2851/2851.pdf.

Shafroth, P.B.; Wilcox, A.C.; Lytle, D.A.; [et al.]. 2010. Ecosystem effects of environmental flows: Modelling and experimental flood in a dryland river. Fresh Water Biology. 55: 68-85.

Smith, D.L.; Crampton, C.G. 1987. The Colorado River survey. Salt Lake City, UT: Howe Brothers. $305 \mathrm{p}$.

Stevens, L.; Burke, K. 2001. Riparian restoration at Lees Ferry. Boatman's Quarterly Review. 14 (1): 17.

Stevens, L.E. 1989. Mechanisms of riparian plant community organization and succession in the Grand Canyon, Arizona. Dissertation. Flagstaff, AZ: Northern Arizona University. 115 p.

Stevens, L.E.; Waring, G.L. 1985. The effects of prolonged flooding on the riparian plant community in Grand Canyon. In: Johnson, R.R.; Ziebell, C.D.; Patton, D.R.; [et al.], tech. coords. Riparian ecosystems and their management: Reconciling conflicting uses. First North American riparian conference; 1985 April 16-18; Tucson, AZ. Gen. Tech. Rep. RM-GTR-120. Fort Collins, CO: U.S. Department of Agriculture, Forest Service, Rocky Mountain Forest and Range Experiment Station: 81-86.

Stevens, L.E.; Schmidt, J.C.; Ayers, T.J.; [et al.]. 1995. Flow regulation, geomorphology, and Colorado River marsh development in the Grand Canyon, Arizona. Ecological Applications. 5(4): 1025-1039.

Stromberg, J.C. 1993. Riparian mesquite forests: A review of their ecology, threats, and recovery potential. Journal of the Arizona-Nevada Academy of Sciences. 27: 111-124.

Theobald, K. 2001. Soap Creek olla project update. Boatman's Quarterly Review. 24 (1): 10-11.

Topping, D.J.; Rubin, D.M.; Vierra, L.E., Jr. 2000. Colorado River sediment transport: 1. Natural sediment supply limitation and the influence of the Glen Canyon Dam. Water Resources Research. 36(2): 515-542. doi: 10.1029/1999WR900285.

Topping, D.J.; Schmidt, J.C.; Vierra, L.E., Jr. 2003. Computation and analysis of the instantaneousdischarge record for the Colorado River at Lees Ferry, Arizona: May 8, 1921, through September 30, 2000. U.S. Geological Survey Professional Paper 1132. 125 p.

Turner, R.M.; Karpiscak, M.M. 1980. Recent vegetation changes along the Colorado River between Glen Canyon Dam and Lake Mead, Arizona. U.S. Geological Survey Professional Paper 1132. Reston, VA: U.S. Department of the Interior, U.S. Geological Survey. 132 p.

U.S. Department of the Interior. 1996. Record of decision, operation of Glen Canyon Dam. Final environmental impact statement. Washington, DC: Department of the Interior, Bureau of Reclamation. $15 \mathrm{p}$.

Ward, J.V.; Tockner, K.; Arscott, D.B.; [et al.]. 2002. Riverine landscape diversity. Freshwater Biology. 47(4): 517-539.

Waring, G.L. 1996. Current and historical riparian vegetation trends in Grand Canyon, using multitemporal remote sensing analyses of GIS sites. Final report to Glen Canyon Environmental Studies. NAU-NPS Cooperative Agreement: CA 8000-8-0002. Flagstaff, AZ: Northern Arizona University; U.S. Department of the Interior, National Park Service. 44 p.

Warren, P.L.; Reichhardt, K.L.; Mouat, D.A.; [et al.]. 1982. Vegetation of Grand Canyon National Park. Tech. Rep. No. 9. Contribution No. 017/06. Tucson, AZ: University of Arizona, Cooperative National Park Resources Study Unit. 
Webb, R. 2005. High, wide and handsome: The river journals of Norman D. Nevills. All USU Press Publications, Book 153. Logan, UT: Utah State University Press. 308 p. http://digitalcommons. usu.edu/usupress_pubs/153.

Webb, R.H. 1996. Grand Canyon, a century of change. Tucson, AZ: The University of Arizona Press. 290 p.

Webb, R.H.; Leake, S.A. 2006. Ground-water surface-water interactions and long-term change in riverine riparian vegetation in the southwestern United States. Journal of Hydrology. 320: 302-323.

Webb, R.H.; Belnap, J.; Scott, M.L.; [et al.]. 2011. Long-term change in perennial vegetation along the Colorado River in Grand Canyon National Park (1889-2010). Park Science. 20(2): 73-77.

Webb, R.H.; Boyer, D.E.; Turner, R.M., eds. 2010. Repeat photography: Methods and applications in the natural sciences. Washington, DC: Island Press. 392 p.

Webb, R.H.; Leake, S.A.; Turner, R.M. 2007. The ribbon of green. Tucson, AZ: The University of Arizona Press. 480 p.

Webb, R.H.; Schmidt, J.C.; Marzolf, G.R.; [et al.], eds. 1999. The controlled flood in Grand Canyon: Scientific experiment and management demonstration. Geophysical Monograph 110. Washington, DC: American Geophysical Union. 367 p.

Wheeler, G.M. 1872. Preliminary report of explorations principally in Nevada and Arizona 1871. Washington, DC: U.S. Government Printing Office. 96 p.

Williams, G.P.; Wolman, M.G. 1984. Downstream effects of dams on alluvial rivers. U.S. Geological Survey Professional Paper 1286. Reston, VA: U.S. Department of the Interior, U.S. Geological Survey. 86 p.

Willson, M.F.; Carothers, S.W. 1979. Avifauna of habitat islands in the Grand Canyon. The Southwestern Naturalist. 24(4): 563-576.

Woodhouse, C.A.; Meko, D.M.; MacDonald, G.M.; [et al.]. 2010. A 1,200-year perspective of 21 st century drought in southwestern North America. Proceedings of the National Academy of Sciences. 107(50): 21283-21288.

Wright, S.A.; Kennedy, T.A. 2011. Science-based strategies for future high-flow experiments at Glen Canyon Dam. In: Melis, T.S., ed. Effects of three high-flow experiments on the Colorado River ecosystem downstream from Glen Canyon Dam, Arizona. U.S. Geological Survey Circular 1366. Reston, VA: U.S. Department of the Interior, U.S. Geological Survey: 127-146.

Zimmermann, R.C. 1969. Plant ecology of an arid basin, Tres Alamos-Redington area, southeastern Arizona. U.S. Geological Survey Professional Paper 485-D. Reston, VA: U.S. Department of the Interior, U.S. Geological Survey. 51 p. 


\title{
Chapter 10. Breeding Waterbirds of the Mexican Portion of the Colorado River Delta
}

\author{
Eric Mellink and Osvel Hinojosa-Huerta
}

\section{Introduction}

Once a mighty and wild river with abundant wetlands, the section of the Colorado River flowing through Mexico has become a trickle ... whenever it flows. Most of the time since the 1960s, until recently, it did not and was completely dry. This brought tremendous changes in the "original" constitution and biological processes of the region, although they have not been fully investigated.

Although any fine-scale reconstruction of the historic characteristics of the Colorado River Delta is impossible, wetlands were widespread over an area of 500,000 ha in what in part is today the Mexicali Valley in Baja California and Sonora. Luxurious riparian forests existed in dozens of braided channels in the deltaic alluvial floodplain and the influence of the river extended $65 \mathrm{~km}$ into the Gulf of California (Felger 2000; Leopold 1953; Rodriguez et al. 2001; Sykes 1937).

However, this image must be seen with a note of caution. What is usually considered the natural conditions of the Lower Colorado River is not accurate, as the picture of large amounts of sediment flowing into the sea through the Colorado River documented by Sykes (1937) was flawed. These large sediment loads were atypical, because they resulted from extensive loss of beaver (Castor canadensis) dams from the river's tributaries due to trapping and from overgrazed watersheds. This began with the arrival of the Spaniards during the 18th century (Dobyns 1978, 1981). These increased sediments must have changed the physiognomy of the lower delta, although the details and consequences remain unknown.

In addition, in the last 100 years, the reduction of freshwater flows and other hydrological changes in the basin have caused biotic degradation of the delta, to the point where wetlands now encompass only about 10 percent of the previous area (Glenn et al. 2001; Zamora-Arroyo et al. 2005). Although some diversions and dams were constructed in the early $1900 \mathrm{~s}$, the major changes in the delta began with the construction of Hoover Dam in 1936 and Glen Canyon Dam in 1963 (Zamora-Arroyo et al. 2005). These reservoirs were filling up until 1979, capturing flows that would otherwise reach the delta, driving the habitat degradation of the region (Glenn et al. 2001).

However, even in their current reduced and altered state, these wetlands continue to provide critical habitat for endangered species and for thousands of migratory waterbirds (Gomez-Sapiens et al. 2013; Hinojosa-Huerta et al. 2007). The area has been recognized as a Wetland of International Importance by the Ramsar Convention and a Site of Hemispheric Importance by the Western Hemisphere Shorebird Reserve Network (Hinojosa-Huerta and Carrillo-Guerrero 2010). This biological richness has been maintained by the persistence of a diversity of habitat types in the area, ranging from riparian forest and freshwater streams to brackish marshes, tidal mudflats, and 
the estuarine/marine environment of the Upper Gulf of California (Hinojosa-Huerta et al. 2007).

Since the late 1970s, periodic river releases, agricultural return flows, and treated effluent of wastewater plants have revitalized portions of the delta, and the populations of some waterbird species have responded accordingly (Glenn et al. 2001; HinojosaHuerta et al. 2004). This resiliency in the delta has been attributed to a number of key elements, including (1) the maintenance of undeveloped land in the river corridor and lower delta, (2) the conservation of a geomorphologically active floodplain, (3) the influence of the large tides of the Upper Gulf of California, and (4) the maintenance of some flows of water as river releases, agricultural drainage, and groundwater flows (Glenn et al. 2013; Nagler et al. 2005; Nelson et al. 2013).

In this chapter, we present information on the current status of breeding waterbirds in the Colorado River Delta in each of the habitat types in the region, including information on historical changes, current threats, and conservation recommendations.

\section{Fresh Water, Riparian, and Marsh Habitat}

Riparian and riverine habitats have been affected the most in the lower Colorado Delta, as they depend on freshwater flows. Nevertheless, approximately 1,200 hectares of cottonwood (Populus fremontii) and Goodding's willow (Salix gooddingii) forests, with about $47 \mathrm{~km}$ of wet channel, remain in the riparian corridor between Morelos Dam and the Hardy River, maintained by groundwater flows and sporadic releases from the dam (Glenn et al. 2013).

The brackish marshes, dominated by southern cattail (Typha domingensis), are in better condition because they benefit from agricultural return flows and can tolerate some influence of tidal seawater. Major brackish marshes include the Ciénega de Santa Clara, with 5,800 ha of emergent vegetation and shallow lagoons, the Hardy River, the El Doctor wetlands, and Laguna del Indio (Zamora-Arroyo et al. 2005). In addition, a 100-ha open water and marsh habitat in the northern portion of the Hardy River subbasin was recently re-created with treated effluents from Las Arenitas Wastewater Plant, $30 \mathrm{~km}$ south of Mexicali.

Freshwater, riparian, and marsh habitats in the delta support four groups of waterbirds: waterfowl (mostly wintering and migrating), divers (mostly grebes), waders, and marshbirds (Patten et al. 2001). Waterbirds were particularly conspicuous before the 1930s, when major reductions in water flow in the river began (Bancroft 1922; Kramer and Migoya 1989; A. Leopold 1949, 1953; A.S. Leopold 1959; Payne et al. 1991; Price 1899). From the descriptions by Aldo Leopold $(1949,1953)$ and others it seems that the current numbers of between 20,000 and 50,000 ducks and geese, especially in the Ciénega de Santa Clara and the Rio Hardy region (Hinojosa-Huerta et al. 2013a), are just a pale reminiscence of what the area used to harbor. Four waterfowl species breed here: cinnamon teal, redhead, mallard, and ruddy duck, while the fulvous whistlingduck was a common breeder before the habitat changes in the delta (Hinojosa-Huerta et al. 2007; Patten et al. 2001; scientific names are in table 10).

Three species of shorebirds, black-necked stilt, American avocet, and killdeer, and seven species of waders breed along waterways and marshlands in the Colorado Delta: great blue heron, snowy egret, great egret, tricolored heron, cattle egret, green heron, 
Table 10-Waterbirds that breed, or have bred recently, in the Mexican portion of the Colorado River Delta. The list follows the taxonomic nomenclature and order of the seventh edition of the Checklist of North American Birds (American Ornithologists' Union 1998), including the changes made in the $56^{\text {th }}$ supplement to the checklist. Risk categories are: Endangered (E, En peligro de extinción), Threatened ( $T$, Amenazado) and under special protection (Pr, sujetos a protección especial), according to the Mexican list of species at risk (NOM-059-SEMARNAT-2010).

Species

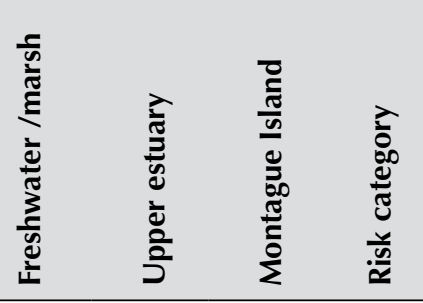

\section{Anseriformes}

Anatidae: ducks and geese

Mallard (Anas platyrhynchos)

Cinnamon teal (Anas cyanoptera)

Redhead (Aythya americana)

Ruddy duck (Oxyura jamaicensis)

\section{Podicipediformes}

\section{Podicipedidae: grebes}

Pied-billed grebe (Podilymbus podiceps)

Eared grebe (Podiceps nigricollis)

\section{Pelecaniformes}

\section{Phalacrocoracidae: cormorants}

Double-crested cormorant (Phalacrocorax auritus)

\section{Ciconiiformes}

\section{Ardeidae: herons, egrets, and bitterns}

\section{Threskiornithidae: ibises}

\section{Gruiformes}

\section{Rallidae: rails and coots}

American bittern (Botaurus lentiginosus)

Least bittern (Ixobrychus exilis)

Great blue heron (Ardea herodias)

Great egret (Ardea alba)

Snowy egret (Egretta thula)

Tricolored heron (Egretta tricolor)

Reddish egret (Egretta rufescens)

Cattle egret (Bubulcus ibis)

Green heron (Butorides virescens)

Black-crowned night-heron (Nycticorax nycticorax)

White-faced ibis (Plegadis chihi)

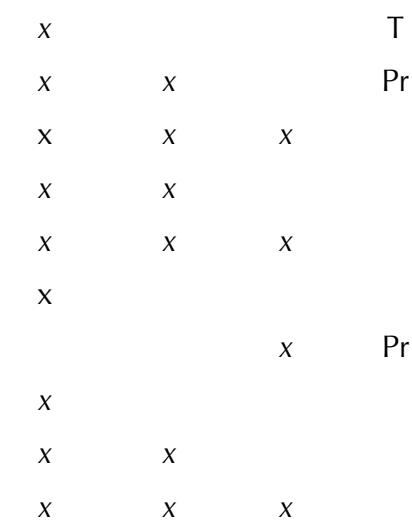

Black rail (Laterallus jamaicensis coturniculus)

Yuma Ridgeway rail (Rallus obsoletus yumanensis)

Virginia rail (Rallus limicola)

Common gallinule (Gallinula galeata)

$\mathrm{T}$

$\operatorname{Pr}$

$\operatorname{Pr}$

American coot (Fulica americana) 
Table 10—Continued.

\begin{tabular}{|c|c|c|c|c|}
\hline Species & 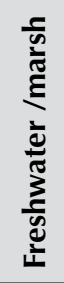 & 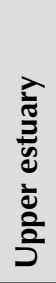 & 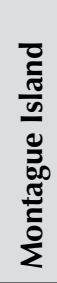 & 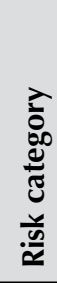 \\
\hline \multicolumn{5}{|l|}{ Charadriiformes } \\
\hline \multicolumn{5}{|l|}{ Recurvirostridae: stilts and avocets } \\
\hline Black-necked stilt (Himantopus mexicanus) & $x$ & $x$ & & \\
\hline American avocet (Recurvirostra americana) & $x$ & $x$ & & \\
\hline \multicolumn{5}{|l|}{ Haematopodidae: oystercatchers } \\
\hline American oystercatcher (Haematopus palliatus) & & & $x$ & $\mathrm{E}$ \\
\hline \multicolumn{5}{|l|}{ Charadriidae: plovers } \\
\hline Snowy plover (Charadrius alexandrinus) & $x$ & $x$ & & \\
\hline Wilson's plover (Charadrius wilsonia) & & $x$ & $x$ & \\
\hline Killdeer (Charadrius vociferus) & $x$ & $x$ & & \\
\hline \multicolumn{5}{|l|}{ Laridae: gulls and terns } \\
\hline Laughing gull (Leucophaeus atricilla) & $x$ & & $x$ & \\
\hline Least tern (Sternula antillarum) & & $x$ & $x$ & $\operatorname{Pr}$ \\
\hline Gull-billed tern (Gelochelidon nilotica) & $\mathrm{x}$ & & $x$ & \\
\hline Caspian tern (Hydroprogne caspia) & $x$ & & & \\
\hline Forster's tern (Sterna forsteri) & $x$ & & & \\
\hline Royal tern (Thalasseus maximus) & & & $x$ & \\
\hline Elegant tern (Thalasseus elegans) & & & $x$ & $\operatorname{Pr}$ \\
\hline Black skimmer (Rynchops niger) & $x$ & & $x$ & \\
\hline
\end{tabular}

and black-crowned night-heron, while little blue heron might do so too (Mellink et al. 2002; Patten et al. 2001). After a rebound from early 20th century hunting for their nuptial plumes (Funcke in Mellink 2000), most breeding species are presumed to have reduced their colonies and their numbers, while some wintering species also have reduced their numbers, although recently some new colonies have formed (Mellink et al. 2002). Conversely, the white-faced ibis has increased its numbers as a result of agriculture (Anderson and Ohmart 1982; Mellink et al. 1997), and the cattle egret, which has bred in the Mexicali Valley since the early 1970s, is increasing in numbers in the region (Garret and Dunn 1981; Rosenberg et al. 1991).

Pied-billed grebes nest in the marshes of the delta, especially in the Ciénega de Santa Clara and the Hardy River, where they are abundant (Hinojosa-Huerta et al. 2013a). Eared grebes are common winter visitors and were documented nesting in the delta for the first time in 2010, at Las Arenitas wetlands, when 75 adults and at least seven nests were observed (Erickson et al. 2011). Since then, pairs, nests with eggs, and adults feeding juveniles have been recorded every year (Edith Santiago, Sonoran Institute, and Eduardo Soto-Montoya, Reserva de la Biosfera Alto Golfo de California y Delta del Río Colorado, personal communication). 
Western and Clark's grebes breed in nearby regions in California and Arizona, and they were common breeding visitors in the delta during the 1980s (Patten et al. 2001) but have not been recorded breeding in the delta since then.

Seven species of marshbirds breed among the emergent vegetation of the wetlands in the area, and some of them have large populations in the Ciénega de Santa Clara (Hinojosa-Huerta et al. 2013b). One of the species of major interest is the Yuma Ridgeway rail, protected both in the United States and Mexico, and whose population in the Ciénega de Santa Clara is almost 75 percent of the known population of the subspecies, with estimates ranging between 6,000 and 8,000 individuals (Hinojosa-Huerta et al. 2001, 2013b). Some minor populations of this rail occur along the marshes of the Colorado and the Hardy Rivers and in vegetated agricultural drains throughout the valley (Hinojosa-Huerta et al. 2013b).

The most sensitive marshbird in the delta is the California black rail, which is protected as Endangered in Mexico and has fewer than 200 individuals in the region. The largest populations of this species in the delta are located at El Doctor wetlands and the Ciénega de Santa Clara (Hinojosa-Huerta et al. 2013b). The same Ciénega de Santa Clara holds important populations of other marshbirds, including Virginia rail, least bittern, and American bittern, as well as common gallinule and American coot.

The habitat changes in the delta and Lower Colorado reduced the populations of marshbirds in this region (Eddleman et al. 1988), but a modest contribution of agricultural return flows (about 140 million $\mathrm{m} 3$ per year, or less than 1 percent of the average annual flow of the Colorado) has created and maintained nearly 10,000 ha of marsh habitat for these birds, sustaining the largest population of these species in Northwestern Mexico and the Sonoran Desert ecoregion (Hinojosa-Huerta et al. 2008).

As a product of the Cerro Prieto Geothermal facility, several ponds were created. These have small islets on which at least 11 species of waterbirds nest: great blue heron, great egret, snowy egret, black-crowned night-heron, laughing gull, gull-billed, Caspian and Forster's terns, black skimmer, snowy plover, American avocet and, possibly, blacknecked stilt (Mellink et al. 2002; Molina and Garret 2001). The nearby 100 ha wetland of Las Arenitas, associated with the wastewater treatment plant, also provides habitat for several breeding waterbirds, including redhead, Yuma Ridgeway rail, Virginia rail, American coot, common gallinule, and eared grebe.

\section{Upper Estuary}

The tides of the Upper Gulf have one of the largest amplitudes in the world and extend $44 \mathrm{~km}$ upstream from the river mouth during the highest tides of the year, connecting with the flows of the Hardy River and other agricultural drains (Nelson et al. 2013). This area, known as the Upper Estuary, covers nearly 12,000 ha and is dominated by mudflats, tidal channels, Palmer's salt grass (Distichlis palmeri) patches, saltcedar (Tamarix spp.) trees, and few patches of emergent vegetation. The mudflats have been traditionally used for nesting by at least five species: American avocet, black-necked stilt, snowy plover, killdeer, and least tern (Mellink et al. 1996).

This area has experienced large-scale changes recently. Most of it was above the highest tidal line, but coseismic subsidence caused by the April 4, 2010, earthquake dropped the elevation of the area by up to $1.5 \mathrm{~m}$ (Nelson et al. 2013), creating this large 
area of mudflats. The decrease in elevation also facilitated the interaction between tides and drains, especially in sites like Laguna del Indio, where the surface of open water increased. These recently formed habitats are being used by a diversity of waterbirds, in particular migratory shorebirds. Prior to the 2010 earthquake, the area had very few birds (Hinojosa-Huerta et al. 2004), and recent aerial counts estimate between 13,000 and 20,000 shorebirds in the area (Gomez-Sapiens et al. 2013).

The increase of open water and flooding of pre-existing saltcedar thickets favored the establishment of new colonies of waterbirds, especially at Laguna del Indio, where a colony started forming in 2012, and, in 2014, had nesting and juveniles of great blue heron (21 nests), black-crowned night-heron (12 nests), snowy egret ( 9 nests), great egret ( 3 nests), green heron ( 2 nests), and double-crested cormorant ( 7 nests) (HinojosaHuerta et al. 2015). We have also detected vocalizing pairs of Yuma Ridgeway rail, Virginia rail, and least bittern during the breeding season.

\section{Montague Island}

Montague Island $(22 \mathrm{~km}$ long and $7 \mathrm{~km}$ in maximum width, surface area $=$ $\left.47 \mathrm{~km}^{2}\right)$, is a low lying, silt island at the mouth of the Colorado River $\left(31^{\circ} 43\right.$ ' $45^{\prime \prime} \mathrm{N}$ and $\left.114^{\circ} 45^{\prime} 05^{\prime} \mathrm{W}\right)$. The island is nearly featureless, but in its southeastern end there are a series of tidal channels, with banks supporting Palmer's salt grass, the only vascular vegetation of the island, and several sub-fossil shell banks of a nearly-extinct clam (Mulinia coloradoensis; Karl Flessa, University of Arizona, personal communication).

Montague Island existed early in the 20th century, but its existence before the 19th century has not been ascertained. It may have been formed by increased sediment supplies produced by the removal of beavers and by cattle grazing in the Colorado River watershed. Its birds, as well as its other biota, have been studied scantly. Of all known early visitors to the Colorado River Delta, only L.J. Goldman is known to have visited Montague Island. He failed to find any nesting birds there, but considered that "... some of the smaller species might have had nests in the grass," possibly referring to the largebilled savannah sparrows (Passerculus sandwichensis rostratus), which he found to be abundant on the island (Smithsonian Institution Archives, Record Unit 7176).

Montague Island remained marginal to biological reconnaissance for nearly eight decades, until 1991, when we began limited and intermittent research work (Mellink 2003; Mellink et al. 2002; Palacios and Mellink 1992, 1993; Peresbarbosa-Rojas and Mellink 1994, 2001). At least 12 species of waterbirds have been documented to nest on Montague Island (table 10). Additionally, one landbird, the large-billed savannah sparrow, also nests there. The data suggest that Montague Island has been used by nesting birds for no more than a century, as we elaborate below.

At the turn of the $20^{\text {th }}$ century the Colorado River carried large, albeit variable, volumes of water all the way to the Gulf of California. At this time, even under conditions of an "unusually low river," as in 1902, Montague and Gore Islands were "frequently submerged at periods of high tide and river ... [and] at high tide a semisubmerged fringe of salt grass is all that is visible" (Sykes 1937). Similar conditions were recorded in 1915 (L.J. Goldman in 1915, Smithsonian Institution Archives, Record Unit 7176), also a relatively dry year (U.S. Claims Court 1988). Conditions in "normal" 
or wet years could only be less suitable. Hence, no successful nesting seems to have been possible at that time.

By 1935, water storing and diversion projects, including Boulder Dam, had been profusely established on the Colorado River and caused a reduction in water flow in the lower delta (Sykes 1937; U.S. Claims Court 1988). In addition to several biological impacts (Mellink and Ferreira-Bartrina 2000), the reduction in flow might have allowed for extended periods of dry ground and the development of channels with vegetated banks on Montague Island, making it suitable for nesting by waterbirds for the first time.

The ardeids nested widely in the region and would have easily colonized Montague Island when nesting habitat became available. The larids present a more intriguing question. On his 1915 trip to Montague Island, Goldman collected 12 specimens (held in the National Museum of Natural History), among them two gull-billed terns (James Dean, National Museum of Natural History, personal communication). This was the first documentation of this species in the delta of the Colorado River, although it was overlooked by both Nelson (1921) and Grinnell (1928). In the Salton Sea, there were at least 500 pairs of gull-billed terns nesting by 1927 (Pemberton 1927). For such a colony to have formed since the creation of the Sea, or in 6 years as Pemberton thought, the founding group must have been large, or gull-billed terns must have been already nesting somewhere in the delta. The two specimens during the breeding season from Montague Island before conditions were adequate suggest this later possibility, in which case gull-billed terns might have nested in some southern, but unsurveyed, sections of the delta.

Not only were laughing gulls and black skimmers not nesting on Montague Island at the time, but they had not been recorded in the delta in the early $20^{\text {th }}$ century at all (Dawson 1923; Grinnell 1928; Murphy 1917). Laughing gulls began to nest in the Salton Sea in the late 1920s (Miller and van Rossem 1929). This species is highly visible, and individuals can feed several kilometers from their breeding sites. They would not have been overlooked by ornithologists visiting the delta if they had nested in the area. This species is now found in the area even in the non-breeding season (Patten et al. 2001). Its scarcity in the Salton Sea in 1928 (Miller and van Rossem 1929) suggest that it might have been a newcomer to the area, perhaps from the southern Sonoranorthern Sinaloa colonies.

Black skimmers are seemingly recent arrivals to the delta, as they were recorded for the first time in the Salton Sea in 1968 (Collins and Garrett 1996; McCaskie et al. 1974). Given the species' post-Salton Sea history, it is possible that black skimmers used Montague Island as a stepping stone to reach it (Peresbarbosa-Rojas and Mellink 2001), as is suggested by banding records. A likely source for the Montague Island colony would have been the southern Sonora-northern Sinaloa wetlands.

Wilson's plovers were detected to nest there only recently (Eduardo Soto, the head of monitoring, Upper Gulf of California and Delta del Río Colorado Biosphere Reserve, personal communication). These would have colonized from nearby colonies in Sonora, where they nest along the entire northern coast (Mellink and Palacios 1993).

One of the most striking characteristics of Montague Island is frequent tidal inundations (Peresbarbosa-Rojas and Mellink 2001). Such inundations result in very low reproductive output of birds in many, or perhaps most, years. However, in some years there is a good crop of chicks. For example, on 28 June 2001, there were abundant 
Table 11-Number of nesting pairs of waterbirds recorded on Montague Island. El Niño conditions prevailed during the breeding seasons of 1992 and 1998.

\begin{tabular}{|c|c|c|c|c|c|c|c|}
\hline Species & 1991 & 1992 & 1993 & 1994 & 1998 & 1999 & 2001 \\
\hline Great blue heron & $?$ & - & 1 & 2 & - & - & $1 ?$ \\
\hline Snowy egret & $>100$ & + & 87 & 23 & 129 & + & + \\
\hline Black-crowned night-heron & $20 ?$ & $2 ?$ & - & 10 & - & 5 & - \\
\hline American oystercatcher & n.r. & - & $?$ & - & 1 & 2 & - \\
\hline Laughing gull & 60 & + & 170 & 127 & 102 & + & + \\
\hline Caspian tern & - & - & - & def. & - & - & - \\
\hline Least tern & n.r. & 20 & $<10$ & 27 & \pm 110 & 8 & - \\
\hline Gull-billed tern & - & \pm 175 & 92 & 94 & $>77$ & + & few \\
\hline Elegant tern & n.r & \pm 275 & - & - & 160 & 2 & 1 \\
\hline Royal tern & n.r. & \pm 275 & - & - & 135 & 16 & 12 \\
\hline Black skimmer & - & $?$ & 14 & 21 & \pm 178 & 20 & low 100s \\
\hline $\begin{array}{l}?=\text { possibly nesting } \\
-=\text { not found nesting } \\
\text { n.r. = not reviewed } \\
\text { def. = nest defense behavior, } \\
+=\text { the species was nesting in } \\
\text { few }=\text { that there were notably }\end{array}$ & $\begin{array}{l}\text { t not se } \\
\text { ers cor }\end{array}$ & $\begin{array}{l}\text { hed fo } \\
\text { rable }\end{array}$ & $\begin{array}{l}\text { ot fou } \\
\text { vious }\end{array}$ & & & & \\
\hline
\end{tabular}

chicks of snowy egret and laughing gull that were old enough to prove that the colonies had not been completely inundated, and giving the prospect of a season with many fledglings of these two species for that year. These inundations also cause within-year dynamics as colonies totally or partially move between the Estero and the Lighthouse or from lower tidal channels of the Estero to higher ones (Peresbarbosa-Rojas and Mellink 2001).

There are also inter-year differences, as exhibited during 1993 and 1994. In these two non-El Niño years there were some differences, at least in the number of snowy egrets, laughing gulls, and least terns (table 11). Not only were there fewer nests of snowy egrets and laughing gulls in 1994, but these species did not begin nesting until June, much later than in 1993 (Peresbarbosa-Rojas and Mellink 2001). During 1993 there was much runoff of fresh water through the Colorado River, and although difference in flow was the only evident difference, it was not clear how it could cause the observed differences in nest numbers.

At a larger scale, during El Niño (Southern Oscillation) years the colonies on Montague Island exhibit remarkable changes (table 11; Mellink 2003). In 1992 and 1998, both El Niño years, there was an influx of nesting elegant and royal terns, and in 1992 there were many more gull-billed tern nests than in 1993 and, in 1998, many more least tern and black skimmer nests. Such increases in Montague Island bird populations do likely not reflect a major increase in available food or favorable breeding conditions. Rather, it might reflect poor conditions at other breeding grounds (Mellink 2003), at least for those species that nest far away and depend on marine resources. However, our knowledge is inadequate to speculate on the particular origin of individuals reaching Montague Island. 


\section{Conservation Problems}

As in other delta ecosystems worldwide, insufficient and unreliable water supplies and poor water quality are the ultimate causes of environmental degradation in the Colorado River Delta, intensified in this particular case by its location in an arid region. The remnant wetlands in the delta have survived with accidental releases or unintentional flows, and until very recently, there was no water secured for environmental purposes. This is a major challenge for all the different wetland areas, including the Ciénega de Santa Clara, that rely almost completely on agricultural return flows coming from the United States. Such flows have been planned to be diverted for desalinization and further consumptive uses, which will likely cause the degradation of these wetlands.

Most of the present delta vegetation has been enhanced and maintained by flood releases during the 1980s and 1990s (Glenn et al. 2001), restoring in part the cottonwood-willow forests. However, lack of a proper flow regime increases the depth to groundwater, reduces the recruitment of native trees, and increases soil salinity, which favors the establishment of exotic plants, and thereby decreases habitat value. This is coupled with a generalized increase of groundwater extractions, which causes drastic declines of the water table in certain sections of the river corridor, drying up remaining wetlands and stressing riparian vegetation (Ramirez et al. 2013).

Pollution is a concern in the delta that has been prevalent for several decades (see García-Hernández et al. 2000, 2013; Mora 1991; Mora and Anderson 1995). The farming areas in Baja California, Sonora, and Arizona that drain toward the delta are under intense, highly mechanized cultivation. This type of farming involves large quantities of agrochemicals, some of which drain into the wetlands of the delta and flow to the sea in the areas with tidal exchange (Daesslé et al. 2008). Major pollutants of concern in these wetlands and their biota include metals such as mercury, copper, arsenic, and selenium, as well as residue of DDT, PCBs and other organic agrochemicals, especially in the Ciénega de Santa Clara, Hardy River, and the Upper Estuary (García-Hernández et al. 2006, 2013; Guardado-Puentes 1975; Mora 1991).

Human disturbance to the colonies has not been a problem yet. However, as extractive activities become more restricted due to the protected status of the area, larger numbers of tourists, especially at the seashore, may have negative impacts on bird communities. Indeed, some fishermen already have taken tourists to Montague Island during the breeding season. If this activity increases without controls to prevent disturbance, the impacts might aggravate natural impacts (inundating tides, for example), and eventually discourage birds from nesting here.

Predation can impact waterbird colonies (e.g., Pratt and Winkler 1985) but has not been documented on the lower Colorado Delta in general. However, on Montague Island nesting waterbirds are subject to predation by coyotes, which sometimes take a heavy toll on the colonies (Peresbarbosa-Rojas and Mellink 2001). It is not possible to determine the real effect of such predation, especially in the presence of other events that destroy eggs such as high tides or possibly ants (Peresbarbosa-Rojas and Mellink 2001). However, prevention of coyote predation might be of benefit and would be easily accomplished, if desired.

Two other potential threats, indicated for seabirds in Baja California (Everett and Anderson, 1991), seem not to be a problem for Montague Island nesting waterbirds: 
(1) human exploitation of birds or eggs, and (2) impacts of fisheries. In the delta, fisheries have been greatly restricted, involve artisanal gill-nets that do not entangle birds, and extract only fish that are much larger than those consumed by the nesting birds.

\section{Restoration and Conservation Actions}

One of the key strategies to restore waterbird habitat has included securing water sources for the different wetland areas in the delta. This has involved securing the effluent of wastewater plants as instream flows, maintaining the agricultural return flows to the wetlands, and the dedication of irrigation water rights to restore key areas (HinojosaHuerta and Carrillo-Guerrero 2010; Zamora-Arroyo et al. 2008). The Colorado River corridor has recently received allocated flows for ecological restoration under Minute 319 of the International Water Treaty, securing 195 million cubic meters of water on a 5-year period (2012-2017), with one-third of the water provided by Mexico, one-third by the United States, and one-third by a binational coalition of environmental organizations (Gerlak 2015). Part of this water (130 million cubic meters) was delivered as a "pulse flow" during 2014, to revitalize the delta ecosystem, to promote the greening-up of the existing vegetation and the germination of new native plants, and to learn more about the hydrological and biological response of the system (Flessa et al. 2013). Since then, and until 2017, the rest of the water (65 million cubic meters) is being delivered as "base flows" at critical areas of the corridor, to maintain the habitat that has been restored (Flessa et al. 2013).

These efforts have been coupled with intensive restoration actions in specific locations along the riparian corridor, where the intervention includes clearing exotic vegetation, grading the land, establishing native plants, and adding water to sustain the new vegetation and create open water zones (Hinojosa-Huerta et al. 2005). Between 2008 and 2014, a total of 337 ha has been restored and maintained.

Part of the efforts in the delta also includes the implementation of land conservation strategies. One of the earliest achievements was the establishment of the Upper Gulf of California and Colorado River Delta Biosphere Reserve, which protects the Ciénega de Santa Clara, El Doctor Wetlands, Laguna del Indio, and the mudflats near the mouth of the river. To complement the public conservation efforts implemented by the Mexican government with the Biosphere Reserve, environmental organizations have established conservation easement agreements with landowners in key wetlands (Ciénega de Santa Clara and El Doctor) to protect priority habitat for endangered and migratory species. A total of 1,200 ha has been protected under this mechanism in the delta.

\section{Concluding Remarks}

Amazingly, despite the intensive and extensive modification of the wetlands of the Mexican portion of the Colorado River Delta, 37 species of waterbirds nest here. Most of those that nested here in the early 20th century, before the large-scale environmental changes, do so still today, albeit perhaps in much lower numbers. Only one species has ceased breeding in the delta (fulvous whistling-duck), but several have been gained, mostly thanks to the creation of new habitat, including Montague Island (as a nesting locale), the Cerro Prieto islets and, on the U.S. side but interconnected, the Salton Sea. 
At the same time, the rise of public and government environmental awareness, public pressure, and careful negotiation by NGOs have opened unprecedented opportunities for the conservation of wetlands and their associated biota in this area. Fulfillment of such opportunities with serious, knowledgeable, science-based wetland restoration and creation will increase the role of the Mexican portion of the Colorado River Delta as an important area for the conservation of regional biodiversity.

\section{Acknowledgments}

We are very thankful to Edith Santiago and Eduardo Soto-Montoya for kindly sharing unpublished information with us, and Karl Flessa and James Dean, for providing important information.

\section{References}

Anderson, B.W.; Ohmart, R.D. 1982. The influence of the interspersion of agriculture and natural habitats on wildlife in southern California and western Arizona. Boulder City, NV: U.S. Department of the Interior, U.S. Bureau of Reclamation, Lower Colorado Region. 316 p.

Bancroft, G. 1922. Some winter birds of the Colorado delta. Condor. 24: 98.

Collins, C.T.; Garrett, K.L. 1996. The black skimmer in California: An overview. Western Birds. 27: $127-135$.

Daesslé, L.W.; Lugo-Ibarra, K.C; Tobschall, H.J.; [et al.]. 2008. Accumulation of As, Pb, and $\mathrm{Cu}$ associated with the recent sedimentary processes in the Colorado River delta, south of the United States-Mexico boundary. Archives of Environmental Contamination and Toxicology. 56: 680-692.

Dawson, W.L. 1923. The birds of California. San Diego, CA: South Moulton Company. 3 volumes, $2121 \mathrm{p}$.

Dobyns, H.F. 1978. Who killed the Gila? Journal of Arizona History. 19: 17-30.

Dobyns, H.F. 1981. From fire to flood: Historic human destruction of Sonoran Desert riverine oases. Socorro, NM: Ballena Press. 222 p.

Eddleman, W.R.; Knopf, F.L.; Meanley, B.; [et al.]. 1988. Conservation of North American rallids. Wilson Bulletin. 100: 458-475.

Erickson, R.A., Carmona, R.; Ruiz-Campos, G. 2011. Baja California peninsula. North American Birds. 64: 90-91.

Everett, W.T.; Anderson, D.W. 1991. Status and conservation of the breeding seabirds on offshore pacific islands of Baja California and the Gulf of California. International Council of Bird Protection Technical Publication. 11: 115-139.

Felger, R.S. 2000. Flora of the Gran Desierto and Rio Colorado of northwestern Mexico. Tucson, AZ: University of Arizona Press. 673 p.

Flessa, K.W.; Glenn, E.P.; Hinojosa-Hurta, O.; [et al.]. 2013. Flooding the Colorado River delta: A landscape-scale experiment. EOS, Transactions of the American Geophysical Union. 94: 485-486.

Garcia-Hernandez, J.; Glenn, E.P.; Artiola, J.; [et al.]. 2000. Bioaccumulation of selenium (Se) in the Cienega de Santa Clara wetland, Sonora, Mexico. Ecotoxicology and Environmental Safety. 45: 298-304.

García-Hernández, J.; Glenn, E.P.; Flessa, K.W. 2013. Identification of chemicals of potential concern (COPECs) in anthropogenic wetlands of the Colorado River delta. Ecological Engineering. 59: 52-60.

García-Hernández, J.; Sapozhnikova, Y.V.; Schlenk, D.; [et al.]. 2006. Concentration of contaminants in breeding bird eggs from the Colorado River delta, Mexico. Environmental Toxicology and Chemistry. 25: 1640-1647. 
Garret, K.; Dunn, J. 1981. Birds of southern California: Status and distribution. Los Angeles, CA: Los Angeles Audubon Society. 408 p.

Gerlak, A.K. 2015. Resistance and reform: Transboundary water governance in the Colorado River Delta. Review of Policy Research. 32: 100-123.

Glenn, E.P.; Flessa, K.W.; Pitt, J. 2013. Restoration potential of the aquatic ecosystems of the Colorado River Delta, Mexico: Introduction to special issue "Wetlands of the Colorado River Delta." Ecological Engineering. 59: 1-6.

Glenn, E.P.; Zamora-Arroyo, F.; Nagler, P.L.; [et al.]. 2001. Ecology and conservation biology of the Colorado River delta, Mexico. Journal of Arid Environments. 49: 5-15.

Gomez-Sapiens, M.M.; Soto-Montoya, E.; Hinojosa-Huerta, O. 2013. Shorebird abundance and species diversity in natural intertidal and non-tidal anthropogenic wetlands of the Colorado River Delta, Mexico. Ecological Engineering. 59: 74-83.

Grinnell, J. 1928. A distributional summation of the ornithology of Lower California. University of California Publications in Zoology. 32: 1-300.

Guardado-Puentes, J. 1975. Concentración de DDT y sus metabolitos en especies filtroalimentadores y sedimentos en el Valle de Mexicali y Alto Golfo de California. CALCOFI Reports. 18: 73-80.

Hinojosa-Huerta, O.; Carrillo-Guerrero, Y. 2010. La Cuenca Binacional del Río Colorado. In: Cotler Ávalos, H., ed. Las Cuencas Hidrográficas de México, diagnóstico y priorización. México, D.F.: Instituto Nacional de Ecología: 180-187.

Hinojosa-Huerta, O.; Briggs, M.; Carrillo-Guerrero, Y.; [et al.]. 2005. Community-based restoration of desert wetlands: The case of the Colorado River Delta In: Ralph, C.J.; Rich, T.D., eds. 2005. bird conservation implementation and integration in the americas: proceedings of the third international Partners in Flight conference; 2002 March 20-24; Asilomar, CA. Gen. Tech. Rep. PSW-GTR-191. Albany, CA: U.S. Department of Agriculture, Forest Service, Pacific Southwest Research Station: 637-645.

Hinojosa-Huerta, O.; Carrillo-Guerrero, Y.; DeStefano, S.; [et al.]. 2004. Waterbird communities and associated wetlands of the Colorado River Delta, Mexico. Studies in Avian Biology. 27: $52-60$.

Hinojosa-Huerta, O.; DeStefano, S.; Shaw, W. 2001. Abundance and distribution of the Yuma Clapper Rail (Rallus longirostris yumanensis) in the Colorado River delta, Mexico. Journal of Arid Environments. 49: 171-182.

Hinojosa-Huerta, O.; García-Hernández, J.; Carrillo-Guerrero, Y.; [et al.]. 2007. Hovering over the Alto Golfo: The status and conservation of birds from the Rio Colorado to the Gran Desierto. In: Felger, R.S.; Broyles, B., eds. Dry borders: Great natural reserves of the Sonoran Desert. Salt Lake City, Utah: University of Utah Press: 383-407.

Hinojosa-Huerta, O.; Guzmán-Olachea, R.; Butrón-Méndez, J.; [et al.]. 2013b. Status of marsh birds in the wetlands of the Colorado River delta, Mexico. Ecological Engineering. 59: 7-17.

Hinojosa-Huerta, O.; Hernández-Morlán, I.; Calvo-Fonseca, A.; [et al.]. 2015. Response of the avian community to environmental flow releases and restoration actions under Minute 319. In: The Floodplain of the Colorado River in Mexico. Progress report presented to the Binational Environmental Work Group of Minute 319. Ensenada, Baja CA: International Boundary and Water Commission. Pronatura Noroeste.

Hinojosa-Huerta, O.; Rivera-Díaz, J.J.; Iturribarría-Rojas, H.; [et al.]. 2008. Population trends of Yuma clapper rails in the Colorado River delta, Mexico. Studies in Avian Biology. 37: 69-73.

Hinojosa-Huerta, O.; Soto-Montoya, E.; Gómez-Sapiens, M.; [et al.]. 2013a. The birds of the Ciénega de Santa Clara, a wetland of international importance within the Colorado River delta. Ecological Engineering. 59: 61-73.

Kramer, G.W.; Migoya, R. 1989. The Pacific coast of Mexico. In: Smith, L.M.; Pederson, R.L.; Kaminski, R.M., eds. Habitat management for migrating and wintering waterfowl in North America. Lubbock, TX: Texas Tech University: 507-528.

Leopold, A. 1949. The green lagoons. In: The Sand County almanac. New York: Oxford University Press: $150-158$. 
Leopold, A. 1953. Round River: From the journals of Aldo Leopold. Leopold, L.B., ed. New York: Oxford University Press. 173 p.

Leopold, A.S. 1959. Wildlife of Mexico: The game birds and mammals. Los Angeles, CA: University of California Press. $568 \mathrm{p}$.

McCaskie, G.; Liston, S.; Rapley, W.A. 1974. First nesting of black skimmer in California. Condor. 76: 337-338.

Mellink, E. 2000. Captain Edward William Funcke: Hunting from sea to desert. Journal of San Diego History. 46: 35-51.

Mellink, E. 2003. Effect of the 1997-1998 El Niño and 1998-1999 La Niña events on breeding waterbirds and sea lions in the Upper Gulf of California, México. Geofísica Internacional. 42: 539-546.

Mellink, E.; Ferreira-Bartrina, V. 2000. On the wildlife of wetlands of the Mexican portion of the Rio Colorado delta. Bulletin of the Southern California Academy of Sciences. 99: 115-127.

Mellink, E.; Palacios, E. 1993. Notes on breeding coastal waterbirds in northwestern Sonora. Western Birds. 24: 29-37.

Mellink, E.; Castillo, J.A.; de la Cerda, A. 2002. Noteworthy waterbird records in the delta of the Río Colorado, México, 2002. Western Birds. 33: 249-253.

Mellink, E.; Palacios, E; Gonzalez, S. 1996. Notes on the nesting birds of the Cienega de Santa Clara saltflat, northwestern Sonora, Mexico. Western Birds. 27: 202-203.

Mellink, E.; Palacios, E; Gonzalez, S. 1997. Non-breeding waterbirds of the delta of the Rio Colorado, Mexico. Journal of Field Ornithology. 68: 113-123.

Miller, L.; van Rossem, A.J. 1929. Nesting of the laughing gull in southern California. Condor. 31: $141-142$.

Molina, K.C.; Garrett, K.L. 2001. The breeding birds of the Cerro Prieto Geothermal Ponds, Mexicali Valley, Baja California. In: Erickson, R.A.; Howell, S.N.G., eds. Birds of Baja California: Status, distribution, and taxonomy. Monographs in Field Ornithology. 3: 23-28.

Mora, M. 1991. Organochlorines and breeding success in cattle egrets from the Mexicali Valley, Baja California, Mexico. Colonial Waterbirds. 14: 127-132.

Mora, M.A.; Anderson, D.W. 1995. Selenium, boron, and heavy metals in birds from the Mexicali Valley, Baja California, Mexico. Bulletin of Environmental Contamination and Toxicology. 54: 198-206.

Murphy, R.C. 1917. Natural history observations from the Mexican portion of the Colorado Desert. Abstracts of the Linnean Society of New York. 24-25: 43-101.

Nagler, P.L.; Hinojosa-Huerta, O.; Glenn, E.P.; [et al.]. 2005. Regeneration of native trees in the presence of invasive saltcedar in the Colorado River delta, Mexico. Conservation Biology. 19: $1842-1852$.

Nelson, E.W. 1921. Lower California and its natural resources. Memoirs of the National Academy of Sciences. 16: 1-194.

Nelson, S.M.; Fielding, E.J.; Zamora-Arroyo, F.; [et al.]. 2013. Delta dynamics: Effects of tides, river flows and a major earthquake on Ciénega de Santa Clara and the Colorado River delta, Mexico. Ecological Engineering. 59: 144-156.

Palacios, E.; Mellink, E. 1992. Breeding bird records from Montague Island, northern Gulf of California. Western Birds. 23: 41-44.

Palacios, E.; Mellink, E. 1993. Additional records of breeding birds from Montague Island, northern Gulf of California. Western Birds. 24: 259-262.

Patten, M.A.; Mellink, E.; de Silva, H. 2001. Colorado Desert avifauna of Baja California. In: Erickson, R.A.; Howell, S.N.G., eds. Birds of Baja California: Status, distribution, and taxonomy. Monographs in Field Ornithology. 3: 29-63

Payne, J.M.; Reid, F.A.; Carrera-Gonzalez, E. 1991. Feasibility study for the possible enhancement of the Colorado Delta wetlands Baja California Norte, Mexico. Ducks Unlimited - Ducks Unlimited de Mexico. 31 p. + appendixes. 
Pemberton, J.R. 1927. The American gull-billed tern breeding in California. Condor. 29: 253-258.

Peresbarbosa, E.; Mellink, E. 1994. More records of breeding birds from Montague Island, northern Gulf of California. Western Birds. 25: 201-202.

Peresbarbosa-Rojas, E; Mellink, E. 2001. Nesting waterbirds of Isla Montague, Northern Gulf of California, Mexico: Loss of eggs due to predation and flooding, 1993-1994. Waterbirds. 24: 265-271.

Pratt, H.M.; Winkler, D.W. 1985. Clutch size, timing of laying, and reproductive success in a colony of great blue herons and great egrets. Auk. 103: 49-63.

Price, W.W. 1899. Some winter birds of the Lower Colorado valley. Bulletin of the Cooper Ornithological Club. 1: 89-93.

Ramírez-Hernández, J.; Hinojosa-Huerta, O.; Peregrina-Llanes, M.; [et al.]. 2013. Groundwater responses to controlled water releases in the limitrophe region of the Colorado River: Implications for management and restoration. Ecological Engineering. 59: 93-103.

Rodriguez, C.A.; Flessa, K.W.; Dettman, D.L. 2001. Effects of upstream diversion of Colorado River water on the estuarine bivalve mollusk Mulinia coloradoensis. Conservation Biology. 15: 249-258.

Rosenberg, K.V.; Ohmart, R.D. Hunter, W.C.; Anderson, B.W. 1991. Birds of the lower Río Colorado valley. Tucson, AZ: University of Arizona Press. 416 p.

Sykes, G. 1937. The Colorado Delta. Washington, DC: American Geographical Society Publication 19. $193 \mathrm{p}$.

United States Claims Court. 1988. Rene B. Gasser et al. and Gordon F. Bailey vs. the United States (33-84L \& 177-84L). Suit for compensation for property damages due to the construction and operation of Hoover Dam and Glenn Canyon Dam.

Zamora-Arroyo, F.; Hinojosa-Huerta, O.; Santiago, E.; [et al.]. 2008. Collaboration in Mexico: Renewed hope for the Colorado River delta. Nevada Law Journal. 8: 871-889.

Zamora-Arroyo, F.; Pitt, J.; Cornelius, S.; [et al.]. 2005. Conservation priorities in the Colorado River delta Mexico and the United States. Tucson, AZ: University of Arizona, Sonoran Institute. Environmental Defense. 103 p. ISBN 968-817-726-1. 


\title{
Chapter 11. Terrestrial Vertebrates of Mesquite Bosques in Southwestern North America
}

\author{
R. Roy Johnson, Elaine E. Johnson, and Steven W. Carothers
}

\section{Introduction}

The major emphasis of this chapter is to address the species richness and population densities of land vertebrates in riparian mesquite bosques (woodlands). We find no single publication that lists vertebrates - amphibians, reptiles, birds, and mammals — of riparian mesquites of the Southwest lowlands. These vertebrates are listed for a few river valleys, such as the Santa Cruz River (Webb et al. 2014) and San Pedro River (Stromberg and Tellman 2009), but not for the Southwest as a whole. This chapter presents a summary of the vertebrate fauna of mesquite bosques. Our lists of vertebrates of bosques and/or associated cottonwood-willow forests and riparian deciduous woodlands have been constructed from literature, historic records and specimens, and our first-hand knowledge.

\section{Mesquite Bottomlands as Wildlife Habitat}

A large number of the vertebrate species occurring as obligate and facultative riparian species in cottonwood-willow gallery forests also occur in mesquite bosques. These species inhabit riparian mesquites not only along streams but also along dry watercourses (tables 12-15). An amphibian or reptile species may often occur in cottonwood-willow or mixed deciduous forests, in mesquite bosques, or in upland ecosystems. A mammal species - except larger mammals and bats - may also often occur in one of these three watershed zones. Although an avian species may use one of those three zones, several species occur in all three zones. Some birds, especially larger species, roost and nest at distances from riparian ecosystems but spend parts of the day flying over and/or foraging in bosques and adjacent zones.

Some vertebrates are so ubiquitous in bosques that two of them are often called the "mesquite warbler" (Lucy's Warbler; Gilman 1909; Johnson et al. 1997) and "mesquite mouse" (Merriam's mouse; Hoffmeister 1986; IUCN 2015; see tables for scientific names). Several tropical species whose ranges extend no farther north than the extreme southwestern United States are now relatively rare in this region, having experienced drastic reductions in their U.S. populations, paralleling the losses of most mesquite bosques. Notable are the ferruginous pygmy-owl (Johnson et al. 2003; Phillips et al. 1964), gray hawk (Bibles et al. 2002; Glinski 1998), and brown vinesnake (Stebbins 1985). Although the species we list (tables 10 to 13) are mainly associated with perennial and larger intermittent streams, some species also maintain populations within xeroriparian ecosystems associated with desert washes.

Birds of mesquite bosques and xeroriparian ecosystems are the best studied of vertebrates. Recent surveys of Sonoran and Chihuahuan desert ecosystems have compared breeding birds of xeroriparian ecosystems along desert washes - most of them lined 
with mesquites - with the surrounding uplands. Numbers of species and/or numbers of individual birds of these xeroriparian ecosystems are commonly 10 times or more compared to those of the surrounding uplands (Johnson and Haight 1985, 1988). Some of the larger drainages, such as Aguajita, Growler, and Vekol washes in southern Arizona, have small bosques with large mesquite trees that support nesting by numerous species of smaller birds and even larger birds, such as Cooper's hawks, red-tailed hawks, and great horned owls (Groschupf et al. 1988) and rare species such as the ferruginous pygmy-owl (Johnson et al. 2003). This small tropical owl was first discovered for the United States in a mesquite bosque along the Rillito River in 1872 by Major Charles Bendire (Bendire 1892; Proudfoot and Johnson 2000). In addition, large mammals often rely on xeroriparian habitat along these washes for food, shelter, and movement corridors, including species such as mule deer (Krausman et al. 1985), javelina, and coyotes (R.R. Johnson, numerous observations, Tucson, Arizona, during several decades).

Of particular interest is a group of amphibians in Vekol Valley in southwestern Arizona, just north of the United States-Mexico international boundary. The arid Vekol Valley is populated by three amphibian species that occur no farther north than southwestern Arizona - Sonoran green toad, lowland burrowing treefrog, and Sinaloan narrow-mouthed toad (Enderson and Bezy 2007; R. Babb, Biologist, Arizona Game and Fish Department, personal communication). These three tropical amphibians are among species that occur in mesquite grasslands of this region (Stebbins 1985). The vegetation of Vekol Valley is largely Sonoran desertscrub (Brown 1982) but has remains of more extensive semidesert grasslands that existed prior to heavy grazing by cattle. The valley is also transected by the large, mesquite-lined Vekol Wash that contains numerous earthen cattle tanks. Amphibians are generally considered inhabitants of at least moist conditions, often perennial water, but these three, as well as several other species, have adapted to more arid conditions. Like several other species of frogs and toads, these three amphibians aestivate during drier and colder parts of the year, emerging during summer rains to breed and lay eggs in resulting pools of water.

\section{The Mesquite-Invertebrate-Vertebrate Foodweb}

It is not surprising to find that avian and mammalian faunas of a region show a preference for mesquites and other riparian habitats because of access to food, shelter, and for some - water - associated with riparian ecosystems (see tables 13, 14, and 15). Most insects are herbivorous; thus insect populations are elevated in the increased vegetation in riparian ecosystems, compared to upland ecosystems of the Southwest lowlands. More than 700 species of insects associated with mesquites in the new world were reported by Ward et al. (1977). This is reflected in the large percentage of insectivorous riparian birds found in mesquite bosques and cottonwood-willow riparian forests (tables 11 and 12).

Lizards are also largely insectivorous (Jones and Lovich 2009; Stebbins 1985) and snakes that prey on lizards and mammals (Stebbins 1985) also occur along with their prey in riparian ecosystems. Some snakes, such as gartersnakes, are aquatic or semi-aquatic and often inhabit hydroriparian or mesoriparian ecosystems along perennial or intermittent streams, feeding on frogs, toads, tadpoles, and other aquatic organisms (Stebbins 1985). Amphibians also commonly occur in riparian habitats 


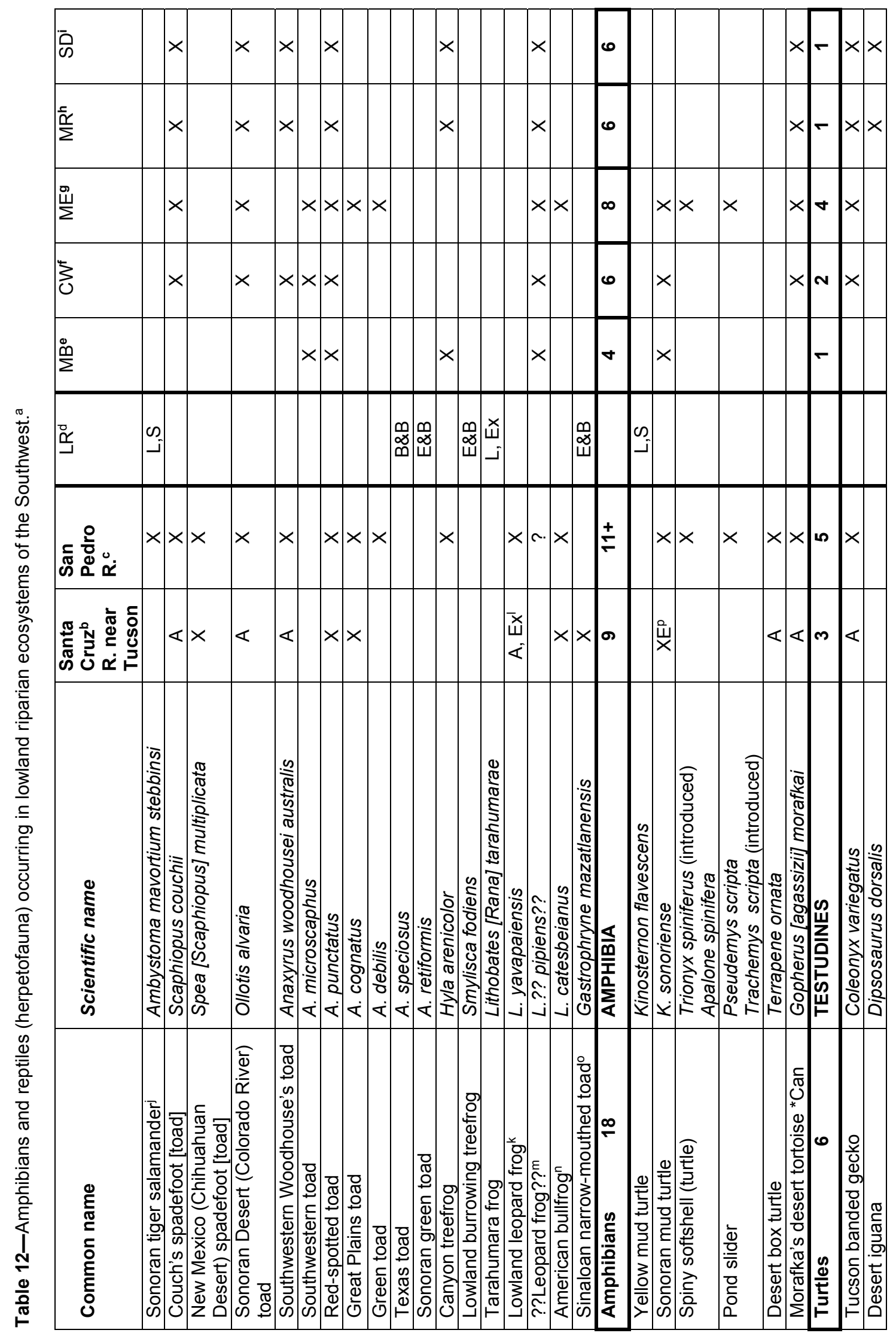




\begin{tabular}{|c|c|c|c|c|c|c|c|c|c|c|c|c|c|c|c|c|c|c|c|c|}
\hline$\overline{\bar{\omega}}$ & $\times$ & $\times$ & & $\times \times$ & $x$ & $\times$ & & $\times$ & $\times \times$ & $\times \mid \times$ & & & & & & & & & $\times$ & \\
\hline$\underline{\underline{\alpha}}$ & $\times$ & $\times$ & & $\times \mid \times$ & $\times$ & $\times$ & & $\times$ & $\times \times$ & $\times \mid \times$ & & & & & & & & & $\times$ & \\
\hline$\stackrel{\Psi}{\Sigma}$ & & $x$ & & & & & & $\times$ & $\times \times$ & & & & & & & & & & $\times$ & \\
\hline$\sum_{0}^{n}$ & $\times$ & $\times$ & & $\times \mid \times$ & $\times$ & $\times$ & $\times$ & $\times$ & $\times$ & $\neg$ & $\times$ & & $\supset$ & & & $\times$ & & $\times$ & $\times$ & \\
\hline 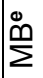 & & $\times$ & & & $\times$ & $x$ & $\times$ & & $\times$ & & $\times$ & & & & & $\times$ & & $\times$ & $\times$ & \\
\hline בּَ & & \lrcorner & & & $\underline{\alpha}$ & z) & $\stackrel{ \pm}{\supset}$ & & & $\left|\begin{array}{l}3 \\
\alpha \\
\partial\end{array}\right|$ & & 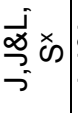 & 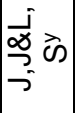 & 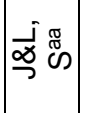 & 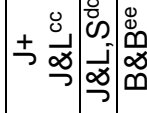 & 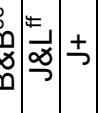 & 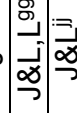 & 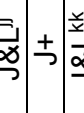 & 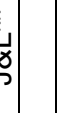 & 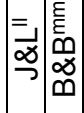 \\
\hline
\end{tabular}

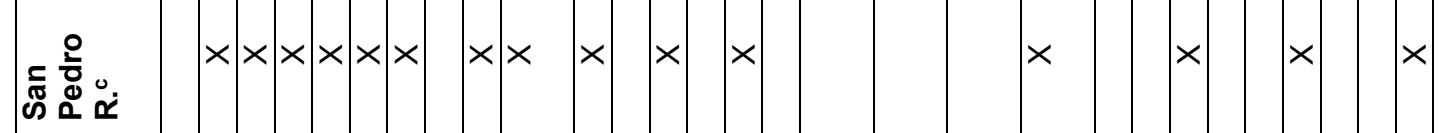

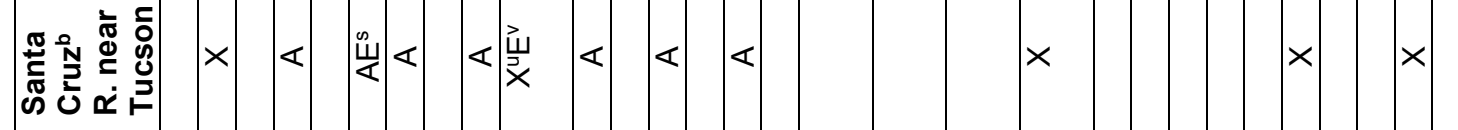

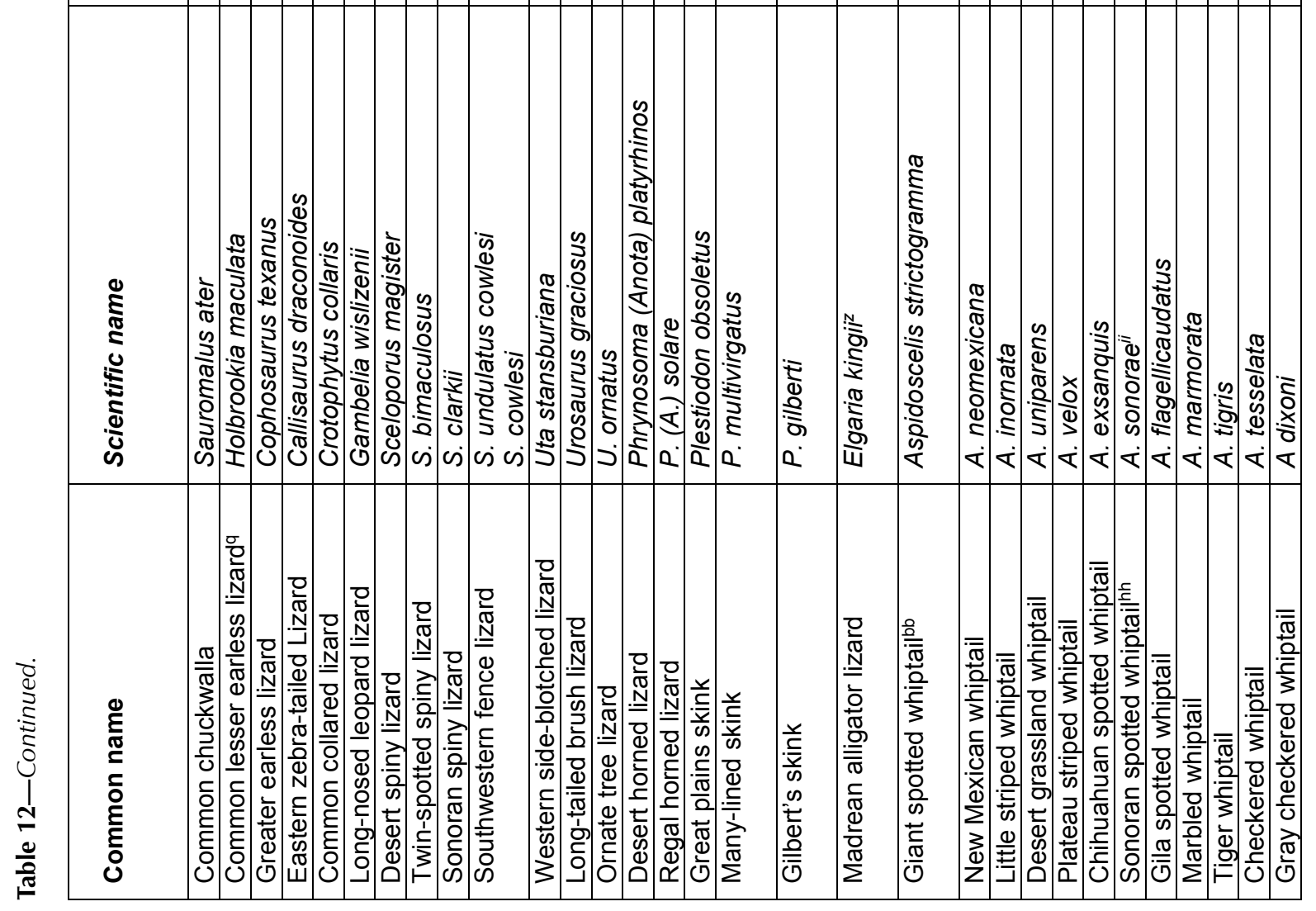




\begin{tabular}{|c|c|c|c|c|c|c|c|c|c|c|c|c|c|c|c|c|c|c|c|c|c|c|c|}
\hline ڤ̄ & $\times$ & $\stackrel{0}{\circ}$ & $x$ & & $\times \times$ & $<\times$ & & $\times \times$ & & & $\times$ & $\times$ & $|\times|>$ & $\times$ & $\times$ & $\times$ & & $\times \times$ & & $\times$ & $\times \mid>$ & $<$ & $\times$ \\
\hline$\frac{\bar{\alpha}}{\frac{\alpha}{\Sigma}}$ & $\times$ & $\stackrel{0}{\circ}$ & $\times$ & & & & & $\times \times$ & & & $\times$ & $\times$ & $|x|>$ & $\times$ & $\times$ & $\times$ & & $\times$ & & & $\times \mid>$ & $x$ & $\times$ \\
\hline$\stackrel{\ddot{m}}{\Sigma}$ & $\times$ & 음 & $x$ & & & & & $x$ & & & $\times$ & & $\times \mid \times$ & $\times$ & $\times$ & $\times$ & $\times$ & $\times \times$ & & $\times$ & & $x$ & $\times$ \\
\hline$\overbrace{0}^{n}$ & $\times$ & $\stackrel{\infty}{\sim}$ & $x$ & & $\times \times$ & & & $\times$ & $\times \times$ & $\times \mid>$ & $\times$ & & $x \mid \times$ & $\times$ & $\times$ & $\times$ & & $\times$ & & $\times$ & $\times \mid>$ & $x$ & $\times$ \\
\hline 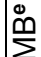 & & a & $x$ & & & & & & $\times$ & $x$ & & & $x \mid \times$ & $\times$ & $\times$ & $\times$ & & & & $\times$ & & & $\times$ \\
\hline בִ & & & & 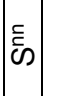 & & o $\begin{array}{l}0 \\
\dot{c}\end{array}$ & $\stackrel{2}{2}$ & & 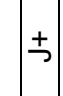 & \pm & 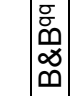 & 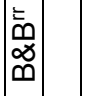 & & $\mid \begin{array}{l}\mathscr{\omega} \\
\infty \\
\infty \\
\infty \\
\infty \\
\infty\end{array}$ & $\begin{array}{l}\mathcal{\omega} \\
\infty \\
\infty \\
\infty\end{array}$ & & $\stackrel{x}{x}$ & & 文 & 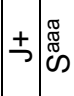 & & & \\
\hline
\end{tabular}

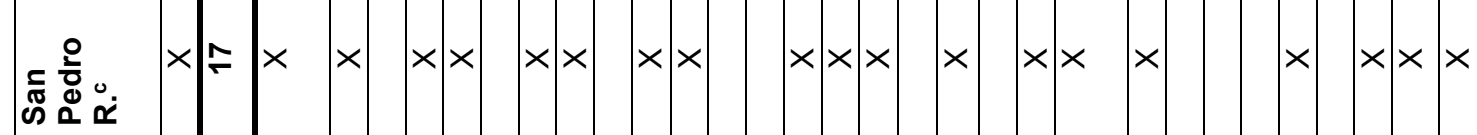

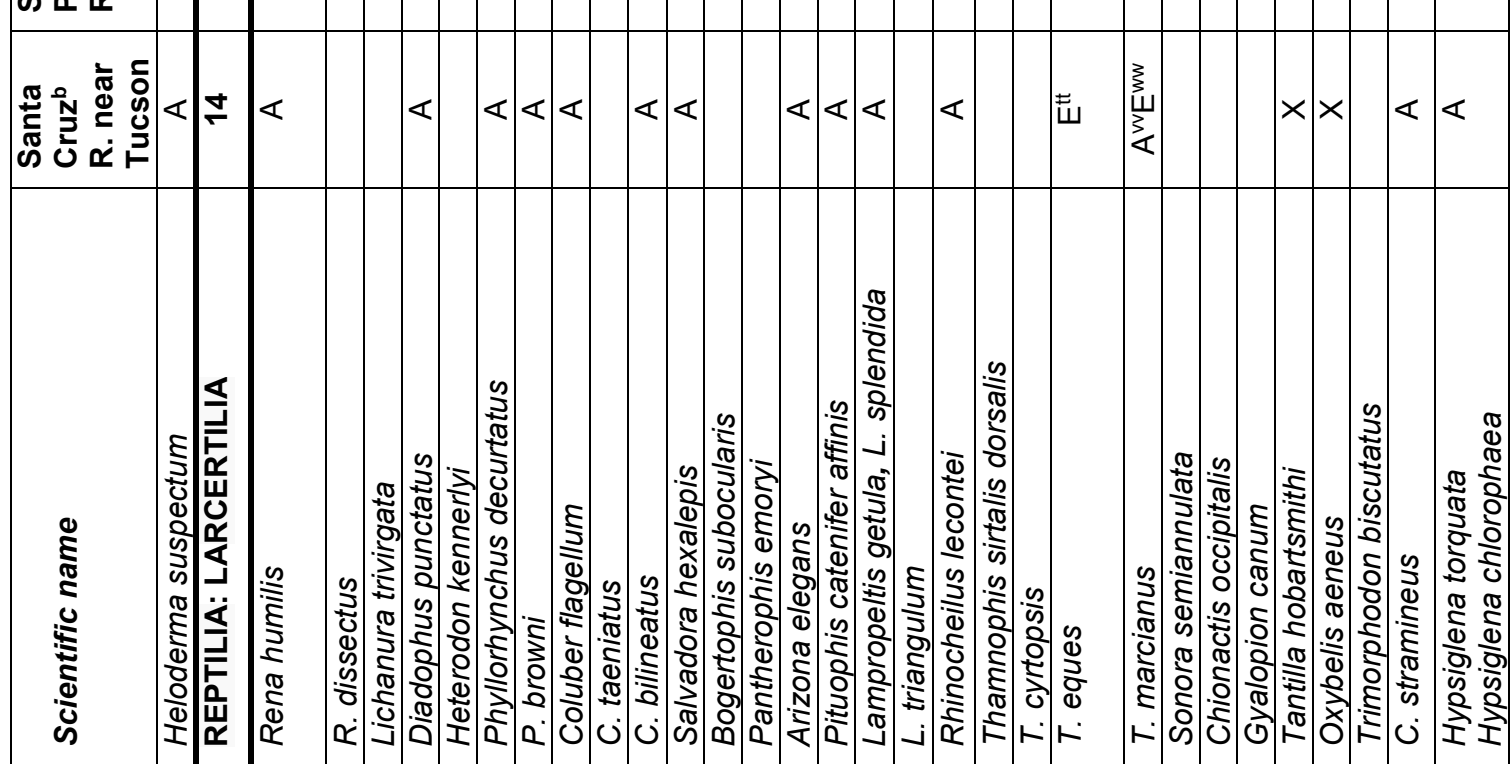

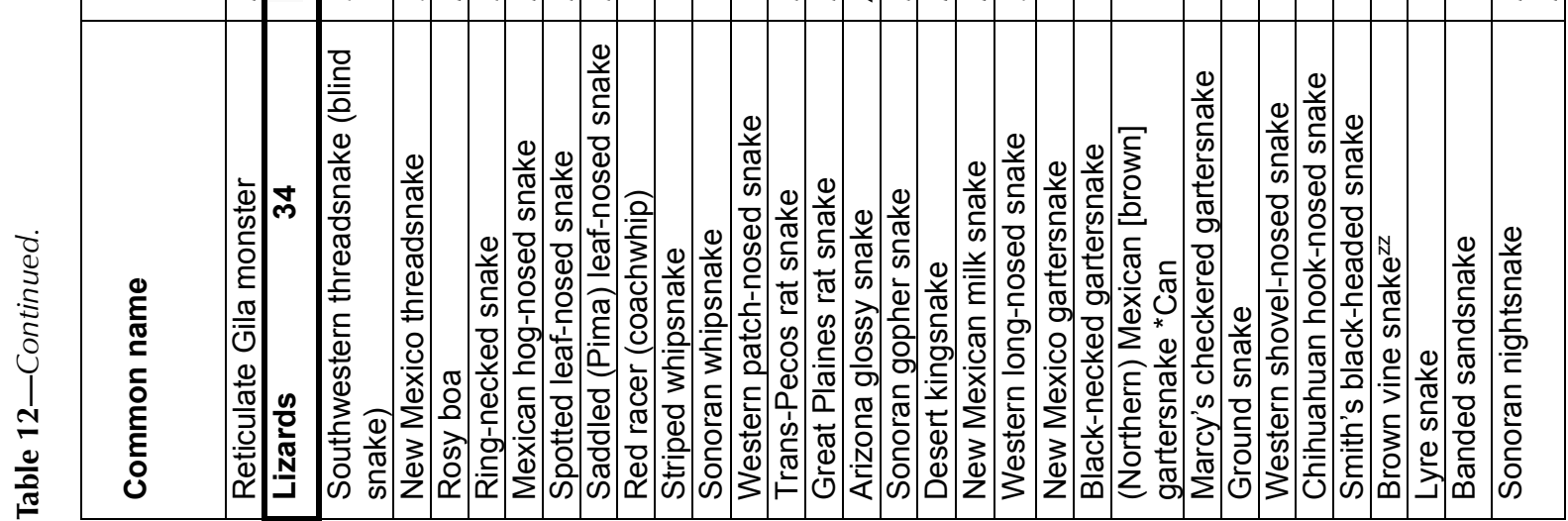




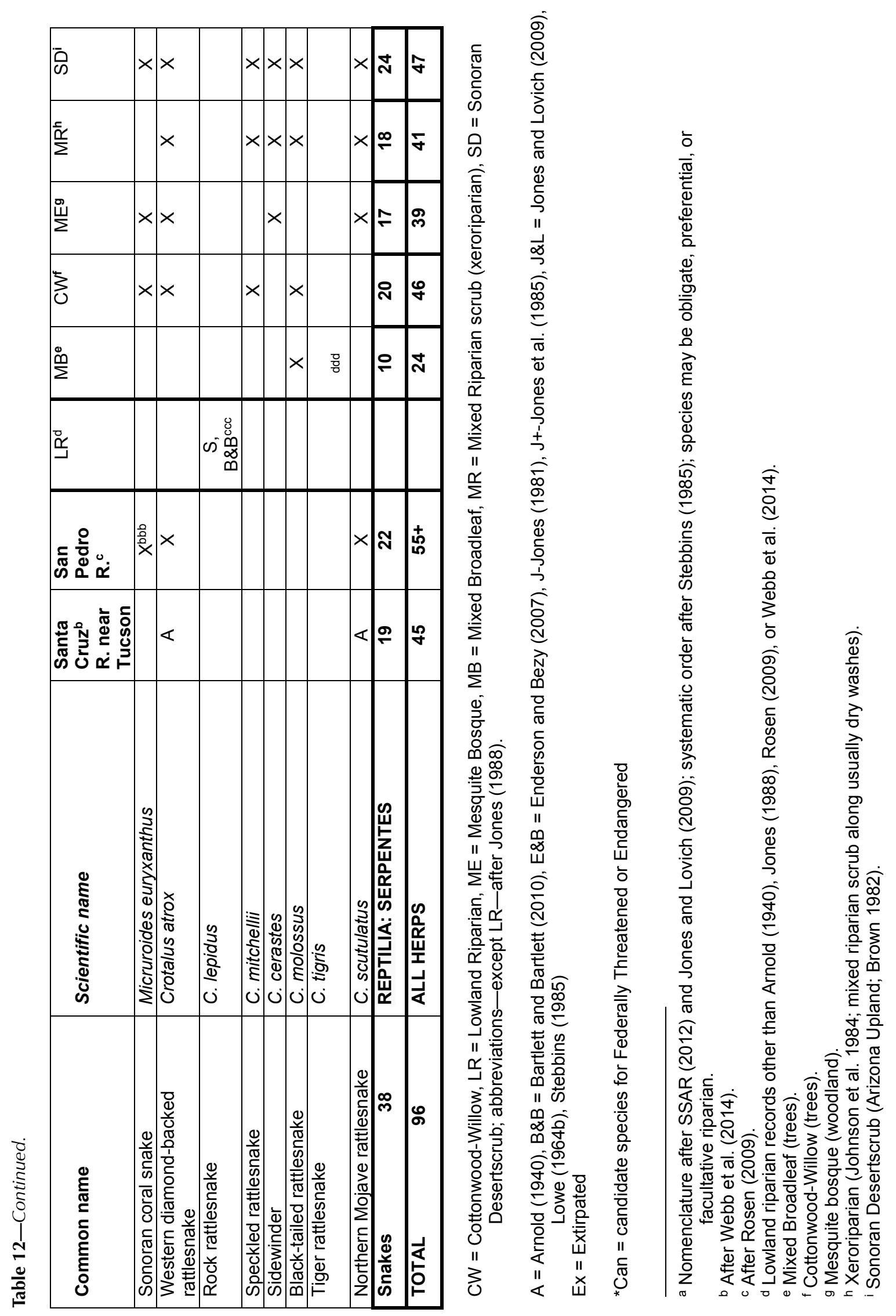




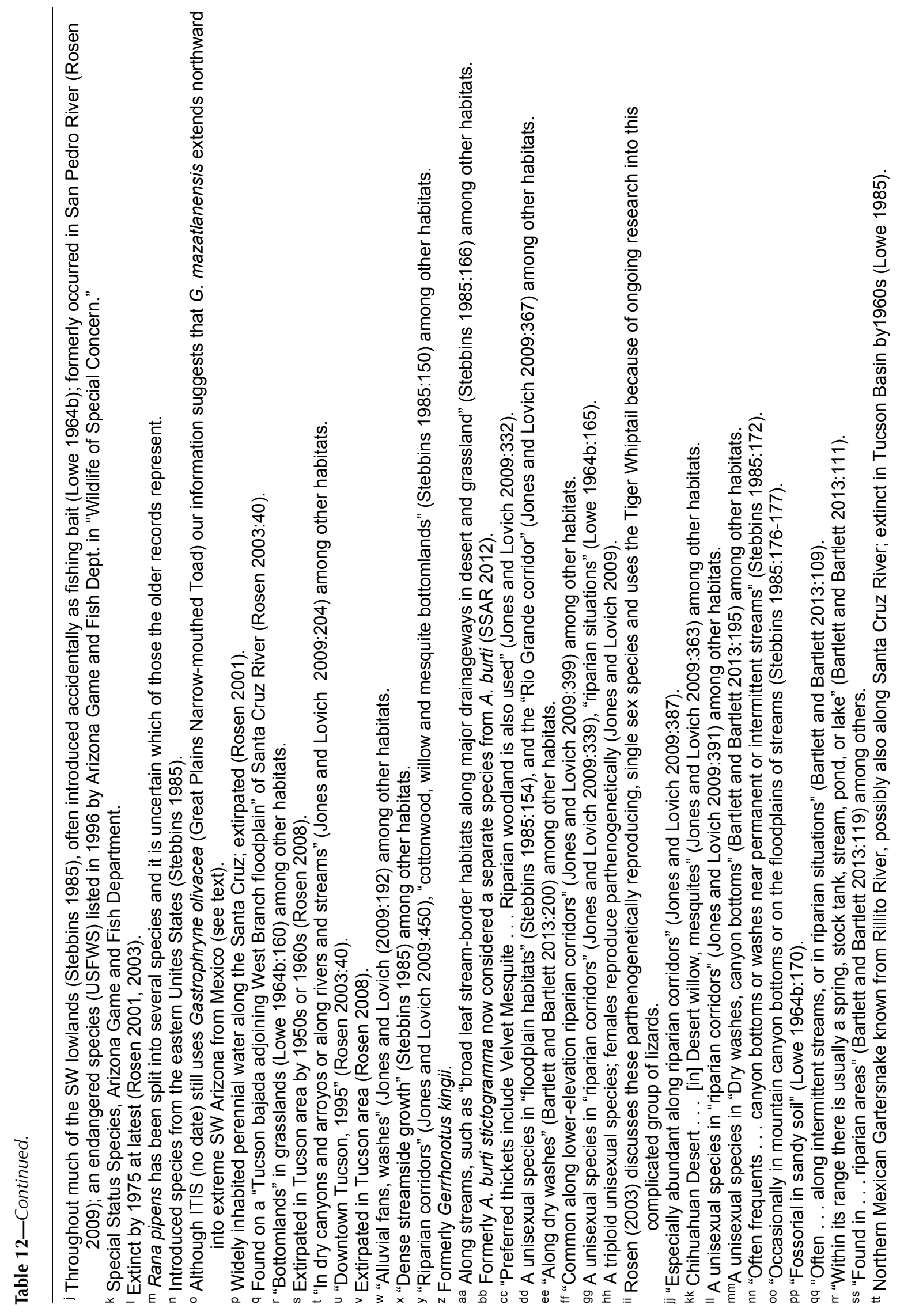




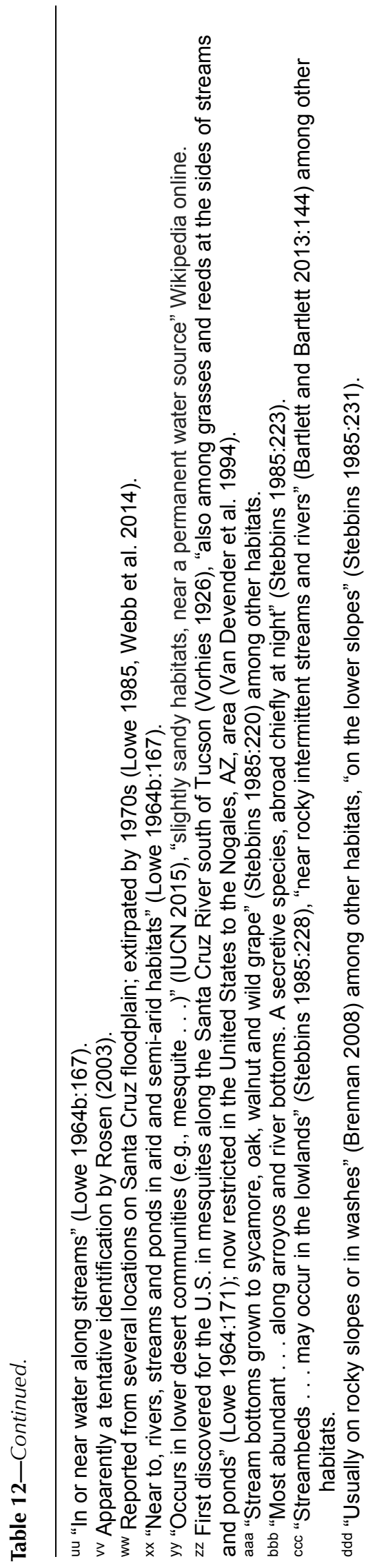


Table 13-Riparian breeding birds ${ }^{a}$ of mesquite bosques and mixed deciduous woodlands.

\begin{tabular}{|c|c|c|c|c|c|c|}
\hline \multirow{2}{*}{ Location } & & \multicolumn{3}{|c|}{ Mesquite } & \multicolumn{2}{|c|}{ Mixed deciduous } \\
\hline & & $\begin{array}{l}\text { Lower } \\
\text { Verde R. }\end{array}$ & $\begin{array}{c}\text { San } \\
\text { Pedro R. }\end{array}$ & $\begin{array}{c}\text { San } \\
\text { Pedro R. }\end{array}$ & $\begin{array}{c}\text { Dry } \\
\text { Beaver } \\
\text { Crk. }\end{array}$ & $\begin{array}{l}\text { West } \\
\text { Clear } \\
\text { Crk. }^{c} \\
\end{array}$ \\
\hline Years of records & & 1975 & $\begin{array}{l}1972- \\
1973\end{array}$ & $\begin{array}{l}2006- \\
2015\end{array}$ & $\begin{array}{c}1969- \\
1974\end{array}$ & $\begin{array}{l}1969- \\
1974\end{array}$ \\
\hline Source & & $\begin{array}{c}\text { NES } \\
(1978)\end{array}$ & $\begin{array}{c}\text { TAG } \\
(1975)\end{array}$ & $\begin{array}{c}\text { IBA } \\
(2015)^{d}\end{array}$ & $\begin{array}{l}\text { SWC } \\
(1974)\end{array}$ & $\begin{array}{l}\text { SWC } \\
(1974)\end{array}$ \\
\hline Common name & Scientific name ${ }^{e}$ & & & & & \\
\hline \#Gambel's quail & Callipepla gambelii & $\mathrm{X}$ & $\mathrm{XO}$ & $\mathrm{X}$ & & \\
\hline Great blue heron & Ardea herodias & & & $\mathrm{X}$ & & \\
\hline Turkey vulture & Cathartes aura & & $\mathrm{F}$ & $\mathrm{X}$ & & \\
\hline \#Cooper's hawk & Accipiter cooperii & & $? ?$ & $\mathrm{X}$ & & \\
\hline \#Gray hawk & Buteo plagiatus & & & $\mathrm{X}$ & & \\
\hline \#Swainson's hawk & Buteo swainsoni & & $\mathrm{F}$ & $\mathrm{X}$ & & \\
\hline Red-tailed hawk & B. jamaicensis & & & $\mathrm{X}$ & & \\
\hline \#White-winged dove & Zenaida asiatica & $\mathrm{X}$ & $\mathrm{XO}$ & $\mathrm{X}$ & & \\
\hline \#Mourning dove & Z. macroura & $\mathrm{X}$ & $\mathrm{X}$ & $\mathrm{X}$ & $\mathrm{X}$ & $\mathrm{X}$ \\
\hline Inca dove & Columbina inca & & & $? ?$ & & \\
\hline \#Common ground-dove & C. passerina & & $\mathrm{X}$ & $\mathrm{X}$ & & \\
\hline \#Yellow-billed cuckoo $^{\dagger}$ & Coccyzus americanus & & & $\mathrm{X}$ & & \\
\hline \#Greater roadrunner & Geococcyx californianus & & $\mathrm{XO}$ & $\mathrm{X}$ & & \\
\hline Barn owl & Tyto alba & & $? ?$ & & & \\
\hline \#Western screech-owl & Megascops kennicottii & & $? ?$ & & & \\
\hline Great horned owl & Bubo virginianus & & $? ?$ & $? ?$ & & \\
\hline \#Elf owl & Micrathene whitneyi & & $? ?$ & & & \\
\hline Lesser nighthawk & Chordeiles acutipennis & & $\mathrm{F}$ & $\mathrm{X}$ & & \\
\hline \#Black-chinned hummingbird & Archilochus alexandri & $\mathrm{X}$ & & $? ?$ & $\mathrm{X}$ & $\mathrm{X}$ \\
\hline Anna's hummingbird & Calypte anna & & & $\ddot{x}$ & & \\
\hline 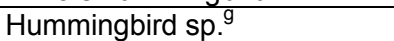 & ????????? & & $\mathrm{XO}$ & & & \\
\hline \#Gila woodpecker & Melanerpes uropygialis & $\mathrm{X}$ & $\mathrm{XO}$ & $\mathrm{X}$ & $\mathrm{X}$ & $\mathrm{X}$ \\
\hline \#Ladder-backed woodpecker & Picoides scalaris & $\mathrm{X}$ & $\mathrm{X}$ & $\mathrm{X}$ & $\mathrm{X}$ & $\mathrm{X}$ \\
\hline Northern flicker & Colaptes auratus & & & & & $\mathrm{X}$ \\
\hline \#Gilded flicker & C. chrysoides & $\mathrm{X}$ & & & & \\
\hline $\begin{array}{l}\text { \#Northern beardless- } \\
\text { tyrannulet }\end{array}$ & Camptostoma imberbe & & $? ?$ & $\mathrm{X}$ & & \\
\hline Western wood pewee & Contopus sordidulus & & & & $\mathrm{X}$ & $\mathrm{X}$ \\
\hline $\begin{array}{l}\text { \#Willow flycatcher } \\
\text { [gray flycatcher] }\end{array}$ & $\begin{array}{l}\text { Empidonax traillii } \\
\text { [E. wrightii] }\end{array}$ & & & & & $X^{n}$ \\
\hline \#Black phoebe & Sayornis nigricans & & & $? ?$ & & $\mathrm{X}$ \\
\hline Say's phoebe & S. saya & & & $? ?$ & & \\
\hline \#Vermilion flycatcher & Pyrocephalus rubinus & & $\mathrm{X}$ & $x$ & & \\
\hline \#Ash-throated flycatcher & Myiarchus cinerascens & $\mathrm{X}$ & $\mathrm{X}$ & $\mathrm{X}$ & $\mathrm{X}$ & $\mathrm{X}$ \\
\hline \#Brown-crested flycatcher & M. tyrannulus & $\mathrm{X}$ & & $\mathrm{X}$ & $\mathrm{X}$ & $\mathrm{X}$ \\
\hline Western kingbird & T. verticalis & & $\mathrm{XO}$ & $\mathrm{X}$ & & $\mathrm{X}$ \\
\hline \#Bell's vireo & Vireo bellii & & $\mathrm{X}$ & $\mathrm{X}$ & $\mathrm{X}$ & $\mathrm{X}$ \\
\hline \#Chihuahuan raven & Corvus cryptoleucus & & $\mathrm{F}$ & & & \\
\hline Common raven & C. corax & & $\mathrm{F}$ & $\mathrm{X}$ & & \\
\hline Violet-green swallow & Tachycineta thalassina & & & & & $\mathrm{X}$ \\
\hline $\begin{array}{l}\text { \#Northern rough-winged } \\
\text { swallow }\end{array}$ & Stelgidopteryx serripennis & & & $\mathrm{X}$ & & \\
\hline Bridled titmouse & Baeolophus wollweberi & & & & $\mathrm{X}$ & $\mathrm{X}$ \\
\hline \#Verdin & Auriparus flaviceps & $\mathrm{X}$ & $\mathrm{X}$ & $\mathrm{X}$ & $\mathrm{X}$ & $\mathrm{X}$ \\
\hline \#Cactus wren & $\begin{array}{l}\text { Campylorhynchus } \\
\text { brunneicapillus }\end{array}$ & & & $? ?$ & & \\
\hline \#Bewick's wren & Thryomanes bewickii & & $\mathrm{X}$ & $\mathrm{X}$ & $\mathrm{X}$ & $\mathrm{X}$ \\
\hline \#Black-tailed gnatcatcher & Polioptila melanura & & & $\mathrm{X}$ & & \\
\hline \#Curve-billed thrasher & T. curvirostre & & $? ?$ & $? ?$ & & \\
\hline \#Crissal thrasher & T. crissale & $\mathrm{X}$ & & & & \\
\hline \#Northern mockingbird & Mimus polyglottos & & & $? ?$ & & $\mathrm{X}$ \\
\hline European starling $^{\prime}$ & Sturnus vulgaris & $\mathrm{X}$ & & & & \\
\hline \#Phainopepla & Phainopepla nitens & & $\mathrm{XO}$ & $\mathrm{X}$ & & $\mathrm{X}$ \\
\hline \#Lucy's warbler & Oreothlypis luciae & $\mathrm{X}$ & $\mathrm{X}$ & $\mathrm{X}$ & $\mathrm{X}$ & $\mathrm{X}$ \\
\hline \#Common yellowthroat & Geothlypis trichas & & & $? ?$ & & \\
\hline
\end{tabular}


Table 13-Continued.

\begin{tabular}{|c|c|c|c|c|c|c|}
\hline \multirow[b]{2}{*}{ Location } & & \multicolumn{3}{|c|}{ Mesquite } & \multicolumn{2}{|c|}{ Mixed deciduous } \\
\hline & & $\begin{array}{l}\text { Lower } \\
\text { Verde R. }\end{array}$ & $\begin{array}{c}\text { San } \\
\text { Pedro R. }\end{array}$ & $\begin{array}{c}\text { San } \\
\text { Pedro R. }\end{array}$ & $\begin{array}{c}\text { Dry } \\
\text { Beaver } \\
\text { Crk. }\end{array}$ & $\begin{array}{l}\text { West } \\
\text { Clear } \\
\text { Crk. }^{c}\end{array}$ \\
\hline Years of records & & 1975 & $\begin{array}{c}1972- \\
1973\end{array}$ & $\begin{array}{l}2006- \\
2015\end{array}$ & $\begin{array}{l}1969- \\
1974\end{array}$ & $\begin{array}{c}1969- \\
1974\end{array}$ \\
\hline Source & & $\begin{array}{c}\text { NES } \\
(1978)\end{array}$ & $\begin{array}{c}\text { TAG } \\
(1975)\end{array}$ & $\begin{array}{c}\text { IBA } \\
(2015)^{d}\end{array}$ & $\begin{array}{c}\text { SWC } \\
(1974)\end{array}$ & $\begin{array}{c}\text { SWC } \\
(1974)\end{array}$ \\
\hline Common name & Scientific name ${ }^{e}$ & & & & & \\
\hline \#Yellow warbler & Setophaga petechia & & $\mathrm{XO}$ & $\mathrm{X}$ & $\mathrm{X}$ & $\mathrm{X}$ \\
\hline \#Yellow-breasted chat & Icteria virens & & $\mathrm{X}$ & $\mathrm{X}$ & $\mathrm{X}$ & $\mathrm{X}$ \\
\hline \#Canyon towhee & Melozone fusca & & & $\mathrm{X}$ & & \\
\hline \#Abert's towhee & M. aberti & $\mathrm{X}$ & & $\mathrm{X}$ & & \\
\hline \#Rufous-winged sparrow & Peucaea carpalis & & & $\mathrm{X}$ & & \\
\hline \#Black-throated sparrow & Amphispiza bilineata & $\mathrm{X}$ & $\mathrm{X}$ & $\mathrm{X}$ & & \\
\hline \#Song sparrow & Melospiza melodia & & $\mathrm{X}$ & $\mathrm{X}$ & & \\
\hline \#Summer tanager & Piranga rubra & & $X$ & $\mathrm{X}$ & $\mathrm{X}$ & $\mathrm{X}$ \\
\hline \#Northern cardinal & Cardinalis cardinalis & $\mathrm{X}$ & & $\mathrm{X}$ & $\mathrm{X}$ & $\mathrm{X}$ \\
\hline \#Pyrrhuloxia & C. sinuatus & & & & & \\
\hline \#Blue grosbeak & Passerina caerulea & & $\mathrm{X}$ & $\mathrm{X}$ & & $\mathrm{X}$ \\
\hline \#Brown-headed cowbird & M. ater & $\mathrm{X}$ & $\mathrm{X}$ & $\mathrm{X}$ & & \\
\hline \#Hooded oriole & Icterus cucullatus & & & $\mathrm{X}$ & $\mathrm{X}$ & $\mathrm{X}$ \\
\hline \#Bullock's oriole & I. bullockii & $\mathrm{X}$ & $? ?$ & & & \\
\hline \#Lesser goldfinch & Spinus psaltria & & $\mathrm{XO}$ & $\mathrm{X}$ & $\mathrm{X}$ & $\mathrm{X}$ \\
\hline \#House finch & Haemorhous mexicanus & $\mathrm{X}$ & $\mathrm{XO}$ & $\mathrm{X}$ & $\mathrm{X}$ & $\mathrm{X}$ \\
\hline Breeding species & & 19 & $30+$ & $43+$ & 19 & $27^{\jmath}$ \\
\hline Pairs/40 ha (100 A) & & 244 & $277+^{k}$ & $? ? ?$ & 332 & 312 \\
\hline
\end{tabular}

\# = Mesquites found in our studies or specifically mentioned under breeding habitat in literature, especially by Corman and WiseGervias. (2005).

$X=$ Known or presumed to be nesting on the plot.

$\mathrm{XO}=$ Recorded during breeding census in small numbers, presumed nesting in the general area but possibly not on plot.

$\mathrm{F}=$ Flying over the area during the breeding season; often large birds foraging.

?? = Species breeding in the region in riparian habitat and recorded on the study plot during the summer but status uncertain, e.g., records early and/or late but no or few mid-summer records.

Sources: IBA = Important Bird Areas, Arizona and Tucson Audubon Society (2015); NES = Stamp (1978; SWC = Carothers et al. (1974); TAG = Gavin and Sowls (1975).

${ }^{a}$ Species may be obligate, preferential, or facultative riparian.

${ }^{\mathrm{b}}$ After Carothers et al. 1974.

${ }^{c}$ After Carothers et al. 1974.

d Website-http://aziba.org/?page id=30 (accessed 20 August 2015).

e After AOU (1998) and AOU Check-list (2015).

${ }^{f}$ Yellow-billed cuckoo, a candidate for listing as a threatened or endangered species (USFWS online 2012, is the last breeding bird to arrive annually, generally in early June) (Phillips et al. 1964, Johnson and Simpson MS b).

${ }^{9}$ Probably black-chinned hummingbird.

${ }^{\mathrm{h}}$ Misidentified in Carothers et al. (1974) as gray flycatcher, actually willow flycatcher.

'European starling introduced into United States from Europe, first reported for Arizona in 1946 (Phillips et al. 1964; Monson and Phillips 1981).

${ }^{\mathrm{j}}$ Includes all species on two sites but number of pairs only for site with greatest number.

${ }^{k}$ Of the 36 species recorded during the breeding season, 16 were in numbers too small to be counted or numbers were not otherwise recorded (designated XO) thus are not included in the total.

'A second mixed deciduous site along West Clear Creek with only 193 pairs was highly disturbed, largely by a large U.S. Forest Service campground. 
Table 14-Riparian breeding birds of cottonwood-willow riparian gallery forests or cottonwood-willow in association with mesquite $^{\mathrm{a}}$.

\begin{tabular}{|c|c|c|c|c|c|c|}
\hline \multirow[b]{2}{*}{ Location } & & \multicolumn{2}{|c|}{$\begin{array}{l}\text { Mesquite } \\
\text { and c-w }\end{array}$} & \multicolumn{3}{|c|}{$\begin{array}{l}\text { Cottonwood- } \\
\text { willow (c-w) }\end{array}$} \\
\hline & & $\begin{array}{l}\text { GMF } \\
\text { Santa } \\
\text { Cruz }^{b}\end{array}$ & $\begin{array}{l}\text { BPC } \\
\text { Salt } \\
\text { R. }^{c}\end{array}$ & $\begin{array}{l}\text { Verded } \\
\text { Valley }\end{array}$ & $\begin{array}{l}\text { Lower } \\
\text { Verde R. }\end{array}$ & $\begin{array}{c}\text { Lower } \\
\text { Rio } \\
\text { Grande }\end{array}$ \\
\hline Years of records & & $\begin{array}{c}1902- \\
1963\end{array}$ & 1930s-1980s & $\begin{array}{c}1969- \\
1974\end{array}$ & 1975 & 1977 \\
\hline Source & & $\begin{array}{l}\text { RHW } \\
(2014)\end{array}$ & $\begin{array}{c}\text { RRJ } \\
(2000)\end{array}$ & $\begin{array}{l}\text { SWC } \\
(1974)\end{array}$ & $\begin{array}{l}\text { NES } \\
(\mathbf{1 9 7 8 )}\end{array}$ & $\begin{array}{l}\text { RE-W } \\
(1979)\end{array}$ \\
\hline Common name & Scientific name $\mathrm{e}^{\mathrm{e}}$ & & & & & \\
\hline \#Gambel's quail & Callipepla gambelii & $\mathrm{xO}$ & $x$ & & $x$ & $x$ \\
\hline Pied-billed grebe ${ }^{f}$ & Podylimbus podiceps & $\mathrm{xO}$ & $x$ & & & \\
\hline Least bittern & Ixobrychus exilis & & $x$ & & & \\
\hline Great blue heron & Ardea herodias & $\mathrm{xO}$ & $x$ & $X^{g}$ & & \\
\hline Green heron ${ }^{\mathrm{h}}$ & Butorides virescens & $\mathrm{xO}$ & $x$ & & & \\
\hline \#Black-crowned night-heron & Nycticorax nycticorax & $\mathrm{xO}$ & & & & \\
\hline Black vulture**i & Coragyps atratus & $\mathrm{F}$ & & & & \\
\hline Turkey vulture & Cathartes aura & $\mathrm{F}$ & $\mathrm{F}$ & & & \\
\hline Ospreyj & Pandion haliaetus & & $\mathrm{F}$ & & & \\
\hline Bald eagle & Haliaeetus leucocephalus & & $x$ & & & \\
\hline \#Cooper's hawk & Accipiter cooperii & $\mathrm{xO}$ & $x$ & & $x$ & \\
\hline \#Common black hawk** & Buteogallus anthracinus & $\mathrm{XO}$ & $x$ & & $x$ & \\
\hline \#Harris's hawk & Parabuteo unicinctus & $\mathrm{xO}$ & $\mathrm{x}$ & & & \\
\hline \#Gray hawk** & Buteo plagiatus & $\mathrm{xO}$ & & & & \\
\hline \#Swainson's hawk & Buteo swainsoni & $\mathrm{XO}$ & & & & \\
\hline Zone-tailed hawk** & B. albonotatus & $\mathrm{xO}$ & & & & \\
\hline Red-tailed hawk & B. jamaicensis & $\mathrm{xO}$ & $x$ & & & \\
\hline Sora & Porzana carolina & & $x$ & & & \\
\hline Common moorhen & Gallinula chloropus & & $x$ & & & \\
\hline American coot & Fulica americana & & $x$ & & & \\
\hline Killdeer & Charadrius vociferus & $\mathrm{XO}$ & $x$ & $x$ & & \\
\hline Spotted sandpiper & Actitis macularia & & & $x$ & & \\
\hline \#White-winged dove ${ }^{k}$ & Zenaida asiatica & $\mathrm{XO}$ & $x$ & & $x$ & $x$ \\
\hline \#Mourning dove & Z. macroura & $\mathrm{XO}$ & $\mathrm{X}$ & $x$ & $x$ & $x$ \\
\hline Inca dove & Columbina inca & $\mathrm{xO}$ & & & & \\
\hline \#Common ground-dove & C. passerina & $\mathrm{xO}$ & & & & \\
\hline \#Yellow-billed cuckoo**l & Coccyzus americanus & $\mathrm{xO}$ & $x$ & $x$ & $x$ & $x$ \\
\hline \#Greater roadrunner & Geococcyx californianus & $\mathrm{XO}$ & $x$ & & & $x$ \\
\hline Barn owl & Tyto alba & $\mathrm{xO}$ & $x$ & & & \\
\hline \#Western screech-owl & Megascops kennicottii & $\mathrm{xO}$ & $x$ & & & \\
\hline Great horned owl & Bubo virginianus & $\mathrm{xO}$ & $x$ & & $x$ & \\
\hline \#Ferruginous pygmy-owl**m & Glaucidium brasilianum & & $x$ & & & \\
\hline \#Elf owl & Micrathene whitneyi & $\mathrm{xO}$ & $x$ & & & \\
\hline Burrowing owl ${ }^{\mathrm{n}}$ & Athene cunicularia & $\mathrm{xO}$ & & & & \\
\hline Lesser nighthawk & Chordeiles acutipennis & $\mathrm{XO}$ & $\mathrm{x}$ & & & \\
\hline \#Common poorwill & Phalaenoptilus nuttallii & $\mathrm{xO}$ & $x$ & & & \\
\hline
\end{tabular}


Table 14-Continued.

\begin{tabular}{|c|c|c|c|c|c|c|}
\hline \multirow[b]{2}{*}{ Location } & & \multicolumn{2}{|c|}{$\begin{array}{l}\text { Mesquite } \\
\text { and c-w }\end{array}$} & \multicolumn{3}{|c|}{$\begin{array}{l}\text { Cottonwood- } \\
\text { willow (c-w) }\end{array}$} \\
\hline & & $\begin{array}{l}\text { GMF } \\
\text { Santa } \\
\text { Cruz }^{b}\end{array}$ & $\begin{array}{c}\text { BPC } \\
\text { Salt } \\
\text { R.c }^{c}\end{array}$ & $\begin{array}{l}\text { Verde }^{d} \\
\text { Valley }\end{array}$ & $\begin{array}{c}\text { Lower } \\
\text { Verde R. }\end{array}$ & $\begin{array}{c}\text { Lower } \\
\text { Rio } \\
\text { Grande }\end{array}$ \\
\hline Years of records & & $\begin{array}{c}1902- \\
1963\end{array}$ & 1930s-1980s & $\begin{array}{c}1969- \\
1974\end{array}$ & 1975 & 1977 \\
\hline Source & & $\begin{array}{l}\text { RHW } \\
(2014)\end{array}$ & $\begin{array}{c}\text { RRJ } \\
(\mathbf{2 0 0 0 )}\end{array}$ & $\begin{array}{c}\text { SWC } \\
(1974)\end{array}$ & $\begin{array}{l}\text { NES } \\
(1978)\end{array}$ & $\begin{array}{l}\text { RE-W } \\
\text { (1979) }\end{array}$ \\
\hline Common name & Scientific name ${ }^{\mathrm{e}}$ & & & & & \\
\hline \#Black-chinned hummingbird & Archilochus alexandri & $\mathrm{xO}$ & $x$ & $x$ & $x$ & $x$ \\
\hline Anna's hummingbird & Calypte anna & & & & $x$ & \\
\hline \#Costa's hummingbird & C. costae & & $x$ & & & \\
\hline \#Gila woodpecker & Melanerpes uropygialis & $\mathrm{xO}$ & $x$ & $x$ & $x$ & \\
\hline \#Ladder-backed woodpecker & Picoides scalaris & $\mathrm{xO}$ & $x$ & $x$ & $x$ & $x$ \\
\hline Northern flicker & Colaptes auratus & & & $x$ & & \\
\hline \#Gilded flicker & C. chrysoides & $\mathrm{xO}$ & $x$ & & $x$ & \\
\hline \#Crested caracara & Caracara cheriway & $\mathrm{xO}$ & & & & \\
\hline American kestrel & Falco sparverius & $\mathrm{xO}$ & $x$ & $x$ & & \\
\hline \#Northern beardless- $\quad$ tyrannulet & Camptostoma imberbe & $\mathrm{xO}$ & & & & \\
\hline Western wood pewee & Contopus sordidulus & & & $x$ & & \\
\hline $\begin{array}{l}\text { \#Willow flycatcher } \\
\text { [gray flycatcher] }\end{array}$ & $\begin{array}{l}\text { Empidonax traillii } \\
\text { E. wrightii } \\
\end{array}$ & $\mathrm{xO}$ & & & & \\
\hline \#Black phoebe & Sayornis nigricans & $\mathrm{xO}$ & $x$ & $x$ & & \\
\hline Say's phoebe & S. saya & $\mathrm{xO}$ & & & & \\
\hline \#Vermilion flycatcher & Pyrocephalus rubinus & $\mathrm{xO}$ & $x$ & $x$ & & $x$ \\
\hline \#Ash-throated flycatcher & Myiarchus cinerascens & $\mathrm{xO}$ & $x$ & $x$ & $x$ & $x$ \\
\hline \#Brown-crested flycatcher & M. tyrannulus & $\mathrm{xO}$ & $x$ & $x$ & $x$ & \\
\hline \#Tropical kingbird**o & Tyrannus melancholicus & $\mathrm{xO}$ & $? \mathrm{p}$ & & & \\
\hline Cassin's kingbird & T. vociferans & $\mathrm{xO}$ & & $x$ & & \\
\hline Western kingbird & T. verticalis & $\mathrm{xO}$ & $x$ & $x$ & & \\
\hline \#Rose-throated becardq & Pachyramphus aglaiae & $\mathrm{xO}$ & & & & \\
\hline \#Loggerhead shrike & Lanius ludovicianus & $\mathrm{xO}$ & & & & \\
\hline \#Bell's vireo & Vireo bellii & $\mathrm{xO}$ & $x$ & & & $x$ \\
\hline \#Chihuahuan raven & Corvus cryptoleucus & & & & & \\
\hline Common raven & C. corax & $\mathrm{xO}$ & $x$ & & & \\
\hline Purple martin & Progne subis & $\mathrm{xO}$ & & & & \\
\hline Violet-green swallow & Tachycineta thalassina & & & & & \\
\hline \#Northern rough-winged swallow & Stelgidopteryx serripennis & $\mathrm{xO}$ & $x$ & & $\mathrm{x}$ & \\
\hline Cliff swallow & Petrochelidon pyrrhonota & & $x$ & & & $x$ \\
\hline Bridled titmouse & Baeolophus wollweberi & & & $x$ & & \\
\hline$\#$ Verdin & Auriparus flaviceps & $\mathrm{xO}$ & $x$ & & $x$ & \\
\hline \#Cactus wren & $\begin{array}{l}\text { Campylorhynchus } \\
\text { brunneicapillus }\end{array}$ & $\mathrm{xO}$ & $x$ & & & \\
\hline Rock wren & Salpinctes obsoletus & $\mathrm{xO}$ & $x$ & & & \\
\hline Canyon wren & Catherpes mexicanus & $\mathrm{xO}$ & & & & \\
\hline \#Bewick's wren & Thryomanes bewickii & $\mathrm{xO}$ & $x$ & $x$ & $x$ & $x$ \\
\hline \#Black-tailed gnatcatcher & Polioptila melanura & $\mathrm{XO}$ & $x$ & & & \\
\hline
\end{tabular}


Table 14-Continued.

\begin{tabular}{|c|c|c|c|c|c|c|}
\hline \multirow[b]{2}{*}{ Location } & & \multicolumn{2}{|c|}{$\begin{array}{l}\text { Mesquite } \\
\text { and c-w }\end{array}$} & \multicolumn{3}{|c|}{$\begin{array}{l}\text { Cottonwood- } \\
\text { willow (c-w) }\end{array}$} \\
\hline & & $\begin{array}{l}\text { GMF } \\
\text { Santa } \\
\text { Cruz }^{\text {b }}\end{array}$ & $\begin{array}{l}\text { BPC } \\
\text { Salt } \\
\text { R. }^{c}\end{array}$ & $\begin{array}{l}\text { Verde }^{d} \\
\text { Valley }\end{array}$ & $\begin{array}{c}\text { Lower } \\
\text { Verde R. }\end{array}$ & $\begin{array}{c}\text { Lower } \\
\text { Rio } \\
\text { Grande }\end{array}$ \\
\hline Years of records & & $\begin{array}{l}1902- \\
1963\end{array}$ & 1930s-1980s & $\begin{array}{l}1969- \\
1974 \\
\end{array}$ & 1975 & 1977 \\
\hline Source & & $\begin{array}{l}\text { RHW } \\
(2014)\end{array}$ & $\begin{array}{c}\text { RRJ } \\
(2000)\end{array}$ & $\begin{array}{l}\text { SWC } \\
(1974)\end{array}$ & $\begin{array}{l}\text { NES } \\
(1978)\end{array}$ & $\begin{array}{l}\text { RE-W } \\
(1979)\end{array}$ \\
\hline Common name & Scientific name $e^{\mathrm{e}}$ & & & & & \\
\hline American robin & Turdus migratorius & & & $x$ & & \\
\hline \#Curve-billed thrasher & T. curvirostre & $\mathrm{xO}$ & $x$ & & & \\
\hline \#Bendire's thrasher & Toxostoma bendirei & $\mathrm{xO}$ & & & & \\
\hline \#Crissal thrasher & T. crissale & $\mathrm{XO}$ & $x$ & & & \\
\hline \#Northern mockingbird & Mimus polyglottos & $\mathrm{XO}$ & & $x$ & & $x$ \\
\hline European starlingr & Sturnus vulgaris & $\mathrm{XO}$ & $x$ & $x$ & $x$ & \\
\hline \#Phainopepla & Phainopepla nitens & $\mathrm{xO}$ & $x$ & & & \\
\hline \#Lucy's warbler & Oreothlypis luciaes & $\mathrm{XO}$ & $x$ & $x$ & $x$ & $x$ \\
\hline \#Common yellowthroat & Geothlypis trichas & $\mathrm{XO}$ & $x$ & & & $x$ \\
\hline \#Yellow warbler & Setophaga petechia & $\mathrm{XO}$ & $x$ & $x$ & $x$ & \\
\hline \#Yellow-breasted chat & Icteria virens & $\mathrm{XO}$ & $x$ & & $x$ & $x$ \\
\hline \#Canyon towhee & Melozone fusca & $\mathrm{xO}$ & $x$ & & & \\
\hline \#Abert's towhee & M. aberti & $\mathrm{xO}$ & $x$ & $x$ & $x$ & \\
\hline \#Rufous-winged sparrow & Peucaea carpalis & $\mathrm{XO}$ & & & & \\
\hline \#Black-throated sparrow & Amphispiza bilineata & $\mathrm{XO}$ & $x$ & & & \\
\hline \#Song sparrow**t & Melospiza melodia & $\mathrm{XO}$ & $x$ & & & \\
\hline \#Summer tanager & Piranga rubra & $\mathrm{xO}$ & $x$ & $x$ & $x$ & $x$ \\
\hline \#Northern cardinal & Cardinalis cardinalis & $\mathrm{XO}$ & $x$ & & $x$ & $x$ \\
\hline \#Pyrrhuloxia & C. sinuatus & $\mathrm{XO}$ & & & & \\
\hline \#Blue grosbeak & Passerina caerulea & $\mathrm{XO}$ & $x$ & $x$ & & $x$ \\
\hline Painted bunting & P. ciris & & & & & $x$ \\
\hline Red-winged blackbird & Agelaius phoeniceus & $\mathrm{XO}$ & $x$ & $\mathrm{X}$ & & $x$ \\
\hline Great-tailed grackle & Quiscalus mexicanus & & & & & $x$ \\
\hline \#Bronzed cowbirdu & Molothrus aeneus & $\mathrm{XO}$ & $x$ & & & \\
\hline \#Brown-headed cowbird & M. ater & $\mathrm{XO}$ & $x$ & $x$ & $x$ & $x$ \\
\hline \#Hooded oriole & Icterus cucullatus & $\mathrm{XO}$ & $x$ & $x$ & & \\
\hline Orchard oriole & Icterus spurius & & & & & $x$ \\
\hline \#Bullock's oriole & I. bullockii & $\mathrm{xO}$ & $\mathrm{X}$ & $\mathrm{x}$ & $\mathrm{x}$ & $x$ \\
\hline House finch & Haemorhous mexicanus & $\mathrm{XO}$ & $x$ & $x$ & $x$ & $x$ \\
\hline \#Lesser goldfinch & Spinus psaltria ${ }^{w}$ & $\mathrm{XO}$ & $x$ & & $x$ & $x$ \\
\hline \#House finch & Haemorhous mexicanus ${ }^{v}$ & $\mathrm{XO}$ & $x$ & $x$ & $x$ & \\
\hline House sparrow ${ }^{x}$ & Passer domesticus & $\mathrm{XO}$ & $x$ & $\mathrm{X}$ & & \\
\hline Breeding species & & $83^{y}$ & 71 & $34^{z}$ & 28 & $27^{\text {aa }}$ \\
\hline Pairs/40 ha (100 A) & & $? ? ? \mathrm{bb}$ & $611 \pm \underline{\mathrm{CC}}$ & $847^{\mathrm{dd}}$ & 684 & 354 \\
\hline
\end{tabular}

\# = Mesquites found in our studies or specifically mentioned under breeding habitat in literature, especially by Corman and Wise-Gervias (2005).

$\mathrm{X}=$ Recorded on area.

$\mathrm{XO}=$ Recorded on area but numbers insufficient to count or numbers not otherwise recorded. 


\section{Table 14-Continued.}

$\mathrm{F}=$ Flying over the area during the breeding season; often large birds foraging.

${ }^{* *}=$ Locally extirpated after earlier observations.

Sources: NES = Stamp (1978); RE-W = Engel-Wilson and Ohmart (1979); RHW = Webb et al. (2014); RRJ = Johnson et al. (2000); SWC = Carothers et al. (1974).

a Species may be obligate, preferential, or facultative riparian.

b Great Mesquite Forest or San Xavier Bosque, Tucson mesquite forest (Phillips et al. 1964), or Grand Mesquite Forest (Brandt 1951), located on the Santa Cruz River on the San Xavier Indian Reservation, 10 miles s. of Tucson. This best known mesquite forest of the Southwest was destroyed by the 1970s through anthropogenic causes, including agricultural clearing by Native Americans, wood-cutting, and excessive groundwater withdrawal (Johnson and Carothers 1982, Webb et al. 2014).

c Blue Point Cottonwoods, located on the Salt River approximately 2 mi upstream from its confluence with the Verde River.

$\mathrm{d}$ The first quantitative riparian bird study for the Southwest, documenting some of the highest avian population densities for the United States and even the world.

e After AOU (1998) and AOU Check-list (2015).

${ }^{f}$ Vorhies saw pied-billed grebes at Indian Dam, GMF, frequently in the 1930s, including three calling on open water, April 15, 1934 (Vorhies et al. 1935). They may have been nesting here since the species begins nesting in December and January in Arizona lowlands (Corman and Wise-Gervais 2005).

$\mathrm{g}$ Great blue heron rookery in cottonwoods off of plots but adults foraged on plots.

h Vorhies saw green heron nests at Indian Dam, GMF, for "three years in a row" in the mid 1930s (Vorhies et al. 1935:244).

i "At least a dozen" black vultures were seen "in the bottom of a ditch" on 7 May 1922, along the Santa Cruz River, 12 miles south of Tucson (Kimball 1923:109).

j Osprey was extirpated as a breeding species after being reported breeding nearby and foraging over BPC (Phillips et al.1964).

k The GMF was one of the most noted sites in Arizona for hunting white-winged doves in the early 1900s (Arnold 1941, 1943; Brown 1989). After visiting the GMF Bent (1937:259) wrote, "White-winged doves fairly swarmed through the thickets, and their tiresome notes were the dominant sounds."

'Yellow-billed cuckoo, a candidate for listing as a threatened or endangered species (USFWS 2015), is the last breeding bird to arrive annually, generally in early June (Phillips et al. 1964; Johnson and Simpson MS b).

$\mathrm{m}$ Herbert Brown took a ferruginous pygmy-owl south of Tucson in 1884, the only Santa Cruz River record (Johnson et al. 2003). The Arizona population was listed as federally endangered in 1997 but delisted in 2007 and extirpated in the Tucson Basin by 2009.

n Western burrowing owl (Athene cunicularia hypugea) is a "Bird of Conservation Concern" (Klute et al. 2003).

o Tropical kingbird was first reported as a breeding species for the United States along the Santa Cruz River between Tucson and GMF (Phillips 1940; Phillips et al. 1964). Brandt thought he saw one in the GMF but was uncertain. The species was first recorded in Arizona (and the United States) by a specimen taken by H.H. Kimball near Fort Lowell on May 12, 1905 (Peters 1936; Phillips et al. 1964). It is unknown if it was a solitary bird or a member of a breeding pair or colony.

p One of a pair collected at BPC.

q Rose-throated becard nest found in 1958 and calling male recorded in 1959 (Phillips et al. 1964).

r European starling introduced into United States from Europe, first reported for Arizona in 1946 (Phillips et al. 1964; Monson and Phillips 1981).

${ }^{\mathrm{s}}$ From Vermivora luciae to Oreothlypis luciae.

${ }^{\mathrm{t}}$ Song sparrow, formerly a common riparian nesting species in the Tucson region (Bendire 1872a, 1872b), was extirpated from the region shortly after 1895 (Phillips et al. 1964). Records by Arnold and Marshall were probably migrating individuals.

u Bronzed cowbird first reported arriving in Arizona from Mexico in 1909 (Visher 1909, Gilman 1914, Phillips et al. 1964).

$\checkmark$ From Carpodacus mexicanus to Haemorhous mexicanus.

${ }^{\mathrm{w}}$ From Carduelis psaltria to Spinus psaltria.

x House sparrow introduced into United States from Europe, first reported in Tucson in 1902-1903 (Howard 1906, Phillips et al. 1964).

y Includes total species breeding, foraging, and flying over area, during breeding season from 1902 to 1960s. It also includes species, especially those nesting, not recorded by listed ornithologists but for whom other records exist, e.g., Vorhies (1935) saw pied-billed grebes frequently at Indian Dam, GMF, in the 1930s and three calling on open water, April 15, 1934, as well as nesting green herons.

$\mathrm{z}$ Includes all species on four sites but number of pairs only for site with greatest number.

aa Excludes a non-breeding species, white-crowned sparrow (Zonotrichia leucophrys), observed during the census period.

$\mathrm{bb}$ During the more than 60 years this plot was studied no one conducted a census to determine numbers of estimated breeding pairs.

cc Censusing on this 250 acre plot was not as rigorous as for other plots included in this table.

dd Of the four cottonwood plots censused in the Verde Valley, only one had not been modified either by cutting cottonwood trees ("phreatophyte control") or other human intervention that impacted the number of trees/acre. 
Table 15-Mammals of mesquite bosques and associated riparian vegetation in the Southwest. ${ }^{a}$

\begin{tabular}{|c|c|c|c|}
\hline Common name & Scientific name & $\begin{array}{l}\text { Santa }^{b} \\
\text { Cruz R. }^{c}\end{array}$ & $\begin{array}{c}\text { San }^{\mathrm{d}} \\
\text { Pedro R. }\end{array}$ \\
\hline Virginia oppossum & Diadelphus virginiana & & $\mathrm{X}$ \\
\hline Desert shrew & Notiosorex crawfordi & & $\mathrm{X}$ \\
\hline California leaf-nosed bat & Macrotus californicus & & $\mathrm{X}$ \\
\hline Yuma myotis & Myotis yumanensis & $\mathrm{X}^{\dagger}$ & \\
\hline Cave myotis & M. velifer & $\mathrm{X}$ & $\mathrm{X}$ \\
\hline 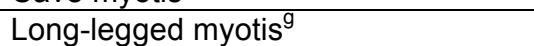 & M. volans ${ }^{n}$ & $\mathrm{X}$ & \\
\hline California myotis & M. californicus & $\mathrm{X}$ & \\
\hline Red bat' & Lasiurus borealis & & $\mathrm{X}$ \\
\hline Hoary bat & L. cinereus & $\mathrm{X}^{\mathrm{J}}$ & \\
\hline Western pipistrelle & Parastrellus hesperus & $x^{k}$ & \\
\hline Big brown bat & Eptesicus fuscus & $\mathrm{X}$ & $\mathrm{X}$ \\
\hline Townsend's big-eared bat & Corynorhinus townsendii & & $\mathrm{X}$ \\
\hline Pallid bat & Antrozous pallidus & $\mathrm{X}$ & $\mathrm{X}$ \\
\hline Brazilian free-tailed bat & Tadarida brasiliensis & $\mathrm{X}$ & $\mathrm{X}$ \\
\hline Pocketed free-tailed bat & Nyctinomops femorosaccus & $X^{\prime}$ & \\
\hline Big free-tailed bat & N. macrotis & $\mathrm{X}^{\mathrm{m}}$ & \\
\hline Western bonneted bat ${ }^{n}$ & Eumops perotis & & $\mathrm{X}$ \\
\hline Desert cottontail & Sylvilagus auduboni & $\mathrm{X}$ & $\mathrm{X}$ \\
\hline Antelope jackrabbit & Lepus alleni & $\mathrm{X}$ & $\mathrm{X}$ \\
\hline Black-tailed jackrabbit & L. californicus & $\mathrm{X}$ & $\mathrm{X}$ \\
\hline Harris' antelope squirrel & Ammospermophilus harrisii & $\mathrm{X}$ & $\mathrm{X}$ \\
\hline Rock squirrel & Otospermophilus variegatus & $\mathrm{X}$ & $\mathrm{X}$ \\
\hline Round-tailed ground squirrel & $\begin{array}{l}\text { Xerospermophilus } \\
\text { tereticaudus }\end{array}$ & $\mathrm{X}$ & $\mathrm{X}$ \\
\hline Botta's pocket gopher & Thomomys bottae & $\mathrm{X}$ & $\mathrm{X}$ \\
\hline Silky pocket mouse & Perognathus flavus & $\mathrm{X}$ & \\
\hline Bailey's pocket mouse & Chaetodipus baileyi & $\mathrm{X}$ & $\mathrm{X}$ \\
\hline Hispid pocket mouse & C. hispidus & & $\mathrm{X}$ \\
\hline Desert pocket mouse & C. penicillatus & $\mathrm{X}$ & $\mathrm{X}$ \\
\hline Rock pocket mouse & C. intermedius & & $\mathrm{X}$ \\
\hline Merriam's kangaroo rat & Dipodomys merriami & $\mathrm{X}$ & $\mathrm{X}$ \\
\hline Ord's kangaroo rat & D. ordii & $\mathrm{X}$ & $\mathrm{X}$ \\
\hline American beaver & Castor canadensis & & $\mathrm{X}$ \\
\hline Plains harvest mouse & Reithrodontomys montanus & & $\mathrm{X}$ \\
\hline Fulvous harvest mouse & R. fulvescens & $\mathrm{X}$ & $\mathrm{X}$ \\
\hline Western harvest mouse & R. megalotis & $\mathrm{X}$ & $\mathrm{X}$ \\
\hline Cactus mouse & Peromyscus eremicus & $X^{\circ}$ & $\mathrm{X}$ \\
\hline White-footed mouse & $P$. leucopus & $\mathrm{X}$ & $\mathrm{X}$ \\
\hline Deer mouse & P. maniculatus & & $\mathrm{X}$ \\
\hline Merriam's mouse (mesquite mouse) ${ }^{p}$ & P. merriami & $\mathrm{X}$ & \\
\hline Northern grasshopper mouse & Onychomys leucogaster & & $\mathrm{X}$ \\
\hline Southern grasshopper mouse & O. torridus & $\mathrm{X}$ & $\mathrm{X}$ \\
\hline Arizona cotton rat ${ }^{q}$ & Sigmodon arizonae & $\mathrm{X}$ & $\mathrm{X}$ \\
\hline Tawny-bellied cotton rat & S. fulviventer & & $\mathrm{X}$ \\
\hline Yellow-nosed cotton rat & S. ochrognathus & & $\mathrm{X}$ \\
\hline White-throated woodrat & Neotoma albigula & $\mathrm{X}$ & $\mathrm{X}$ \\
\hline Common muskrat & Ondatra zibethicus & & $\mathrm{E}$ \\
\hline Common porcupine & Erethizon dorsatum & & $\mathrm{X}$ \\
\hline Coyote & Canis latrans & $\mathrm{X}$ & $\mathrm{X}$ \\
\hline Gray wolf $^{r}$ & C. lupus & $\mathrm{E}$ & $\mathrm{E}$ \\
\hline Kit fox & Vulpes macrotis & $\mathrm{X}$ & $\mathrm{X}$ \\
\hline Common gray fox & Urocyon cinereoargenteus & $\mathrm{X}$ & $\mathrm{X}$ \\
\hline American black bear & Ursus americanus & & $\mathrm{X}$ \\
\hline Grizzly bear & U. arctos & & $\mathrm{E}$ \\
\hline Ringtail & Bassariscus astutus & $\mathrm{X}$ & $\mathrm{X}$ \\
\hline
\end{tabular}


Table 14-Continued.

\begin{tabular}{|c|c|c|c|}
\hline Common name & Scientific name & $\begin{array}{c}\text { Santa }^{\mathrm{b}} \\
\text { Cruz R. }^{\mathrm{c}}\end{array}$ & $\begin{array}{c}\text { San }^{\mathrm{d}} \\
\text { Pedro R. }^{\mathrm{e}}\end{array}$ \\
\hline Northern raccoon & Procyon lotor & $\mathrm{X}$ & $\mathrm{X}$ \\
\hline White-nosed coati & Nasua narica & & $\mathrm{X}$ \\
\hline Long-tailed weasel & Mustela frenata & & $\mathrm{E}$ \\
\hline American badger & Taxidea taxus & $\mathrm{X}$ & $\mathrm{X}$ \\
\hline Northern river otter & Lontra canadensis & & $E$ \\
\hline Western spotted skunk & Spilogale gracilis & $\mathrm{X}$ & $\mathrm{X}$ \\
\hline Hooded skunk & Mephitis macroura & $\mathrm{X}$ & $\mathrm{X}$ \\
\hline Striped skunk & M. mephitis & $\mathrm{X}$ & $\mathrm{X}$ \\
\hline White-backed hog-nosed skunk & Conepatus leuconotus & $\mathrm{X}$ & $\mathrm{X}$ \\
\hline Mountain lion (puma) & Puma concolor & & $\mathrm{X}$ \\
\hline Bobcat & Lynx rufus & $\mathrm{X}$ & $\mathrm{X}$ \\
\hline Jaguar & Panthera onca & & $E$ \\
\hline Collared peccary (javelina) & Pecari tajacu & $\mathrm{X}$ & $\mathrm{X}$ \\
\hline Mule deer & Odocoileus hemionus & & $\mathrm{X}$ \\
\hline White-tailed deer & O. virginianus & & $\mathrm{X}$ \\
\hline Total species & & 44 & 60 \\
\hline
\end{tabular}

\section{$E=$ Extirpated}

${ }^{a}$ List of mammals after Duncan (1988) and Soykan et al. (2007); systematic order after Baker et al. (2003) and Cockrum (1960); nomenclature after Baker et al. (2003) and ITIS (no date); species may be obligate, preferential, or facultative riparian.

${ }^{\mathrm{b}}$ Elevation along Santa Cruz River from 2,450+ ft to 2,900+ ft.

${ }^{c}$ Records from the San Xavier bosque (Webb et al. 2014) unless otherwise noted.

${ }^{\mathrm{d}}$ Elevation along San Pedro River from 1,900+ ft to 4,200+ ft.

${ }^{\mathrm{e}}$ Mesquite bosques and cottonwood-willow riparian forests not separated by Soykan et al. (2007).

f "Gravel Pit waterhole, S end Cottonwood Lane, Tucson” (Cockrum (1960:37).

$\mathrm{g}$ This and some other species of bats that breed at higher elevations or in other geographic regions may be recorded during migration.

${ }^{\mathrm{h}}$ Not listed by Hoffmeister (1986), perhaps either a misidentification or a migrant, since breeding localities in Arizona are generally 5,000 ft elevation and higher (Cockrum 1960).

i "Probably statewide in riparian communities of the Upper Sonoran and Transitional Life Zones" (Cockrum 1960:53).

j "Valencia Rd. and Santa Cruz R., Tucson" (Cockrum 1960:55), Hoffmeister (1986).

k "Florida Canyon, 35 mi. S Tucson" (Cockrum 1960:50; Hoffmeister (1986).

1 "Gravel Pit, S end Cottonwood Lane, Tucson" (Cockrum (1960:64), Hoffmeister (1986).

m "Mission Manor, 10 mi. S Tucson" (Cockrum (1960:65).

${ }^{\mathrm{n}}$ Mesquite specifically mentioned in habitat for Eumops perotis (Best et al. 1996).

${ }^{\circ}$ Specimen from Contentinal, on the Santa Cruz (Cockrum 1960).

${ }^{\mathrm{p}}$ Peromyscus merriami is so closely associated with mesquite bosques it is often called mesquite mouse.

${ }^{\mathrm{q}}$ Originally considered a subspecies of Sigmodon hispidus, S. arizonae is more likely the species here.

${ }^{\mathrm{r}}$ Extirpated; in 1850, Judge Benjamin Hayes of California wrote in his journal of the San Xavier bosque south of Tucson "they [wolves] were howling all around us, and one of very large size, was seen" (Davis 1982:51). 
and lay their eggs in the adjacent water. In addition, numerous species of lizards and snakes inhabit sandy bottoms of desert washes and/or xeroriparian trees along their banks (Jones and Lovich 2009; Stebbins 1985). Mesquites are the first trees listed as habitat for the tree-dwelling ornate tree lizard (Hasse 2009) and Clark's spiny lizard (Schwalbe and Rosen 2009).

A group of lowland, broadleaf, winter deciduous obligate riparian trees termed the riparian "big five" by Lowe (1961, 1964a) consists of cottonwood (Populus fremontii), willow (Salix spp.), sycamore (Platanus wrightii), ash (Fraxinus velutina), and walnut (Juglans major). The importance of most of the riparian trees, especially to birds, is discussed in other parts of this paper. Lowe's riparian big five all produce flowers that are insignificant and generally not attractive to insects, other invertebrates, or vertebrates. Contrastingly, mesquite trees produce large, fragrant inflorescences in the spring and summer that attract insects and, in turn, insectivorous birds and amphibians and reptiles.

Numerous species of insects feed on wood, flowers, and fruits of mesquites. Mesquites also produce beans that are fed upon by a large number of animals while the only tree of the "big five" that produces large, edible fruit is the walnut with an outer shell so hard that few animals feed on it. By contrast, mesquite beans are fed on by insects, rodents (Phillips and Comus 2000), javelinas (Eddy 1961), coyotes (Lantz 1905), and even wild turkey (Bendire 1872). Mesquite beans are fed on so extensively by insects that suggestions have been made to use some species of insects in biological control of "undesirable" mesquites on rangelands (Smith and Ueckert 1974). At times, coyote scat (feces) consists almost entirely of mesquite beans (R.R. Johnson, numerous observations, Tucson, Arizona during several decades).

A number of vertebrate species extend northward from Mexico into extreme southwestern United States, often occurring in mesquite bosques, or narrow xeroriparian patches of mesquites and other small trees along washes. Some reptiles, such as the brown vinesnake and several amphibians, discussed earlier, extend northward from Mexico, occurring in the United States only in southern Arizona. Another previously mentioned species, the gray hawk, is an uncommon tropical species occurring in the United States largely in southern Arizona. It preferentially utilizes mesquites and "mesquite woodland occupies large proportion of home ranges (about 54 percent), and majority of foraging locations (about 80 percent) occur within mesquite woodland" (Bibles et al. 2002). The range of the previously mentioned mesquite mouse, or Merriam's mouse, extends northward from Mexico, occurring in the United States only in southern Arizona (Hall and Kelson 1959).

An arboreal food chain associated with mesquite bosques, illustrative of the importance of riparian mesquites, consists of arthropods, the ornate tree lizard, brown vinesnake, and gray hawk. This food chain extends northward from Mexican thornscrub (Brown 1982) into the mesquite bosques of the Santa Cruz Valley of extreme southern Arizona and has been documented through scientific records and by online photos. The ornate tree lizard, a resident of this region, forages preferentially in mesquite trees on "insects and other small arthropods" (Jones and Lovich 2009) and, in turn, this lizard is prey for the brown vinesnake. Recent photos show brown vinesnakes in mesquite trees, one eating an ornate tree lizard (Dancing Snake Nature Photography 2013).

Finally, completing the food chain, the gray hawk feeds "almost entirely on vertebrates, especially reptiles" (Bibles et al. 2002) and an online photo shows a 
gray hawk grasping a brown vinesnake (Tucson Herpetological Society, no date). Both tropical species, the brown vinesnake and gray hawk, occur no farther north than southern Arizona. The gray hawk occurs in extreme southern Arizona and Texas (Bibles et al. 2002) and the brown vinesnake was first discovered for the United States in mesquites along the Santa Cruz River south of Tucson (Brown et al. 2015; Vorhies 1926; Webb et al. 2014). This small snake has now been pushed farther south and, due to riparian habitat loss, is now restricted in the United States to near Nogales, Arizona (Stebbins 1985; Webb et al. 2014).

\section{Mesquite Bosques and Cottonwood-Willow Riparian Gallery Forests}

The preferential use of riparian habitats by birds is well documented. Studies in both mesquite bosques and cottonwood-willow forests have reported some of the highest avian population numbers and greatest biodiversity in North America (Carothers et al. 1974; Johnson et al. 1977; Szaro 1980). Johnson et al. (1987) list 69 percent of the Southwest lowlands avifauna either as obligate riparian-nesting birds or showing a preference for riparian and other wetland habitats. Early in-depth studies in riparian ecosystems of the desert Southwest concentrated largely on birds of cottonwood-willow (Populus-Salix) forests with later studies conducted in bosques. The first quantitative analysis of avian populations in southwestern riparian habitats was by Carothers et al. (1974). That study and a following publication (Carothers and Johnson 1975) found that no other habitat in North America is more important to non-colonial nesting birds than Fremont cottonwood (Populus fremontii) forests along the Verde River in central Arizona. This same finding was later echoed by Szaro (1980) in an extensive survey of studies in southwestern riparian forests. Studies in both bosques and cottonwood-willow forests were later conducted by others, including Gavin and Sowls (1975), Stamp (1978), and Engel-Wilson and Ohmart (1979) (see tables 13 and 14).

Especially important to birds are combinations of riparian mesquites and cottonwood-willow forests. Mesquite bosques constitute prime avian habitat (Johnson and Simpson 1971; Johnson et al. 2000). Cottonwood trees are generally taller than mesquites and provide additional structure for nesting and other avian activities. Bird species diversity (BSD) is directly related to foliage height diversity (FHD). FHD is determined by the arrangement of vegetation in three-dimensional space. A lack of taller trees (and thus reduction in the value of the dimension of height) also results in a reduction of BSD (Carothers et al. 1974; MacArthur et al. 1962). A combination of bosques and cottonwood-willow forests tend to support greater avian biodiversity than either alone (Johnson et al. 2000; Webb et al. 2014; table 14). In addition, the soft wood of cottonwood trees provides ideal nesting cavities in contrast to very dense mesquite wood, which is difficult for cavity-nesting birds to excavate.

Along larger rivers, notably the Lower Colorado River Valley and Rio Grande Valley, bosques and/or cottonwood-willow forests have been largely replaced by dense Tamarix (saltcedar or tamarisk) thickets. Some vertebrates, especially several avian species, have adapted to saltcedar, but many have not (Webb et al. 2014).

Extensive changes to riparian ecosystems in general have also occurred with the advent of agricultural fields and rural and suburban areas that have developed in major river valleys, often replacing riparian ecosystems. Again, some species have adapted 
to trees and shrubs planted in city parks and cemeteries, or to shade trees around housing areas, many have not.

Grazing has also been identified as a major impact to riparian ecosystems (Knopf et al. 1988). Krueper et al. (2003) found that populations of 40 species of riparian birds showed detectable increases within 3 years after cattle were removed from a section of the San Pedro River, Arizona.

In addition to birds, a large percentage of amphibians and reptiles and mammals have also been affected by deterioration of riparian vegetation. Most of these are ground dwellers, many of them living in burrows, and resulting changes on the ground include loss of shade, increasing temperatures, and even modification of chemical composition, such as increased soil salinity (Shafroth et al. 1995).

\section{Summary}

The importance of mesquite bosques to the riparian fauna and flora of lowlands of the western United States cannot be overemphasized and in recent times there has been an ever-increasing effort toward stream restoration (Appendix B; Carothers et al. 1974; Stanley et al., in prep.) and reestablishment of cottonwood-willow riparian gallery forests. There has, however, been a general lack of effort toward reestablishment of riparian mesquite bosques. An online search found several references to planting cottonwoods and willows to reestablish riparian forests, including a 22-page manual published by the Natural Resources Conservation Service (Hoag 2007). Contrastingly, the only online references to planting of mesquites was as ornamentals or as urban shade trees. Until there is equal emphasis on reestablishment of mesquite bosques as well as cottonwood-willow riparian gallery forests, there will be a continuing, and possibly increasing, loss in biodiversity of riparian vertebrate faunas of the lowlands of the western United States.

\section{References}

American Ornithologists' Union (AOU). 1998. Check-list of North American birds. 7th ed. Washington, DC: American Ornithologists' Union. 829 p.

American Ornithologists' Union (AOU). 2015. Check-list of North American birds. Database. Washington, DC: American Ornitologists' Union, North American Classification Committee. http://checklist.aou.org. [Accessed October 13, 2015].

Anderson, B.W.; Ohmart, R.D. 1977. Vegetation structure and bird use in the lower Colorado River valley. In: Johnson, R.R.; Jones, D.A., tech. coords. Proceedings: Symposium on importance, preservation, and management of riparian habitat. Gen. Tech. Rep. RM-43, Fort Collins, CO: U.S. Department of Agriculture, Forest Service, Rocky Mountain Forest and Range Experiment Station: 23-34.

Arizona and Tucson Audubon Society. 2015. Important bird areas. Tucson, AZ: Tucson Audubon Society; Phoenix, AZ: Audubon Arizona; Phoenix, AZ: Arizona Game and Fish, Arizona Bird Conservation Initiative; Cambridge, UK: BirdLife Interntional. 23 p. www.tucsonaudubon. org/iba/IBA_Booklet_06-2012_in percent20numerical percent20order.pdf. [Accessed December 7, 2015].

Arizona Game and Fish Department (AZGF) 2015. Special status species by taxon, scientific name. Phoenix, AZ: Arizona Game and Fish Department. 22 p. http://www.azgfd.gov/w_c/ edits/documents/ssspecies_bytaxon_017.pdf. [Accessed October 17, 2015]. 
Arnold, L.W. 1940. An ecological study of the vertebrate animals of the mesquite forest. Thesis. Tucson, AZ: University of Arizona. 79 p.

Arnold, L.W. 1941. The mesquite forest and the white-wing. Arizona Wildlife and Sportsman. 3(11): 5-6.

Arnold, L.W. 1943. The white-winged dove in Arizona. Pittman-Robertson Project Arizona 9- R. Phoenix: Arizona Game and Fish Commission, Federal Aid Division.

Baker, R.J.; Bradley, L.C.; Bradley, R.D.; [et al.]. 2003. Revised checklist of North American mammals north of Mexico. Occasional Paper Number 229. Lubbock, TX: Museum of Texas Tech University: 1-23.

Bartlett, R.D.; Bartlett, P.P. 2010. New Mexico's reptiles and amphibians: A field guide. Albuquerque, NM: University of New Mexico Press. 248 p.

Bendire, C.E. 1872. List of birds shot or observed $\&$ seen in the vicinity of Tucson and Rillitto [sic] Creek Arizona in the years 1871 and 1872. Field Books I (SIA Acc 12-279). Washington, DC: Smithsonian Institution Archives Capital Gallery: 1-112.

Bendire, C.E. 1892. Life histories of North American birds with special reference to their breeding habits and eggs. Washington, DC: U.S. National Museum, Special Bulletin 1: 1-446.

Bent, A.C. 1937. Urubitinga anthracinus anthracinus (Lichtenstein): Mexican goshawk. In: Life histories of North American birds of prey, part 1. Washington, DC: U.S. National Museum Bulletin 167: 259-264.

Best, T.M.; Kiser, W.M.; Freeman, P.W. 1996. Eumops perotis, Greater mastiff bat. Mammalian Species. 534: 1-8. American Society of Mammalogists. http://digitalcommons.unl.edu/cgi/ viewcontent.cgi?article $=1018 \&$ context $=$ museummammalogy. [Accessed August 30, 2015].

Bibles, B.D.; Glinski, R.L.; Johnson, R.R. 2002. Gray hawk (Buteo plagiatus). In: Poole, A., ed. The birds of North America. Ithaca, NY: Cornell Lab of Ornithology. http://bna.birds.cornell. edu/bna/species/652. [Accessed August 30, 2015].

Brandt, H. 1951. Arizona and its bird life. Cleveland, OH: The Bird Research Foundation. 723 p.

Brennan, T.C. 2008. Tiger rattlesnake, Crotalis tigris. http://www.reptilesofaz.org/SnakesSubpages/h-c-tigris.html. [Accessed December 7, 2015].

Brown, D.E., ed. 1982. Biotic communities of the American Southwest-United States and Mexico. Desert Plants. 4(1-4). 342 p.

Brown, D.E. 1989. Arizona game birds. Tucson, AZ: University of Arizona Press and Phoenix: Arizona Game and Fish Department. 307 p.

Brown, D.E.; Babb; R.D.; Johnson, R.R. 2015. Charles Taylor Vorhies (1879-1949): Arizona's premier nongame biologist. Journal of Arizona-Nevada Academy of Science. 46(1): 17-22.

Carothers, S.W.; Johnson R.R. 1975. Water management practices and their effects on nongame birds in range habitats. In: Smith, D.R., tech. coord. Proceedings: Symposium on management of forest and range habitats for-nongame birds. Gen. Tech. Rep. W0-1. Washington, DC: U.S. Department of Agriculture, Forest Service: 210-222.

Carothers, S.W.; Johnson R.R.; Aitchison, S.W. 1974. Population structure and social organization of southwestern riparian birds. American Zoologist. 14(1): 97-108.

Cockrum, E.L. 1960. The recent mammals of Arizona. Tucson, AZ: University of Arizona Press. $276 \mathrm{p}$.

Corman, T.E.; Wise-Gervais, C. 2005. Arizona breeding bird atlas. Albuquerque, NM: University of New Mexico Press. 636 p.

Dancing Snake Nature Photography. 2013. Neotropical vine snake eating an ornate tree lizard. Tucson, AZ: Tucson Herpetological Society. https:/tucsonherpsociety.org/inhabitants/brownvine-snake/ [Accessed December 12, 2017].

Davis, G.P., Jr. 1982. Man and wildlife in Arizona: The American exploration period, 18241865. Carmony, N.B.; Brown, D.E., eds. Phoenix: Arizona Game and Fish Department. 232 p.

Duncan, D.K. 1988. Small mammal inventory of the upper San Pedro River Valley, Cochise County, Arizona: Progress report. Safford, AZ: U.S. Department of the Interior, Bureau of Land Management. $57 \mathrm{p}$. 
Eddy, T.A. 1961. Foods and feeding patterns of the collared peccary in southern Arizona. Journal of Wildlife Management. 25(3): 248-257.

Enderson, E.F.; Bezy, R.L. 2007. Amphibians of Vekol Valley. In: Felger, R.S.; Broyles, B., eds. Dry borders: Great natural reserves of the Sonoran Desert. Salt Lake City, UT: University of Utah Press: 338-342.

Engel-Wilson, R.W.; Ohmart R.D. 1979. Floral and attendant faunal changes on the lower Rio Grande between Fort Quitman and Presidio, Texas. In: Johnson, R.R.; McCormick, J.F., tech. coords. Proceedings: Strategies for protection and management of floodplain wetlands and other riparian ecosystems. Gen. Tech. Rep. GTR-WO-12. Washington, DC: U.S. Department of Agriculture, Forest Service: 139-147.

Gaines, D.A. 1973. Floodplain riparian woodland. American Birds. 27(6): 995.

Gavin, T.A.; Sowls, L.K. 1975. Avian fauna of a San Pedro Valley mesquite forest. Journal of the Arizona Academy of Science. 10(1): 33-41.

Gilman, M.F. 1909. Nesting notes on the Lucy Warbler. Condor. 11(5): 166-168.

Gilman, M.F. 1914. Breeding of the Bronzed Cowbird in Arizona. Condor. 16(6): 255-259.

Glinski, R.L. 1998. Gray Hawk. In: Glinski, R.L., ed. Raptors of Arizona. Tucson, AZ: University of Arizona Press: 82-85.

Groschupf, K.D.; Brown, B.T.; Johnson, R.R. 1988. An annotated checklist of the birds of Organ Pipe Cactus National Monument, Arizona. Tucson, AZ: Southwest Parks and Monuments Association. $45 \mathrm{p}$.

Hall, E.R.; Kelson K.R. 1959. The mammals of North America. New York, NY: Ronald Press. Vol. 1: 1-546, Vol. 2: 547-1083.

Hasse, R. 2009. Ornate tree lizard, Urosaurus ornatus, (Baird and Girard,1852). In: Jones, L.L.C.; Lovich, R.E., eds. Lizards of the American Southwest. Tucson, AZ: Rio Nuevo Publishers: 290-293.

Hoag, J.C. 2007. How to plant willows and cottonwoods for riparian restoration. TN Plant Materials No. 23. January 2007 revision. Boise, ID: U.S. Department of the Interior, Natural Resources Conservation Service. 22 p. http://www.nrcs.usda.gov/Internet/FSE_ PLANTMATERIALS/publications/idpmetn7064.pdf. [Accessed August 30, 2015].

Hoffmeister, D.R. 1986. Mammals of Arizona. Tucson, AZ: University of Arizona Press. 602 p.

Howard, O.W. 1906. The English sparrow in the Southwest. Condor. 8(3): 67-68.

Ingles, L.G. 1950. Nesting birds of the willow-cottonwood community in California. Auk. 67: 325-332.

Integrated Taxonomic Information System (ITIS). Last update November 7, 2017. Database. Department of Commerce, Department of the Interior, Department of Agriculture, Environmentl Protection Agency, Smithsonian Institution. http://www.itis.gov/servlet/ SingleRpt/SingleRpt. [Accessed 12-19-15].

International Union for Conservation of Nature (IUCN). 2015. The IUCN red list of threatened species, 2015.2. Gland, Switzerland: International Union for Conservation of Nature. http:// www.iucnredlist.org/details/16680/0. [Accessed October 17, 2015].

Johnson, R.R.; Carothers, S.W. 1982. Riparian habitat and recreation: Interrelationships and impacts in the Southwest and Rocky Mountain Region. Eisenhower Consortium Bulletin. 12: $1-31$.

Johnson, R.R.; Haight, L.T. 1985. Avian use of xeroriparian ecosystems in the North American warm deserts. In: Johnson, R.R.; Ziebell, C.D.; Patton, D.R.; [et al.], tech. coords. Proceedings: Riparian ecosystems and their management: Reconciling conflicting uses. Gen. Tech. Rep. RM-120, Fort Collins, CO: U.S. Department of Agriculture, Forest Service, Rocky Mountain Forest and Range Experiment Station: 156-160.

Johnson, R.R.; Haight, L.T. 1988. Avian use of xeroriparian systems in the Big Bend Region, Texas. Contributed papers of second symposium on resources of the Chihuahuan Desert region: United States and Mexico, No. 16. Alpine, TX: Chihuahuan Desert Research Institute. $9 \mathrm{p}$. 
Johnson, R.R.; Simpson, J.M. 1971. Important birds from Blue Point Cottonwoods, Maricopa County, Arizona. Condor. 73(3): 379-380.

Johnson, R.R.; Simpson, J.M. [n.d.] Manuscript b (MS b); Birds of Blue Point Cottonwoods, Maricopa County, Arizona. Unpublished manuscript on file with: Johnson-Simpson Archives, Tucson, AZ.

Johnson, R.R.; Carothers, S.W.; Simpson, J.M. 1984. A riparian classification system. In: Warner, R.E.; Hendrix, K.M., eds. California riparian systems. Berkeley, CA: University of California Press: $375-382$.

Johnson, R.R.; Cartron, J-L.E.; Haight, L.T.; [et al.]. 2000. A historical perspective on the population decline of the cactus ferruginous pygmy-owl in Arizona. In: Cartron, J-L.E.; Finch, D.M., eds. Ecology and conservation of the cactus ferruginous pygmy-owl in Arizona. Gen. Tech. Rep. RMRS-43. Ogden, UT: U.S. Department of Agriculture, Forest Service, Rocky Mountain Research Station: 17-26.

Johnson, R.R.; Cartron, J-L.E.; Haight, L.T.; [et al.]. 2003. The cactus ferruginous pygmy-owl in Arizona, 1872-1971. Southwestern Naturalist. 48: 389-401.

Johnson, R.R.; Haight, L.T.; Simpson; J.M. 1977. Endangered species vs. endangered habitat: A concept. In: Johnson, R.R.; Jones, D.A., tech. coords. Proceedings: Symposium on importance, preservation, and management of riparian habitat. Gen. Tech. Rep. RM-43, Fort Collins, CO: U.S. Department of Agriculture, Forest Service, Rocky Mountain Forest and Range Experiment Station: 68-79.

Johnson, R.R.; Haight, L.T.; Simpson, J.M. 1987. Endangered habitats versus endangered species: A management challenge. In: Laymon, S.A., ed. Management and preservation of endangered birds in riparian ecosystems. Western Birds. 18(1): 89-96.

Johnson, R.R.; Yard, H.K.; Brown; B.T. 1997. Lucy's warbler (Vermivora luciae). In: Poole, A.; Gill, F., eds. The birds of North America. No. 318. Philadelphia, PA: Academy of Natural Sciences; Washington DC: American Ornithologists' Union. 20 p.

Jones, K.B. 1981. Effects of grazing on lizard abundance and diversity in western Arizona. Southwestern Naturalist. 26(2): 107-115.

Jones, K.B. 1988. Distribution and habitat associations of herpetofauna in Arizona: Comparisons by habitat type. In: Szaro, R.C.; Severson, K.E.; Patton, D.R., tech. coords. Proceedings: Management of amphibians, reptiles, and small mammals in North America: Symposium, 1988 July 19-21; Flagstaff, AZ. Gen. Tech. Rep. RM-166. Fort Collins, CO: U.S. Department of Agriculture, Forest Service, Rocky Mountain Forest and Range Experiment Station: $109-128$.

Jones, K.B.; Kepner, L.P.; Martin, T.E. 1985. Species of reptiles occupying habitat islands in Western Arizona: A deterministic assemblage. Oecologia (Berlin). 66: 595-601.

Jones, L.L.C.; Lovich, R.E., eds. 2009. Lizards of the American Southwest. Tucson, AZ: Rio Nuevo Publishers. 567 p.

Kimball, H.H. 1923. Bird notes from Arizona and California. Condor. 25(3): 109.

Klute, D.S.; Ayers, L.W.; Green, M.T.; [et al.]. 2003. Status assessment and conservation plan for the western burrowing owl in the United States. Biological Technical Publication FWS/ BTP-R6001-2003. Washington, DC: U.S. Department of the Interior, Fish and Wildlife Service. 120 p. http://www.californiachaparral.com/images/Burrowing_Owl_Status_USFW. pdf. [Accessed October 14, 2015].

Knopf, F.L; Johnson, R.R.; Rich, T.; [et al.]. 1988. Conservation of riparian ecosystems in the United States. Wilson Bulletin. 100(2): 272-284.

Krausman, P.A.; Rautenstrauch, K.R.; Leopold; B.D. 1985. Xeroriparian systems used by desert mule deer in Texas and Arizona. In: Johnson, R.R.; Ziebell, C.D.; Patton, D.R.; [et al.], tech. coords. Riparian ecosystems and their management: Reconciling conflicting uses. Gen. Tech. Rep. RM-120. Fort Collins, CO: U.S. Department of Agriculture, Forest Service, Rocky Mountain Forest and Range Experiment Station: 144-149. 
Krueper, D.; Bart, J.; Terrell, D.R. 2003. Response of vegetation and breeding birds to the removal of cattle on the San Pedro River, Arizona (U.S.A.). Conservation Biology. 27(2): $607-615$.

Lantz. D.E. 1905. Coyotes in their economic relations. Washington, DC: U.S. Government Printing Office. $48 \mathrm{p}$.

Lowe, C.H. 1961. Biotic communities in the sub-Mogollon region of the inland Southwest. Journal of the Arizona Academy of Science. 2(1): 40-49.

Lowe, C.H., ed. 1964a. The vertebrates of Arizona. Tucson: AZ: University of Arizona Press. $270 \mathrm{p}$.

Lowe, C.H. 1964b. Amphibians and reptiles of Arizona. In: Lowe, C.H., ed. The vertebrates of Arizona. Tucson, AZ: University of Arizona Press: Part 3, 153-174.

Lowe, C.H. 1985. Amphibians and reptiles in Southwest riparian ecosystems. In: Johnson, R.R.; Ziebell, C.D.; Patton, D.R.; [et al.], tech. coords. Riparian ecosystems and their management: Reconciling conflicting uses. Gen. Tech. Rep. RM-120. Fort Collins, CO: U.S. Department of Agriculture, Forest Service, Rocky Mountain Forest and Range Experiment Station: 339-341.

MacArthur, R.H.; MacArthur, J.W.; Preer, J. 1962. On bird species diversity. II. Prediction of bird census from habitat measurements. American Naturalist. 96: 167-174.

Marshall, J.T. 1960. Interrelations of Abert and Brown towhees. Condor. 62(1): 49-64.

Marshall, J.T., Jr., Johnson, R.R. 1968. The Canyon Towhee. In: Bent, A.C.; Austin, O.L., Jr., eds. Life histories of North American cardinals, grosbeaks, buntings, towhees, finches, sparrows, and allies. Bulletin U.S. National Museum 237, Pt. 2: 622-630.

Monson, G.; Phillips A.R. 1981. Annotated checklist of the birds of Arizona, 2nd ed. Tucson, AZ: University of Arizona Press. 220 p.

Moriarty, J.J., ed. 2012. Scientific and standard English names of amphibians and reptiles of North America north of Mexico, with comments regarding confidence in our understanding, 7th edition. Herpetological Circular Number 39. Salt Lake City, UT: Society for the Study of Amphibians and Reptiles. https://ssarherps.org/wp-content/uploads/2014/07/HC_39_7thEd. pdf. [Accessed October 14, 2015].

Peters, J.L. 1936. Records of two species new to Arizona. Condor. 38(5): 218.

Phillips, A., Marshall, J.; Monson, G. 1964. The birds of Arizona. Tucson, AZ: University of Arizona Press. 240 p.

Phillips, A.R. 1940. Two new breeding birds for the United States. Auk. 57(1): 117-118.

Phillips, S.J.; Comus, P.W. 2000. A natural history of the Sonoran Desert. Tucson, AZ: ArizonaSonora Desert Museum. 629 p.

Proudfoot, G.A.; Johnson, R.R. 2000. Ferruginous Pygmy-Owl (Glaucidium brasilianum). In: Poole, A.; Gill, F., eds. The birds of North America, number 498. Philadelphia, PA: Academy of Natural Sciences; Washington, DC: American Ornithologists' Union. 20 p.

Rosen, P.C. 2001. Biological values of the West Branch of the Santa Cruz River with an outline for a potential park or reserve. Report to Pima County Board of Supervisors, 15 October 2001. Tucson, AZ: Pima County. https://repository.asu.edu/items/21389. [Accessed October $16,2015]$.

Rosen, P.C. 2003. Herpetology of the West Branch of the Santa Cruz River, Tucson. Sonoran Herpetologist. 16 (4): 38-42.

Rosen, P.C. 2008. Urban amphibian and reptile biodiversity: Report to the technical advisory committee (TAC) for City of Tucson Habitat Conservation Plan (HCP). Unpublished report on file with: City of Tucson, Tucson, AZ. https://www.tucsonaz.gov/files/sustainability/ CMS1_033865.pdf. [Accessed October 16, 2015].

Rosen, P.C. 2009. Reptiles and amphibians. In: Stromberg, J.C.; Tellman, B., eds. Ecology and conservation of the San Pedro River. Tucson, AZ: University of Arizona Press: 175-191.

Rosenberg, K.V.; Ohmart, R.D.; Hunter W.C.; [et al.]. 1991. Birds of the lower Colorado River Valley. Tucson, AZ: University of Arizona Press. 416 p. 
Schwalbe, C.R.; Rosen, P.C. 2009. Clark's Spiny Lizard, Sceloporus clarki Baird and Girard, 1852. In: Jones, L.L.C.; Lovich, R.E., eds. Lizards of the American Southwest. Tucson, AZ: Rio Nuevo Publishers: 206-209.

Shafroth, P.B.; Friedman, J.M.; Ischinger, L.S. 1995. Effects of salinity on establishment of Populus fremontii (cottonwood) and Tamarix ramosissima (saltcedar) in southwestern United States. Great Basin Naturalist. 55(1): 58-65.

Simpson, B.B., ed. 1977. Mesquite: Its biology in two desert ecosystems. Stroudsberg, PA: Dowden, Hutchinson and Ross, Inc. 250 p.

Smith, L.L.; Ueckert, D.N. 1974. Influence of insects on mesquite seed production. Journal of Range Management. 27(1): 61-65.

Snyder, K.A.; Williams, D.G.; Gempko, V.L. [n.d.] Water source determination in cottonwood/ willow and mesquite forests on the San Pedro River in Arizona. Tucson, AZ: University of Arizona. 4 p. http://www.tucson.ars.ag.gov/salsa/archive/publications/ams_preprints/snyder. PDF. [Accessed November 23, 2015].

Soykan, C.U.; Brand, L.A.; Sabo, J.L. 2009. Causes and consequences of mammal species richness. In: Stromberg, J.C.; Tellman B., eds. 2009. Ecology and conservation of the San Pedro River. Tucson, AZ: University of Arizona Press: 107-126.

Stamp, N.E. 1978. Breeding birds of riparian woodland in south-central Arizona. Condor. 80(1): 64-71.

Stanley, J; Griggs, T.; Rieger, J. [In prep.]. The development of riparian ecosystem restoration in California. In: Johnson, R. Roy; Carothers, Steven W.; Finch, Deborah M.; [et al.], tech. eds. [In prep.]. Riparian research and management: Past, present, future. Volume 2. Gen. Tech. Rep. RMRS-GTR-XXX. Fort Collins, CO: U.S. Department of Agriculture, Forest Service, Rocky Mountain Research Station.

Stebbins, R.C. 1985. A field guide to western reptiles and amphibians, 2nd ed. revised. The Peterson field guide series. Boston: Houghton Mifflin. 335 p.

Stromberg, J.C.; Tellman, B., eds. 2009. Ecology and conservation of the San Pedro River. Tucson, AZ: University of Arizona Press. 524 p.

Szaro, R.C. 1980. Factors influencing bird populations in southwestern riparian forests. In: DeGraff, R.M.; Tilghman, N.G., comps. Workshop proceedings: Management of western forests and grasslands for nongame birds. Gen. Tech. Rep. INT-GTR-86. Ogden, UT: U.S. Department of Agriculture, Forest Service, Intermountain Research Station: 403-418.

Tucson Herpetological Society. [n.d.] Neotropical vinesnake (Oxybelis aeneus). Tucson, AZ: Tucson Herpetologiccal Society. https://tucsonherpsociety.org/inhabitants/brown-vine-snake/. [Accessed August 30, 2015].

U.S. Fish and Wildlife Service (USFWS). 2015. Yellow-billed Cuckoo. http://www.fws.gov/ southwest/es/arizona/Yellow.htm. [Accessed October 16, 2015].

Van Devender, T.R.; Lowe, C.H.; Lawler, H.E. 1994. Factors influencing the distribution of the neotropical vine snake (Oxybelis aeneus) in Arizona and Sonora, Mexico. Herpetological Natural History. 2 (1): 25-42.

Visher, S.S. 1909. The capture of the red-eyed cowbird in Arizona. Auk. 26(3): 307.

Vorhies, C.T. 1926. A new Ophidian record for Arizona. Copeia. 157: 156-157.

Vorhies, C.T.; Jenks R.; Phillips, A.R. 1935. Bird records from the Tucson region, Arizona. Condor. 37(5): 243-247.

Ward, C.R.; O’Brien; C.W.; O’Brien, L.B; [et al.].1977. Annotated checklist of new world insects associated with Prosopis (mesquite). Res. Serv. Tech. Bull. No. 1557. Washington DC: U.S. Department of Agriculture. $115 \mathrm{p}$.

Webb, R.H.; Betancourt, J.L.; Johnson, R.R.; [et al.]. 2014. Requiem for a river: The Santa Cruz River through Tucson, Arizona. Tucson, AZ: University of Arizona Press. 279 p. 


\title{
Appendix A: Western Pioneers of Riparian Study Through the 1980s
}

\author{
Compiled by: Kenneth J. Kingsley, John T. Stanley, Steven W. Carothers, R. Roy \\ Johnson, Deborah M. Finch, Duncan T. Patten, Anne Sands, Bo Shelby, and Frederick \\ J. Swanson
}

Table A.1 is a list of people who had significant early roles in the development of the study of riparian resources in the western United States during the period of time prior to and through the 1980s. Nominees were selected based on their meeting one or more of the following criteria involving developing the science of riparian ecology and/ or advancing the "riparian environmental movement" through the 1980s.

1. Conducted early riparian studies and published or presented results that advanced the establishment of riparian ecology as an emerging science.

2. Published at least three papers on some aspect of riparian science; or if fewer than three, a landmark or state of the art paper that would advance the establishment of the science. These publications are usually listed online, especially in Google Scholar and Web of Science.

3. Assumed leading roles in encouraging resource management agencies to support and set policy for management and protection of riparian ecosystems.

4. Organized conferences, symposia, riparian councils, or similar undertakings.

5. Published manuals on riparian restoration and/or completed a project that serves as a demonstration site that is an outstanding illustration of important restoration factors.

6. Attracted regional or national attention by advocating the study and conservation of riparian ecosystems.

Persons listed are ordered alphabetically within the decade of first known involvement in riparian ecology, based upon authors' recollections and/or first known publication or formal presentation. Undoubtedly, some names have been inadvertently omitted and some aspects of the work of some individuals included below have been overlooked. Contributions to the science are briefly summarized based on best-known work, and some important contributions may have been omitted. The conferences mentioned in the table are those listed in a separate appendix in this general technical report. 
Table A.1-Listing of people who had a significant role in the development of the study of riparian resources in the western United States, prior to and through the 1980s.

\begin{tabular}{|c|c|c|}
\hline Person & Affiliation & Riparian activities and results \\
\hline \multicolumn{3}{|l|}{ Pre-1960s } \\
\hline Willis L. Jepson & $\begin{array}{l}\text { University of California, } \\
\text { Berkeley }\end{array}$ & $\begin{array}{l}\text { Published paper in } 1893 \text { on the riparian botany of the lower } \\
\text { Sacramento River. }\end{array}$ \\
\hline Lloyd G. Ingles & Fresno State University & $\begin{array}{l}\text { First known quantified population studies of riparian nesting } \\
\text { birds for California or the West. }\end{array}$ \\
\hline Luna B. Leopold & $\begin{array}{l}\text { University of California, } \\
\text { Berkeley }\end{array}$ & $\begin{array}{l}\text { One of nation's leading hydrologists; published several books } \\
\text { and scientific papers on streams. }\end{array}$ \\
\hline Richard G. Beidleman & $\begin{array}{l}\text { University of Colorado; } \\
\text { Colorado College }\end{array}$ & $\begin{array}{l}\text { Cottonwood riparian thesis, } 1948 \text { and similar dissertation, } 1954 \\
\text { at University of Colorado; numerous publications but none of } \\
\text { this riparian work. }\end{array}$ \\
\hline \multicolumn{3}{|l|}{$1960 s$} \\
\hline Robert L. Beschta & Oregon State University & $\begin{array}{l}\text { Prolific author and co-author on watershed management, forest } \\
\text { and range hydrology, sediment transport, channel morphology, } \\
\text { water quality, wetlands and riparian areas, effects of logging, } \\
\text { grazing, and predator presence or absence on watersheds and } \\
\text { riparian areas. }\end{array}$ \\
\hline Bud Bristow & $\begin{array}{l}\text { Arizona Game and Fish } \\
\text { Department }\end{array}$ & $\begin{array}{l}\text { Secured funding for Carothers' and Johnson's earliest Verde } \\
\text { River avian projects; actively fought "phreatophyte control" } \\
\text { through public presentations and writings. }\end{array}$ \\
\hline C. J. Campbell & USDA Forest Service & $\begin{array}{l}\text { Published paper in } 1968 \text { on "pseudoriparian" plants; } \\
\text { coauthored } 1964 \text { "phreatophyte" publication with Dick-Peddie. }\end{array}$ \\
\hline Steven W. Carothers & $\begin{array}{l}\text { Museum of Northern } \\
\text { Arizona; SWCA } \\
\text { Environmental Consultants }\end{array}$ & $\begin{array}{l}\text { Co-principal on earliest avian riparian studies along Verde R., } \\
\text { first in-depth riparian avian population study for SW; several } \\
\text { publications on riparian birds and riparian management and } \\
\text { restoration; several publications on ecology of riparian area } \\
\text { along Colorado River in Grand Canyon. }\end{array}$ \\
\hline William A. Dick-Peddie & $\begin{array}{l}\text { New Mexico State } \\
\text { University, Las Cruces }\end{array}$ & $\begin{array}{l}\text { Publications on classification and ecology of riparian } \\
\text { ecosystems, especially in New Mexico. }\end{array}$ \\
\hline R. Roy Johnson & $\begin{array}{l}\text { Prescott College; National } \\
\text { Park Service; University of } \\
\text { Arizona }\end{array}$ & $\begin{array}{l}\text { Co-principal with Carothers on early avian studies along Verde } \\
\text { River, first in depth riparian avian population study for the } \\
\text { Southwest; coordinator of research on Colorado River corridor } \\
\text { in Grand Canyon; numerous publications on riparian birds and } \\
\text { riparian management; organized three regional and national } \\
\text { riparian conferences and presented numerous papers. }\end{array}$ \\
\hline Dale A. Jones & USDA Forest Service & $\begin{array}{l}\text { Obtained funding for Carothers and Johnson's Verde Valley } \\
\text { avian projects; organized early riparian field training sessions; } \\
\text { assisted in organizing first regional riparian conference for the } \\
\text { United States (1977). }\end{array}$ \\
\hline Charles H. Lowe & University of Arizona & $\begin{array}{l}\text { Developed early definition and classification of riparian } \\
\text { ecosystems; first published what would become the Brown and } \\
\text { Lowe classification system for Biotic Communities. }\end{array}$ \\
\hline Wendell L. Minckley & Arizona State University & $\begin{array}{l}\text { Primarily an ichthyologist also contributed to publications on } \\
\text { cienegas, riparian classification systems, and other riparian } \\
\text { studies. }\end{array}$ \\
\hline Douglas Morrison & USDA Forest Service & $\begin{array}{l}\text { The } 1977 \text { Tucson riparian conference was dedicated to Doug } \\
\text { for his role in halting destruction of mature cottonwood trees as } \\
\text { "phreatophyte control" projects along the Verde River in central } \\
\text { Arizona. }\end{array}$ \\
\hline
\end{tabular}


Table A.1-Continued.

\begin{tabular}{|c|c|c|}
\hline Person & Affiliation & Riparian activities and results \\
\hline Amadeo M. Rea & $\begin{array}{l}\text { Prescott College; San Diego } \\
\text { Natural History Museum; } \\
\text { University of San Diego }\end{array}$ & $\begin{array}{l}\text { Studied ecological history of the Gila River Indian Community. } \\
\text { Published book on riparian biota of the Gila River documenting } \\
\text { losses after construction of upstream Coolidge Dam. }\end{array}$ \\
\hline Kenneth Thompson & $\begin{array}{l}\text { University of California, } \\
\text { Davis }\end{array}$ & $\begin{array}{l}\text { In 1961, published article titled "Riparian Forests of the } \\
\text { Sacramento Valley, CA." Presented papers at the } 1976 \text { and } 1977 \\
\text { CA conferences. }\end{array}$ \\
\hline Raymond M. Turner & $\begin{array}{l}\text { University of Arizona; U.S. } \\
\text { Geological Survey }\end{array}$ & $\begin{array}{l}\text { Pioneered repeat photography showing environmental changes } \\
\text { in riparian vegetation along rivers of the southwest and mapped } \\
\text { Arizona streams and wetlands. }\end{array}$ \\
\hline \multicolumn{3}{|l|}{ 1970s } \\
\hline Dana L. Abell & $\begin{array}{l}\text { University of California, } \\
\text { Davis }\end{array}$ & $\begin{array}{l}\text { Conducted research on river systems in Sequoia NP. Member of } \\
\text { steering committee for } 1981 \text { California conference; Technical } \\
\text { Coordinator of } 1988 \text { California conference. }\end{array}$ \\
\hline Bertin W. Anderson & $\begin{array}{l}\text { Arizona State University; } \\
\text { Revegetation and Wildlife } \\
\text { Management Center, Blythe, } \\
\text { CA }\end{array}$ & $\begin{array}{l}\text { Conducted research on experimental revegetation of riparian } \\
\text { trees and their use by birds along the lower Colorado River } \\
\text { and Kern River Preserve; published papers in journals and } \\
\text { conference proceedings and co-author of book on birds of the } \\
\text { lower Colorado River. }\end{array}$ \\
\hline George T. Austin & $\begin{array}{l}\text { University of Nevada, Las } \\
\text { Vegas }\end{array}$ & $\begin{array}{l}\text { Conducted early studies of birds in desert riparian ecosystems, } \\
\text { as well as butterflies and birds of Nevada. }\end{array}$ \\
\hline W. James Barry & $\begin{array}{l}\text { California Department of } \\
\text { Parks and Recreation }\end{array}$ & $\begin{array}{l}\text { Leader in protection and management of riparian ecosystems } \\
\text { in California's State Park System; member of California Riparian } \\
\text { Revegetation Study Group; presented papers at 1981, } 1984 \\
\text { and } 1987 \text { California conferences; advisor for } 1988 \text { California } \\
\text { conference. }\end{array}$ \\
\hline Mark M. Brinson & East Carolina University & $\begin{array}{l}\text { An exceptionally versatile expert on water based ecosystems, } \\
\text { including not only riparian wetlands of the West but also coastal } \\
\text { and Eastern wetlands. }\end{array}$ \\
\hline David E. Brown & $\begin{array}{l}\text { Arizona Game and Fish } \\
\text { Department; Arizona State } \\
\text { University. }\end{array}$ & $\begin{array}{l}\text { Published classification system for Biotic Communities of North } \\
\text { America with Charles H. Lowe, map of Arizona's perennial } \\
\text { streams and wetlands, and book on wetlands and waterfowl in } \\
\text { Arizona. }\end{array}$ \\
\hline James W. Burns & $\begin{array}{l}\text { Office of California Secretary } \\
\text { of State }\end{array}$ & $\begin{array}{l}\text { Led Sacramento River Task Force. Presented papers at } 1976, \\
\text { 1977, and } 1981 \text { California conferences and paper at } 1978 \\
\text { Georgia conference. }\end{array}$ \\
\hline Kenneth W. Cummins & $\begin{array}{l}\text { OR State University; } \\
\text { Humboldt State University, } \\
\text { California }\end{array}$ & $\begin{array}{l}\text { Numerous publications on interaction between aquatic and } \\
\text { riparian ecosystems; co-author of River Continuum Concept. }\end{array}$ \\
\hline Robert B. Ditton & Texas A\&M University & $\begin{array}{l}\text { Studied riparian mammals, recreation, and livestock impacts in } \\
\text { Big Bend National Park. }\end{array}$ \\
\hline Jerry F. Franklin & $\begin{array}{l}\text { USDA Forest Service; } \\
\text { University of Washington; } \\
\text { National Science Foundation } \\
\text { (NSF) }\end{array}$ & $\begin{array}{l}\text { Large number of publications on riparian and related forest } \\
\text { issues; recipient of numerous awards for conservation and } \\
\text { related environmental issues; chaired and served on many } \\
\text { related boards and commissions; Program Officer at NSF that } \\
\text { provided funding for River Continuum Concept. }\end{array}$ \\
\hline David A. Gaines & $\begin{array}{l}\text { Davis Audubon Society, CA; } \\
\text { Mono Lake Committee, CA }\end{array}$ & $\begin{array}{l}\text { Conducted breeding bird censuses in Sacramento Valley } \\
\text { riparian woodland in early 1970s; organized } 1976 \text { California } \\
\text { conference; member of } 1977 \text { California conference committee; } \\
\text { led Mono Lake Committee; published and presented papers on } \\
\text { riparian birds and destruction of riparian habitat at } 1977 \text { and } \\
1981 \text { California conferences. }\end{array}$ \\
\hline Richard L. Glinski & $\begin{array}{l}\text { Arizona State University; } \\
\text { Arizona Game and Fish }\end{array}$ & $\begin{array}{l}\text { Conducted studies on riparian raptors; published several papers } \\
\text { and books. }\end{array}$ \\
\hline
\end{tabular}


Table A.1-Continued.

\begin{tabular}{|c|c|c|}
\hline Person & Affiliation & Riparian activities and results \\
\hline Bernard H. Goldner & $\begin{array}{l}\text { Santa Clara Valley Water } \\
\text { District, San Jose, CA }\end{array}$ & $\begin{array}{l}\text { Managed contracts for riparian revegetation projects in } \\
\text { Santa Clara County, CA; member and host of CA Riparian } \\
\text { Revegetation Study Group; presented papers at 1981, 1987, and } \\
1988 \text { California conferences. }\end{array}$ \\
\hline Lois T. Haight & National Park Service & $\begin{array}{l}\text { Co-author of } 25 \text { publications, mostly on riparian birds; assisted } \\
\text { with organization of } 1977 \text { Tucson riparian conference. }\end{array}$ \\
\hline Robert H. Hamre & USDA Forest Service & $\begin{array}{l}\text { Editor and leading advocate of publications of several riparian } \\
\text { conference proceedings. }\end{array}$ \\
\hline Burchard H. Heede & USDA Forest Service & $\begin{array}{l}\text { Studies and publications on stream dynamics and riparian } \\
\text { vegetation. }\end{array}$ \\
\hline Robert F. Holland & $\begin{array}{l}\text { California Department of } \\
\text { Fish and Game }\end{array}$ & $\begin{array}{l}\text { Developed system for the classification of natural communities } \\
\text { in California. Served on Advisory Committee for } 1988 \text { CA } \\
\text { conference and presented papers at } 1977 \text { and } 1988 \text { California } \\
\text { conferences. Co-author of field guide to common riparian plants } \\
\text { of California. }\end{array}$ \\
\hline J. Greg Howe & $\begin{array}{l}\text { University of California, } \\
\text { Davis }\end{array}$ & $\begin{array}{l}\text { Member of Conference Committee and assistant editor of } \\
\text { proceedings for } 1977 \text { California conference. Co-author of } \\
\text { several conference papers. }\end{array}$ \\
\hline John P. Hubbard & $\begin{array}{l}\text { Delaware Museum of } \\
\text { Natural History; New } \\
\text { Mexico Game \& Fish }\end{array}$ & $\begin{array}{l}\text { Early inventories of the Gila River Valley in New Mexico. } \\
\text { Publications on birds of New Mexico and classification and } \\
\text { inventory of riparian ecosystems in New Mexico. }\end{array}$ \\
\hline Edward A. Keller & $\begin{array}{l}\text { University of California, } \\
\text { Santa Barbara }\end{array}$ & $\begin{array}{l}\text { Presented papers at } 1977 \text { and } 1988 \text { California conferences } \\
\text { on fluvial systems and processes to minimize adverse effects } \\
\text { of stream channelization. Co-author of } 1989 \text { USFWS report } \\
\text { profiling riparian habitats of southern California. }\end{array}$ \\
\hline Stephen Laymon & $\begin{array}{l}\text { University of California, } \\
\text { Berkeley }\end{array}$ & $\begin{array}{l}\text { Conducted 5-year study of riparian ecosystem at Dog Island } \\
\text { on the Sacramento River; presented papers at California } \\
\text { conferences. Involved in riparian revegetation at TNC Kern River } \\
\text { Preserve. }\end{array}$ \\
\hline Robert E. Manning & University of Vermont & $\begin{array}{l}1979 \text { review paper on impacts of recreation use on riparian } \\
\text { soils and vegetation. Author of best-known text on recreation } \\
\text { research, "Studies in Outdoor Recreation" (1986; third edition } \\
2011) \text {. }\end{array}$ \\
\hline Robert D. Ohmart & Arizona State University & $\begin{array}{l}\text { Studies of riparian ecology along the lower Colorado River; } \\
\text { several publications, largely with B.W. Anderson and graduate } \\
\text { students on aspects of riparian ecology. }\end{array}$ \\
\hline Duncan T. Patten & $\begin{array}{l}\text { Arizona State University; } \\
\text { Montana State University }\end{array}$ & $\begin{array}{l}\text { Founding President, Arizona Riparian Council 1985-1989. } \\
\text { Studies of several southwestern and eastern Sierra riparian areas } \\
\text { and mentor of several leading riparian ecologists; numerous } \\
\text { publications. }\end{array}$ \\
\hline David R. Patton & USDA Forest Service & $\begin{array}{l}\text { Published numerous papers on management and research needs } \\
\text { for riparian habitat. }\end{array}$ \\
\hline William S. Platts & USDA Forest Service & $\begin{array}{l}\text { Studied impacts of grazing on riparian ecosystems; published } \\
\text { large number of scientific papers. Lead author of } 1987 \\
\text { "Methods for Evaluating Riparian Habitats with Applications to } \\
\text { Management." }\end{array}$ \\
\hline John N. Rinne & USDA Forest Service & $\begin{array}{l}\text { Studied impacts of grazing on riparian and aquatic ecosystems, } \\
\text { with emphasis on fish and reptiles. }\end{array}$ \\
\hline Anne Sands & Riparian Systems, Davis, CA & $\begin{array}{l}\text { Coordinator and Editor of } 1977 \text { California conference; member } \\
\text { of Advisory Committee for } 1988 \text { California conference; author } \\
\text { or co-author of papers presented at riparian conferences; chair } \\
\text { of the Riverlands Council. Co-author of } 1989 \text { USFWS report } \\
\text { profiling riparian habitats of southern California. }\end{array}$ \\
\hline
\end{tabular}


Table A.1-Continued.

\begin{tabular}{|c|c|c|}
\hline Person & Affiliation & Riparian activities and results \\
\hline David J. Schmidly & TX A\&M University & $\begin{array}{l}\text { Studied riparian mammals, recreation, and livestock impacts in } \\
\text { Big Bend National Park. }\end{array}$ \\
\hline James R. Sedell & $\begin{array}{l}\text { Oregon State University; } \\
\text { Weyerhauser Corp.; USDA } \\
\text { Forest Service }\end{array}$ & $\begin{array}{l}\text { Studied forest-stream interactions in Pacific Northwest. Co- } \\
\text { author of River Continuum Concept, led aquatic component of } \\
\text { FEMAT/NW Forest. }\end{array}$ \\
\hline Bo Shelby & $\begin{array}{l}\text { Oregon State University; } \\
\text { Confluence Research and } \\
\text { Consulting }\end{array}$ & $\begin{array}{l}\text { River/riparian recreation studies in Grand Canyon (1976), later } \\
\text { Alaska and Lower 48; studies of flows for recreation from Alaska } \\
\text { to Georgia; organized national conferences and agency training } \\
\text { programs. Publications on recreation impacts, flows, and hydro- } \\
\text { licensing. }\end{array}$ \\
\hline Felix E. Smith & US Fish and Wildlife Service & $\begin{array}{l}\text { Presented papers at 1976, } 1977 \text { and } 1981 \text { California riparian } \\
\text { symposia. }\end{array}$ \\
\hline Lawrence E. Stevens & $\begin{array}{l}\text { Prescott College; Northern } \\
\text { Arizona University; Museum } \\
\text { of Northern Arizona }\end{array}$ & $\begin{array}{l}\text { Assisted Carothers and Johnson in Verde River study. Leading } \\
\text { expert on North American springs; founder of Springs } \\
\text { Stewardship Institute; published studies of many taxa, especially } \\
\text { insects, in the Colorado Plateau region and Colorado River } \\
\text { corridor. }\end{array}$ \\
\hline Frederick J. Swanson & $\begin{array}{l}\text { Oregon State University; } \\
\text { USDA Forest Service }\end{array}$ & $\begin{array}{l}\text { Studied forest-stream interactions in Pacific Northwest region; } \\
\text { co-author of numerous publications; input into development of } \\
\text { management policies. }\end{array}$ \\
\hline Dale A. Zimmerman & $\begin{array}{l}\text { Western New Mexico } \\
\text { University }\end{array}$ & $\begin{array}{l}\text { Studied birds of the Gila River, New Mexico. Several U.S. Forest } \\
\text { Service reports; published notes on riparian birds. }\end{array}$ \\
\hline Bill Zeedyk & $\begin{array}{l}\text { USDA Forest Service; } \\
\text { Restoration Services }\end{array}$ & $\begin{array}{l}\text { Published manual on riparian restoration "Let the Water do the } \\
\text { Work." }\end{array}$ \\
\hline \multicolumn{3}{|l|}{$1980 s$} \\
\hline Betty Andrews & $\begin{array}{l}\text { Friends of the River; Philip } \\
\text { Williams and Associates, San } \\
\text { Francisco, CA }\end{array}$ & $\begin{array}{l}\text { Provided hydrologic and geomorphic consulting expertise for } \\
\text { multiple stream and riparian restoration projects in California; } \\
\text { member of steering committee for } 1981 \text { California conference. }\end{array}$ \\
\hline Ward Brady & Arizona State University & $\begin{array}{l}\text { Several riparian papers, especially on regeneration and growth } \\
\text { of riparian forests. }\end{array}$ \\
\hline Bryan T. Brown & $\begin{array}{l}\text { National Park Service; } \\
\text { University of Arizona; SWCA }\end{array}$ & $\begin{array}{l}\text { Riparian studies on birds along the Colorado River in the Grand } \\
\text { Canyon; studied fauna of Rio Yaqui in Sonora, Mexico. }\end{array}$ \\
\hline Thomas C. Brown & USDA Forest Service & $\begin{array}{l}\text { Organized } 1989 \text { Forest Service funding which led to } 1992 \text { short } \\
\text { book on instream flows for recreation and aesthetics with Bo } \\
\text { Shelby and Jonathan Taylor. Several other articles and book } \\
\text { chapters about benefits of instream flows for recreation and } \\
\text { aesthetics. }\end{array}$ \\
\hline David N. Cole & $\begin{array}{l}\text { Aldo Leopold Wilderness } \\
\text { Research Institute }\end{array}$ & $\begin{array}{l}\text { Publications and agency training on measuring and mitigating } \\
\text { recreation impacts at camps and attraction sites. Organized } \\
\text { conferences and training sessions on stewardship, with a focus } \\
\text { on recreation impacts in alpine and riparian settings. }\end{array}$ \\
\hline David W. Crumpacker & $\begin{array}{l}\text { University of Colorado, } \\
\text { Boulder }\end{array}$ & $\begin{array}{l}\text { Published several papers on riparian ecosystems and their } \\
\text { management. }\end{array}$ \\
\hline Clifford N. Dahm & University of New Mexico & $\begin{array}{l}\text { Published numerous papers on riverine activities and } \\
\text { interactions between streams and riparian ecosystems. }\end{array}$ \\
\hline Wayne Elmore & Bureau of Land Management & $\begin{array}{l}\text { Studied effects of livestock grazing on riparian areas and } \\
\text { restoration methods on public lands in the Great Basin } \\
\text { of Eastern Oregon. Presented papers at } 1988 \text { California } \\
\text { conference. Author or co-author of several papers on riparian } \\
\text { ecology. }\end{array}$ \\
\hline
\end{tabular}


Table A.1-Continued.

\begin{tabular}{|c|c|c|}
\hline Person & Affiliation & Riparian activities and results \\
\hline Christopher C. Estes & $\begin{array}{l}\text { Prescott College; Washington } \\
\text { State University; Alaska } \\
\text { Dept. Fish and Game; Chalk } \\
\text { Board Enterprises, LLC }\end{array}$ & $\begin{array}{l}\text { Aquatic Resources \& Habitat Scientist, involved in Verde } \\
\text { Valley, AZ, riparian avian studies in 1970s; as Chief of Alaska } \\
\text { Department of Fish and Game, Aquatic Resources Coordination } \\
\text { Unit and At-Large Director, Instream Flow Council, integrated } \\
\text { riparian habitat assessment elements in instream flow/water } \\
\text { level conservation actions and publications. }\end{array}$ \\
\hline Phillis M. Faber & $\begin{array}{l}\text { CA Native Plant Society; } \\
\text { Pickleweed Press, Mill } \\
\text { Valley, CA }\end{array}$ & $\begin{array}{l}\text { Editor of articles on riparian plants of California in CNPS } \\
\text { journal Fremontia (1983-1999). Co-author of } 1988 \text { field guide } \\
\text { to common riparian plants of California. Lead author of } 1989 \\
\text { USFWS biological report on ecology of riparian habitats of } \\
\text { southern California. Editor of } 2001 \text { California riparian systems } \\
\text { conference. }\end{array}$ \\
\hline Deborah M. Finch & USDA Forest Service & $\begin{array}{l}\text { Field researcher and co-author or author of more than } 150 \\
\text { published papers, especially on riparian birds; technical } \\
\text { coordinator or editor of many USFS research reports. }\end{array}$ \\
\hline Randall L. Gray & $\begin{array}{l}\text { Natural Resources } \\
\text { Conservation Service }\end{array}$ & $\begin{array}{l}\text { Co-author of several publications, and presentations at riparian } \\
\text { conferences; co-founder of California Riparian Revegetation } \\
\text { Study Group. }\end{array}$ \\
\hline Stanley V. Gregory & Oregon State University & Studied forest-stream interactions in Pacific Northwest region. \\
\hline F. Thomas Griggs & $\begin{array}{l}\text { The Nature Conservancy, CA; } \\
\text { River Partners, Chico, CA }\end{array}$ & $\begin{array}{l}\text { TNC Project Manager for riparian restoration throughout } \\
\text { California. Served on Advisory Committee for } 1988 \text { California } \\
\text { conference. Author/co-author of several papers on riparian } \\
\text { habitat restoration. Author of California Riparian Habitat } \\
\text { Restoration Handbook. }\end{array}$ \\
\hline Barry Hecht & $\begin{array}{l}\text { HEA, Berkeley, CA; Balance } \\
\text { Hydrologics Inc., Berkeley, } \\
\text { CA }\end{array}$ & $\begin{array}{l}\text { Provided hydrologic and geomorphic consulting expertise for } \\
\text { multiple stream and riparian restoration projects in California. } \\
\text { Member of CA Riparian Revegetation Study Group; presented } \\
\text { paper at } 1981 \text { California riparian conference and other } \\
\text { conferences. }\end{array}$ \\
\hline Dean A. Hendrickson & $\begin{array}{l}\text { Arizona State University; } \\
\text { University of Texas, Austin }\end{array}$ & $\begin{array}{l}\text { Primarily an ichthyologist but also a leading U.S. expert on } \\
\text { cienegas. }\end{array}$ \\
\hline Kathleen M. Hendrix & $\begin{array}{l}\text { University of California, } \\
\text { Davis }\end{array}$ & $\begin{array}{l}\text { Assistant Coordinator and Assistant Editor of } 1981 \text { California } \\
\text { Riparian Systems Conference. Co-author of California } \\
\text { Department of Fish and Game report on the riparian resources } \\
\text { of the Central Valley and California desert. }\end{array}$ \\
\hline William C. Hunter & $\begin{array}{l}\text { Arizona State University; } \\
\text { U.S. Fish and Wildlife } \\
\text { Service }\end{array}$ & $\begin{array}{l}\text { Author or co-author of several papers on riparian birds. Co- } \\
\text { author with Ohmart, Anderson, and Rosenberg of book on Birds } \\
\text { of the Lower Colorado River Valley (published in 1991). }\end{array}$ \\
\hline Diana Jacobs & $\begin{array}{l}\text { California State Lands } \\
\text { Commission }\end{array}$ & $\begin{array}{l}\text { Member of Advisory Committee for } 1988 \text { California Riparian } \\
\text { Systems Conference. Chair of SB1086 Riparian Habitat } \\
\text { Committee overseeing preparation of Sacramento River Riparian } \\
\text { Habitat Management Plan. Major contributor to California } \\
\text { public trust reports on California rivers and delta. }\end{array}$ \\
\hline William L. Jackson & $\begin{array}{l}\text { Bureau of Land Management } \\
\text { and National Park Service }\end{array}$ & $\begin{array}{l}\text { Early flow studies for BLM. Lead author on } 1989 \text { value-based } \\
\text { interdisciplinary approach for protecting instream flows applied } \\
\text { to rivers in Arizona, Colorado, and Alaska. Managed water } \\
\text { operations branch for NPS, including the National Water } \\
\text { Quality Assessment in the national parks. }\end{array}$ \\
\hline Sherman E. Jensen & $\begin{array}{l}\text { White Horse Associates, } \\
\text { Smithfield, UT }\end{array}$ & $\begin{array}{l}\text { Studied riparian-stream interactions and soils. Several } \\
\text { publications, especially on Great Basin riparian and wetland } \\
\text { soils; co-author of riverine publications. }\end{array}$ \\
\hline K. Bruce Jones & $\begin{array}{l}\text { Environmental Protection } \\
\text { Agency, Las Vegas, NV }\end{array}$ & $\begin{array}{l}\text { Author of numerous publications on amphibians and reptiles; } \\
\text { authority on the riparian herpetofauna of the Southwest. }\end{array}$ \\
\hline
\end{tabular}


Table A.1-Continued.

\begin{tabular}{|c|c|c|}
\hline Person & Affiliation & Riparian activities and results \\
\hline Edwin F. Katibah & $\begin{array}{l}\text { University of California, } \\
\text { Berkeley }\end{array}$ & $\begin{array}{l}\text { Principal investigator for California Department of Fish and } \\
\text { Game Central Valley Riparian Mapping Project. Presented paper } \\
\text { at } 1981 \text { California conference on distribution and condition of } \\
\text { riparian resources. }\end{array}$ \\
\hline Kenneth J. Kingsley & $\begin{array}{l}\text { University of Arizona; } \\
\text { National Park Service; SWCA }\end{array}$ & $\begin{array}{l}\text { Published studies on irrigated pecan orchard as a riparian } \\
\text { ecosystem and riparian taxa associated with springs, temporary } \\
\text { aquatic habitats, and washes; presented paper at } 1985 \text { Arizona } \\
\text { conference. }\end{array}$ \\
\hline Fritz L. Knopf & US Fish and Wildlife Service & $\begin{array}{l}\text { Author or co-author of several papers on riparian birds and } \\
\text { conservation of riparian woodlands. }\end{array}$ \\
\hline G. Mathias Kondolf & $\begin{array}{l}\text { University of California; } \\
\text { Santa Cruz and Berkeley }\end{array}$ & $\begin{array}{l}\text { Consulting hydrologist for multiple stream and riparian } \\
\text { restoration projects. Developed a database of stream restoration } \\
\text { projects in California as part of the National River Restoration } \\
\text { Science Synthesis. Presented papers at } 1981 \text { and } 1988 \\
\text { California conferences and other conferences. }\end{array}$ \\
\hline Jon Kusler & $\begin{array}{l}\text { Founder and Executive } \\
\text { Director, Association of State } \\
\text { Wetland Managers }\end{array}$ & $\begin{array}{l}\text { With a law degree has been instrumental in formulating and } \\
\text { improving wetland and floodplain programs and laws for } \\
\text { numerous states; served on the staffs of the University of Mass. } \\
\text { and Harvard University; editor of numerous publications on } \\
\text { wetlands and floodplains. }\end{array}$ \\
\hline Laurel Marcus & $\begin{array}{l}\text { California Coastal } \\
\text { Conservancy }\end{array}$ & $\begin{array}{l}\text { Managed cooperative planning for stream and riparian } \\
\text { restoration; published papers on riparian restoration and } \\
\text { watershed management at } 1987 \text { SWS Seattle conference, } 1988 \\
\text { AWM Oakland symposium and } 1988 \text { California conference. }\end{array}$ \\
\hline Jeffrey L. Marion & Virginia Tech University & $\begin{array}{l}1988 \text { review paper on recreation impacts in eastern riparian } \\
\text { forests with David Cole. Leader in recreation ecology research, } \\
\text { with several review articles. }\end{array}$ \\
\hline Joe R. McBride & $\begin{array}{l}\text { University of California, } \\
\text { Berkeley }\end{array}$ & $\begin{array}{l}\text { Conducted and published research on riparian trees, seed } \\
\text { dispersal and hydrology, role of fire in riparian woodlands, and } \\
\text { urban forestry. }\end{array}$ \\
\hline L. Richard Mewaldt & San Jose State University & $\begin{array}{l}\text { Founder of San Jose State University Avian Biology Laboratory, } \\
\text { Point Reyes Bird Observatory, San Francisco Bay Bird } \\
\text { Observatory and Coyote Creek Riparian Station. Active in bird } \\
\text { banding in riparian systems; author or co-author of numerous } \\
\text { avian papers. }\end{array}$ \\
\hline G. Wayne Minshall, & Idaho State University & $\begin{array}{l}\text { Numerous publications on interaction between aquatic and } \\
\text { riparian ecosystems; co-author of River Continuum Concept. }\end{array}$ \\
\hline Robert J. Naiman & $\begin{array}{l}\text { Oregon State University; } \\
\text { University of Washington }\end{array}$ & $\begin{array}{l}\text { Early studies on beavers and riparian ecosystems; studied } \\
\text { forest-stream interactions in Pacific Northwest region; numerous } \\
\text { publications. }\end{array}$ \\
\hline John Rieger & $\begin{array}{l}\text { California Department of } \\
\text { Transportation }\end{array}$ & $\begin{array}{l}\text { Research and publications on nesting habitat requirements } \\
\text { for endangered Least Bell's Vireo; designed and supervised } \\
\text { installation of riparian revegetation projects in San Diego region } \\
\text { for Caltrans; coordinator and editor of } 1985 \text { and } 1987 \text { native } \\
\text { plant revegetation symposia; member of California Riparian } \\
\text { Revegetation Study Group. }\end{array}$ \\
\hline Michael Rigney & $\begin{array}{l}\text { Coyote Creek Riparian } \\
\text { Station, San Jose, CA }\end{array}$ & $\begin{array}{l}\text { Co-founder/director of Coyote Creek Riparian Station; } \\
\text { participated in design of riparian revegetation projects; } \\
\text { monitored avian use of riparian revegetation sites. Member of } \\
\text { California Riparian Revegetation Study Group. Presented paper } \\
\text { at } 1988 \text { California conference. }\end{array}$ \\
\hline
\end{tabular}


Table A.1-Continued.

\begin{tabular}{|c|c|c|}
\hline Person & Affiliation & Riparian activities and results \\
\hline Ann L. Riley & $\begin{array}{l}\text { California State Water } \\
\text { Resources Control Board; } \\
\text { Waterways Restoration } \\
\text { Institute }\end{array}$ & $\begin{array}{l}\text { Co-founder of the Urban Creeks Council and Coalition to } \\
\text { Restore Urban Waters; Executive Director of Waterways } \\
\text { Restoration Institute; coordinated redesign of flood channel } \\
\text { restoration projects; member of conference advisory } \\
\text { committees; author of books on restoration of urban riparian } \\
\text { areas and waterways; member of California Riparian } \\
\text { Revegetation Study Group. Presented papers at multiple } \\
\text { conferences. }\end{array}$ \\
\hline Stewart B. Rood & $\begin{array}{l}\text { University of Lethbridge, } \\
\text { Alberta, Canada }\end{array}$ & $\begin{array}{l}\text { Plant physiologist with many publications on the ecology of } \\
\text { riparian trees, especially water needs and establishment of } \\
\text { Populus spp. }\end{array}$ \\
\hline Kenneth V. Rosenberg & $\begin{array}{l}\text { Arizona State University; } \\
\text { Louisiana State University; } \\
\text { Cornell University }\end{array}$ & $\begin{array}{l}\text { Published several papers on riparian birds and suburban } \\
\text { habitats. }\end{array}$ \\
\hline David L. Rosgen & $\begin{array}{l}\text { USDA Forest Service; } \\
\text { Wildland Hydrology }\end{array}$ & $\begin{array}{l}\text { Developed a system of stream classification based on } \\
\text { morphology, and related this to evaluating riparian conditions } \\
\text { and planning restoration efforts. Involved in the design of } \\
\text { numerous stream and riparian restoration projects. }\end{array}$ \\
\hline Ronald F. Schultze & $\begin{array}{l}\text { USDA Soil Conservation } \\
\text { Service, Davis, CA }\end{array}$ & $\begin{array}{l}\text { Member of steering committee for } 1981 \text { and } 1988 \text { California } \\
\text { conferences. Presented papers on restoration at } 1981 \text { CA } \\
\text { conference and } 1985 \text { Arizona conference. Co-founder of } \\
\text { California Riparian Revegetation Study Group (ca. 1981). }\end{array}$ \\
\hline John T. Stanley & $\begin{array}{l}\text { Harvey and Stanley } \\
\text { Associates, Inc., Alviso, CA; } \\
\text { The Habitat Restoration } \\
\text { Group, CA }\end{array}$ & $\begin{array}{l}\text { Involved in planning and installation of riparian and stream/ } \\
\text { watershed restoration projects; co-chair of CA Riparian } \\
\text { Revegetation Study Group; active in organizing several } \\
\text { conferences, authoring or co-authoring publications, including } \\
\text { chapter on riparian wetland creation and restoration in the far } \\
\text { west in } 1989 \text { EPA publication. }\end{array}$ \\
\hline Juliet C. Stromberg & Arizona State University & $\begin{array}{l}\text { Many publications and presentations on riparian plant ecology, } \\
\text { particularly along the San Pedro River; active in Arizona } \\
\text { Riparian Council and activist for riparian conservation. }\end{array}$ \\
\hline Robert C. Szaro & USDA Forest Service & $\begin{array}{l}\text { Several publications on riparian vegetation and wildlife, } \\
\text { including studies of effects of various perturbations. }\end{array}$ \\
\hline Richard E. Warner & $\begin{array}{l}\text { Field Studies Center, } \\
\text { University of California, } \\
\text { Davis }\end{array}$ & $\begin{array}{l}\text { Editor of } 1979 \text { USFWS workshop proceedings on fish and } \\
\text { wildlife resources needs in riparian ecosystems. Technical } \\
\text { Coordinator and Editor of } 1981 \text { California riparian conference. } \\
\text { Presented paper at the } 1981 \text { California Riparian Systems } \\
\text { Conference. Lead author of } 1985 \text { California Department of } \\
\text { Game and Fish report on the riparian resources of the Central } \\
\text { Valley and California Desert. }\end{array}$ \\
\hline Doug Whittaker & $\begin{array}{l}\text { Bureau of Land } \\
\text { Management, National Park } \\
\text { Service, and Confluence } \\
\text { Research and Consulting }\end{array}$ & $\begin{array}{l}\text { River/riparian recreation planning and management studies } \\
\text { on Alaska and Lower } 48 \text { rivers starting in the late 1980s. Co- } \\
\text { organized first national conferences and agency training on } \\
\text { flows and recreation. Papers on recreation impacts, flows, and } \\
\text { hydro-licensing. }\end{array}$ \\
\hline Philip B. Williams & $\begin{array}{l}\text { Philip Williams and } \\
\text { Associates, Inc., San } \\
\text { Francisco, CA }\end{array}$ & $\begin{array}{l}\text { Hydrologist/civil engineer involved in design of numerous } \\
\text { stream and riparian restoration projects; member of California } \\
\text { Riparian Revegetation Study Group. Author or co-author of } \\
\text { several papers on riparian corridor management and restoration, } \\
\text { esp. in relation to flood control. }\end{array}$ \\
\hline
\end{tabular}




\title{
Appendix B: Conferences, Symposia, and Other Gatherings Pertaining To Riparian Ecosystems, Riparian Ecology, Riparian Habitat Restoration, and Riparian Area Conservation
}

\author{
Compiled by: John T. Stanley, R. Roy Johnson, Steven W. Carothers, Duncan T. \\ Patten, and John S. Richardson
}

Beginning in the late 1970 s, research of riparian systems increased. This ecosystem of decreasing cover across the semi-arid West captured more interest among academia, government agencies, and the interested public. Consequently, several conferences and symposia were developed to share information on riparian ecosystems, their processes, and management of these threatened ecosystems.

Table B. 1 is a list of conferences and symposia that focused on riparian ecosystems, riparian ecology, riparian habitat restoration, and/or riparian area conservation. This list was compiled to provide an understanding of the timing and progression of the evolution of the field of riparian ecology in western North America. Some, but not all, of these conferences/symposia have the word riparian in their title. Not every conference focused exclusively on riparian ecosystems; however, those that addressed other ecosystems (e.g., wetlands other than riparian ecosystems) also contained a significant number of papers related to riparian ecosystems and are included here. Emphasis was placed on documenting conferences that occurred in the early years of development of the field (1970s and 1980s) while conferences from the 1990s and 2000s are also included (cut-off date is 2010). This cut-off date was selected by the team members because, after exhaustive research, we were able to find information on conferences and symposia up to that date; however, since 2010 many more agencies and organizations have been conducting riparian conferences and symposia unfamiliar to us. Due to space limitations, we have omitted almost all of the worthwhile riparian workshops that also occurred during these years.

We have referenced each conference/symposium by the editor(s), date, and title of the conference proceedings. Conferences are listed in chronological order in which they were held, which is not necessarily the years in which the proceedings were published. Some of the types of conferences that have been omitted from this table include those addressing aquatic ecosystems, including instream habitat improvement, salmonid stream restoration, trout stream improvement, as well as floodplain management, watershed management, rangeland management, and invasive species management, even though many of these conferences have also included some papers dealing with riparian ecosystems.

Many of these conferences were organized by individuals who were experts in riparian ecology or had a great interest in helping disseminate information on riparian ecosystems. The names of these individuals are shown below as editors and/or coordinators of the conference proceedings listed; see also the Appendix A, riparian pioneers, this volume. We have also provided the URL for those conference materials, which are hard to locate on the web. 
The following criteria were applied for the selection of conferences included in table B.1:

1. Word "riparian" is included in conference title and majority of papers deal with riparian ecosystems, riparian ecology, riparian habitat restoration, and/or riparian area conservation and management.

2. Word riparian is not included in conference title; however, a sizeable percentage of the papers deal with the above.

3. Selected papers presented at conference reported on some of the earliest work leading to the development of the "riparian" fields mentioned above.

4. Conference represents a key link in the history of the development of the "riparian" fields mentioned above.

5. Conference was held in the western United States, or if held elsewhere, a sizeable percentage of the papers dealt with western riparian areas.

6. Conference may have focused on river systems and their management; however, a sizeable percentage of the papers addressed the role of riparian ecosystems as a component of riverine systems and their restoration.

Annotations next to date in the left-hand column indicate the relative availability of conference proceedings:

$\mathrm{a}=$ Conference proceedings were published in hard copy shortly after, or within a few years of, conference date; proceedings are readily available from academic institutions, government agencies, or on the web.

$\mathrm{b}=$ Conference proceedings were published in hard copy within a few years of conference date; however, proceedings do not appear to be readily available from academic institutions, government agencies, or on the web.

$\mathrm{c}=$ Conference proceedings were published, but only electronically, within a few years of conference date; proceedings are readily available on the web.

$\mathrm{d}=$ Conference proceedings were not published at time of conference; however, proceedings have been scanned and are currently available on the web from an electronic content provider (generally at a fee).

$\mathrm{e}=$ Conference proceedings were not published (or cannot confirm publication) nor are the proceedings available on the web; however, selected papers from the conference have been published in scientific journals and/or are available on the web.

$\mathrm{f}=$ Conference proceedings were never published nor were selected papers ever published; only hard copy materials were distributed to individuals in attendance.

$\mathrm{g}=$ Conference proceedings were never published nor were selected papers ever published; however, abstracts and/or a summary/overview were prepared and distributed to participants but are not readily available.

$\mathrm{h}=$ Conference proceedings were never published nor were selected papers ever published; no abstracts or summary were prepared. 
Since the early 1980s, a number of statewide organizations have been formed by individuals interested in exchanging information on riparian ecosystems, riparian area conservation, and riparian habitat restoration. Two of the earliest were the California Riparian Revegetation Study Group, organized circa 1981, and the Arizona Riparian Council, organized in 1985-1986. Table B.2 lists some of these organizations that have held annual, semi-annual, or regular meetings, workshops, and/or conferences on riparian topics. Not included in this table are the many professional societies (e.g., American Fisheries Society, American Society of Civil Engineers, California Invasive Plant Council, California Society for Ecological Restoration, Society for Ecological Restoration, Society for Range Management, Society of Wetland Scientists, The Wildlife Society) and conservation organizations (e.g., watershed councils, State native plant societies) and their chapters that have included riparian issues at their annual conferences and workshops and are to be credited with playing a significant role in advancing the field of riparian ecology. Additionally, a myriad of place-based non-profit organizations were formed in the latter half of the $20^{\text {th }}$ century to address the protection, management, and restoration of specific river systems and their watersheds. Typically named after the river, creek, or watershed where they were located, these organizations also have held conferences and trainings promoting the care and management of riparian corridors. Finally, there have been agency personnel and academic faculty who have taken it upon themselves to conduct workshops and field trainings pertaining to riparian ecology and riparian ecosystem restoration. We mention two of these individuals in table B.1. 
Table B.1-Conferences, symposia, and other gatherings focused on riparian ecosystems, riparian ecology, riparian habitat restoration, and/or riparian area conservation.

\begin{tabular}{|c|c|}
\hline Year held & Publications including date and location of event \\
\hline $1976^{g}$ & $\begin{array}{l}\text { Gaines, D., ed. 1976. Abstracts from the conference on the riparian forests of the Sacramento Valley; } \\
1976 \text { May 22; Chico, CA. Oakland, CA: Davis and Altacal Audubon Societies. } 25 \text { p. (Hard copy but not } \\
\text { published). }\end{array}$ \\
\hline $1977^{a}$ & $\begin{array}{l}\text { Sands, A., ed. 1977. Riparian forests in California: Their ecology and conservation: A symposium; } 1977 \\
\text { May 14; Davis, CA. Davis, CA: Institute of Ecology, University of California, Davis, and Davis Audubon } \\
\text { Society. Institute of Ecology Publication No. 15.122 p. }\end{array}$ \\
\hline $1977^{\mathrm{e}}$ & $\begin{array}{l}\text { Menke, J., ed. Circa 1981. A symposium on livestock interactions with wildlife, fisheries, and their } \\
\text { environments; } 1977 \text { May; Sparks, NV. Berkeley, CA: U.S. Department of Agriculture, Forest Service, } \\
\text { Pacific Southwest Forest and Range Experiment Station. Refer to: Platts, W.S.1979. Livestock interactions } \\
\text { with fish and their environments: A symposium summary. p. 92-96. http://www.tws-west.org/transactions/ } \\
\text { Platts\%20'78.pdf. }\end{array}$ \\
\hline $1977^{a}$ & $\begin{array}{l}\text { Johnson, R.R.; Jones, D.A., tech. coords. 1977. Importance, preservation, and management of riparian } \\
\text { habitat: A symposium; } 1977 \text { July 9; Tucson, AZ. Gen. Tech. Rep. RM-43. Fort Collins, CO: U.S. } \\
\text { Department of Agriculture, Forest Service, Rocky Mountain Research Station. } 217 \text { p. }\end{array}$ \\
\hline $1978^{b}$ & $\begin{array}{l}\text { Graul, W.D.; Bissell, S.J., tech. coords. 1978. Lowland river and stream habitat in Colorado: A } \\
\text { symposium; } 1978 \text { October 4-5; Greeley, CO. Greeley, CO: Colorado Chapter, Wildlife Society and } \\
\text { Colorado Audubon Council. } 195 \text { p. }\end{array}$ \\
\hline $1978^{a}$ & $\begin{array}{l}\text { Cope, O.B., ed. 1979. Proceedings of the forum: Grazing and riparian/stream ecosystems; } 1978 \text { Nov. } \\
\text { 3-4; Denver, CO. Arlington, VA: Trout Unlimited. } 94 \text { p. }\end{array}$ \\
\hline $1978^{a}$ & $\begin{array}{l}\text { Johnson, R.R.; McCormick, J.F., tech. coords. 1979. Strategies for protection and management of } \\
\text { floodplain wetlands and other riparian ecosystems: Proceedings of the symposium; } 1978 \text { December } \\
\text { 11-13; Callaway Gardens, GA. Gen. Tech. Rep. GTR-WO-12. Washington, DC: U.S. Department of } \\
\text { Agriculture, Forest Service. } 410 \text { p. }\end{array}$ \\
\hline $1979^{b}$ & $\begin{array}{l}\text { Warner, R. E. 1979. Proceedings of a workshop on fish and wildlife resource needs in riparian } \\
\text { ecosystems; } 1979 \text { May 30-31; Harpers Ferry, WV. Kearneysville, WV: U.S. Department of Interior, Fish } \\
\text { and Wildlife Service, National Water Resources Analysis Group, Eastern Energy and Land Use Team, U.S. } \\
\text { Fish and Wildlife Service. } 53 \text { p. }\end{array}$ \\
\hline $1979^{b}$ & $\begin{array}{l}\text { Great Plains Agricultural Council, Forestry Committee (Program Committee) 1979. Riparian and wetland } \\
\text { habitats of the Great Plains: Proceedings of the 31st annual meeting; } 1979 \text { June 18-21; Fort Collins, } \\
\text { CO. Fort Collins, CO: U.S. Department of Agriculture, Forest Service, Rocky Mountain Forest and Range } \\
\text { Experiment Station. Great Plains Agricultural. Council. Publ. No. 91. } 88 \text { p. }\end{array}$ \\
\hline $1981^{\mathrm{a}}$ & $\begin{array}{l}\text { Warner, R.E.; Hendrix, K.M., eds. 1984. California riparian systems: Ecology, conservation and productive } \\
\text { management; } 1981 \text { September 17-19; University of California, Davis, CA. Berkeley, CA: University of } \\
\text { California Press. 1,035 p. }\end{array}$ \\
\hline $1984^{a}$ & $\begin{array}{l}\text { Rieger, J.P.; Steele, B.A., eds. 1985. Proceedings of the native plant revegetation symposium; } 1984 \\
\text { November 15; San Diego, CA. California Native Plant Society. } 99 \text { p. }\end{array}$ \\
\hline $1985^{\mathrm{a}}$ & $\begin{array}{l}\text { Johnson, R.R.; Ziebell, C.D.; Patton, D.R.; Ffolliott, P.F.; Hamre, R.H., tech. coords. 1985. Riparian } \\
\text { ecosystems and their management: Reconciling conflicting uses - First North American riparian } \\
\text { conference; } 1985 \text { April 16-18; Tucson, AZ. Gen. Tech. Rep. RM-120. Fort Collins, CO: U.S. Department } \\
\text { of Agriculture, Forest Service, Rocky Mountain Research Station. } 523 \text { p. }\end{array}$ \\
\hline $1985 \mathrm{~g}$ & $\begin{array}{l}\text { Patten, D.T., ed. 1986. Report to Pacific Gas and Electric Co. and Southern California Edison Co.: } \\
\text { Riparian workshop; } 1985 \text { November 13-14; Sam Ramon, CA. Pacific Gas and Electric Company, } \\
\text { Research and Development. Tempe, AZ: Arizona State University, Center for Environmental Studies. } 24 \text { p. }\end{array}$ \\
\hline $1986^{\mathrm{e}}$ & $\begin{array}{l}\text { Salo, E.O.; Cundy, D.W., eds. 1987. Streamside management: Forestry and fishery interactions } \\
\text { - proceedings of the symposium; } 1986 \text { February 12-14; Seattle, WA. Seattle, WA: University of } \\
\text { Washington, Institute of Forest Resources, Contribution No. } 57.471 \text { p. }\end{array}$ \\
\hline $1987^{a}$ & $\begin{array}{l}\text { Mutz, K.M.; Lee, L.C., tech. coords. } 1987 \text {. Proceedings of the Society of Wetland Scientists' eighth annual } \\
\text { meeting: Wetland and riparian ecosystems of the American west; } 1987 \text { May 26-29; Seattle, WA. Denver, } \\
\text { CO: Planning Information Corporation. } 346 \text { p. }\end{array}$ \\
\hline
\end{tabular}


Table B.1-Continued.

\begin{tabular}{|c|c|}
\hline Year held & Publications including date and location of event \\
\hline $1987^{a}$ & $\begin{array}{l}\text { Raedeke, K. J., ed. 1988. Streamside management: Riparian wildlife and forestry interactions; } 1987 \\
\text { February 11-13; Seattle, WA. Seattle, WA: University of Washington, College of Forest Resources, } \\
\text { Institute of Forest Resources, Contribution No. 59. } 277 \text { p. }\end{array}$ \\
\hline $1987^{\mathrm{a}}$ & $\begin{array}{l}\text { Rieger, J.P.; Williams, B.K., eds. 1988. Proceedings of the second native plant revegetation symposium; } \\
1987 \text { April 15-18; San Diego, CA. Madison, WI: Society for Ecological Restoration and Management. } \\
220 \text { p. }\end{array}$ \\
\hline $1988^{f}$ & $\begin{array}{l}\text { USFS Region } 5 \text { 1988. Riparian management workshop; } 1988 \text { June 14-17; Reno, NV. U.S. Department of } \\
\text { Agriculture, Forest Service, Region 5. (Unpublished binder of presentation materials.) }\end{array}$ \\
\hline $1988^{a}$ & $\begin{array}{l}\text { Kusler, J.A.; Daly, S.; Brooks, G., eds. 1988. Proceedings of the national wetland symposium: Urban } \\
\text { wetlands; } 1988 \text { June 26-29; Oakland, CA. Berne, NY: Association of State Wetland Managers, Inc. } 402 \text { p. }\end{array}$ \\
\hline $1988^{b}$ & $\begin{array}{l}\text { Mutz, K.M.; Cooper, D.j; Scott, M.L.; [et al.], tech. coords. 1988. Restoration, creation and management } \\
\text { of wetland and riparian ecosystems in the American West: Proceedings of a symposium; } 1988 \text { November } \\
\text { 14-16; Denver, CO. Boulder, CO: Society of Wetland Scientists, Rocky Mountain Chapter. } 239 \text { p. }\end{array}$ \\
\hline $1988^{a}$ & $\begin{array}{l}\text { Abell, D.L., tech. coord. 1989. Proceedings of the California riparian systems conference: Protection, } \\
\text { management and restoration for the 1990's; } 1988 \text { September 22-24; Davis, CA. Gen. Tech. Rep. PSW- } \\
\text { 110. Berkeley, CA: U.S. Department of Agriculture, Forest Service, Pacific Southwest Forest and Range } \\
\text { Experiment Station. } 544 \text { p. }\end{array}$ \\
\hline $1989^{a}$ & $\begin{array}{l}\text { Gresswell, R.E.; Barton, B.A.; Kershner, J.L., eds. 1989. Practical approaches to riparian resource } \\
\text { management: An educational workshop; } 1989 \text { May 8-11; Billings, MT. Billings, MT: U.S. Department of } \\
\text { the Interior, Bureau of Land Management. } 193 \text { p. }\end{array}$ \\
\hline $1989^{f}$ & $\begin{array}{l}\text { USFS Region } 5 \text { 1989. Integrated approaches to riparian area management through forest plan } \\
\text { implementation; } 1989 \text { November 13-17; Sequoia National Forest, Porterville, CA. U.S. Department of } \\
\text { Agriculture, Forest Service, Region 5. (Unpublished binder of presentation materials.) }\end{array}$ \\
\hline $1990^{h}$ & $\begin{array}{l}\text { Kusler, J. 1990. Urban stream and river corridors: A multi-objective management symposium; } 1990 \text { April } \\
\text { 23-28; Portland, OR. Portland Oregon Audubon Society in cooperation with Association of State Wetland } \\
\text { Managers. }\end{array}$ \\
\hline $1991^{d}$ & $\begin{array}{l}\text { Anonymous 1994. Riparian resources: Proceedings of a symposium on the disturbances, management, } \\
\text { economics, and conflicts associated with riparian ecosystems; } 1991 \text { April 18-19; Logan, UT. Logan, UT: } \\
\text { Utah State University, College of Natural Resources. Natural Resources and Environmental Issues } 1.82 \text { p. }\end{array}$ \\
\hline $1991^{a}$ & $\begin{array}{l}\text { Clary, W.P.; McArthur, E.D.; Bedunah, D.; [et al.], comps. 1992. Proceedings-Symposium on ecology } \\
\text { and management of riparian shrub communities; } 1991 \text { May 29-31; Sun Valley, ID. Gen. Tech. Rep. INT- } \\
\text { 289. U.S. Department of Agriculture, Forest Service, Intermountain Research Station. } 232 \text { p. }\end{array}$ \\
\hline $1992^{d}$ & $\begin{array}{l}\text { McCoy, M.C., ed. 1992. California's river heritage: A conference on conservation issues, policy and } \\
\text { implementation strategies; } 1992 \text { May 18-19; Sacramento, CA. Davis, CA: University of California } \\
\text { Extension. (Not numbered.) https://books.google.com/books/about/California s River Heritage. } \\
\underline{\text { html?id=092oPgAACAAl }}\end{array}$ \\
\hline $1993^{a}$ & $\begin{array}{l}\text { Tellman, B.; Cortner, H.; Wallace, M.; [et al.], tech. coords. 1993. Riparian management: Common } \\
\text { threads and shared interests, a western regional conference on river management strategies; } 1993 \\
\text { February 4-6; Albuquerque, NM. Gen. Tech. Rep. RM-226. Fort Collins, CO: U.S. Department of } \\
\text { Agriculture, Forest Service, Rocky Mountain Forest and Range Experiment Station. } 419 \text { p. }\end{array}$ \\
\hline $1994^{f}$ & $\begin{array}{l}\text { McCoy, M.C., ed. 1994. Conservation of California's rivers: A practicum in tools and techniques; } 1994 \\
\text { June 15-16; Sacramento, CA. (Not numbered.) }\end{array}$ \\
\hline $1995^{f}$ & $\begin{array}{l}\text { Laird, A.; Jacobs, D.; McCoy, M., chairs. 1995. California's riparian-river ecosystems conference IV: } \\
\text { Addressing current land use and resource conflicts; } 1995 \text { November 14-16; Sacramento, CA. Davis, CA: } \\
\text { UC Davis Extension. (Not numbered.) }\end{array}$ \\
\hline $1995^{a}$ & $\begin{array}{l}\text { Laursen, S.B., ed. 1995. At the water's edge: The science of riparian forestry: Conference proceedings; } \\
1995 \text { June 19-20; Duluth, MN. University of Minnesota, Minnesota Extension Service, Minnesota } \\
\text { Environmental Initiative. } 160 \text { p. }\end{array}$ \\
\hline $1995^{a}$ & $\begin{array}{l}\text { Macdonald, K.B.; Weinmann, F., eds. 1997. Wetland and riparian restoration: Taking a broader view- } \\
\text { Proceedings of a conference; } 1995 \text { September 14-16; Seattle, WA. Society for Ecological Restoration } \\
\text { International Conference. EPA 910-R-97-007. Seattle, WA: U.S. Environmental Protection Agency, Region } \\
\text { 10, Office of Ecosystems and Communities, Aquatic Resources Unit. } 326 \text { p. }\end{array}$ \\
\hline
\end{tabular}


Table B.1-Continued.

\begin{tabular}{|c|c|}
\hline Year held & Publications including date and location of event \\
\hline $1995^{\mathrm{a}}$ & $\begin{array}{l}\text { Shaw, D.W.; Finch, D.M., eds.1996. Desired future conditions for Southwestern riparian ecosystems: } \\
\text { Bringing interests and concerns together; } 1995 \text { September 18-22; Albuquerque, NM. Gen. Tech. Rep. } \\
\text { RM-GTR-272. Fort Collins, CO: U.S. Department of Agriculture, Forest Service, Rocky Mountain Forest } \\
\text { and Range Experiment Station. } 359 \text { p. }\end{array}$ \\
\hline $1998^{\mathrm{a}}$ & $\begin{array}{l}\text { Finch, D.M.; Whitney, J.C.; Kelly, J.F.; [et al.], eds. 1999. Rio Grande ecosystems: Linking land, water, and } \\
\text { people: Toward a sustainable future for the Middle Rio Grande Basin; } 1998 \text { June 2-5; Albuquerque, NM. } \\
\text { Proc. RMRS-P-7. Ogden, UT: U.S. Department of Agriculture, Forest Service, Rocky Mountain Research } \\
\text { Station. } 245 \text { p. }\end{array}$ \\
\hline $1999^{a}$ & $\begin{array}{l}\text { Native Plant Society of New Mexico } 1999 . \text { Wetland and riparian plant communities of New Mexico: } \\
\text { New Mexico Native Plant Society } 1999 \text { symposium proceedings; } 1999 \text { August 26-29; Albuquerque, NM. } \\
\text { Santa Fe, NM: New Mexico Native Plant Society. (Copy at UNM Centennial Science and Engineering } \\
\text { Library.) }\end{array}$ \\
\hline $2000^{a}$ & $\begin{array}{l}\text { Wigington, P.J., Jr.; Beschta, R.L., eds. 2000. International conference on riparian ecology and } \\
\text { management in multi-land use watersheds; } 2000 \text { August 28-31; Portland, OR. AWRA } 2000 \text { Summer } \\
\text { Specialty Conference. Middleburg, VA: American Water Resources Association. } 616 \text { p. }\end{array}$ \\
\hline $2001^{a}$ & $\begin{array}{l}\text { Faber, P.M., ed. 2003. California riparian systems: Processes and floodplain management, ecology, and } \\
\text { restoration; } 2001 \text { March 12-15; Sacramento, CA. Sacramento, CA: Riparian Habitat Joint Venture. Mill } \\
\text { Valley, CA: Pickleweed Press. } 557 \text { p. }\end{array}$ \\
\hline $2002^{\mathrm{e}}$ & $\begin{array}{l}\text { UBC 2002. Symposium on small stream channels and their riparian zones: Their form, function, and } \\
\text { ecological importance in a watershed context; Abstracts. } 2002 \text { February 18-20 [or 19-21]; Vancouver, } \\
\text { B.C. The University of British Columbia (UBC), Vancouver, B.C., Canada. } 38 \text { p. (Limited number of papers } \\
\text { published in the Canadian Journal of Forest Research. 33(8). Refer to Moore, R.D.; Richardson, J.S. } 2003 . \\
\text { Introduction: Progress towards understanding the structure, function, and ecological significance of small } \\
\text { stream channels and their riparian zones. Canadian Journal of Forest Research. 33: 1349-1351.) (Some } \\
\text { papers also published in Journal of the American Water Resources Association [JAWRA] in August } 2005 . \\
\text { Refer to Moore, R.D. 2005. Small stream channels and their riparian zones in forested catchments of the } \\
\text { pacific northwest: Introduction. JAWRA August 2005: 759-761.) }\end{array}$ \\
\hline $2004^{e}$ & $\begin{array}{l}\text { Dwire, K.A.; Lowrance, R.R. 2006. Riparian ecosystems and buffers-Multiscale structure, function, and } \\
\text { management: Introduction. Journal of the American Water Resources Association (JAWRA).42(1): 1-4. } \\
\text { February 2006. (AWRA Summer Specialty Conference. June 2004, Olympic Valley, CA.) }\end{array}$ \\
\hline $2005^{\mathrm{e}}$ & $\begin{array}{l}\text { OHRC 2005. Science and management of headwater streams in the pacific northwest; } 2005 \text { November } \\
\text { 17-18; Corvallis, OR. Oregon Headwaters Research Cooperative (OHRC). (Refer to Danehy, R.J.; Ice, } \\
\text { G.G. 2007. Introduction to special issue on headwater streams. Forest Science. 53(2): 101-103. Society } \\
\text { of American Foresters. }\end{array}$ \\
\hline $2007^{c}$ & $\begin{array}{l}\text { RHJV 2007. Riparian habitat conservation and flood management in California; } 2007 \text { December 4-6; } \\
\text { Sacramento, CA. Sacramento, CA: Riparian Habitat Joint Venture (RHJV). } 116 \text { p. http://www.prbo.org/ } \\
\text { calpif/rhjvconference/proceedings/2007RHJVConfProceedings complete.pdf }\end{array}$ \\
\hline $2007 \mathrm{~g}$ & $\begin{array}{l}\text { Richardson, J.S. } 2007 \text {. Riparian management in headwater catchments: Translating science into } \\
\text { management; } 2007 \text { February 19-21; University of British Columbia, Vancouver, BC, Canada. Refer to } \\
\text { Maclsaac, E.A.: Moore, R.D.; Richardson, J.S. 2007. Riparian management in headwater catchments: } \\
\text { Translating science into management-Meeting summary. Streamline Watershed Management Bulletin. } \\
\text { 11(1): 1-4. }\end{array}$ \\
\hline $2008^{a}$ & $\begin{array}{l}\text { Ryan, D.F.; Calhoun, J.M., tech. eds. } 2010 \text {. Riparian adaptive management symposium: A conversation } \\
\text { between scientists and management; } 2008 \text { November 3-4; Forks, WA. University of Washington, } \\
\text { Olympic Natural Resources Center. Portland, OR: Gen. Tech. Rep. PNW-GTR-830. U.S. Department of } \\
\text { Agriculture, Forest Service, Pacific Northwest Research Station. } 135 \text { p. }\end{array}$ \\
\hline
\end{tabular}


Table B.2-Organizations holding annual, semi-annual, or regular meetings pertaining to riparian ecosystems, riparian ecology, riparian habitat restoration, and/or riparian area conservation.

\begin{tabular}{|c|c|}
\hline Start date & Organizations including date formed and beginning and end of meetings \\
\hline 1981 & $\begin{array}{l}\text { California Riparian Revegetation Study Group. (Organized circa 1981; Ron Schultze and Randy } \\
\text { Gray.) Annual or semi-annual meetings in both northern and southern California (1981-1991). No } \\
\text { proceedings. Function taken over by SERCAL Riparian Guild in 1992. }\end{array}$ \\
\hline 1983 & $\begin{array}{l}\text { Salmonid Restoration Federation (SRF). (Incorporated 1986.) Annual Salmonid Restoration } \\
\text { Conference including riparian topics held in California since 1983. Proceedings for conferences } \\
\text { since } 2006 \text { published on website. }\end{array}$ \\
\hline 1985 & $\begin{array}{l}\text { North American Riparian Council. (Organizational 1985; R. Roy Johnson, Founding President; } \\
\text { disbanded by 1990.) No proceedings. }\end{array}$ \\
\hline 1986 & $\begin{array}{l}\text { Arizona Riparian Council. (Organized 1985-1986; Duncan Patten, Founding President.) Annual } \\
\text { meetings held in Arizona (1986 to present.) No proceedings. }\end{array}$ \\
\hline 1989 & $\begin{array}{l}\text { Colorado Riparian Association (CRA). (Formed in 1989.) Sustaining Colorado Watersheds } \\
\text { Conference ( } 2006 \text { to present). (See archives on website.) }\end{array}$ \\
\hline 1992 & $\begin{array}{l}\text { SERCAL Riparian Guild, California Society for Ecological Restoration. (Organized 1992: John } \\
\text { Stanley.) Annual meetings (1992 to present). No proceedings; riparian topics often addressed at } \\
\text { annual SERCAL conferences. }\end{array}$ \\
\hline 1995 & New Mexico Riparian Council. (Incorporated 1995.) \\
\hline 1995 & $\begin{array}{l}\text { Great Basin Ecosystem Management Project (GBEMP): Restoring and Maintaining Riparian } \\
\text { Ecosystem Integrity. (Organized 1995; Jeanne Chambers) U.S. Department of Agriculture, Forest } \\
\text { Service, Rocky Mountain Research Station-Annual Symposium and Field Tour of riparian ecosystem } \\
\text { research in Great Basin (1995 to present); renamed RiversEdge West (2018). }\end{array}$ \\
\hline 2001 & $\begin{array}{l}\text { Tamarisk Coalition. (Incorporated } 2002 \text { in Colorado) Annual riparian restoration research } \\
\text { conferences and symposiums since 2001. Presentations recorded and made available online at } \\
\text { Tamarisk Coalition's YouTube page. }\end{array}$ \\
\hline 2005 & $\begin{array}{l}\text { Berkeley River Restoration Symposium. (Organized 2005; G. Matt Kondolf.) Annual symposium held } \\
\text { at U.C. Berkeley (2005 to present). }\end{array}$ \\
\hline 2008 & $\begin{array}{l}\text { Texas Riparian Association. Annual meetings (2008 to present). Sponsor of Urban Riparian Symposia } \\
\text { and Southwest Stream Restoration conferences ( } 2013 \text { to present). No proceedings. }\end{array}$ \\
\hline
\end{tabular}


Federal Recycling Program Printed on Recycled Paper 
In accordance with Federal civil rights law and U.S. Department of Agriculture (USDA) civil rights regulations and policies, the USDA, its Agencies, offices, and employees, and institutions participating in or administering USDA programs are prohibited from discriminating based on race, color, national origin, religion, sex, gender identity (including gender expression), sexual orientation, disability, age, marital status, family/parental status, income derived from a public assistance program, political beliefs, or reprisal or retaliation for prior civil rights activity, in any program or activity conducted or funded by USDA (not all bases apply to all programs). Remedies and complaint filing deadlines vary by program or incident.

Persons with disabilities who require alternative means of communication for program information (e.g., Braille, large print, audiotape, American Sign Language, etc.) should contact the responsible Agency or USDA's TARGET Center at (202) 720-2600 (voice and TTY) or contact USDA through the Federal Relay Service at (800) 877-8339. Additionally, program information may be made available in languages other than English.

To file a program discrimination complaint, complete the USDA Program Discrimination Complaint Form, AD-3027, found online at http://www.ascr.usda.gov/complaint_filing_cust.html and at any USDA office or write a letter addressed to USDA and provide in the letter all of the information requested in the form. To request a copy of the complaint form, call (866) 632-9992. Submit your completed form or letter to USDA by: (1) mail: U.S. Department of Agriculture, Office of the Assistant Secretary for Civil Rights, 1400 Independence Avenue, SW, Washington, D.C. 20250-9410; (2) fax: (202) 690-7442; or (3) email: program.intake@usda.gov. 